\title{
Paulo de Tarso
}

\section{Grego e Romano, Judeu e Cristão}

José Augusto Ramos, Maria Cristina de Sousa Pimentel, Maria do Céu Fialho e Nuno Simões Rodrigues (coords.) 


\section{Paulo de Tarso:}

\section{Grego e Romano, Judeu e Cristão}

José Augusto Ramos, Maria Cristina de Sousa Pimentel, Maria do Céu Fialho e Nuno Simões Rodrigues (coords.)

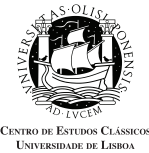


Todos os volumes desta série são sujeitos a arbitragem científica independente.

\section{Coordenadores}

José Augusto Ramos, Maria Cristina de Sousa Pimentel, Maria do Céu Fialho, Nuno Simões Rodrigues Título

Paulo de Tarso: Grego e Romano, Judeu e Cristão

\section{Editor}

Centro de Estudos Clássicos e Humanísticos da Universidade de Coimbra

EDIÇÃO:

1a/ 2012

\section{Coordenador Científico do Plano de Edição}

Maria do Céu Fialho

Conselho editorial

José Ribeiro Ferreira, Maria de Fátima Silva, Francisco de Oliveira e Nair Castro Soares

Director Técnico da Colecção:

Delfim F. Leão

Concepção Gráfica e Paginação:

Rodolfo Lopes, Nelson Ferreira

Index nominvm; Index Graecvs, Romanvs Hebraicvseve

Nídia Santos

INDEX LOCORVM

Nelson Ferreira

IMPRESSÃO:

Simões \& Linhares, Lda. Av. Fernando Namora, n. 83 Loja 4. 3000 Coimbra

ISBN: 978-989-721-005-1

ISBN DigitAL: 978-989-721-006-8

Depósito LegAL: 343418/12

CCentro de Estudos Clássicos e Humanísticos da Universidade de Coimbra, Centro de História da Universidade de Lisboa, Centro de Estudos Clássicos da UNIVERSIDADE DE LisBoA

(C) Classica Digitalia Vniversitatis Conimbrigensis (http://classicadigitalia.uc.pt)

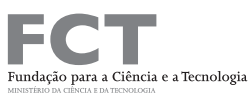

POCI/2010

Reservados todos os direitos. Nos termos legais fica expressamente proibida a reprodução total ou parcial por qualquer meio, em papel ou em edição eletrónica, sem autorização expressa dos titulares dos direitos. É desde já excecionada a utilização em circuitos académicos fechados para apoio a lecionação ou extensão cultural por via de e-learning. 


\section{SUMÁRIO}

Introdução: Paulo de Tarso: Grego e Romano, Judeu e Cristão

José Augusto M. Ramos (Universidade de Lisboa), Maria Cristina de Sousa Pimentel (Universidade de Lisboa), Maria do Céu Fialho (Universidade de Coimbra), Nuno

Simões Rodrigues (Universidade de Lisboa)

PAUlO de TARSO: EM TORNO DA ORIGEM

Rodrigo Furtado (Universidade de Lisboa)

De Tarso na Cilícia à Roma Imperial. A educação de Saulo

Abel N. Pena (Universidade de Lisboa)

Paulo no caminho de Damasco

Maria do Céu Fialho (Universidade de Coimbra)

Paulo de Tarso: a conversão como acto hermenêutico

José Augusto M. Ramos (Universidade de Lisboa)

Eis Spanian. Paulo de Tarso na Hispânia

Nuno Simões Rodrigues (Universidade de Lisboa)

A Lusitânia no tempo de Paulo de Tarso:

TÓPICOS DO MUNDO PROVINCIAL EM FASE PÓS-TIBERIANA

Amílcar Guerra (Universidade de Lisboa)

Paulo de Tarso e a Justiça dos Homens.

Helenismo e Impiedade Religiosa nos Actos dos Apóstolos

Delfim F. Leão (Universidade de Coimbra)

Paulo e a controvérsia sobre os alimentos Permitidos aos Cristãos:

A MESA ENTRE DOIS MUNDOS

Paula Barata Dias (Universidade de Coimbra)

A Caminho da nova AEON: TOlerar ou ATURAR?

O gue teria Paulo em mente?

Maria Ana T. Valdez (Universidade de Yale)

Moisés e Paulo em busca de um povo

Ana Paula Goulart (Universidade de Lisboa)

Séneca e Paulo de Tarso:

CONJECTURAS EM TORNO DE UMA CORRESPONDÊNCIA INCERTA

Paulo Sérgio Ferreira (Universidade de Coimbra) 
Os Actos apócrifos de Paulo e Tecla:

ASPECTOS DA SUA RECEPÇÃO E INTERPRETAÇÃO

Cláudia Teixeira (Universidade de Évora)

IN VIRTVTE SIGNORVM:

Paulo de Tarso na hagiografia medieval

Cristina Sobral (Universidade de Lisboa)

São Paulo na Arte Portuguesa da Idade Média

Luís U. Afonso (Universidade de Lisboa)

O Apóstolo na obra de Vieira

Arnaldo do Espírito Santo (Universidade de Lisboa)

Paulo de Tarso e Teixeira de Pascoaes

António Cândido Franco (Universidade de Évora)

Bibliografia Geral

INDEX NOMINVM

Index Graecvs, Romanvs Hebraicvsque

INDEX LOCORVM

CoOrdenadores E AUtores 


\section{Paulo de Tarso: Grego e Romano, Judeu e Cristão}

Muito provavelmente, Paulo de Tarso, antes conhecido como Saulo, nasceu na primeira década do século I d. C., o que significa que seria pouco mais novo do que Jesus de Nazaré. Judeu da diáspora, o apóstolo seria natural da Cilícia, tendo decerto tido uma educação de tipo helenizante. Cidadão romano, como ele próprio se identifica pela mão do autor dos Actos dos Apóstolos, Paulo viajou por todo o Mediterrâneo, designadamente pela Síria, Chipre, Ásia Menor, Antioquia, Galácia, Macedónia, Corinto, Jerusalém, Éfeso, Roma e, muito possivelmente, pela Península Ibérica. Paulo terá vivido sob os principados de Augusto, Tibério, Gaio Calígula e Cláudio, acabando por ser condenado à morte, em Roma, no tempo de Nero. A sua vida coincidiu, por conseguinte, com a vigência de toda a chamada dinastia Júlio-Cláudia, assistindo assim à emergência do Principado ou Império Romano bem como a todas as transformações que o Mundo Antigo conheceu nessa época.

A vida e a obra de Paulo de Tarso podem ser conhecidas através de várias fontes, sendo as mais significativas o livro dos Actos dos Apóstolos, tradicionalmente atribuído a Lucas, e as cartas escritas a várias comunidades cristãs mediterrâneas emergentes e a alguns indivíduos, como Filémon e Timóteo. Aliás, não menos de treze dos vinte e sete escritos do chamado Novo Testamento são cartas atribuídas a Paulo. Se a esses juntarmos o facto de o apóstolo ser um dos principais caracteres dos Actos, então a presença de Paulo de Tarso nessa parte da Bíblia traduz-se num protagonismo que ocupa quase um terço de todo o corpus.

As epístolas paulinas relacionam-se com o «nascimento» do cristianismo enquanto movimento sócio-cultural e religioso. Como fontes históricas, as cartas de Paulo são autênticos documentos, com destinatários reais, nos 
quais se reflectem as vicissitudes do surgimento dos grupos e instituições que deram corpo ao cristianismo nos primeiros séculos da sua existência. Notese aliás que Paulo de Tarso foi um dos protagonistas de todo esse processo, que podemos classificar como o da geração formativa do movimento cristão. Como conclui T. L. Donaldson, Paulo e os seus escritos representam uma «janela de inestimável valor para o cristianismo emergente» ${ }^{1}$. E se levarmos em conta a influência dos escritos paulinos na formação da cultura ocidental como um todo, então ficamos com uma percepção ainda mais clara da amplitude da importância histórica de Paulo de Tarso. A título de exemplo, salientamos o facto de o pensamento e os discursos paulinos, independentemente de concordarmos ou não com a forma como foram, e são, retoricamente usados, terem sido evocados em contexto de problemáticas sociais e políticas relevantes para a sociedade ocidental, de que são exemplos o tratamento dos Judeus e do judaísmo, a instituição da escravatura nos séculos XVIII e XIX, a colonização de África e do Extremo Oriente - onde a actividade missionária cristã foi particularmente significativa -, as estruturas e práticas de tipo patriarcal e a exclusão das mulheres da participação efectiva das mais variadas circunstâncias sociais e políticas, as atitudes intolerantes para com as questões da orientação sexual, além de temáticas estritamente teológicas, como os problemas do «pecado», da «culpa» e da «morte», centrais, por exemplo, nas diferenças estabelecidas entre as correntes católica e protestantes do cristianismo.

Juntamente com os Actos dos Apóstolos, as cartas paulinas remetem os investigadores para uma necessária reconstituição, contextualização e interpretação históricas, trazendo à colação as várias problemáticas em causa. Com efeito, mais do que pelas várias facções judaicas no activo durante o século I d. C., o enquadramento coevo pauta-se pelo domínio greco-romano, tanto ao nível político-institucional, como ao nível estritamente cultural literário, filosófico, religioso, material, científico - e mental. A propósito, podemos citar o elucidativo exemplo evocado por T. L. Donaldson. Segundo este exegeta, o leitor moderno dificilmente compreenderá na plenitude o passo citado em Gl 3,1 («Oh Gálatas insensatos! Quem vos enfeitiçou, a vós, a cujos olhos foi exposto Jesus Cristo crucificado?»), se não levar em conta o facto de a magia ser, naquele contexto, um assunto na ordem do dia e pleno de sentido objectivo, que iria muito além da simples metáfora ${ }^{2}$.

Se os Actos dos Apóstolos proporcionam essencialmente informação de natureza biográfica - acerca dos vários episódios vividos pelo apóstolo, dos itinerários e do ministério de Paulo de Tarso -, as cartas são fontes privilegiadas para conhecer o pensamento teológico, filosófico e até sócio-político do homem. Mas, como qualquer fonte histórica, estes documentos não estão

\footnotetext{
${ }^{1}$ Donaldson 1993, 1062.

${ }^{2}$ Donaldson 1993, 1063.
} 
isentos de crítica, havendo que submetê-los à dura avaliação da hermenêutica. Esse deve ser o meio privilegiado para compreendermos a profunda crítica e constestação dos "partidos» judaicos do seu tempo, assim como a adopção, senão mesmo construção, do pensamento que culminará na teologia cristã. Ao mesmo tempo, reconhecemos no teorizador as categorias e formas do pensamento grego, nomeadamente ao nível do uso da retórica, assim como os vestígios das estruturas institucionais que o Império Romano lhe proporcionou e de que ele de forma tão inteligente se serviu.

Refira-se, aliás, que a biografia de Paulo de Tarso é riquíssima do ponto de vista historiográfico-literário. Da conversão ou «experiência de Damasco» - como alguns autores hoje lhe chamam - ao topos do naufrágio; da vivência e rejeição do judaísmo à itinerância proselitista; da prisão e outras provações à condenação, o percurso biográfico do apóstolo não só segue pari passu o de Cristo - levando mesmo à conclusão de que estamos perante uma mimese biográfica que pretende colocar o Tarsense em referência directa com o Nazareno - como se apresenta com uma vitalidade própria de qualquer herói da Antiguidade.

O Vaticano designou o período de 28 de Junho de 2008 a 29 de Junho de 2009 como «Ano Paulino». No âmbito dessas comemorações, três Centros de investigação - o de História e o de Estudos Clássicos da Universidade de Lisboa e o de Estudos Clássicos e Humanísticos da Universidade de Coimbra, a que se associou ainda a colaboração do Centro de Estudos de História Religiosa da Universidade Católica Portuguesa - decidiram reconhecer e relembrar a importância histórica e cultural da personalidade de Paulo de Tarso, atribuindolhe os epítetos de "Grego e Romano, Judeu e Cristão», reivindicando para o Apóstolo das Nações categorias que o definem como síntese e desse modo o tomam como um homem do seu tempo. Para concretizar esta reflexão, as unidades de investigação científica mencionadas decidiram avançar com o debate feito nos planos histórico, filológico, arqueológico, filosófico, e até mesmo teológico, dando-lhe forma através da investigação que originou uma série de estudos, cujo principal objectivo é contextualizar a figura e a obra de Paulo de Tarso. Para isso, os centros universitários referidos «convocaram» um grupo de investigadores nacionais, que aceitaram o desafio e avançaram com problemáticas que contribuíram para a discussão em torno do valor e importância do Apóstolo das Nações nos fundamentos da Cultura Ocidental.

É o conjunto das propostas então apresentadas que reunimos neste volume. Os textos que o integram podem ser agrupados em três grandes blocos: os que tratam de questões biográficas e de contexto sócio-cultural do tempo de Paulo de Tarso; os que abordam problemáticas do pensamento teológico-filosófico do apóstolo; e os que estudam a problemática da tradição, influência e recepção de Paulo nas mais variadas expressões culturais e épocas, 
da Antiguidade à Contemporaneidade. Assim, no primeiro bloco incluímos as investigações de Rodrigo Furtado (Paulo de Tarso: em torno da origem), Abel N. Pena (De Tarso na Cilícia à Roma Imperial. A educação de Saulo), Maria do Céu Fialho (Paulo no caminho de Damasco), José A. Ramos (Paulo de Tarso: a conversão como acto hermenêutico), Nuno Simões Rodrigues ("Eis Spanian». Paulo de Tarso na Hispânia), Amílcar Guerra (A Lusitânia no tempo de Paulo de Tarso: tópicos do mundo provincial em fase pós-tiberiana) e Delfim F. Leão (Paulo de Tarso e a justiça dos homens. Helenismo e impiedade religiosa nos «Actos dos Apóstolos»). Ao segundo grupo pertencem os trabalhos de Paula Barata Dias (Paulo e a controvérsia dos alimentos permitidos aos cristãos: a mesa entre dois mundos), Maria Ana Valdez (A caminho da Nova «Aeon»: tolerar ou aturar? O que teria Paulo em mente?) e Ana Paula Goulart (Moisés e Paulo em busca de um povo). O terceiro e último conjunto de textos é constituído pelas reflexões e conclusões de Paulo Sérgio Ferreira (Séneca e Paulo de Tarso: conjecturas em torno de uma correspondência incerta), Cláudia Teixeira (Os Actos apócrifos de Paulo e Tecla: aspectos da sua recepção e interpretação), Cristina Sobral («In uirtute signorum»: Paulo de Tarso na hagiografia medieval), Luís U. Afonso (São Paulo na Arte portuguesa da Idade Média), Arnaldo do Espírito Santo (O Apóstolo na obra de Vieira) e António Cândido Franco (Paulo de Tarso e Teixeira de Pascoaes).

Com a sua publicação, as reflexões então apresentadas pelo grupo de investigadores ficam acessíveis a todo o público. Os organizadores do volume, que coordenaram os trabalhos, esperam assim fazer justiça ao Apóstolo, ao que ele significa para a nossa cultura e ainda ao facto de ter sido um pensador com o objectivo de intervir no seu mundo e no seu tempo, mas que não se ficou por aí. Longe disso. Recordando as suas próprias palavras:

Vede com que grandes letras vos escrevo pela minha mão.

Os coordenadores

José Augusto Ramos Maria Cristina de Sousa Pimentel

Maria do Céu Fialho Nuno Simões Rodrigues

\footnotetext{
${ }^{3}$ Gl 6,11.
} 
Paulo de Tarso:

Grego e Romano, Judeu e Cristão 


\title{
PaUlo de TARso: EM TORno dA ORIGeM
}

\author{
Rodrigo Furtado \\ Universidade de Lisboa \\ Centro de Estudos Clássicos da Universidade de Lisboa
}

Corria o ano de 387 ou já 388. Jerónimo deambulava então pelo Egipto com as suas companheiras, Paula e Eustóquio, visitando os sítios dos ascetas cristãos. A pedido delas, começou por essa altura uma série de comentários a algumas das cartas atribuídas a São Paulo; entre eles, escreveu um Comentário à Epistola a Filémon. Aproveitando o facto de estar no Egipto, Jerónimo deve ter então consultado um outro Comentário a este mesmo texto, escrito mais de um século antes por Orígenes, em Alexandria. Deve ter sido neste texto ${ }^{1}$ que, a propósito do versículo 23 da Epistola a Filémon, Jerónimo encontrou uma estranha notícia que decidiu incluir também na sua própria obra²: «quando toda a província [da Judeia] foi devastada pelo exército romano e os Judeus se espalharam pelo mundo", os pais de Paulo teriam sido levados de uma povoação chamada Gíscalis, de onde seriam originários, para Tarso; e ainda mais: «o muito jovem Paulo seguiu o destino dos pais» (in Phil. 23, PL26.617). Paulo teria, pois, nascido, antes de ir para Tarso, em Gíscalis. É possível que Jerónimo não estivesse seguro acerca da localização do povoado: não aparecia uma única vez na Bíblia e não parece ter tido qualquer comunidade cristã ${ }^{3}$. Situa-o, pois, na Judeia, corónimo que permitia recobrir sem grande precisão o território da Palestina (Luc. 1.5, 23.5, Act. 10.37). Esta Gíscalis deve, no entanto, ser identificada com Gíscala, a moderna Jish (شלוג)/Gush Halav) בלח), bem ao norte na Galileia, pátria do famoso João de Gíscala, que liderou a grande guerra judaica do século $\mathrm{I}^{4}$.

Esta origem singular de Paulo, ao arrepio da versão convencional que se encontrava nos textos sagrados, continuou a interessar Jerónimo. De facto, anos depois, em 393, já em Belém, ele decidiu escrever um De uiris illustribus à maneira de Suetónio, que elencava 135 personalidades cristãs. Paulo foi a quinta. Aí, Jerónimo decidiu ser ainda mais explícito e clarificou a informação anterior, ao afirmar que Paulo era «de Gíscalis, uma vila da Judeia; quando esta foi capturada pelos Romanos, emigrou para Tarso, na Cilícia, com os pais». (uir. ill. 5) $)^{5}$.

${ }^{1}$ Hipótese apresentada por Harnack, 1919, 145ff. Cf. Kelly, 1975, 145-149.

${ }^{2}$ Apresenta-a como fábula o que não significa necessariamente ficção.

${ }^{3}$ Zahn, 1904, 29; Deissmann, 1926, 90, n. 5, retomados por Murphy-O’Connor, 2007, 18.

${ }^{4}$ Cf. Thomsen, 1907, 52 .

${ }^{5}$ Paulo seria assim, como Jesus de Nazaré, Paulo «de Tarso» devido ao local onde passara a sua infância, e não por ser essa a sua cidade natal. Cf. Murphy-O’Connor, 2007, 16. 
Esta singular versão foi aceite já no séc. XIX por T. Zahn, A. Deissman, A. von Harnack e, mais recentemente, por J. Murphy-O'Connor ${ }^{6}$. E T. Zahn não deixava de ter razão: percebe-se mal por que razão Jerónimo (ou Orígenes?) teria inventado tal notícia, já que Paulo não parece ganhar nada de relevante com esta sua «nova» origem. T. Zahn considerava por isso provável que ele tenha mesmo sido levado como escravo para Tarso talvez na sequência da rebelião de Judah ben Hezekiah, em 4 a.C. $(A J 17.271)^{7}$.

Há, no entanto, um problema: a primeira vez que ouvimos falar desta origem «diferente» de Paulo é apenas mais de trezentos anos depois de ele ter vivido; ela não é referida em nenhum dos textos mais próximos da vida do Apóstolo: nem nos Actos, nem nas Cartas. Eusébio de Cesareia também a omite e o mesmo fazem Lactâncio, Rufino, Ambrósio ou Agostinho. Ninguém conhecia ou a ninguém pareceu credível esta versão. Só Fócio (a partir de Orígenes? ${ }^{28}$, já bem mais tarde, em 867, também mostrou conhecê-la: para ele, e preservando a versão bíblica, Paulo teria sido concebido ainda em Gíscala, mas nascera já em Tarso (quaest. Amphil. 116, PG 101.687).

É nos Actos dos Apóstolos que encontramos a mais completa informação sobre as origens de Paulo. Corria talvez o ano 57. $\mathrm{Na}$ atribulada Jerusalém, a multidão de Hebreus enfurecida acusara Paulo de introduzir Gentios no templo, arrastara-o para fora do santuário e parecia prestes a linchá-lo, não fora a intervenção dos soldados romanos (Act.21.27-36). Posto em segurança, Paulo teve a possibilidade de se explicar em Grego ao confundido tribuno romano: que não, não era o Egípcio que se tinha há tempos revoltado9; «eu sou mesmo

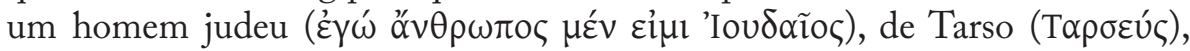
cidadão de uma não obscura cidade da Cilícia» (Act. 21.39). Tal pedigree foi suficiente para que fosse autorizado a dirigir-se à multidão, e desta vez em

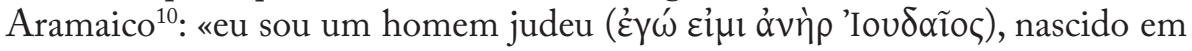

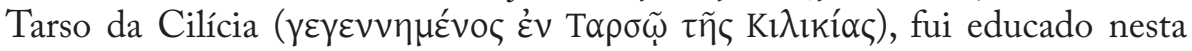

${ }^{6}$ Zahn, 1904,24-34; Harnack, 19244,63 n. 1; Deissmann, 1926, 90, n. 5; Murphy-O’Connor, 2007, 16-20.

7 Zahn, 1904, 24-34; Harnack, 19244, 63 n. 1. Esta hipótese foi também retomada por Murphy-O'Connor, 2007, 19-20. Contudo, Fucks, 1985, mostra que haveria outras datas possíveis para uma possível escravização da família de Paulo.

${ }^{8}$ É a hipótese avançada por Hengel, 1991, 14.

${ }^{9} \mathrm{Cf}$. talvez Jos. Bel. 2.261-263. Esta confusão era socialmente aviltante tendo em conta a péssima reputação de que os Egípcios gozavam. Segundo Jos. c. Apion 2.41, apenas aos Egípcios era recusada a cidadania romana; de modo geral, também Fílon de Alexandria mostra particular desprezo pelos Egípcios (e.g. Phil., all. 2.84, 3. 13, 3.38, 3.81, 3.87, de somn. 2.55); veja-se também Strab. 17.1.12-13.

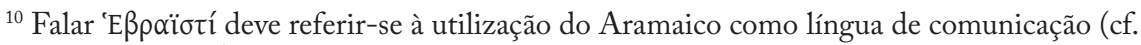
Jo. 5.2, Jos. Aj 18.228). Embora não me pareça convincente, veja-se para uma opinião diferente desta Ott, 1967, 22. 
cidade, instruído aos pés de Gamaliel, em todo o rigor da Lei dos nossos pais e cheio de zelo pelas coisas de Deus» (Act. 22.3). Trata-se de um autêntico curriculum uitae, onde não faltam os dados pessoais ou as habilitações: (i) pertença étnica/religiosa ao mundo hebraico, reforçada pela utilização do pronome pessoal, do presente do indicativo ( $\dot{\varepsilon} \gamma \omega \dot{~ \varepsilon i \jmath \mu l) ~ e, ~ n o ~ p r i m e i r o ~ d i s c u r s o, ~}$ pela partícula $\mu \varepsilon ́ v$; nada sobre Gíscala ou sobre o norte da Galileia; (ii) o seu local de nascimento foi Tarso, informação reforçada pela lítotes que a refere

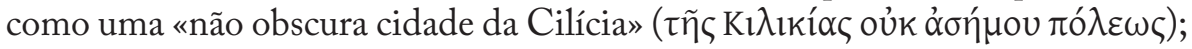
de novo, sem referência, nem mesmo indirecta, a Gíscala; (iii) em Tarso, gozaria do extraordinário estatuto de cidadão; (iv) a sua instrução fora em Jerusalém, «aos pés de Gamaliel»; por fim, (v) insistência no rigor desta instrução e no zelo que mostrava no cumprimento da Lei.

Contudo, o tribuno não se deixou impressionar. Paulo até podia ser judeu,

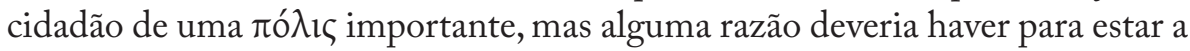
ser perseguido. A vergasta seria decerto boa opção para fazer o prisioneiro falar. Ditada a decisão, Paulo revela então novo pormenor sobre a sua identidade:

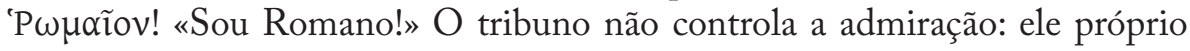
tinha comprado com custo a sua cidadania! Paulo responde: «Pois eu já nasci com esse direito» (Act. 22.25-28)!

Acabado de chegar da Grécia, Paulo fora mal recebido em Jerusalém, onde corriam rumores de que negara a Lei, ensinando os Judeus da diáspora a trocá-la pelos mais polidos costumes gregos; dizia-se que no Templo teria introduzido Gregos; quase linchado por Hebreus, fora salvo pela guarnição romana; a esta dirigira-se em Grego, em Aramaico aos Hebreus. Prestes a ser flagelado como peregrinus, confessa-se cidadão romano. «Sou judeu de Tarso» funciona, pois, como uma espécie de «dois em um» que caracteriza bem Paulo. O seu nome é também sinal disso: Saulo para os Hebreus, no mundo grecoromano chamava-se Paulo ${ }^{11}$.

Sendo assim, será de rejeitar a hipótese «Gíscala»? Ainda não. Jerónimo e Fócio não são tolos, conhecem os Actos dos Apóstolos e também admitem a relação de Paulo com Tarso, mesmo se há contradição entre o texto bíblico e a versão transmitida por Jerónimo; e pelo menos Fócio tenta conciliar as duas versões. Os próprios discursos dos Actos não estão isentos de problemas ${ }^{12}$, já que não foram escritos por Paulo, mas por autor anónimo, já no séc. II tido como Lucas, companheiro de Paulo ${ }^{13}$. Naturalmente, por si só esta evidência

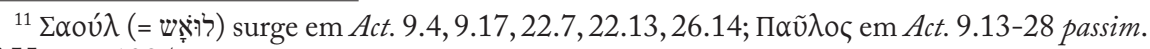
Cf. Hemer, 1985.

12 Conzelman, 1987, 186: «The entire defense speech given before the people is Luke's creation». Igual opinião em Haenchen, 1971, 622. Contra veja-se Bruce, 1988 rev, 399-400.

${ }^{13}$ Ver Kümmel, 1975, 147-150 e McDonald, Porter, 1999, 296. Os passos escritos na $1^{\mathrm{a}}$ pessoa são muitas vezes utilizados para defender que o autor dos Actos foi companheiro de 
não descredibiliza a narrativa, sob pena de termos de recusar quase todas as Histórias que hoje temos. Contudo, Lucas (por comodidade e tradição, continuarei a referi-lo deste modo) atribui às origens de Paulo um conjunto de pormenores que pode ser cotejado com fontes mais directas, como as 7 cartas de autoria certa que o próprio Paulo nos deixou ${ }^{14}$.

As Cartas confirmam que Paulo nascera Judeu, pois fora circuncidado ao oitavo dia do seu nascimento, era filho de Judeus, pertencia à tribo de Benjamim, era Israelita e falante de Aramaico (Fil. 3.4-5; Rom. 9.3b-5, Rom. 11.1, 2Cor. 11.22): ora, tudo isto não comprova, mas é historicamente compatível com a hipótese "Gíscala». Ao contrário do que se passa com Jerusalém (Rom. 15, 19, 25, 31, 1Cor. 16.3, Gal. 1.17, 2.1, 4.25), Corinto (1Cor. 1.2, 2Cor. 1.1, 23), Éfeso (1Cor. 15.32, 16.8), Damasco (2Cor. 11.32, Gal. 1.17) ou Antioquia (Gal. 2.11), nenhuma das Cartas refere uma única vez Tarso nem sequer como cidade por onde Paulo tivesse passado, quanto mais nascido. Apenas com base nas Cartas, a hipótese «Tarso» é tão verosímil como a hipótese «Gíscala»: ambas são omitidas. E não é esta a única omissão nas Cartas: nos textos do próprio Paulo também nunca vêm referidas nem a sua cidadania romana nem a sua cidadania em Tarso nem a sua educação «aos pés de Gamaliel».

De facto, não fora existirem os Actos dos Apóstolos, creio que muitos autores admitiriam bem, apenas com base nas Cartas, que Paulo tivesse nascido na Palestina, talvez no norte da Galileia, em Gíscala. Contudo, os Actos existem e são explícitos; em outros passos, Lucas supõe também com naturalidade a origem de Paulo na Cilícia (Act. 9.11, 9.30, 11.25, 15.23, 15.41. Cf. Gal. 1.21).

Reclamar-se de Tarso, na Antiguidade, não era pequena coisa: antes de Paulo, Estrabão afirmara que os cidadãos desta $\pi$ ó $ı \leftrightharpoons ~ t e r i a m ~ u l t r a p a s s a d o$ Atenas e Alexandria nas suas escolas e no ensino dos filósofos (Strab. 14.5.1215); depois, de Paulo, Díon Crisóstomo continua a elencar as razões para o orgulho dos cidadãos de Tarso pela sua cidade (Dio Cheys. 33.17, 33.28); mais tarde ainda, embora considerando que lhes interessava pouco a filosofia, Filóstrato menciona o luxo destes cidadãos (Philostr. Apol. Tyan. 1.7) ${ }^{15}$; uma

Paulo (Act. 16.10-17, 20.5-15, 21.1-18, 27.1-29, 28.1-16). Nas Cartas, Lucas surge em Flm 24 e nas epístolas deuteropaulinas (Col. 4.14,2Tim. 4.11). O Cânone de Muratori, do século II, é o primeiro texto que chegou até nós a identificar Lucas como autor do terceiro Evangelho e dos Actos dos Apóstolos: Acta autem omnium apostolorum sub uno libro scribta sunt. Lucas obtime Theofile comprindit quia sub praesentia eius sincula gerebantur (ed. Lietzmann).

${ }^{14}$ Incluo aqui a Epistola aos Romanos, a $1^{a}$ e a $2^{a}$ Epistolas aos Coríntios, as Epistolas aos Gálatas e aos Filipenses, a $1^{a}$ Epistola aos Tessalonicenses e a Epistola a Filémon. Na sequência de Harrison, 1921, aceito como «Deuteropaulinas» as Epistolas aos Efésios e aos Colossenses, a $1^{a}$ e a $2^{a}$ Epistolas a Timóteo e a Epistola a Tito (além, naturalmente, da Epistola aos Hebreus).

${ }^{15}$ Veja-se também Xen. Anab. 1.2.22-33, Jos. AJ1.6.7, Dio Chrys. 33.49. Cf. Ramsay, 1908, 85-116; Böhlig, 1913; Jones, 1940, 207; Jones, 1971², 192-215. 
inscrição chega mesmo a reivindicar Tarso como «a primeira, a maior e a mais bela metrópole» (OGIS 578.7-8).

Contudo, ser cidadão de Tarso não era algo que qualquer um pudesse reivindicar ser: em nenhuma ró $\lambda_{\imath \varsigma}$ o conjunto dos cidadãos foi equivalente ao conjunto dos habitantes do sexo masculino; ser cidadão era uma situação de privilégio político e de manifesto relevo social. Concretamente em Tarso, no final do século I a.C., o célebre Atenodoro, professor de Augusto, tinha limitado severamente a cidadania, ao estipular como condição para o seu acesso o rendimento de 500 dracmas (Dio Chrys.34.21-23), o que correspondia ao que um legionário auferia durante dois anos ${ }^{16}$. Aceitar que Lucas está certo é situar, pois, Paulo não apenas entre a elite política, mas também entre a elite económica de Tarso ${ }^{17}$. Ora, Lucas parece confirmar esta condição económica privilegiada: em Jerusalém, Paulo teria pago os dispendiosos rituais de purificação de quatro Nazireus (Act. 21.23) ${ }^{18}$; Félix teria esperado um suborno da parte de Paulo (Act. 24.26), que teria também tido de pagar do seu bolso a viagem a Roma e o apelo ao imperador (Act. 25.11); aí chegado, teria arrendado uma casa durante dois anos $(\text { Act. 28.30 })^{19}$. Por fim, o facto de Paulo pertencer à tribo de Benjamim, que o nome Saúl/Saulo comprova, confirma o seu estatuto social: como M. Hengel admite, «only a few families could clearly derive their origin from a particular tribe $[\ldots]$. Here we may with justification speak of a "lay nobility by birth" $»^{20}$. Os membros desta tribo tinham o prestígio de descender do único filho de Jacob a ter nascido em Israel (Gen.35.16) e de pertencer à única tribo que se mantivera fiel a Judá; continuaram depois a ter influência: Jehuda-ha-Nāsī, por exemplo, o redactor da Mishnah e trisavô de Gamaliel, era benjaminita ${ }^{21}$.

Em Tarso, ser judeu, cidadão e rico não era natural. É verdade que J. Goldstein admite que a ida ao gymnasium ou a participação em cerimónias da $\pi$ ó $\lambda_{1} \varsigma$ seria rejeitada pelos Judeus mais estritos ${ }^{22}$. Contudo, foi também rejeitada por A. D. Nock e S. Applebaum ${ }^{23}$ a tese de que a concessão da cidadania de uma Tódıৎ aos Judeus deveria obrigar à apostasia ${ }^{24}$. O próprio Goldstein mostrou que houve quem se tivesse deixado atrair pela política e cultura helenísticas, sem deixar de ser Judeu ${ }^{25}$.

${ }^{16}$ Cf. Hengel, 1991, 98-99, n. 43; 100, n.54.

${ }^{17}$ Dio Chrys. 34.23. Cf. Bruce, 1988rev, 398.

${ }^{18} \mathrm{Cf}$. as ofertas devidas pelo Nazireu em $\mathrm{Nm}$ 6.14-15.

${ }^{19}$ Hock, 2008, 7-18, defendeu que o trabalho artesanal de Paulo teria sido aprendido já depois da sua conversão.

${ }^{20}$ Hengel, 1991, 17.

${ }^{21}$ Hengel, 1991, 26-27.

${ }^{22}$ Goldstein, 1981, 66-67.

${ }^{23}$ Nock, 1972, 960ff.; Applebaum, 1974a.

${ }^{24}$ Tarn, Griffith, 1959, 222.

${ }^{25}$ Goldstein, 1981. 
Jerónimo não é claro, mas é muito provável que supusesse, pelo menos no Comentário a Filémon, que Paulo e os pais teriam sido levados (fuisse translatos) para Tarso como escravos na sequência de uma das revoltas na Palestina. Nesse caso, em determinada altura, a família teria sido alforriada. De resto, seria por certo um dever que os familiares de um Judeu tornado escravo o procurassem resgatar: se a família de Paulo na Palestina fosse rica, tal situação pode mesmo ter sucedido ${ }^{26}$. No de uiris illustribus, Jerónimo matiza um pouco a afirmação ao referir apenas que Paulo teria emigrado (commigrauit) com os pais. Mas, numa e noutra hipótese, seria possível que os pais de Paulo pudessem ter rendimento suficiente para adquirirem depois a cidadania em Tarso? Não é assim tão simples, porque a alforria ou a posse de um rendimento mínimo não

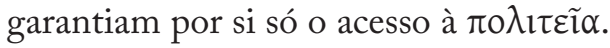

W. M. Ramsay considera verosímil que a cidadania de Paulo proviesse da sua concessão em bloco aos Judeus de Tarso. Mas terá esta concessão, de facto, ocorrido? Seleuco I terá concedido direitos completos de cidadania aos Judeus das cidades que fundou na Ásia e na Síria (Jos. AJ 12.121). Contudo, Judeus em Tarso só são atestados a partir de 171 a.C., durante o governo de Antíoco $\mathrm{IV}^{27}$. Ora, precisamente este rei procurou aplicar na Palestina um muito severo programa de helenização e não há notícias de que mostrasse especial liberalidade para com os Judeus fora desse território. Além disso, parece que Josefo não terá completa razão: embora com um estatuto diferente do de outros não-cidadãos, os Judeus, como grupo, não terão gozado de direitos plenos de cidadania nas $\pi$ ó $\lambda \varepsilon ı \varsigma$ helenísticas, que, de resto, lhes teriam exigido a participação nas liturgias políticas, onde festivais e serviços religiosos assumiam papel determinante. De facto, são problemáticas as informações de Josefo acerca da cidadania de Judeus em Antioquia, Sardes e na Jónia (Jos. AJ 12.121, 125-127, 16.27-60)28. É também duvidoso o caso de Alexandria (cf. Philo, Flaccus 53, Jos. AJ 12.1, 19.5, 281, c. Apion. 2.38-39). V. Tcherikover defendeu que aqui os Judeus estariam organizados numa corporação cívica

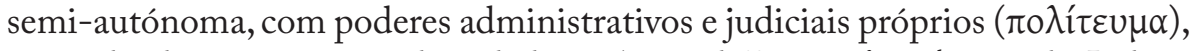
gozando de uma espécie de cidadania limitada ${ }^{29}$; e По $\lambda \imath \tau \varepsilon u ́ \mu \alpha \tau \alpha$ de Judeus como o de Alexandria parecem, de facto, ter existido em Berenice na Cirenaica, em Selêucida-sobre-o-Tigre e em Corinto $^{30}$. E se roגítns nos Actos não

${ }^{26}$ Exemplos de resgates em Hengel, 1971, 173-174.

${ }^{27}$ Ramsay, 1908, 139, aventou a possibilidade de que a família de Paulo habitasse em Tarso antes de 171 a.C., data proposta para a concessão da cidadania aos Judeus da cidade (p. 185). Cf. também Böhlig, 1913, 128-129.

${ }^{28}$ Tcherikover, 1961,309-332; Applebaum, 1974a,420-463; Applebaum,1974b; Applebaum, 1974c, 701-727; Smallwood, 1976, 201-255; Rabello, 1980 (esp. 691-695, 719-725); Kasher, 1985; e, recentemente, Gruen, 2002.

${ }^{29}$ Tcherikover, 1961, 313-317; Jones, 1971², 159-162, 172-174; Lentz, 1993, 39-42.

${ }^{30}$ Jos. AJ. 18.372.378. Cf. Lentz, 1993, 40. 


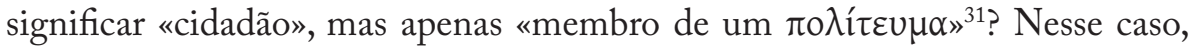
Paulo pode não ter sido cidadão, mas apenas membro da congregação semiautónoma de Judeus de Tarso. Aí chegados, alforriados ou emigrados, os pais de Paulo poderiam ter sido admitidos nesta organização de Judeus de Tarso, a ter esta existido. Ora, é precisamente este o problema: a ausência de fontes que

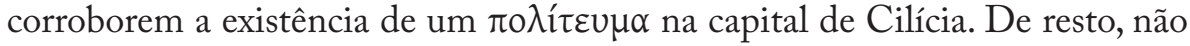
fora Paulo, nenhum indício teríamos da existência de uma comunidade judaica de cidadãos de Tarso, nem plenos nem «semi-autónomos» ${ }^{32}$.

É claro que Paulo pode também ter sido cidadão pleno de Tarso ${ }^{33}$; um sobrinho de Fílon foi de facto cidadão de Alexandria (Jos. AJ 20.100, BJ 2.309, 492, 4.616, Tac. ann. 15.28.4) e um certo Antíoco foi-o de Antioquia (Jos. c. Apion. 2.38-39). No final do séc. III d.C., os Judeus de Sardes tinham a sua sinagoga no edifício termal da cidade $^{34}$, e, na mesma altura, em Acmoneia na Frígia, pelo menos dois Judeus desempenharam vários cargos políticos ${ }^{35}$ : contudo, nestes dois casos, estamos já mais de duzentos anos depois de Paulo e pelo menos cinquenta anos depois de Caracala. Há também exemplos de apóstatas como o

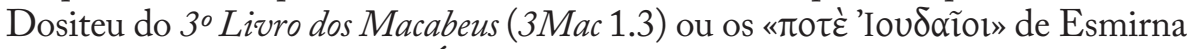
$(C I G 3148=I G R 4.1431)^{36}$. É, pois, admissível que, atestando terem as tais 500 dracmas, Paulo, o pai ou um antepassado possam por exemplo ter comprado a cidadania de Tarso, como sucedia em Atenas (antes da proibição imposta por

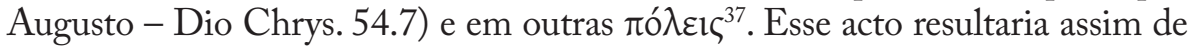
uma vontade consciente em participar na vida política da cidade.

Seria esta cidadania compatível com a história de Jerónimo/Fócio? Pelo menos, creio, não seria incompatível: seria possível que os pais de Paulo se tivessem instalado em Tarso e tivessem depois comprado a cidadania. Terá T. Zahn razão, e indicará a expressão fuisse translatos do Comentário a Filémon que Paulo e os pais teriam sido levados como escravos para Tarso? A ser assim, no entanto, Paulo seria então um liberto, condição de que nenhuma das fontes próximas do Apóstolo permite suspeitar. Pelo contrário, se Paulo tiver sido um liberto, a informação dos Actos, para quem ele já teria nascido cidadão romano, estará errada.

${ }^{31}$ Пoגírns aparece apenas quatro vezes no Novo Testamento (Lc. 15.15, 19.19, Act. 21.39, Heb. 8.11). Apenas a ocorrência nos Actos dos Apóstolos supõe uma semântica política.

32 Tajra, 1989, 79-80 vai mais longe e defende que ro $\lambda$ ítns «most likely refers to Paul's membership in the resident Jewish community at Tarsus rather than to any citizenship in the

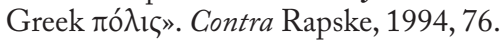

${ }^{33} \mathrm{Nem}$ os Macabeus/Hasmoneus foram capazes de porfiar na sua rejeição do Helenismo. Cf. Goldstein, 1981, 64-87, 318-326; Kraabel, 1982; Levine, 1999; Gruen, 2003.

${ }^{34}$ Kraabel, Seager, 1983; e Trebilco, 1991, 37-57.

${ }^{35}$ Sobre Acmoneia, veja-se a síntese de Trebilco, 1991, 58-84.

${ }^{36}$ Kraabel, 1982, 455.

${ }^{37}$ Cf. Robert, 1940; Stern, 1987; Hengel, 1991, 100-101, n. 55. 
De facto, o Paulo dos Actos não teria sido apenas cidadão de Tarso, mas também cidadão de Roma (Act. 16.37-38, 22.25-29, 23.27, 25.10-12). Não é demasiado estranho: era, de facto, possível que um homem fosse cidadão da sua cidade natal e, ao mesmo tempo, cidadão de Roma ${ }^{38}$ - a partir de Augusto começara a surgir esse fenómeno no Oriente, tornando-se comum na época de Cláudio. $\mathrm{O}$ acesso à cidadania romana também não era limitado por um rendimento mínimo. Por fim, na época de Paulo, o cidadão romano já não tinha especiais obrigações políticas e religiosas: já não as tinha dentro da Urbe, onde por exemplo os comícios tinham perdida importância com o advento do Principado, muito menos as tinha fora de Roma. Era até mais fácil que um Judeu, mesmo sem grandes recursos ou estatuto, fosse cidadão romano do que cidadão de uma $\pi$ ó $\lambda \varsigma^{39}$ : Silas/Silvano, companheiro de Paulo, é tido também como cidadão romano (Act. 16.37); em Jerusalém, havia Judeus que eram cavaleiros romanos (Jos. AJ 14.228, 232, 234, 237, 240, 19.52, BJ 2.308). Admito que é estranho que Paulo, se de facto era cidadão romano, tenha sido flagelado três vezes (2Cor. 11.25. Cf. 2Cor. 6.5, 11.23-24). No entanto, havia certamente distância entre a letra da lei e a sua aplicação: por exemplo, conhecem-se cidadãos romanos que, apesar disso, foram crucificados ${ }^{40}$. De resto, a parte final dos Actos apoia-se nos direitos garantidos a Paulo pela sua cidadania romana. Por isso, não é de crer que ela seja uma criação de Lucas, sob pena de poder vir a abalar a credibilidade do seu texto: se Paulo não tivesse sido cidadão romano, seria recurso infantil relacionar a sua ida a Roma e a consequente expansão do Cristianismo com uma inventada prouocatio ad imperium.

O problema não reside, pois, na cidadania de Paulo, que é verosímil, mas na sua origem. Um escravo de cidadão romano, quando alforriado, adquiria normalmente a cidadania. Vários Judeus conseguiram tornar-se cidadãos deste

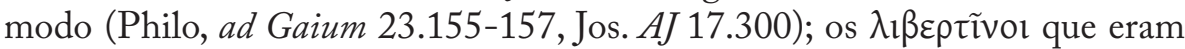
membros de uma sinagoga em Jerusalém deviam provavelmente ser também cidadãos romanos (Act. 6.9). Era ainda possível que a cidadania fosse concedida como recompensa por determinada acção em favor de Roma (Cic. Balb. 8.19, Strab. 5.1.6): o idumeu Antípatro e o filho, o célebre Herodes-o-Grande, eram cidadãos romanos (Jos. AJ 14.137, BJ 1.194, 2.308); contudo, há também que admiti-lo, a família de Paulo não era comparável com a de Herodes; e, antes de Cláudio, esta atribuição da cidadania romana no Mediterrâneo oriental parece

${ }^{38}$ Díon Crisóstomo era cidadão de Apameia, Nicomédia, Niceia e outras ró $\lambda \varepsilon ı \varsigma$ da Ásia Menor (cf. 38, 39, 41). Veja-se Sherwin-White, 1972; Jones, 1971², 172.

${ }^{39}$ Ver Gauthier, 1974, 207-215.

${ }^{40}$ Jones, 1968; Hengel, 1977. 
ter sido rara: para que um antepassado de Paulo tivesse conseguido a cidadania romana deste modo teria, pois, de se ter evidenciado no apoio a Roma em algum contexto muito excepcional. Era ainda possível comprar a cidadania (como o

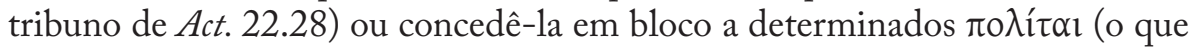
não aconteceu em Tarso). Era ainda possível que um peregrinus que tivesse servido como auxiliar nas legiões romanas adquirisse depois a cidadania; contudo, em 49 a.C. Lêntulo (Jos. AJ 14.228) e em 43 a.C. Dolabela (Jos. AJ 14.226) tinham isentado do serviço militar os Judeus ${ }^{41}$.

Ora, o Paulo lucano assegura que «nascera cidadão romano». Aceitar esta afirmação como certa significa que Paulo não pode ter sido levado como escravo para Tarso, com os pais, na sequência de uma revolta contra Roma. Além disso, aceitar que Paulo nasceu cidadão romano implica que esse privilégio tenha sido concedido pelo menos ao seu pai, antes ainda do nascimento do Apóstolo, em circunstâncias que desconhecemos; é assim possível que o pai de Paulo fosse já cidadão romano na Palestina e, na sequência de distúrbios políticos, tivesse emigrado livremente para uma cidade mais pacífica e próspera; é possível que o pai de Paulo pudesse ter sido levado para Tarso como escravo de algum cidadão romano, na sequência de uma das revoltas da Palestina, como parece supor Jerónimo, tendo sido libertado e adquirido a cidadania, ainda antes de Paulo ter nascido; é também possível que o pai de Paulo, ou algum dos seus antepassados, tenha comprado a cidadania, tal como o tribuno romano referido nos Actos, o que deve ter acontecido muito raramente antes do início da era cristã.

Há um pormenor que parece confirmar o elevado estatuto social de Paulo: a sua boa formação retórica e cultural. Sobre a educação de Paulo já tudo se disse e o seu contrário. Contudo, têm-se recentemente evidenciado os que defendem a sua sólida formação retórica ${ }^{42}$. Não é propósito deste texto analisar os argumentos em que vários autores se têm baseado para mostrar a qualidade retórica das Cartas (mais do que dos discursos em Actos, que, em rigor, não são da pena de Paulo, mas de Lucas). É facto que em nenhuma das Cartas Paulo mostra conhecer os auctores com que se estudava Grego, usados pela própria disciplina retórica como fonte de exempla e de emulação ${ }^{43}$. Contudo, a familiaridade de Paulo com as técnicas retóricas e os topoi argumentativos e culturais helenísticos são verificáveis: ele teve

\footnotetext{
${ }^{41}$ Applebaum, 1974a, 429-432, 459. Vejam-se também Smallwood, 1976, 127; e Rabello, 1980, 692 .

42 A bibliografia é infinita. Para um estado da questão, veja-se o já antigo, mas útil, Howell, 1964, 7-29; Fairweather, 1994; Litfin, 1994, 137-140; Martin, 1995, 38-68; Stamps, 1995. 15.33 .

${ }_{43}$ Apesar disso Menandro, Monostichoi 88 (ed. S. Jaekel), por exemplo, é citado em 1Cor
} 
certamente formação retórica em algum lado. Onde? O próprio não no-lo diz nas Cartas. Com base nos Actos, onde nunca se fala sobre uma formação «retórica», pelo menos dois locais surgem como possíveis: Tarso e Jerusalém. Nunca o norte da Galileia.

É verdade que a Jerusalém do século I não era propriamente um grande centro de cultura helenística ${ }^{44}$. Contudo, metade das epígrafes aí encontradas são em Grego, 7\% são bilingues ${ }^{45}$ e, como Sevenster mostrou, muitas delas nem sequer se referem a Judeus da diáspora ou a gentios, mas a Hebreus da Palestina ${ }^{46}$. As epígrafes testemunham, pois, razoável literacia em Grego, talvez possível de adquirir em Jerusalém em escolas que ensinassem Grego com base nos Septuaginta e não em Homero ${ }^{47}$. Estas escolas não deviam ser frequentadas apenas por imigrantes da diáspora e estrangeiros, mas também por crianças locais, apesar da falta de fontes que no-lo confirmem. De qualquer modo, há pelo menos três $\delta_{1} \delta$ ó $\sigma \kappa \alpha \lambda$ ol a aparecer nas epígrafes da época $(C I J 1266,1268)$; e, em Jerusalém, já em 175 a.C. fora fundado o primeiro gymnasium e instituída a efebia (1Mac. 1.14, 2Mac. 4.9-14). Aí, no séc. I, circulavam indivíduos que sabiam Grego, como o próprio Paulo, mas também talvez Silas, João Marcos, Barnabé ou Menasão, referidos no Novo Testamento, bem como Josefo, que conhecia muito bem Grego e literatura grega, embora não saibamos onde os terá aprendido ( $A J$ 20.263). O mesmo Josefo também garante ter havido homens de cultura grega na corte de Herodes (BJ 2.21). Os diáconos cristãos, entre os quais um prosélito chamado Nicolau (Act.6.5), dão conta das necessidades de uma comunidade grega ou helenizada em Jerusalém, onde havia também sinagogas de Judeus vindos de Cirene, Alexandria, Ásia e até da própria Cilícia (Act. 6.9). Repare-se, ainda, no carácter pujante da literatura pseudoepigráfica judaico-helenística. Um outro pormenor interessante é o facto de a única inscrição de uma sinagoga que chegou até nós estar escrita em Grego - o dedicatário chama-se Teodoto (nome grego), era liberto de Agripina minor, a mãe de Nero, e filho de um Vetteno (nome latino) ${ }^{48}$. Por fim, na Galileia, o Grego era certamente ainda mais utilizado do que em Jerusalém ${ }^{49}$ : eram helenísticas as cidades de Séforis, Tiberíades e talvez Betsaida, de onde eram alguns dos apóstolos de Jesus, como André, João, Filipe ou Bartolomeu, cujos nomes são gregos.

${ }^{44}$ De entre a extensa bibliografia, veja-se Lieberman, 1965²; Sevenster, 1968; Fitzmyer, 1970; Hengel, 1974, 58-65; Mussies, 1976; Hengel, 1991, 54-61; Porter, 1994; e, por fim, como excelentes sínteses, Heszer, 2001, 251-450, e Pitts, 2008.

${ }^{45}$ Sevenster, 1968, 143-148, e Rahmani, 1994.

${ }^{46}$ Sevenster, 1968, 146-149.

${ }^{47}$ Pitts, 2008, 36.

${ }^{48}$ Hachlili, 1979, 31-65.

${ }^{49}$ Veja-se a excelente síntese de Fitzmyer, 1970. 
Van Unnik analisou com particular pormenor Actos 22.3, precisamente

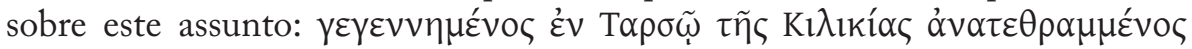

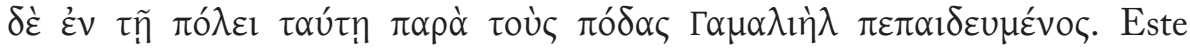
autor flamengo concluiu que a utilização dos particípios $\gamma \varepsilon \gamma \varepsilon v \nu \eta \mu \varepsilon ́ v o \varsigma$,

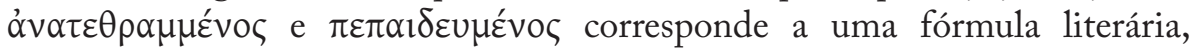
comum para referir o nascimento, a educação familiar e a instrução formal de um indivíduo. $\mathrm{O}$ problema reside na pontuação da frase. Van Unnik relaciona

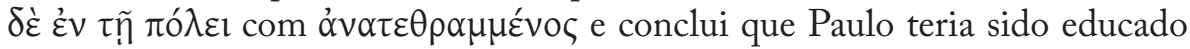
inteiramente em Jerusalém ${ }^{50}$. De resto, a Agripa II, o Paulo lucano assegura

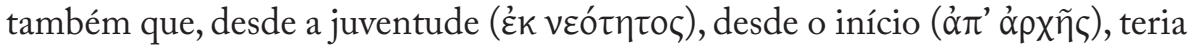
vivido entre o seu povo, em Jerusalém (Act. 26.4). Nas Cartas, diz-se Hebreu, [filho de] Hebreus (Fil. 3.5. Cf. 2Cor. 11.22), e, segundo Lucas, uma sua irmã viveria em Jerusalém (Act. 23.16), o que confirmaria a ligação da família à cidade.

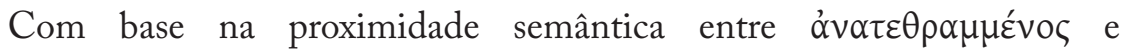
$\pi \varepsilon \pi \alpha 1 \delta \varepsilon v \mu \varepsilon v_{v} \circ \varsigma, A$. W. Pitts propôs recentemente uma alternativa: que $\delta \dot{\varepsilon} \varepsilon \dot{\varepsilon} v$ $\tau \tilde{n} \pi$ ó $\lambda \varepsilon l$ se ligasse antes a $\pi \varepsilon \pi \alpha l \delta \varepsilon v \mu \varepsilon ́ v o \zeta^{51}$. Seria assim de situar em Jerusalém apenas a instrução formal de Paulo e não também a sua educação em casa paterna, que teria decorrido em Tarso ${ }^{52}$. De qualquer modo, a ser assim, com base neste passo de Actos, ter-se-ia sempre de situar a educação superior de Paulo já em Jerusalém, «aos pés de Gamaliel», um dos reputados líderes fariseus, também ele da tribo de Benjamim. Paulo conhecia bem os Septuaginta ${ }^{53}$, talvez com correcções nos textos do $1^{\circ}$ Livro dos Reis, Job e Isaías ${ }^{54}$. Ora não seria necessário supor que Paulo conhecia os Septuaginta por ser um judeu da diáspora. Ele conheceria bem os Septuaginta quer a sua educação tenha começado em Tarso (onde apenas os Septuaginta seria usada) quer tenha sido feita em Jerusalém junto de Gamaliel. Infelizmente, isto não resolve o problema, uma vez que sabemos pouco sobre este tipo de ensino. Seria possível usar os Septuaginta em Jerusalém, mas, indo mais longe, seria possível ter junto de Gamaliel uma boa formação retórica, que no mundo helenístico durava 5-6 anos? Ou haveria em Jerusalém escolas de retórica de matriz helenística que Paulo pudesse ter frequentado? Estes problemas são difíceis de resolver - os

${ }^{50}$ Unnik, 1962. Mesma posição de Haenchen, 1971, 624-625; Conzelman, 1987, 186; Bruce, 1988rev, 415. A. Pinto Cardoso na Bíblia dos Capuchinhos segue esta interpretação: «nascido em Tarso na Cilícia, mas fui educado nesta cidade [Jerusalém] e instruído aos pés de Gamaliel».

${ }^{51}$ «Nascido em Tarso na Cilícia e educado; contudo, fui instruído nesta cidade aos pés de Gamaliel».

${ }^{52}$ Pitts, 2008, 27-33.

${ }^{53}$ Becker, 1989, 55: «Das Griechische ist für Paulus also nicht eine marginale Angleichung an seine Leser und Hören, sonden ein Aspekt seiner eigenen Bildung. Aus diesen Grund hat es Sinn, hier Schulbildung aus seiner Jugendzeit vorauszusetzen».

${ }^{54}$ Cf. Koch, 1986, 46-67. 
estudos mais recentes sobre a educação hebraica padecem de evidente falta de fontes e do perigo de se projectar sobre o séc. I o que sabemos sobre a escola dos Tanaítas a partir do séc. III ${ }^{55}$.

M.Haengel defendeu que havia de facto escolas de retórica em Jerusalém ${ }^{56}$ : afinal houvera na corte de Herodes homens versados na cultura grega (BJ 2.21) e por aí passara o retor Nicolau de Damasco (mas teriam sido aí professores?) ${ }^{57}$; Josefo tinha boa formação grega e quando o sumo-sacerdote e o Sinédrio quiseram acusar Paulo, pediram ajuda a um orador chamado Tértulo (Act. 24.1-9); contudo, desconhecemos a origem deste (o nome é latino), se vivia em Jerusalém ou se estava ligado a alguma escola ${ }^{58}$. De facto, nenhum destes argumentos mostra que Gamaliel ensinava retórica clássica; e, apesar de B. Z. Wacholder supor que os líderes fariseus haveriam de ter formação em Grego ${ }^{59}$ e de M. Hengel e C. Markschies afirmarem que «multiform "Hellenistic" influence on rabbis is manifest» ${ }^{60}$, não encontrei informações de que alguma vez um rabbi no séc. I tivesse frequentado escolas de retórica helenísticas nem que este tipo de escolas tivesse sequer existido em Jerusalém ${ }^{61}$. De resto, quando Herodes quis que os filhos tivessem uma educação clássica mandou-os para Roma ${ }^{62}$. Por isso, concordo com A. W. Pitts, que defende que em Jerusalém «opportunities for rhetorical education were probably not available» ${ }^{63}$.

Analise-se então a possibilidade de a formação retórica de Paulo ter sido feita fora de Jerusalém. Em Tarso? É muito possível, se aceitarmos a versão dos Actos sobre a origem de Paulo. Estrabão assegura que Tarso teria «todos os tipos

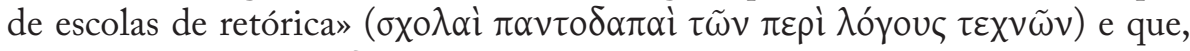

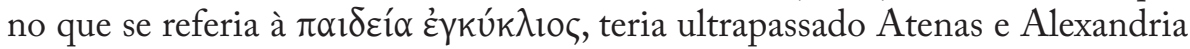
(14.5.13). Seria extraordinária coincidência o facto de Paulo mostrar boa formação retórica e, simultaneamente, Lucas dizê-lo originário de uma cidade onde funcionava uma das mais importantes escolas de retórica do tempo. Mesmo aceitando a história de Gíscala, ajustada com Tarso, isso confirmaria

${ }^{55}$ Daube, 1949, defendeu que «Rabbinic methods of interpretation derive from Hellenistic rhetoric» (240). Contudo, os textos em que se baseia são tardios, provenientes precisamente do ambiente dos Tanaítas: Gerhardson, 1998rev, 58, e Heszer, 2001, 46-50.

${ }^{56}$ Murphy-O’Connor, 1996, 46; Witherington, 1998, 97-98; Hock, 2003, esp. 215.

${ }^{57}$ Hengel, 1991, 59. Contra Wacholder, 1960, 30.

${ }^{58}$ Hengel, 1991, 59-60. Contra Pitts, 2008, 49-50.

${ }^{59}$ Wacholder, 1960, 48.

${ }^{60}$ Hengel, Markschies, 1989, 29. Contudo, a evidência apresentada por estes autores é tardia, posterior à queda do Templo, e quase sempre do século III d.C.

${ }^{61}$ Heszer, 2001, 106: «There is absolutely no evidence that a Palestinian rabbi mentioned in Palestinian rabbinic documents ever studied properly at a philosophical (or rhetorical) school». Contudo, as tardias fontes rabínicas contêm discussão sobre se um pai deveria ou não ensinar Grego ao filho - m. Sotah 9.14, t. Sotah 15.8. Cf. Heszer, 2001, 92.

${ }^{62}$ Como também argumenta Pitts, 2008, 47.

${ }^{63}$ Pitts, 2008, 50. 
também que, nesta cidade, os pais de Paulo disporiam de suficiente capacidade financeira para investir na comprovada formação retórica do seu filho. Mas esta interpretação significa também que a interpretação de van Unnik sobre a formação de Paulo está equivocada. O mesmo se passa com a versão dos Actos segundo a qual Paulo teria vivido «desde o início» em Jerusalém, já que boa parte da educação de Paulo teria de ter sido feita fora desta cidade.

Tudo isso, tant bien que mal, até poderia formar um quadro coerente... se Paulo não se apresentasse ainda como um zeloso fariseu.

São também os Actos dos Apóstolos a informar que Paulo teria estudado

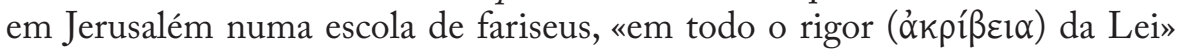

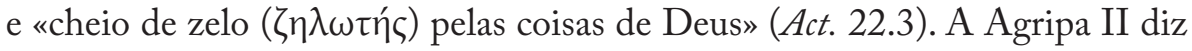
ter vivido como fariseu (Act.26.5). Ele próprio seria fariseu, «filho de fariseus» (Act. 23.6, 26.5). É seguro que os Actos dos Apóstolos foram escritos depois da queda de Jerusalém e em plena ascensão das escolas de fariseus, perante o colapso das estruturas sacerdotais dos saduceus. Ora, ser fariseu, quando os Actos foram escritos, era pertencer à única elite judaica da época. Sendo assim, o Paulo lucano reclama não pequena coisa: ele pertenceria à elite grega, romana e judaica. $\mathrm{O}$ próprio Paulo parece corroborar Lucas, quando afirma que seria fariseu «quanto à lei» (Fil. 3.5). Contudo, tal relação com o fariseísmo está ausente do curriculum apresentado em outras Cartas (em Rom.11.1 e 2Cor. 11.22. Cf. contudo Gal. 1.13-14). E, sobretudo, parece que Paulo não corrobora nas Cartas ter nascido numa família de fariseus (cf., contudo, Gal. 1.14).

Ora, mesmo havendo exemplos de fariseus a circular fora da Palestina, como Eleazer (Jos. AJ 20.38-41), Hilel, ou uns fariseus no Evangelho (Mat. 23.15), tanto quanto pude averiguar Paulo é o único exemplo de um fariseu que

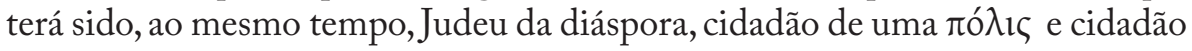
de Roma ${ }^{64}$; por outro lado, tendo em conta as características do fariseísmo do séc. I d.C. (e.g. interpretação e observância estritas da Lei mosaica, sobretudo quanto aos preceitos relacionados com a pureza ritual e aos interditos ligados às refeições ${ }^{65}$ ), parece-me difícil compatibilizá-las com a cidadania romana e

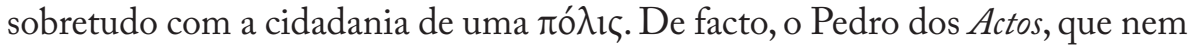
sequer era fariseu, terá dito a Cornélio que não seria «permitido a um Judeu ter contacto com um estrangeiro ou entrar em sua casa» (Act. 10.28), e, já no séc. IV, Epifânio de Salamina há-de dizer que os fariseus não se misturavam com o resto da sociedade (1.16).

\footnotetext{
${ }^{64}$ Cf. Jeremias, 1969 b, 252 n. $26:$ : it is doubtful if there were Pharisees in foreign parts». Cf. Lentz, 1993, 54.

${ }^{65}$ Sigo a síntese de Jeremias, 1969b, 246-267: «as the true Israel, Pharisees drew a hard line between themselves and the masses [...] who did not observe as they did the rules laid down by pharisaic scribes on tithes and purity». Cf. Jos. AJ 1.110.
} 
É certo que o fariseísmo do séc. I estava longe de ser uniforme, mas terá sido marcado pela disputa entre duas escolas, uma muito rigorista quanto ao cumprimento da Torah e defensora da libertação da Palestina, a de Shammai, e a outra, de maior compromisso com o helenismo e com a aceitação de prosélitos, a de $\mathrm{Hilel}^{66}$ : no início da guerra judaica, os partidários de ambas as tendências enfrentaram-se violentamente e serão recordados como tendo estado na origem de duas Toroth diferentes (Sota 14.9) ${ }^{67}$. Pelo menos os descendentes de Gamaliel parecem representar esta versão do fariseísmo ${ }^{68}$. Já Paulo surge como uma espécie de melting pot onde até as diferentes tendências do fariseísmo se parecem cruzar, oscilando entre o zelo pela lei e o uso da força por um lado, e a ligação ao mundo da Diáspora e posterior defesa do proselitismo por outro ${ }^{69}$. Além de Paulo, nenhum outro fariseu conhecido terá conseguido conjugar em si tantas influências contraditórias, entre Tarso, Roma, Jerusalém (e eventualmente Gíscala).

Ora, a admitir o fariseísmo dos pais de $\mathrm{Paulo}^{70}$, creio que dificilmente este seria compatível com a aquisição e/ou gozo da cidadania de Tarso e com um investimento na formação retórica do filho. E seria possível que esta formação retórica tivesse sido posterior a uma primeira educação, apenas realizada na órbita paterna? É que Van Unnik e Hengel recordam que ele não mostra conhecimento dos poetas gregos ${ }^{71}$. Contudo, esta hipótese também suscita problemas: francamente, não sei se será credível que, sem uma formação pelo menos elementar que lhe permitisse o contacto escolar com a cultura helenística do tempo, Paulo teria ainda assim os pré-requisitos necessários para frequentar depois uma escola helenística de retórica.

Pertinente hipótese foi avançada por J. Jeremias para quem a expressão «víò $\phi \alpha \rho ı \alpha$ í $\omega v »$ poderia ser metáfora de «aluno de fariseus», ou até sinónimo de fariseu ${ }^{72}$. Nesse caso, talvez Paulo não pertencesse a uma família de fariseus, mas ter-se-ia ele próprio tornado fariseu mais tarde na sua vida, por hipótese quando foi estudar para Jerusalém, já depois de ter efectuado a sua formação retórica em Tarso... De facto, ao contrário do que acontecia com a retórica, dificilmente se adquiria a formação de um fariseu sem ser na Palestina, e sobretudo em Jerusalém: de facto, não há notícia de uma escola de fariseus na diáspora, nem mesmo em Nisibis, na época de Jehuda ben Bathyra ${ }^{73}$. Por isso,

\footnotetext{
${ }^{66}$ Neusner, 1971, 208-211, 294-302, 338-340.

${ }^{67}$ Hengel, 1991, 45.

${ }^{68}$ Neusner, 1971, 341-376; Hengel, 1991, 27-29, 43-45: «it is by no means certain that he belonged to Hillel's school» (28).

${ }^{69}$ Jeremias, 1969a, 88-94. Cf. também Hengel, 1991, 46-49.

${ }^{70}$ Como Bruce, 1988rev, 427; Tajra, 1989, 95.

${ }^{71}$ Unnik, 1962, 52-58; Hengel, 1991, 34-39.

${ }^{72}$ Jeremias, 1969, 177, 252 n. 26. Cf. Lentz, 1993, 54; Rapske, 1994, 95-96.

${ }^{73}$ Hengel, 1991, 33.
} 


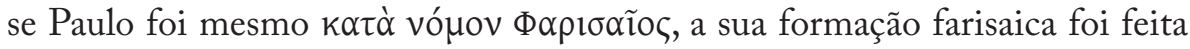
possivelmente em Jerusalém ${ }^{74}$, o que seria compatível com a notícia acerca do seu estudo junto de Gamaliel.

\section{Quem era Paulo?}

(i) Era Hebreu, filho de Hebreus; (ii) era provavelmente trilingue (sabia Grego, Aramaico e talvez Hebraico, pelo menos); (iii) era sem dúvida cidadão romano; (iv) detinha um particular estatuto social e uma ampla capacidade financeira, como os Actos dos Apóstolos testemunham; (v) tinha formação retórica apurada, compatível já com um ensino de terceiro nível. Muito provavelmente, esta formação não se fazia nem nas escolas rabínicas nem em Jerusalém; (vi) segundo Lucas, seria cidadão de Tarso, o que, no entanto, Paulo nas Cartas não confirma. A ser verdadeira, tal cidadania referia-se talvez ao estatuto especial de que várias comunidades da diáspora gozavam nas $\pi$ ó $\lambda \varepsilon ı \zeta$ onde se instalavam - essa é uma possibilidade que se coadunaria melhor com o facto de ele ser e ter permanecido Judeu; (vii) creio que Lucas e van Unnik não estão correctos ao supor que, mesmo tendo nascido em Tarso, Paulo se teria mudado ainda criança para Jerusalém. Pelo contrário, creio que é mais verosímil que Paulo tenha permanecido em Tarso tempo suficiente para ter estudado as técnicas retóricas clássicas, pelas quais a cidade era tão conhecida. Isso significa que Paulo deve ter permanecido em Tarso pelo menos até ao fim da adolescência, início da idade adulta; (viii) isso só aconteceu se a família de Paulo não tiver sido demasiado rigorista na aplicação da Torah: neste sentido, a família de Paulo não deve ter sido uma família de fariseus. Não creio, de resto, que a formação de Paulo em escolas helenísticas fosse compatível com o seu fariseísmo, se este tiver sido uma «herança» de família. Por isso, Paulo não era certamente filho de fariseus; (ix) é certo que o próprio Paulo refere uma vez nas Cartas a sua condição de fariseu e sobretudo o rigor com que teria vivido a Torah. Creio que a possibilidade mais plausível de isso ser realidade é situar a sua "conversão ao fariseísmo» já em Jerusalém. De facto, já depois dos seus estudos de retórica em Tarso, Paulo estabeleceu-se em Jerusalém onde pelo menos uma sua irmã já vivia ou veio a viver. Aí contactou com os fariseus e conheceu Gamaliel, certamente o mais prestigiado mestre fariseu. $\mathrm{Na}$ sua passagem pelo fariseísmo, Paulo revelou-se particularmente rigorista e zeloso na observância da Torah; até ao seu contacto com os primeiros Cristãos.

${ }^{74}$ Hengel, 1991, 27: «before the destruction of the Temple, Jerusalem was the only proper place for strict Jews [...] to study the Torah». 
Não é de agora que o problema da origem de Paulo é colocado. De facto, desde a Antiguidade existem dúvidas sobre esta origem e, pelo menos no século IV, circulava uma versão harmonizada da origem mais ortodoxa e canónica (Tarso) com uma outra sem apoio bíblico (Gíscala). Esta última coadunar-se-ia com a imagem de uma família rica de Hebreus que, apanhada na revolta de 4 a.C., poderia ter sido feita escrava e levada para Tarso ou simplesmente emigrado para a Cilícia. No primeiro caso, teria sido depois libertada (talvez por familiares endinheirados que teriam comprado a sua liberdade); na sequência da alforria, a família de Paulo poderia ter assim adquirido a cidadania romana. Ou então, a família de Paulo gozaria já da cidadania romana (o que não é muito provável), antes de ter simplesmente emigrado. É também possível que a família de Paulo possa ter enriquecido em Tarso e passado a

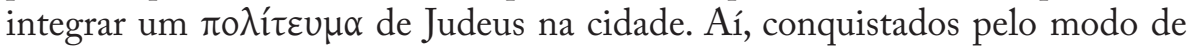
vida helenístico, os pais de Paulo ter-lhe-iam proporcionado uma educação clássica, iniciando-o no estudo da retórica.

Tenho de admitir, contudo, que a versão de Jerónimo/Fócio, apesar de harmonizável com a versão tradicional, não acrescenta nem é essencial para explicar nenhum dos problemas em torno da origem de Paulo. Ela chega mesmo a causar sérios problemas de interpretação às afirmações dos Actos dos Apóstolos, mais próximas dos acontecimentos, sobre a origem de Paulo, sobre o facto de ele ter nascido cidadão romano, e não explica a formação retórica do Apóstolo. Por isso, se a versão "Gíscala» não é essencial para esclarecer qualquer dos problemas em torno das origens de Paulo e até causa dificuldades ao próprio texto de Actos, percebe-se realmente mal por que razão teria sido inventada. Se fosse uma pura invenção, ter-se-ia talvez preferido indicar uma outra cidade, como sugeriu T. Zahn. E, por vezes, em ciência é mesmo assim. Não encontrei nenhuma boa razão nem para confirmar nem para infirmar a possibilidade de a família de Paulo ter estado de algum modo ligado a «Gíscala». A história de Gíscala é uma boa história e é historicamente verosímil; contudo, isso não a torna necessariamente verdadeira."

*Agradeço a amabilidade, as sugestões e o apoio bibliográfico dos Professores Manuel Alexandre Júnior e Nuno Simões Rodrigues. 


\title{
De Tarso na Cilícia à Roma Imperial. \\ A educação de Saulo
}

\author{
Abel N. Pena \\ Universidade de Lisboa \\ Centro de Estudos Clássicos da Universidade de Lisboa
}

As primitivas tradições hagiográficas e a própria iconografia paulina deixaram para a posteridade a imagem de um Paulo intelectual, um philomatheis «envolto numa toga como qualquer retor ou filósofo pagão, transportando os rolos de doutor e calçando sandálias como um homem de letras» ${ }^{1}$. O objectivo deste estudo é averiguar os fundamentos desta tradição, reconstituindo algumas das etapas da educação de Saulo, primeiro em Tarso, sua terra natal, depois em Atenas e Corinto, até à épica viagem que o leva à Roma Imperial.

\section{Tarso na Cilícia}

Em frente da costa da Ásia Menor desenha-se um quase triângulo de terra situado entre altas montanhas que se estendem para o sul: é a Cilícia. Não longe da costa mediterrânica, junto às margens do Cidno, situa-se Tarso, uma cidade «não sem renome» segundo a narrativa dos Actos 21,37-40. Em 67 a.C., a cidade foi anexada à recente Província romana da Cilícia, da qual se tornou capital administrativa. Em 51 a. C., teve como procônsul Marco Túlio Cícero. Depois da morte de César, Marco António deslocou-se à Cilícia para contemplar do alto do Tauro metade do seu império. Diz-se que Cleópatra foi ter com ele, transportada num barco de velas de púrpura e remos de prata ao longo do Cidno e ambos ali passaram uma parte do seu idílio. Ainda hoje se pode admirar a célebre «Porta de Cleópatra», um dos exlibris de Tarso. Depois da batalha de Áccio em 31 a.C., os habitantes de Tarso não esqueceram o prestígio que Marco António e Cleópatra tinham trazido à cidade. Segundo Estrabão, a reaç̧ão à morte dos dois amantes foi violenta, tendo havido revoltas e tumultos que se prolongaram até ao tempo de Tibérioº

Helenizada durante a longa dinastia dos Selêucidas, que mantinham como padrão cultural as tradições, a literatura e a língua gregas, bem como um sentimento de autonomia profundamente enraizado, Tarso era, no século I, um dos eixos do comércio internacional entre o mundo semita, o planalto anatólio e as cidades gregas viradas para o Egipto e a Europa. O solo era fértil e o Cidno constituía uma via fluvial altamente estratégica para o comércio do trigo e

\footnotetext{
${ }^{1}$ Baslez, 2008, 37.

${ }^{2}$ Estrabão 14.14; Apiano, BC 4.52.60.64; Filóstrato, $V A 1.12$.
} 
do linho provenientes do Egipto. Díon de Prusa (40-120 d.C.) refere que o artesanato têxtil florescia sumptuosamente em Tarso, assim como o comércio de perfumes e aromas de alta qualidade ${ }^{3}$. As cidades municipais helenizadas da Ásia Menor gozavam de grande autonomia administrativa e na época imperial constituem os principais centros da vida cultural grega. Promovia-se o liberalismo e reconhecia-se publicamente o poder de iniciativa dos cidadãos em todo os domínios bem como a prática do mecenato cultural, modelo de desenvolvimento cuja tradição remonta aos diádocos e epígonos de Alexandre Magno ${ }^{4}$. Esta demonstração pública (apodeixis) do poder dos cidadãos traduzia de certo modo a antiga tradição grega do agon, o espírito competitivo dos helenos, e está hoje bem documentada em papiros, pergaminhos, ostraca ou inscrições numerosas encontradas em várias regiões do antigo império de Alexandre (Wolff 1973, Pestman 1974). Seguindo esta política de helenização, a administração romana das províncias da Ásia dava uma importância crescente à educação. Nestas regiões qualquer cidade possuía escolas públicas. Mesmo nos mais pequenos centros rurais havia escolas primárias, como confirmam os decretos escolares de Mileto e Teos. O sistema de ensino era oneroso, mas gratuito. Ginásios e palestras, financiados por evergetas, tornaram-se os principais centros do ensino básico e secundário atraindo sofistas, filósofos e poetas em busca de auditório. Concebidas em modelos arquitectónicos adaptados ao ensino moderno, dotadas de exedras, pórticos e bibliotecas, estas instituições eram presididas pelo gymnasiarchos que tinha a responsabilidade de educar os paides ${ }^{5}$.

Pela sua posição estratégica, a cidade de Tarso era um dos grandes centros culturais do Oriente helenizado que concorria com outras cidades da Ásia Menor e do Oriente, Pérgamo, Teos, Cós ou mesmo Alexandria. O ensino procurava imitar a universidade de Atenas, mantendo em vigor o modelo de ensino superior ateniense. Estrabão elogia a qualidade da educação em Tarso que tinha a terceira melhor universidade da Grécia a seguir a Atenas e Alexandria. Todos os ramos das artes liberais figuravam em Tarso: poesia, retórica e filosofia, esta sobretudo com forte ascendente na tradição estóica local. O geógrafo alude a esses filósofos estóicos que deambulavam pelas ruas de Tarso, mas acentua que o meio intelectual, mais propenso à educação física que intelectual, carecia de solidez institucional, tornando-se pouco atractivo e os professores não sabiam cativar os melhores alunos ${ }^{6}$. Contudo, nomes sonantes das correntes filosóficas estão ligados a Tarso. Da sua escola estóica

\footnotetext{
${ }^{3}$ Discurso em Tarso (94), 21-22.

${ }^{4}$ Billows, 2008, 209-211.

5 Will, Mossé, Goukowsky, 1985, 508-513.

${ }^{6}$ Estrabão 14.5.13.
} 
é natural o filósofo Atenodoro, tutor de Augusto e mais tarde seu conselheiro. Segundo Filóstrato, Apolónio de Tiana, filósofo neopitagórico e itinerante, contemporâneo de Paulo, ensinou filosofia em Tarso, viajando depois até à Índia ${ }^{7}$. A tradição retórica de Tarso manteve-se viva pelo menos até ao século II, com Hermógenes de Tarso, continuador dos Progymnasmata de Téon, cujo modelo oratório radicava em Platão, Xenofonte, Isócrates e Demóstenes.

Segundo H.-I. Marrou, o modelo de educação era bastante parecido entre gregos e romanos ou melhor a educação romana não era senão uma adaptação da educação helenística que, por sua vez, diferia da escola grega clássica ${ }^{8}$. O sistema educativo helenístico prepara o indivíduo para ser um cidadão do mundo, implementando a sophrosyne, a moral da justa medida e do equilíbrio, conveniente e digna de um homem livre. $\mathrm{O}$ sábio helenístico não reflecte a polis, nem está preso à cidade, pensa no universal, é um cidadão essencialmente cosmopolita, Grego, Romano, Judeu ou Cristão. Estes preceitos simples cumprir-se-ão mais tarde no filo-helenismo apaixonado dos imperadores Adriano e Juliano num derradeiro esforço de síntese cultural que aliava a paideia grega às virtudes fundamentais romanas: fides, gravitas, constantia, fortitudo. $\mathrm{O}$ modelo de educação compreendia três etapas, três escolas e três mestres: aos sete anos a criança entra na escola primária e aprende o alfabeto de trás para frente e da frente para trás com o grammatistês correspondente ao magister ludi (mestre-escola) latino 9 ; aprende a utilizar o estilete e a pena, aprende aritmética e decora máximas morais de dois ou três versos. Aos doze anos, a secundária, a escola do ludus literarius ou grammaticus. A escola secundária segue as grandes reformas da escola helenística que consistia no estudo teórico da boa língua e na explicação dos poetas clássicos, especialmente os textos homéricos que a partir dos sofistas são uma enciclopédia de referência. Os estudos literários, a retórica e a língua assumem um papel central nesta educação. Quanto ao ensino da música pouco se sabe. Um decreto de Teos refere-se à contratação de «professores de letras» e a um citarista encarregado de ensinar ta mousika e a técnica de instrumentos musicais para fins recitativos e dança $\operatorname{coral}^{10} . \mathrm{Na}$ Cilícia, como noutras províncias helenizadas do império, um estrangeiro de boas famílias devia aprender a ler e a escrever o latim e o grego, este sobretudo, com a sua pronúncia ática e as regras de acentuação livres de toda a corruptela. Por sua vez, o modelo greco-romano implementava o ensino correcto (orthoépeia) da gramática ${ }^{11}$. Convém recordar que a crítica textual e os estudos gramaticais sofreram um incremento considerável na época helenística, nas

\footnotetext{
${ }^{7}$ Filóstrato, V.Ap. 4.19.

${ }^{8}$ Marrou, 1948, 63-64.

${ }^{9}$ Aristóteles, Pol. 8.2, 1337a, preconizava a educação compulsiva aos cinco anos.

${ }^{10}$ Will, Mossé, Goukowsky, 1985, 509.

${ }^{11}$ Veja-se Clark, 1966, 59ss.
} 
escolas de Alexandria e Pérgamo. No século II a.C., Dioniso Trácio compôs a sua Téchne grammatiké que se impôs como manual de referência das escolas. Ao dividir a gramática em seis partes, este discípulo de Aristarco contribuiu decisivamente para o ensino científico da gramática grega que se divulgou pelo mundo helenístico.

A partir dos quinze anos, quando o jovem (meikárion) atinge a adolescência, entra na escola do retor, sendo os estudos superiores prolongados até aos vinte anos quando o jovem atingia a categoria de neos. Entre os gregos atenienses, o neos compreendia uma idade entre os dezanove e os vinte anos, mas podia ir até mais tarde. A dificuldade está em saber se o termo neos tinha o mesmo significado entre as comunidades judaicas do século I que tradicionalmente consideravam maior de idade um rapaz de treze anos.

\section{Saulopedia ou a educação de Saulo}

Segundo os Actos, 21;22,3, Saulo era filho de um emigrante judeu fixado em Tarso. Teria deixado a Palestina por altura das guerras de Pompeio (60 a.C.) e viajado até à Cilícia através da Via Egnatia, estrada romana que ligava o Mar Egeu ao Adriático, a Ásia à Itália, passando pela cadeia rochosa do Tauro. A família de Saulo pertencia à tribo de Benjamim (Rom., $11,1)$, esse guerreiro mítico e vitorioso, fundador da realeza no séc. IX ${ }^{12}$. Era certamente de uma família de letrados, da seita dos fariseus, sujeita a estritas observâncias religiosas, mas intelectualmente receptiva e aberta, mesmo às correntes da filosofia estóica, tendo promovido uma elite de escribas e exegetas da bíblia em oposição ao tradicionalismo da casta sacerdotal ${ }^{13}$. Ao certo, porém, pouco se sabe da família de Saulo, nem do seu tão falado nome gentílico, e as controvérsias em torno de um suposto Iulius, um notável de Tarso membro da sua família, cujo privilégio de cidadania fora outorgado por César, Octávio Augusto e Tibério, devem ser lidas com circunspecção. O jovem Saulo terá recebido uma educação hebraica no meio familiar e na sinagoga, estudando a Bíblia e aprendendo o hebraico e talvez o aramaico, e frequenta simultaneamente a escola grega. Em Tarso como noutras capitais de província o percurso escolar grego ou romano não era muito diferente do judeu e a família ter-se-á socorrido dos serviços de um escravo culto como era costume e terá frequentado a escola do grammaticus graecus conduzido pelo paedadogus que na época helenística assumia cada vez mais o papel de

\footnotetext{
12 Sam 9,10; 1 Reis 9.

${ }^{13}$ Ao longo da época helenística, os fariseus destacaram-se por terem promovido uma elite de escribas e exegetas da bíblia. Oponham-se ao tradicionalismo radical da casta sacerdotal argumentando que qualquer homem dotado de inteligência era capaz de interpretar a Tradição e as Leis. Paulo diversas vezes fará eco desse conflito (1Cor. 14,13 e 28).
} 
educador, não apenas de escravo acompanhante. Não é improvável que tenha tido uma iniciação à música instrumental e por isso alude à lira, à cítara e à trombeta, embora segundo H.-I., Marrou, o aulós estivesse cada vez mais ausente das competições escolares desde o século II a.C., seguindo, aliás, o conselho de Aristóteles ${ }^{14}$. Por volta dos quinze anos, Saulo terá recebido a toga viril e um nome civil completo com os tria nomina. O Apóstolo nunca se refere aos tria nomina, designando-se sempre por Paulus, nome eventualmente latinizado do hebreu ou, por assimilação fonética, da forma helenizada Saoulos, mas que foi mal entendido pelas comunidades judaicas helenizadas. De qualquer modo a mudança de nome era uma prática onomástica corrente, um traço característico da influência helenística entre os Judeus da Diáspora e um sinal de interacção social, moral e cultural, como refere Fílon de Alexandria ao interpretar o significado da mudança de nome de grandes figuras bíblicas ${ }^{15}$. Por outro lado, o nome podia ser adoptado de uma figura ilustre, pois desde o fim da República até ao reinado de Cláudio era prática corrente um cidadão poder escolher o nome de um patrono influente ou de um mecenas que o fizesse singrar na administração, bastando para tal ser cidadão romano e exprimir-se em latim. Ora, o estatuto de cidadão romano era um privilégio apenas concedido a uma elite de quatro ou cinco milhões de romanos, mas Saulo parece ter adquirido consciência desse ideal arcaico e colectivo que desde o berço consagra o indivíduo ao Estado, ao proclamar diante do Governador da Judeia o seu estatuto de Civis Romanus Sum, um direito que fará prevalecer no Oriente e na Grécia e que o levará prisioneiro a Roma ${ }^{16}$.

Além da sólida formação clássica adquirida em Tarso nos seus primeiros anos, nomeadamente filosófica e retórica, Saulo era um poliglota. Embora a questão seja controversa por falta de documentação fidedigna, terá aprendido latim, mas seguramente falava e escrevia grego, essa língua comum ou koiné da época helenística. Domina o chamado code-switching, isto é, passa de um a outro registo linguístico ou, para utilizar uma expressão consagrada por Horácio,

${ }^{14}$ Marrou, 1948, 89ss.

${ }^{15}$ Fílon (Mut, 59-65). Em Rom, 16,7.15, Paulo refere-se a um irmão, chamado Rufo, apelido frequente no império romano, provável nome romanizado do hebraico «Reuben»/Ruben. Da mesma maneira fala de Andronico e de Júnia, nomes também helenizados e membros da sua família. Sobre o assunto, veja-se Rutgers, 1995, 170.

${ }^{16}$ Ser cidadão romano não era, só por si, prova de imunidade, até porque a prova de identidade era um dos problemas mais espinhosos que se punha a qualquer viajante na Antiguidade e disso temos vários exemplos nas narrativas hagiográficas e no romance grego cujo âmbito geográfico é a Ásia Menor e o Egipto helenizado. Só com Marco Aurélio é que as naturalizações começam a ser registadas gerando, no entanto, trocas de identidade e intermináveis confusões burocráticas. Cf. Gagé, 1964, 146-149. 
expressa-se em utraque lingua ${ }^{17}$. O facto é tanto mais relevante quanto se sabe que poucos gregos se interessavam por outras línguas e se aprendiam o latim era por questões administrativas ou atraídos pelo prestígio do direito romano ${ }^{18}$. O Apóstolo é considerado um bom aticista, pois não consta que durante a sua permanência em Atenas ou em Corinto alguém lhe chamasse a atenção para faltas de pronúncia. Resta saber se frequentou os estudos superiores em Tarso, estudando retórica e exercitando-se nos progymnasmata sobre Homero ou se terá frequentado alguma efebia na cidade?

No Período Helenístico, a retórica tinha por mentor o deus Hermes, guia desses exercícios nas escolas e ginásios. Comprava-o a utilização proverbial da expressão "por Hermes». De facto, no tempo de Paulo, quando alguém dizia «Hermes» significava dizer "discurso», e disso temos testemunho nos Actos, 14,11 e mais tarde em santo Agostinho ${ }^{19}$. Depois do seu discurso em Listra, os Licónios, no seu dialecto local, chamaram a Paulo «Hermes», não só devido à eloquência das suas palavras mas devido à forma como construiu e «conduziu o discurso». Os seus dotes oratórios e o tom retórico das suas palavras surpreendem igualmente os Atenienses e os Coríntios com alusões à filosofia de Platão, a Epiménides, um poeta cretense do séc. IV, e ao deus imortal de Cleanto $(\mathrm{I}, 16)$, esse filósofo estóico que nos legou um dos mais belos hinos a Zeus, do qual se inspirará Epicteto ${ }^{20}$. É bem provável que as diversas epicleses deste hino, em particular a fórmula de que «somos feitos à imagem de Deus», tenham tocado o coração de um jovem philomatheis como Saulo. Tendo atingido a categoria dos neoi, isto é, dos «Jovens», termo institucional adoptado pelos Judeus helenizados, mas ambíguo do ponto de vista legal e cívico $^{21}$, Saulo terá prosseguido os seus estudos superiores em Jerusalém na escola de Gamaliel, um dos mestres mais helenizados e liberais do seu tempo. Há quem sustente que o Apóstolo terá deixado a sua cidade natal aos catorze ou por volta dos vinte anos, insatisfeito com as poucas perspectivas intelectuais para um excelente aluno e estimulado pelo pai por motivos religiosos ${ }^{22}$. Seja como for, o Apóstolo reconhecerá mais tarde o valor do sistema educativo no

${ }^{17}$ Carmen 3.8.5; Sat. 1.10.20-30. Quintiliano (Inst. or., 1.1.12-14) aconselhará mesmo a aprender o grego antes do latim, com a condição dessa aprendizagem não diminuir ou eliminar a latinitas, a Romanitas e a Vrbanitas; Juvenal (15.110) cantará a universalidade da cultura grego-latina: Nunc totus Graias nostrasque habet orbis Athenas. Sobre o bilinguismo, cf. Kaimio, 1979; Nicolas, Leuven-Paris, 1996

${ }^{18}$ Entre os intelectuais gregos bilingues destacam-se entre outros Plutarco (Lusc. 1) e Díon Cássio 59.3.1.

${ }^{19}$ Civ. Dei 7.14: «sermo ipse dicitur esse Mercurius».

${ }^{20}$ Sobre Cleanto veja-se Chapot, Laurot, 2001, 181-183. Sobre a influência da filosofia estóica na pregação de Paulo, cf. Brenk, 2007, 402-440. Sobre a relação entre modelos filosóficos e retóricos e a pregação paulina, consulte-se Meeks, Fitzgerald, 2007.

${ }^{21}$ Modrzejewski, 2005, 346-348.

${ }^{22}$ Baslez, 2008, 47. 
qual foi formado, fazendo da paideia grega um modelo de educação cristã. Testemunhos da sua formação retórica e do seu talento oratório são, entre outros, o discurso em Éfeso e em Atenas, o discurso contra Cefas em Antioquia, os discursos de teor judiciário diante de Félix e Agripa e uma parte da carta aos Gálatas. Depois da partida para Jerusalém, manteve-se fiel aos ensinamentos da cultura clássica, uma vez que os Judeus da Diáspora conviviam nas mesmas sinagogas expressando-se em grego e em latim. Nesse campo de convergência cultural, Paulo estava bem apetrechado não só no domínio da cultura e das línguas como no campo das novas sensibilidades e descobertas helenísticas que vão da medicina à antropologia, passando pela recuperação de um fundo mitológico clássico reconhecido também como património comum ao mundo dos semitas ${ }^{23}$. Na escola de Gamaliel, familiariza-se cedo com a versão grega da Bíblia dos 70 levada a cabo em Alexandria no reinado de Ptolemeu Filadelfo II (283-246 a.C.), e cuja leitura inspirará uma série de conceitos terminológicos como "pecado», «descida», «herança divina», "passagem», assim como o uso de termos técnico-administrativos como «ecclesia», «episcopos»e outros ${ }^{24}$. O ensino, a aprendizagem e a difusão do grego helenístico, com a sua riqueza dialectal e variantes lexicais fizeram recuar os índices de iliteracia em todas as classes sociais do império, ao contrário de épocas anteriores ${ }^{25}$. O grego era falado não só pelos judeus helenizados como o Apóstolo Estêvão, mas também nas sinagogas espalhadas por todo o Mediterrâneo, como recorda Fílon de Alexandria que escreve para os seus compatriotas judeus imbuídos de cultura helenística ${ }^{26}$. Mas nem todos aceitavam esta aculturação sem aquela resistência ancestral que caracterizava certas comunidades da Diáspora. É sabido que o confronto civilizacional entre Hebreus e Judeus de língua grega já vinha de épocas anteriores ao séc. II a.C., e disso mesmo dá testemunho o autor dos Actos, 6, 1, quando se refere aos tôn Hellenistôn, àqueles que trocaram a língua materna pelo grego ou que adoptaram os hábitos e os costumes dos gregos. Embora a forma nominal hellenismós, derivada do verbo hellenizein, seja atribuída a Teofrasto, discípulo de Aristóteles, o primeiro a utilizá-la foi Tucídides $(2,68,5)$ aplicada a «bárbaros», isto é, gente cuja língua materna não era o grego, mas que tinha adoptado a língua grega em contacto com os gregos. Contudo, o alcance histórico-cultural do conceito assume dimensão universal

${ }^{23}$ Ramos, 2009, 27-28.

${ }^{24}$ É possível que nesses meios os estudantes tivessem acesso às versões do texto noutras línguas. O papiro de Oxirrinco publicado em 1978 (POxy. 46, 3285) fornece prova de que a colecção demótica da Torá fora traduzida para grego no século III a.C., no reino de Ptolemeu II.

${ }^{25}$ Como é sabido, a derrota militar em Queroneia em 338 a.C., levada a cabo por Filipe II da Macedónia e seu filho Alexandre, transformou-se numa vitória linguística de Atenas. Alexandre levou o ático até ao Oriente e utilizou-o como língua oficial do império, difundindo-o por todo o Mediterrâneo.

${ }^{26}$ Jaeger, 1991, 19. 
em plena época helenística com o judeu Jasão de Cirene ${ }^{27}$. Este eminente professor da escola helenística de Cirene, por volta do ano 130 a.C., refere-se à forma como os governantes gregos de Antioquia queriam impor pela força o helenismo às populações judaicas da Palestina. E o primeiro grande testemunho desse conflito civilizacional encontra-se precisamente no Segundo Livro dos Macabeus (2 Mac 4.13), um livro que se reporta à revolta dos judeus sob o reinado do selêucida Antíoco IV (175-164). Mas, independentemente da sua origem e autoria, é de assinalar a sensibilidade linguística e a relevância cultural do termo utilizado pelos Actos, mais do que doutrinal ou teológica, porque o autor dos Actos, sem dúvida influenciado pelos modelos clássicos, é também o primeiro a utilizar o agentivo hellenistês, derivado do mesmo verbo hellenizein, ou seja aquele que fala grego. No século XIX, o alemão Johann Gustav Droysen (1808-1884) retomou o tema na sua obra monumental, considerando o hellenismós um produto resultante de fusão das culturas que se seguiram às conquistas de Alexandre e estabelecendo os limites históricos e políticos da chamada época helenística que vai desde a morte de Alexandre Magno (323) à batalha de Áccio (31 a.C. $)^{28}$.

Paulo integra no seu curriculum alguns dos princípios estruturantes da paideia grega desde Homero: o espírito agonístico, a memória e o primado do logos. Partilha desse espírito agonístico que preconiza a igualdade das aptidões físicas e das faculdades intelectuais. Com efeito, nos escritos paulinos são frequentes as imagens do atleta em competição, o esforço, a corrida, a coroa do vencedor, o preço do combate. Naturalmente não estamos a ver em Paulo nem um sábio combatente, nem um filósofo hoplita, como o foi Sócrates, mas era certamente um atleta bem treinado no ginásio e na palestra como qualquer outro jovem em meio grego. Sabe-se que as corridas no estádio de Tarso eram frequentes e nas moedas da época encontra-se cunhada a figura de Perseu, o herói fundador da cidade, com o símbolo do corredor e asas nas sandálias. A participação dos Judeus da Ásia nos espectáculos do mundo pagão é um facto bem conhecido ${ }^{29}$. Em Mileto, por exemplo, os Judeus tinham lugares reservados no teatro e gozavam de vários outros privilégios. Segundo os Actos, 6,9, os Judeus «Libertos» da Ásia Menor, incluindo a Cilícia, gozavam de vários privilégios outorgados pela recente legislação romana que lhes concedia a plena integração na ordem romana.

A formação inicial do jovem estudante tinha por base o exercício da

${ }^{27}$ Em Cirene, vigorava a Paideia grega, com forte pendor retórico, e a educação física no seu conhecido ginásio.

${ }^{28}$ Droysen, 1952-53. Contudo, alguns aspectos da obra de Droysen, como o facto de considerar o helenismo uma simples fusão de culturas entre o Ocidente grego e o Oriente bárbaro, estão hoje claramente ultrapassados.

${ }^{29}$ Cf. Robert, 1964, 41-45. 
memória e da palavra, dizíamos acima. Saulo aprendeu de cor provérbios e fragmentos de poesia de Menandro (Thais 218), do poeta cretense Epiménides, de Arato (Fenómenos 5), um poeta natural da Cilícia como ele ${ }^{30}$, refere-se a Platão e ao estóico Cleanto. Quanto ao logos, ao mesmo tempo palavra, razão e inteligibilidade, fazia parte do património cultural dos gregos, era o elemento identitário que distinguia o Grego do Bárbaro como ele próprio afirma: «Ora, se eu não sei o valor da palavra, serei um Bárbaro para aquele que fala e aquele que fala será para mim um Bárbaro» ${ }^{31}$. Mas o logos está também associado à liberdade de palavra ou parrhesia, essa virtude da idade de ouro da democracia ateniense que designava o direito do cidadão à palavra. Nos Actos e no corpus paulinum, a parrhesia constituir-se-á em paradigma da pregação cristã (Actos 2,29), como se pode constatar em várias intervenções de Paulo, nomeadamente no discurso do Areópago (Actos 17,16ss), um discurso cinzelado como uma jóia de retórica consagrado ao agnostos theós, na controversa expressão de Norden ${ }^{32}$, discutida e liminarmente refutada por Jaeger ${ }^{33}$.

\section{De Atenas a Corinto}

Nascido e educado em Tarso, cidade que rivalizava com o modelo universitário ateniense, Paulo, como qualquer outro intelectual, não podia viajar por toda a Grécia sem passar por Atenas onde nunca houve uma comunidade de judeus organizada que o pudesse apoiar. Deixando as comunidades da Macedónia, chega a Atenas desembarcando no porto de Faleros. Era o primeiro grande encontro entre o Apóstolo e a intelectualidade pagã. Paulo sentiu instintivamente a cidade cosmopolita e a efervescência das suas ruas, frequentou escolas filosóficas de estóicos e epicuristas, participou em debates públicos, passeou pelas ruas cheias de gente e de estudantes apressados vindos de várias regiões do império, assistiu a rituais e a cerimónias religiosas marcadas pelo politeísmo e observou não sem irritação o esplendor das estátuas consagradas aos deuses pagãos e a grandeza dos monumentos ${ }^{34}$.

\footnotetext{
${ }^{30}$ Act. 17,28.

${ }^{31} 1$ Cor 14,11 .

${ }^{32}$ Norden, 1974.

${ }^{33}$ Jaeger, 1991, 25.
}

${ }^{34}$ Paulo sente-se vivamente irritado com estas manifestações de idolatria pagã, irritação que demonstra também na sua passagem por Éfeso. Segundo os Actos 19,26, um certo Demétrio, um «fabricante de ídolos» para os templos de Ártemis em Éfeso, denuncia publicamente e de forma pitoresca a pregação de Paulo que negava a natureza divina dos ídolos feitos pela mão do homem. A verdade é que alguns pagãos sentir-se-ão atraídos por esta negação dos ídolos que suportava a pregação de Paulo. Sabemos por Díon Cássio (Hist. Rom. 67.14.1-3) que Tito Flávio Clemente e sua mulher Flávia Domitília, ilustres cidadãos romanos, terão sido condenados por «ateísmo» no tempo do imperador Domiciano, não tanto por manifestarem a sua fé cristã, mas por simpatizarem com «certos costumes judeus». 
Mas a sua colheita em termos de conversão foi bem magra, o seu discurso no Areópago foi um fiasco, não passando de mais uma diatribe mirabolante de um estrangeiro bizarro e contestatário. $\mathrm{O}$ conselho do Areópago não era uma escola filosófica de estóicos e epicuristas, nem uma ágora ou palestra grega, era o principal órgão que na época imperial velava pela integridade do estado, julgava os processos de magia e as causas de impiedade. Na verdade, aos olhos do Areópago, Paulo não passava de mais um spermológos, um «fala-barato» a lançar sementes sobre os novos demónios (xénon daimonion), embora o seu discurso monoteísta não soasse a delito religioso, uma vez que em Atenas vigorava uma total liberdade de culto e de opinião e só os delitos contra a ordem pública e os deuses tutelares eram punidos por lei $i^{35}$. Apesar de tudo, o discurso do Areópago, com claras alusões à filosofia estóica do deus único, deixará marcas indeléveis na filosofia patrística, pois o cristianismo floresceu desde os seus primórdios em Atenas, um cristianismo à medida da cidade, feito de intelectuais e apologistas que parecem ter surgido da escola estóica ${ }^{36}$.

Reconhecido o fracasso da sua presença e mensagem naquela polis orgulhosa e conservadora, Paulo saiu da cidade acompanhado de alguns convertidos. Nunca mais voltará a Atenas. Dirige-se à opulenta Corinto onde permanece dezoito meses. O principal testemunho de Corinto no tempo de Paulo é Pausânias, o Periegeta, esse grande viajante da Grécia cujo testemunho nos deixa impresso na sua Descrição da Grécia I, 36, 3; 44, $10^{37}$. No tempo de Paulo, Corinto era uma grande metrópole helenística sob administração romana. Saqueada em 146 a.C. pelas legiões romanas, a cidade foi restaurada e repovoada a partir de 44 a.C., por César e Augusto e reconstruído o célebre santuário de Asclépio em torno do qual se reunia uma das maiores festas pagãs da cidade, os Jogos Ístmicos que tinham lugar por alturas da primavera. Nos dezoito meses que passou em Corinto, Paulo familiariza-se com a cidade e os seus costumes, fazendo-se valer da sua arte de «fazedor de tendas». Ali, ao ideal do sábio junta Paulo o retrato do artesão aplicado ao trabalho, resistindo a essa ideologia fisiocrática que se remonta aos heróis homéricos também é partilhada pela generalidade dos filósofos gregos e romanos, à excepção de Epicteto, o desprezo pelo trabalho manual tão ferozmente desqualificado por Cícero no $D e$ officiis I,42,150-151 ${ }^{38}$. No pleno exercício dessa arte ancestral talvez aprendida

${ }^{35}$ Baslez, 2008, 157.

${ }^{36}$ Os filósofos Eudoro (séc. I a.C.) e Amónio de Alexandria, contemporâneo de Paulo, partilhavam da ideia de um dualismo cósmico e da existência de um Deus-Uno. Mas os filósofos estóicos mais célebres contemporâneos de Paulo são Musónio Rufo, Séneca e Aneu Cornuto. Desenvolvimento em Ramelli, 2008, 153ss.

${ }^{37}$ Cf. Estrabão e Apuleio, Met. 10.19-35; 11.8-16

${ }^{38}$ Terá sido em ainda em Tarso ou em Damasco (Gal. 1,17-18) que aprendeu a arte de «fabricar tendas, tendeiro», profissão a que se refere umas vezes com orgulho em auxílio da sua subsistência, outras com alguma «amargura». Como Judeu fiel à tradição dos seus antepassados 
em Tarso, encontramo-lo a trabalhar em Cencres e no mercado de Corinto, sob a tutela de Febo, um patrão (prostatos) influente no grande porto de Cencres, perto da cidade. Jerome-Murphy O'Connor reconstitui de forma pitoresca o ambiente de trabalho de Paulo no mercado recém-construído de Corinto ${ }^{39}$, concluindo que o seu ateliê se teria transformado numa igreja doméstica, não luxuosa, mas limpa, onde as pessoas vinham ouvir a sua palavra sentadas nas longas tiras de couro e pano espalhadas pelo chão. Entre esses ouvintes contam-se Priscila e Áquila, seus correligionários romanizados, naturais da Ásia Menor e expulsos de Roma pelos éditos de Cláudio ${ }^{40}$. Corinto é uma cidade poliglota, o latim era a língua mais falada e não só pela administração, mas é em grego que Paulo se dirige aos Coríntios (1 Cor., 1,26). Os seus métodos de pregação reflectem a experiência e o fracasso de Atenas. É mais estratégico e parenético. Torna-se mais próximo e persuasivo. Fala mais ao coração do que à razão. Os seus discursos seguem não tanto os artifícios da retórica clássica quanto o modelo litúrgico e o aretológico, que vê no exercício cultual o poder de um deus e no sacrifício a virtude e o supremo destino do homem, mesmo sob a sua face mais trágica. E não terá sido por acaso, porque em Corinto vigoravam ainda alguns dos mais trágicos e perturbadores mitos gregos da Antiguidade: Medeia, Jasão, Sísifo, Édipo. É certo que o culto de Afrodite dava má reputação à cidade e Paulo confrontou-se com prostitutas e proxenetas que exerciam a sua actividade nos bairros do florescente porto de Cencres e nas ruas circundantes ao santuário de Afrodite.

A medicina evoluiu imenso na época helenística, graças sobretudo aos trabalhos de investigação e divulgação de Praxágoras, Herófilo e Erasístrato, eminentes anatomistas alexandrinos do século II a.C., para cuja divulgação em Roma muito contribuíram Asclepíades de Prusa e Dioscórides no séc. I d.C. Em princípio, todo o viajante medianamente culto da antiguidade possuía alguns rudimentos de medicina. Paulo não era excepção. Fosse por curiosidade intelectual ou para testar os seus conhecimentos médicos, Paulo visita o templo de Asclépio, pai da medicina, situado junto à fonte de Lerna, e terá ficado chocado com os numerosos e bizarros ex-voto em terra cozida que aí encontrou: cabeças, mãos, pés, braços, pernas, órgãos sexuais, olhos, orelhas. Não é de excluir que essas imagens tão perturbadoras da anatomia humana tenham sugerido a sua teologia do corpo (soma) (1Cor., 12,12-31), ou melhor,

pensa e age como Judeu entre os Judeus, como grego age e pensa como os gregos. A actividade artesanal aproxima e une naturalmente as populações. Por diversas vezes, Paulo dá provas dessa synergia, esse ideal corporativista dos mercadores de Tarso que contactam com mercadores helenizados de púrpura em Filipos, tecelões em Corinto, mercadores de lã em Éfeso (Actos $16,14 ; 18,3)$.

${ }^{39}$ Murphy-O'Connor, 2002.

${ }^{40}$ Provavelmente no nono ano do reinado de Cláudio entre 49 e 50. Cf. Orósio 7.6.15. 
a sua antropologia da salvação. É também em Corinto que Paulo introduz o tema da moria stou staurou (a loucura da cruz) apresentando-se ele próprio como um salós (um louco) talvez como ironia a essa retórica da antífrase tão enraizada nos meios intelectuais de Corinto (1 Cor., 4,10), que a todo o raciocínio opunham um senão, ou talvez porque o tema da mania fazia evocar nos seus auditores os grandes mitos da loucura, do absurdo e do desespero consubstanciados nas figuras de Medeia ou Sísífo. Mas o topos retórico de um Cristo crucificado, «loucura para os Gentios», ou a estrutura argumentativa da oração do louco (2 Cor.,11,1-12), como foi chamada, tanto na dispositio como na elocutio, não bastou para convencer os altivos e empedernidos Coríntios ${ }^{41}$.

\section{A escola da vida. Viagem e naufrágio. Roma}

A aprendizagem faz-se ao longo da vida, não só na escola. É o que acontece a Paulo, filho de um judeu da Diáspora, sempre em busca da sabedoria em qualquer lugar habitado. Paulo, ele próprio é um viajante infatigável, protótipo do viajante helenístico lançado num perpetumm mobile, percorrendo milhares e milhares de quilómetros. Vemo-lo enfrentar os perigos das longas viagens, sobreviver a quatro naufrágios e resistir aos abismos do mar nadando ininterruptamente um dia e uma noite ${ }^{42}$ ou evadindo-se de prisões de forma destemida e algo rocambolesca.

Ao tempo, as viagens por mar eram perigosas e não só de piratas que infestavam todo o Mediterrâneo mesmo depois da forte repressão de Pompeio. Referimo-nos ao naufrágio. O naufrágio está associado ao léxico básico dos périplos marítimos, pertence intrinsecamente à ideia de viagem por mar, viagem que é simultaneamente uma conquista e uma apropriação do espaço desconhecido e não-humano, e, como para Ulisses, o lugar da metamorfose e do homem-memória. Só no oikos ou na ecúmene conhecida e habitada se pode evitar o naufrágio. Pelo que sabemos por documentos e narrativas da época, podemos reconstituir o que seria uma dessas viagens a bordo de um pequeno navio, com duzentas e setenta e seis pessoas, no fim de Setembro, justamente quando se anunciavam as primeiras tempestades do equinócio e a navegação estava interdita pelas leis do Mare clausum. Segundo a tradição neo-testamentária (Actos, 28,11-12), depois da sua prisão na Judeia, o apóstolo embarca num navio em Cesareia que o levaria a Roma, seguindo as costas da Síria e da Ásia Menor, até Lesbos. Ele que estava habituado a uma visão

${ }^{41}$ Barret, 1973. Apesar do bom acolhimento que teve, Paulo acabará por ser condenado em Corinto. Entre aqueles que se opuseram à sua condenação encontrava-se o irmão de Séneca, Gálio, que era o primeiro ministro de Nero quando Paulo foi processado em Roma pela primeira vez. Sobre a eventual relação entre Séneca e Paulo, cf. Sordi, 2000,113-122.

42 Cor 11,24-26. 
estruturada do mundo, bastante limitada ao Mediterrâneo Oriental nas suas primeiras viagens, vê-se agora lançado num périplo desconhecido e sem retorno em direcção à Europa. A primeira grande escala é Sídon, pátria de Cadmo, irmão de Europa, esses heróis míticos e fundadores, cujas efígies circulavam orgulhosamente nas moedas dos Fenícios do século I d.C. Conhecida pelos numerosos templos dedicados a Astarte, Sídon era sobretudo famosa pelo seu limen, um porto seguro e bem apetrechado com duas entradas e enseadas bem protegidas contra ventos e marés e contra a pirataria costeira, cujas operações de saque e pilhagem (syla e androlepsia) constituíam a principal fonte de escravatura na Antiguidade.

A viagem iniciava-se com os votos de boa-viagem (euploia) e os rituais e preces dedicados aos theoi sotêres (deuses salvadores). $\mathrm{O}$ navio alexandrino onde Paulo embarcou depois de uma escala em Mira, na Lícia, tinha como emblema (parasemon) os Dióscuros, Castor e Pólux, símbolos da navegação, cujo culto era comum entre os navegadores da época greco-romana ${ }^{43}$. As condições em que viajavam os passageiros (epibatai) eram precárias. Os navios não dispunham de cabines para passageiros e estes deviam ocupar um espaço reduzido, limitado à ponte. Havia leis que proibiam comer peixes fritos ou fritá-los a bordo, prática supersticiosa que traduzia a incompatibilidade entre consumo dos produtos do mar e uma boa travessia ${ }^{44}$. A água potável era racionada e distribuída pela tripulação. Se bem que cidadão romano e tratado com humanidade (philanthropia) pelo centurião Iulius, o estatuto de prisioneiro de Paulo não lhe permitia ter privilégios especiais.

Era Novembro. O vento nordeste, o aquilão de inverno, temido por todos os navegadores, começa a soprar com intensidade. Contrariando os avisos experimentados de Paulo para aportar em Creta, no abrigado porto de Gortina, o piloto segue precipitadamente a sua rota contornando a ilha para evitar os ventos contrários que sopravam da costa asiática e o navio é apanhado por uma violenta tempestade. Durante treze dias, o barco anda à deriva pelo mar Jónio, evitando contudo a costa africana. Paulo assistiu às manobras de navegação para evitar os escolhos e a uma das operações mais perigosas e ruinosas, conhecida por embolé (iactus). $\mathrm{Na}$ eminência de naufrágio, o kybernetes estava autorizado a lançar ao mar uma parte ou a totalidade da carga para aliviar

${ }^{43} \mathrm{O}$ culto dos Dioscuros também está atestado no grande centro comercial de Alexandria, mas também havia outras divindades tutelares da navegação tais como Zeus Sóter e Atena Sotera, Asclépio e Dioniso, este não tanto como deus do vinho, mas como deus navegador. A epifania de Dioniso assinalava a abertura da época da navegação que, por sua vez, coincidia com a época em que frutificavam as vinhas. A constelação dos Dioscuros guiava os navegadores e sob a forma de fogo-de-santelmo anunciava o fim de uma tormenta

${ }^{44}$ Esta proibição manteve-se na famosa «lei marítima de Rodes». Cf. Rougé, 1975, 363 e Velissaropoulos, 1980, 74-77. 
o navio. Esta operação estava sujeita a uma série de procedimentos jurídicos muito rigorosos e daí a presença no navio do naucleros, o representante do armador que registava toda a operação ${ }^{45}$. Sabemos que os passageiros lançaram ao mar, primeiro a carga, depois a enxárcia e finalmente os próprios haveres. Perto da ilha de Malta, o navio acaba por naufragar. O primeiro impulso dos soldados foi lançar ao mar os prisioneiros, acto a que Paulo se opôs com a sua habitual e destemida argumentação. Paulo teve de nadar vigorosamente até chegar a terra firme na ilha de Malta (Actos, 27,11,44) e assim sobreviveu ao seu quarto e último naufrágio.

O autor dos Actos introduz aqui duas expressões de grande valor cultural, alusivas ao imaginário do mundo desconhecido, talvez numa vaga alusão ao mítico périplo de Ulisses: «barbaroi» e "philanthropia» (Actos 28,2). Os habitantes da ignota ilha de Malta não passam de bárbaros para aqueles marinheiros hostis, mas acolhem os náufragos segundo as leis sagradas da hospitalidade e facilmente se rendem aos conhecimentos médicos e aos poderes taumatúrgicos do herói dos Actos no bizarro episódio da víbora. Marie-Françoise Baslez ${ }^{46}$ refere que o episódio da víbora não tem paralelo no Novo Testamento. Tratar-se-ia de mais um fenómeno portentoso (mirabilia) atribuído ao Apóstolo ou de um ordálio local a que se sujeitavam os taumaturgos da época, uma espécie de prova de verediç̧ão destinada a testar os falsos e os verdadeiros profetas ${ }^{47}$. Nada disto, porém, era novidade para Paulo, dada a sua cultura de theîos anér, ou da sua experiência de taumaturgo e exorcista em Filipos, Listra ou Éfeso, cidade onde o misticismo e o racionalismo, a magia e a religião, Oriente e Ocidente confluem em torno do grande santuário de Ártemis ${ }^{48}$. Recorde-se que foi em Éfeso que Paulo conheceu Apolo, um jovem Alexandrino imbuído de cultura clássica, conhecedor de todas as técnicas oratórias gregas. Depois de uma breve escala no porto cosmopolita de Puzoles, no golfo de Nápoles, Paulo chega finalmente a Roma seguindo a Via Ápia, percorrendo mais de $20 \mathrm{~km}$ por dia.

${ }^{45}$ Se o navio conseguisse chegar a porto seguro, os danos causados aos proprietários das mercadorias perdidas deviam ser comparticipados por todos. Os encargos e a responsabilidade jurídica e civil que comportava tal operação são amplamente discutidos por Velissaropoulos, 1980, 319-328.

${ }^{46}$ Baslez, 2008, 97. O médico Celso (Sobre a Medicina 5.27.3c) conta que havia mágicos que introduziam as mãos na boca de serpentes venenosas que tinham sido previamente drogadas.

${ }^{47}$ A víbora foi objecto de curiosidade «científica» por parte de Aristóteles, HA 504b 34 e Plínio, $H N$ 9.39.76; 32.5.14, que desenvolvem uma estranha teoria sobre os amores da víbora e da moreia. Curiosidade que se tornou pela primeira vez tema literário com Aquiles Tácio, Leucipe e Clitofonte 1.18. Como símbolo da fidelidade e do amor conjugal, o tópico teve eco na retórica cristã, vindo registado no Emblematum Libellus (1531) de André Alciato e na raríssima edição de Baltasar Moreto em 1647.

${ }^{48}$ É a chamada "penetração pacífica» do Ocidente pelo Oriente, como lembra Cumont, 1987, 18. Cf. Danielou, 1961; Bultmann, 1969. 
A partir daqui, o que faz o homem é a sua relação com a lenda do herói fundador de comunidades ou do apóstolo viajante e infatigável que ainda anseia por conhecer os limites ocidentais do mundo, a Occidua Plaga. Assim nesta breve retrospectiva, o horizonte cultural do jovem Judeu de Tarso alargouse e enriqueceu-se até aos extremos do mundo conhecido. Entre familiares e amigos, entre filósofos e retores, entre viagens e naufrágios, entre pagãos e convertidos ou entre o Oriente e o Ocidente, Paulo herdou, assimilou e fundiu o cosmopolitismo do mundo helenístico com o ecumenismo tão característico do primitivo mundo cristão. 


\title{
Paulo no caminho de Damasco
}

\author{
Maria do Céu Fialho \\ Universidade de Coimbra \\ Centro de Estudos Clássicos e Humanisticos da Universidade de Coimbra
}

Da impressionante e inesperada conversão do prosélito rabi Saulo, saído do Templo de Jerusalém, rumo a Damasco, com a incumbência de, em nome da Lei, perseguir os que seguiam a Cristo como o novo e verdadeiro Templo, para chegar a Damasco frágil, silencioso e abatido, após a grande e misteriosa revelação no seu trajecto, muitas devem ter sido as narrativas que circularam ao tempo, tentando compreender, no próprio processo que configura uma narrativa, o mistério do acontecido. $\mathrm{O}$ médico evangelista Lucas, um dos que o conheceram, dá-nos nos Actos dos Apóstolos, nada menos que três versões do episódio do caminho de Damasco, o que atesta bem a importância que, para os Cristãos do tempo, assumiu este episódio ${ }^{1}$ e a conversão do grande perseguidor, transformado em grande evangelizador no seio de uma Igreja para a qual ele mesmo é elemento determinante na afirmação da vocação universal desta, transbordante do espaço original do Judaísmo.

No tríplice relato verificam-se aspectos coincidentes e aspectos divergentes (Act. 9,1-19; Act 22,4-21; Act. 26,8-18), o que deixa adivinhar a variedade de versões correntes, a par das alusões feitas pelo próprio Paulo ao seu passado e à sua conversão, não como aprendizagem, mas como revelação, nas Cartas².

É meu propósito deter-me no narrado e na narrativa, dentro das minhas competências hermenêuticas, que são as de filóloga de Línguas e Literaturas Clássicas, de modo algum as de teóloga biblista, encarado aquele como um motivo que estimula o discurso literário, como o discurso adequado, pela

${ }^{1}$ Vários, (1996). Uma leitura dos Actos dos Apóstolos. Lisboa: Difusora Bíblica, 43. Cf. E. Cothenet (1983), São Paulo no seu tempo, trad. Ir. M. L. Lavado, Lisboa: Difusora Bíblica, $1983,16$.

${ }^{2}$ E.g. Gl1,11-17: «Com efeito, faço-vos saber, irmãos, que o Evangelho por mim anunciado, não o conheci à maneira humana; pois eu não o recebi nem aprendi de homem algum, mas por uma revelação de Jesus Cristo. Ouvistes falar do meu procedimento outrora no judaísmo: com que excesso perseguia a Igreja de Deus e procurava devastá-la; e no judaísmo ultrapassava a muitos dos companheiros da minha idade, tão zeloso eu era das tradições dos meus pais. Mas, quando aprouve a Deus - que me escolheu desde o seio de minha mãe e me chamou pela sua graça - revelar o seu Filho em mim, para que o anuncie como Evangelho entre os gentios, não fui logo consultar criatura humana alguma, nem subi a Jerusalém para ir ter com os que se tornaram Apóstolos antes de mim. Parti, sim, para a Arábia e voltei outra vez a Damasco.», trad. port. de Bíblia Sagrada (2008). Vide Cothenet, 1991,14-16. Cf. 1Cor. 9,1 («Não vi Jesus Nosso Senhor?»); 1Cor 15,8-9: «Em último lugar, [Cristo] apareceu-me também a mim, como a um aborto. É que eu sou o menor dos apóstolos, nem sou digno de ser chamado Apóstolo, porque persegui a Igreja de Deus.» 
sua riqueza imagético-simbólica, ao inefável da experiência em causa ${ }^{3}$. Essa riqueza expressiva condensa, por sua vez, no contexto cultural e espiritual em que toma corpo, a simbiose de universos que se entrelaçaram e que produziram uma síntese cultural e expressiva imensamente rica, inesgotável em recursos do pensamento e da palavra - o mundo, afinal, a que Paulo pertencia, hebraico e grego de origem, romano por adopção formal; o mundo que é espaço da sua evangelização e que espera a sua acção como agente globalizador de uma fé.

O episódio em si inscreve-se na situação-arquétipo de estar a caminho, em que um acontecimento inesperado e excepcional altera ou o rumo tomado ou o próprio sentido existencial desse caminho a percorrer. Em Act. 9,3-9, Lucas relata que, já próximo de Damasco, Paulo «foi de súbito envolvido por uma luz

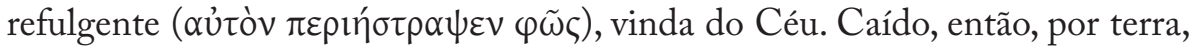
ouviu uma voz que lhe dizia: «Saulo, Saulo, porque me persegues?» Ao que ele disse: «Quem és Tu, Senhor?»E este respondeu: «Eu sou Jesus, a quem tu moves perseguição...». Mais adiante prossegue o narrador «os homens que o acompanhavam na jornada tinham estacado, estupefactos. Ouviam a voz, mas nada viam. Saulo ergueu-se do chão mas, ainda que os seus olhos estivessem abertos, nada via. Tomando-o pela mão, os seus companheiros conduziram-no a Damasco. E aí permaneceu três dias, sem ver, sem comer e sem beber».

A manifestação divina opera-se, pois, sob a forma de luz intensa que só a Paulo envolve - não aos companheiros que, todavia, ouvem, como ele, a voz. É nítida, nesta versão, a estigmatização de Paulo como o eleito, aquele a quem a luz envolve, ainda que a Voz a todos chegue. E o seu carácter excepcional traduz-se nas consequências da luz intensa que dele irradia, descida do Céu enquanto cai, prostrado, por terra, e se ergue, de olhos abertos, mas sem visão, os companheiros não caem, já que o cair, sinónimo de despojamento, a ele o atinge só, assim como a cegueira. Os companheiros não caídos conduzem o cego a Damasco. Este cego, porém, foi capaz de perceber que a relação entre a Voz e a sua pessoa era a do Kyrios e a do servo (toma assim mais sentido a queda que, mais do que queda é prostração, despojamento, reconhecimento). Percebe também que o seu destino se traçará em Damasco, para onde não hesita em prosseguir. E este cego, que a si se priva de outras fontes de alimento vital, preanunciando o valor penitencial do jejum, que tantas vezes referirá nas suas Cartas, é capaz de receber a visão de Ananias, que lhe imporá as mãos para lhe restituir a visão. Também Ananias é tocado por uma visão ( $\varepsilon$

\footnotetext{
${ }^{3}$ Não posso deixar de referir uma interessante e pertinente observação, registada em Vários, (1996). Uma leitura dos Actos dos Apóstolos. Lisboa: Difusora Bíblica, 9: a limitação de espaço de escrita, no papiro ou pergaminho, obriga o escritor antigo a rentabilizar a utilização do material pela sua própria estratégia de escrita sucinta, obedecendo a um plano de conjunto em que cada um dos elementos narrados possui um significado múltiplo e denso, o que aproxima o texto das características do texto literário.
} 
ópó $\mu \alpha \tau \imath, 9,10)$, em que o Senhor o incumbe da missão de restituir a vista ao «instrumento da Minha escolha para levar o Meu nome perante os gentios, os reis e os filhos de Israel» (9-15). Confirma-se, pois, o estatuto de eleito para a revelação e para a missão de Paulo.

Este cego a quem, na cegueira física, uma visão da Verdade se revelou, virá a aprofundar, pela graça, a capacidade de ser objecto da revelação como uma dádiva do Kyrios'.

Em Act. 22,6-21 confrontamo-nos com a reprodução de uma narrativa na primeira pessoa: no mesmo caminho, próximo de Damasco, o grupo é surpreendido, em pleno dia, com a luz radiosa que desce do Céu, envolve Paulo e o prostra por terra. A mesma Voz se faz ouvir, com a mesma pergunta «porque me persegues?» e a mesma pergunta de Paulo lhe responde: "Quem és Tu, Senhor (Kyrios)?» e a mesma resposta é recebida do Alto. Desta feita, porém, segundo as palavras reconstituídas de Paulo, os companheiros de jornada viram a luz mas não ouviram a Voz. Quanto a Paulo, fica suspenso das determinações do seu Kyrios: «Que hei-de fazer?». Idêntica é a cena da condução do novo cego pela mão, até Damasco, onde Ananias o procura com a missão de the restituir a vista. É Ananias quem explicita a peculiaridade do cego, escolhido por Deus para conhecer a sua vontade, para «ver o justo e ouvir as palavras da sua boca» e "ser testemunha, perante todos os homens, do que viste e ouviste» (Act. 22,14-15). Pouco depois, em Jerusalém, Paulo conhecerá, no templo, o

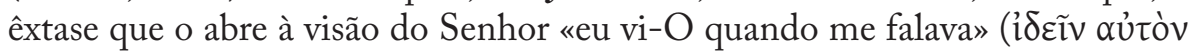

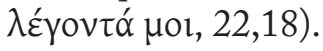

A reprodução da defesa de Paulo perante Agripa apresenta uma variante do relato bem mais explanada no que toca à intervenção divina (Act. 26,1219): «Assim, quando eu ia para Damasco, investido do poder e delegação dos sacerdotes, vi no caminho, em pleno dia, ó rei, uma luz vinda do céu, mais refulgente que o sol, e que me envolveu com o seu brilho, a mim e aos meus companheiros de jornada. Todos nós caímos por terra e eu ouvi uma voz que se me dirigia na língua hebraica: «Saulo, Saulo, porque me persegues? É duro para ti recalcitrar contra o aguilhão. Eu disse-lhe então: "Quem és tu, Senhor?” E o Senhor respondeu: "Eu sou Jesus, a quem tu persegues, mas vamos, erguete e firma-te nos teus pés, pois foi para isso que te apareci (lit. «que fui visto por ti»), para te constituir servidor e testemunha do que viste e do que te hei-de revelar, livrando-te do povo e dos gentios aos quais te vou enviar, a fim de lhes abrires os olhos e os fazeres passar das trevas à luz, e da sujeição de Satanás a Deus"».

O envolvimento colectivo pela luz parece insinuar, em meu entender, um envolvimento de todo o grupo na manifestação divina e, quiçá, na conversão.

\footnotetext{
${ }^{4}$ Lembre-se o tão comentado passo de 2 Cor. 12,1-8.
} 
Reforça esta ideia o gesto colectivo da queda ou prostração. Mantém-se, todavia, o estatuto excepcional de Paulo. É ele o único que, em terras estranhas, é chamado pelo seu nome. A narrativa ecoa a versão segundo a qual os companheiros não ouviram a voz, apenas Paulo, em língua hebraica. E esta a única versão que alude a este aspecto. Mas não esqueçamos que o texto está escrito em grego e que as palavras de Paulo estão reproduzidas em grego. É provável que se tivesse defendido perante o rei Agripa na língua helénica, a língua culta do tempo. Não é improvável que o tivesse feito em hebraico, tendo em conta o revivalismo patriótico de Agripa para reforço do seu próprio poder. Que a mensagem divina tivesse recorrido ao hebraico quer, sem dúvida, significar que, ainda que aquele homem fosse um cosmopolita, comunicador no contexto do cosmopolitismo, Jesus Cristo nasceu hebraico, os seus seguidores primeiros, que $\mathrm{S}$. Paulo perseguiu eram hebraicos, mas o novo Cristo fala também por Paulo, a Israel, tanto quanto ao mundo mais vasto. Paulo toma, assim, a missão de Estêvão - missão a que estava destinado desde o ventre de sua mãe, como afirma no passo acima citado da Carta aos Gálatas, para ser instrumento da sua universalização.

Paulo parece, assim, ter pressa de passar a sua mensagem e salta o episódio da sua própria cegueira. A pressuposta primeira abertura à Mensagem, na pergunta ao Senhor, é rasgada, oferecendo novos horizontes, nas primeiras palavras de Cristo: não vale a pena lutar contra a força da revelação. É, assim, Cristo quem lhe abre os olhos na ordem para se manter firme sobre os seus pés e partir a cumprir a missão. Não há tempo de fragilidades, nem de recolhimento e jejum, mas Paulo é aqui o Ananias, incumbido de abrir os olhos ao mundo, de libertar das trevas para a luz judeus e gentios. Paulo, partido de Jerusalém com uma missão - a de perseguidor - continua em missão, qual soldado, mas a missão muda radicalmente, com a revelação: ser apóstolo, servo (pela prostração), arauto (ao erguer-se) daquele a quem perseguiu. A força da visão perpassa o texto como uma vigorosa dominante, em consonância com o vigor dado à palavra, em função do seu ouvinte primitivo: Agripa.

Tidos em conta os aspectos divergentes dos relatos, é notória a convergência de outros aspectos. A revelação é apenas parcial para os companheiros de Paulo que, percebendo tratar-se de uma manifestação excepcional, não são por ela contemplados na totalidade. Paulo é o único a sê-lo, como eleito para uma missão. Luz e voz de chamamento fazem parte dela, bem como a queda.

$\mathrm{Na}$ primeira versão, os companheiros ouviram a voz mas nada viram. Paulo ficou cego. $\mathrm{Na}$ segunda versão, os companheiros viram a luz mas não ouviram a voz, não tendo tido noção de se encontrarem frente à manifestação da divindade. Paulo conhece a queda e fica também cego. Na terceira versão, todos são envolvidos pela luz que vem dos céus e caem por terra. Não fica especificado se ouviram ou não a voz que interpelava Saulo em hebraico. Nos 
dois primeiros relatos é empregue o verbo $\pi i ́ \pi \tau \omega$ para o gesto de cair, verbo que tanto pode indicar a queda involuntária como a voluntária, de quem se precipita sobre alguma coisa. No terceiro relato o verbo utilizado é $k \alpha \tau \alpha \pi i ́ \pi \tau \omega$, que significa, mais precisamente, deixar-se cair. Daí a enérgica ordem do Senhor, para que Paulo se erga e se mantenha a pé firme, qual soldado animado pelo espírito de uma nova missão.

Seria difícil, neste contexto, aludir a uma cegueira que fosse individual e não colectiva. A cegueira que Paulo refere é a daqueles junto de quem vai levar a luz da palavra revelada, a luz de Deus, para os resgatar das trevas. Esses são os cegos que passam a ver. $\mathrm{O}$ grande denominador comum é familiar às culturas antigas da bacia do Mediterrâneo oriental: a vista do deus é difícil de suportar. Sente-o, por exemplo, Abraão (Gen. 17,3), de rosto prostrado em terra, quando Javeh the aparece e lhe oferece a aliança que lhe proporcionará uma prolífera descendência, ou Moisés, perante a sarça ardente, mas sentemna também os Gregos no imaginário dos seus mitos. Tirésias, o adivinho, de acordo com algumas variantes do mito, fica cego ao avistar Atena desnuda, no banho ${ }^{5}$. Outras implicações, mais funestas que a cegueira, teve a visão de Ártemis no banho para Actéon. Teseu, por seu turno, em gesto de devoção exemplar, tapa os seus olhos, como Moisés, perante o espectáculo transcendente da misteriosa morte e heroização de Édipo, em Édipo em Colono (1650 sqq.).

Mas o Senhor revela-se a Paulo como aquele que é perseguido e que agora domina o perseguidor, esmagando-o momentaneamente com o peso da sua omnipotência, paradoxalmente manifestada pela luz excepcional, de origem divina, pela voz, vinda do alto, mas com a pergunta «porque me persegues?», como se a divindade ou o Cristo ressuscitado fossem passíveis de outra perseguição que não aquela efectuada sobre aqueles que seguem a nova fé. Nesse contexto, assume uma outra dimensão adicional a cegueira de Paulo, ainda que secundária e momentânea: a da punição pela sua hybris, que outra coisa não representou, segundo a perspectiva que Paulo convertido tantas vezes refere nas suas Cartas, em relação aos que se não deixam converter, senão a cegueira do espírito. Recordemos, a título de exemplo, 2 Coríntios 4,3-6:

Mas se ainda estiver encoberto o nosso Evangelho, está encoberto para aqueles que se perdem, aqueles cujas inteligências (noemata) descrentes o deus deste mundo cegou, de modo a impedir que neles brilhasse a luz do Evangelho, da glória de Cristo, que é imagem (eikon) de Deus...Deus, que disse que das trevas resplandecesse a luz, foi ele mesmo quem brilhou nos nossos corações, para que irradiássemos o conhecimento da glória de deus, que se reflecte na face de Cristo.

\footnotetext{
${ }^{5} \mathrm{O}$ mito, nas suas variantes, foi estudado por Brisson, 1976.
} 
A ablação punitiva de uma competência sensorial ou comunicativa, sobretudo da visão, pelos deuses, quer temporária quer definitivamente, na sequência de um acto de excesso, está abundantemente documentada desde textos antigos, de que recordo um exemplo bíblico, como a privação da fala, em Zacarias (Luc 1,18-19), que a recuperará aquando do nascimento de João e da escolha do seu nome ( $L u c$ 1,63-64), ou o exemplo egípcio do filho de Sesóstris, narrado por Heródoto (2.111), que, após arremessar uma lança ao Nilo, irado pelas cheias avassaladoras, ficou cego por dez anos, ou o do poeta Estesícoro, cego até repor a versão correcta da história de Helena no seu poema, ou algumas variantes do mito grego de Fineu (como a de Sófocles, Antígona 966 sqq.), ou de Tirésias, cego por Hera como castigo pelo veredicto que a desautorizava na polémica com Zeus. A cegueira deste último, por ser entendida por Zeus como injusta, foi compensada pela dádiva de uma outra visão - a do espírito, capaz de ver o que quem vê fisicamente não enxerga. Assim ocorre com Evénio, consoante relata Heródoto (9.93-94): punido pelos habitantes de Apolónia com a cegueira, é compensado por Apolo com o dom da clarividência profética.

Tocamos um dos mais férteis motivos simbólicos: o do cego que vê para além do que os outros enxergam, por inspiração dos deuses ou por reconhecimento feito sobre si mesmo. Nele se enquadra o imaginário à volta do poeta, o inspirado pelas Musas, cego e visionário, como Homero ou o mais conseguido dos aedos, Demódoco, na terra dos Feaces, e o do profeta. Lembro, de novo, o Tirésias grego. Édipo, finalmente, ao apresentar-se cego, assume a sua cegueira de espírito, o que, paradoxalmente, representa o ícone de um autoconhecimento que lhe abriu os olhos do espírito.

Ora é esta dimensão simbólica e paradoxal, a do cego que vê com os olhos do espírito, que prevalece nas duas primeiras narrativas do caminho de Damasco - e a de um cego que, subitamente, se vislumbra como cego de espírito até àquele momento. E que, como tal, fragilizado, se deixa guiar, pela mão, ele, o perseguidor recente, ele, os olhos e a aplicação da Lei, como fariseu de outrora. Esta estonteante constatação, a par da conversão ofuscante, só se conciliarão e conhecerão o apaziguamento na alma de Paulo mediante a imposição de mãos de Ananias, após as trevas do silêncio e do jejum.

O episódio de Ananias não pode deixar de me fazer evocar a panóplia de cegos do Novo Testamento que, tocados pela presença de Cristo e pela consciência de que Ele é o esperado Filho de David, clamam pela misericórdia que lhe dará a visão pela imposição de mãos ou pelo barro amassado com saliva. Eles já haviam, contudo, saído das trevas. A visão física representa apenas o pleno gozo da luz. Assim parece ocorrer com Paulo, a quem a cegueira física, simbólica ou não, pesou como um tempo de reflexão e mortificação - misto 
de punição transitória, de acordo com a tipologia de cegueiras, mas à maneira do Deus dos Cristãos, e de provação do homem justo, em que se converte com uma espécie de recolhimento penitente. A tipologia da provação sofrida pelo homem justo, incluindo a cegueira, como a de Tobite, não é grega mas hebraica.

$\mathrm{Na}$ terceira das versões, Paulo não tem tempo de cegar. Não se pode dar como cego, ainda que episodicamente, no momento da grande revelação, mas como aquele que foi tocado por uma revelação - viu e há que dar testemunho. Há que impor, bem sublinhada, a importância da sua missão perante um rei que favorece os seguidores da Lei antiga, como o foi Herodes Agripa. A transferência da cegueira de espírito é feita sobre aqueles que não conhecem o Evangelho ou o não aceitam, Judeus ou Gentios. Paulo é o grande viajante a quem a sua nova missão, como eleito, confere um novo sentido ao caminho e à sua vida, como o grande caminho de evangelização, ao serviço de um Kyrios que transcende os poderes temporais e que ele reconhece - aliás, que parece ter insinuado subtilmente a sua presença, até ao momento em que ela se torna esmagadora, impositiva, tornando vão qualquer esforço por ignorá-la.

Consonante com a perspectiva que nos deixam as três versões, de Paulo, o eleito para a missão, se encontram referências do próprio Paulo, como em Gálatas 1,15-17:

Mas, quando aprouve a Deus, que me escolheu desde o ventre materno e me chamou pela Sua graça para revelar o Seu Filho em mim, para que eu o anunciasse entre os gentios, não consultei a carne nem o sangue, nem regressei a Jerusalém ao encontro dos que foram apóstolos antes de mim.

Este passo atesta a urgência da missão, captada no contexto da terceira narrativa, bem como a vocação cosmopolita da evangelização de Paulo.

A síntese que assinalei, de elementos simbólicos de proveniências culturais e valências diversas à volta do motivo da cegueira e do paradoxo cegueira-visão, ao serviço do relato da conversão de Paulo, vale ainda mais por si, na polissemia que oferece, por representar, ela mesma, a linguagem de um contexto cultural complexo, variegado, de diálogos e fusões, correspondente ao universo a que o próprio Paulo pertenceu - judeu profundamente helenizado, a quem o estoicismo, de forte divulgação no mundo helenístico e já implantado em Roma, marcou. E essas marcas foram transferidas para a sua mensagem cristã, no que com esta têm de compatível. Não deixa de ser expressivo que a divindade estóica, que é Logos supremo, cuja natureza é fogo, encontre um paralelo na forma da descida do Espírito sobre os Apóstolos - línguas de fogo ou na manifestação aberta e determinante de Cristo ressuscitado a Paulo: a luz fulgurante que cega e que inunda Paulo, que lhe abre a inteligência e o obriga a viver de acordo com o equivalente cristão da Razão estóica - essa nova Razão 
que tudo ilumina e que lhe abre um novo sentido para o mundo, Cristo, a nova luz. Por isso a acção de Cristo não representou apenas um desvelamento, mas implicou uma reviravolta interior (Gálatas 1,12). A constantia do sábio estóico romano torna-se a perseverança apostólica de Paulo, que engloba a prudência, a justiça, a fortaleza e a temperança, pilares da sua uirtus. Por isso se há-de pôr firme, sobre os seus pés, na terceira versão, após receber a luz de Cristo, e prosseguir o caminho para que foi escolhido, até ao fim. Inundado por Cristo, reconhecera-o, por exemplo, em Gálatas 2,20:

Já não sou eu que vivo, é Cristo que vivo em mim; e a vida que agora vivo na carne, vivo-a na fé do Filho de Deus, que me amou e Se entrega a si mesmo por mim.

Essa é a diferença estóica entre os sophoi e os phauloi ou anoetoi, que resistem à mensagem, na sua cegueira. A percepção da ordem de toda a existência (ennoia) levá-lo-á a sublinhar o carácter transitório da existência terrena, cujo sentido último é contemplar a face divina, como recompensa da virtude e do testemunho, no Reino dos Céus. A versão estóica da existência como prisão da alma é convertida na linguagem hebraica da tenda, provisória (pois Cristo não aprisionou e a sua existência terrena teve sentido, como a de Paulo e dos seus ouvintes tem - um sentido individual e comunitário, que o estoicismo não valoriza), antes da chegada à casa do Pai (2 Cor 5,1-2). É, pois, introduzida no pensamento e no discurso a noção de "Plano divino», que esbate a eimarmene estóica (destino) e sublinha a pronoia (providência), decantada na noção de «eleição», «escolha», de matriz hebraica, presente no episódio do caminho de Damasco.

Paulo afirma em 2 Coríntios 4,10-11:

Trazemos sempre no nosso corpo os traços da morte de Jesus, para que também a vida de Jesus se manifeste no nosso corpo. Estando vivos, somos toda a hora entregues à morte por amor de Jesus, para que a vida de jesus se manifeste também na nossa carne mortal.

Isto é, a tenda que é a vida humana acolhe a presença do divino e a transitoriedade e finitude são encaradas, tal como o verbaliza o Sócrates platónico de Fédon, 81a, como uma espécie de melete thanatou, «exercitação da morte». Neste contexto refere Paulo a enigmática «leve e momentânea tribulação», qualquer que ela seja, como a provação bíblica a que se abre, à partida, sentido: a manifestação da mortalidade e do sacrifício são sinal da esperança para além deles. Paulo aprendeu-o no recolhimento de Damasco. Ultrapassada a Lei, que vincula e prende, pela Luz e pela Palavra que libertam, a esperança vem iluminar a tradição antiga, inclusivamente a de motivos 
bíblicos, e envolver vivências culturais, verbalizadas como visão do Absoluto, que, pertencendo aos "gentios», contêm já um germe de iluminação. A Lei foi mediadora, mas já o não é (Gál 3,19 sqq.). A promessa cumprida faz de Cristo o grande mediador que conduz ao Pai. O destino de Paulo e a competência da sua cultura, da sua linguagem, da sua capacidade comunicativa têm uma história que vem já do seio materno e da terra-mãe onde viu a luz: judeu pelo sangue, helenizado pelas raízes na terra e na cultura-síntese.

Por isso percebemos, quer nas três versões, dadas por Lucas do episódio do caminho de Damasco, quer nas palavras de Paulo, quando afirma, sob a forma de pergunta retórica, em 1 Cor 9,1: «Não sou eu um homem livre? Não sou eu um apóstolo? Não vi eu a Jesus, nosso Senhor?» que no relato de Lucas ou nas alusões de Paulo à conversão se combinam experiências de revelação diversas, hebraica e helénica, em que o primado da Palavra e do Olhar se associam. Paulo «viu» ao ficar cego e ouvir a Palavra. Como viu? Sendo chamado. Por isso é Cristo que nele vive, como Luz, destinada a ser difundida pela Palavra.

Com a fé se há-de aliar o exercício que o apóstolo, tal como o filósofo platónico, preconiza, salvaguardadas as diferenças (2 Cor 4,18):

Não contemplemos as coisas visíveis (ta blepomena), mas as invisíveis, porque as visíveis são passageiras, enquanto que as invisíveis são eternas.

Como «viu» então Paulo? Com os olhos do espírito, concepção tão arreigada na filosofia grega desde os Pressocráticos ${ }^{6}$, olhos iluminados pelo supremo Logos, que é Palavra e razão divinas, para contemplar, platónicamente, o supremo Bem e a Suprema Beleza que são o Deus cristão, em Cristo, Seu filho ressuscitado. A luz que brilhar em Paulo é a luz da verdade de que é portador, da esperança para além do espaço do visível finito, da palavra que difunde. Os três relatos, na convergência e divergência das suas versões, iluminados pelas alusões do próprio Paulo, nas suas cartas, permitem-nos mergulhar num texto cuja densidade polissémica se vai progressivamente impondo e nele perceber a própria densidade e complexidade do momento da conversão e no que nele se concentra de tradição reformulada e de futuro vocacional do Apóstolo de um Cristo globalizado.

A palavra de Paulo, a reforçar o vigor da tríplice versão da sua cegueira de revelação inundante e avassaladora, há-de cruzar-se com a tradição neoplatónica da «visão da alma» e contribuir para a formação de um conceito tão rico e estimulante, pela experiência que verbaliza, de illuminatio, nos

${ }^{6}$ Crítias 25.18, B DK, Epicarmo 12 B DK (nou"' oJrh'i kai; nou"' ajkouvei: talla kwfa; kai; tuflav), Emped. 17. 21 (su; novwi devrkeu, mhvd jo[mmasin...). 
caminhos da tradição cristã e da cultura do Ocidente?

\footnotetext{
${ }^{7}$ Vide Ratzinger, 1960, 368-378.
} 


\title{
Paulo de Tarso: a conversão como acto hermenêutico
}

\author{
José Augusto M. Ramos \\ Universidade de Lisboa \\ Centro de História da Universidade de Lisboa \\ Centro de Estudos de História Religiosa da Universidade Católica Portuguesa
}

\section{Acto hermenêutico ou percurso de vida}

Se tivesse que matizar mais o título apresentado para esta comunicação num colóquio sobre Paulo de Tarso, aqui considerado na sua múltipla condição de grego e romano, judeu e cristão, podia ainda sublinhar que, em vez de focar a atenção num acto hermenêutico para definir a conversão de Paulo, seria mais pertinente considerar que a narração da sua conversão pode ser vista como uma forma de concentrar a sua vida e todo o seu percurso hermenêutico como uma ocorrência única. Assim, valorizamos o significado da sua vida inteira, vista como a densa textura de um sistema em crescimento coerente e lógico. $\mathrm{O}$ próprio Lucas, como provável redactor dos Actos dos Apóstolos, trata este «acto» de conversão por três vezes, retomando sempre o essencial e sugerindo, de cada vez, matizes diferenciados ${ }^{1}$.

$\mathrm{Na}$ primeira vez que aborda esta matéria ${ }^{2}$, Lucas pretende mostrar como se transformou o posicionamento e a militância de Paulo entre o seu judaísmo de origem e a nova seita, cujo retumbante sucesso o intrigava e o deixava cada vez mais exasperado. $\mathrm{O}$ seu conceito de militância implicava uma parte visível e intensa de agressividade contra aquela «via» cristã, com a qual se reformulava de forma tão intrigante o património religioso dos judeus. A intensidade que o vemos colocar na sua obra apostólica posterior em prol do cristianismo atesta bem como era autêntica aquela agressividade anti-cristã do princípio.

Não é propriamente sobre a adesão a um diferente credo religioso que está a insistir a ideia de conversão aqui pressuposta. Esta mudança acontece logo nos primeiros tempos a seguir e muito próximos da morte de Jesus ${ }^{3}$. Nessa altura, era ainda muito difícil saber com que corpo de doutrina se identificava verdadeiramente o grupo dos cristãos. Estes deviam reconhecer já elementos

${ }^{1}$ Cf. Alvarez Valdés, 2008, 4-10; Murphy-O'Connor, 1994, 121-122.

${ }^{2}$ Act 9, 3-19.

${ }^{3}$ Jesus terá morrido crucificado provavelmente no dia 7 de Abril do ano 30. A «conversão» de Paulo poderia ter ocorrido nos primeiros anos que se seguiram. Segundo Walker, 2008, 15, Jesus morreu provavelmente no dia 7 de Abril do ano 30; e a ocorrência da estrada de Damasco teria sido em 31 ou 32. Também Oliveira, 2008, 191, refere o ano 32. Pulcinelli, 2008, 12, aponta igualmente para os anos 32-33. Referimos a insistência dos estudiosos numa data precoce, porque é essa que mais nos pode intrigar. Quanto mais tarde fosse, mais natural nos pareceria, porque contaríamos com mais tempo para o desenvolvimento do cristianismo como um grupo social e como volume crescente de doutrina. 
de identidade mais ou menos profundos na sua maneira de interpretar a tradição judaica; e alguns desses elementos poderão vir directamente da boca de Jesus e do seu contexto. Parece inquestionável que, por esta altura, os cristãos deviam começar a ser já reconhecidos. Nesta onda de entusiasmo, haveria provavelmente lugar sobretudo para acolher os novos aderentes mais do que para ocorrerem actos de conversão como uma mudança radical, abandonando uma ortodoxia já bem definida para entrar noutra que não tinha uma identidade ainda tão burilada.

O que a narrativa de Lucas nos expõe verdadeiramente é a reformulação das solidariedades de Paulo, posicionado entre ambas as comunidades. Este entra claramente em cena com uma intensa militância, que representa uma sua marca pessoal bem definida. Antes, ele era a favor do judaísmo; depois, passa a ser a favor do cristianismo. Na militância judaica, ele fora bem mais agressivo; na militância cristã, haveria de ser igualmente entusiasta e eficaz, mas mais tolerante. Com esta apresentação, Lucas institui a personagem principal da sua historiografia, com a qual preenche de forma brilhante as primeiras décadas de cristianismo. E esta imagem derivada da historiografia de Lucas tornou-se a imagem historiográfica mais representativa das origens do cristianismo.

Também não pretendemos tomar este acontecimento como um facto milagroso, que devêssemos apenas contemplar. Gostaríamos de o abordar como um objecto acessível e analisável, pelo menos sob os seus aspectos psico-culturais. É claro que os meandros psicológicos desta transformação se podem imaginar bastante intensos e complexos. Não é, contudo, nossa intenção ultrapassar esse olhar de intuição essencial e pretender entrar noutros recônditos.

A segunda narrativa dessa mesma conversão e transformação na estrada de Damasco é o próprio Paulo que a relata ${ }^{4}$. Foi ao ser preso no templo de Jerusalém e como uma maneira de justificar o seu comportamento que estava decididamente a ser posto em causa pelos seus antigos correligionários judeus. De forma resumida, é recuperado todo o contexto da primeira passagem de Paulo para o cristianismo, incluindo o ter sido testemunha da morte de Estêvão.

A transformação de Paulo, neste contexto, é explicitamente ligada com as outras raízes que o ligam a Tarso, à língua grega e à cidadania romana.

$\mathrm{Na}$ terceira vez que se fala da conversão de Paulo na estrada de Damasco ${ }^{5}$, é já de forma mais resumida, a modo de argumentação específica dirigida a uma autoridade romana. Deixados de fora aspectos da narrativa mais internos à comunidade cristã, é sobretudo sublinhado aquilo que diz respeito

\footnotetext{
${ }^{4}$ Act 22, 6-16.

${ }^{5}$ Act 26,12-18.
} 
ao apostolado junto dos pagãos. Esta reutilização da história da conversão volta, mais uma vez, a ocupar um lugar de grande repercussão e dinamismo no decurso da história que Lucas pretende contar.

\section{Segundo Lucas, a conversão de Paulo é um relato de vocação.}

Aquilo que a tradição entendeu da leitura de Lucas foi um quadro matizado e pormenorizado da conversão de Paulo. Essa imagem resulta sobretudo da primeira narrativa referida nos Actos dos Apóstolos, que é literariamente o quadro mais completo. Esta narrativa acabou por tornar-se quase um paradigma e um modelo literário histórico para exprimir o tema das conversões. Este acontecimento mereceu mesmo que lhe fosse atribuído um dia especial como festa litúrgica, no dia 25 de Janeiro. E não é nada habitual que a um santo se dedique uma festa litúrgica de conversão, independente da festa litúrgica que, em princípio, se referiria à sua morte, considerada como o seu dies natalis, coisa que Paulo também tem.

A narrativa em questão parece até ter sido propositadamente escrita com a finalidade de garantir uma configuração de modelo para a personagem de Paulo. Com efeito, Lucas é um colaborador de Paulo e os seus Actos dos Apóstolos apresentam-se como se fossem mais propriamente os Actos de Paulo.

Sabíamos já, desde o seu Evangelho, que a intenção de escrita, no caso de Lucas, tende a criar modelos de discipulado. Paulo seria agora o super-modelo dessa atitude de discípulo de Jesus. Porém, sendo verdade que o conceito de conversão aparece utilizado para descrever a adesão de muitos do povo à mensagem de Jesus transmitida pelos apóstolos 6 , e apesar de, nos seus dois livros, Evangelho e Actos, Lucas ser o campeão neotestamentário quanto ao uso do vocabulário de conversão, este conceito não aparece utilizado nas referidas narrativas sobre Paulo.

A verdade é que a conversão que, segundo Lucas, faz um bom discípulo não é a bem dizer uma mudança de religião; é, antes de mais, um aperfeiçoamento nas atitudes e na prática, dentro da mesma religião que se professava. Isto é, tornar-se discípulo modelar não é uma conversão é um aperfeiçoamento, um progresso e uma performance. O que nesta narrativa se diz de Paulo é apresentado como um acontecimento espiritual diferente. Seria, acaso, este a inaugurar uma conversão como ruptura? E, contudo, Paulo não estava a transitar de uma religião para outra assim tão diferente da primeira. Nem essa diferença é especificamente sublinhada nas narrativas em questão.

Lucas compôs esta narrativa de conversão, tomando por modelo diálogos de aparição e de vocação, conhecidos no Antigo Testamento. E os casos com maior convergência são os seguintes.

Abraão é chamado para a sua longa viagem de migração que o há-de levar

\footnotetext{
${ }^{6}$ Act 2,38; 8,19.22.
} 
a uma nova terra ${ }^{7}$; e, mais tarde recebe uma ordem para oferecer o seu filho em sacrifício .

Jacob recebe assim também a ordem para regressar à sua terra, rico em rebanhos'; e, mais tarde, é informado igualmente de que a ida para o Egipto é promissora para o seu futuro como povo ${ }^{10}$.

Moisés recebe, um dos mais famosos chamamentos da Bíblia, isto é, a missão de ir ao Egipto com a função de libertar o seu povo ${ }^{11}$.

Samuel, por sua vez, é objecto de um dos relatos vocacionais mais personalizados, íntimos e impressionantes, até por ser colocado em tão tenra idade $^{12}$.

Outros chamamentos análogos mantêm a intenção de definir uma vocação para alguém ${ }^{13}$. Como modelo para o relato de vocação de um discípulo, chamado a seguir o mestre, ficou a narrativa de investidura de Eliseu, por parte do seu mestre Elias ${ }^{14}$. E, de modo sugestivo, Lucas convoca literariamente esta passagem, como contendo traços de modelo ${ }^{15}$.

Segundo a narrativa de Lucas, Paulo viveu, a caminho de Damasco, uma conversão que ele expressa com as formas do maravilhoso característico destes acontecimentos. Para isto, assumiu um género literário da conversão psicologicamente forçada, que era de grande atractivo entre os judeus e que continua a oferecer grandes características de autenticidade.

Um dos casos mais famosos, numa época anterior e proxima, tinha sido a conversão de Heliodoro, um inimigo de Israel, o qual por um relato miraculoso de conversão fora transformado em seu propagandista ${ }^{16}$.

Ao repetir por três vezes a conversão de Paulo, Lucas poderia ter a intenção de fazer a investidura de Paulo como o «apóstolo» que cumpriu a profecia de Jesus de chegar com o evangelho até Roma, isto é, até aos «confins do mundo» ${ }^{17}$. Este era o pórtico da sua historiografia cristã, antecipando a totalidade da acção. A evolução da narração de conversão de Paulo em Lucas visa a intenção da criação de modelos de discipulado, tal como acontecia também no seu evangelho. Ser discípulo em Paulo não significa, no entanto, uma simples atitude obediencial. Paulo é investido numa função de enviado como apóstolo.

\footnotetext{
${ }^{7}$ Gn 12,1-3.

${ }^{8}$ Gn 22,1-2.

${ }^{9} \mathrm{Gn} 31,11-13$.

${ }^{10} \mathrm{Gn} 46,2-4$.

${ }^{11} E \times 3,2-10$.

12 S Sm 3,4-14.

${ }^{13} \mathrm{Jz} 6,11-24 ; 13,1-25 ;$ Is 6,1-13; Jr 1,4-19.

${ }_{14} 1 R s$ 119,19-21.

${ }^{15}$ Lc 9,61-62.

${ }_{16} 2 \mathrm{Mac} 3$.

${ }_{17}$ Act 1,8.
} 
Aliás, Lucas escreve sobre estas coisas, depois daquilo que Paulo, autobiograficamente, tinha já escrito sobre si mesmo, nomeadamente na Carta aos Gálatas. Esta é seguramente anterior à redacção dos Actos dos Apóstolos.

$\mathrm{O}$ «diálogo de aparição» é um género literário religiosamente familiar no contexto do Antigo Testamento; ele apresenta um duplo chamamento, uma pergunta ao Senhor, a auto-apresentação da personagem que é objecto de visão $\mathrm{e}$, finalmente, o encargo que se pretendia ${ }^{18}$. Foi precisamente neste sentido que se processou o diálogo de Jesus com Paulo, segundo o relato ocorrido na estrada de Damasco.

\section{A transformação relatada por Paulo é a da Carta aos Gálatas ${ }^{19}$.}

Como vimos, a imagem de conversão como um acto concreto e circunstanciado é aquela que transparece no livro dos Actos. A imagem que se deduz dos escritos de Paulo é mais hermenêutica do que psicológica, mais processual do que instantânea. Quanto a este último modelo, parece mesmo que o apóstolo o recusa, até nas circunstâncias em que o recurso a uma experiência específica como a descrita na estrada de Damasco poderia ser fácil e bastante útil, em resposta da Galácia que duvidavam da sua investidura como «apóstolo». No entanto, Paulo apenas se refere a esses factos muito de passagem ${ }^{20}$.

Para além da narrativa principal ${ }^{21}$ sobre os acontecimentos, o narrador dos Actos coloca Paulo, noutro momento, a expor o tema da sua conversão diante de uma verdadeira multidã ${ }^{22}$. $\mathrm{O}$ redactor pretende com esse estratagema retórico dar validade e grande ressonância pública ao assunto. Representaria um quadro quase oficial.

Se, na perspectiva do livro dos Actos, se trata de uma experiência de audição ${ }^{23}$, Paulo parece, pelo contrário, achar mais adequado referir-se ao caso como tendo sido de uma experiência de visão ${ }^{24}$. Esta escolha da categoria de visão pode depender do facto de a argumentação, em ambos os contextos referidos para retomar o tema, estar a ser desenvolvida como referência às aparições pós-pascais dos outros apóstolos, que viam legitimado o seu estatuto de apóstolos com base no facto de terem sido escolhidos por Jesus durante a sua vida. As aparições pascais a estes como que ratificavam a sua legitimidade apostólica. Paulo, que se assumia como um apóstolo e não como o menor deles, devia ter certamente também uma visão de Jesus que pudesse invocar como argumento.

\footnotetext{
${ }^{18}$ Gn 22, 1-2; 31, 11-13; 46,2-3; Ex 3,2-10; 1 Sm 3,4-14.

${ }^{19}$ Gl 1,11-2,21.

${ }^{20}$ Gl 1,15 .

${ }^{21}$ Act 9.

${ }^{22}$ Act 22.

${ }^{23}$ Act 9,3-4.

${ }^{24} 1$ Cor 9,$1 ; 15,8$.
} 
Paulo sublinha precisamente que a sua recepção do Evangelho foi por «revelação», isto é, directamente e não por intermédio de ninguém ${ }^{25}$. Pelo contrário, Lucas $^{26}$ diz que foi Ananias quem procedeu à instrução do neo-convertido Paulo na perspectiva do cristianismo.

Para Paulo, o que lhe aconteceu foi uma experiência íntima de vocação e de iluminação, um acto de hermenêutica com grande projecção nas suas atitudes de vida e de comportamento. Esta interpretação é, no seu sentido essencial, coincidente com aquela que ele nos dá na sua fundamental Carta aos Galátas $^{27}$.

E se esta carta tivesse eventualmente alguma possibilidade de vir a ser reconhecida como o seu mais antigo escrito, ela poderia ainda ter sido escrita antes do famoso "concílio» de Jerusalém, o qual teve como motivo e como principal resultado aprovar as perspectivas de Paulo para o desenvolvimento do cristianismo. Ali, não estaria somente em causa abrir a porta para a uma estratégia que Paulo gostaria de propor e vir a realizar. Estaria já, bem mais profundamente, a aceitação daquilo que este já teria praticado e proclamado oralmente e até por escrito, junto das comunidades da Ásia romana. Tratavase, portanto, de ratificar aquilo que viria a ser chamado o «cristianismo de recepção grega». Este é essencialmente paulino e é deste que derivam directamente quase todas as modalidades de cristianismo que têm existido até agora.

Isto pode convergir, de algum modo, com o tema historiográfico que considera Paulo como «fundador» deste cristianismo ${ }^{28}$. Para além de ser um tema com irrecusável pertinência, é também muito matizado pela ressonância que tem suscitado nas várias épocas da história da exegese. O facto é que, com esta conversão, Paulo transpôs o judaísmo e transpôs igualmente a fórmula que, até então, parecia ser a mais natural e a mais evidente para a definição do cristianismo da época das origens.

Tanto Lucas como Paulo aceitam que existe uma analogia entre esta visão de luz que experimentou Paulo e as aparições de Jesus ressuscitado aos outros apóstolos ${ }^{29}$. Nesse sentido, aquilo que aparece sublinhado não é tanto um acto de conversão; é mais propriamente uma espécie de investidura. O próprio Paulo insiste em ele próprio ser um apóstolo especialmente designado. A expressão

${ }^{25}$ Gl 1.11 .

${ }^{26}$ Act $9,10-18$.

${ }^{27}$ Gl 1,15-16.

${ }^{28}$ Este tema de uma fundação paulina do cristianismo ecoa de tempos a tempos com maior veemência. Podem estar aqui em causa as sensibilidades diversificadas no perceber os seus matizes como religião ou ser o resultado de uma reavaliação da história e da literatura, como acontece com alguns autores de hoje. Cf. Lüdeman, 2002.

${ }^{29}$ Gl 1,11-17. 
kletós apóstolos, que gosta especialmente de utilizar para si mesmo ${ }^{30}$, não é uma espécie de alcunha, como se fosse um «chamado apóstolo»; é, pelo contrário, uma designação e um título de «chamado a ser apóstolo». É muito significativo que a entrada da Carta aos Gálatas ${ }^{31}$ defina este estatuto de apóstolo, que ele para si avoca, como uma designação não humana, mas fundada na iniciativa de Jesus e de Deus. Se esta for a primeira carta de autoria paulina ${ }^{32}$, esta entrada pode ser considerada como o seu grande manifesto apostólico, a sua apresentação de credenciais.

Trata-se, por outras palavras, de uma definição para fundamentar uma nova identidade. Esta constitui uma função específica: a missão de Paulo fora do judaísmo. Se tivermos em consideração a posição do judaísmo tradicional, a conversão de Paulo seria não uma con-versão, mas mais propriamente uma diversão, pois não convergia, apenas divergia. Com este passo, Paulo definia-se num dos dois campos de judaísmo, que se insinuavam como alternativos, por entre as narrativas do início do livro dos Actos. Transformação é certamente uma expressão pertinente para significar o que aqui se passa e há especialistas de Paulo que a preferem ${ }^{33}$.

Para além de constituir uma investidura pessoal para uma missão específica, Paulo sublinha o facto de isso não ter sido feito pelos canais institucionais do jovem cristianismo, mas de lhe ter acontecido a ele directamente, com a força de uma revelação; ele próprio recebeu um «apocalipse» de Jesus Cristo ${ }^{34}$. Este título é o mesmo que, cerca de meio século mais tarde, virá a ser atribuído por João a um tipo de texto que parece representar um género de literatura completamente diferente da de Paulo. Aliás, tanto o verbo como o substantivo de revelar (apokalyptolapokalypsis), no Novo Testamento, são sobretudo utilizados na literatura paulina, precisamente. $\mathrm{O}$ famoso livro com este nome apenas usa a palavra aquela única vez em que ela aparece no título.

Esta insistência na ideia de uma revelação recebida está sobretudo voltada para o estatuto epistemológico e teológico da sua mensagem, marginalizando o lado factual e os aspectos banais de auto-exibição. É de notar que, quando trata de experiências de revelação ou iluminação sob o ponto de vista do acontecimento, Paulo as relata em $3^{\text {a }}$ pessoa ${ }^{35}$, eclipsando desta maneira a sua imagem pessoal, mesmo que o efeito assim conseguido se possa considerar apenas de alcance retórico ou mesmo potenciador.

\footnotetext{
${ }^{30} R m 1,1 ; 1$ Cor 1,1 . Não diminui a força desta definição o facto de, em 1Cor 15,8-9, Paulo se declarar um aborto de apóstolo, indigno de ser chamado tal, por ter perseguido a igreja de Deus.

${ }^{31}$ Gl 1,1 .

${ }^{32}$ Cf. Walker, 2008.

${ }^{33}$ Cf. Walker, 2008, 20.

${ }^{34}$ Gl 1,12 .

2 Cor 12,2 .
} 


\section{A conversão de Paulo é a de um intelectual fariseu.}

A narrativa de Lucas e as cartas de Paulo concordam neste ponto concreto. Isto é, Paulo era, de facto, um fariseu de formação, de estudo e também de militância. A sua atitude radical de intolerância ultrapassava mesmo a do seu mestre, o fariseu Gamaliel, de que dá testemunho o livro dos Actos. A posição deste último ${ }^{36}$ poderá estar ali referenciada quer para servir como modelo de tolerância, quer para sugerir como indício profético do crescimento que haveria de conhecer o cristianismo. Essa perspectiva está numa consonância bastante coerente com os horizontes de Lucas.

Quanto à construção da figura de Paulo, pelo contrário, Lucas começa pelas conotações negativas, se bem que esta pudesse ser também uma dinâmica natural do processo narrativo.

A conversão de Paulo é a conversão de um intelectual e espelha o processamento da sua evolução e acção cultural, com os respectivos conteúdos. Lucas aproveita estas etapas de acção e estas metas sucessivamente conquistadas, para comprovar o cumprimento de uma profecia de Jesus, nomeadamente a de os seus discípulos haverem de chegar, na difusão da mensagem cristã, até aos «confins da terra». Isto devia significar, pelo menos, que se conduziria o cristianismo até Roma. E é ali que há-de acabar realmente a narrativa empreendida por Lucas no livro dos Actos.

Mesmo que qualquer conversão seja um acto de hermenêutica, implicando uma definição intelectual acompanhada de uma opção ética correspondente, a conversão de Paulo é-o de uma forma muito específica e bem documentada.

O ambiente histórico e cultural da época, sobretudo no interior do judaísmo, tinha já desenvolvido uma concentração maior de tarefas hermenêuticas complexas. Este investimento hermenêutico era o seu mais notório processo cultural de continuidade. O devir histórico, para além de ser aquilo que realmente vai acontecendo, é também um continuado processamento hermenêutico do acontecer.. Avança-se em articulação hermenêutica com o passado, mesmo que o salto possa, por vezes, ter de equivaler a uma revolução.

A radicalidade das transformações e dos posicionamentos doutrinais, com particular expressão na carta aos Gálatas e na carta aos Romanos, constitui uma espécie de transgressão transcendental através de um aprofundamento radical da atitude de fidelidade hermenêutica. Esta relação não constitui uma subtileza diplomática. Pelo contrário, ela pode derivar da mais profunda obrigação de fidelidade. A imagem de conversão, que Paulo dá ao longo dos seus escritos, sublinha este tipo radical de processamentos, que implica aprofundamentos e saltos, na subtileza das suas posições.

\footnotetext{
${ }^{36}$ Act 5, 36-39.
} 
Em última instância, esta perspectiva recupera a noção bíblica de conversão, expressa pela raiz šub: regressar, re-(con)duzir, re-encontrar, como ocasião de aprofundamento ${ }^{37}$. De qualquer modo, Paulo declara não dizer mais nada, para «além do que os profetas e Moisés predisseram que havia de acontecer, que o Messias tinha de sofrer e que, sendo o primeiro a ressuscitar de entre os mortos, anunciaria a luz ao povo e aos pagãos» ${ }^{38}$.

\section{Paulo é um afluente e não um simples aderente ao cristianismo}

Os textos sobre a conversão de Paulo definem o entendimento da sua acção futura, concebida como estando em perfeita linha de convergência com a de Jesus. Não se tratou tanto de entrar para uma religião doutrinalmente madura e bem reconhecida; antes, a dita conversão ocorre num tempo em que o cristianismo era ainda considerado como uma heresia perigosa e deslizante. Os argumentos já aduzidos a seu favor podiam ser sérios, pertinentes e entusiasmantes, mas não provocavam ainda uma evidência generalizada. Lucas sublinha alguns momentos iniciais de vistoso sucesso ${ }^{39}$ na adesão de novos crentes. Mas não há razões incontornáveis que nos obriguem a prescindir da imagem de humildade com que se descrevem naturalmente as origens de qualquer movimento complexo.

Sublinhar, como fazem Lucas e Paulo, que a conversão deste último implicou assumir como nova fé aquela que, antes, ele programava erradicar totalmente. Serve para exprimir a parte de drama e a intensidade implicadas na experiência. Uma semana de viagem, na companhia de uma pequena caravana, para chegar de Jerusalém a Damasco, continha ingredientes capazes de intensificar várias emoções e sentimentos, tanto mais que Paulo pretendia assumir uma intervenção decisiva contra a preocupante seita dos cristãos.

Mais do que ser apresentado como uma conquista famosa por parte do novo movimento religioso, Paulo representa uma nascente original de onde dimanam novas ideias. Procurando aprofundar a sua matriz patrimonial judaica, ele acaba por se encontrar com um outro caminho, «a via» ${ }^{40}$; e descobre que está em confluência com a sua orientação. Para o inicial movimento de Jesus, são igualmente assinalados outros movimentos de real ou aparente convergência. Foi o caso dos discípulos de João Baptista que se tinham associado ao grupo de Jesus, desde os primeiros tempos da sua vida pública ${ }^{41}$.

Paulo traz para o cristianismo o mundo cultural e antropológico que

\footnotetext{
${ }^{37}$ Soggin, 1984, 884-891.

${ }^{38}$ Act 26,22-23.

${ }^{39}$ Act 2,41.

${ }^{40}$ Act 9,$3 ; 19,9.23 ; 22,4 ; 24,22$.

${ }^{41}$ Mt 11,2-15; Lc 7, 18-28.
} 
caracteriza os não judeus; traz a experiência do judaísmo da diáspora; e traz, por exemplo, o uso e a familiaridade com o texto de uma Bíblia em grego, que ele utiliza e cita para redigir os seus escritos e a qual acabou por se tornar uma leitura e um texto matricial para o cristianismo da recepção grega, aquele que, a muitos títulos, nos diz respeito.

Uma expressão chamativa desta convergência entre Jesus e Paulo é a própria concepção de um recente livro de Jerome Murphy-O'Connor, Jesus e Paulo. O ponto de partida de ambos pode considerar-se diferente: Jesus parte de dentro do judaísmo e confronta-se com a necessidade de purificação do seu espírito e mentalidade. Paulo parte da consciência de uma meta externa que o próprio judaísmo precisa de atingir. Entretanto, o percurso de Jesus é longo e traumático, enquanto o de Paulo é rápido ${ }^{42}$.

O carácter de afluente que caracteriza o contributo de Paulo ao cristianismo está evidente no facto de este ser um brilhante produtor de discurso cristológico, de uma forma naturalmente mais intensa do que aquilo que se poderia dizer de Jesus, cujas auto-declarações nunca podiam ser um tratado.

\section{Paulo assume o Jesus histórico como objecto da sua cristologia.}

Para além da referência discipular e crente, pela qual Paulo confessa e proclama um evangelho directamente recebido por uma revelação do próprio Jesus; para além de uma antropologia teológica universalista que fazia parte do seu património bíblico, Paulo sublinha particularmente uma síntese muito específica entre as coordenadas históricas de Israel e a antropologia fundamental de teor simbólico e mítico. Esta antropologia fundamental era de sabor mais ecuménico e era, talvez, mais acessível no seu contexto helenista do que no próprio ambiente cultural judaico da Palestina.

O mundo helenístico, com efeito, ia procedendo a uma síntese entre várias antropologias tradicionais do Mediterrâneo oriental. Gerava-se desta maneira uma antropologia ecuménica que se tornou património cada vez mais comum e foi, na sua estrutura essencial, adoptada até no interior do judaísmo e do cristianismo. Dessa antropologia, havia versões mais elaboradas, segundo as perspectivas místicas e gnósticas, facilmente acessíveis às sensibilidades mais religiosas.

O Jesus da primeira comunidade foi sendo interpretado e passou a ser rapidamente denominado como messiânico: Jesus, o Messias ou Cristo. Daí o nome de «cristãos» com que começaram a ser designados em Antioquia os seguidores de Jesus ${ }^{43}$.

O sentido normal deste messianismo seria o de modelo histórico.

\footnotetext{
${ }^{42}$ Murphy-O'Connor, 2008, 126.

${ }^{43}$ Act 11, 26.
} 
Segundo esta concepção, o Messias deveria definir-se pelas coordenadas de um rei perfeito e eficaz, projectando modelos de sociedade para os horizontes do ideal e da utopia.

Sem renegar propriamente a solidariedade semântica com essa concepção tradicional no judaísmo, Paulo vai traduzir e redefinir claramente o seu messianismo, marcando-o com uma coordenada de antropologia teológica, dotada de grande significado e projecção. É a concepção de um messias como mediador de redenção. Esta perspectiva garante-lhe uma semântica, mais universal, tanto na extensão como na compreensão e no sentido. É claro que a tradição judaica conhecia bem o sentido de redenção, mas este incidia bastante mais numa dimensão histórico-social, de libertação ou resgate em situações de opressão. Com esta ideia de redenção de cariz mítico-antropológico na intervenção de Paulo, projecta-se a coordenada teológica para um espaço de mediação marcadamente conotada com as preocupações gnósticas.

A fórmula messiânica tradicional do judaísmo poderia até ser mais aceitável historicamente, mas não respondia às necessidades antropológicas do homem helenístico, que requeria mais coordenadas antropológico-míticas do que políticas. Paulo percebeu bem as questões para as quais era necessário dar uma resposta.

Esta é a sua maneira de fazer a aproximação à mitologia fundamental ${ }^{44}$, jogando com as duas teologias, por vezes contrastantes, mas também já presentes na tradição hebraica bíblica. Por aqui se justificam igualmente algumas aproximações suas à mentalidade apocalíptica. Apesar de contar com algumas passagens de particular cumplicidade com as perspectivas históricas da apocalíptica, o discurso de Paulo não está tão repassado do espírito e das tonalidades que reconhecemos claramente no discurso apocalíptico.

No entanto, chama claramente a nossa a atenção o facto de Paulo ser o maior utilizador neotestamentário do vocabulário que tem a ver com apocalipse ou revelação. E já não acumulamos aqui referências aos temas de sabor gnóstico ou de conhecimento, tão afins aos de teor apocalíptico.

O seu conceito de pecado como degradação estrutural de todo o humano e social é, mais uma vez, claramente convergente com os conceitos apocalípticos de desordem e de injustiça. Essa é a porta através da qual se introduz e se afirma o seu messianismo de redenção, mais do que de vitória triunfal e política. Para afirmar e sublinhar este aspecto, Paulo nem sequer precisou de usar de violência conceptual.

A maneira como humanamente se assume e gere esta mitologia/cristologia assenta sobre o conhecimento que utiliza uma modalidade «esotérica» da revelação, como processo e sobretudo como maneira de estruturar níveis e

\footnotetext{
${ }^{44}$ Col 1, 15-20.
} 
significados hierarquizados, dentro do conhecimento. A revelação é, com efeito, vista como inserida na própria estrutura do conhecimento, como se fosse uma iluminação de investidura ou processo de esclarecimento e aprofundamento «assistido». Paulo pressupõe um conceito de revelação que parece apontar para uma compreensão e estruturação da própria experiência de conhecimento e não para uma eventual explicação mecânica e processual, para a qual a imaginação muito facilmente poderia pender.

$\mathrm{Na}$ verdade, o conceito de revelação era amplamente utilizado por parte de civilizações e culturas antigas pré-clássicas. Mas os utilizadores do conceito judaico-cristão e islâmico de revelação não reconhecem que o conceito se possa aplicar aos outros. Haverá certamente que reencontrar um significado unívoco e universal para o conceito de revelação. Está bem de ver e parece incontornável que isso aconteça. Esta será uma tarefa a merecer ulteriores esforços.

$O$ processo de revelação tem uma dinâmica convergente com as narrativas de aparição no Novo Testamento. O seu núcleo significativo é o de constituírem um caminho de convicção. No caso das aparições, essa dinâmica pode estabelecer-se passo a passo na narrativa ${ }^{45}$. O próprio núcleo de convicção e o conhecimento assim expresso sugerem uma estrutura de complexidade e hierarquização de matizes, de forma permanente. O conhecimento revelado é um conhecimento em que preponderam outras ordens de matizes e não propriamente um conhecimento obtido por meios mais assim ou mais assado ${ }^{46}$. A revelação tem a ver com o teor e a estrutura; não com o processamento ou com a aquisição.

Paulo tem uma linha alargada de sintonia com o gnosticismo. A sua hermenêutica está integrada no seu próprio tempo: ele assume, com efeito, a sensibilidade da gnose, com um grande equilíbrio entre a dimensão mítica sugerida pela cultura antropológica em vigor e a dimensão histórica, mais representada pelas suas raízes judaicas. Daí o seu modo de entroncar a antropologia fundamental com a função teológico-simbólica atribuída ao Jesus histórico, o mais histórico possível até ao escândalo que podia provocar a imagem do Jesus crucificado, cuja pertinência teológica, no entanto, ele sublinha da forma mais taxativa ${ }^{47}$.

De qualquer modo, para além da imagem política e social da crucificação, o mistério da morte e ressurreição de Jesus, particularmente tendo em conta as circunstâncias injustas e polémicas em que tal tinha acontecido, oferecia conotações de grande ressonância simbólica e antropológica. O

${ }^{45}$ Cf. Murphy-O'Connor, 2008, 119.

${ }^{46}$ Cf. Murphy-O'Connor, 2008, 124-125. Vale a pena citar uma frase de J. M. O'Connor, nesta página 125: «Ver coisas familiares e normais de um ângulo radicalmente diferente pode legitimamente ser descrito como uma revelação».

${ }^{47} 1$ Cor $2,2$. 
proto-cristianismo valorizou cedo e bem estes significados já no seu contexto palestinense; e Paulo deu-lhes igualmente grande eco e eficácia no contexto cultural grego.

Desta maneira, Paulo pode sublinhar que esta mensagem é realmente o «seu» evangelho, sem, por isso, deixar de ser o evangelho que recebeu ${ }^{48}$. E continua a assumir a Cristo como seu senhor e seu modelo integral de vida ${ }^{49}$.

\section{O percurso hermenêutico de Paulo foi sempre um acto de militância.}

Lucas descreve, com a sua construção da personagem de Paulo, dois percursos de militância. O primeiro é o da sua militância anti-cristã. Esta é apresentada quase com o recurso a sumários rápidos e não vem acompanhada de um caderno doutrinal que represente o programa em nome do qual combate. É a ortodoxia tradicional expressa pelo discurso dos fariseus. Em contrapartida a militância cristã de Paulo é continuamente acompanhada por um discurso enunciativo que tem estilo de manifesto, quer seja feito oralmente e de imediato, quer se transforme em escritos de circunstâncias ou de objectivos mais profundos e complexos.

A sua posição é completamente diferente da atitude representada pelo pequeno discurso com que ficou célebre o seu mestre Gamaliel ${ }^{50}$, em que se sugeria aos seus compatriotas judeus que simplesmente se abstivessem de controlar os movimentos dos adeptos da seita cristã. O futuro haveria de dizer se esse movimento tinha ou não cobertura divina. Se ele sobrevivesse, era sinal de que Deus reconhecia que o seu aparecimento estava justificado. Podia, entretanto, não conseguir enraizar, como já tinha acontecido com outros bem conhecidos e que eram igualmente de sabor messiânico. Isso significava que, em tais casos, a sua pertinência não se confirmava.

Gamaliel estava claramente a jogar com os conceitos judaicos de um movimento tendente a confirmar uma figura de messias, que seria bem sucedido se chegasse realmente a instalar essa figura, de uma forma social e politicamente conseguida. Paulo encaminha o seu programa de militância para uma hermenêutica de leitura e de vivência comunitária. Tem outra ambição e a respectiva validação faz-se pelo assentamento de factos de vivência.

Se Paulo, no seu horizonte judaico, assumiu uma militância mais intolerante, no seu horizonte cristão, mostrou-se um militante bastante mais construtivo. E é verdadeiramente notório o contraste com que, desta maneira, ele acaba por se posicionar face ao seu mestre Gamaliel.

\footnotetext{
${ }^{48}$ Col 1,21-23.

${ }^{49} 2$ Cor 4,10-11; Fl 1,2.24; 2 Tm 4,6-8.

${ }^{50}$ Act 5,33-39.
} 


\section{Em conclusão}

O ponto de ligação para esta deriva pode situar-se, como que em ponte, entre duas categorias aqui referenciadas, a do acto de conversão e a do percurso hermenêutico. Converter-se acaba finalmente por consistir em apurar melhor o acto de ler, aprofundando-o até ao eclodir consequente de uma atitude ética, militante e realmente alternativa. E Deus é uma leitura; a sua aparição acontece no campo da hermenêutica; não ocorre somente nos textos. Deus é uma legibilidade que se vai conseguindo matizar, formular e assumir, por entre a realidade toda com os seus múltiplos sentidos. Conhecer a Deus é um caminho responsabilizante e um meritório sucesso hermenêutico, conseguido através da leitura das criaturas. É este o postulado fundamental de Paulo no início do seu magno tratado hermenêutico que é a Carta aos Romanos ${ }^{51}$.

${ }^{51} \operatorname{Rm} 1,12-20$. 


\title{
EIS SPANLAN. \\ Paulo de Tarso na Hispânia
}

\author{
Nuno Simões Rodrigues \\ Universidade de Lisboa \\ Centro de História da Universidade de Lisboa \\ Centro de Estudos Clássicos e Humanísticos da Universidade de Coimbra
}

A conversão de Saulo é uma problemática que transcende os objectivos desta reflexão. Mas ela é essencial para que se compreenda a missão evangélica de Paulo e a razão por que o Apóstolo se dirigirá a Roma, o centro do Império, bem como às periferias do mesmo, fazendo desses espaços importantes percursos teológicos para o cristianismo emergente. Em Saulo, a conversão significa a aceitação de Jesus como o Cristo, o Messias da cultura judaica, o que implica uma reavaliação das ideias de Salvação e dos destinos do mundo. Com a mudança vem o projecto de difundir a Boa Nova, que passa a levar em conta todos os que não pertenciam ao judaísmo. A consciência da missão de Paulo está bem delineada na carta que escreveu aos Gálatas: «para que anuncie como Evangelho entre os gentios» ${ }^{1}$. Doravante, o principal objectivo do apóstolo será converter, o que não deixa de traduzir uma ruptura dentro do próprio judaísmo, visto que se envereda por um espírito essencial e militantemente proselitista, característica que não definia a essência daquela religião, ainda que não estivesse excluída dela.

$\mathrm{O}$ ano 34 d.C., enquanto em Roma governava Tibério, terá assistido à primeira viagem evangélica de Paulo, que teve como destino Petra, na Arábia Nabateia ${ }^{2}$. O périplo continuou nos anos seguintes por Damasco, Jerusalém, Chipre, Antioquia, pelas cidades da Ásia Menor, por Filipos, Tessalonica, Bereia, Atenas, Corinto, Éfeso, Cós, Rodes e Pátaros ${ }^{3}$. Mais tarde, depois de ser preso no Templo, em Jerusalém, Paulo declara-se cidadão de Roma e comparece perante o sinédrio, onde se confessa fariseu, granjeando desse modo o apoio dessa facção, naquele órgão. $\mathrm{Na}$ sequência deste acontecimento, os fariseus presentes no sinédrio proclamam a inocência de Paulo, ainda que sob os protestos dos saduceus. $\mathrm{O}$ apóstolo é retirado da assembleia e, segundo o autor dos Actos, Jesus aparece ao apóstolo, comunicando-lhe que deveria ir a Roma dar testemunho da sua verdade.

${ }^{1}$ Gl1,16. Como conclui Murphy-O’Connor, 2008, 93-94, «a missão de Paulo aos pagãos não foi desenvolvimento tardio, nem mero prolongamento de uma suposta expansão de helenistas em Jerusalém».

${ }^{2}$ Gl 1,17. Sobre a identificação da «Arábia» com Petra, Murphy-O'Connor, 2008, 94-95.

${ }^{3}$ Act 9,19-30; 13,4-5; 13,16-50; 14,1-20; 16,11-13; 17,1-8; 17,10-34; 18,1-11; 18,19; 19,111; 20,17-38; 21,1-3. 
Este passo introduz a necessidade de a pregação se dirigir à Vrbs caput mundi.

Perante as ameaças dos judeus, Paulo apela a César, preferindo enfrentar um processo em Roma do que entre os seus conterrâneos. Por certo, o apóstolo das nações sabia que entre estes teria menos hipóteses do que junto das autoridades romanas, leigas em questões de teologia judaica. Só isso explica a razão do apelo, quando sabemos que o magistrado romano em exercício na província tinha poderes para julgar um cidadão romano e condená-lo, inclusive, à pena capital. Neste quadro, Paulo teria recorrido à prouocatio ad imperium, confirmada pela lex Iulia de ui publica, que autorizava qualquer cidadão romano a apelar ao imperador contra uma condenação infligida por um governador provincial, ao mesmo tempo que proibia os funcionários imperiais de se lhe oporem. O conhecimento que [António?] Félix, o então legado provincial de Nero, teria das questões envolvidas e um eventual compadrio com as autoridades judaicas locais poderá também não estar excluído das motivações que levaram a esta decisão ${ }^{4}$. Note-se que o procurador propõe a Paulo o julgamento em Jerusalém, perante as autoridades judaicas, ainda que na sua presença $a^{5}$. $\mathrm{Na}$ verdade, parece que Félix pretendia demitir-se do problema, entregando-o nas mãos dos judeus, como anos antes Pilatos fizera em relação a Jesus de Nazaré. Este episódio confirma, aliás, a ideia segundo a qual a construção literário-biográfica do percurso de Paulo acompanha pari passu a do Cristo ${ }^{6}$.

É então que se inicia a narrativa que descreve a viagem do apóstolo a Roma, que deverá ter ocorrido por volta de 60 d.C. ${ }^{7}$ A descrição sustenta-se da estrutura tópica da viagem literária antiga, em particular da greco-latina: a ida de Jerusalém para Sídon, na Fenícia; o barco proveniente do Egipto; a passagem por Creta; o naufrágio; a tensão dramática dos náufragos perante a morte; a ilha de Malta; a chegada ao Adriático e o desembarque em Putéolos são elementos com afinidades com várias viagens célebres, como a de Ulisses, na Odisseia, e a de Flávio Josefo, tal como a narra na Vita. Ou com outras ainda, que podem ser lidas nos Argonautica de Apolónio de Rodes, no romance grego, no Satyricon de Petrónio, em epigramas da Anthologia Palatina ou até mesmo na historiografia de Tácito, em Plínio-o-Velho e nos Acta Petri ${ }^{8}$. Deve, por isso,

${ }^{4}$ Act 24,22. Ver Rodrigues, 2007, 675-704; Mélèze-Modrzejewski, 1989, 407-409.

${ }^{5}$ Act 25,9.

${ }^{6}$ Ver e.g. Lc 23,6-12; Murphy-O'Connor, 2008.

${ }^{7}$ Thiede, 1986, 102, sugere o ano 60 d.C., como possível data da chegada de Paulo a Roma.

${ }^{8}$ Od.14,250-320; J., Vit. 13-16; A.R. 4, 1223-1240,1634-1690, em que Creta é igualmente um ponto de passagem; Petr. 114-116; $A G$ 7, 289, 290 e 550. Sobre o tema, ver Medeiros, 2000, 519-526. Recordemos que, nos Annales, Agripina Menor é vítima de uma emboscada armada por Nero, quase sucumbindo a um naufrágio, Tac., Ann. 14, 5. Aqui o facto histórico coincide com o topos literário. Sobre a travessia de Itália a Alexandria, ver Plin., Nat. 19, 1, 3. Alexandria era, ao que parece, um ponto favorável na viagem da Judeia à Itália. Sobre o naufrágio de Paulo, ver Rapske, 1994, 1-47. 
ter-se em conta a possibilidade de estarmos perante um topos literário comum na época em análise, relativizando o valor historiográfico que a descrição em causa poderá ter, visto que a coincidência temática é demasiada9 ${ }^{9}$ Note-se, todavia, que não negamos a viagem do apóstolo enquanto facto; antes, problematizamos o conteúdo da narrativa que a descreve.

$\mathrm{O}$ texto dos Actos que menciona a estada de Paulo em Roma refere que o judeu teve autorização, apesar de estar sob custódia das autoridades, para ficar em alojamento próprio ${ }^{10}$. Isso deve significar que Paulo ficou como que em prisão domiciliária na cidade, o que atesta em favor da ideia de que as autoridades romanas não o teriam como um perigoso fora-da-lei ou um político sedicioso. De qualquer modo, esse procedimento estava previsto no Direito Romano: tratava-se da custodia militaris ${ }^{11}$.

Alguns têm alegado que, em Roma, nessas condições, Paulo teria escrito algumas cartas a várias igrejas cristãs espalhadas pelo Mediterrâneo. Estariam nesse grupo as dos Filipenses, Colossenses, Efésios e a pequena missiva dirigida a Filémon. A epístola aos Romanos, contudo, terá sido composta antes de o apóstolo se ter deslocado a Roma e de ter conhecido a comunidade local in persona, anunciando a intenção de o fazer quando se deslocasse à Hispânia:

«como não tenho mais nenhum campo de acção nestas regiões, e há muitos anos que ando com tão grande desejo de ir ter convosco, quando for de viagem para a Hispânia... Ao passar por aí, espero ver-vos e receber a vossa ajuda para ir até lá, depois de primeiro ter gozado, ainda que por um pouco, da vossa companhia... Portanto, quando este assunto estiver resolvido, e lhes tiver entregado o produto desta colecta devidamente selado, partirei para a Hispânia, passando por junto de vós» ${ }^{12}$.

${ }^{9}$ Sobre esta questão, diz Rajak, 1984, 44: «a conventional motif, and... in spite of its length, its first person form and its abundance of nautical detail, that it need not be an authentic account.» Ver ainda Dauvillier, 1960, 3-26. O tema do naufrágio é também discutido por Légasse, 2000, 226, 231-233; Rougé, 1952, 316-325; Rougé, 1960, 193-203; Rougé, 1967, 237-247; Miles, Trompf, 1976, 259-267; Ladouceur, 1980, 435-449.

${ }^{10}$ Act 28,16. Sordi, 1960, 393-409, atrasa a datação deste processo em cerca de quatro anos.

${ }^{11}$ A referência de Sen., Ep. 5, 7, deve coincidir com a situação em que Paulo se encontrava: algemado por um braço ao de um soldado. Algumas interpretações dos Act 28,16, indicam que o apóstolo se teria instalado perto do campo pretoriano, na região nordeste da cidade. Não sendo esta propriamente uma zona onde se ateste uma forte densidade populacional judaica, note-se que ficava relativamente próxima da Subura, bairro popular, situado entre o Viminal e o Esquilino, onde se instalaram alguns dos judeus de Roma. É possível, por isso, que esses tivessem sido a estrutura de apoio do apóstolo. Rapske, 1994, 232-239, sugere que Paulo tenha ficado perto dos Castra Praetoria, em algum tipo de alojamento em insulae ou cauponae ou deuersoria. Nesse texto discutem-se as condições de vida na área da cidade em que Paulo se teria alojado. Sherwin-White, 1963, 108-119.

${ }^{12} \mathrm{Rm}$ 15,23-24, 28. A viagem à Hispânia é também aceite, entre outros, por Légasse, 2000, 242-243; Rougé, 1967, 237-247; Baslez, 1991, 2008, 210, 278-280. 
Estas palavras provam que haveria, da parte de Paulo de Tarso, intenção de se deslocar à Península Ibérica, eis Spanían, e que essa viagem teria tanta ou mais importância do que a que o levaria à capital do Império. Alguns autores chegaram mesmo a desvalorizar a missão romana e a fazer depender a sua interpretação da carta aos Romanos da missão hispânica, em que Paulo reclamaria para si um cumprimento profético em relação ao livro de Isaías, o que não deixou de originar críticas antagónicas ${ }^{13}$.

Mas terá Paulo de Tarso de facto vindo à Hispânia?

É bem provável que a prisão de Paulo corresponda a uma primeira estada do apóstolo em Roma, datada de entre 60 e 62. Esse é também o período em que se verifica a influência da imperatriz Popeia Sabina na corte imperial - a qual, como sabemos, era filo-judaizante -, e uma relação cordial com os judeus, como se percebe por figuras como Festo ou por situações como a da embaixada judaica a $\mathrm{Nero}^{14}$. Por essa época, o conflito judaico que haveria de se manifestar alguns anos mais tarde, estava ainda razoavelmente latente, em germinação. Por outro lado, a corte imperial vivia momentos de perturbação interna, de transformações, como a neutralização da factio de Agripina Menor, que anteriormente fora influente junto do imperador, e a ascensão de um novo partido, do qual se destaca precisamente a figura de Popeia. As boas relações com os judeus ter-se-iam traduzido na detenção do sedicioso Paulo de Tarso, que, à cautela, não foi eliminado de imediato. A condenação de Paulo far-se-á num segundo momento, em 67 d.C., na sequência dos graves conflitos com os judeus, na Judeia e talvez em Roma, estes derivados da oposição ao cristianismo emergente e de acontecimentos paralelos, como o incêndio de 64 , que acabaram por ser relacionados com os cristãos. A tolerância romana revelara-se incompatível com aquela «factio judaica» e tornou-se difícil poupar um cabecilha judeu à frente de um movimento messiânico. Talvez resida aí a explicação do tratamento dado a Paulo de Tarso durante a sua primeira prisão e a diferença de comportamento das autoridades, no momento da segunda, que acabou por conduzi-lo à morte.

$\mathrm{Na}$ verdade, desconhecemos o quadro político da libertação de Paulo em 62, havendo que considerar hipóteses como uma decisão imperial favorável ou uma amnistia com vista a libertar presos de delito menor ${ }^{15}$. É provável

${ }^{13}$ Esta leitura parte da premissa segundo a qual tanto a carta como a visita de Paulo aos cristãos em Roma teria tido como objectivo principal a missão hispânica e a angariação de apoios para essa viagem, através da plataforma romana. Ver Jewett, 2007, 70-80; Jewett, 1982, 5-20; Jewett, 1988, 142-161; Dewey, 1994, 321-349; Zeller, 1973, 38-77; Aus, 1979, 232-262; Murphy-O'Connor, 2008, 258-259. Contra esta tese, talvez demasiado redutora em relação à importância da comunidade romana, ver Das, 2008, 60-73.

${ }^{14}$ Murphy-O'Connor, 2008, 24, 43, 46; cf. Act 24,26-27 e J., AJ 20, 189-195.

${ }^{15}$ Murphy-O'Connor, 2008, 285-286. 
ainda que esta se tenha verificado na sequência de um vazio jurídico ou na falta de libelo acusatório que permitisse mantê-lo preso. $\mathrm{O}$ mesmo vazio que possibilitou a Paulo ficar em prisão domiciliária e não ser encerrado num cárcere. Isso significa também que nem a pressão dos judeus romanos ou sequer uma eventual intervenção de Popeia conseguiram manter o apóstolo na prisão.

É na sequência desta libertação que encontramos folga para a hipótese da deslocação de Paulo à Península Ibérica. Efectivamente, é bem possível que, depois da sua libertação, ele tenha encetado nova viagem. Alguns dos textos mais tardios dão como facto a deslocação à Hispânia. Esta é sugerida pela expressão «ter ido até aos confins do Ocidente» ${ }^{16}$ em Clemente Romano e referida explicitamente nos Acta Petri, que chamam mesmo ao apóstolo o medicus qui constituti in Spania sunt $t^{17}$. É evidente que poderá tratar-se do desenvolvimento apócrifo de um tema anunciado no texto bíblico, mas, como nota Murphy-O'Connor, a viajem a território hispânico não oferecia qualquer esforço excepcional, pois a península estava a uma distância relativamente curta do porto de Óstia: em quatro dias, o Apóstolo teria chegado às costas da Catalunha e em sete a Cádis. Além disso, a Hispânia estaria natural e claramente na mira da igreja emergente de Roma, enquanto território de evangelização ${ }^{18}$.

Mas que motivações e argumentos suplementares teria Paulo de Tarso para se deslocar à Hispânia?

Como tivemos já oportunidade de registar, os primeiros a converteremse à fé em Cristo provinham do judaísmo ${ }^{19}$. Eram esses quem preenchia o espaço que preparara a expectativa messiância que dava sentido ao Cristo e, como tal, seria daí que surgiriam os primeiros a reconhecerem que a promessa de Javé se teria cumprido. Os próprios apóstolos testemunham-no. Este facto é válido quer para o território de Israel e da Judeia, como para a diáspora, onde muitos dos filhos de Abraão se tinham instalado, na sequência de várias vicissitudes históricas. A leitura dos Actos dos Apóstolos confirma esta ideia, visto que, nas várias cidades por onde os apóstolos passam, é em primeiro lugar aos judeus e só depois aos não judeus que aqueles transmitem a Palavra. Ainda que muitos de entre os judeus recusem a chegada do Messias

${ }^{16}$ Clem. Rom. Cor 5, 7. A expressão está de acordo com o que Estrabão diz sobre a Península Ibérica, Geog. 3, 1, 4. Consideramos que esta expressão deverá ter uma conotação efectivamente geográfica e não simbólica, atendo-se a Roma, como alguns sugerem, e.g. Walker, 2008, 193, 200. Recordemos que a Hispânia, como a Gália, eram territórios já bem conhecidos no Império Romano do século I. Clemente, que escreve em 95, chega mesmo a falar de «deportação» e com base neste termo vários autores sugeriram que Paulo teria sido deportado para a Hispânia, Pherigo, 1951, 277-284; Bruce, 1977, 445-446.

${ }_{17}^{17}$ Acta Petri 1.

${ }^{18}$ Tese defendida por Murphy-O’Connor, 2008.

${ }^{19}$ Rodrigues, 2007. 
em Jesus, outros há, entre esses, que o aceitam. E apesar de Paulo surgir como um apóstolo especialmente vocacionado para as nações, certamente não desprezaria nenhuma ovelha que tivesse já lugar no rebanho original. Como em todos os locais até então visitados Paulo começava a evangelização pelos judeus, não há razões para pensarmos que não tivesse previsto o mesmo programa em relação à Hispânia, cujas comunidades judaicas teriam funcionado como motor e motivação da viagem ${ }^{20}$.

Emerge então uma outra problemática: havia judeus na Hispânia no tempo de Paulo de Tarso?

Alguns autores discordam da ideia, mas consideramos que a presença judaica na Península Ibérica no século I era um facto, que poderá ter funcionado como pólo de atracção para o projecto paulino ${ }^{21}$. Foram várias as razões para a diáspora judaica. A chegada à Ibéria inserir-se-á em algumas delas: exílio político, voluntário ou forçado; superpovoamento; atracção económica e cultural ${ }^{22}$.

\footnotetext{
${ }^{20}$ Segundo os textos bíblicos, a intenção evangelizadora de Paulo era a de pregar primeiro aos judeus e depois aos gregos, "primeiro o judeu e depois o grego», $R m$ 1,16. A este propósito, Santos Yanguas, 1982, 277, citou já Díaz y Díaz, 1967, 429, que diz: «También tendremos que plantearnos como condición previa el conocimiento de la existencia o no de comunidades judías, que existieron, sin duda, pero sobre cuyo número, densidad y localización carecemos de datos, pues en ellas era donde se realizaba siempre la primera siembra». Bowers, 1975, 390-402, discorda desta hipótese, considerando que a viagem de Paulo à Hispânia significava o esgotamento de comunidades judaicas a Oriente, até Roma, surgindo agora a possibilidade de evangelizar de raiz. Com García Iglesias, 1978, pensamos que esta tese é inconvincente. Bowers, porém, aceita a ideia de comércio entre Judeus e Iberos, o que, para ele, não implica a existência de comunidades enraizadas. Uma coisa, contudo, não exclui a outra. O mesmo Bowers salienta que não há evidência de comunidades judaicas na Península antes de 70 d.C. Pensamos que isso é um argumentum e silentio, que não invalida a sua existência. Há comércio e isso não implica que não houvesse comunidades também. De qualquer modo, Bowers crê que o desenvolvimento dessa comunidade tem as suas raízes nos acontecimentos de 70-135 d.C., sendo inverosímil a sua existência no tempo de Paulo. Um dos argumentos evocados é o texto de $A c t$ 2,9-11, onde se mencionam várias áreas do Império e não a Hispânia. Mas pensamos que esse não é um argumento que invalide a questão. Além disso, o passo de Actos deverá antes indicar que aquelas eram as áreas da diáspora mais conhecidas no Oriente e não porque Roma era o limite ocidental. Talvez se possa também deduzir a relação das comunidades hispânicas com Roma ou Cartago, onde poderão ter tido origem. A tese da chegada do cristianismo à Península no século I, ainda que não se afirme a evangelização de Paulo de Tarso como um dado histórico, é também admitida por Sánchez Salor, 1995, 165-181, e Sánchez Salor, 1986, 69. Nestes textos evoca-se a hipótese da lenda da evangelização peninsular por Paulo de Tarso, mas há que salientar que essa ideia não faz sentido, porque foi pronunciada pelo próprio Paulo na epístola aos Romanos, não se tratando de uma criação local. Smallwood, 1976, 2001, 122, também se mostra cautelosa na conclusão/hipótese da existência de comunidades judaicas na Hispânia no tempo de Paulo. Efectivamente, não há prova disso, mas cremos que se torna verosímil como hipótese de trabalho. Já Murphy-O'Connor, 2008, 285-290, considera que a densidade populacional judaica na Península Ibérica seria pouco significativa ou mesmo nula. Ver ainda, Jewett, 2007, 924, e Das, 2008, 61, que também consideram que a presença judaica na Hispânia nesta época seria pouco significativa. Sobre os Judeus na Gália, Blumenkranz, 1969, 162-174; Blumenkranz, 1971, 62-64. Uma síntese desta problemática pode ser lida em Rodrigues, 2006, 9-34.

${ }^{21}$ Ideia que defendemos em Rodrigues, 2006, 9-34.

${ }^{22}$ Ver Smallwood, 1976, 2001, 120-122.
} 
Baslez salientou inclusivamente que as gentes de Tarso, em particular, tinham já absorvido o hábito de visitar os territórios ocidentais ${ }^{23}$. A Hispânia, mais até do que a Gália, atraía comerciantes e intelectuais da Síria e da Palestina, desde os tempos da talassocracia fenícia, movidos pelas trocas e pelos cultos localizados no estreito de Gibraltar ${ }^{24}$. A tese parece-nos verosímil, tanto mais que isso poderá ter acontecido em vários momentos, inclusivamente a partir do século I a.C.: na sequência da chegada de judeus a Roma, após a intervenção de Pompeio na Judeia em 63 a.C., a partir de onde poderão ter chegado à Hispânia ${ }^{25}$; aquando da expulsão nos principados de Tibério $^{26}$ e de Cláudio ${ }^{27}$; no tempo da nova vaga migratória judaica, após a destruição do Templo por Tito ${ }^{28}$; ou ainda em outros momentos como os dos conflitos do tempo de Domiciano ${ }^{29}$ e da conjuntura que se seguiu aos acontecimentos de Bar Kokhba. Além disso, em Roma, a «fuga» para a Ibéria não era, de modo algum, novidade. Recordemos os casos de Sertório, de Marco Sálvio Otão e do sábio capadócio Apolónio de Tíana, os dois últimos no tempo de Nero e, portanto, contemporâneos de Paulo de Tarso ${ }^{30}$. Outro exemplo a destacar é o dos judeus Herodes Ântipas e Herodíade, exilados talvez na Hispânia, no tempo de Gaio Calígula. Este facto sugere também a possível existência de judeus no território, para junto dos quais o casal real poderia ter sido enviado (ou talvez não, e precisamente por isso aí exilado) ${ }^{31}$. De

${ }^{23}$ A este propósito, recordamos o livro de Jonas (Jn 1,3), datado dos séculos V-IV a.C. e com acção situada no século VIII a.C., em que, para fugir à missão ninivita, o profeta embarca em direcção a Társis, território que tem sido localizado na Península Ibérica.

${ }^{24}$ Baslez, 1991, 2008, 278; ver ainda o estudo de Gomes, 2011.

${ }^{25}$ Rodrigues, 2007, 241-242.

${ }^{26}$ García Moreno, 2005, 45. Sobre esta questão, ver Rodrigues, 2007, 395-398.

${ }^{27}$ Rodrigues, 2007, 501-516.

${ }^{28}$ Este momento parece ganhar consistência se se tiver em conta que, segundo as fontes talmúdicas, chegaram à Península, na sequência dos conflitos de 66-70 na Judeia, novos grupos de judeus palestinenses. García Iglesias, 1978, 47; García Moreno, 1994, 47-48; Rodrigues, 2007, 690-697. Havia famílias judaicas ibéricas, como os Aibalia, que reclamavam uma ancestralidade que remontava a este período, Rabello, 1980, 159.

${ }^{29}$ Rodrigues, 2007, 722-732. A situação no tempo de Domiciano é controversa. Santos Yanguas, 1982, 271-278.

${ }^{30}$ Plu. Gal. 20,1; Sert. 12, 2; Philost. V.Ap. 4, 37-38. Sem referir períodos anteriores, como o das Guerras Púnicas.

${ }^{31}$ Mantém-se, porém, a dúvida sobre se terá sido a Hispânia ou a Gália, o local do degredo. A escolha do local de exílio, contudo, terá advindo do factor distância, relativamente à Judeia. Segundo Josefo, Calígula considerou a ousadia do tetrarca um ultraje e, na sequência do acontecimento, baniu Ântipas e Herodíade para a Gália, ou para a Hispânia, onde, provavelmente, acabaram por morrer. J., BJ2, 181, na Hispânia; segundo AJ18, 252, o exílio foi na Gália, na cidade de Lugduno. As palavras de Herrmann, 1973, 55, quanto ao lugar do exílio, não nos parecem convincentes: «il s'agissait de Lugdunum Conuenarum, c'est-à-dire de Saint-Bertrand-de-Comminges, localité de Haute-Garonne, où on prétend posséder le tombeau d'Hérode et d'Hérodiade!» Deverá tratar-se de uma tradição de origem medieval, provavelmente derivada da leitura de Josefo, uma vez que Hier. Contra Vigilianum, ignora completamente o facto. De qualquer modo, o mais plausível é que o exílio se tenha verificado na Gália, porque Arquelau fora banido para Vienne, na Gália Narbonense, cidade das margens do Ródano, tal como Lugduno; cf. Str. 16, 2, 46; J., AJ 17, 344; 
qualquer modo, a continuidade das comunidades judaicas ibéricas deverá radicar neste contexto.

As palavras de Paulo à igreja de Roma fornecem ainda informação adicional acerca da mobilidade dos judeus do mundo romano, bem como de outros grupos: Febe que viaja de Cêncreas a Roma, com a missão de entregar uma carta; Priscila e Áquila, que saem de Roma no tempo de Cláudio e ali voltam no tempo de Nero, passando por Corinto e por Éfeso; Andronico e Júnia são «concidadãos» de Paulo; e o cômputo geral de cristãos mencionados, alegadamente conhecidos do apóstolo antes da sua visita a Roma, a que se juntam os exemplos de Simão Pedro e do próprio Paulo de Tarso. Assinale-se ainda a existência de embaixadas e acrescentem-se os interesses comerciais que decerto alguns judeus de Roma tinham ${ }^{32}$. Estes são factores que apontam para a mobilidade entre o Oriente e o Ocidente que explica a continuidade dos contactos com a cultura matricial judaica, a manutenção das redes de solidariedade étnico-religiosa, bem como a forma como funcionava a transmissão da informação relativa ao que ia acontecendo na Judeia e na Palestina em geral, e até o modo como se difundiram pelo Império as primeiras notícias acerca do movimento do Nazareno.

Há ainda um argumento adicional que passamos a explanar. No século VI, quando, na sequência da tomada de Jerusalém por Nabucodonosor II, o profeta Abdias redigiu o seu livro, referiu-se a Sefarad, o nome judaico da Hispânia:

«Os deportados deste exército, os filhos de Israel ocuparão as terras dos cananeus até Sarepta. Os deportados de Jerusalém que estão em Sefarad possuirão as terras do Négueb.» ${ }^{33}$

Partindo do princípio de que a Sefarad mencionada é a Península Ibérica, sugere-se a localização de comunidades hebraicas nesse território. Há dúvidas, todavia, acerca da identificação do topónimo, preferindo alguns associar esta Sefarad a Sárdis, na Ásia Menor ${ }^{34}$. Mas, no século I d.C., Jónatas ben Uziel,

BJ 2, 111; D. C. 55, 27; Eus. HE 1, 11, 3, onde também se indica Vienne; Crouzel, 1970, 275 280. Uma tradição, baseada num texto antigo (Profugus a facie Dei uixt in Tarracone et Emerita, et foede occiditur in Rhodio Lusitaniae oppido), assinala que Herodes teria morrido em território hoje português, e várias terras «reclamam» o lugar: Roda, Ródão, Redinha. A tradição popular, porém, crê tratar-se de Herodes-o-Grande, pela «fama» que o cristianismo lhe deu. Mas a origem da eventual lenda deverá remontar a Herodes Ântipas e a uma tradição medieval que relacionou o Ródano gaulês com o topónimo peninsular e se divulgou popularmente. Ver ainda Rodrigues, 2005, 417-431; Rodrigues, 2006, 9-34.

${ }^{32}$ O que explicará, e.g., a importante sinagoga de Óstia; ver Olsson, 2001. Sobre Áquila e Priscila, ver Barbero, 2001.

${ }^{33}$ Abd 20.

34 Neiman, 1963, 128-130. Alguns consideram bastante improvável que houvesse comunidades hebraicas em espaços tão distantes como a Península Ibérica, na sequência da dispersão causada pelos Babilónios. Isso não impediu, porém, que se desenvolvessem lendas 
comentador bíblico e discípulo do rabino Hilel, preferiu entender esta Sefarad como a Península Ibérica ${ }^{35}$. O que levou a essa exegese? Como nota García Moreno, e com pertinência, a explicação mais plausível para o facto é que a quantidade de judeus que habitava a Península no tempo de ben Uziel, e não no de Abdias, seria de tal forma significativa, que se justificava então esta interpretação. O que equivale a dizer que, no tempo de Paulo de Tarso, haveria efectivamente implantação judaica expressiva na Hispânia.

Deparamos assim com uma série de argumentos que tornam verosímil a hipótese da vinda de Paulo à Hispânia. Acrescente-se ainda que se nenhum documento prova de forma inequívoca que a viagem efectivamente aconteceu, também não dispomos de nenhum que demonstre o contrário ${ }^{36}$. Apenas conhecemos factos que nos permitem equacionar cenários e nós, como outros, consideramos essa hipótese com um elevado grau de plausibilidade. A sua admissão permite-nos explicar inclusivamente a razão por que Paulo de Tarso não teria sido implicado no processo que se desenrolou em Roma contra os cristãos, na sequência do grande incêndio de 64 d.C., e ter morrido três a quatro anos após a perseguição neroniana ${ }^{37}$. Em 64, ano em que tudo leva a crer que a percepção romana do cristianismo terá sido pertinentemente renovada, o apóstolo deveria estar de novo no Oriente, regressado do desaire hispânico.

Efectivamente, o facto de Paulo se ter deslocado ao território ibérico não significa que a sua missão evangelizadora tivesse tido êxito. Ao que parece, não o teve mesmo, pois nada aparenta ter resultado dessa visita. Não conhecemos, por exemplo, nenhuma epístola «aos Tarraconenses», «aos Emeritenses» ou «aos Olisiponenses», além de que, como notou M.-F. Baslez, que considera este um projecto «possible et même vraisemblable», não existe qualquer tradição local que conserve a memória de uma missão paulina hispânica ${ }^{38}$. Mas o carácter factual da viagem é verosímil. Para justificar a ausência de tradições na memória colectiva e de outra documentação referente a essa deslocação sugeriu-se

que relacionassem as comunidades sefarditas com a diáspora consequente das conquistas de Nabucodonosor II, como testemunham os escritos de Isaac Abravanel, García Iglesias, 1978, 36-37; Beinart, 1962, 1-32; Beinart, 1992, 15-17.

${ }^{35}$ Laredo, 1944, 351-352.

${ }^{36}$ Meinardus, 1978, 61-63. A omissão da viagem hispânica nos Actos poderá simplesmente explicar-se pelo problema da datação dos mesmos ou com o desaire da missão, que não interessaria ao autor do texto bíblico.

${ }^{37}$ Murphy-O'Connor, 2008, 373, que afina estas datas e atrasa a viagem à Hispânia em cerca de dois anos. Tratámos esta questão em Rodrigues, 2007, 609-637, 643-657.

${ }_{38}$ Ao contrário da Gália, onde, curiosamente, nada aponta para que tivesse sido visitada pelo apóstolo. Como refere esta autora, o cristianismo terá atingido a Gália através de evangelizadores romanos por via alpina e não por via mediterrânea. Baslez, 1991, 2008, 280. Este argumento, contudo, não é, quanto a nós válido para negar a vinda de Paulo à Península Ibérica. Na verdade, o apóstolo terá passado por vários locais dos quais não possuímos qualquer notícia (de novo um argumentum e silentio). De igual modo, Paulo não terá escrito cartas a todas as comunidades que conheceu. 
o fracasso da missão ibérica. Com efeito, como nota Murphy-O'Connor, a viagem terá sido «um fiasco» e ao apóstolo teria bastado um Verão para o perceber $^{39}$. Em grande parte, o desaire terá derivado do desconhecimento praticamente generalizado do grego e da difusão maioritária do latim, que convivia com os inúmeros dialectos locais, nas terras do Ocidente. Tenha-se ainda em conta que, à época, a Península Ibérica seria o mais romanizado dos territórios sob controlo romano ${ }^{40}$. Estas condições teriam levado o apóstolo a abandonar o projecto e a desistir de novos ensaios em espaços adjacentes, como a Gália ${ }^{41}$. Verificado o falhanço, Paulo deverá ter regressado ao Egeu, com o objectivo de «edificar, exortar e encorajar as igrejas que fundara» ${ }^{42}$.

Depois da grande perseguição de 64-65, notícias preocupantes ter-se-ão espalhado pela bacia mediterrânea oriental. A situação previa que, à custa de uma política de terror baseada no martírio, facilmente se erradicaria a comunidade cristã da Urbe, o que poderá ter «forçado» Paulo a regressar à capital ${ }^{43}$. Aí terá sido de novo preso, desta vez encarcerado ${ }^{44}$, e envolvido no processo que terminou com a execução do apóstolo. Mas esta é já uma outra problemática. Deixemos claro, todavia, que o tema aqui abordado está longe de ser uma questão pacífica, independentemente da interpretação geral que se faça da Epistola aos Romanos, não faltando quem discorde da tese de que a viagem de Paulo de Tarso à Hispânia se tenha efectivamente concretizado e que tudo não tenha passado de uma mera declaração de intenções ${ }^{45}$.

${ }^{39}$ Murphy-O'Connor, 2008, 287. Este autor considera que Paulo terá protagonizado um processo conflituoso com a igreja emergente de Roma, precisamente pela concessão da evangelização da Hispânia, onde poderia afirmar o seu protagonismo no âmbito da religião que então começava a propagar-se.

${ }^{40}$ Eventualmente, poder-se-ia considerar que a língua não deverá ter sido um verdadeiro obstáculo, pois o latim poderia ter sido usado para a evangelização. Como Paulo escreveu em grego, porém... Por outro lado, isso poderá apenas expressa a importância da língua franca do Mediterrâneo oriental.

${ }^{41}$ Clem. Rom. 5, 5-7; Acta Petri 1, 3; Murphy-O'Connor, 2008, 364. De qualquer modo, o cristianismo acabou por se difundir nestes territórios.

${ }^{42}$ Murphy-O'Connor, 2008, 367.

${ }^{43}$ Murphy-O’Connor, 2008, 296-298.

${ }^{44} 2 \operatorname{Tm} 2,9$.

${ }^{45}$ Walker, 2008, 193, 200. 


\section{Proposta de cronologia da vida de Paulo de Tarso ${ }^{46}$}

c. 6 a.C.:

33 d.C.:

34 d.C.:

34-37 d.C.;

37 d.C.:

37 d.C.:

45-46 d.C.:

46-48 d.C.:

48-50 d.C.:

50-51 d.C.:

51 d.C.:

51-52 d.C.:

52-54 d.C.:

54-55 d.C.:

55 d.C.:

55-56 d.C.:

56 d.C.:

59 d.C.:

60-62 d.C.:

62 d.C.:

62-65 d.C.:

65 d.C.:

67 d.C.: nascimento

conversão

viagem a Petra

viagem a Damasco

$2^{\text {a }}$ visita a Jerusalém

viagem à Síria e à Cilícia

viagem a Antioquia

viagem e ministério na Galácia

viagem e ministério na Macedónia

viagem e ministério em Corinto

$3^{\text {a }}$ visita a Jerusalém e organização do concílio

viagem a Antioquia

viagem a Éfeso

viagem à Macedónia

viagem à Ilíria

$2^{\mathrm{a}}$ viagem a Corinto

$3^{\mathrm{a}}$ visita a Jerusalém

estada em Jerusalém e viagem a Cesareia

$1^{\text {a }}$ viagem e estada em Roma como prisioneiro

viagem à Hispânia

viagem pelo Egeu

regresso a Roma

morte em Roma

${ }^{46}$ Ver Murphy-O'Connor, 1996. Propostas alternativas podem ser lidas em Donaldson, 2001, 1071, 1073. 


\title{
A Lusitânia no tempo de Paulo de Tarso: TÓPICOS DO MUNDO PROVINCIAL EM FASE PÓS-TIBERIANA
}

\author{
Amílcar Guerra \\ Universidade de Lisboa \\ Centro de Arqueologia da Universidade de Lisboa \\ Centro de História da Universidade de Lisboa
}

Correspondendo ao amável convite que me foi dirigido pelos meus colegas e amigos que organizaram este oportuno encontro, decidi afrontar um tema que, em boa verdade, só marginalmente se relaciona com a personagem carismática que esta iniciativa celebra. Não tendo orientado a minha investigação para domínios relacionados com essa figura, pensei que seria de qualquer modo vantajoso abordar uma realidade coeva, ainda que manifestamente desligada da acção do apóstolo, mas directamente vinculada com o território em que nos encontramos. Tendo em conta o núcleo de questões que me tem ocupado, em especial nos últimos anos, considerei mais oportuno contribuir com uma síntese sobre a evolução político-cultural da Lusitânia numa fase coetânea da vida de Paulo de Tarso, coincidente com um momento decisivo da formação dessa província romana.

Neste sentido, defini um arco cronológico para o tema a tratar situado entre o reinado de Calígula e o fim da dinastia júlio-cláudia, coincidente grosso modo com o período em que o apóstolo exerceu a sua missão, em terras longínquas. Trata-se, pois, de delinear o perfil da Lusitânia pós-tiberiana, abarcando um conjunto de imperadores de que as fontes literárias latinas e a historiografia moderna construíram uma imagem pouco favorável, marcada por episódios que revelam comportamentos estranhos, por vezes mesmo bizarros e ridículos. De facto, se percorrermos algumas das páginas que se escreveram sobre Calígula, Cláudio e Nero, em especial a incontornável obra de Suetónio, não podemos evitar a ideia de que certamente terá sido muito atribulada a vida da província nesse período tão conturbado pelas intrigas palacianas em Roma e pela inaptidão dos seus governantes.

Por isso, talvez pareça estranho que, na história da Hispânia antiga, esses sinais tais negativos de descontrolo do poder e de perda de valores na urbe, não tenham aparentemente deixado marcas, nem apresentem uma correspondência com o que sabe a respeito do percurso histórico, nessa fase, destas terras à beira do Oceano. Um conjunto de circunstâncias pode justificar esta discrepância. Por um lado, a perspectiva de Suetónio em relação à dinastia júlio-cláudia e em especial a alguns dos seus membros (Calígula e Nero são os mais visados), que denegriu o carácter destas personagens, ainda que a acção de cada um deles contenha muitos aspectos positivos e a organização do império assegurou, 
mesmo ao longo deste período, uma estabilidade que não corresponde à imagem da política romana que se poderia eventualmente deduzir da obra desse historiador. Como amplamente se sublinha na tradição historiográfica, a simpatia deste pela dinastia que se lhe seguiu deve estar na origem de uma sistemática postura hostil em relação aos imperadores que a precederam, forma de dignificar os príncipes que o protegeram. Alguma razão havia, de resto, para esta adesão de Suetónio aos Flávios, responsáveis pela resolução de um período de grande instabilidade político-militar, que se traduziu na sucessiva deposição dos imperadores Galba, Otão e Vitélio, num curto período.

Por isso, como se compreende facilmente, nem tudo são desgraças neste período Hispânia júlio-cláudia. De resto, mesmo que estas tenham ocorrido, tal como muitos dos aspectos positivos, encontram-se remetidas para o amplo território das memórias (talvez definitivamente) apagadas. Na realidade, a informação de que dispomos para essa fase no contexto do Ocidente peninsular é bastante circunscrita e referente especialmente a alguns acontecimentos marcantes, onde muitas vezes eventuais episódios negativos se perderam no sinuoso processo de transmissão. A imagem dos imperadores que chega a esta paragens, transmitida essencialmente por agentes de uma administração já bastante organizada, mais preocupada em veicular uma imagem de coerência e estabilidade do império, não repercute eventuais irresponsabilidades dos principais intervenientes da cena política da urbe.

Contamos, acima de tudo, com elementos que reflectem a vida nas cidades hispânicas, entidades com o seu percurso próprio e onde os reflexos do que se passa na longínqua capital do império chegam muito atenuados. Tornase, naturalmente, bastante complicado identificar muitos dos problemas que a sociedade hispano-romana enfrentou nesse momento e, ainda que tenham tido algumas consequências menos positivas, os seus efeitos não deixaram geralmente marca na literatura da época. Resta-nos, por isso, recolher algumas outras informações, necessariamente muito fragmentárias, que de algum modo permitem forjar uma ideia muito parcelar da evolução da Lusitânia ao longo do período indicado. Tendo em conta a natureza dos dados, onde a documentação epigráfica e arqueológica detêm um peso considerável, apresentaremos alguns aspectos da situação político-administrativa, que em boa parte são indissociáveis das vertentes social e cultural.

Para não se correr o risco de dispersar a análise por cada uma das diferentes entidades que constituíam a província, escolheram-se alguns casos paradigmáticos, que permitem, em boa medida, imaginar o que se poderia ter passado nos restantes. Ainda que cada cidade tenho o seu percurso específico, muitos aspectos são certamente comuns, em especial em determinadas áreas, com bastantes afinidades que radicam em tempos passados, mas que a presença romana não elimina. 
Naturalmente que a capital da província não pode comparar-se com a maioria das cidades da Lusitânia e, pelo seu desenvolvimento, patentearia um nítido contraste em especial com algumas estruturas urbanas da área mais setentrional, a respeito das quais por vezes se conhece pouco mais que o seu nome - como acontece, por exemplo, com as remotas Arabriga e civitas dos Coilarni, cujas localizações ainda não se estabeleceram com segurança. Relativamente a outras, todavia, a investigação encontra-se mais avançada, permitindo, com alguma extrapolação, traçar um perfil mais completo das cidades desta remota província.

$\mathrm{O}$ processo de desenvolvimento de núcleos do interior como a civitas Igaeditanorum, Ammaia, da cidade romana a que correspondem as ruínas da Bobadela (a cidade dos Tapori, na mais fundamentada das propostas) ou mesmo da civitas Cobelcorum, contribuem para a construção de um quadro cada vez mais completo, ainda que se lamente sistematicamente a exiguidade de dados de que dispomos, um tópico comum a boa parte da investigação. Algumas cidades do litoral, beneficiadas por uma posição estratégica mais favorável, como Olisipo e Aeminium, contribuem para delinear uma outra vertente do mundo urbano da Lusitânia. Analisam-se, portanto, aqui alguns casos paradigmáticos, todos eles já bem conhecidos, que de alguma forma ajudam a construir uma imagem das cidades provinciais, na sua coerência e ao mesmo tempo na sua diversidade.

\section{Aritium Vetus e o juramento dos seus habitantes ao imperador Calígula.}

Neste fase, terminado o período tiberiano, já se consolidou na Lusitânia a imagem de uma província completamente estável e pacificada. A organização administrativa estabelecida por Augusto funciona regularmente há décadas, o que foi permitindo a progressiva integração das populações num âmbito cultural de matriz itálica.

A imagem do imperador reinante, mesmo quando eventuais intrigas palacianas ou perturbações psíquicas ${ }^{1}$ afectam os destinos da Urbe, não parece reflectir-se negativamente no governo das províncias, muito menos na gestão das diferentes comunidades locais, bastante autónomas no que

1 Tem-se discutido de modo particularmente intenso a eventual loucura de Calígula diagnosticada com segurança por alguns estudiosos (Sandison, 1958, esp. 208, sugere que ele foi acometido de uma encefalite epidémica; para Benediktson 1989, p. 370-375 sofria de determinada uma forma de epilepsia), mas que tem sido com alguma frequência questionada. Pelo menos tem-se afirmado, na moderna historiografia, uma tendência para aceitar que o imperador Gaio evidenciava alguns problemas de saúde e de estabilidade emocional, mas que as fontes, em geral adversas, tendem a ampliar estes problemas, transformando-os em graves anomalias psíquicas (sobre esta perspectiva pode ver-se p. ex. Barrett, 1989, 213-216; ultimamente Sidwell, 2010, sublinha a ausência de qualquer fundamento que dê consistência à sua presumível loucura, considerando-a historicamente insustentável). 
respeitava ao seu funcionamento e organização. A figura do princeps, todavia, não deixou de constituir um elemento unificador do império, mesmo no caso de uma personagem que, como Calígula, se revela tão controversa, pelo menos a acreditar por alguns notícias transmitidas pelas fontes. As cidades homenageiam, na figura do imperador que não conhecem a não ser por eventuais representações que alguns espaços públicos acolhem, a excelência de Roma e compreendem as vantagens que o seu domínio confere a cada uma das entidades autonomamente constituídas.

Não surpreende, pois, que algumas delas declarem explicitamente a sua conformidade com a integração na esfera de Roma e o seu desejo de voluntariamente assumirem as consequências que daí decorrem. Deste modo se justifica que, numa imitação de tradições e modelos romanos, mas também num espírito de fides, com ampla tradição na Hispânia², declarem, de acordo com um formulário bem conhecido, a sua submissão ao imperador e à sua família, com todas as suas implicações. O caso mais paradigmático revela-se num texto inscrito numa placa de bronze, hoje infelizmente desaparecida, pelo qual o oppidum de Aritium Vetus presta juramento ao imperador Calígula.

Trata-se de um modelo de juramento público, certamente bastante difundido no mundo antigo e de que há abundantes testemunhos literários ${ }^{3}$. Ao contrário, os vestígios epigráficos equivalentes são bastante raros por todo o império, registando-se sete casos em todo o mundo romano, dois dos quais na Península Ibérica. Para além do texto originário de Aritium Vetus, é conhecido um outro documento proveniente dos arredores de Sevilha e respeitante a um iusiurandum do senatus populusque Co[nobariensisum], entidades que devem associar-se à antiga cidade correspondente, com muita probabilidade, aos vestígios subsistentes no Cortijo de las Palmillas, Cabezas de S. Juán (Sevilha) ${ }^{4}$. Sendo datável de 6-5 a. C., este constitui-se como o mais antigo documento do género ${ }^{5}$, englobando a jura pela saúde e honra do imperador Augusto e dos

${ }^{2}$ V. Étienne, 1958, 59-66, 75-80.

3 Além da entrada correspondente do Dizzionario de De Ruggiero (De Ruggiero; E. Passerini, 1961, 277-282, para este tipo de juramentos, 280-282), a obra primordial de estudo deste tipo de documentos é a de A. von Premerstein (1937, esp. 26ss.), seguida de Herrmann, 1968; mais recentemente alguns destes documentos são analisados em Cancik, 2003. Sobre o documento ariciense em especial v. d'Ors 1953, 21-24; Encarnação, 1984, 703-706, 752-753; 2007, 356-358. Até ao momento identificaram-se textos similares, englobados sob a desginação de iusiuranda, em Samos (Herrmann, 1960; 1968, 122 ss.), Assos, na Tróade (IGR IV, 251), Phazimon/Neapolis, Paflagónia (Cumont, 1901, 27-31), Palaipaphos, Chipre (Mitford, 1960), Sestinum, Itália (CIL XI, 5998a; AE 1991, 649) e Conobaria, na Bética (González, 1988; 1990, 175-178).

${ }^{4}$ González, 1990, 175; para uma ampla fundamentação desta identidade v. Beltrán , 1999.

${ }^{5}$ A uma data similar deve pertencer o de Samos, sendo igualmente augustano, de 3 a. C., o de Phazimon/Neapolis. O juramento cipriota integra-se no reinado de Tibério, enquanto os mais tardios são precisamente os dois que envolvem a figura de Calígula, ambos do ano 37, como se disse. A cronologia do texto fragmentário de Sentinum, na Úmbria, não é consensual, sendo 
seus dois netos, Gaio e Lúcio. O modelo e ponto de partida para este tipo de manifestações, repetidas ao longo de um período bastante circunscrito ${ }^{6}$, deve residir no juramento a Octaviano, do ano 32 a. C., a que se alude nas Res gestae Divi Augusti ${ }^{7}$.

Estes dois testemunhos hispânicos são bem distintos, tanto no que respeita à datação como no que concerne ao seu texto, ainda que, numa observação mais geral, os conteúdos de ambos sejam equivalentes. Numa primeira parte estabelece-se o objecto do juramento, que, no caso de Aritium, começa por definir as obrigações assumidas de uma forma muito mais circunstanciada que no documento bético. Aí cada um se compromete a ser «inimigo dos que souber serem inimigos de César Augusto Germânico»; a perseguir por terra e por mar, não desistindo até lhe aplicar o merecido castigo, todo aquele que trouxer perigo à saúde do princeps, afirmando «que não considerarei mais caros os meus filhos que a sua saúde».

Numa segunda parte enunciam-se as penalidades que se aceitam pelo incumprimento da palavra proferida: «que Júpiter Óptimo Máximo, o divino Augusto e todos os demais deuses imortais me privem, a mim e aos meus filhos, da pátria (patria), da saúde (incolumitas) e de todos os bens (fortunae omnes).» Se a inclusão do deus supremo constitui uma referência tópica dos juramentos ${ }^{8}$, e não apenas dos que pertencem a esta categoria, ao contrário a inclusão específica doo divino Augusto repete-se unicamente no ius iurandum de Assos', precisamente o que se cumpriu na mesma data.

No final do texto identificam-se, para dos cônsules epónimos, como elemento datante, os magistrados locais, patenteando uma onomástica inequívoca da sua origem hispânica. A designação da sua função, abreviada como MAG, não tem ainda um desenvolvimento consensual, oscilando as propostas entre mag(istrati) e mag(istri). De qualquer modo, não restam dúvidas de que essa é a designação que identifica a estes aglomerados que na terminologia pliniana se registam como oppida stipendiaria, comunidades

geralmente (Herrmann, 1968) colocado a par destes dois últimos. No entanto, a confrontação com o iusiurandum bético levou a que se sustentasse a sua integração no período augustano (Wardle, 1997, 610, n. 5).

${ }^{6}$ Os documentos datados (e só o de Sestinum não fornece indicadores cronológicos seguros) integram-se num arco cronológico compreendido entre 5 a. C. e $37 \mathrm{~d}$. C.

7 Res gestae 25.2: «Prestou-me juramento, de espontânea vontade, toda a Itália e reclamou-me como seu chefe na guerra que venci em Áccio; nos mesmos termos juraram as províncias da Gália e da Hispânia, África, Sicília e Sardenha.» (Cfr. De Ruggiero; Passerini, 1961, 281; Rosado Martín, 2010). V. Tb. Suet. Aug. 17.2. Aparentemente esta aproximação decorre igualmente de um texto de Díon Cássio (57.3.2), no qual um juramento a Tibério se põe em paralelo com esse modelo augustano (Osgood, 2006, 360).

${ }^{8}$ De facto Júpiter/Zeus está presente nos iusiuranda de Aritium (Iupiter Optimus Maximus) Assos (Zeus Soter), da Phazimon/Neapolis (Zeus).

${ }^{9}$ Neste a divindades referidas são Júpiter Conservador, o divino Augusto e a «virgem santa

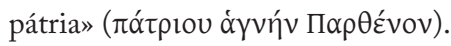


locais não privilegiadas e tributárias. À frente delas se encontra precisamente essa magistratura composta por quatro indivíduos que naturalmente assume um papel fundamental nestas circunstâncias de grande relevância política. E provavelmente são eles que assumem, em nome da colectividade cívica, as obrigações inerentes a este compromisso público.

Tem-se discutido até que ponto estes episódios corresponderiam a iniciativas das próprias comunidades e em que medida os juramentos proferidos representam verdadeiramente a vontade destas populações. Naturalmente, os poucos documentos que se conhecem, geográfica e cronologicamente muito diferenciados, apresentam todos peculiaridades inequívocas. Todos obedecem, porém, a modelos que conjugam a vertente jurídica com a religiosa, seguindo uma longa tradição romana. Uma indicação concreta de Suetónio a respeito destes juramentos, permite pensar que os seus formulários consagrados eram alterados pontualmente também por vontade do imperador. Diz Suetónio, Calig. 15, que Calígula alterou os termos do juramento, associando o nome das irmãs ao do seu. É sintomático, a respeito das fórmulas que este texto assumia, que o documento epigráfico de Aritium Vetus corresponda precisamente à versão anterior a este alteração ${ }^{10}$.

Neste caso concreto, há alguns elementos que nos permitem compreender as razões que podem ter levado a uma difusão de uma iniciativa neste contexto histórico. O juramento dos Aricienses, certamente reproduzido em outras comunidades, pode ter sido consequência de uma pressão política com origem na própria urbe. Roddaz ${ }^{11}$ sugere que a forma como se promovem estas iniciativas, destinadas a reforçar os laços entre as gentes do império e o princeps, se devem, neste caso, à actuação do prefeito do pretório, Macro, que teria pressionado os governadores das províncias no sentido de sua ampla concretização.

O juramento, datado com precisão do dia 11 de Maio de 37 da nossa era, corresponde, portanto, aos primeiros meses do reinado de Calígula, iniciado no dia 18 de Março do mesmo ano. Constata-se, desde logo, que o acto público é contemporâneo do de Assos, uma vez que regista os nomes dos mesmos cônsules (ainda que este último não indique o dia exacto em que teve lugar o acto sagrado). Se tivermos em conta que uma situação similar, isto é, o facto de respeitar aos momentos iniciais do reinado, ocorre com o ius iurandum de Palaipaphos (Chipre), correspondente ao ano de $14 \mathrm{~d}$. C. e prestando juramento a Tibério recém investido, pode facilmente deduzir-se que estas manifestações

${ }^{10} \mathrm{O}$ texto por essa razão alterado e que Suetónio reproduz é o seguinte: Neque me liberosque meos cariores habeo quam Gaium habeo et sorores eius. Compare-se este com a fórmula transmitida no documento epigráfico de Alvega: /.../ ne[que] liberosque meos eius salute cariores habebo /.../.

${ }^{11}$ Roddaz, 2002, 214. 
tendem a associar-se aos momentos específicos de ascensão de um novo princeps. Desta forma, as comunidades locais de todo o império, não só afirmam a sua lealdade para com o novo chefe do império, como reiteram nesse acto a sua fidelidade a Roma ${ }^{12}$. Ainda que algumas indicações levem a presumir a sua renovação anual, a natureza destes actos, mais formalmente registados num suporte típico de muitos dos documentos jurídicos, seria distinta da sua eventual reedição com carácter regular.

De qualquer modo, ambos têm algo que ver com o culto imperial e as suas diversificadas realizações. Os templos nos espaços públicos, quer especificamente dedicados à figura dos imperadores, que às divindades capitolinas e outras, convertidas em «augustas», a organização de um complexo e completo sacerdócio a eles especificamente devotado, as celebrações religiosas em sua honra (jogos, sacrifícios, cortejos), tudo isso se associa a esta demonstração de fides, contribuindo para a coerência do império e para uma mais sólida integração das comunidades que promovem estas iniciativas.

\section{O desenvolvimento da civitas Aeminiensis e o seu forum.}

Se quisermos tomar como termo de comparação o mundo oriental, em concreto a Ásia Menor, na qual Paulo formou a sua personalidade, as realidades urbanas da Lusitânia nesta fase são, de uma forma geral, muito distintas. $\mathrm{Na}$ maioria dos casos o seu processo de desenvolvimento ainda há pouco começou e está agora a implantar-se um modelo urbanístico novo, que de alguma forma procura assemelhar-se a paradigmas que no Oriente são de há muito conhecidos e aplicados e se vão imitando por todo o império.

Por via da regra, esse processo mimético implantou-se ou foi desenvolvido especialmente a partir do principado de Augusto, com maior ou menor amplitude e rapidez consoantes as áreas, levando à construção de edifícios públicos de diversa natureza, uma das manifestações emblemáticas dos novos tempos. Um dos espaços mais característicos dessas realidades urbanas politicamente autónomas era o forum, com as estruturas a ele associadas, que se assumiam precisamente como o símbolo maior da vida pública e da afirmação da autonomia dessas comunidades cívicas ${ }^{13}$. Não surpreende, por isso, que a partir dos inícios do principado, coincidindo com a criação

${ }^{12}$ É claro, deste modo, que o compromisso assumido implica uma submissão, que para além do próprio imperador empossado, se estende a todos os seus descendentes, seguindo-se uma fórmula muito comum em actos jurídicos similares, e habitual nos pactos de hospitalidade e de clientela.

13 A apreensão de alguns aspectos concretos desse processo encontra-se actualmente facilitada pela recente edição de um volume dedicado especificamente aos fora da Lusitânia (Nogales, 2010), resultado de uma oportuna iniciativa promovida pelo Museo Nacional de Arte Romano, para onde remetemos. Para uma síntese da questão, no que especialmente se refere ao território português v. Fabião, 2006, 55-60. 
da província da Lusitânia, o desenvolvimento de programas urbanísticos ganhe uma maior dinâmica, justificada pela nova organização política e administrativa provincial. Neste contexto, compreende-se que os núcleos principais, especialmente aqueles que já aparecem sob este imperador com um estatuto privilegiado, iniciem obras públicas com certa dimensão, sinal claro dessa sua mais elevada condição.

São bem conhecidas as carências da investigação arqueológica nesta vertente $^{14}$, o que naturalmente limita de forma muito substancial a localização no tempo do lançamento destas iniciativas, bem como das sucessivas alterações que as afectaram. A título exemplificativo, constata-se que o desconhecimento quase completo a respeito dos complexos forenses afecta quase todas as cidades lusitanas de estatuto colonial, à excepção de Augusta Emerita ${ }^{15}$. Do mesmo modo, de entre as que Plínio regista como municípios ou oppida de direito latino (Olisipo, Salacia, Ebora e Myrtilis) nenhuma proporciona elementos que permitam esclarecer essa mesma questão ${ }^{16}$. Presume-se, na maioria dos casos, o seu arranque no principado de Augusto, associando muitas vezes as obras à promoção jurídica dessas comunidades cívicas, a qual a partir de Octaviano recebe um forte impulso, mas os dados materiais que sustentam esta convicção são ou escassos, ou inexistentes.

De qualquer modo, uma intervenção urbanística augustana envolvendo a construção do forum encontra-se documentada em Conimbriga ${ }^{17}$ e parece provável na civitas Igaeditanorum ${ }^{18}$, comunidades que se constituem como casos excepcionais, num domínio em que as incertezas são tantas. Todavia, tendo em consideração o período que interessa a este contributo - como se disse, o da dinastia júlio-cláudia em fase pós-tiberiana, alguns elementos se podem coligir sobre o desenvolvimento de edifícios públicos.

${ }^{14}$ V. mais recentemente Fabião, 2010, 345-346.

${ }^{15}$ Reportamo-nos, em primeiro lugar, ao conjunto que é conhecido como o forum colonial, no qual se integrava a chamado templo «de Diana», cuja origem augustana é normalmente aceite (Mateos, 2001, 191-196; Alvarez, Nogales, 2003). Mais discutida é a natureza e a cronologia do chamado «forum provincial», a respeito se admite uma fase de construção tiberiana, mas se discute a existência de algumas das suas componentes já em fase precedente. Sobre as questões respeitantes a estes edifícios públicos, entre a abundante bibliografia destacam-se, para além das obras atrás citadas, Alvarez, Nogales, 2006; Mateos, 2006; Nogales, 2009; Ayerbe, Barrientos, Palma, 2009.

${ }^{16}$ Esta questão encontra-se amplamente tratada nas actas do recente encontro sobre o tema (Nogales, 2010), sendo especificamente abordada no contributo de Carlos Fabião (2010, esp. 354-355).

17 Alarcão, Étienne, 1977, 27-39.

18 Para a cronologia augustana das primeiras estruturas forenses igeditanas v. Mantas, 1988; Alarcão, 1990, 52; Mantas, 2010, 181, tomando-se como sugestivo o facto de o cidadão emeritense Q. Tálio ter oferecido um orarium à comunidade, no ano 16 a. C. Sobre as recentes escavações arqueológicas que, no essencial, corroboram esta cronologia v. Carvalho, 2009, 122124. 
Ao contrário do que se regista em algumas cidades de desenvolvimento mais precoce, nas quais uma actividade construtiva de amplas dimensões se regista sob Augusto, em outros casos, parece evidente que as mais importantes realizações em contexto urbano se atestam a partir desta fase. E ainda que, no estado actual dos nossos conhecimentos, também os dados a respeito dos edifícios públicos sejam ainda muito limitados, em alguns casos as intervenções arqueológicas parecem ter conduzir já a alguns resultados animadores ${ }^{19}$. Esta realidade é aqui ilustrada com o exemplo da cidade que subjaz à actual Coimbra.

Da antiga Aeminium conhece-se acima de tudo o imponente criptopórtico sobre o qual, segundo uma já consagrada interpretação, assentaria o forum, espaço em que se realizaram vários trabalhos arqueológicos e a respeito do qual contamos já com abundante bibliografia ${ }^{20}$. As condições particulares inerentes ao desenvolvimento deste espaço ao longo do tempo limitam a compreensão do monumento e da sua história, mas mesmo assim o conjunto constitui uma das estruturas forenses da Lusitânia mais profundamente investigada.

De uma forma geral há uma coincidência em atribuir a construção do edifício eminiense ao período cláudio ${ }^{21}$, estrutura que viria substituir outra da mesma natureza, mas de menor porte, que dataria de fase augustana ${ }^{22}$. Além disso, chegou a ser sugerido que o conjunto monumental teria sido projectado por Gaio Sévio Lupo, figura notabilizada como o construtor do farol romano designado como a «Torre de Hércules», n’A Coruña ${ }^{23}$. Infelizmente a cronologia desta estrutura de apoio à navegação é controversa ${ }^{24}$. Estas hesitações da investigação

${ }^{19}$ Nestas circunstâncias assume sempre uma posição particular o exemplo de Conimbriga, em que o forum augustano, remodelado em período flávio (Alarcão, Étienne, 1977, 85-111), forneceu um paradigma que se aplicou, por vezes abusivamente, a outras situações.

${ }^{20}$ Especialmente Oleiro, 1955-56; Oleiro, Alarcão, 1973; Mantas, 1992; Carvalho, 1998; Alarcão 2008; Carvalho et alii, 2009; Alarcão et alii, 2010.

${ }^{21}$ Esta atribuição cronológica foi em primeiro lugar sugerida por Vasco Mantas (1992, 505506), considerando em particular a descoberta no sítio de bustos de Agripina e de Lívia. A proposta cronológica foi seguida por P. Carvalho (1998, 180, 184 e ss.), que sugeriu a associação desta obra a uma modificação do estatuto do lugar, decorrente da sua instituição como civitas (Carvalho, 1998, 181) ou à concessão de um estatuto municipal de direito latino ao oppidum (Carvalho, 1998,181-184). Na sequência de trabalhos arqueológicos, considera confirmada esta datação, apontando a construção do forum e todo o conjunto adjacente para os meados do séc. I d. C. (Carvalho, 1998, 180; Alarcão et alii, 2010, 87).

22 A existência em Aeminium de uma estrutura forense anterior, do início do principado, é sustentada especialmente em Alarcão et alii, 2009, 32, 59-65, sublinhando-se aí os escassos indícios que dele subsistiram e as dificuldades em determinar a sua primitiva estrutura.

${ }^{23}$ V. Alarcão 1988, 184, e Carvalho, 1998, 202. Não há, objectivamente, qualquer elemento que permita sustentar esta hipótese, que depende da cronologia a atribuir ao famoso farol, a qual pouco adianta na resposta a esta questão (v. infra).

${ }^{24}$ Uma antiga tradição, que remonta pelo menos a Cornide (1792, 7-10), atribui a sua construção a Trajano, fundando-se em boa parte na ideia de que o monumento não poderia ser anterior a Vespasiano, uma vez que o arquitecto responsável pela obra se apresentaria, para este estudioso setecentista, como Aquiflaviensis, designação que não poderia ser anterior a esse imperador flávio. No entanto, a convicção de que o farol seria obra desse período foi-se mantendo, 
recomendam, por isso, alguma ponderação quando se trata de associar esse mesmo arquitecto a uma obra realizada na sua cidade de origem ${ }^{25}$, uma vez que essa hipótese assenta em várias conjecturas e numa única certeza: o origo eminiense de Gaio Sévio Lupo.

A confirmar-se a ligação entre esta personagem e o projecto inicial do forum teríamos aqui um sugestivo exemplo do progresso destas comunidades e da projecção que algumas das suas figuras adquiriram em domínios especializados. Disporíamos, ao mesmo tempo, de um exemplo de acesso dos habitantes destes aglomerados aos privilégios da cidadania romana, o sinal mais evidente de uma plena integração social e política.

O estudo planimétrico do que resta da construção romana e o que se sabe a respeito de algumas das suas áreas adjacentes permitiram estabelecer algumas particularidades do edificado e delinear as soluções concretas encontradas pelos construtores para a implantação deste espaço forense numa área algo acidentada. Em primeiro lugar sublinha-se a imponência do criptopórtico em que a praça do forum assentava, precisamente um dos seus aspectos mais peculiares, identificado de forma extensiva na sequência das escavações aí realizadas entre 1955 e $1962^{26}$. Esta estrutura de suporte, necessária devido às características do espaço escolhido para a implantação do complexo, apresentaria uma fachada voltada a poente que atingiria cerca de $29 \mathrm{~m}$, circunstância que lhe conferiria o estatuto de uma das mais elevadas construções do género na Península Ibérica, constituindo por si só uma construção com um forte impacto na paisagem ${ }^{27}$. Os estudos recentes, baseados em trabalhos arqueológicos realizados entre 1992 e

mesmo após a correcção da leitura da epígrafe. Hübner insiste uma proposta cronológica desse mesmo período, apontando-a aos inícios do séc. II d. C. (ad CIL II, 2559). São estas considerações que continuam a servir de referência aos estudiosos posteriores, os quais, de uma maneira geral, se limitam a remeter para estas auctoritates (v.g. García y Bellido, 1955, 14; Hutter, 1973, 2). A situação altera-se com os primeiros trabalhos arqueológicos realizados à volta da Torre. As antigas escavações de L. Monteagudo, cujos resultados foram divulgados no jornal El Ideal Galego de 20.9.1945, proporcionaram alguns vestígios materiais, nomeadamente sigillata integrável nos séc. I-II d.C. O largo âmbito cronológico apontado não alterou substancialmente os dados do problema, mas permitiu recuar o seu limite. Como sublinha Hauschild (1977, 139), é legítimo estabelecer uma relação entre os vestígios da ocupação identificados e a construção do farol, a qual, portanto, se deveria situar nesse arco temporal mais amplo que o postulado pela investigação precedente. As escavações mais recentes, levadas a cabo em 1992 e 1993, também não lograram responder a essa interrogação fundamental, uma vez que só muito parcialmente incidiram sobre estratos de período romano, tendo proporcionado objectos situáveis entre os séc. II e IV da nossa era (Bello Diéguez, 1997). Apesar da ausência de uma fundamentação estratigráfica, mas tomando como base algumas particularidades construtivas, os responsáveis por estes trabalhos retomam as propostas anteriores, segundo as quais a Torre de Hércules se teria erigido num qualquer momento situado nos séculos I e II d. C. (Caballero, Latorre, 1999, 508).

${ }^{25}$ Hauschild, 1977, 139.

${ }^{26}$ Oleiro 1955-56; Oleiro, Alarcão, 1973.

${ }^{27}$ Carvalho et alii, 2010, 70. 
199728, permitiram delinear com mais precisão a disposição destas estruturas, atribuídas ao período cláudio, pondo em evidência algumas peculiaridades do pórtico de dois pisos que circundava a praça, da configuração desta e dos principais edifícios que a integravam.

A circunstância de uma epígrafe recolhida aquando das escavações de 1955-62 ser dedicada Genio Baselecae veio dar mais tarde suporte à convicção de que o complexo forense incluiria este tipo de edifício ${ }^{29}$, que ocuparia todo o topo norte do conjunto arquitectónico. $\mathrm{O}$ espaço em que esta se integraria contemplava uma estrutura de configuração absidal, marcada de forma clara nos restos arquitectónicos subsistentes ${ }^{30}$. Esta, por sua vez, seria ladeada por dois compartimentos rectangulares, os quais se interpretam como espaços de apoio a funções públicas de natureza administrativa, nos estudos mais recentes ${ }^{31}$. Neles se apresenta, igualmente, uma proposta de reconstituição do edifício basilical, com colunata interna de duas naves com capitéis jónios e uma estrutura apainelada suportada por pilares de madeira ${ }^{32}$, a qual, todavia, se pode revelar algo controversa.

Na sua concepção geral, o complexo apresentar-se-ia como um grande átrio coríntio, constituído por um pórtico de dois pisos, ganhando uma complexidade arquitectónica, uma imponência e uma originalidade consideráveis ${ }^{33}$. No âmbito da Lusitânia, onde a consolidação da cultura romana se acentua nesta fase, uma obra deste tipo integra-se num processo de desenvolvimento de estruturas onde se associam a monumentalidade e utilidade, tendo em vista as funções políticas que estas novas entidades cívicas vão progressivamente assumindo.

Aeminium, pela sua estratégica posição de cidade de fácil acessibilidade marítima, situada na primeira importante travessia do Munda e ponto de passagem de uma via estruturante de ligação entre sul e norte, corresponderia certamente a um núcleo de grande desenvolvimento. $\mathrm{O}$ novo espaço agora criado respondia igualmente às necessidades decorrentes do desenvolvimento económico, constituindo-se como um espaço de apoio a esta vertente da vida urbana. Não surpreende, por isso, que um primitivo espaço forense de origem augustana justificasse nesta altura uma intervenção que lhe conferisse maior dimensão e outra dignidade, adaptando-se, assim ao percurso da cidade e às suas exigências.

${ }^{28}$ Uma síntese dos resultados destas intervenções pode ver-se especialmente em Carvalho et alii, 2010.

${ }^{29}$ Le Roux, Fabre, 1971, 117-121. Bairrão Oleiro (1955-56, 156), ao dar a primeira notícia desta inscrição, não estabeleceu de imediato uma ligação entre o Génio aí referido e um edifício basilical, tendo-se mesmo considerado que o espaço disponível seria demasiado estreito para integrar praça, pórtico, templo e basílica (Oleiro, Alarcão, 357).

${ }_{30}$ Carvalho, 1998, 187; Alarcão et alii, 2009, 49, 51, 66-67.

31 Alarcão et alii, 2009, 67.

32 André, 2009, 101.

${ }^{33}$ Alarcão et alli, 2009, 37 


\section{O voto anual a Cláudio e a promoção de Ammaia.}

As comunidades cívicas da Lusitânia, neste período, seguem o seu percurso de forte desenvolvimento, como se pode ver com o exemplo precedente, manifestações concretas de uma estratégia romana de transformação das suas províncias de acordo com o modelo romano. Outra das formas de esta tendência se manifestar reside numa vertente muito particular, relacionada com o culto imperial, em que também o juramento de Aritium Vetus a Calígula, a que acima se aludiu, se pode inserir ${ }^{34}$. Mas um dos exemplos que, neste plano, se revela mais sugestivo, e por isso insistentemente, referido diz respeito ao voto anual de Ammaia a Cláudio, atestado numa conhecida epígrafe ${ }^{35}$ originária de S. Salvador de Aramenha, lugar de assentamento dessa cidade romana ${ }^{36}$.

A decisão de levar a cabo esse compromisso regular, da responsabilidade da própria civitas, evidencia a solenidade, a relevância do acto e a sua natureza oficial, aspectos que se manifestam na enunciação da titulatura imperial completa e na referência ao legado imperial na província, no caso L(ucius) Calventius Vetus Carminius, bem como aos dois magistrados locais. Sobre estas últimas personagens - Proculus Pisiri f(ilius); Omuncio Cilai f(ilius - deve ter pesado a obrigação de executarem a resolução tomada pela assembleia.

Ainda que não se identifiquem como tal, tem-se admitido pacificamente que exerceriam o cargo por norma designado nas inscrições como MAG., abreviatura cuja resolução não é consensual (v. supra). No entanto, a documentação similar relativa a estes cargos, que engloba já um abundante repertório de nomes, tal como as duas personagens locais aqui referidas, evidenciam uma onomástica que não deixam dúvida sobre a sua situação de peregrini. Ora esta situação revela uma realidade político-administrativa correspondente a comunidades não privilegiadas ${ }^{37}$. A situação, no entanto, irá

${ }^{34}$ Étienne, 1958, 435-436.

${ }^{35}$ AE 1950, 217 - Tib(erio) Claudio / Caesari Aug(usto) / Germanico imp(eratori) IIII / pont(ifici) max (imo) trib(unicia) pot(estate) / IIII (quarta) co(n)s(uli) III (tertium) desig(nato) IIII (quartum) / civitas Ammaiensis / ex voto annuo / L(ucio) Calventio Vetere / Carminio leg(ato) Tib(erii) Claudi(i) Caesaris Aug(usti) / Proculo Pisiri f(ilio) / Omuncione Cilai(i) f(ilio). "A Tibério Cláudio César Augusto Germânico, imperador pela quarta vez, pontífice máximo, com o poder tribunício pela quarta vez, cônsul pela terceira vez, designado pela quarta. A civitas de Amaia dedicou-lhe este monumento na sequência de um voto anual, sendo legado de Tibério César Augusto Lúcio Calvêncio Velho Carmínio e (magistrados) Próculo, filho de Pisiro, e Omuncião, filho de Cilaio».

${ }^{36}$ Vasconcelos, 1913, 5-9; Jalhay, 1947, 630-632; Nony, 1968, 60-61; Encarnação, 1984, 676-677, 751-752; Ribagorda, 1994; Guerra, 1996, especialmente 14-17; Mantas, 2000, 391395; Mantas, 2010, 171-175.

${ }^{37}$ Em sentido contrário, a epigrafia revela que magistrados de cidades dotadas do estatuto municipal ostentam, por via da regra, a marca característica da sua condição de cidadãos romanos, reflectida na onomástica. 
mudar num período relativamente curto, como se deduz de uma outra epígrafe proveniente do mesmo lugar.

Trata-se de um documento indissociável deste, não apenas pela sua ligação a Cláudio, mas pela importância que assume na história da cidade, uma notável e não menos discutida inscrição em que se homenageia $P$ (ublius) Cornelius $M$ acer $^{38}$. O primeiro aspecto relevante decorre da circunstância, raramente documentada na epigrafia, de este ter recebido, a título individual, a cidadania romana, precisamente do imperador Cláudio. Mas confere-lhe igualmente uma dimensão rara a circunstância de aquele se apresentar como quaestor e duunvir, cargos que têm naturalmente que ver com a sua participação nos dois níveis das magistraturas locais ${ }^{39}$.

Apresenta-se como uma questão pacífica o facto de cada uma delas ser exercida por dois indivíduos, numa periodicidade anual, e se alinharem hierarquicamente, cabendo ao duunvirato a posição proeminente. Estas considerações derivam do que a epigrafia patenteia com frequência a respeito das estruturas políticas dos municípios no âmbito da Lusitânia, como em outras províncias. A situação de Ammaia difere das outras realidades lusitanas a quem foi conferido esse privilégio pelo facto de o cargo municipal que Macro exerceu antes do duunvirato ser o de quaestor ${ }^{40}$, enquanto nos nos restantes casos conhecidos ser o de aedilis.

As duas epígrafes a que se aludiu têm em comum, portanto, uma referência ao imperador Cláudio, mas documentam uma transformação na estrutura política da cidade, uma vez que mag(istrati ou istri) referidos na inscrição mais antiga foram substituídos, pelo menos por questores e duúnviros. Por essa razão se aceita geralmente que entra a elaboração de uma e outra se tenha registado concomitantemente a uma alteração do seu estatuto jurídico, que se reflectiu na sua promoção a município.

${ }^{38}$ CIL II 159; IRCP 618, cujo texto é normalmente interpretado do seguinte modo: [P(ublio) C]ornelio / Q(uirina) Macro / [vi]ritim a divo / Claudio civit[ate] / donato / [qu]aestori II[vir(o)] / [ex te]stamento ip[sius] / [Qui] ntius Ca[p]ito / [c]um Q(uinto?) f(ilio?) h(eredes?) p(osuerunt?). «A Públio Cornélio Macro, da tribo Quirina, a quem Cláudio concedeu a cidadania romana a título pessoal, questor, duúnviro. Por disposição testamentária do próprio, Quíncio Capitão, juntamente com o seu filho Quinto, seus herdeiros, colocaram este monumento.» 24.

${ }^{39}$ Sobre a possibilidade de ser magistrado de uma outra cidade v. Salinas; Rodríguez, 2000,

${ }^{40}$ Através de algumas leis municipais da Bética, sabemos que os quaestores são igualmente magistrados das cidades, juntando-se aos duúnviros e edis. A sua função, de acordo com a Lex Irnitana, 20, respeitaria essencialmente a administração do erário municipal, de acordo com os duúnviros: /.../eisque pecuniam communem municipum eius municipii exigendi erogandi custodiendi atministrandi dispensandi arbitratu IIvirorum ius potestasque esto - «e que eles (questores) tenham o direito e o poder de, sob parecer dos duúnviros, reclamar, gastar, guardar, administrar e distribuir o dinheiro comum dos munícipes deste município». Apesar de a sua existência estar registada na legislação, não se documentam, contudo, na epigrafia dessa província (Abascal, Espinosa, 1989, 129). 
Cornélio Macro recebeu a cidadania a título individual e não per honorem, isto é, por via dos exercícios dos cargos referidos, tendo-os assumido, portanto, quando já possuía a condição de ciuis romanus (IRCP, p. 748; Le Roux, 1990, p. 44; Stylow, 1995, p. 108; Faria, 1999, p. 30). A epígrafe em questão corresponde já a um momento em que o estatuto da cidade teria mudado e, por essa razão, seria importante estabelecer a cronologia da epígrafe. Infelizmente apenas se pode estabelecer que ela respeita ao período neroniano ou a uma fase posterior, podendo corresponder de igual modo às duas principais posturas que a investigação tem assumido.

Por um lado, os defensores de uma promoção cláudia ${ }^{41}$, assentam a sua posição na especial relação que a cidade manifesta ter com o princeps, tomando-a o voto anual que lhe dedica como uma das suas manifestações, circunstância que poderia estar na origem de uma benesse de natureza política, correspondente precisamente à sua elevação a um estatuto privilegiado. Nessas circunstâncias, uma das figuras mais notáveis do lugar, Públio Cornélio Macro, teria sido um dos primeiros a ser investido das magistraturas locais, sendo homenageado alguns anos mais tarde, já depois do falecimento de Cláudio.

Não subsiste qualquer dúvida, tendo em conta especialmente estes dois documentos, de que Ammaia se encontra estreitamente ligada a este imperador e que daí deve ter resultado algum benefício para a comunidade. Por isso, excluindo a possibilidade de vir a receber um estatuto privilegiado sob Nero, por falta de fundamento e paralelos para tal, preferiram atribuir essa medida ao imperador que o precedeu. Todavia, algumas objecções e levantaram a esta hipótese.

Desde logo contrariava uma proposta de McElderry segundo a qual não existiriam na Hispânia municípios inscritos na tribo Quirina cuja constituição fosse anterior a Vespasiano ${ }^{42}$. Contra esta hipótese opunha-se precisamente o exemplo de Ammaia e mais concretamente o caso de Cornelius Macer, a quem Cláudio concedera o civitas, inscrevendo-o nessa tribo, a mesma a que pertencia esse município. Os defensores desta perspectiva preferiram contestar o pressuposto de McElderry, admitindo, em consequência, que durante este período se adscreveram comunidades cívicas privilegiadas tanto à Claudia como à Quirina.

Alguns autores, porém, afastaram esse argumento, propondo um outro desenvolvimento para a identificação da personagem em causa, considerando preferível que o Q, que se interpretava desde Hübner ${ }^{43}$ como Q(uirina tribu), correspondesse, na realidade, a Q(uinti) [f(ilius)]. Esta perspectiva abriu caminho aos que se sustentam que uma mudança de estatuto jurídico ocorre

\footnotetext{
${ }^{41}$ Alarcão, 1988, 49; Mantas, 1993, 524; Carvalho, 1998, 183; Schattner, 1998, 114, n. ${ }^{\circ} 134$.

${ }^{42}$ McElderry, 1918, esp. 68; sobre esta questão v. também Mantas 2000, 410-411.

${ }^{43}$ CIL II, 159.
} 
só em período flávio ${ }^{44}$, na sequência da concessão do direito latino a toda a Hispânia por parte de Vespasiano ${ }^{45}$. Neste caso, conjectura-se que a epígrafe em causa se deve situar em período flávio, num momento em que Ammaia teria de recente recebido deste imperador uma elevação a um estatuto que atingiu, nesta fase, um número significativo de cidades hispânicas.

Mesmo resolvendo esta questão a favor da Quirina, alguns autores admitem que essa circunstância não altera os dados do problema, uma vez que se atestaria igualmente pelo menos uma outra promoção cláudia, registada na Mauritânia Cesariense, cujos cidadãos são inscritos nessa mesma tribo ${ }^{46}$. Teria, isso sim, relevância a cronologia da inscrição, pela circunstância de reflectir um momento em que se teria já registado a promoção de $\mathrm{Ammaia}^{47}$. A sua atribuição a Vespasiano teria a vantagem de não recorrer a uma explicação de natureza excepcional, para a qual não haveria, de resto, a necessária fundamentação. Deste modo, afigura-se realmente preferível, do ponto de vista metodológico, manter o princípio da prevalência da regra geral, enquanto não se confirmar, de forma inequívoca, o contrário.

Não restam dúvidas, em qualquer caso, que a comunidade amaiense se mantém bastante activa e pode ter obtido, com o patrocínio de algumas personalidades importantes da capital provincial ${ }^{48}$, benesses de natureza política, que a própria cidade agradecia com uma dedicação particular ao imperador e aos seus representantes. Constata-se, pelo menos, a evidente projecção que assumem, na vida pública da província alguns dos seus cidadãos mais notáveis, a ponto de justificaram uma honra excepcional. Ammaia revelase, no contexto das cidades lusitanas, como mais um exemplo de sucesso no percurso, nem sempre fácil, de adaptação da comunidade local às novas realidades. A projecção das suas elites compaginam-se com um desenvolvimento económico que conhecemos apenas parcialmente, mas no qual desempenham um papel relevante aos explorações auríferas ${ }^{49}$, bem documentadas do ponto de vista arqueológico e o cristal de rocha, a que enciclopédia pliniana alude, recompilando uma informação de Cornélio Boco, um autor lusitano que se integrará possivelmente no período que aqui se analisa ${ }^{50}$.

${ }^{44}$ Stylow, 1995, 107-108; Mayer, Rodà, 1998, 245-246; Faria, 1999, 30-31; a promoção flávia da cidade decorre igualmente de Andreu, 2004, 356.

${ }^{45}$ Mais recentemente, Andreu, 2004, 356.

${ }^{46}$ Castillo, 1988, 237; Faria 1995, 30.

${ }^{47}$ Faria, 1995, 30 postula uma cronologia flávia, tanto para a inscrição como para o estatuto municipal da cidade.

${ }^{48}$ Vasco Mantas $(2000,402)$ sugere que entre estes se encontraria precisamente o legado do imperador na província referido na inscrição, L(ucius) Calventius Vetus Carminius, o que se manifestaria na presença de alguns Carminii entre a população da cidade.

${ }^{49}$ Sobre estas explorações v. Vermeulen, Taelman, 2010, 318-321; sobre as minas de cristal de rocha v. Guerra, 1996, 12; Vermeulen, 2010, 321-322.

${ }^{50}$ Subsiste alguma incerteza a respeito da cronologia deste autor. A antiga ideia de Mommsen 


\section{Os Coilarni e as delimitações territoriais no reinado de Cláudio.}

A adicionar a estas duas vertentes distintas das transformações concretas registadas na Lusitânia sob Cláudio, assinala-se, por fim, uma outra, que se prende com as delimitações dos espaços atribuídos às entidades políticas constituídas. O processo de integração da Lusitânia reflecte-se também nestes vestígios, especialmente documentados pela epigrafia, com os quais se continua a tarefa de delimitação territorial de comunidades cívicas da província, dando sequência a uma acção que se leva a cabo especialmente ao principado de Augusto, a acreditar na documentação subsistente ${ }^{51}$.

A sua manifestação mais típica deste ordenamento consiste nos termini augustales, monumentos que assumem formas não muito diversificadas, com os quais se marcavam em concreto os limites ou confrontações das diferentes entidades $^{52}$. Desta forma o princeps configurou, de modo rigoroso e estável, o espaço provincial e as suas unidades, ao mesmo tempo que se lançavam as bases de uma orgânica administrativa, uma das marcas mais características do domínio romano.

Revela-se particularmente elucidativa, no âmbito cronológico em análise, uma acção conduzida sob Cláudio, atestada por um monumento epigráfico encontrado em Goujoim (Armamar), um marco terminal que se deve encontrar na posição original, apontando, com a designação dos populi em faces opostas, as vertentes que correspondiam às entidades dos Coilarni e dos Arabrigenses.

O texto da inscrição, com alguns problemas pontuais de leitura, permitiu interpretações muito distintas, com implicações no que respeita à identificação do imperador e, em consequência, à sua cronologia. As leituras inicialmente

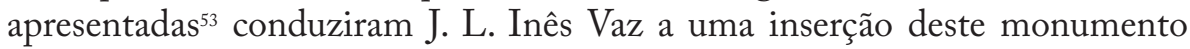

(1895, XIV) de que se deveria situar no reinado de Cláudio, tem sido reiterada por diversos autores, ainda que os mas cautelosos prefiram evitar uma alusão a esta proposta algo incerta.

${ }^{51}$ Os termini augustales deste período, centrados especialmente em torno a 6-5 a. C., foram identificados nas localidades de Peroviseu, Fundão (Vaz, 1977, 27-29; HEp 14, 424); Salvador, Penamacor (CIL II, 460); Guardão, Tondela (AE 1954, 88; Alföldy, 1969, 134; Guerra, 1998, 166-168) e U1, Oliveira de Azeméis (AE 1958, 10), todos estes, portanto, em território português; na província de Salamanca registaram-se achados idênticos em Yecla de Yeltes, Ledesma e Ciudad Rodrigo, neste último local dois monumentos similares; ultimamente identificou-se um outro (HEp 13, 242, com correcção e comentário de J. Gómez-Moreno), da referida cronologia, em Jarandilla de la Vera, Cáceres, com o qual se delimitava o território dos Avile(n) ses dos desconhecidos Pobri[...] e de outra entidade que não é possível identificar.

${ }^{52}$ Para a diversidade deste tipo de vestígios no âmbito peninsular v. Le Roux, 1994; Ariño et alii, 2004, 23-32; 39-40.

${ }^{53}$ As duas leituras iniciais, algo distintas, são as seguintes: Vaz, 1979, 133-138 [Ti(berio) Claudio Cae]/ [sa]ri Aug(usto) Ge[r] (manico) / [p]ont(ifici) max(imo) tr[i]/[b]u(nitia) potestate V/I (sexta) p(atri) p(atriae) co(n)s(uli) III (tertium) ter/mi(nus) aug(ustalis) // inte[r] Coila[r](nos) // i(n)ter Raba...; Silva, 1985, 222-224 (= HEp 1, 694) reconstitui as duas primeiras linhas como [Imp(eratore) Nerua Cae]/[s]are Aug(usto) Ge[r] (manico) e, além disso, corrigiu, na última 
no principado de Cláudio ou Nero e Armando Coelho a optar pela atribuição a Nerva (97-98 d. C.). Tal como já tinha sugerido Le Roux e se procurou demonstrar anteriormente ${ }^{54}$, o monumento corresponde ao primeiro dos imperadores referidos, sendo o monumento datável do início do seu principado, mais concretamente de um momento compreendido entre 1 e 25 de Janeiro de 43, embora anómala a indicação do sua segunda aclamação imperial, quando deveria ser indicada a terceira.

É muito provável que esta importante acção delimitadora exercida sobre o território dos povos da região se relacione igualmente com um outro terminus augustalis subsistente na capela de S. Pedro de Balsemão (Lamego) ${ }^{55}$, no qual se registam os mesmos elementos da titulatura imperial da inscrição a que antes se aludiu, mas com o numeral correcto da aclamação imperial. Embora não se indiquem, neste último caso, os povos cujos territórios se definiam com este marco, creio não ser ousado pensar que entre eles se deveriam incluir, com maior probabilidade, os Coilarni $i^{56}$.

Estes vestígios epigráficos demonstram, portanto, que a importante tarefa de organização territorial não se esgota no período augustano, mas continua, em contexto e com uma extensão que não é possível determinar, em fase mais avançada. De quanto é possível estabelecer com os dados concretos, no principado de Cláudio este tipo de acção é levado a cabo ${ }^{57}$ pelo menos no que respeita ao território dos Coilarni e, naturalmente, das entidades que com eles confinam. Mas, como se referiu, a existência de um terminus coetâneo em território próximo dos limites entre Lusitania e Baetica, confirma que este tipo de iniciativas atingiu maiores dimensões.

A associação destas acções à autoridade do princeps reflecte a elevada importância no plano político e administrativo que elas assumiam, intervindo certamente nelas o representante do imperador na província, o seu legado,

linha, o nome dos Arabr(igenses). Como procurei demonstrar (Guerra, 1998, 115-116), estas interpretações devem ser corrigidas para [Ti(berio) Claudio Cae]/[s]are Aug(usto) Ge[r] (manico) I [p]ont(ifice) max(imo) tr[i]/bu(nicia) potes(tate) II (secunda) imp(eratore) / II (iterum) p(atre) p(atriae) co(n)s(ule) III (tertium) ter/mi(nus) aug(ustalis) // [i]nter/Arabr(igenses)// inte[r] Coila[r] $n(o s)$.

${ }^{54}$ Le Roux, 1994, 40-41, 50; Guerra, 1998, 115-116.

55 A proveniência original deste monumento é desconhecida, devendo presumir-se que se encontra deslocado. Para tal contribui o facto de nessa mesma capela se recolhe uma ara dedicada a Júpiter Óptimo Máximo pela $c$ (ivitas) C(olarnorum), seguindo uma interpretação de Inês $\operatorname{Vaz}(2007 ; 2010,319)$ que me parece plenamente justificada.

${ }^{56}$ V. Guerra, 1998, 116. Alarcão, 2004, 333 sustenta que se esse terminus se reportaria igualmente aos Arabrigenses. Que os Coilarni deveriam ocupar o território da região de Lamego é aspecto que não levanta grande controvérsia, embora sejam incertos os limites do seu território. João Luís Inês Vaz (2007; 2010, 319-320), sustentou que esta cidade beirã deveria corresponder precisamente à sede dessa antiga civitas lusitana.

${ }^{57} \mathrm{Na}$ localidade Magacela (Badajoz), já no conventus Cordubensis, mas junto ao limite com a Lusitânia, foi identificado outro terminus deste imperador (CIL II, 2364; CIL II²/7, 963). 
como se verifica explicitamente no caso do marco de Guardão, Tondela. As comunidades locais afirmam deste modo uma consciência cada vez mais forte da sua autonomia, enquadrando-se ao mesmo tempo numa estrutura mais vasta onde a legalidade e o direito assume um papel relevante. A noção de fronteira juridicamente delimitada constitui, nesta perspectiva, uma novidade que chega com a romanidade e à qual estas cidades aderem, manifestando a sua capacidade de adaptação aos novos tempos.

\section{A remodelação do teatro de Olisipo sob Nero.}

Revelam-se igualmente, na documentação epigráfica, algumas das manifestações de prosperidade que marcam a vida urbana no período de Nero. Sem dúvida que um dos exemplos mais conhecidos diz respeito à cidade de Olisipo e em particular a um dos seus edifícios públicos mais emblemáticos, o teatro. Desde o período de reconstrução de Lisboa na fase pós-terramoto que se conhecem duas epígrafes que dão conta do excepcional revelo que assumiu, na vida da cidade, um próspero e influente liberto, Gaio Heio Primo ${ }^{58}$.

Juridicamente impedido, dada a sua origem servil, de exercer as mais elevadas magistraturas no âmbito do seu município, esta personagem atingiu o mais alto cargo a que poderia aspirar na sua condição. Foi membro destacado do colégio dos augustais, tendo recebido a honra de este cargo lhe ter sido concedido a título perpétuo, menção que assumia um especial valor honorífico. Os seus filhos e alguns dos seus libertos sublinharam, com uma homenagem de que nos ficou a inscrição, a notoriedade desta figura tão prestigiada, à qual associaram os seus nomes, de forma perene.

Gaio Heio Primo pode apresentar-se como um dos exemplos de que uma antiga condição de escravo não impedia a construção de colossais fortunas, no extremo do mundo conhecido. $\mathrm{O}$ mundo hispânico deste, partilhando muitos aspectos de uma cultura de matriz itálica, oferece amplas hipóteses de forjar a prosperidade e modificar de forma substancial a sua condição social. Mesmo que marcados pelo estigma de uma anterior vida servil, aos libertos abriam-se, pelo, menos teoricamente, as possibilidades de construção de uma fortuna rápida, mas que só alguns, naturalmente, logravam conseguir. Seria provavelmente essa circunstância, a de cada homem livre ter iguais hipóteses de

${ }^{58}$ Sobre esta personagem e o seu acto benemerente v., em particular, Fernandes, 2005. É relativamente pacífico que o nomen desta personagem decorra da presença em Olisipo de famílias de origem itálica. O gentilício, não muito frequente (na Hispânia aparece unicamente em Olisipo e numa epígrafe de Archena, Múrcia, CIL II, 3541), encontra-se bem representado em Roma e em algumas regiões da Itália antiga. Associa-se a abastadas e influentes famílias da Campânia (Caldelli, 2002, 226, n. 14), tendo-lhe sido atribuída uma origem Osca (Camodeca, 1982, 105; Fernandes, 2005, 33). 
aumentar consideravelmente o seu património, mas só alguns o conseguirem com sucesso, que deveria concitar a admiração por estas figuras.

Por isso, Gaio Heio Primo, pelo prestígio que dessa circunstância advinha, podia encarar a possibilidade de se colocar num plano similar ao das eminentes figuras locais, imitando os actos benemerentes que as elites municipais exerciam, em especial na sua condição de magistrados. Deste modo, o rico liberto olisiponense decidiu contribuir para que um dos monumentos públicos da cidade se tornasse mais esplendoroso, apondo a sua firma numa obra de particular notoriedade, o teatro, que já deveria acusar, nesta altura, o peso dos anos ${ }^{59}$. A marca da sua generosidade ficou assinalada numa inscrição monumental que se patenteava no púlpito do edifício, com a qual, segundo a interpretação tradicional, se homenageava o imperador em título, Nero ${ }^{60}$. Ao mesmo tempo indicava-se explicitamente em que tinha consistido a sua acção em benefício da comunidade cívica: oferecer proscaenium et orchestram cum ornamentis.

Quem observa a monumental inscrição, gravada em grossas placas de colorações fortes (vermelhão e cinzento) não tem dúvidas sobre o forte impacto da sua intervenção. $\mathrm{O}$ teatro sofreu, portanto, importantes benfeitorias a nível do seu revestimento «marmóreo» ${ }^{61}$, particularmente nas suas partes mais visíveis, $o$ proscénio e a orquestra ${ }^{62}$. É possível que a iniciativa do liberto endinheirado não fosse propriamente um modelo da mais fina sensibilidade. Os contrastes entre vermelho e cinzento não parecem resultar numa conjugação particularmente feliz, mas a uma acentuada tendência para o exuberante, muito típica da época - e que o próprio princeps ostenta de modo superlativo, pelo menos a acreditar nas fontes - não deveriam causar estranheza estas conjugações mais chocantes. Afirma-se, naturalmente, um gosto mais popular nestas obras em que regularmente se juntava a comunidade, a quem não passava por certo despercebida a acção generosa do augustal perpétuo.

${ }^{59}$ Considera-se que a primitiva traça do edifício deveria remontar ao período augustano (Hauschild, 1994, 65-66; Fernandes, 2007, 36-37).

${ }^{60}$ Esta opinião radica na leitura dos que, no séc. XVIII, observaram o sector correspondente ao início da inscrição de que a referência ao imperador se encontrava em dativo. Uma proposta de leitura alternativa foi sugerida por A. Stylow (2001, 145), segundo a qual a alusão ao princeps se faria em ablativo, assumindo a epígrafe, em primeiro lugar, uma notação cronológica. Naturalmente, não se perde, mesmo neste caso, uma implícita homenagem a Nero.

${ }^{61} \mathrm{Na}$ realidade, a pedra utilizada nas obras de beneficiação é, por via da regra, o calcário. Devemos, no entanto, ter em conta na língua latina o termo marmor tinha uma acepção muito mais ampla da que actualmente possui, correspondendo genericamente a toda a pedra dura. Deste modo se entende igualmente que esta obra se integra nos frequentes programas de «marmorização» que caracterizam esta fase de prosperidade de muitas cidades hispânicas.

${ }^{62}$ Para a natureza concreta das transformações que o teatro olisiponense sofreu nesta fase $\mathrm{v}$. em especial Hauschild, 1990;1994, 65-66; Fernandes, 2007, 32-38. 
Não são, portanto, apenas as elites políticas que marcam os tempos que correm, mas também personagens socialmente menos consideradas, tornando patente assim que o mundo romano oferece oportunidades a todos, independente da sua origem e condição: as populações autóctones, chamados à intervenção na vida da sua comunidade ou que recebem o privilégio da cidadania romana; os antigos escravos a quem se abrem novas perspectivas de vida depois da manumissio, todos eles estão ali para testemunhar que se pode apresentar uma janela de oportunidades nesse mundo vasto e globalizado, nesta fase final da dinastia júlio-cláudia.

Este breve percurso por alguns monumentos paradigmáticos da Lusitânia na fase mais avançada da dinastia júlio-cláudia patenteia as transformações que atingem algumas cidades desta província remota. Revela, por um lado, as estratégias romanas conducentes a uma irreversível integração destas comunidades na esfera cultural itálica. Mas evidencia, ao mesmo tempo a facilidade destas populações de se adaptarem a novos modelos de vida, muitas vezes substancialmente distintos dos que conheciam, mas nos quais se escondem novas oportunidades e novos desafios. $\mathrm{Na}$ maioria dos casos emergem evidências claras de uma ruptura com as tradições; mas é sobre ela que se constrói uma nova sociedade, mais desenvolvida economicamente e culturalmente mais aberta. Emerge uma mentalidade diferente, globalizada, com todas as suas vantagens e problemas, mas que não parece encontrar resistências significativas, apenas casos de maior o menor capacidade de adaptação.

As cidades do extremo ocidente, periféricas em relação ao espaço mediterrâneo, vão-se progressivamente aproximando, por essa via, dessa realidade mais desenvolvida em todos os planos. Por essa via, encurtam-se também as distâncias com florescente mundo oriental, no qual Paulo de Tarso tem as suas origens e constrói a sua personalidade cultural. 


\title{
Paulo de Tarso e a Justiça dos Homens. Helenismo e Impiedade Religiosa nos Actos dos Apóstolos
}

\author{
Delfim F. Leão \\ Universidade de Coimbra \\ Centro de Estudos Clássicos e Humanisticos da Universidade de Coimbra
}

\section{O cosmopolitismo de Paulo}

O empenho e espírito de entrega das primeiras comunidades cristãs bem como o acompanhamento das deambulações missionárias dos anunciadores da boa nova de Jesus Cristo fazem com que o livro dos Actos dos Apóstolos represente, além de um importantíssimo escrito doutrinário e de um notável testemunho de fé, também um revelador documento de época. Os Actos dos Apóstolos estão permeados de situações que se traduzem em verdadeiros motivos recorrentes (na sequência aliás do que seria de esperar do assunto da narrativa), como aclamações, discursos inflamados de apoio ou de repúdio, perseguições, preces e também acusações várias, que por vezes desembocam em ordem de prisão e em processos formais. $\mathrm{O}$ facto de estes eventos acontecerem num amplo espaço geográfico sob domínio romano leva a que certos aspectos do procedimento legal tivessem de ser globalmente respeitados, como acontecia com a disposição prevista na Lex Porcia que proibia que um cidadão romano fosse flagelado em público, ainda por cima sem julgamento. Os efeitos práticos provocados pelo receio de desrespeitar esta lei são várias vezes explorados por Paulo, ao revelar de improviso que era cidadão romano, seja em Filipos (16.3539) seja em Jerusalém (22.23-29), onde insiste aliás que obtivera esse direito por nascimento (i.e. por herança de um antepassado seu) e não por compra, como acontecia com o tribuno que o mandara algemar (22.28), o que vem de resto aumentar ainda mais o seu desconforto e receio. ${ }^{1} \mathrm{~A}$ cidadania romana permitia-lhe, por conseguinte, ficar sob a protecção das autoridades imperiais romanas e apelar inclusive ao julgamento do imperador, que funcionava como tribunal de recurso de última instância para os cidadãos das províncias que achassem estar a ser injustiçados pelas autoridades locais. ${ }^{2}$

Por outro lado, as viagens de Paulo, que o conduzem desde Jerusalém até Roma, depois de percorrer regiões asiáticas e gregas, levam a que seja possível identificar, no seu discurso e actuação, a confluência de

\footnotetext{
${ }^{1}$ Cf. ainda 23.27.

2 Alexander, 2001, 1057-58. Aliás, tanto Festo como Agripa reconhecem a inocência de Paulo, mas como este houvera apelado ao imperador, deveria, em consequência, ser enviado para Roma (26.32). Em vez de ser vista como uma contrariedade processual, a ida para Roma é interpretada como sendo a concretização de um projecto apostólico prévio (19.21) e ainda a realização da vontade divina (23.11).
} 
múltiplas sensibilidades, em relação às quais o cristianismo nascente vem trazer perturbadoras novidades. E se isso justifica plenamente que Paulo, proveniente de Tarso, possa ser considerado (enquanto grego, romano, judeu e cristão) um verdadeiro kosmopolites do ponto de vista da experiência religiosa, política e legal, também ajuda a entender parte das estratégias de argumentação que, muito habilmente, soube produzir e adaptar, segundo o auditório formal ou de ocasião que escutava as suas palavras. Esta realidade faz com que as potencialidades de interpretação decorrentes da existência de Paulo sejam muito ricas, mas também dificulta grandemente a identificação exacta do substrato histórico e cultural que pode estar por detrás de algumas das situações evocadas pelo autor dos Actos dos Apóstolos. Para minorar os riscos de uma operação que procure examinar o fundo legal subjacente aos percalços vividos por Paulo, a análise agora proposta vai centrar-se unicamente nos eventos que ocorreram em espaço helénico e, destes, irá ser explorada em particular a acusação e a ordem de prisão que Paulo e Silas tiveram de enfrentar, em Filipos, depois de o apóstolo ter exorcizado uma escrava que se dedicava à adivinhação (16.16-40). Será defendido que os termos da acusação sugerem, na essência, uma proximidade com os processos de impiedade religiosa (asebeia) que marcaram Atenas na viragem do séc. V para o séc. IV a.C. E embora a experiência de Paulo ocorra já na segunda metade do séc. I da nossa Era, não deixa ainda assim de afigurar-se legítimo fazer essa aproximação, num espaço herdeiro dos reinos helenísticos, cuja matriz cultural e linguística continuava a ter um reconhecido influxo de origem ática. A análise será iniciada, portanto, pela enunciação das linhas gerais que caracterizam o primeiro termo de comparação: a especificidade da religião grega, a forma como a asebeia se manifestava e a tipologia de faltas e penalizações a que poderia dar origem. Feito esse enquadramento inicial, será depois altura de ponderar mais em particular a acusação enfrentada pelo apóstolo de Cristo em Filipos.

\section{Peculiaridades da religião grega antiga}

A religião grega estava intimamente relacionada com a comunidade, a ponto de ser próprio de cada pólis ter a sua divindade protectora, a qual constituía um traço distintivo da cidade, à semelhança do que se passava com a constituição, o dialecto ou a moeda nela cunhada. ${ }^{3}$ No entanto, a identidade da Hélade afirmava-se também pelo facto de as diferentes cidades-estado partilharem determinado sistema de valores, onde a religião assumia um papel importante. Assim, ser grego implicava igualmente, em termos latos, crer numa concepção

\footnotetext{
${ }^{3}$ Nesta secção, usa-se, com adaptações e acrescentos, parte da informação apresentada em Leão, 2004, esp. 201-205.
} 
politeísta da divindade, onde o correcto desempenho de certas práticas rituais era a face mais visível das diligências necessárias para garantir o favor dos deuses. Por outro lado, na Grécia antiga não existia nada de comparável ao que a Bíblia significa para os Cristãos, nem uma casta sacerdotal propriamente dita, que tivesse a seu cargo o ofício religioso e a orientação espiritual. É certo que determinado tipo de cultos se encontrava, tradicionalmente, nas mãos de algumas famílias aristocráticas, como os Eumólpidas e os Cerices em relação aos Mistérios de Elêusis. Ainda assim, era mais característico do fenómeno religioso na Grécia que as manifestações públicas de honra aos deuses fizessem parte das funções normais dos magistrados, a par de outras responsabilidades cívicas. Daqui resulta a vertente marcadamente ritual e legalista da religião grega e até, de alguma forma, o seu pendor contratual: ao cumprir os preceitos, o crente espera obter a correspondente protecção divina. ${ }^{4}$ O maior representante do legalismo era o oráculo de Apolo em Delfos, cuja importância ultrapassava a acção das diferentes divindades próprias de cada pólis e dos cultos locais, afirmando-se assim como uma das mais expressivas manifestações de pan-helenismo, já desde as épocas arcaica e clássica. ${ }^{5}$

No entanto, a Grécia conhecia ainda, no plano geral, uma outra grande tendência religiosa, que pressupunha uma iniciação e, por conseguinte, um maior envolvimento pessoal: as correntes mistéricas. Já acima se fazia alusão aos Mistérios de Elêusis, que são talvez o caso mais significativo, sobretudo atendendo ao facto de que este culto conjugava a celebração ligada a um santuário local com uma importância e projecção que ultrapassavam as fronteiras da Hélade. ${ }^{6}$

\subsection{Definição de asebeia}

Esta breve abordagem preliminar do fenómeno religioso entre os Gregos visava apenas evocar alguns dados necessários à definição daquilo que poderá constituir uma ofensa aos deuses, ou seja, um acto de asebeia. Contudo, a delimitação do conceito de asebeia, a que geralmente se dá o equivalente moderno de «impiedade», tem-se revelado um tópico difícil. De facto, na linguagem comum o termo é com frequência usado de forma vaga, para designar a omissão de certas práticas. Um passo de Platão (Êutifron, 7a) poderá

${ }^{4}$ Visível, por exemplo, na oração formal feita por Crises a Apolo (Il. 1.33-42), onde o sacerdote recorda ao deus os serviços prestados. Em todo o caso, também já em Homero se notam marcas de uma devoção mais sincera e dedicada, como quando Aquiles roga a Zeus que garanta o regresso a salvo do seu amigo Pátroclo (Il. 16.231-248).

${ }^{5}$ Conforme deixa bem patente o impressionante testemunho de P1., Rep. 427b-c.

${ }^{6}$ Sobre o sacrilégio que, no ano de 415 a.C., envolveu a representação paródica destes Mistérios, levada a cabo em lugar impróprio e por indivíduos que não estavam habilitados para o efeito, vide Leão, 2004, 214-220. 
fornecer um elucidativo exemplo daquilo que os Gregos, através das palavras de Sócrates, consideravam ser uma falta em matéria religiosa:

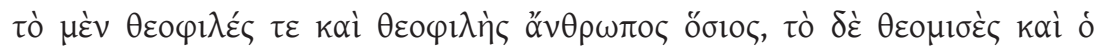

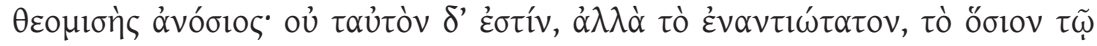
àvooí

A coisa e a pessoa que agradarem aos deuses (theophiles) serão piedosas (hosios); a coisa e a pessoa que lhes forem detestáveis (theomises) serão impiedosas (anosios). E estas duas realidades não são idênticas, pois o piedoso (hosios) e o impiedoso (anosios) constituem o exacto oposto um do outro. ${ }^{7}$

Embora o paralelo não seja total, já que o filósofo está a explorar as implicações semânticas do binómio hosios/anosios (que também pode ser entendido como «santo, devoto, legítimo» vs «irreligioso, profano, ilegítimo») e não propriamente do termo asebeia, não deixa de assinalar que a noção de «impiedade» estabelece uma relação directa com a natureza da atenção e deferência dispensadas à divindade, no sentido de cumprir ou não o que agradaria aos deuses. Contudo, outras ocorrências mostram que o conceito poderia ser mais abrangente. Assim acontece, por exemplo, com o pequeno tratado Sobre as Virtudes e os Vícios, que circula no corpus atribuído a Aristóteles. Ainda que o opúsculo seja quase certamente espúrio, isso não invalida a pertinência das afirmações que nele são feitas (1251a30-1251b2):

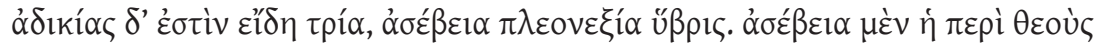

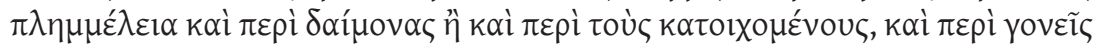

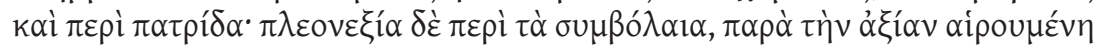

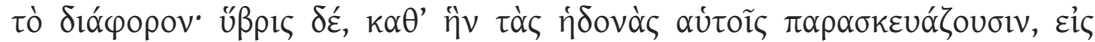

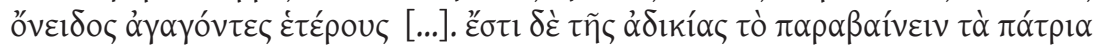

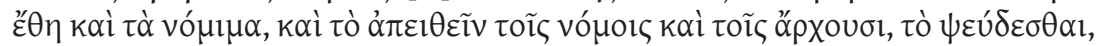

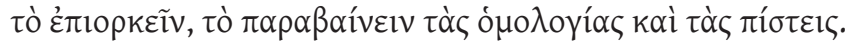

Há três formas de comportamento incorrecto (adikia): a impiedade (asebeia), a avidez (pleonexia) e a insolência (bybris). A impiedade (asebeia) consiste em ter um mau procedimento para com os deuses (theoi) e génios divinos (daimones), para com os mortos, os pais e a pátria; a avidez (pleonexia) consiste em desrespeitar os contratos (symbolaia), tomando em disputa o que é contrário ao merecimento; a insolência (bybris) consiste na conduta que leva a buscar o próprio prazer à custa da desgraça alheia. [...] É portanto característico do comportamento incorrecto (adikia) desrespeitar os costumes e preceitos

\footnotetext{
${ }^{7}$ Salvo expressa indicação em contrário, todas traduções apresentadas são da responsabilidade do autor deste estudo.
} 
ancestrais (ta patria ethe kai ta nomima), desobedecer às leis (nomoi) e aos governantes (archontes), enganar, cometer perjúrio, desrespeitar os acordos (homologiai) e as garantias dadas (pisteis).

Este testemunho é bastante curioso, pois a asebeia vem apresentada como uma forma de conduta incorrecta (adikia), a par de outras expressões de injustiça como a avidez (pleonexia) e a insolência (bybris). Não obstante a aproximação sugerida para os três conceitos enquanto expressão de uma realidade mais ampla e a ambiguidade relativa da última frase (que não esclarece de forma inequívoca qual a falta correspondente a cada um dos tipos de incorrecção definidas na primeira parte do texto), é ainda assim legítimo deduzir que a asebeia se aplicava a afrontas cometidas contra os deuses, os mortos, os progenitores e a pátria — instâncias e entidades que se encontram precisamente protegidas por «costumes e preceitos ancestrais» (ta patria ethe kai ta nomima), cuja origem se perde na raiz dos tempos e por isso tendem a ser considerados sagrados. ${ }^{8}$ Se for feito o cruzamento da informação veiculada por ambos os textos aduzidos, chega-se de alguma forma à noção de que a asebeia é a expressão de um comportamento reprovável à luz da moral divina e social, por constituir uma afronta em domínios que são determinantes para assegurarem estabilidade na existência humana e na vida em comunidade: a protecção dos deuses, a hierarquia familiar (bem como a sua memória) e a consciência de uma identidade política solidária.

Aceitando, como ponto de partida, esta definição genérica de asebeia, importa agora avançar para o problema da incidência jurídica do conceito. Há uma série de crimes onde é previsível a sobreposição entre o uso da linguagem comum e a aplicação legal do termo asebeia. Nesse rol se podem incluir delitos como a profanação de mistérios, realização imprópria de sacrifícios, violação de proibições rituais ou de interdições relativas à frequência de locais sagrados, saque de templos, desrespeito pelos suplicantes, mutilação de objectos sagrados. ${ }^{9}$ Contudo, não é improvável que alguns destes crimes fossem cobertos também por outras categorias, como acontece com a subtracção de objectos sagrados (bierosylia), que representa, de resto, uma categoria especial entre os casos de roubo, precisamente por ser um delito com incidência na esfera religiosa. ${ }^{10}$

${ }^{8}$ Conforme reflectia o termo hosios usado no passo de Platão anteriormente comentado. Não é também de pôr de lado a hipótese de que o conceito de asebeia cobrisse, em termos genéricos, a falta ao respeito devido «às leis (nomoi) e aos governantes (archontes)», embora isso também possa estar implícito nas ofensas de pleonexia e de bybris.

${ }^{9}$ Vide sistematização de Cohen, 1991, 205-206, que fornece amplo espectro de fontes.

${ }^{10}$ Conforme Todd, 1995, 307 e n. 19, salienta, o facto de haver uma acção pública específica para estes delitos (graphe hierosylias) mostra a gravidade do crime, se bem que os exemplos destes casos fornecidos pelas fontes não tenham uma natureza linear. 
Por conseguinte, mantém-se a dúvida básica em relação aos limites legais precisos em que se poderia aplicar este processo, cenário que tem levado a maioria dos estudiosos a admitir que a multiplicidade dos casos puníveis por asebeia é uma consequência natural da elasticidade e vagueza do próprio conceito. ${ }^{11}$ Esta interpretação afigura-se ainda pertinente e encontra um paralelo, de resto, nas dificuldades para definir o alcance legal de um processo por bybris («insolência»), destinado a punir atentados contra a dignidade de outra pessoa. ${ }^{12}$ No entanto, a não definição clara da natureza de um crime para o qual são estipuladas determinadas penas é uma limitação característica do sistema legal ático, bem como de outros códigos antigos (com a usual excepção do homicídio). ${ }^{13}$ Esta circunstância, aliada ao falto de, em Atenas, os tribunais serem constituídos por cidadãos comuns e não por especialistas, deixava um maior espaço de manobra à intervenção reguladora da comunidade, representada pelo colectivo de juízes, em cujo consciente entrariam em linha de conta posições semelhantes às enunciadas nos dois textos que serviram de mote a esta reflexão. Ora seria a partir deste conjunto de factores que era avaliada a justeza legal de uma acusação de asebeia.

É também frequente partir do princípio de que os processos de asebeia seriam motivados por desvios na prática ritual e não pela expressão de opiniões religiosas pouco ortodoxas, isto é, por actos e não tanto por palavras e pelas ideias que as motivavam. ${ }^{14}$ Este cenário sofreria uma alteração com os efeitos da chamada Aufklärung grega, decorrente do ensino sofista, que se traduziu, entre outros aspectos, também numa abordagem crítica da visão religiosa tradicional. Não cabe agora entrar nessa discussão igualmente complexa. No entanto, valerá a pena salientar que algumas fontes mais tardias referem uma série de processos de asebeia instaurados contra intelectuais como Protágoras e Anaxágoras. ${ }^{15}$ Em termos legais, o passo que marcaria a reacção contra esses

${ }^{11}$ Lipsius, 1905-1915, II.359-360, foi o primeiro grande impulsionador desta posição. Perspectiva diferente em Rudhardt, 1960, que entende, pelo contrário, que a asebeia tinha uma incidência legal clara e aplicável apenas a determinado tipo de faltas.

${ }^{12} \mathrm{Cf}$. a definição apresentada por Demóstenes (21.45-48) e por Ésquines (1.15-17). De resto, não deixa de ser significativo que, no passo do Sobre as Virtudes e os Vicios, a asebeia e a hybris apareçam ambas entre as formas que caracterizam um comportamento desviante.

${ }^{13}$ De resto, Aristóteles (Rhet. 1374a) já apontava os inconvenientes que decorriam da insuficiente definição dos crimes, discutindo, entre outros exemplos, as acusações de hierosylia e de hybris. Vide as observações de Cohen, 1991, 207-209.

${ }^{14}$ E.g. MacDowell, 1978, 200.

${ }^{15}$ Cf. Diod. 12.39.2; Plut., Nic. 23. Uma das versões da acusação referida por Diógenes

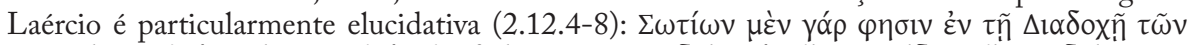

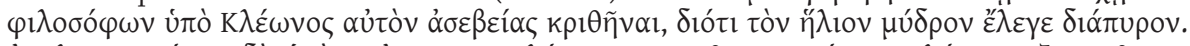

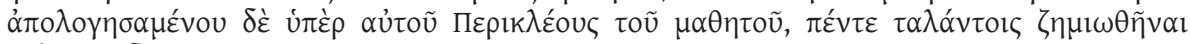

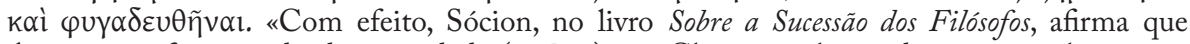
Anaxágoras foi acusado de impiedade (asebeia) por Cléon, por haver dito que o sol era uma massa incandescente. A defesa foi assumida por Péricles, seu discípulo, mas ainda assim foi 
perigos de ateísmo seria um decreto promulgado por certo Diopites, talvez cerca de 430, portanto na última fase do governo de Péricles e nos primeiros momentos da Guerra do Peloponeso, numa altura em que, segundo as fontes, além de Anaxágoras, outras pessoas próximas do estadista (Fídias e Aspásia) terão sido alvos de processos judiciais. ${ }^{16} \mathrm{~A}$ informação é facultada por Plutarco (Vida de Péricles, 32.2), em termos que valerá a pena recordar:

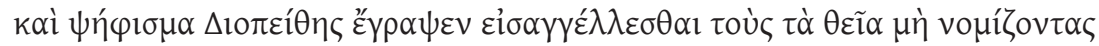

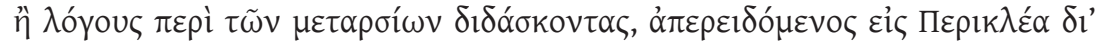

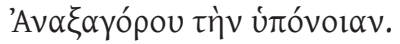

Então Diopites propôs um decreto (psephisma), segundo o qual quem não acreditasse (me nomizontes) nas divindades (ta theia) ou ministrasse ensinamentos sobre fenómenos celestes, seria sujeito a um processo de eisangelia («denúncia pública»), dirigindo as suspeitas contra Péricles, por causa de Anaxágoras.

À parte as eventuais manobras políticas que terão acompanhado a promulgação deste decreto e dos processos atrás mencionados, afigura-se claro deduzir que o seu âmbito de aplicação visava de forma directa filósofos como Anaxágoras e representaria a primeira tentativa legal de alargar a incidência jurídica da asebeia, de maneira a nela incluir também a expressão de ideias ateístas, além das práticas rituais consideradas ímpias. ${ }^{17}$ Contudo, estas hipóteses só podem ser avançadas com alguma reserva, já que Plutarco é o único autor a mencionar o decreto de Diopites e nenhuma fonte próxima dos acontecimentos confirma a existência dos referidos processos contra filósofos.

Por conseguinte, o outro processo de impiedade que poderá contribuir para sustentar a hipótese de uma extensão da asebeia também às convicções interiores é o julgamento de Sócrates, sobre o qual há muita informação contemporânea dos eventos, pese embora a parcialidade ideológica que possa, com alguma legitimidade, ser-lhe apontada. Não cabe agora discutir os pormenores do processo movido ao filósofo; ${ }^{18}$ mais importante, para a

condenado a uma multa de cinco talentos e ao exílio.»

${ }^{16}$ Curiosamente, Plutarco (Per. 32.1) sustenta que Aspásia foi também acusada de asebeia.A veracidade histórica desta informação tem sido posta em causa, mas, a ter existido esse processo, é improvável que a asebeia fosse motivada pela afirmação de ideias ateístas, à imagem do que aconteceu com Anaxágoras. Talvez tivesse que ver com o facto de ela ter entrado em locais (como santuários) ou participado em rituais que lhe estavam vedados por causa das liberalidades da sua vida privada. Ainda assim, o facto de o acusador ser um comediógrafo tem levado a pôr a hipótese de esta tradição se basear somente numa cena de comédia. Vide Stadter, 1989, 297-298.

${ }^{17}$ Estudiosos como Dodds, 1971, 189, serviram-se deste passo para ilustrar as marcas de intolerância política em Atenas.

${ }^{18}$ Entre os estudos mais recentes dedicados a esta questão, vide Scholz, 2000; Brickhouse \& Smith, 2002. Estes últimos fornecem uma colectânea das fontes antigas ligadas ao processo e da 
presente discussão, é saber se as alegadas crenças de Sócrates poderiam servir de base à acusação, independentemente de corresponderem ou não à verdade. Valerá a pena, por isso, evocar os termos exactos em que a acusação teria sido feita, tal como nos é transmitida por dois dos testemunhos mais importantes, Platão e Xenofonte: ${ }^{19}$

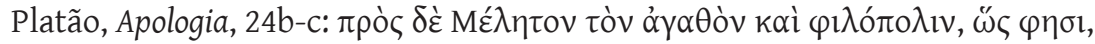

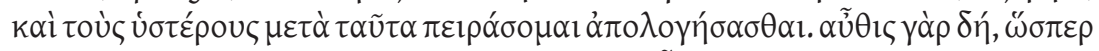

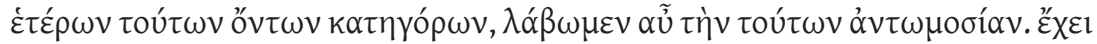

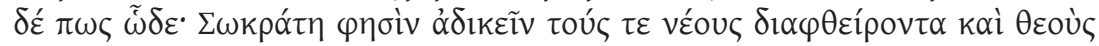

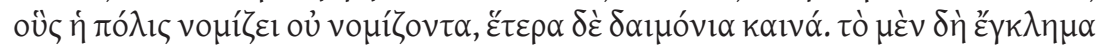

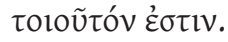

Tentarei agora responder a Meleto, este homem virtuoso e amigo da sua cidade, como ele próprio diz, e aos meus últimos acusadores. Tal como fizemos com os outros, comecemos por recordar a sua declaração jurada. Ela foi feita mais ou menos nestes termos: «Sócrates é culpado (adikein) de corromper (diaphtheironta) a juventude (neoi) e de não crer (ou nomizonta) nos deuses (theoi) em que crê (nomizei) a cidade, mas em divindades novas (daimonia kaina).» Este o teor da acusação.

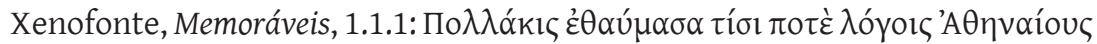

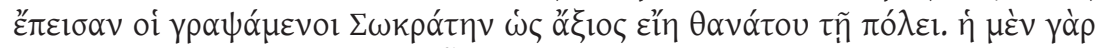

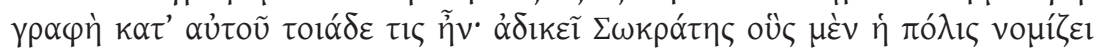

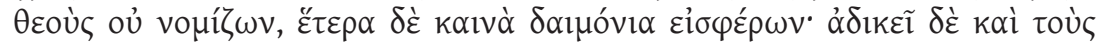
vह́ouৎ $\delta 1 \alpha \varphi \theta \varepsilon i ́ p \omega v$.

Muitas vezes me tenho perguntado, perplexo, com que argumentos aqueles que acusavam (grapsamenoi) Sócrates convenceram os Atenienses de que a sua morte era um bem para a cidade. A acusação (graphe) que apresentaram contra ele dizia qualquer coisa como: «Sócrates é culpado (adikei) de não reconhecer (ou nomizon) os deuses (theoi) que a cidade reconhece (nomizei) e de, em sua vez, ter introduzido divindades novas (kaina daimonia); e é culpado (adikei) também de corromper (diaphtheiron) os mais novos (neoi).»

Os termos da acusação encontram-se muito próximos, nos dois textos, de forma que ambos se devem ter baseado num documento oficial. ${ }^{20}$ Por outro lado, tanto Platão como Xenofonte parecem indicar, de forma clara,

controvérsia, entre os estudiosos modernos, decorrente da sua interpretação.

${ }_{19}$ Para a tradução, usa-se respectivamente a versão portuguesa de M. Oliveira Pulquério, Platão - Apologia de Sócrates. Críton (Coimbra, 1991²), e de A. Elias Pinheiro: Xenofonte Memoráveis (Coimbra, 2009).

${ }^{20}$ Cf. Diog. Laer. 2.40. 
que o motivo próximo da acusação estava ligado, efectivamente, a uma visão pouco abonatória da religião tradicional (ao não crer nos deuses da cidade e ao defender a introdução de outros novos), bem como à divulgação dessas ideias, em particular entre os jovens que auferiam do seu magistério. Por conseguinte, o que está em causa, além do carácter provocador do comportamento de Sócrates, é também e talvez sobretudo o cultivo e expressão de uma ideologia religiosa aparentemente contrária à visão ortodoxa. ${ }^{21}$

Xenofonte (secundado aliás por Diógenes Laércio, 2.40) usa o termo graphe para designar o tipo de acusação, o que deixa prever que o julgamento de Sócrates resultara de uma graphe asebeias, portanto de um processo público normal. Contudo, no decreto de Diopites falava-se de eisangelia, que é um tipo de procedimento mais excepcional, iniciado pelo fornecimento directo de informação à Ekklesia ou Boule. Isto coloca a questão de saber se o processo usual durante o séc. V seria a eisangelia e se, talvez como resultado do esforço de revisão legislativa, terá passado ou não a graphe. As dúvidas relativas à autenticidade do decreto de Diopites não facilitam a análise do problema, mas não se afigura improvável que o processo mais usual fosse a graphe, tanto no séc. V como no IV, mas que a eisangelia também pudesse ser aplicada em casos que se afigurassem mais sérios. ${ }^{22} \mathrm{E}$ isso que terá acontecido a propósito do envolvimento (real ou fictício) de Alcibíades no escândalo que abalou Atenas em 415, nas vésperas da expedição à Sicília, que se traduziu na mutilação das estátuas de Hermes e na paródia aos Mistérios de Elêusis. Este duplo sacrilégio iria motivar, de resto, uma verdadeira histeria colectiva, que levaria a soberania popular a cometer sucessivos erros de governação. ${ }^{23}$ Por comparação, o processo movido contra Sócrates e outros filósofos terá produzido um impacto relativamente menor na opinião pública, embora a morte do filósofo transitasse para a posteridade, sobretudo por influência de Platão, como exemplo de um dos «pecados mortais» da democracia ateniense, tornando Sócrates numa espécie de mártir do pensamento libertador. É nessa perspectiva que a memória do crime de asebeia em geral e a natureza das acusações a Sócrates em particular interessam para a análise das acusações que visaram Paulo.

\section{Paulo em Filipos, Corinto e Atenas}

No decurso das suas missões apostólicas (15.35-21.16), Paulo faculta uma notável imagem de viajante, descrevendo uma impressionante rota através

${ }^{21}$ Desenvolvimento desta argumentação em Cohen, 1991, 212-217.

${ }^{22}$ Perspectiva sustentada por MacDowell, 1978, 183-184; 199-200.

${ }^{23}$ De resto, Alcibíades só parece ter estado envolvido no crime de paródia aos Mistérios de Elêusis. Para uma análise deste processo, vide Leão, 2004, 205-220. 
do Mediterrâneo oriental que o leva não apenas a zonas profundamente helenizadas como ao coração da própria Grécia, ao visitar cidades como Filipos, na Macedónia, Atenas e Corinto. Em todas estas cidades viverá experiências marcantes do ponto de vista doutrinário, mas que são igualmente elucidativas da sua capacidade para argumentar e adaptar-se à realidade sociológica e às expectativas culturais das audiências com que se deparava. Conforme se dizia na secção introdutória, neste contexto geográfico o cosmopolitismo de Paulo encontra igualmente uma expressão de eleição, porquanto era um judeu, que gozava de cidadania romana, ao mesmo tempo que desenvolvia a missão apostólica em território helénico. As tensões derivadas do esforço de harmonização destas três forças centrífugas afloram em vários momentos dos Actos dos Apóstolos, potenciadas pela tarefa de anunciar uma ideologia religiosa onde a tradicional prática ritualista da salvação através da Lei (15.1.5) se via ultrapassada pela salvação garantida através da fé em Cristo (15.7-11). A mensagem evangélica possuía, por conseguinte, alguns dos elementos que poderiam resgatar da poalha dos tempos a reminiscência das antigas acusações de asebeia. $\mathrm{O}$ termo não chega a ser usado expressamente, mas não será abusivo argumentar que o velho conceito continuava operativo na memória colectiva helénica, mesmo que dela não houvesse uma consciência clara.

Com efeito, Filipos, sendo embora uma colónia romana organizada à imagem da metrópole, não deixava de se encontrar em espaço grego e de acusar essa influência. ${ }^{24}$ De resto, isso mesmo vem confirmado no momento em que Paulo e Silas se cruzam com uma escrava que possuía a poder da adivinhação (16.16):

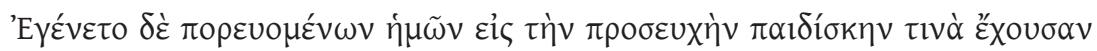

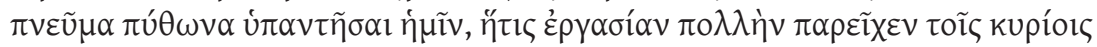

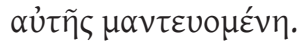

Um dia, quando íamos à oração, encontrámos uma serva que tinha um espírito pitónico (pneuma pythona) e dava muito lucro aos seus senhores, exercendo a adivinhação (manteuomene). ${ }^{25}$

Teria sido fácil ao autor dos Actos optar por uma expressão mais neutral para designar as capacidades divinatórias da escrava (e.g. pneuma mantikon), mas a opção pelo termo pythona estabelece uma relação directa com o imaginário ligado à actuação da Pítia, profetisa de Apolo no santuário de Delfos, o representante máximo do legalismo na religião grega. Discretamente, é assim

${ }^{24}$ Sobre o estatuto de Filipos enquanto colónia romana, vide Omerzu, 2002, 116-123.

${ }_{25}$ Para a tradução de passos da Bíblia, adopta-se a versão da Nova Bíblia dos Capuchinhos (Lisboa, 1998). 
estabelecida uma oposição entre o influxo desta falsa forma de religiosidade e a actuação do Espírito Santo, que vela pelo trabalho dos apóstolos e marcará a sua superioridade ao permitir-lhes exorcizar a escrava. Este confronto de duas manifestações religiosas será depois transposto para o plano humano, quando os donos da escrava decidem acusar formalmente Paulo e Silas (16.19-21):

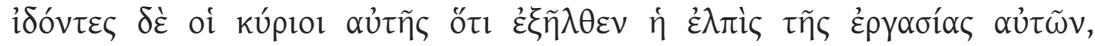

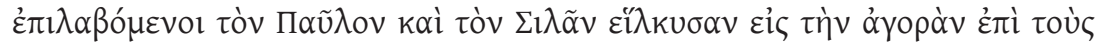

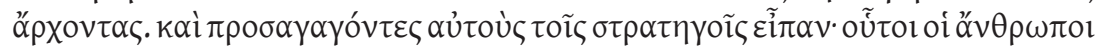

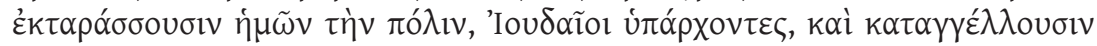

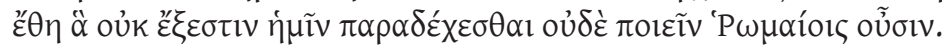

Mas os senhores da escrava, vendo desaparecer a esperança do lucro (ergasia), apoderaram-se de Paulo e de Silas e arrastaram-nos até à praça pública, à presença dos magistrados (strategoi). Apresentando-os aos estrategos, disseram: «Estes homens espalham a desordem na nossa cidade (polis); são judeus, e apregoam usos (ethe) que não nos é permitido a nós, romanos, nem admitir nem praticar.

A propósito deste episódio, são discutidos quer o motivo que terá levado os donos da escrava a acusarem formalmente os apóstolos, quer a natureza objectiva da acusação. ${ }^{26}$ Ainda assim, a motivação apontada por Lucas afigura-se bastante convincente. Com efeito, ao longo dos Actos dos Apóstolos fica bem patente que a prática da adivinhação era um negócio que envolvia bastantes recursos (e.g. 19.19), de maneira que o móbil dos donos terá sido a perda de uma importante fonte de rendimento, decorrente da danificação do principal atributo que distinguia a escrava. ${ }^{27}$ Quanto à natureza da acusação formal, faz recordar, de maneira bastante próxima, o crime de asebeia evocado na secção anterior: perturbar a ordem da cidade (significativamente, usa-se o termo típico para designar a cidade-estado ou polis) e visar a introdução de costumes (ethe) cuja prática era vedada aos locais.

Um outro exemplo ocorre em Corinto, quando Paulo foi novamente levado a tribunal (18.12-13):

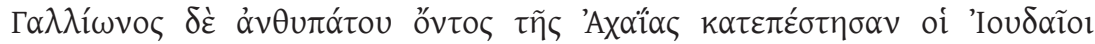

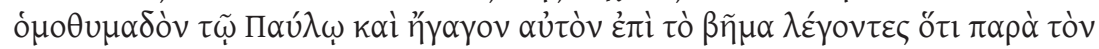

${ }^{26}$ Para uma análise de algumas das principais interpretações, vide de Vos, 1999, que se inclina para a ideia de que os donos da escrava teriam acusado Paulo da prática de magia com intuito de provocar danos a outrem. Análise mais sistemática da natureza da acusação em Omerzu, 2002, 124-141.

${ }^{27}$ É bastante significativo notar que Simão (8.9-11), antes de se ter convertido, se dedicava com sucesso à arte da magia. E ao perceber que o Espírito Santo era concedido através da simples imposição das mãos, tentou comprar esse dom, com a oferta de dinheiro, para grande escândalo de Pedro e João (8.18-24). 


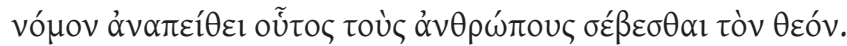

Sendo Galião procônsul da Acaia, levantaram-se os judeus, de comum acordo, contra Paulo e levaram-no a tribunal. «Este homem - disseram eles - induz as pessoas a prestar culto (sebesthai) a Deus de uma forma contrária à Lei (para ton nomon).»

Embora a acusação seja movida por judeus e não por Gregos, é curioso notar que os termos evocam, novamente, o imaginário ligado à asebeia. De facto, o conceito aparece referido de forma indirecta quando é sustentado que Paulo incitava as pessoas a prestar culto (sebesthai) de forma contrária à lei (para ton nomon). A acusação pretende, obviamente, expor uma prática incorrecta de rituais determinados por lei. Ora é interessante notar que, em relação aos escândalos que abalaram Atenas em 415 a.C. e à actuação de Alcibíades, certamente a figura mais «mediática» de quantos foram envolvidos nesses crimes de asebeia, Tucídides (6.28.2) afirme que os inimigos políticos do estadista classificavam o seu comportamento irreverente como um desprezo pela legalidade (paranomia). ${ }^{28}$ Daqui será legítimo depreender que, volvidos embora muitos séculos, o consciente colectivo continuava a funcionar com um padrão mental idêntico, na altura de definir as formas de impiedade religiosa.

Curiosamente, o trabalho de Paulo havia de encontrar maior compreensão em Atenas, a mesma cidade onde, cerca de cinco séculos antes, a população havia movido vários processos de asebeia contra figuras ilustres de filósofos e notáveis comunicadores. Isso verifica-se na altura em que ele profere o famoso discurso diante do Areópago, onde simbolicamente o apóstolo de Cristo quase parece absolver, de forma implícita, os Atenienses pela morte de Sócrates, salientando agora a "piedade» ou eusebeia que tão singularmente os distingue (17.22-23):

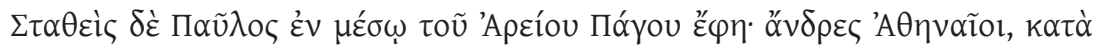

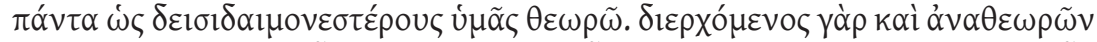

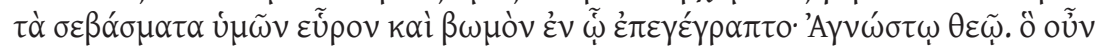

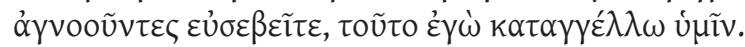

De pé, no meio do Areópago, Paulo disse, então: «Atenienses, vejo que sois, em tudo, os mais religiosos dos homens. Percorrendo a vossa cidade e examinando os vossos monumentos sagrados (sebasmata), até encontrei um altar com esta inscrição: "Ao deus desconhecido." Pois bem! O que venerais (eusebeite) sem conhecer é o que eu vos anuncio.»

${ }^{28}$ Vide Leão, 2004, 213-214. 
Paulo de Tarso e a Justiça dos Homens. Helenismo e Impiedade Religiosa nos Actos dos Apóstolos

Por outras palavras: como resposta à acusação implícita de que a sua actividade missionária era uma forma de asebeia, Paulo vem esclarecer, junto de um auditório que estaria bem familiarizado com esse conceito de impiedade religiosa, que o objecto da sua pregação é, bem pelo contrário, a manifestação da verdadeira eusebeia - a mesma aliás que os Atenienses já veneravam, de forma inconsciente, ao dedicarem um altar «Ao deus desconhecido». 


\title{
PAUlo E A CONTROVÉRSIA SOBRE OS ALIMENTOS PERMITIDOS AOS CRISTÃOS: AMESA ENTRE DOIS MUNDOS
}

\author{
Paula Barata Dias \\ Universidade de Coimbra \\ Centro de Estudos Clássicos e Humanísticos da Universidade de Coimbra
}

As cartas paulinas dão testemunho de uma controvérsia que teria abalado os primeiros anos do cristianismo, a dos alimentos permitidos aos cristãos. Durante este período, Paulo participou na edificação das primeiras comunidades cristãs fora de Jerusalém, nelas intervindo no sentido de interpretar a revelação cristã e de a posicionar face a um quadro religioso precedente, o do judaísmo. Neste domínio, é nosso objectivo analisar, nos textos atribuídos a Paulo, as referências aos alimentos e à problemática da sua utilização pelos discípulos de Cristo, tendo em conta os condicionamentos dos costumes precedentes do judaísmo.

De entre os diversos ângulos suscitados pela magna figura de Paulo, seus ensinamentos e contributos para a construção teológica do cristianismo, estamos conscientes de que esta, - a da controvérsia alimentar - pode ser facilmente considerada como menor, ou mesmo lateral. No entanto, quisemos observar nos escritos de Paulo as mensagens que aludem à problemática alimentar, na medida em que estas, analisadas à luz do específico processo histórico, social e cultural da diversificação religiosa, podem ser consideradas enquanto manifestação explícita de construção de identidade ${ }^{1}$.

Partimos do pressuposto de que os hábitos alimentares são uma dimensão essencial para a caracterização do ser humano enquanto parte integrante de uma construção colectiva. Comer os mesmos alimentos que o outro, ou reconhecer-se nos alimentos que o outro usa na sua dieta, na forma de os preparar, nos horários e nos rituais de refeição, ou seja, identificar-se com as várias dimensões das práticas alimentares dos outros, são comportamentos que geram mecanismos de aproximação e de afecto, de associação, de reconhecimento, de inclusão, em suma desenham um modo de agir que, uma vez aprendido e posto em prática, colabora na produção de identidade.

Este valorizar da alimentação pelo que significa de construção cultural distinta não é um dado adquirido para o comum dos mortais, habituado que está a limitar o fenómeno alimentar a uma leitura orgânica ou artística: para o homem contemporâneo ocidental, comer significa satisfazer uma necessidade

${ }^{1}$ Ochs, Elinor, 1996, 8: «...what one eats, how one eats, when and with whom are guided by understanding of one's identity within society; or to put in another way, alimentary conduct helps to define one's identity within society». 
com vista à conservação da energia e da saúde, ou então, na dimensão oposta, aceder, por via do exótico, do raro e do caro, a uma experiência estética e artística $^{2}$. Perdeu-se um pouco, neste homem ocidental, a consciência explícita de que o alimentar-se traduz uma experiência de partilha e de vinculação a uma comunidade. A frase «somos o que comemos», tão em voga nas campanhas em defesa de uma alimentação saudável, pode, nestas circunstâncias, ser lida pelo seu valor colectivo, isto é parte da nossa identidade enquanto grupo, e parte da nossa construção mental de pertença a uma comunidade restrita ou alargada é quotidianamente definida pelas práticas alimentares que observamos.

Ainda que hoje, nas nossas sociedades contemporâneas, vejamos emergir comportamentos que contrariam este simbolismo da partilha da mesma refeição como acto produtor de identidade (prolifera a ingestão solitária, não sujeita a horários, de pé - fenómenos que são justamente analisados pela sua dimensão disruptiva, não só indicadores da alteração de um paradigma social mas também pelo seu carácter pouco saudável), ainda nos reconhecemos dentro de uma prática que, analisada, traduz a actualidade do conceito de refeição enquanto forma de estabelecer comunidade. Ainda nos reconhecemos, num diagrama de círculos concêntricos conforme a intensidade dos laços afectivos e do reconhecimento de proximidade, ou de partilha de interesses, no jantar diário da família nuclear, no almoço domingueiro da família, na celebração do Natal, da Páscoa, dos baptizados e casamentos, dos aniversários, das formaturas da família alargada e dos amigos; no jantar com os colegas de trabalho, na celebração dos finais dos anos lectivos da comunidade escolar integrada pelas nossas crianças, no jantar das colectividades, associações, confrarias, ligas de amigos... portanto, não nos faltam ocasiões de partilhar os mesmos alimentos, nem momentos em que nos observamos mutuamente nesse acto que, ultrapassada a necessidade orgânica e biológica do alimentar-se ou a rara e quase inatingível experiência estética, solitária e individualista, da arte culinária, se afirma enquanto um dos mais perenes mecanismos de vinculação social.

Ora, o facto de as refeições e a partilha dos alimentos, ou um tipo específico de prática alimentar participarem na produção de identidade, está presente nas primeiras manifestações literárias dos nossos antepassados. Por exemplo, nos poemas homéricos, o epíteto frequente de «homens comedores de pão» pode ser interpretado no sentido lato enquanto uma extensão poética, metonímica, sinónimo de «homens», sendo «comer pão» um dos múltiplos comportamentos próprios dos homens. Mas este epíteto apresenta um significado suplementar diante dos episódios dos lotófagos, do Ciclope, dos lestrígones ou das sereias, seres cujo estatuto não humano se define pelo facto de não ingerirem pão,

${ }^{2}$ Cf. Bourdieu, 1979, cap. III «Gôuts de classe et styles de vie». Para o Sociólogo, há dois princípios que organizam o gosto humano, a «escolha do necessário» e o «desejo do luxo». 
ou de seleccionarem por alimento espécies rejeitadas ou marginalizadas pelo consumo humano3. O Mito das cinco idades, em Trabalhos e Dias, de Hesíodo, apresenta, entre outras categorias com que descreve os homens da Idade do Bronze, o facto de não comerem pão, num modo de acentuar a diferença entre os homens comuns, grupo a que pertence o autor, e que naturalmente terá como comportamento plausível o facto de comer pão, e estes seres diferentes e distantes.

Também a tragédia grega apresentará algumas ocasiões em que o acesso ao interdito está associado à obediência ou quebra de preceitos alimentares tidos como «humanos». A obra As Bacantes, de Eurípides, apresenta provavelmente o exemplo mais sólido de perda de humanidade associada à transgressão de uma norma alimentar. No desfecho da obra, Penteu torna-se a vítima sacrificial do ritual dionisíaco de sparagmos e de omofagia, isto é, de dilaceração e ingestão ritual de um animal selvagem. Sem pretendermos aprofundar a análise de As Bacantes, parece-nos claro que, nesta obra, a impiedade de Penteu se converteu numa ameaça à sua própria humanidade, ameaça esta que se efectiva sob a forma de uma alteração à normalidade de um padrão alimentar. Como tal, a sua transgressão é acompanhada pelo seu afastamento simbólico da comunidade humana, e, uma vez corrompido este estatuto, Penteu deixa de estar salvaguardado pelo interdito alimentar da antropofagia, que vincula os humanos. Assim, é devorado pelas bacantes, que o confundiram com um animal selvagem ${ }^{4}$.

Com estes sumários exemplos, de todos conhecidos, pretendemos ressaltar que a possibilidade de exprimir a identificação e a inclusão pela menção à partilha das mesmas espécies alimentares e, inversamente, a de exprimir estranheza ou exclusão pelo acentuar da divergência em relação a um padrão alimentar tido como normal, corresponde a um universal do comportamento humano e que essa realidade foi percebida desde os mais antigos textos da literatura ocidental até aos hábitos de sociabilidade vigentes até hoje.

Ao transferirmos estes pressupostos para o estudo das referências alimentares em S. Paulo, imergimos na complexidade que o tema reveste na cultura religiosa matricial do Apóstolo. É comummente sabido que a religião judaica apresenta uma disciplina alimentar precisa, que fornece regras quanto à

${ }^{3}$ Lotófagos, Od 9.82-97 «Ao décimo dia desembarcámos na terra dos lotófagos, que comem alimento floral. (...) Mas depois de termos provado a comida e a bebida, mandei sair alguns companheiros para se informarem acerca dos homens que daquela terra comiam pão...»; 9.190193 «Fora criado assim: um monstro medonho. Não se assemelhava a quem se alimente de pão, mas antes ao cume dos arvoredos de uma vasta montanha...»; 10.100 «Então enviei alguns companheiros para se informarem sobre quem eram os homens, que desta terra comiam pão» (trad. F. Lourenço, 2003); Hes., Erg. 147-148 Rocha Pereira, 110: «Não comiam pão; tinham um ânimo forte como o aço, eram inquebrantáveis».

${ }^{4}$ Eur., Bac. 913-1150 (trad. M. H. da Rocha Pereira, 1992). 
qualidade, preparação e ingestão dos alimentos. Esta disciplina afecta não só a relação entre os fiéis e o meio natural envolvente - que é modificado no sentido de se adequar às necessidades rituais da nova fé - como também as relações entre os judeus e os não judeus, enquanto membros de distintos grupos étnicos e religiosos e, sobretudo, as relações que os fiéis estabelecem entre si enquanto grupo religioso coeso.

Não nos deteremos a analisar as motivações desta disciplina alimentar, questão bastante complexa, mas apontamos algumas das que têm sido discutidas como mais plausíveis, e que não se excluem mutuamente ${ }^{5}$. De todo o modo, o célebre «lamento pelas cebolas do Egipto» ${ }^{6}$ é prova de que, do ponto de vista histórico, se teria dado uma evolução na codificação das leis alimentares, já que os hebreus cativos no Egipto não teriam uma dieta muito distinta da dos habitantes autóctones. Desta forma, a regulação do regime alimentar permitido aos judeus, tendo feito parte do núcleo central da fé judaica, é cronologicamente considerada como uma construção pósmosaica. A leitura desta codificação permite-nos destacar características interessantes ${ }^{7}$.

${ }^{5} \mathrm{Na}$ base da regulação alimentar judaica poderão estar critérios de salubridade, ou seja, a selecção dos alimentos permitidos obedece a um princípio higienista de rejeição do que é potencialmente nocivo. Trata-se de um argumento um pouco anacrónico, na medida em que se torna tentador projectar para o passado noções de segurança alimentar que hoje estão construídas em sólidas descobertas científicas e inovações tecnológicas. Assim, a rejeição do sangue dos animais pode ter que ver com o facto de as carnes sufocadas se conservarem com mais dificuldade, e a rejeição do porco, por ele ser portador de parasitas que podem contaminar o homem. Para outros autores, há uma motivação sociológica, nascida da necessidade de cerrar uma identidade, em resposta a uma envolvência hostil. Neste sentido, teria sido no períodos de exílio e de cativeiro da Babilónia, ou nos períodos de ocupação helenística que se teria concentrado uma codificação do regime alimentar baseada na diferença em relação às culturas contíguas. Para outros, ainda, e sobretudo entre os exegetas cristãos, os interditos alimentares judaicos têm um propósito moralista. Ensinar aos judeus as virtudes da disciplina e da contenção alimentar é preparar a santidade do povo. Desta maneira, os animais rejeitados são alvo de uma interpretação alegórica, que os identifica com o bem ou com o mal, conforme são adequados à dieta ou não. A antropóloga M. Douglas, em dois trabalhos fundamentais enquanto propostas de interpretação para a questão alimentar e sacrificial judaica $(1991 ; 1966 ; 1971)$, apresenta as diversas interpretações que citámos e, a sua concepção quanto à disciplina alimentar judaica: esta é uma projecção da criação do mundo e do modo específico de conceber a sua organização pelo judaísmo.

${ }^{6}$ Todas as citações bíblicas seguem a tradução da Bíblia Sagrada, Difusora Bíblica, $11^{\text {a }}$ ed. 1984. Nm 11,4-5 «Quem nos dará carne para comer? Lembramo-nos do peixe que comíamos no Egipto, sem nos custar nada, dos pepinos, dos melões, dos alhos porros, das cebolas e dos alhos..."

${ }^{7} E x$ 23,14-19. A ingestão ritual do pão ázimo. A instituição das três festas anuais. A consagração das primícias ao sacrifício. Vs. 18 «Não derramarás o sangue do Meu sacrifício junto ao pão fermentado, e a gordura das minhas vítimas não ficará por oferecer até ao dia seguinte (...)»; 19 «Não cozerás um cabrito no leite de sua mãe». Cf. Lv 1-2, a disciplina do sacrifício ao Senhor, conforme as diferentes espécies; a classificação segundo animais puros e impuros quer para o sacrifício quer para a alimentação (11,1-47). Em Lv 17, a obrigatoriedade 
Em primeiro lugar, há a considerar uma ligação entre o que hoje classificaríamos como preceitos especificamente religiosos, como a instituição dos sacrifícios e dos rituais de purificação, e o regime alimentar enquanto realidade organicamente e culturalmente motivada. Não é possível no mundo antigo, em particular no mundo judaico, estabelecer uma fronteira entre estas duas esferas do comportamento humano. Mesa e altar são realidades concêntricas, e, ao nível dos animais consumidos pelos homens, há-os que também são indicados para o sacrifício a Deus e outros que só servem para o consumo humano. À excepção do sangue, tudo o que é sacrificável a Deus pode ser comido pelos homens, mas nem tudo o que os homens comem pode ser sacrificado a Deus.

Depois, temos a tipologia das espécies interditas: nas interessantes passagens do Exxodo, Levítico e do Deuteronómio, surge descrito o intrincado casuísmo das espécies animais impuras, que atravessa todo o reino animal8. Analisando os excertos, e procurando extrair das listas de interditos regras que expliquem esta gramática, verifica-se que estão arredados os animais que, apresentam características anatómicas e comportamentais ambíguas, isto é, os que são difíceis de introduzir em categorias cerradas ${ }^{9}$, por viverem em mais do que um habitat, por apresentarem cruzamentos de características, por, terem, eles próprios, comportamentos contaminantes, alimentares ou outros. Este esquema, associado às orientações relativas à higiene e saúde e aos condicionamentos de acesso à vida comunitária segundo critérios de pureza, ordem e categoria, apresenta-se não só enquanto um poderoso modo de ler e disciplinar o homem enquanto ser religioso, mas também como um condicionador do quotidiano das comunidades. Aprendidas e vividas, estas normas ultrapassam a esfera religiosa que as fundamentou para afectarem todos os domínios de expressão humana, as rotinas diárias, a sexualidade, a alimentação, o agir em comunidade. Acabam por estabelecer-se enquanto fundamento ético, não exclusivamente religioso, de uma comunidade, conforme demonstrou Jacob Milgrom ${ }^{10}$.

O modo de preparação dos alimentos é também alvo de uma ordenação específica: a separação extrema do leite e derivados da carne, inclusive dos objectos e dos agentes que os manipulam; a separação absoluta da carne e do sangue nas espécies sacrificadas (porque o sangue é fonte de vida, e essa a Deus pertence, e deve-lhe ser consagrado) envolve um modo e mesmo um local

de sacrificar os animais no altar do Tabernáculo.

${ }^{8}$ Ex. 22,30; Lv 11,2-47; 20,22-26; Dt 14,3-20; in Douglas, 1991 (1966), 57-74.

${ }^{9}$ A título de exemplo, são rejeitados os anfíbios, que tanto vivem na água como em terra; as aves que não voam, como a avestruz; os coelhos e as lebres, bem como qualquer quadrúpede que apresente dismorfia entre as patas traseiras e dianteiras (ou seja, que tenha «mãos»).

${ }^{10}$ Milgrom, 1963, 288-301. 
específico para o sacrifício, o altar do tabernáculo; a limpeza rigorosa de cada utensílio usado na preparação dos alimentos. Para garantir o cumprimento das orações e dos estreitos critérios de preparação dos alimentos, o vinho, o pão, as refeições quotidianas tinham de ser preparados por judeus. Esta disciplina, quando cruzada com os ritmos próprios definidos pelas festividades judaicas, impunha-se como definição do ser judeu enquanto entidade distinta e dissociada dos não judeus. A alimentação participa, assim na estratégia de diferenciação étnica e religiosa dos que se reviam na obediência a uma disciplina que não era apenas alimentar, antes condicionava todo o relacionamento do homem com o seu espaço.

Podemos vislumbrar já a controvérsia suscitada pelo cristianismo. É significativo que a emergência dos traços particulares do cristianismo enquanto expressão religiosa divergente, mas nascida do meio judaico, e por ele rodeada, se reflicta também na problematização dos hábitos alimentares permitidos aos primeiros cristãos e Paulo surge como um dos participantes e teorizadores deste debate.

É geralmente aceite que o cristianismo, vinho novo a requerer odres também novos, doutrina de vocação ecuménica e universal, reagiu criticamente aos preceitos alimentares judaicos, por os considerar como fazendo parte da antiga lei, uma tradição que se sobrepunha ao real escutar da palavra de Deus, um abuso da forma sobre a substância religiosa que agora se encontrava posta em causa pela nova instância de legitimação da fé que era a crença em Cristo ressuscitado. Deste modo, os preceitos alimentares judaicos foram alvo da mesma crítica que fundamentara a relativização do rito da circuncisão ou do descanso do Sábado. A revisão destas normas ocupou as primeiras gerações de cristãos, empenhados em expor a singularidade da sua fé em confronto com as religiões vizinhas ou, no caso do judaísmo, com a religião matriz.

Se nos colocarmos no presente, ponto de chegada do cristianismo enquanto corpo dogmático, a ninguém escapará o facto de o cristianismo quase não apresentar preceitos alimentares, e mesmo os que apresenta são pouco relevantes. Podem consumir-se alimentos de todos os tipos, é recomendada a parcimónia e a contenção (disciplina sobre a quantidade), e existem recomendações quanto à periodicidade e exclusão de alguns alimentos, adaptadas ao calendário das celebrações litúrgicas (e. g. a abstinência da carne nas sextas feiras da quaresma, o jejum prévio à Eucaristia). Fazendo apelo ao conhecimento empírico da realidade que nos cerca, não será errado dizer que a disciplina alimentar não é hoje algo que caracterize a identidade de um cristão, ou seja, não é pelo seu comportamento alimentar que um cristão é identificado enquanto tal por alguém que não partilhe da sua fé. Portanto, um longo caminho traçado entre a cepa judaica, religião que valorizava a disciplina 
alimentar como produtora de identidade, e o ramo cristão, religião cuja ausência do condicionalismo alimentar se combina com um carácter universal, mais aberto, liberto de vinculações étnicas e sociais.

As cartas de Paulo fornecem informações quanto às primeiras etapas deste processo de afastamento entre o cristianismo e o judaísmo, e dão-nos conta de uma realidade complexa, feita de delicados avanços e recuos em face de uma cultura que era a da procedência dos primeiros convertidos, isto é, judeus da Palestina e comunidades judaicas da diáspora. Com estes, objectivamente ligados à matriz religiosa judaica, começava a conviver um grupo de cristãos "gentios», sem qualquer ligação prévia ao judaísmo. E surge neste contexto a necessidade de avaliar o peso da tradição judaica para um cristão. Sendo Cristo o Messias do AT, constituindo os primeiros exercícios exegéticos uma demonstração de como o cristianismo completa as profecias do judaísmo, como incluir no projecto de salvação e na divulgação da mensagem pessoas que não fizeram um percurso inicial no judaísmo?

Está em causa o estatuto da nova fé perante o judaísmo, do qual derivou. Para os judeus da Palestina que aceitam Cristo, a revelação é algo que se acrescenta ao mosaísmo, tornando mais perfeita a raiz judaica, sendo Cristo uma das etapas de uma tradição milenar. Assim, os preceitos alimentares judaicos, tais como a observância do sábado ou a circuncisão, são pacíficos. O problema põe-se nos dois outros grupos sociológicos que aderiram ao cristianismo: os judeus de língua grega, das comunidades da diáspora, que aderiram com entusiasmo à revelação cristã, alguns deles já em ruptura com as estritas normas do templo, devem continuar, contudo, as observâncias antigas? Também quanto os gentios, ou seja, não judeus que recebem o cristianismo, ao converterem-se, é ou não esperado que adoptem os preceitos judaicos sobre a alimentação, ou devem apenas cingir-se à verdade anunciada pelos apóstolos e à fé revelada por Cristo? Finalmente, poderá haver um só povo cristão, se permanecerem diferentes interpretações? Como devem relacionar-se as duas comunidades?

Nas suas cartas, assistimos à sua tentativa hábil de coordenar os costumes de uma população etnicamente diferente, minimizando, numa primeira etapa, o significado de regimes alimentares conflituantes.

A primeira comunidade nascida da propagação do cristianismo junto de comunidades não judaicas foi Antioquia' ${ }^{11}$. Após a evangelização de Barnabé e Tiago, alguns cristãos de Jerusalém visitaram a comunidade e instalaram

${ }^{11}$ Act 11,19-26; 15,1-20. A Evangelização de Antioquia começou pela comunidade judaica aí sedeada. Alguns, homens de Chipre e de Cirene, espalharam a palavra também pelos gregos. Barnabé primeiramente, depois com Paulo, dedicaram-se a esta comunidade, que foi a primeira a receber o epíteto de «cristãos». Act 15,20; "por isso, sou de opinião que não se devem importunar os pagãos convertidos a Deus. Que se lhes diga apenas para se absterem de tudo quanto foi conspurcado pelos ídolos, da impudicicia, das carnes sufocadas, do sangue». Também Act 15,29. 
a confusão, impondo a obrigatoriedade da circuncisão e o cumprimento dos preceitos alimentares. E Tiago estabelece uma doutrina, que chegará a Antioquia como oficial: «os pagãos convertidos devem abster-se de carnes imoladas aos ídolos, do sangue, de carnes sufocadas e da impudicícia».

Este princípio emanado do Concílio de Jerusalém, que Tiago apresenta como tolerante, implicava contudo uma segregação considerável em relação à comunidade alargada não judaica e não cristã: no mundo greco-romano, toda a carne disponível para consumo era previamente sacrificada aos Deuses, ou aos ídolos, numa perspectiva judaico-cristã. A distribuição e o comércio da carne eram antecedidos pelo sacrifício ritual das espécies, a cargo do mageiros, que cuidava do seu sangramento e da reserva de uma porção para ser integralmente consumida no fogo ${ }^{12}$. Ou seja, os cristãos deviam abster-se de consumir carne preparada por não cristãos e não judeus, cumprindo-se portanto os princípios da pureza ritual verificados no judaísmo. Do ponto de vista da prática ritualista do sacrifício judaico, Tiago concedeu que o mesmo pudesse ocorrer fora do tabernáculo (o que é adequado para uma comunidade em ampla difusão espacial). Mas o potencial segregador permanece intocado, na medida em que separa, na preparação, os judeus e cristãos dos pagãos.

Paulo deu-se conta das dificuldades criadas por esta disciplina na criação de uma comunidade cristã verdadeiramente unida. Na Carta aos Gálatas, critica o comportamento dúplice de Pedro, por ocasião da sua viagem a Antioquia ( $G l$ 2,12) «Antes de terem chegado alguns homens da parte de Tiago, ele comia juntamente com os gentios (hoi hellenes); mas quando eles chegaram, retraiu-se e separou-se deles, com receio dos da circuncisão. E outros judeus também dissimulavam com ele, de maneira que até Barnabé se deixou levar pela dissimulação». A denúncia de Paulo quanto ao modo de Pedro se comportar à mesa, distinguindo os companheiros segundo os critérios de pureza judaicos, não é resultado de um espírito excessivamente crítico, mas antes da consciência do potencial divisor da mesa e da alimentação para as comunidades emergentes. A dificuldade em partilhar a mesa denuncia a existência de duas comunidades em Antioquia, num dado momento de propagação do cristianismo.

As cartas de Paulo, os primeiros textos da tradição apostólica a serem compostos, apresentam um cenário mais dinâmico e menos assertivo do que o que vamos encontrar nos Evangelhos e nos Actos dos Apóstolos. De algum modo, Paulo foi pioneiro no modo de lidar com os primeiros conflitos, apresentando propostas e soluções que também são fluidas e são evidentemente sinal de uma realidade em construção. A controvérsia em relação aos alimentos, tal como é abordada por Paulo, partirá desde logo pelo assumir do conflito existente entre as suas origens, como judeu étnico

\footnotetext{
${ }^{12}$ Detienne, Vernant, 1989.
} 
e fiel cumpridor das leis religiosas mosaicas, e a sua missão de anunciar, particularmente aos gentios, a revelação de Cristo. Que lugar conceder aos preceitos judaicos que o acompanharam grande parte da sua vida? Paulo, pastor de comunidades, lida com dois problemas, ligados entre si: a controvérsia suscitada em comunidades etnicamente diversificadas entre si e cada uma delas a lidar com a presença de minorias; o seu problema de consciência, quanto ao lugar a conceder à matriz judaica após o acontecimento da sua conversão que, segundo o relato bíblico, mais do que procurar, the acontece (Act. 9).

É possível detectar na mensagem atribuída a Paulo a oscilação entre vários tipos de discurso: temos o evitar da controvérsia pela omissão estratégica das fontes de conflito, atitude mais evidente na 1 Cor. e em Rom., mas também a declaração assertiva da nulidade dos preceitos judaicos, característica das cartas do cativeiro e de Gal.. Num outro plano, surge a sustentação teológica da validade histórica da tradição judaica, à luz dos planos divinos, ou seja, uma interpretação retrospectiva dos preceitos mosaicos, ou seja, uma atitude conciliadora entre as duas religiões. Esta última está presente na Carta aos Hebreus, texto cuja autoria paulina é posta em causa. Nessa medida, a validade informativa do seu conteúdo, bem com o propósito deste texto conciliador atribuído à autoridade paulina devem ser problematizados, embora esta seja uma questão que não nos interessa aqui aflorar ${ }^{13}$.

Colocado no terreno real da evangelização de gentios, Paulo evita decidir sobre a correcção de um comportamento alimentar, declarando-o como não determinante para a essência do cristianismo. Na Carta aos Romanos, texto de maturidade produzido cerca do ano 58, verdadeiro tratado teológico dirigido aos cristãos de Roma, Paulo sustenta a parcimónia no uso da comida e de bebida (Rom. 13-14) e defende a bondade, mas não a obrigatoriedade, da abstinência do vinho e da carne (Rom.14,21). Quanto aos outros aspectos das regras alimentares, no entanto, Paulo assume uma posição liberal, entregando ao destinatário a liberdade de decidir. Cada um deve comer conforme a sua consciência, convicção (podemos dizer, conforme os seus costumes?) e conforme a aceitabilidade das suas escolhas na comunidade em que se insere (Rom 14,15): «se por causa dum alimento entristeces o teu irmão, já não andas segundo a caridade». Ou seja, devem evitar-se, na comunidade, as querelas decorrentes das escolhas alimentares, pois nelas não reside o fundamento do cristianismo (Rom 14,20): «Não tornemos, pois, a julgar-nos uns aos outros» (Rom 14,13): «Por causa da comida, não destruas a obra de Deus». De facto, (Rom 14,17): «... o reino de Deus não consiste em comer ou beber, mas em justiça, paz e alegria no Espírito Santo».

${ }^{13}$ Barbaglio, 1980, 45. Veja-se, na Introdução Geral (15-56), a discussão sobre a cronologia e a autenticidade dos escritos paulinos, em particular sobre a Carta aos Hebreus. 
A mensagem de Paulo é propositadamente ambivalente, na medida em que não precisa qual o comportamento visado, se o do cumprimento rigoroso das normas judaicas se o do que as rejeitam. Neste sentido, as comunidades são instadas a desvalorizar as normas alimentares como fonte de vinculação e de reconhecimento recíproco. Embora haja motivações mais profundas para a valorização do vegetarianismo, $($ Rom 14,21$)$ pensamos que o apoio de Paulo a este regime apresenta esta vantagem instrumental que é o de eliminar o grave ponto de discórdia que constituíam as normas de preparação da carne.

Alguns anos antes, por volta de 56, Paulo dirigira aos cristãos de Corinto palavras em que se pronunciara claramente sobre a ingestão da carne consagrada aos ídolos, isto é, toda a carne que estava disponibilizada nos mercados da cidade. Afirma que tal não tem importância em si mesmo, pois esse alimento, para um cristão, está desprovido de significado religioso (1Cor 8,8): «porque não ganhamos se comermos, nem perdemos se não comemos». Paulo parece contribuir, com as suas palavras, para esclarecer uma questão premente na jovem comunidade cristã.

Todos temos ciência, todos sabemos (1Cor 8,1), mas o conhecimento não é tudo, nem sustenta uma comunidade. Portanto, embora saibamos que os ídolos não existem, e que, em consequência, ingerir carnes imoladas é um acto desprovido de significado religioso, sendo por isso aceitável, há que evitar fazêlo, por ser causa de escândalo para os mais fracos $(1$ Cor 8,10$)$ : «pois se alguém te vê a ti, que possuis ciência, sentado à mesa no templo dos ídolos, a consciência dele, que é fraco, não será induzida a comer as carnes sacrificadas aos ídolos?». Ou seja, Paulo aconselha a uma atitude sensata e não instigadora de divisões, em função de um bem maior que é, diríamos nós, o acolhimento dos fracos, ou seja, o bem da evangelização e do acolhimento universal da Igreja por todos. Se a alimentação é causa de más interpretações por assimilação a costumes religiosos anteriores, seja o judaico seja o costume sacrificial greco-romano, então que se elimine da dieta o motivo de conflito $(1$ Cor 8,13): «jamais comerei carne para não escandalizar o meu irmão» ${ }^{14}$.

Mais adiante, Paulo confirma a irrelevância quanto ao que se come, adoptando uma postura politicamente correcta (1Cor 10,23-33): «Tudo é permitido, mas nem tudo convém. Tudo é permitido, mas nem tudo edifica. (...) comei de tudo o que se vende no mercado, sem nada perguntar por motivo de consciência (...) se algum infiel vos convidar e vós quiserdes ir, comei de tudo o que vos for servido, sem nada perguntar, por motivo de consciência.

\footnotetext{
${ }^{14}$ Neste cap. 8, é magistral a oscilação da pessoa do discurso, entre um «nós» cristãos amadurecidos, que temos ciência e que estamos empenhados na edificação da Igreja; um «tu» que é aconselhado a omitir a ingestão de carne por razões metodológicas $(1$ Cor 8,10) «pois se alguém te vê a ti, que possuis ciência, sentado à mesa no templo dos ídolos, a consciência dele, que é fraco, não será induzida a comer as carnes sacrificadas aos ídolos?»; e por fim um «eu» que adopta a atitude radical, que não se impõe aos outros, de jamais comer carne.
} 
Mas, se alguém vos disser: Isto foi sacrificado aos ídolos, não comais por causa desse que vos advertiu, e da consciência. E quando digo consciência, refiro-me à do outro e não à tua (...) portai-vos de modo que não deis escândalo, nem aos judeus nem aos gentios (...) fazei como eu, que em tudo procuro agradar a todos».

Tudo é permitido, o comer e o não comer, sem que tal signifique um problema de consciência para o cristão. Mas deve evitar-se escandalizar judeus e gentios, ou seja, deve agradar-se a todos, adoptando os hábitos dominantes da comunidade em que se está.

Esta flexibilidade de Paulo, assente na afirmação da irrelevância das escolhas alimentares, desde que pautadas pela parcimónia, e na adequação das mesmas às normas da comunidade a ser cristianizada, constitui, no nosso entender, uma das explicações para a expansão e sucesso do cristianismo: por um lado, aceita como dado adquirido o facto de não se instalar sobre um vazio cultural, ou seja, o cristianismo lida com populações educadas dentro de modelos éticos e religiosos que, embora desprovidos de sentido para a essência do cristianismo, não devem ser hostilizados, nem o cristianismo deve fazer da sua irrisão o fundamento do seu combate. Por outro lado, Paulo contribui para a formação do cristianismo como uma religião indiferente à valorização religiosa de uma dieta ou das escolhas alimentares. Esta neutralidade adequa-se à estratégia de preservação de um objectivo mais vasto, que era a vontade de integrar um universo humano etnicamente e culturalmente indeterminado. $\mathrm{O}$ modo de Paulo abordar a questão alimentar constitui, por isso, um dos aspectos da sua contribuição para o desenvolvimento do cristianismo enquanto religião global.

Nas chamadas «Cartas do cativeiro» (Ef, Fil, Col, Flm), escritas já na década de 60, dirigidas fundamentalmente aos seus dilectos discípulos de origem grega, ele proclama sem hesitações a supremacia da revelação sobre a lei de Moisés, e a igualdade de todos, judeus e não judeus, diante do cristianismo ${ }^{15}$. Teologicamente densas, é já um Paulo firme nas suas convicções, que não cessa de combater a postura dos judaizantes, «os da circuncisão», que desviam os convertidos da verdadeira mensagem de Cristo. Paulo insiste na universalidade da revelação e reprova, tenazmente qualquer tentativa de estabelecer facções, uma espécie de duas velocidades entre cristãos

${ }^{15}$ Ef 2,15 (falando da obra de Cristo): «anulando pela carne a Lei, os preceitos e as prescrições, a fim de, em si mesmo fazer dos dois um homem novo, estabelecendo a paz»; 2,19 «já não sois hóspedes nem peregrinos, mas sois concidadãos dos santos e membros da família de Deus»; 3,6 «os gentios são co-herdeiros, pertencem ao mesmo corpo e comparticipam na promessa...»; Fl3 «cuidado com os cães, cuidado com os maus obreiros, cuidado com os da mutilação. Porque nós é que somos os verdadeiros circuncidados...»; Col 2,16 «Que ninguém vos condene pela comida ou pela bebida, pelas festas e pelos Sábados» Col 2,21 «Não tomes, não proves, não toques... (citando as prescrições do Levítico)... proibições estas que se tornam perniciosas pelo uso que delas se faz e que não passam de preceitos e doutrinas dos homens». 
de primeira, os que juntam o cristianismo à disciplina judaica e de segunda, os convertidos de origem não judaica ${ }^{16}$. $\mathrm{O}$ tom é determinado, frontal, e não deixa de reprovar explicitamente, com alguma ironia até, as condenações do Levítico, resumindo-as ao seu núcleo de proibição «não tomes, não proves, não toques...». Na Carta pastoral a Tito, escrita cerca de 63, Paulo tem de se haver com um caso concreto que afecta a missão apostólica deste seu discípulo. Há falsos doutores, particularmente «entre os da circuncisão» (Ti 1,10), aos quais é necessário «fechar a boca», pois perturbam famílias inteiras. Um deles, considerado profeta, categoriza os cretenses dentro de uma definição pejorativa «os cretenses são sempre mentirosos, feras e glutões (gasteres) perigosos» (Ti 1,12). Nesta crítica vinda de um cristão de origem judaica, vemos associada uma caracterização ética a um comportamento alimentar criticável, o que mais uma vez confirma a intrínseca ligação entre as normas alimentares e padrão ético fundamental para o judaísmo. Mas este tipo de preconceitos corrompe a universalidade do cristianismo, para quem «tudo é puro para os puros» $(T i 1,15)$.

Trata-se também de um bom testemunho das dificuldades reais dos alvores do cristianismo para conciliar povos coexistentes e conviventes no mesmo espaço, chamados de igual modo à nova religião, mas com um património étnico, religioso e cultural definido. A diáspora judaica que caracterizou o período helenístico, associada à ocupação em período romano, tendo proporcionado contacto e mobilidade aos povos, gerou fenómenos de assimilação, mas também de pressão e de resistência sobre as identidades, reforçando também fenómenos hiper-identitários, isto é, do aparecimento de grupos que cerram a sua identidade interna graças ao reforço de normas simples e tipificadas, que de outra forma talvez não adquirissem tanta visibilidade.

Assim, não sendo segredo que tanto o judaísmo como o cristianismo, nestes primeiros séculos da era cristã, reforçaram as suas características separativas, também Paulo fica preso, pelo menos ao nível da eficácia retórica, dentro desta tentação simplificadora e algo maniqueísta: o epíteto «os da circuncisão», dirigido aos cristãos de origem judaica que não abandonaram os seus rituais de filiação ao judaísmo, é um bom exemplo desta tendência de recorrer a categorizações simples como estratégia de identificação de grupos diferentes.

Esta controvérsia, presente nas Cartas de Paulo enquanto testemunha e protagonista, tem um vencedor, e ele define o cânone cristão que iremos encontrar como dominante na composição dos Evangelhos e dos Actos. Deste

${ }^{16}$ Ti 1,10-12: «Porque ainda há muitos desobedientes, faladores e sedutores, principalmente entre os da circuncisão, aos quais é necessário fechar a boca (...) um deles, considerado como profeta, disse "os cretenses são sempre mentirosos, feras e glutões preguiçosos não dêem ouvidos às fábulas judaicas e a preceitos de homens que se apartam da verdade». 
modo, alguns passos do Novo Testamento denunciam, com alguma crueza de linguagem, a irrelevância de uma série de preceitos judaicos, entre os quais figuram o regime alimentar e os rituais de purificação que antecediam as refeições, não havendo pejo em mencionar aspectos contaminantes para este conceito de pureza ritual ${ }^{17}$. Noutros passos do Evangelho, Jesus surge ostensivamente, para escândalo dos escribas e dos fariseus, isto é, dos guardiões da tradição judaica, a partilhar a sua mesa e a tocar fisicamente pessoas marcadas por formas de exclusão social ou pela doença, impuros à luz dos preceitos judaicos, como estrangeiros, publicanos e pecadores (o episódio do cobrador Levi, filho de Alfeu, mas também, o episódio da hemorroíssa, o encontro com a samaritana, com a pecadora arrependida, a cura de leprosos, a cura da filha do centurião ${ }^{18}$ ), ou nos $A c t$., a visão de Pedro que surge, significativamente, a anteceder o encontro do Apóstolo com o gentio Cornélio, ilustram o tipo de tensões a que estaria submetido o cristianismo nos seus alvores: a religião judaica proibia o contacto com os gentios, particularmente o comportamento familiar de entrar nas suas casas e de com eles comer, fonte de contaminação. Impossível, portanto, aliar esta limitação à obrigação de Evangelizar todos os povos, acolhida pelos apóstolos com a descida do Espírito Santo, marcada pela carisma da poliglossia? ${ }^{19}$.

A realidade contida pelos Evangelhos, contudo, não deixa de ser complexa, e, à parte uma controvérsia que afecta o modo de estar do cristianismo no mundo, que proclama a nulidade da alimentação enquanto fonte de caracterização religiosa, do ponto de vista substantivo e teológico, há a apropriação, num registo mais profundo, de uma valorização dos alimentos e da ritualização da

${ }^{17} M t$ 15,1-20; $M c$ 7,1-15 «Alguns escribas e fariseus, vindos de Jerusalém, reuniram-se à volta do Senhor. Notaram que vários dos seus discípulos comiam pão com as mãos impuras (...) Isto é, sem cumprir as abluções"; "e há muitos outros costumes que seguem por tradição: lavagem das taças, dos jarros, e das vasilhas de cobre (...) Chamando de novo a multidão, dizialhe: "-Ouvi-me, e procurai compreender. Nada há fora do homem o que, entrando nele, o possa tornar impuro. Mas o que sai do homem é que o torna impuro». A vanidade da disciplina alimentar judaica manifesta-se no reforço extremo da sua mensagem aos apóstolos incrédulos (Mc 18-19) «Também vós não percebeis que tudo quanto de fora entra no homem não pode torná-lo impuro, porque não penetra no seu coração, mas no ventre, e depois é expelido em local próprio?». Afinal, «comer» é só uma etapa do processo biológico de ingerir, digerir e expelir, e não tem nada que ver com o coração e a consciência.

${ }_{18}$ Mc 2,13-16: «Uma vez que se encontrava à mesa em casa dele, muitos publicanos e pecadores também se puseram à mesma mesa com Jesus e os Seus discípulos (...) os escribas do partido dos fariseus, vendo-o comer com pecadores e publicanos, disseram aos discípulos "Porque é que ele come com publicanos e pecadores?"

${ }_{19}$ Act 10,9-16: «Estava cheio de todos os quadrúpedes e répteis da terra e de todas as aves do céu. E uma voz dizia-lhe: Vamos Pedro, mata e come! De modo algum Senhor! Nunca comi nada de profano nem de impuro. E a voz falou-lhe novamente, pela segunda vez: "O que foi purificado por Deus não o consideres tu impuro»; Act 11,3. Observe-se que, nesta visão Deus dá duas ordens a Pedro, que mate e que coma espécies indiferenciadas. A mensagem é taxativa: Pedro está livre de cumprir os rituais judaicos de abate e de ingestão da carne. 
mesa enquanto elementos simbólicos, isto é, dotados de eficácia comunicativa. Apesar da explicitação da necessidade de ruptura com a tradição judaica, ela própria fazendo parte da novidade revolucionária do cristianismo, encontramos também manifestações do reconhecimento da disciplina alimentar enquanto via de identificação religiosa.

Em primeiro lugar, temos o condicionamento da quantidade dos alimentos (jejum e abstinência), presente nos Evangelhos e nas cartas de Paulo, como método de preparação da vinda do Messias e como modo de treinar, tal como um atleta, as vontades do corpo $^{20}$. Alguns dos milagres de Cristo tiveram como foco a multiplicação de alimentos, tal como muitas parábolas se constroem em volta de banquetes, celebrações comunitárias, naquilo que podemos, quanto a nós, classificar como uma estratégia de exploração da angústia da carência e do desejo da abundância típicas do homem comum do mundo antigo ${ }^{21}$. Não seria pois, de estranhar, que o reino dos céus se apresentasse como uma boda, a antevisão da abundância, para um povo que devia conhecer bem a experiência da luta diária pelo pão de cada dia.

Juntemos o ritual da consagração, e da Eucaristia, todo ele assente no desenvolvimento não metafórico, mas explícito, da ideia da refeição colectiva proporcionada pela celebração de uma festa, momento central do cristianismo que se fixa tipologicamente na celebração da Páscoa judaica, agora renovada por um novo sacrifício e por novos comensais, a quem é proposto o desafio de romper com os costumes do seu passado religioso ${ }^{22}$. Renovam-se os referentes, permanece, contudo, a estrutura de codificação da linguagem. A narrativa da história sagrada apresenta inúmeros episódios marcados, subtilmente, por uma encenação de que se destaca o fenómeno alimentar. Assim, depois de ressuscitado, Cristo dá-se a conhecer aos discípulos de Emaús pelo modo como fracciona o pão. Desfaz as dúvidas aos apóstolos incrédulos quanto à sua identidade e sua humanidade, comendo peixe diante deles ${ }^{23}$.

Há, na narrativa da Última Ceia, um pormenor que nos acorda para

${ }^{20} M t$ 4,2; 6,16-18; 9,14-15; Lc 4,2; 5,33; Mc 2,18-20. Neste domínio, o cristianismo encontra-se com um apelo característico dos temas da filosofia prática greco-romana, pelo que a continência seria uma característica cristã simpática ao meio culto pagão.

${ }^{21}$ Dias, 2008, 157-175.

${ }^{22}$ Harril, 2008, 133-158. A Eucaristia, tal como é apresentada no Evangelho de João, constitui um polémico momento de conflito entre os que estavam dispostos a acompanhar Cristo e os que temiam o desafio. As palavras de Cristo desafiam os apóstolos a quebrar o interdito do sangue e o (universal, diríamos) do canibalismo (Jo 6,53): «... se não comerdes a carne do Filho do homem e não beberdes o Seu sangue, não tereis a vida em vós...»; (Jo 6,61) «muitos dos Seus discípulos disseram: “ - duras são estas palavras! Quem pode escutá-las?» Cristo, ao aperceber-se do murmúrio, pergunta-lhes se isto os «escandaliza», havendo de seguida um momento narrativo em que a ênfase recai na distinção entre os que $\mathrm{O}$ seguem e os que se afastam $\left(J_{0} 5,66\right)$ «a partir de então muitos dos Seus discípulos retiraram-se e já não andavam com ele».

${ }^{23}$ Lc 24,30; 41; Jo 21,15. 
o facto de o partilhar dos alimentos constituir, mesmo para Cristo, uma manifestação externa e uma consequência de uma vinculação religiosa e um modo de construção de uma comunidade: apresentando aos apóstolos a antevisão dos acontecimentos próximos da paixão, Jesus descreve aquele que o há-de trair como «alguém que mete comigo a mão no prato», na feliz expressão de Marcos $^{24}$. Jesus será entregue por alguém que integra o seu círculo de intimidade, podendo ser qualquer um dos doze. Partilhar o prato, mais até do que partilhar a mesa, é um gesto que preserva a concepção da partilha alimentar como instância de vinculação de um grupo afectivo e religioso.

Em conclusão, pensamos que é o próprio Paulo quem, apesar do esforço em contribuir para a superação do critério alimentar e da partilha da mesa como fonte de dissociação e de conflito que obstaculizasse a universalidade da mensagem cristã, ao mesmo tempo, mostra estar prisioneiro desta visão última dos alimentos e do acto de alimentar-se como uma instância de comunhão ou fonte de faccionalismo e de segregação.

Em Paulo, o conflito relacionado com a alimentação não é apenas de ordem externo, definindo um dos aspectos de debate entre si e a comunidade a edificar; mas também de ordem interna, de Paulo em luta consigo próprio, não fosse ele um homem de palavras e de carácter apaixonados, mas também um homem dividido entre várias culturas, capaz de assumir criticamente a distância e a ruptura em relação a elas, mas incapaz de se distanciar da linguagem e das estruturas de comportamento, necessários para manter um nível razoável de comunicação que permitisse a fixação de uma nova mensagem. Assim, os escritos de Paulo mostram que o cristianismo reformou a gramática do condicionamento alimentar judaico, mas participou na manutenção da sua simbologia, nomeadamente pela utilização do discurso da mesa como forma de indiciar a inclusão identitária numa comunidade ou o seu inverso, a exclusão e o afastamento da comunidade.

Assim, dirigida aos cristãos de Corinto, cidade bem conhecida na Antiguidade pela liberalidade de costumes, o zeloso Paulo adverte os fiéis quanto aos perigos do impudor (1Cor. 5, 9-11): «Disse-vos, por carta, que não vos devíeis misturar (synanamignysthai) com os impudicos. Não era, certamente, aos imorais deste mundo, aos avarentos, ladrões ou idólatras, porque assim teríeis de sair deste mundo. $\mathrm{O}$ que vos escrevi foi para que não tenhais comunhão com aquele que, dizendo-se vosso irmão, é imoral, avarento, idólatra, maldizente, dado à embriaguez ou ladrão. Com estes nem sequer deveis comer (synesthiein)».

Recusar a partilha da mesa surge como uma forma drástica e última de exclusão, que completa e agrava o sentido da antes prenunciada recusa de

${ }^{24}$ Mt 26,23; Mc 14,20; Lc 22,21. Num registo diferente, em Jo 14,26 «É aquele a quem eu der o bocado que eu vou molhar». 
qualquer tipo de associação ${ }^{25}$.

${ }^{25}$ Schwiebert, 2008, 159-164, afirma que esta atitude valida a interpretação de que a partilha dos mesmos alimentos pelas mesmas pessoas é um factor de vinculação identitária, e a quebra extrema deste laço, aqui aplicado ao comportamento diário e concreto do cristão, representa a própria constituição da comunidade cristã enquanto realidade definida e diferenciada. 


\title{
A CAMINHO DA NOVA AEON: TOLERAR OU ATURAR? O Que teria Paulo em Mente?
}

\author{
Maria Ana T. Valdez \\ Universidade de Yale \\ Centro de História da Universidade de Lisboa
}

A primeira coisa que gostaria de referir é que a questão sobre uma eventual tolerância religiosa em Paulo surgiu no contexto dos meus estudos sobre o modelo de Quinto Império de António Vieira, onde em última instância se apela a uma universalização religiosa de tipo ecuménico com o objectivo de atingir o prometido reino de Deus. Daí que a tolerância religiosa se apresentasse como um factor fundamental nos trabalhos de Vieira. Desse modo, Vieira compilou nos vários cadernos da Clavis Prophetarum ${ }^{1}$ exemplos retirados de vários textos e autores, entre os quais se encontra Paulo. Por isso, a minha questão relativamente ao conteúdo das cartas que o apóstolo endereçou à comunidade de Corinto, mas também pelo que este mesmo conteúdo pode significar da parte do cristianismo em termos de abertura religiosa.

O objectivo último, tanto de judeus como de cristãos, é semelhante: a consumação do reino divino na Terra. Só que isso não pode acontecer antes que algumas condições básicas estejam reunidas. Destas, talvez a mais importante seja a união da Humanidade em volta de uma religião universal que tivesse Deus como única divindade. Esta é claramente uma premissa complicada, não só pela multiplicidade religiosa existente no mundo, mas também devido às divisões fracturantes existentes entre judeus e cristãos.

O nosso propósito neste momento não é discutir filosoficamente o conceito de tolerância e como é que ele se pode aplicar no contexto da religião. Mas antes, tentar observar se nos textos de Paulo, um dos mais importantes agentes do cristianismo dos primeiros tempos, existe alguma abertura para que aqueles que não seguissem o Evangelho pudessem ser admitidos no reino de Deus que se deveria consumar após a parousia de Cristo.

Apesar de Paulo representar de alguma forma a ruptura entre a tradição judaica e a cristã, especialmente no que diz respeito à temática do Messias, uma coisa é certa: a figura de Paulo e os textos que lhe são atribuídos tiveram grande influência quer na criação e no estabelecimento da identidade cristã, quer mesmo no desenvolvimento da doutrina do novo grupo religioso.

A vida de Paulo e o período histórico em que viveu dizem-nos como o momento era conturbado e como foi possível a fariseu tornar-se em um dos mais fervorosos apóstolos de Cristo. Mas as acções e as palavras de Paulo

\footnotetext{
${ }^{1}$ António Vieira, Clavis Prophetarum in ANTT, Conselho Geral do Sto. Ofício, Ms. 122.
} 
são testemunho da diferença dada pelo apóstolo aos desvios dentro das comunidades cristãs por si formadas e às diferenças entre judeus e cristãos. Por isso mesmo, parece-nos de extrema importância que voltemos a pensar em Paulo em termos que nos permitam equacionar a existência ou não de tolerância religiosa no seu pensamento, e especialmente, nas suas palavras.

Tendo em conta a vastidão de assuntos tratados por Paulo, vamos limitar a nossa análise a dois trechos onde o autor discute a existência de dois períodos histórico-temporais distintos: duas aeones. A isto, teremos ainda que adicionar o significado que Paulo atribui a questões como a vinda de Cristo e a sua ressurreição, bem como o que ele parece pensar sobre a esperança escatológica judaica. É que não podemos esquecer que uma das questões fracturantes entre judeus e cristãos reside exactamente no papel que cada um atribui à figura de Cristo e que se pode traduzir no facto de os judeus continuarem à espera de um Messias, enquanto que os cristãos estão à espera do momento da parousia.

Assim sendo, é necessário tentar compreender de uma forma abrangente como é que o Paulo cristão entendeu este período de espera entre o presente, especialmente dado o facto de que Cristo já tinha morrido e ressuscitado, e o futuro tempo da parousia, e depois, o relacionamento entre os judeus, o povo da Lei antiga, como lhes chama, e os cristãos, o povo da nova aliança com o Espírito, através de Cristo. Disto se pode compreender imediatamente que a esperança escatológica expressa nos escritos paulinos é aparentemente diferente da anteriormente descrita em Daniel. ${ }^{2} \mathrm{Na}$ verdade, para Paulo, a morte de Cristo significava já o início de um novo mundo, de uma nova idade, de um tempo novo, apesar de os cristãos ainda esperarem pela vinda definitiva do Messias. Mas isto não significa que Paulo não achasse que já se tinha passado para a nova aeon como veremos adiante.

Acima mencionámos que os escritos paulinos iniciavam uma ruptura com os judaicos no que diz respeito às esperanças escatológicas expressas por cada um dos dois grupos. No entanto, é necessário que fique claro desde já que Paulo não parece ter tido como intenção acentuar essa ruptura. Simplesmente, os fundamentos judaicos e cristãos são diferentes no que diz respeito a questões de cariz messiânico. E de facto, as nomenclaturas que usa para se referir a um e a outro grupo são reflexo disso mesmo, e como tal, podem ser entendidas do nosso ponto de vista como representando desde já uma certa tolerância no que diz respeito aos judeus. No entanto, é útil não esquecer que Paulo não ousa negar seu passado, muito menos os elos que o ligam ao povo judaico. Disso é exemplo, apesar de em contexto diferente, o que lemos em 2Cor 11, 22: «São hebreus? Também eu. São israelitas? Também eu. São descendentes de Abraão? Também eu.»

\footnotetext{
${ }^{2}$ Para uma análise mais completa dos passos escatológicos de Daniel, cf. Collins, 1993.
} 
Na segunda epístola aos Coríntios Paulo menciona claramente a existência de duas alianças com Deus. Uma primeira teria sido efectuada com Moisés e regia-se pela aplicação da Lei que Deus lhe teria dado no topo do Sinai. Uma segunda, teria sido celebrada através de Cristo, filho de Deus e por isso mesmo directamente com Deus, e que não menciona a nenhum momento um seguimento literal da lei mosaica, especialmente em questões como a circuncisão e a prática do Sabat.

Uma coisa parece certa quando lemos Paulo: os Judeus não estão excluídos de forma alguma do novo pacto com Deus ou do novo mundo que será estabelecido após a segunda vinda de Cristo. O que o autor salienta de forma continuada é a necessidade de conversão dos gentios pela fé, de modo a que mais tarde todos os povos pudessem participar do Reino Divino. Na realidade, Paulo não exclui ninguém, especialmente, dado o facto de que para ele pregar o Evangelho e difundi-lo é uma forma de união universal dos povos sob Deus.

Antes de avançarmos e analisarmos mais pormenorizadamente algumas passagens dos textos de Paulo é necessário demorarmo-nos um pouco sobre o conceito de tempo, o qual se reflecte consequentemente naquilo que designamos normalmente por filosofia da história.

Nos textos bíblicos o tempo no seu todo é normalmente dividido em pequenas unidades de modo a tornar o seu uso mais prático, mas especialmente, de uma maneira que permita ao leitor compreender que o seu presente está mais perto do futuro desejável, do que aquilo que ele poderia inicialmente pensar. Como diz A. Collins, sobre este assunto, «time division is a way to organize larger blocks of time, in a way that will make time itself understandable to people» ${ }^{3}$. É neste contexto que o leitor, especialmente o do Novo Testamento, se depara com uma diversidade imensa do vocabulário usado para descrever o tempo. $\mathrm{Na}$ realidade, o uso de termos como «anos», «semanas», «gerações», «décadas», «jubileus» ou «anos sabáticos», entre outros, é corrente nos textos bíblicos desde os tempos mais antigos e onde a temática do tempo, especialmente quando incide sobre escatologia, é apresentada ou discutida. Aliás, uma das principais características da literatura apocalíptica, onde a temática do tempo escatológico deve ser inserida, é a divisão da história em períodos temporais não só compreensíveis para o leitor, mas especialmente úteis do ponto de vista do assunto em causa, isto é, permitir datar os acontecimentos que iniciarão o fim deste mundo e o estabelecimento do Reino divino na Terra para um momento próximo daquele em que o autor está4.

$\mathrm{O}$ «Fim dos Tempos» é outro dos assuntos do qual não se pode de modo algum passar ao lado quando se discute, como Paulo o faz, estratégias para o

\footnotetext{
${ }^{3}$ Em relação a este assunto, recomendamos como leitura suplementar: Collins, 1996.

${ }^{4}$ Cf. Collins, 1998.
} 
atingir, acentuando que o presente ainda não é o tempo do fim, mas sim mais uma das etapas para o atingir. Afinal, o Reino de Deus é o objectivo último dos cristãos e Paulo está consciente de que isso só será possível seguindo uma estratégia baseada numa fé inabalável. Sendo que esta é uma temática já amplamente discutida por nós, basta-nos por ora salientar a sua importância no ambiente judaico-cristão ${ }^{5}$.

Como mencionámos, a questão escatológica é um tema fulcral do pensamento judaico-cristão e quase que nem seria necessário referir que de ambos os lados, isto é, quer entre judeus, quer entre cristãos, são vários os exemplos que nos chegam de reflexões sobre esta matéria. Deste ponto de vista, os escritos de Paulo são insubstituíveis por reflectirem claramente a existência no seu tempo de uma distinção entre a via judaica e a cristã, se é que assim lhes podemos chamar.

Paralelamente, a forma como Paulo não entra nas questiúnculas que abundavam no seu tempo relativamente ao «desvio» que o cristianismo revelava em relação ao judaísmo tradicional, parece-nos ser já o resultado de alguma ponderação sobre este assunto de uma personagem conhecida pelas suas ligações aos fariseus. Por isso mesmo, é importante que nos detenhamos sobre este assunto, particularmente sobre a abordagem iniciada pelo autor. Ao mesmo tempo, parece-nos possível afirmar de imediato que o relacionamento que Paulo propunha que existisse entre os diferentes "povos de Deus» parece representar desde logo uma abertura no sentido que nos pode levar a questionar se o que Paulo tinha em mente era algum tipo de tolerância religiosa, ou se por outro lado, ele estaria simplesmente à espera que os judeus «entendessem que Cristo era o Messias por quem esperavam». Que fique claro, que nos referimos a uma tolerância entre judeus e cristãos e não àquilo que são as normais atitudes de Paulo relativamente ao que se passa dentro das comunidades por si fundadas e a quem parece não admitir desvios aos ensinamentos do Evangelho. Ou seja, Paulo tinha uma atitude claramente distinta para com os judeus e os gentios, e os desvios que encontrava nas comunidades por si fundadas.

Uma leitura mais atenta dos escritos paulinos parece dar a entender que o apóstolo tinha uma visão tripartida do tempo, isto é, existia 1) o passado marcado pela lei mosaica, 2) o presente marcado pelo pacto com Cristo e, 3) um futuro reino de Deus na Terra. Em certa medida, esta visão tripartida do tempo antecipa já a leitura que $O$ Apocalipse fará do tempo histórico, mas enveredar por aí levar-nos-ia a outras reflexões.

Voltando a Paulo, esta interpretação do tempo histórico comum nas suas obras e reflecte-se particularmente nas cartas que escreve à comunidade de Corinto. Por isso mesmo, a nossa análise terá essencialmente em conta

\footnotetext{
${ }^{5}$ Valdez, 2007.
} 
1Corintios 15,20-28 e 2Corintios 3,7-18. Estas passagens, onde o apóstolo usa abundantemente da sua interpretação do tempo histórico de modo a explicar a esta comunidade as razões que o levavam a chamar-lhe a atenção para o seu comportamento e aparente falta de fé, são também esclarecedoras sobre o que Paulo espera destas mesmas comunidades, especialmente, da sua forma de viver o cristianismo. Por outro lado, a segunda passagem acaba por nos dar uma visão mais completa sobre o que pensava Paulo relativamente ao facto de os judeus não considerarem Cristo como o Messias e continuarem a seguir fervorosamente a lei mosaica.

No tempo de Paulo, Corinto era de facto uma cidade do Império, onde os mais variados tipos de pessoas, credos, etnias, etc., se cruzavam e se influenciavam mutuamente. Por isso, era quase que impossível pensar que a comunidade fundada por Paulo seria impermeável a tamanho número de influências externas. Paulo era certamente sabedor disto. Mais, este talvez tenha sido um dos desafios que o levou a fundar a comunidade de Corinto. Mas isso, não significa que a tolerância de Paulo para com os desvios resultantes destas miscigenações fosse grande, ou mesmo, existente.

Corinto era um lugar de troca de ideias, práticas e rituais que, de algum modo, se reflecte até na existência de várias escolas filosóficas que competiam entre si. Além disso, sendo uma cidade cuja história é marcada por altos e baixos e pela sua recuperação fulgurante devido ao papel comercial que desempenhava na região, Corinto é também no tempo do apóstolo uma cidade onde os hábitos do Império Romano dominavam. Daí as preocupações acrescidas de Paulo para com esta pequena comunidade e a sua necessidade de lhe incutir ânimo e esperança, ao mesmo tempo que lhe aponta os erros e o caminho a seguir.

Em 1Corintios 15,20, Paulo introduz a temática da ressurreição de Cristo. Esta questão vai-lhe ser especialmente útil para explicar que apesar de parecer que já se teria iniciado um novo período temporal com a vinda, morte e ressurreição de Cristo, ainda era preciso esperar pelo momento da segunda vinda, para que de facto pudesse ter início a nova aeon. Ou seja, Paulo descreve a ressurreição de Cristo como comparável aos primeiros frutos que se podem colher de uma colheita e a que se seguirão muitos mais, isto é, muitas mais ressurreições: as dos fiéis.

Segundo alguns dos estudiosos que se têm dedicado ao estudo e comentário deste texto, o uso desta temática nesta secção em particular da carta dever-se-á mais aos rumores que terão chegado aos ouvidos de Paulo do que ao conteúdo da carta a que Paulo estaria naquele momento a responder ${ }^{6}$.

No capítulo 15, Paulo refere-se à «ressurreição» não só porque esperava a segunda vinda de Cristo, mas especialmente porque era necessário que a

\footnotetext{
${ }^{6}$ Cf. Conzelmann, 1981; Thiselton, 2000.
} 
comunidade entendesse que se deveria manter fiel e ter fé na parousia. De facto, tal como Kreitzer escreve, Paulo fala de «ressurreição» enquanto «synonym for a new era for the ones of faith» ${ }^{7}$. Como tal, é necessário sublinhar que mais uma vez Paulo não está a falar de «ressurreição» do ponto de vista apocalíptico, mas sim a fazer uso de um conceito de história dividida em duas aeones, isto é, em duas idades. Isto reflecte-se em última instância numa divisão dualística do mundo: o tempo do antes e o do depois. No passado, Paulo descreve acontecimentos como a morte e a ressurreição de Cristo, enquanto o futuro representa a vinda final de Cristo e o estabelecimento do reino divino na Terra. Deste modo, é possível equacionar neste momento a existência de uma dialéctica entre estes dois tempos. Dialéctica esta que é fundamental para compreendermos que Paulo via o presente como sendo já parte na nova era sendo que Cristo já tinha ressuscitado uma vez, à semelhança do que mais tarde viria a fazer Sto. Agostinho..

Consequentemente, o que Paulo tinha em mente quando aborda esta questão não é tanto se Cristo teria sido ou não ressuscitado de entre os mortos, mas algo mais complexo como é a ideia de que esse acontecimento teria dado início a um período de mudança que levaria a uma nova idade. Esta seria então representada pela consumação do reino de Deus na Terra. Só dessa forma seria possível pensar que depois dos primeiros frutos da colheita se poderiam colher os seguintes.

Diz Paulo em 1Cor 15,20: «Mas não! Cristo ressuscitou dos mortos, como primícias dos que morreram $»^{8}$, numa tentativa de explicar aos membros da comunidade de Corinto de que Cristo tinha sido apenas o primeiro a ressuscitar, mas que todos os homens de fé se lhe seguiriam no momento certo. Desta maneira, Paulo explica também que o baptismo que tinham recebido não é por si só garantia de entrar no Reino de Deus. Mais incisivamente, o facto de terem recebido o baptismo também não lhes grangeava as portas da nova aeon. Desta maneira, Cristo transforma-se no paradigma daquilo que acontecerá a todas as comunidades que viverem de acordo com os príncipios do cristianismo: ressuscitarão e viverão no Reino de Deus. E por isso, diz Paulo aos seus ouvintes: "Não vos iludais: As más companhias corrompem os bons costumes." Sede sóbrios, como convém, e não continueis a pecar! Pois alguns de vós mostram que não conhecem a Deus: para vossa vergonha o digo.» No fundo, a ressurreição necessária para que partilhem o reino de Deus, só pode acontecer em Cristo. E, por isso mesmo, não pode haver lugar a qualquer tipo de desvio. Neste ponto, Paulo parece totalmente intolerante no que diz respeito

\footnotetext{
${ }^{7}$ Kreitzer, 1993, 259.

${ }^{8}$ As citações bíblicas em português usadas neste texto foram retiradas da versão electrónica da Bíblia dos Capuchinhos, Difusora Bíblica, 2001. No entanto, alguns outros passos foram estudados a partir da versão NRSV publicada pela Harper Collins.
} 
a qualquer tipo de desvio que a comunidade ou os seus membros pudessem efectuar em relação aos ensinamentos do Evangelho.

Consequentemente, a metáfora dos «primeiros frutos» tal como usada por Paulo contém uma lógica temporal e uma representativa. Isto é, temporal porque Cristo foi apenas o primeiro a ser levantado de entre os mortos; e representativa, porque Cristo é também sinónimo da Humanidade. Consequentemente, a ressurreição de Cristo representa não só um facto temporal, mas também a promessa de que muitas outras se lhe seguirão no futuro.

Um pouco mais abaixo, no versículo 22, Paulo introduz ainda a analogia entre Adão e Cristo. Escreve ele que «E, como todos morrem em Adão, assim em Cristo todos voltarão a receber a vida», o que nos leva a ter que necessariamente apontar duas questões: 1) o autor não introduz aqui nenhuma ruptura entre os descendentes de Adão e os seguidores de Cristo, e, 2) Paulo sublinha que por serem descendentes de Adão todos os homens morrerão, mas aqueles que seguirem os princípios do cristianismo serão depois ressuscitados em Cristo. Parece que de alguma maneira, Paulo consegue obter uma extensão temporal que chega até ao esperado momento do estabelecimento do Reino de Deus, mas de uma maneira onde claramente existe uma divisão entre o passado e o presente.

Deste modo, podemos concordar que a visão da história descrita aqui por Paulo deve ser considerada como linear. Isto é, parte-se de um momento de Criação divino até se poder atingir o reino divino. No entanto, isto implica não esquecer que o autor faz uso de três momentos temporais específicos: 1) o tempo antes da morte de Cristo; 2) o tempo depois da Sua ressurreição; e 3) o momento da parousia.

As questões entre Paulo e a comunidade de Corinto não acabam por aqui. $\mathrm{Na}$ realidade, o apóstolo continua preocupado e atento, o que leva à existência de mais cartas onde se verifica de alguma maneira a existência de uma subida do tom usado. Isto é particularmente claro em 2Corintios 9 . Neste momento, e de acordo com os dados da carta, parece que a comunidade não só questionava a autoridade de Paulo enquanto apóstolo de Cristo, mas também a legitimidade do peditório para Jerusalém para o qual ele tinha solicitado a sua colaboração.

No entanto, para a nossa análise sobre se o discurso de Paulo abre ou não caminho ao estabelecimento de uma certa tolerância religiosa, provavelmente a passagem mais importante encontra-se em 2Cor 3,7-18. Aqui Paulo discute o tipo de ministério que era o dele por oposição ao dos novos ministros que se apresentavam em Corinto e eram recebidos pela sua comunidade como verdadeiros apóstolos. Ao mesmo tempo, discursa sobre a diferença existente

\footnotetext{
${ }^{9} \mathrm{~A}$ unidade do texto de 2Coríntios é ainda hoje largamente discutida pelos teólogos. Por isso mesmo, e visto que não cabe aqui abrir um parênteses sobre o assunto, sugerimos que para mais detalhes se considerem as obras de Furnish, 1984; Murphy-O'Connor, 1991.
} 
entre o ministério cristão e o judaico. Uma diferença que era básica: o primeiro assentava no apostolado do Espírito, enquanto que o segundo no apostolado da lei transmitida a Moisés. De certa maneira, Paulo identifica desta maneira a existência de duas alianças com Deus: a primeira que teria sido efectuada entre Deus e Moisés e que se regia pelo seguimento da Lei, e uma segunda, feita com Cristo e que se manifestaria através de um apostolado do Espírito.

Nesta passagem (2 Cor 3,7-18), Paulo descreve detalhadamente como é que entende o tempo histórico. Ou seja, é aqui que introduz uma perspectiva dualista do tempo, segundo a qual a história deveria ser dividia em duas aeones distintas. Consequentemente, introduz a questão das duas alianças celebradas por Deus com o seu povo, como representando também elas dois momentos distintos. Não mencionando apenas uma aliança, mas sim duas, explica como é que o cristianismo era a nova imagem da Aliança com Deus. Ao mesmo tempo, nesta carta o Apóstolo responde à polémica sobre a identidade dos verdadeiros ministros de Cristo. É disso exemplo 2Cor 2,17 onde lemos: «É que, de facto, não somos como muitos outros que falsificam a palavra de Deus, mas é com sinceridade, como enviados de Deus, que falamos em Cristo, diante de Deus.» Só de seguida, e já no capítulo 3, é que Paulo inicia o seu discurso sobre os diferentes ministérios e o que separa o judaísmo do cristianismo, mas não sem antes repreender os membros da comunidade que parece terem questionado o verdadeiro papel de Paulo e, especialmente, a sua autoridade. O tom fica dado em 2Cor 3,1 quando pergunta se «Vamos começar de novo a recomendar-nos a nós mesmos? Ou temos necessidade, como alguns, de cartas de recomendação para vós ou da vossa parte?» e ao que responde que a sua autoridade lhe foi dada por Deus através de Cristo. Por isso mesmo, como o que Paulo tem é uma aliança pelo Espírito com Deus através de Cristo, não há forma de comprovar a sua autoridade sem que seja pela fé que os membros da comunidade de Corinto depositam nele. E Paulo, continua, explicando que a aliança que representa não está manifesta em qualquer pedaço de Lei escrita (uma alusão a Moisés e aos judeus). Daí que Paulo se auto-retrate como «ministro do Espírito» já que «a letra mata, enquanto o Espírito dá a vida» (2Cor 3,6), numa clara alusão ao tempo que há-de seguir a parousia.

Ao fazer isto, Paulo está, e não muito subtilmente, a afirmar a superioridade da nova aliança, em detrimento da anterior feita com Moisés, já que a nova, por ter sido feita através de Cristo permite equacionar um relacionamento mais próximo entre a Humanidade e a divindade. Sendo assim, também a nova aeon seria superior à anterior em qualidade. No entanto, apesar de a ressurreição de Cristo poder ser entendida enquanto o início da nova idade, o facto era que não tendo ainda acontecido a parousia, Paulo não pode dizer que já vivem realmente numa nova era. Por isso mesmo, sublinha que ainda há tarefas a realizar e que mais do que nunca a fé de cada um será a sua chave de 
entrada no Reino de Deus. Isto claramente representa um problema no que diz respeito ao conceito de futuro tal como ele foi entendido por Paulo. Como diz Murphy-O'Connor, «his assessment that it was the last and permanent phase enjoyed only the certitude of hope ${ }^{10}$, já que não havia qualquer certeza de que o tempo em que Paulo vivia fosse já o último tempo antes da inauguração da nova aeon, ou se seria apenas mais uma de várias fases que se sucederiam até que esse momento chegasse. Isto, de alguma maneira explica porque é que Paulo está tão interessado em demonstrar o valor do Evangelho e porque é que as comunidades cristãs o devem seguir.

Deixando de lado este tipo de questões sobre o tempo em que viviam de facto, Paulo continua a sua exposição sobre a qualidade do seu ministério de modo a clarificar a sua inerente superioridade em relação à antiga aliança que tinha sido celebrada com os judeus. É neste contexto que Paulo vai utilizar a descrição de como Moisés velava o seu rosto após transmitir à comunidade aquilo que Deus lhe tinha dito ${ }^{11}$.

Esta questão relativa ao facto de Moisés velar o rosto após transmitir as ordens de Deus vai ser usada por Paulo para sublinhar a superioridade da nova aliança. Aliás, Paulo empreende uma comparação entre as duas alianças, sublinhando a superioridade do Espírito por oposição à Lei, mas explicando que as duas são parte de plano divino, isto é, são sequências temporais, necessárias para se atingir o reino de Deus.

Ao mesmo tempo, enquanto assinala as diferenças entre o relacionamento de Moisés com a sua comunidade e a forma como os Apóstolos espalhavam o Evangelho, Paulo mais uma vez introduz a questão de como a Antiga Aliança representava a morte, enquanto a Nova representava a vida eterna em Cristo. De certa maneira, a Antiga Aliança era passageira porque finita, enquanto a segunda era eterna. Por isso, diz Paulo «se, com efeito, foi glorioso o que era transitório, muito mais glorioso é o que permanece» (2Cor 3,11), para evidenciar que se a glória da aliança com Deus já antes era enorme, então no momento em que a aliança tinha sido feita através de Cristo era impossível negar a superioridade deste novo pacto. Resumindo, a aliança feita com Moisés tinha carácter temporário, ao passo de que a celebrada com Cristo era eterna e, como tal, o ministério dos Apóstolos também tinha mais esplendor e glória do que o de Moisés ${ }^{12}$. Afinal, não tinham os Apóstolos recebido o Espírito Santo que lhes dava força para levar o Evangelho aos quatro cantos do mundo e enfrentar as maiores dificuldades?

${ }^{10}$ Murphy-O'Connor, 1991, 36.

${ }^{11}$ Cf. o passo de Ex 34,29-30,em que se descreve como Moisés desceu do Sinai com as tábuas da lei na mão e o rosto brilhante e, como depois de transmitir o conteúdo das ordens dadas por Deus cobria o rosto para só o descobrir quando estava na presença de Deus e quando de seguida transmitia aquilo que Deus lhe tinha dito.

${ }^{12}$ Furnish, 1984, 230. 
Mas para acentuar ainda mais as diferenças entre as duas alianças Paulo vai mais longe. Não lhe basta explicar que a nova aliança foi feita através de Cristo, filho de Deus. Na realidade, Paulo afirma também que os judeus que insistem em seguir a lei do Antigo Testamento continuam com uma visão obscurecida, a qual só acabará quando se converterem. E por isso escreve em 2 Cor 3, 15-16 «sim, até hoje, todas as vezes que lêem Moisés, um véu cobre-lhes o coração. Mas, quando se converterem ao Senhor, o véu será tirado», referindo-se àquela parte do povo de Deus ainda não tinha percebido que a antiga aliança tinha terminado. De acordo com Paulo, os apóstolos de Cristo não tinham vergonha do seu apostolado e, como tal, divulgavam o Evangelho sem medo e enfrentando grandes perigos. ${ }^{13}$ Assim, esta nova Era inaugurada com a morte e ressurreição de Cristo, representava um claro contraste com o período anterior marcado pelo seguimento da lei mosaica.

É necessário, no entanto, sublinhar que ao longo do texto Paulo nunca refere a aliança com Moisés como não tendo valor. Cataloga-a antes como diferente e representativa de um tempo onde o relacionamento com Deus era também ele diferente.

As palavras usadas por Paulo em 2Cor 3,14 devem ser lidas com cautela e não podem ser entendidas literalmente. Quando escreve que «mas o entendimento deles foi obscurecido» o autor está de certa maneira a dizer que aquilo em que acreditamos depende de nós mesmos, ao mesmo tempo que diz que esta situação só poderá ser alterada quando crerem em Cristo. Paulo não diz frontalmente que os Israelitas, isto é, os judeus, tinham perdido a fé. Pelo contrário, ainda não tinham visto que tinha acontecido uma mudança. $\mathrm{Da}$ mesma maneira que os judeus tinham poder de escolha, também os membros da comunidade de Corinto o tinham. E é exactamente isso que Paulo lhes diz: que devem acreditar no que o seu coração ditar, apesar de tudo o que ele lhes disse sobre o valor do ministério do Espírito.

Mas quando Paulo salienta o poder da escolha ele não se refere exclusivamente aos judeus. Refere-se sim a toda Humanidade, a qual segundo ele tem o poder para acreditar ou não em Cristo e seguir os seus mandamentos tal como os Apóstolos os pregavam. Desta maneira, Paulo abre as portas do cristianismo não apenas aos judeus, mas também aos gentios, o que nos permiteconfirmar que ele tinha em mente uma religião universal. Naturalmente, isto implica um alargar de horizontes. Ou seja, se em um momento Paulo estava apenas preocupado com os desvios da comunidade de Corinto, no momento seguinte está a dizer que o Reino de Deus é acessível a todos quantos os que acreditarem. É desta maneira que Paulo explica a universalidade do Evangelho e da nova aliança com Cristo. Mais uma vez parece que Paulo antecipa as

\footnotetext{
${ }^{13}$ Ibid. 231.
} 
palavras d'O Apocalipse quando fala em universalismo como se fosse uma premissa para a realização da parousia. Só a prática do Evangelho permitiria o acesso e a partilha do reino escatológico. Desta maneira, Paulo ainda faz mais uma distinção entre os que seguem a Lei e os crentes que seguem o Evangelho.

Depois de analisadas estas duas pequenas passagens, parece que Paulo faz uma distinção clara entre o tempo da primeira aliança em que era necessário cumprir a Lei, e o tempo da nova aliança com Cristo em que a fé desempenhava um papel muito mais importante. Consequentemente, para Paulo esta nova aliança era superior à primeira visto que levaria não só à consumação do Reino de Deus, mas permitiria também um entendimento de tipo universalista do cristianismo enquanto religião que reunia todos quantos quisessem crer nas palavras do Evangelho.

No entanto, e isto é importante frisar, Paulo não ataca a validade da lei judaica. Pelo contrário, demonstra-a necessária e válida a um dado momento, apesar de a considerar ultrapassada por algo que lhe é superior. ${ }^{14} \mathrm{O}$ deus que tinha dado a lei a Moisés era o mesmo do tempo de Paulo, mas as circunstâncias eram diferentes e com Cristo passou a ser possível ultrapassar a morte pela eternidade. Era esse o significado último da ressurreição, que também demonstrava como a nova aeon, ainda por inaugurar, seria a-histórica por oposição ao tempo histórico que marcava a aliança com Moisés.

Voltando à nossa questão inicial sobre a hipótese de existência de tolerância nas palavras de Paulo, achamos possível confirmar tal interpretação. Se de facto Paulo se mostra muito duro e repreende severamente a comunidade de Corinto por esta não estar a cumprir aquilo que lhe tinha sido ensinado do Evangelho, por outro lado, Paulo abre as portas a uma religião de tipo universal. Aliás, não acentua a ruptura entre judaísmo e cristianismo, mas antes diferencia-as como indicadores de dois tempos diferentes, de circunstâncias também elas distintas, apesar de parte de uma mesma realidade. Mas no fim, todos os que acreditassem e seguissem as palavras do Evangelho participariam na eternidade que se iniciaria após a parousia. Não haveria excluídos excepto os que se auto-excluíssem.

Por isso, parece-nos que explorar a questão da tolerância em Paulo do ponto de vista do universalismo do cristianismo é algo que se deve ter em conta. Mais, a sua intolerância para com aqueles que não seguem o Evangelho depois de o terem recebido é compreensível. Por um lado, parece que Paulo considerava a existência da livre escolha, e ao mesmo tempo, parece mostrar-se incrédulo que perante tamanhas provas da superioridade da segunda aliança com Cristo ainda assim fosse possível não se ter fé suficiente para seguir o Evangelho enquanto se esperava pela parousia. Mas como em tudo, o tempo

\footnotetext{
${ }^{14}$ Murphy-O’Connor, 1991, 36.
} 
de espera pelo mundo que há-de vir, neste caso, a consumação do reino de Deus, não ajuda nem a divulgação nem o seguimento do Evangelho. É difícil crer quando não se compreende porque demora o momento da parousia e da consumação do Reino e, de certa maneira, é isso que Paulo tenta explicar a uma comunidade que estava permeável a influências externas que questionariam certamente o seu empenhamento em seguir o Evangelho ${ }^{15}$.

${ }^{15}$ Este estudo resulta em parte de um capítulo da minha tese de doutoramento, Historical Interpretations of the "Fifth Empire»: The Dynamics of Periodization from Daniel to Antonio Vieira, S.J., defendida na Universidade de Lisboa em Dezembro de 2008. 


\title{
Moisés e Paulo em busca de um povo
}

\author{
Ana Paula Goulart \\ Universidade de Lisboa \\ Centro de História da Universidade de Lisboa
}

Moisés e Paulo são duas enormes personagens no compêndio civilizacional que constitui a Bíblia. Constatá-lo é por si só uma evidência,já que a sua simples menção povoa a mente de episódios, controvérsias e epistemologias. Moisés, que durante um longo período de tempo foi também considerado o autor do Pentateuco, estruturou em torno de si amplos e significativos discursos que nutriram diversos pensamentos religiosos em toda a sua significância histórica, cultural e antropológica. Paulo, no outro extremo cronológico e conceptual do espectro bíblico é aquele a quem se atribui o papel de transformar uma variante do judaísmo tradicional num discurso materializado numa igreja que integra, modifica, universaliza e sobrevive às contingências de uma longa diacronia.

$\mathrm{O}$ que me propus foi pois fazer uma reflexão sobre estes dois agentes produtores, receptores e organizadores de um singularíssimo tipo de discurso: o discurso divino/o discurso sobre o divino.

Será que estas figuras têm entre si - tão só por o serem - particularidades que as tornam únicas e, apesar do muito tempo que as separa, cotejáveis? Vejamos. No início... No início foi Moisés...

O nascimento de Moisés, como é narrado em $E x 2^{1}$, omite os detalhes prosopográficos, tradicionalmente abundantes, que enquadravam a vida dos anteriores patriarcas e correspondiam a uma prática cultural corrente. Não há referência ao nome dos seus pais ou irmãos, restringindo-se a única menção genealógica, à ligação dos seus progenitores à casa de Levi. Na sequência de arbitrariedades faraónicas, a criança será depositada no Nilo dentro de um pequeno cesto. $\mathrm{O}$ resgate que depois acontece - a princesa egípcia que o salva significa a sua adopção para um meio que representava uma realidade em tudo oposta à da sua proveniência, propiciando o conhecimento desse mesmo meio. Nessa medida, a adopção de Moisés poderia também traduzir um discurso de apropriação por parte da realidade cultural hebraica sobre a dominante cultura egípcia. É um momento dissociativo entre um povo e aquele que irá ser o seu libertador. «Este é um dos hebreus»² diz a filha do Faraó; a partir desse momento e até à sua maturidade, Moisés estará longe do seu povo.

Quase nada se sabe sobre a família de Paulo; mesmo o seu lugar de

\footnotetext{
${ }^{1}$ Todas as citações da Bíblia foram feitas a partir da Nova Bíblia dos Capuchinhos, Fátima, Difusora Bíblica, 1998.

${ }^{2} \operatorname{Ex} 2,6$.
} 
nascimento, mais frequentemente mencionado, Tarso, pode, segundo alguns autores, antes ter sido um lugar de chegada ${ }^{3}$. Variadas são também as opiniões sobre o seu estatuto social e jurídico, bem como sobre a sua formação intelectual. É claro que sobre estas controvérsias há que estabelecer uma factologia minimamente consensual. Daí que se afirme que Paulo seja natural de Tarso, filho de uma família farisaica detentora de estatuto social e económico elevados, tendo o próprio Paulo a cidadania romana. Quanto às suas competências linguísticas são-lhe reconhecidas no aramaico, no hebraico e no grego e acredita-se que terá estado ligado à «escola» de Gamaliel.

Uma coisa é certa - quando Estêvão foi morto, Paulo estava presente e talvez tenha ouvido parte da história que o mártir evocava antes de ser lapidado: «Nessa altura nasceu Moisés que era agradável aos olhos de Deus. Foi criado durante três meses em casa de seu pai» ${ }^{4}$. Saulo estava com o seu povo.

Atentemos agora no significativo e complexo processo que é a nomeação destas duas personagens. Voltemos a Moisés: «E deu-lhe o nome de Moisés,dizendo: "Porque o tirei das águas".»"

Embora postas na boca da filha do Faraó, as palavras são hebraicas, propiciando o aparecimento de uma etimologia popular em torno do verbo 'machab que significa «tirar».

Às pessoas egípcias que rodeassem o pequeno Moisés esta explicação seria incompreensível. E há efectivamente a possibilidade de explicar a etimologia deste nome, à luz do significado das palavras e da estrutura dos nomes egípcios.

Vejamos no nome Ramsés - em egípcio $R c-m e-s w$. «Ra», a primeira parte do nome, contém a referência expressa ao nome do deus - neste caso «Re» e a segunda parte, $m s-s w$ é o verbo e significa «criou-o». Ramsés quer pois dizer «o deus "Re" criou-O» ${ }^{6}$.

No caso de Moisés, ter-se-ia dado a aférese do componente teofórico, fosse ele qual fosse, mantendo-se a segunda parte do nome, o verbo, MS, «criou». Estes fonemas teriam originado um fenómeno de homofonia com o verbo hebraico machah, consentindo uma abordagem plural, erudita e popular de dois nomes para dois mundos.

Os nomes de Paulo por sua vez, estão também sujeitos a alguma controvérsia. Saulo, o desejado, passa a ser Paulo o que estaria aparentemente muito consentâneo com a sua qualidade de cidadão romano. Desconhece-se contudo uma razão ponderosa que explique a utilização de um ilustre nome romano como cognome de um judeu. Deixar o nome Saulo teria algumas

\footnotetext{
${ }^{3}$ Murphy-O'Connor, 2004, 2-3.

${ }^{4}$ Act 7,20.

${ }^{5}$ Ex 2,10.

${ }^{6}$ Goulart, 2001.
} 
vantagens, já que em grego soa muito semelhante a saulósch, que significa «o que se move com lentidão, o efeminado», o que seriam alusões pouco abonatórias para uma personagem que pretende impor-se nas diásporas de falares gregos ${ }^{7}$.

Assim, afirma-se com frequência, que a passagem de «Saulo» a «Paulo» se baseia antes numa certa homofonia consentida pela convivência de dois nomes em dois mundos que se sobrepõem.

Para Moisés e Paulo a aventura ainda nem começou; improváveis protagonistas de desempenhos ainda ignorados, em breve estarão em viagem. E, como motor destes movimentos estará uma das entidades mais significantes no discurso do humano - deus. Para Moisés, está consignado o regresso, para Paulo inicia-se uma interminável partida.

O regresso de Moisés é literal ${ }^{8}$ - já crescido, Moisés vem visitar os seus irmãos, e como tivesse visto um egípcio a maltratá-los, matou o egípcio e enterrou-o na areia. Quando o faraó é informado do sucedido, manda matar Moisés. Este foge para Madiã. Aí chegado, irá integrar a família de Jetro pelo casamento com Séfora. O tempo de Madiã é um tempo de maturação e resgate. Nos Actos dos Apóstolos 7,30 é referido que a estadia de Moisés teria durado quarenta anos. Esta referência temporal, comum a várias passagens do relato bíblico, é decifrada como contendo a menção a «um tempo certo para»... e serão também quarenta os dias que Moisés passa na montanha. Ex 24,18 . Volvidos estes, estaria pronto para o fogo - a hierofania da sarça ardente e para a palavra de Javé: «Moisés, Moisés!»

$\mathrm{Na}$ vida de Saulo nenhuma alteração de conteúdos nos alerta para uma possível mudança. O que há é o anúncio da viagem. Uma viagem para Damasco onde o jovem Paulo desejava continuar as suas aturadas perseguições aos seguidores de Cristo. «Estava a caminho e já próximo de Damasco quando se viu subitamente envolvido por uma intensa luz vinda do céu. Caindo por terra ouviu uma voz que lhe dizia: Saulo, Saulo, porque me persegues?» ${ }^{10}$ Dominando a cena mais uma vez - a luz e a palavra.

A resposta de Paulo a esta pergunta, e a subsequente alteração dos seus valores e modos de vida, vão para além de um episódio na história religiosa. É pertinente inquirir a que é que se converte Paulo e com que consciência. Que atitude é esta, que terá por consequência a desintegração social, política e religiosa de quem a assume, reposicionando o indivíduo num futuro inconstruto. Será aqui a conversão um acto de debilidade cultural ou será justamente o seu contrário?

Devo confessar que quando reflicto, a partir desta contemporaneidade, sobre a metáfora da estrada de Damasco alguma desconfiança me invade.

\footnotetext{
${ }^{7}$ Rodrigues, 2007, 677.

${ }^{8}$ Ex 2, 11-12.

${ }^{9}$ Soggin, 1997, 188.

${ }^{10}$ Act 9,34.
} 
Fantasio-a como um momento em que dois planos discursivos se interceptam e, quem disso se apercebe, pode efectivamente cair de um cavalo... São as hodiernas auto-estradas de Damasco, cheias de engarrafamentos e de travagens bruscas e onde se tem de escolher, com a maior rapidez, o meio de transporte mais adequado.

Nada sei das íntimas motivações de Paulo. Mas todos sabemos do seu percurso. No início, é anónimo perseguidor das primeiras comunidades cristãs, no fim, é o obreiro reconhecido da expansão dessas comunidades, o grande doutrinador do cristianismo, e de facto, o homem mais importante da igreja. As vastas comemorações por altura do seu bimilenário o comprovam.

O tempo certo de Paulo, os seus simbólicos quarenta anos, na acepção de «o tempo necessário para» conta-se desde o ano do seu nascimento 6 a.C. até à viagem a Antioquia, ocorrida em 46 d.C. pois, como é referido em Actos 2,26 «Foi em Antioquia que pela primeira vez os discípulos começaram a ser tratados pelo nome de "cristãos"”.

Pode-se perguntar se no tempo de Paulo a evocação desta cifra teria ainda o significado que tivera em tempos mais remotos; a passagem da segunda carta aos Coríntios faz-nos crer que sim - «cinco vezes recebi dos judeus quarenta açoites menos um» ${ }^{11}$. Esta precisão parece uma paráfrase antinómica, conscientemente construída, e que contraria a perfeição que o número quarenta sugere. É pois com alguma naturalidade que verificamos tópicos comuns nos dados da biografia mosaica e paulina, como se ecos fossem de realidades sujeitas às múltiplas transformações inerentes à evolução dos discursos culturais.

Em Ex 4,2-5 é narrado o episódio da vara de Moisés; vara que se transforma em serpente, para depois, com as instruções de deus, voltar a ser vara. Este «voltar a ser» é meramente descritivo, pois a vara transmutada não poderá nunca mais ser a mesma, uma vez que, após o acto ritualizado, ela fica enriquecida pelo poder do simbólico.

Em Actos 28,1-6 é narrado o incidente, que em Malta, Paulo também teve com uma cobra que o morde. Só que ao contrário das expectativas dos que o observavam, esta não o mata. «Depois de terem aguardado e verem que nada lhe acontecia, mudaram de opinião e começaram a dizer que ele era um deus».

Paulo já não precisa da vara de pastor transformada em bastão mágico, mas a verdade é que tal como em $E x 4,31$ «o povo acreditou». No mesmo sentido se orienta a acção de Paulo quando intervém perante a serva que tinha espírito pitónico. (Actos 16,16-18). Será pois legítimo concluir que qualquer que fosse o mundo que alvorecia, pelo menos uma parte dele denotava manter antigas preocupações quanto à delimitação do domínio da magia e da religião, e na separação dos planos humano e divino.

112 Cor 11,24 . 
Recordamos o episódio do bezerro de ouro, narrado em Ex 32, cujas consequências iam fazendo perigar a aliança entre Javé e o seu povo.

Atentemos agora no episódio narrado em Actos 14,13-14, "Então o sacerdote do templo de Zeus, fronteiro-à-cidade, trazendo touros e grinaldas para as portas da cidade, pretendia juntamente com a multidão, oferecer-lhes um sacrifício. Ao terem conhecimento disso, os apóstolos Barnabé e Paulo rasgaram as vestes e precipitaram-se para a multidão gritando».

Esta violenta rejeição é-nos explicada na carta aos Romanos «de facto antes da lei, já existia o pecado no mundo; mas o pecado não é tido em conta quando não há lei.» ${ }^{12}$

Apesar disso desde Adão até Moisés reinou a morte. Nesta afirmação Paulo delimita o horizonte pretérito das significâncias para o seu discurso em construção. A ordem de Javé, estabelecida em Génesis, é insuficiente. Não será bem uma ordem: é só um não caos; é pois necessário o aparecimento de Moisés para dar deus, tradições, rituais, terra e passado ao povo do Êxodo. A Moisés é revelado o Deuteronómio - a outra lei.

É sobre esta experiência que Paulo, tendo certamente em conta as inúmeras modificações sociais, políticas e económicas entretanto ocorridas, começa a escrever a «Nova Lei» para os povos de todos os Êxodos e de todos os Eisodos. A mítica epopeia de Moisés, guiando o povo através do deserto, inspirado por Javé durante quarenta anos (o tempo necessário), teria agora, em renovada aliança, a sua continuação.

Desta vez com Paulo, o apóstolo de Cristo, com todos os povos, por todos os territórios «meu pai era um arameu errante», lia-se no pequeno credo $^{13} \mathrm{e}$ poderia talvez agora ler-se, sem forçar muito a imaginação: «Meu pai é um cidadão de Roma».

Os discursos que servem um conjunto de nómadas e semi-nómadas, não podem ser os mesmos que irão servir às sociedades de um vasto conjunto de povos organizados pela estrutura política, social e económica do império romano.

As viagens de Paulo evocam essa diversidade e introduzem um novo tópico em relação à viagem exódica. Moisés buscava a terra para o seu povo e esperava que durante a viagem ocorressem todas as alquimias culturais que criassem nas pessoas a consciência de povo. Paulo antes procurava os povos e levava-lhes a palavra: «não em tábuas de pedra, mas em tábuas de carne, que são os vossos corações» ${ }^{14}$. O espaço onde poderá ocorrer esse encontro está no enunciado de Tertuliano: ubique populus...

A hierofania de Damasco feita em moldes de outros tempos, tem exactamente essa pertinência - a de possibilitar o reconhecimento. Mas para

\footnotetext{
${ }^{12} \operatorname{Rm} 5,13-14$.

${ }^{13}$ Dt 26,5-9.

${ }^{14} 2$ Cor 3,3.
} 
Paulo, mais do que tudo, fora necessário agir, como ele próprio reconhece na $2^{a}$ Carta a Timóteo 4,7: «combati o bom combate, terminei a corrida, permaneci fiel.»

Fiel por oposição a Pedro que também assistira à transformação de Cristo, no célebre episódio narrado em Mateus 17: «Pedro disse a Jesus: Senhor, é bom estarmos aqui; se quiseres, farei aqui três tendas uma para ti, uma para Moisés e outra para Elias».

A metáfora das três tendas, evocando o regresso às tribos, há muito que fora ultrapassada pelas novas realidades que integram o ideário de Paulo. Tendo ainda presente a oferta de Pedro e as três tendas, voltemos a Actos dos Apóstolos 18,1-4: «Depois disso, Paulo afastou-se de Atenas e foi para Corinto. Encontrou ali um judeu chamado Áquila, natural do Ponto, recentemente chegado da Itália, com Priscila, sua mulher, porque um édito de Cláudio ordenara que todos os judeus se afastassem de Roma. Paulo foi procurá-los e, como eram da mesma profissão - isto é, fabricantes de tendas - ficou em casa deles e começou a trabalhar».

As tendas irão ser retecidas, e o tecelão é Paulo de Tarso. 


\title{
Séneca e Paulo de Tarso: \\ CONJECTURAS EM TORNO DE UMA CORRESPONDÊNCIA INCERTA
}

\author{
Paulo Sérgio Ferreira \\ Universidade de Coimbra \\ Centro de Estudos Clássicos e Humanísticos da Universidade de Coimbra
}

\section{Considerações introdutórias}

Quando se consideram as catorze epistulae Senecae ad Paulum aut Pauli ad Senecam, o que imediatamente chama a atenção não é a qualidade literária do texto, isto é, o seu conteúdo estilístico e ideológico, mas, dado o contraste, no tocante aos dois aspectos referidos, com a obra de ambas as personagens cuja autenticidade não suscita discussão, a necessidade de perceber se a correspondência inicialmente referida será autêntica e, neste caso, a que se deve a diferença de registo, ou se será apócrifa e, como tal, os pretextos e os propósitos que terão presidido à criação de semelhante falsificação.

Do ponto de vista da história literária, não se afigura esta reflexão inconsequente, uma vez que, se se pensar que a 180 d.C. remonta o primeiro documento em latim cristão de autenticidade insuspeita - os Acta Martyrum Scillitanorum -, facilmente se percebe que, tivesse a correspondência efectivamente sido escrita por Séneca e Paulo de Tarso, facilmente se tornaria o primeiro testemunho de literatura latina cristã.

\section{A origem e a evolução do problema}

Intimamente relacionada com a reflexão sobre a autenticidade do epistolário passou a andar, a partir de determinada altura, a que tinha por alvo uma eventual adesão senequiana ao Cristianismo, mas, antes de tratarmos este assunto mais de espaço, vale a pena analisarmos os depoimentos dos Padres da Igreja, no propósito de percebermos como encaravam a figura de Séneca e, deste modo, começarmos a depreender confluências e divergências entre Cristianismo e Estoicismo e esboçarmos os primeiros limites temporais para a elaboração do epistolário.

Dos Padres da Igreja, o primeiro a mostrar um bom conhecimento de Séneca foi Quinto Tertuliano, que viveu entre c. 160 e c. 240 d.C., e, por volta de 195, se converteu ao Cristianismo. Entre os oito passos onde explicitamente se menciona o nome ou apenas se pressente o texto de Séneca, conta-se Anim. 20.1, onde se por ler: Seneca saepe noster. ${ }^{1}$ Não sugerem, no entanto, estas palavras,

\footnotetext{
${ }^{1}$ Outras alusões directas a Séneca encontram-se em Anim. 42.2, Ap. 12.6, 50.14 e Res. 1.4, ao passo que o hipertexto senequiano se pressente claramente em $A$ p. 22.11, 48.8 e 50.5 .
} 
no entender da maior parte dos investigadores modernos, uma conviç̧ão do Apologeta e Teólogo numa conversão de Séneca ao Cristianismo - tanto mais que, conforme observa Bocciolini Palagi, «Tertulliano citando altrove Seneca ne parla inequivocabilmente come di un pagano» ${ }^{2}-$, mas apenas a consciência de algumas confluências temáticas. ${ }^{3} \mathrm{~A}$ termos e frases senequianas recorreu ainda Cipriano (c. 200-258 d.C.) para expor o seu próprio pensamento. ${ }^{4}$ Séneca, descrito por Lactâncio (c. 240-c. 320) como omnium Stoicorum acutissimus e como morum uitiorumque publicorum et descriptor uerissimus et accusator acerrimus (Inst. 1.5.19), no dizer do referido Padre da Igreja, quam multa alia de deo nostris [Christianis] similia locutus est (Inst. 1.5.28).

$\mathrm{E}$ tais foram as afinidades ideológicas que o teólogo encontrou no Cordubense, que chegou a admitir que, mediante orientação adequada, poderia este «homem ignaro da verdadeira religião» ter abraçado o Cristianismo (Inst. 6.24.13-14):

Quid uerius dici potest ab eo, qui Deum nosset, quam dictum est ab homine uerae religionis ignaro? [....] Potuit esse uerus Dei cultor si quis illi monstrasset, et contempsisset profecto Zenonem et magistrum suum Sotionem, si uerae sapientiae ducem nanctus esset.

Do exposto, parece, por conseguinte, legítimo concluir que, na esteira do que a tradição apologética havia feito relativamente a outros filósofos, pretenderia Tertuliano procurar, numa filosofia que tinha chegado aos mais diversos estratos da população, pontos de contacto com uma religião que sentia urgência em ganhar adeptos. O processo e o propósito aparecem, de resto, documentados num contemporâneo dos dois primeiros, Minúcio Félix (fl. 200-40 d.C.), que, em Oct. 20.1, observa: aut nunc Christianos philosophos esse aut philosophos fuisse iam tunc Christianos.

Se, para alguns investigadores, o silêncio dos Padres referidos relativamente ao epistolário e sobretudo o testemunho de Lactâncio acerca do desconhecimento senequiano da religião cristã, constituem indícios seguros de que, entre 304 e 324 - período de composição provisória e de redacção definitiva das Institutiones diuinae -, ainda não tinham sido forjadas as epistulae Senecae ad Paulum aut Pauli ad Senecam, outros há que, com a falta de profundidade religiosa e filosófica da mensagem veiculada nas referidas cartas, e a sua escassa difusão na época de Lactâncio, justificam o desinteresse que por elas manifestaram os referidos teólogos. ${ }^{5}$

${ }^{2}$ Palagi, 1978, 7-8.

${ }^{3}$ Scarpat, 1977, 110.

${ }^{4}$ Scarpat, 1977,110 n. 3.

${ }^{5}$ Entre os primeiros investigadores contam-se, Momigliano, 1950, 326; Palagi, 1978, 9; e Natali, 1995, 12; e entre os segundos, Franceschini, 1981, 830-831; e Ramelli, 1997, 300 e 307. 
Apesar de se não referirem a qualquer correspondência entre Paulo e Séneca, já os Actos Apócrifos dos Apóstolos, que devem ter sido compostos entre os séc. II e IV d.C., relatavam a gesta de Paulo na corte de Nero. E seria precisamente aqui que, para Bocciolini Palagi, estaria a origem da lenda do contacto entre Paulo de Tarso e o Séneca que teria servido de intermediário entre o apóstolo e Nero. ${ }^{6}$

No âmbito de uma reflexão sobre escritos "não cristãos" que tratam de temas cristãos (Fílon, cap. 11; Flávio Josefo, cap. 13 - ambos considerados por Herrmann cristianófobos; ${ }^{7}$ e Justo de Tiberíades, cap. 14), e depois de ter procedido à distinção entre os escritos autentici e os apocrifi que então circulavam sob o nome dos apóstolos, fez Jerónimo, em De viris illustribus $X I I$, a primeira referência conhecida a uma correspondência entre Séneca e Paulo de Tarso:

Lucius Annaeus Seneca Cordubensis, Sotionis stoici discipulus et patruus Lucani poetae, continentissimae uitae fuit. Quem non ponerem in catalogo sanctorum, nisi me illae epistolae pronocarent quae leguntur a plurimis, Pauli ad Senecam aut Senecae ad Paulum, in quibus, cum esset Neronis magister et illius temporis potentissimus, optare se dicit eius esse loci apud suos, cuius sit Paulus apud Christianos. Hic ante biennium quam Petrus et Paulus martyrio coronarentur a Nerone interfectus est. ${ }^{8}$

«Lúcio Aneu Séneca de Córduba, discípulo do estóico Sócion e tio paterno do poeta Lucano, levou vida assaz regrada. Não o incluiria no catálogo dos santos se a tal me não tivessem induzido as cartas que são lidas por muitos, de Paulo a Séneca ou de Séneca a Paulo, e onde, embora mestre de Nero e o homem mais poderoso do tempo, diz que desejava ser tido junto dos seus na mesma conta em que era tido Paulo junto dos Cristãos. Dois anos antes de Pedro e Paulo receberem a coroa do martírio, foi mandado assassinar por Nero.»

Com base na possibilidade de, em 392, ano da publicação de De uiris illustribus, se encontrar Jerónimo na Terra Santa, admite Barlow a hipótese de o autor não ter contactado directamente com o epistolário, mas dele ter tido notícia por carta de amigos. ${ }^{9}$ Depois de, na esteira de Westerburg (1881), propor a supressão, em nam qui meus tuus apud te locus, qui tuus uelim ut meus (Ep. 12 Barlow), da expressão apud te, e de afirmar que o teor da frase resultante diverge do da seguinte de Jerónimo: optare se dicit eius esse loci apud suos, cuius sit Paulus apud Christianos -; e após rejeitar a emenda adoptada por Erasmo (nam qui tuus est apud tuos locus, uelim ut apud meos sit meus) - por cuidar

\footnotetext{
${ }^{6}$ Palagi, 1978, 10.

${ }^{7}$ Herrmann, 1979, 10.

${ }^{8}$ Cito a partir de Barlow, 1938, 122.

${ }^{9}$ Barlow, 1938, 81.
} 
que, embora aproxime o passo do de Jerónimo, o afasta substancialmente de Paulo, Gl 4.12, onde se lê: estote sicut ego quia et ego sicut uos - formula Momigliano a hipótese de Jerónimo ter lido um manuscrito corrupto ou de ter recebido uma impressão errada de algum correspondente. Em todo o caso, não deixa o investigador de reconhecer a precedência da referida carta relativamente ao passo do Padre da Igreja. ${ }^{10}$ Exposta a teoria de Kreyher, que, no séc. XIX, sustentara a existência de uma correspondência efectiva entre Séneca e Paulo de Tarso; o conhecimento, por parte de Lino, Agostinho e Jerónimo, da referida correspondência; e o carácter completamente espúrio da que nos chegou, demarca-se Sevenster desta perspectiva, ao afirmar: «Nevertheless it still seems most likely to me that Jerome is here drawing on his imperfect, probably second-hand knowledge of the contents of the correspondence known to us.» ${ }^{11}$ Com perspicácia observou Herrmann que, à luz da data indicada na Ep. 12 Barlow, não faz qualquer sentido o desejo de Séneca de ocupar junto dos seus uma lugar semelhante ao de Paulo junto dos Cristãos, uma vez que, embora o quinquennium estivesse no fim, não se encontrava Paulo em situação assaz favorável junto dos partidários de Tiago, o Menor, e de Pedro. ${ }^{12}$

Além das dificuldades relacionadas com a identificação exacta do corpus a que S. Jerónimo se referia, outras têm surgido quanto ao modo como o Padre da Igreja o encararia: se, para alguns, o passo citado e o cotexto em que ocorre são absolutamente neutros no que à resolução do problema da autenticidade diz respeito, ${ }^{13}$ outros há que registam um certo embaraço de S. Jerónimo relativamente à aceitação da autenticidade do epistolário, ${ }^{14}$ e outros ainda a quem tanto texto como cotexto não oferecem quaisquer dúvidas de que $\mathrm{S}$. Jerónimo consideraria o epistolário autêntico. ${ }^{15}$

Adepto da última perspectiva, justifica, no entanto, Mastandrea o contraste entre, por um lado, o silêncio, em De uiris illustribus, relativamente aos rituais socráticos e catonianos que tornaram a morte de Séneca um símbolo supremo de liberdade e autodomínio, e, por outro, o conhecimento que, ao traduzir Eusébio de Cesareia, Chronicon, p. 184, Jerónimo revela das circunstâncias concretas da morte de Séneca, com o facto de aquele modo de encarar a morte ser absolutamente injustificável à luz dos valores cristãos e com o propósito de

${ }^{10}$ Momigliano, 1950, 326-327.

11 Sevenster, 1961, 14.

${ }^{12}$ Herrmann, 1979, 10.

${ }^{13}$ Erbetta apud Natali, 1995, 9; e Palagi, 1978, 12. Com base no pressuposto de Jerónimo e Agostinho não terem analisado as Epistulae, sustentou Aubertin, apud Scarpat, 1977, 71314, que os referidos Padres da Igreja terão deliberadamente deixado ao critério do leitor uma tomada de posição relativamente à autenticidade da correspondência.

${ }^{14}$ Momigliano, 1950, 329; Herrmann, 1979, 10-11.

15 Scarpat, 1977, 114 e 116-117; Gamba, 1998, 212-213. 
enriquecer o epistolário de conteúdos ideológicos que haveriam de preparar o processo que acabaria por desembocar na lenda da conversão de Séneca ao Cristianismo, e, noutro plano, com o propósito de elevação do Filósofo a paradigma de um ética estóica não conflitual com o ensinamento religioso, e a «"martire laico" della coerenza estrema ai propri principî, oggetto nei secoli di devota meraviglia per tante generazioni di intellettuali cristiani impegnati in politica.» ${ }^{16}$

Quanto ao pormenor do uso da expressão a Nerone interfectus est, depois da alusão ao martírio de Pedro e de Paulo e em referência a Séneca, chamou Mastandrea, com perspicácia, a atenção para os propósitos de juntar, num fim comum - o martírio -, os destinos de Pedro, de Paulo e de Séneca, e de fazer recair sobre Nero o odioso das três mortes. ${ }^{17} \mathrm{O}$ efeito do passo junto de católicos e romanos curiosos relativamente ao cristianismo é fácil de imaginar.

Embora Jerónimo ainda discorde das oscilações do pensamento senequiano relativamente ao destino post mortem da alma e, mais concretamente, do teor epicurista de Troades 397 (Post mortem nibil est ipsaque mors nibil ${ }^{18}$ ), não deixa o Padre da Igreja, conforme se depreende de passo do Aduersus Iouinianum (2.6: manducet et bibat, qui post cibos expectat interitum, qui cum Epicuro dicit Post mortem nibil est et mors ipsa nibil est) composto em 393 e descoberto por Ilona Opelt, de omitir qualquer referência a Séneca, de modo a fazer recair sobre Epicuro o odioso de tal pensamento. ${ }^{19}$

Algum tempo depois, mais propriamente em 413, é Santo Agostinho quem, em Epistula ad Mecedonium, se refere à correspondência nestes termos: Merito ait Seneca (qui temporibus Apostolorum fuit, cuius etiam quaedam ad Paulum apostolum leguntur epistolae): Omnes odit qui malos odit. ${ }^{20}$ "Justamente Séneca (que viveu no tempo dos Apóstolos e do qual ainda se lêem algumas das cartas a Paulo Apóstolo) diz: Odeia todos quem odeia os malvados.»

Do ponto de vista linguístico, importa registar a ocorrência, em S. Agostinho, da forma leguntur, que já encontrámos no depoimento de $\mathrm{S}$.

${ }^{16}$ Mastandrea, 1988, 54. Se, na época medieval, muitos eram os que recordavam, em toada elogiosa, o comportamento de Séneca, outros havia que a jogos etimológicos recorriam para o criticarem: Quodam presagio Seneca nomen habuit quasi 'Se necans', quia quodammodo licet coactus manu propria se necauit (Jacopo da Varazze, apud Mastrandrea, 1988, 55).

${ }^{17}$ Mastandrea, 1988, 52.

${ }^{18}$ Cito a partir de L. Annaei Senecae Tragoediae, recognouit breuique adnotatione critica instruxit Otto Zwierlein, Oxonii, e Typographeo Clarendoniano, 1986, 397.

${ }^{19}$ Sobre o assunto, v. Mastandrea, 1988, 56-7. Antes de Jerónimo havia Tertuliano citado a sentença epicurista de Séneca, fr. 28 Haase de De imatura morte, ou, segundo Marion Lausberg, de De remediis fortuitorum, em Anim. 42.2 (multo coactius Seneca 'Post mortem - ait - omnia finiuntur, etiam ipsa'), em Resurr. 1.4 (ait et Seneca omnia post mortem finiri, etiam ipsam), e 3.3 (et cum aiunt 'Mortuum quod mortuum est' est 'Viue dum uiuis' et 'Post mortem omnia finiuntur, etiam ipsa', tunc meminero et cor uulgi cinerem a deo deputatum et ipsam sapientiam saeculi stultitiam pronuntiatam).

${ }^{20}$ Ep. 153.14 = PL 33, 659 
Jerónimo e que, conjugada com a ausência, na restante obra do primeiro, de qualquer outra referência ao epistolário, pode indiciar a possibilidade de o autor da Ep. 153 (ad Macedonium) não ter tido entre mãos a correspondência e se ter fundado no passo citado de De uiris illustribus.

Ora no âmbito de uma polémica contra a religião pagã e ao considerar os tria genera theologiae (o mythicon, ou fabulosum; o physicon, ou naturale; e o ciuile) discriminados por Varrão, que condenara o primeiro, mas defendera os outros dois e mostrara preferência pelo naturale, haveria Agostinho, em De ciuitate Dei 6-7 - o tratado foi escrito entre c. 413 e 426 -, de recorrer a Séneca, que considerava inferior a Varrão, para, num primeiro momento e na linha de outras convergências do pensamento do filósofo estóico com o dos autores cristãos, refutar a distinção varroniana entre a teologia civil e a mítica que se apresentava nos espectáculos teatrais; e, num segundo momento, acusar Séneca de incoerência: se, por um lado, condenava a teologia mítica e, em Contra superstitiones - tratado amplamente citado e hoje perdido -, os ritos orgiásticos e as celebrações religiosas oficiais que ocorriam no Capitólio, não se coibia, por outro lado, de preceituar o dever do intelectual, da pessoa culta e do filósofo, de conservar, observar e respeitar os rituais religiosos oficiais, não por devoção sentida, mas por serem instituídos pelo estado. ${ }^{21}$

Embora este modo de encarar a dependência da religião relativamente ao estado se justifique como forma de assegurar e reforçar o respeito das massas pelos seus políticos e pelas instituições políticas; ${ }^{22}$ já se verificasse $\mathrm{p}$ ex. na época de Cícero e, em Séneca, ainda se compreenda melhor à luz das suas responsabilidades governativas, a verdade é que, ao considerar os fundamentos desta visão da religião como instrumentum regni, não deixará Agostinho de criticar o desprezo estóico do sapiens pelo populus, ou pelos stulti; ou a crença na capacidade humana que leva à busca de uma falsa liberdade; ${ }^{23}$ ou ainda, em 6.11, o facto de Séneca, apesar de reconhecer a superioridade da religião

${ }^{21}$ Sobre este assunto, v. Gallicet, 2000, 445ss. Que esta crítica remontava à época do próprio Séneca, mostram-no Dial. 7. 17-28. Para justificar as divergências de S. Agostinho relativamente a Séneca, invoca Traina, citado por Gallicet, 2000, 452, o uso que da superbia do segundo fizeram Pelágio e seus seguidores para rejeitarem o pecado original e negarem a necessidade de graça divina para a salvação, e, deste modo e por meio de uma perspectiva optimista da natureza humana, entrarem em rota de colisão com o intransigente teocentrismo de Agostinho. Veja-se, a propósito, Mastandrea, 1988, 75-77, que fala de "controversie teologiche attuali, che spesso sceglievano il loro terreno di scontro nella valutazione etica della cultura profana e della società secolare.» No que a Agostinho diz respeito, importa notar que já havia cedido à perigosa tentação de se aliar ao estado, mais concretamente ao imperador Constantino, para vencer os donatistas.

${ }^{22}$ Vejam-se os testemunhos de Pol. 6.56.6-15, Cic. Diu. 2.70, e Liv. 1.19.4-5, em Scarpat, 1977, 25-31.

${ }^{23}$ Mastandrea, 1988, 77. 
hebraica sobre a pagã, nela criticar a observância do sábado e o desperdício, no ócio, de um sétimo da vida dos Judeus.

Em De ciuitate Dei 5, tinha já S. Agostinho refutado a teoria do fatalismo astral. De um passo que Séneca dissera traduzido de Cleantes, mas o Bispo de Hipona atribui ao Cordubense (Ep. 107.11), isolara o Padre da Igreja o verso ducunt uolentem fata, nolentem trabunt, e, depois de citar Od. 18.136-7 em tradução de Cícero, em Fat. frg. 4, que Stoicos dicit uim fati asserentes istos ex Homero uersus solere usurpare, e após dizer que estes filósofos Iouem appellant quem summum deum putant, a quo conexionem dicunt pendere fatorum, "Agostino prosegue rifiutando il tentativo di Cicerone che, pur di respingere il fatum necessitante e salvare liberam uoluntatem degli uomini (....), giunge sino a negare la praescientia futurorum da parte di Dio (....). Posizione, questa di Cicerone, che, pur opponendosi ad essa, sta alla pari com quella degli stoici, i quali, pur sostenendo omnia fato fieri, negano, con una clamorosa contraddizione, omnia necessitate fieri, l'uno e gli altri proprio per salvare l'umana libertà (....). Erronee ambedue le posizioni - continua Agostino -, anche se piú condannabile è la posizione di Cicerone: quod uero negat ordinem omnium causarum esse certissumum et Dei praescientiae notissimum, plus eum quam Stoici detestamur (....). Tuttavia, anche la posizione stoica è da respingere, perché nella sostanza essi negano, al di là dei sofismi verbali, l'umana libertà: "Perciò, se volessi usare il termine "fato" per indicare qualche situazione reale, direi che fato del piú debole è la volontà del piú forte che lo ha in suo potere, piuttosto che dire che la capacità di scelta della nostra volontà ci sia sottratta da quella serie di cause che gli stoici, secondo un uso non comune, ma loro proprio, chiamano, fato.mm ${ }^{24}$

Embora S. Agostinho se recuse a identificar Deus com qualquer entidade que, por meio da coacção e da privação da capacidade de escolha, torne escravo o ser humano; reitere o livre arbítrio de cada indivíduo em De libero arbitrio (escrito entre 388 e 395/6), De correptione et gratia (de 428) e em Opus imperfectum contra Iulianum 6.11 (de 428-30); mesmo em caso de renitência ou recusa humana, negue o trahere do verso senequiano; e, por conseguinte, critique a ambiguidade subjacente à identificação do fatum com a summi patris uoluntas, não deixa o Bispo de Hipona de ter presente a sua própria conversão, parcialmente descrita em Conf. 8.5.11, onde, depois de reconhecer que já se encontrava mais no que em si aprovava, observa: Ibi enim magis iam non ego, quia ex magna parte id patiebar inuitus quam faciebam uolens. "Pois já aí havia mais de não eu, porque, em grande parte, mais o sofria, contra vontade, do que o fazia, querendo.» (trad. Espírito Santo e Pimentel) De qualquer modo, em contraste com o que diz Séneca do fatum, o Deus de Agostinho, constante, amoroso, paciente e sábio, incita stimulis internis (Conf. 7.8).

\footnotetext{
${ }^{24}$ Gallicet, 2000, 464.
} 
Sem ser propósito desta reflexão uma análise exaustiva da relação de Séneca com Santo Agostinho, serviram os exemplos aduzidos para mostrar algumas das divergências entre Séneca e Santo Agostinho e, por conseguinte, a pouca importância que o segundo dá à correspondência entre o filósofo de Córduba e Paulo de Tarso. Além disso, foi o próprio Agostinho quem, em C.D. 6.1, chamou a atenção para o facto de Séneca nunca referir os Cristãos, mesmo quando se encontravam em diferendo com os Judeus. $\mathrm{O}$ mais provável é que não acreditasse na autenticidade do epistolário.

Na Passio sancti Pauli apostoli dos Acta Pauli, atribuída ao Papa Lino talvez sucessor directo de São Pedro e, por conseguinte, contemporâneo de Pedro e Paulo -, emprega-se a forma amicitia para descrever a relação de Séneca com Paulo de Tarso, e a expressão amicali colloquio para caracterizar a correspondência. ${ }^{25}$ Se Kreyher fez remontar o início de uma tradição sobre os contactos entre Séneca e Paulo de Tarso a cerca de cinquenta anos após os factos referidos na Passio, chamou, no entanto, Sevenster a atenção para o carácter posterior das referências à Trindade, ao Santíssimo Sacramento e às fórmulas do Credo niceno (de 325), e ainda para as semelhanças por vezes literais com a Vulgata (posterior a 390); ${ }^{26}$ e Ramelli situou a referida Passio no séc. IV, ${ }^{27}$ Vouaux e Leclercq situaram no séc. V, ${ }^{28}$ Bocciolini Palagi no VI, ${ }^{29}$ Barlow no $\mathrm{VII},{ }^{30}$ e Momigliano entre o fim do séc. VI e o do VII d.C. ${ }^{31} \mathrm{Na}$ medida em que a obra referida não passa de uma reelaboração latina dos Acta Apocrypha Petri et Pauli, que, por sua vez, escritos em grego, não continham qualquer referência ao episódio senequiano, é legítimo supor que se trate de uma interpolação da autoria de quem traduziu o original grego que aparecia junto à tradução latina.

Por volta de 795 d.C., antepôs Alcuíno (c. 730-804), na edição que preparou para Carlos Magno, o seguinte dístico ao epistolário: Hic Pauli et Senecae breuiter responsa leguntur - quaenam notauit nomine quisque suo. ${ }^{32} \mathrm{~A}$

${ }^{25}$ Pseudo-Lino, Passio sancti Pauli apostoli, Acta apostolorum apocrypha, I ed. R. A. Lipsius, Leipzig, 1891, p. 24: Concursus quoque multus de domo Caesaris fiebat ad eum [sc. Paulum] credentium in dominum Iesum Christum et augmentabatur cotidie fidelibus gaudium magnum et exultatio. Sed et institutor imperatoris adeo illi est amicitia copulatus, uidens in eo diuinam scientiam, ut se a colloquio illius temperare uix posset, quatinus si ore ad os illum alloqui non ualeret, frequentibus datis et acceptis epistolis ipsius dulcedine et amicali colloquio atque consilio frueretur, et sic eius doctrina agente spiritu sancto multiplicabatur et amabatur, ut licite iam doceret et a multis libentissime audiretur. Disputabat siquidem cum ethnicorum philosophis et reuincebat eos, unde et plurimi eius magisterio manus dabant. Nam et scripta illius quaedam magister Caesaris coram eo relegit et in cunctis admirabilem reddidit. Senatus etiam de illo alta non mediocriter sentiebat. Apud Natali, 1995, 113 n. 177.

${ }^{26}$ Sevenster, 1961, 10-11.

${ }^{27}$ Ramelli, 1997, 307.

${ }^{28}$ Colhi esta informação em Natali, 1995, 64.

${ }^{29}$ Palagi, 1978, 19.

${ }^{30}$ Barlow, 1938, 7.

${ }^{31}$ Momigliano, 1950, 327.

${ }^{32}$ Colhi esta informação em Franceschini, 1981, 827-828. 
partir do séc. IX, começam as cartas a circular em conjunto com as L. Annaei Senecae ad Lucilium epistulae morales, mas nunca com o corpus paulino. É, de resto, entre este século e o XII ou XIII que se situam os manuscritos das Epistulae Senecae ad Paulum aut Pauli ad Senecam de que dispomos.

Embora investigadores como Fleury e Barlow tenham feito remontar à época medieval a ideia de que Séneca se teria convertido ao Cristianismo, demonstrou Momigliano que, na referida época, em outra conta não seria Séneca tido senão na de amigo de Paulo de Tarso ou do Cristianismo, ${ }^{33}$ e que o início da lenda se devia procurar nos primórdios do Humanismo italiano, mais propriamente em Giovanni Colonna que, por volta de 1332 e em De uiris illustribus, escreveu:

bunc saepe credidi christianum fuisse, maxime cum magnus doctor Ieronimus ipsum in sanctorum catalogo ascribat... sed potissime inducor ad credendum bunc fuisse christianum ex iis epistolis notis toti orbi terrarum que inscribuntur Pauli ad Senecam etc. ${ }^{34}$

${ }^{33}$ Momigliano, 1950, 334. «Freculfo, lo storico del IX secolo, definisce Seneca uirum nobilem et Pauli apostoli amicum. Ottone di Frisinga scrive in un passo L. Seneca non tam philosophus quam pene Christianus dicendus e in un altro, che allude alla corrispondenza, Christianae religionis amicum se fore ostendit. Pietro il Venerabile abate di Cluny nel trattato Contra Petrobusianos cita le lettere di Seneca a Paolo come scritte da un pagano. Pietro Comestor nella Historia scholastica, parlando di S. Paolo, fa una distinzione: multos de familia Neronis conuertit et familiaritatem S. magistri Neronis comparauit. Giraldo Cambrense chiama Seneca philosophum gentilem. Anche Ruggiero Bacone nel suo Opus Maius non va al di là di una parafrasi di certi complimenti di S. Paolo a Seneca contenuti nella corrispondenza. Nessun filosofo medievale espresse la sua ammirazione per Seneca in termini più forti di Abelardo: maximus ille paupertatis et continentiae sectator et summus inter uniuersos philosophos morum aedificator. Quando Eloisa volle persuadere Abelardo a non sposarla, citò l'Epistola 72 di Seneca: quando volle persuaderlo a scriverle, citò Epistola 40. Ma per Abelardo Seneca è gentilis.» No que a Freculfo diz respeito, importa notar que, pouco depois das palavras citadas, haveria de retomar quase à letra as palavras de Jerónimo citadas. Otloh de Saint'Emmeran (séc. XI) mostra-se surpreso com a presença de tanta prudentia num dos infiéis quanta a que se pode encontrar em algum dito dos seus provérbios (cf. Natali, 1995, 66 e 113 n. 183). Com Feculfo concordam Honório de Autun, Vicente de Beauvais, Martinho Polono, Rogério Bacon (cf. Natali, 1995, 67-8). Outro testemunho da amizade entre Séneca e Paulo de Tarso ocorre em Pseudo-Agostinho, Sermones ad fratres in eremo commorantes, Sermo XVII: De uigilatione et otiositate uitanda (PL 40, 1263): Vigilate ergo, fratres, otiositatem deponentes in cunctis. Quid enim otium est, nisi uiui hominis sepultura, ut ait paganus ille sanctissimi Apostoli amicus charissimus? O passo ecoa Séneca, Ep. 82.3, onde se lê: otium sine litteris mors est et hominis uiui sepultura. João de Salisbúria, discípulo de Abelardo, emprega uma forma do substantivo familiaritas para descrever a relação entre Séneca e Paulo de Tarso (cf. Natali, 1995, 69). Entre os autores cristãos que apreciavam os ensinamentos de Séneca e o não consideravam cristão, vale finalmente a pena mencionar Guilherme de Malmesbúria, Guilherme de Saint-Thierry, Godofredo de Saint-Victor e Vivaldo, abade de Corvey.

${ }^{34}$ Apud Momigliano, 1950, 336. Em composição poética sobre Séneca e Paulo, tinha um anónimo empregado, na última folha de um manuscrito de Metz designado por M (séc. XIXII), a frase fit mox per cuncta fidelis "por causa de tudo isto em breve se torna cristão", para descrever a relação entre Séneca e o Cristianismo, mas, pouco depois, haveria o mesmo autor de considerar Séneca indignus... baptismate Christi (apud Natali, 1995, 114 n. 185 e 186). 
Nesta linha e em comentário a Dante, datado de 1373, recorreu pela primeira vez Giovanni Boccaccio a Tácito, Ann 11-16 e Hist. 1-5, para estudar a vida de Séneca, e interpretou a libação de Séneca a Júpiter Libertador, em Tácito, Ann. 15.64, como dirigida a Jesus Cristo, e, por conseguinte, como uma confirmação da adesão de Séneca ao Cristianismo. Vale, de resto, a pena transcrever as palavras de Boccaccio sobre o epistolário: «Esser parole scritte da S. Paolo, le quali, bem intese, assai chiaro mi pare dimostrino S. Paolo lui aver per cristiano.» ${ }^{35}$

Foi já no séc. XV que Lionello d'Este (1407-1450), com eventual influência de Guarino da Verona (1374-1460), e Lorenzo Valla (1405-1457) pela primeira vez refutaram as teorias de Colonna e de Boccaccio, e, ao cabo, negaram a autenticidade do epistolário.

Convencido de que as Epistulae tinham sido compostas para demonstrar o Cristianismo de Séneca, sustentou o protestante Erasmo, em prefácio à edição de Séneca de 1515, que maior proveito retiraria o leitor se considerasse os escritos de Séneca como os hominis ignari nostrae religionis, ${ }^{36} \mathrm{e}$, no prefácio à edição de 1529, criticou o carácter insulso e desajustado da correspondência (frigidius aut ineptius ${ }^{37}$ ); acusou Jerónimo de ter conhecimento do engano e de ter abusado da credulidade das pessoas simples (Hieronymus non ignarus fuci, abusus est simplicium credulitate); observou que nada existe nas cartas supostamente escritas por Paulo digno do pensamento paulino (nibil est in Paulinis epistolis illo Pauli spiritu dignum); e notou a escassez de referências por parte de Paulo ao nome de Cristo - só ocorre em Ep. 14.9. Apreensivo quanto ao facto de Paulo, conhecido na tradição cristã pela sua coragem e determinação, se limitar a repreender Séneca por ter mostrado a Nero cartas que o natural de Tarso tinha escrito para todas as igrejas, e a justificar-se quod epistolis suis nomen suum soleat subscribere, interrogou-se Erasmo sobre como se poderia conciliar esta tentativa de ocultar o Evangelho com a corajosa e longa carta que há muito tinha o natural de Tarso enviado aos Romanos, ou se a mensagem que pretenderia transmitir poderia legitimar uma ocultação de crenças religiosas para agradar ao imperador. Dado o facto de a cólera do imperador pelos Cristãos ser amplamente conhecida em Roma, estranha Erasmo as palavras de Séneca a Paulo sobre os suplícios a que o imperador sujeitava os membros daquela religião e sobretudo a opção do Cordubense por um suporte escrito, em detrimento da segurança associada à oralidade,

${ }^{35}$ Apud Momigliano, 1950, 337.

${ }^{36}$ Apud Natali, 1995, 75 e 117 n. 225. Erasmo ainda completou deste modo a sua reflexão sobre o assunto: Etenim si legas illum ut paganum, scripsit Christiane, si ut Christianum, scripsit paganice.

${ }^{37}$ O juízo de Erasmo, na edição de 1529 das Senecae opera (Basel), acerca do epistolário, aparece transcrito em Franceschini, 1981, 840-841. Também se pode encontrar em Bouillet et al., $1829,470-473$. 
para tecer tais considerações. Quanto ao estilo e aos temas tratados, não deixa Erasmo de registar o contraste entre, de um lado, a copia e o affectus com que Paulo escreve a Filémon acerca de coisas vulgares e, do outro, a forma árida (ieiune) e fria (frigide) como o Apóstolo se dirige a um homem culto, como Séneca, para lhe falar da necessidade de abraçar o Cristianismo; ou, no propósito de melhorar o latim de Paulo, o envio, por parte de Séneca, de um livro De copia uerborum, a um homem que, como ele próprio, dominaria perfeitamente a língua grega; ou a contradição resultante de Séneca ensinar que a dicção do filósofo deve ser mais grave em sentenças do que ornada com palavras, e requerer de Paulo Romani sermonis copiam; ou o facto de, nas suas próprias cartas, se não revelar Séneca mais culto e desembaraçado do que Paulo. ${ }^{38}$

Ao considerar o passo a que Jerónimo se refere nas palavras supracitadas e que o leva a incluir Séneca no catálogo dos santos, onde também se mencionam não só judeus mas também hereges expulsos da comunidade da Igreja, refere Erasmo que, embora Jerónimo justifique, com a modéstia senequiana, as palavras parafraseadas, a verdade é que o desejo de Séneca de ocupar, apud .... ethnicos, um lugar semelhante ao de Paulo entre os Cristãos, se pode compreender a partir de um testemunho de Tácito segundo o qual, acossado por invejas e calúnias de muitos, tinha Séneca solicitado a Nero que o deixasse opes ac dignitatem... resignare qui dederat. Interroga-se, no entanto, o humanista holandês:

Sed quid refert magnusne sit an humilis, modo sit apud idolatras? Optare potius debuit ut sibi liceret uel inter humiles Pauli discipulos numerari. Talis nox poterat illum commendare Christianis affectibus.

Para rematar a refutação da lenda do Cristianismo senequiano e da autenticidade da correspondência, aduziu, por fim, Erasmo as circunstâncias da morte do filósofo, mais propriamente o contraste entre o modelo socrático, seguido por Séneca, e os princípios da moral cristã, que, em circunstância alguma, aceitam o suicídio; bem como o facto de, nem naquele momento, ter Séneca ousado proferir o nome de "Cristo", mas ter libado Ioui Liberatori. ${ }^{39}$

${ }^{38}$ E Erasmo conclui, desta forma, esta parte da sua reflexão: Scurrilis impudentia est sic facere loquentem Senecam, blasphemia est sic facere loquentem Paulum. Non dubito quin uel mulio uel agaso Senecae minus inepte fuerit scripturus: Paulo uero quid est minus ieiunum aut somniculosum? Et tamen in has epistolas extant uerbosi commentarii. Quid his iudiciis caecius? Haec non admonerem nisi talibus imposturis nimium et in aliis tribuant interdum Christiani.

${ }_{39}$ Postremo si uerum est quod hae fingunt epistolae, quis unquam Christianus sibi fuit supplicii minister? Quis in uxore sua probauit ut citra necessitatem sibi mortem conscisceret? Sed in balneum calidum illatus, quum iam deficeret, sparsit aquam sanguine mixtam, et Socraticum quiddam referens dixit, 'Hoc libo Ioui liberatori'; per Iouem, ut aiunt, liberatorem, uerum Deum intelligens. Adeo ne moriens quidem ausus est nominare Christum. Sed ego nimis multa de re nibili. 
Pelo séc. XVIII se prolongou, de um modo geral, o esforço de demonstração do carácter infundado da lenda, mas o séc. XIX assistiu a um reflorescimento da ideia da conversão de Séneca ao Cristianismo. Para isso, muito contribuíram duas obras de fôlego: uma da autoria de Amedée Fleury, intitulada Saint Paul et Sénèque. Recherches sur les rapports du Philosophe avec l'Apotre et sur l'infiltration du Christianisme Naissant (Paris 1853) - que sugeriu a perda do epistolário autêntico, a que se referiam os Padres da Igreja, e a atribuição a um monge do séc. IX ou X do contrafeito que nos chegou; continuou a notar as semelhanças entre o pensamento de Séneca e o de Paulo (cf., p. ex., Bouillet et al. 1829); registou coincidências biográficas passíveis de proporcionarem um contacto directo ou indirecto entre ambas as personagens; e, ao cabo, concluiu pela influência do Cristianismo em Séneca ${ }^{40}$; e outra de Johannes Kreyher (L. Annaeus Seneca und seine Beziehungen zum Urchristentum, 1887), que, a cada passo da obra de Paulo, vislumbrava a influência senequiana (e.g. 2Ts 2.1-12, o anticristo seria Nero, e o katechon Séneca) $)^{41}$.

Da refutação de Fleury se encarregaram Ch. Aubertin, em Étude critique sur les rapports supposés entre Sénèque et Saint Paul (Paris 1857), que sustentou a possibilidade de a correspondência ter sido forjada no séc. $I V,{ }^{42}$ e, já no séc. XX e na esteira de Aubertin, Sevenster, que cuidadosamente reexaminou as afinidades encontradas por Fleury entre Séneca e Paulo de Tarso para chegar à conclusão de que se encontram ao serviço de duas mundividências completamente diferentes.

Ao considerarmos as diversas edições da correspondência e os vários estudos que no séc. XX se publicaram sobre o assunto, deparamos com investigadores que a consideraram apócrifa (Barlow, 1938, 1; Momigliano, 1950, 333; Palagi, 1978, 10-11; Natali, 1995, 96); outros que, embora a tenham considerado apócrifa, não deixaram, baseados sobretudo na vida de Séneca e na de Paulo de Tarso, na cronologia das cartas e em dados de natureza arqueológica, de notar uma evolução senequiana, ditada pelo Estoicismo, de uma hostilidade inicial e familiar, para certa tolerância relativamente ao Cristianismo, mesmo sem a assumir expressamente na sua obra poética e filosófica (Scarpat, 1977, 112 e 142; Herrmann, 1979, 5 e 10-17); outros que procuram aduzir argumentos que sustentassem a possibilidade de o epistolário, na totalidade ou em grande parte, ser autêntico (Franceschini, 1981, 827-31; Ramelli, 1997, 301 e 310); e, por fim, os que defenderam mais convictamente o carácter genuíno da correspondência (Gamba, 1998, 209-250).

É, por conseguinte, altura de considerarmos os argumentos de natureza

\footnotetext{
${ }^{40}$ Colhi esta informação em Sevenster, 1961, 2.

${ }^{41}$ Sobre o assunto, v. Scarpat, 1977, 113-114; e Natali, 1995, 79.

${ }^{42}$ Sobre o assunto, v. Scarpat, 1977, 113-114; e Natali, 1995, 79.
} 
biográfica e arqueológica, antes de procedermos à análise das afinidades e das diferenças entre o Cristianismo paulino e o Estoicismo senequiano.

\section{A biografia de Séneca, de Paulo e a cronologia das epistulae Senecae ad Paulum aut Pauli ad Senecam}

Quando se considera a biografia de Jesus Cristo, de Séneca e de Paulo, o que se nota imediatamente é a contemporaneidade das três personagens: se Jesus Cristo teria nascido pouco tempo antes da morte de Herodes-oGrande a 4 a.C., ${ }^{43}$ já Griffin situou o nascimento de Séneca entre 4 e 1 a.C. e, na terceira edição revista do $O C D$, com Reynolds e Fantham, estendeu o referido intervalo temporal a 1 d.C..$^{44}$ - ano por volta do qual Pimentel situou o nascimento de Séneca ${ }^{45}$, e no qual Costa e os demais tradutores da Bíblia situam o nascimento de Paulo de Tarso, embora Murphy-O'Connor, mencionado por Rodrigues, aponte, para o último facto, a data de 6 a.C. ${ }^{46}$

Nos anos vinte do séc. I d.C., rumou Séneca ao Egipto, mais propriamente a casa de uma irmã de sua mãe Hélvia, então casada com o prefeito local (Gaio Galério), para se restabelecer dos acessos de tosse e da magreza e, ao cabo, escapar às ameaças de tuberculose. Embora muito se tenha especulado sobre a actividade de Séneca até 31 , ano em que regressa a Roma, ${ }^{47}$ o que, com alguma segurança, se pode afirmar é que, na sequência de uma longa tradição de literatura étnica, iniciada em Alexandria e promovida, com propósitos políticos, pelos Ptolemeus, ${ }^{48}$ a essa altura remontarão as seguintes obras senequianas de carácter étnico-geográfico: De situ Indiae e De situ et sacris Aegyptiorum. Ora foi precisamente a propósito da primeira das duas obras referidas que Fleury, na esteira de Justo Lípsio, admitiu a hipótese - impossível de demonstrar com a informação actualmente disponível - de Séneca ter passado pela Judeia na sua

${ }^{43}$ Félix Sanson, 1988, 36; e Fuller, 1993, 356. Embora Dionísio, o Pequeno tenha, em 526, determinado que a data do nascimento de Cristo teria sido o ano de 753 ab Vrbe condita, a verdade é que, da conjugação da informação de Flávio Josefo, segundo a qual Herodes, o Grande teria falecido no ano 750 ab Vrbe condita (4 a.C.), com a bíblica de que o rei da Judeia tinha mandado assassinar todas as crianças do sexo masculino de dois anos para baixo ( $M t$ 2.16-18), facilmente se conclui que o nascimento de Cristo data dos últimos anos do reinado de Herodes. Puig, 2006, 160-162, situa-a em 7/6 a.C.

${ }_{44}$ Griffin, 1976, 36. Reynolds, Griffin, Fantham, 2003, 96. Para a definição do primeiro intervalo temporal referido, jogou Griffin com o facto de Séneca ainda se lembrar de Asínio Polião, provavelmente falecido em 5 d.C. (Dial. 9.17.7; $P I R^{2}$ A 1241); de ainda ter assistido aos prodígios que acompanharam a morte de Augusto (Nat.1.1.3); e de o seu iuuentae tempus se ter situado no reinado de Tibério e de se referir concretamente o ano 19 (Ep. 108.22).

${ }^{45}$ Pimentel, 2000, 7.

${ }^{46}$ Costa et al., 1991, 1481; Rodrigues, 2007, 675.

${ }^{47}$ Pimentel, 2000, 12.

${ }^{48}$ Rodrigues, 2007, 41. O investigador exemplifica com a incumbência de Ptolemeu I Sóter a Hecateu, no sentido de o natural de Abdera escrever uma História do Egipto. 
viagem para a Índia. ${ }^{49}$ É possível que as viagens deste período e/ou o contacto com a comunidade judaica local e/ou com a de Roma tenham proporcionado a Séneca alguma da informação utilizada na elaboração de De superstitione, ${ }^{50}$ tratado de que nos dão conta os Padres da Igreja, sobretudo Agostinho, e onde Séneca consideraria vários cultos orientais, entre os quais o Judaísmo.

Mas se dos contactos senequianos com o Judaísmo ainda encontramos ecos relativamente seguros na obra senequiana citada pelos Padres da Igreja, já no que concerne a um eventual contacto com o Cristianismo não deparamos com qualquer indício absolutamente irrefutável em obra senequiana de autenticidade insuspeita. Resta, por conseguinte, considerar o círculo de amigos e conhecidos do Filósofo para ver se, por esse meio, poderia ter conhecido Paulo de Tarso e o Cristianismo.

No propósito de demonstrar uma evolução mais ou menos oscilante de uma hostilidade primordial e familiar de Séneca para certa tolerância relativamente ao Cristianismo, ditada pelo estoicismo, começou Herrmann por considerar as lendas sobre os vários tipos de relações entre diversas personagens pagãs e o Cristianismo; as catorze epistulae Senecae ad Paulum aut Pauli ad Senecam, em cuja autenticidade o investigador não acredita; e o epitáfio de Séneca, que, conforme o próprio Herrmann conclui, «est monothéiste, mais sans trace de christianisme. ${ }^{51}$ Em seguida, aduziu Herrmann, como forma de conciliar $M t$ 2.13-18 com $L c 2.21$, a possibilidade de Jesus se não ter apresentado no templo de Jerusalém, mas no de Onias em Leontópolis, que, por sua vez, ficava perto de Heliópolis, onde se dizia que a fénix costumava nascer e perecer e que fazia parte de uma região de onde proviria o livro pseudo-sibilino lançado a 19 d.C., pouco posterior à morte de Germânico e de forte pendor messiânico, que Séneca teria conhecido no Egipto, e segundo o qual, no termo de um dos

${ }^{49}$ Fleury, 1853, I 155-6

${ }^{50}$ Três foram, de acordo com Rodrigues, 2007, 38 ss., os momentos mais importantes da emigração judaica para o Egipto: o descrito nos livros do Génesis e do Êxodo, com as figuras de Abraão, José e Moisés; o do hegemonia neobabilónica e do domínio persa (525399 a.C.) - os vestígios documentais situam no séc. VII a.C. (período assírio na Palestina) a ocorrência, no Egipto, dos primeiros sítios judaicos; e o momento decorrente das conquistas de Alexandre, nomeadamente após a batalha de Gaza, em 312 a.C., e entre 301 e 198 a.C., quando a Palestina se encontrava sob domínio político dos Lágidas. À numerosa e poderosa comunidade judaica de Alexandria (cf. Fílon, Flacc. 55-56 e Legat. 132) se ficou a dever a tradução da Bíblia hebraica para grego (versão dos Setenta), a criação de textos de conteúdo judaico e de forma grega (o romance José e Assenat ou a tragédia Exagoge, de Ezequiel), a filosofia de Aristobulo e de Fílon, o livro da Sabedoria e, em parte, a obra de Flávio Josefo. Conforme demonstrou Kasher, referido por Rodrigues, os judeus de Alexandria lutaram com os gregos por um politeuma que coexistisse em pé de igualdade com a polis grega. Em 55 a.C., foram os Judeus que, por intermédio de Pelúsio, franquearam as portas da cidade a Ptolemeu XII, e tiveram um papel fundamental na campanha alexandrina de Júlio César em 48 a.C. A presença de Judeus em Roma - que se não organizaram em politeuma - remonta pelo menos à anexação da Itália e às Guerras Púnicas.

${ }^{51}$ Herrmann, 1979, 17. 
ciclos da ave mítica, Roma haveria de cair às mãos dos Hebreus (Díon 57.45). ${ }^{52} \mathrm{O}$ problema é que, conforme sustentou Puig, os dois passos bíblicos se não afiguram incompatíveis, uma vez que poderão descrever dois momentos distintos da vida de Cristo. ${ }^{53}$

Sustentou depois Herrmann que Paulo de Tarso seria o chefe do grupo de Judeus dissidentes que, em benefício pessoal e do templo de Jerusalém, havia extorquido a Fúlvia, esposa de (Sêncio) Saturnino, púrpura, ouro e outros bens (cf. Josefo, AJ 17.81-82). Embora não seja possível determinar se existiria ou que tipo de relação existiria entre Fúlvia e Séneca, o que o investigador conclui é que, encoberto pelo antimessianismo e pelo anti-semitismo de seu tio Galério, estaria Séneca a par da propaganda cristã, levada a cabo por Paulo de Tarso, junto da comunidade aristocrática romana. À luz dos dados apresentados, parecem estas conclusões algo imaginosas. ${ }^{54}$

Depois de referir o possível apoio de Séneca, enquanto senador, à oposição de Tibério à adopção, proposta por Canínio Galo e Quintiliano (Tácito, Ann. 5.18 e 6.12), de um novo livro sibilino pelo senado, ou o eventual regozijo senequiano com o edicto de Nazaré, onde Tibério havia censurado os Cristãos por, de acordo com os Judeus, terem violado sepulturas, classificou Herrmann de cristianizantes, Públio Pompónio Secundo, que, de acordo com Quintiliano, Inst. 8.3.31, haveria de ter uma discussão com Séneca sobre a propriedade do uso em tragédia da expressão gradus eliminat; ${ }^{55} \mathrm{~S}$. Mário, um riquíssimo compatriota de Séneca que foi acusado de incesto (Díon 63.22); um Paulo, que, salvo por um escravo de uma associação de lesa-majestade (Séneca, Ben.

${ }^{52}$ Herrmann, 1979, 19 ss. O conteúdo do livro haveria de ser reproduzido por Díon 62.18, no rescaldo do incêndio de Roma, a propósito da perseguição movida por Nero aos Cristãos; e que corresponde aos versos 139 ss. do $8^{\circ}$ livro sibilino subsistente.

${ }^{53}$ Puig, 2006, 154-5. A propósito, ainda observou, de forma perspicaz, o investigador que Lucas silencia as viagens de Jesus adulto fora do território de Israel (Fenícia, Mc 7.24; duas a Decápole, $M c 7.31$ e 5.20; Cesareia e Filipos, $M c$ 8.27), a fim de realçar a importância da primeira comunidade cristã na difusão da mensagem bíblica além-fronteiras (Samaria, Act 8.5; Síria, Act 9.22; Fenícia, Act 11.19). Quanto à fénix, teria, de acordo com Herrmann, 1979, 29, aparecido no Egipto, antes das mortes do adivinho Trasilo e de Tibério, para anunciar a do imperador. O mesmo investigador observa que, no Livro dos segredos de Enoch, de um cristão do círculo de Paulo de Tarso, se referem muitas fénices, e que, na tragédia Exodus, de PseudoEzequiel, as setenta fénix vegetais (palmeiras) simbolizam os discípulos dos apóstolos, que, por sua vez, aparecem simbolizados pelas 12 fontes.

${ }^{54}$ Herrmann, 1979, 27-28. Em abono da sua teoria, relacionou Herrmann a descrição do crime no passo referido com as considerações de Josefo, em $A J$ 20.97-203, onde se fala de um judeu expatriado, com receio de represálias por ter transgredido certas leis; da apresentação de certas pessoas diante do Sinédrio por terem violado certas leis; com a ligação, em Filipos, de Paulo a Lídia de Tiatiros, comerciante de púrpura; com a possibilidade de o grupo que girava em torno de Fúlvia ser helenizante e com a sólida cultura grega de Paulo.

${ }^{55}$ Herrmann, 1979, 28. Após o castigo de Sejano, foi Pompónio Secundo acusado de ter dado guarida a Asínio Polião [Tac., Ann. 6.3 (5.8)]. Segundo Herrmann, teria sido salvo pelo irmão, Quinto Pompónio. 
3.36), talvez fosse o cônsul que Paulo de Tarso haveria de converter em Chipre (Act. 13.45); Pompónia Grecina; Júlia Drusila, casada com Rubélio Blando [Tácito, Ann. 6.33 (6.27)] e amiga da anterior.

O problema é que, além de o próprio investigador reconhecer a dificuldade em perceber como Séneca encararia Pompónia Grecina e Júlia Drusila, ${ }^{56}$ o que se nota no raciocínio de Herrmann é uma tentativa de dar significado a situações que poderão não passar de coincidências e certas generalizações que se poderão afigurar algo abusivas. Embora Rodrigues note a existência, entre os judeus de Roma, de indivíduos que conservam o nomen da gens Pomponia (inscrições n. ${ }^{\text {os } 340 / 384, ~ 473 / 11 \# ; ~ u m ~ n a ~ C a t a c u m b a ~ d a ~ V i a ~ N o m e n t a n a ~ e ~ u m ~}$ na de Monteverde) - em sinal de que membros dessa gens haviam libertado escravos judeus ou adoptado judeus livres -, a verdade é que também se encontram indivíduos com nomina das gentes Iulia, Claudia, Flauia e Aurelia, e, mesmo tendo em conta a difusão do nomen Iulius e de outros a partir do séc. I ou a relação da representatividade da gens Aurelia com a Constitutio Antoniana, a existência de libertos com os referidos nomina não significa que os Imperadores com os referidos gentílicos fossem adeptos dos Judaísmo. ${ }^{57}$ Admitindo a hipótese de a esmagadora maioria das inscrições romanas ser dos séc. III-IV d.C., poder-se-ia considerar a possibilidade de se tratar de descendência de antigos libertos ou senhores, mas, como o próprio Rodrigues também refere, as regras onomásticas tinham alcançado tal flexibilidade que se não podia taxativamente afirmar que certo Júlio Hérmias pertencesse à casa dos Júlios.

Da proximidade entre «Herodes» Agripa e Lúcio Pompónio Flaco dá por diversas vezes conta o referido investigador..$^{58}$ Ora Aristobulo, irmão de «Herodes» Agripa, também fazia parte do círculo de Lúcio Pompónio Flaco, que, nomeado governador da Síria em 32 a.C., era tio de Pompónia Grecina, que era casada com Aulo Pláucio, que, por sua vez, era da família de Pláucia Urgulanila, primeira esposa do imperador Cláudio (filho de Antónia), e da família de Lúcio e de Públio Vitélio, que, além de fazerem parte do círculo de Antónia, foram respectivamente pai do imperador Vitélio e companheiro de armas de Germânico, também filho de Antónia. Não é possível determinar se existiria algum parentesco entre Lúcio Pompónio Flaco e Públio Pompónio Secundo, mas, mesmo que tal se verificasse, não significaria forçosamente que ambos fossem, com a Pompónia Grecina que no tempo de Nero haveria de ser acusada de superstitio externa, dos primeiros cristãos romanos, uma vez que o facto de Grecina ser cristianizante não levou os membros da família do marido a aderirem ao Cristianismo.

\footnotetext{
${ }^{56}$ Herrmann, 1979, 29.

${ }^{57}$ Rodrigues, 2007, 145 ss.

${ }^{58}$ Rodrigues, 2007, 479, 481, 511, 670 e 674.
} 
Considerada a reserva de Séneca relativamente aos Cristãos no tempo de Calígula, procurou Herrmann demonstrar que, durante o exílio na Corsega e para manter viva a esperança de regresso a Roma, se teria o Filósofo sentido obrigado a alinhar, pela hostilidade de Cláudio aos Cristãos, a sua própria atitude em relação àquela seita religiosa. Nessa medida, viu Herrmann, na alusão de Dial. 12.16.2 às mulheres que, uma vez adoptada a tristeza, a conservam até à morte, uma crítica velada à Pompónia Grecina que, perante a relegatio e a morte de Júlia Livila numa ilha, não mais abandonara o luto (Tácito, Ann. 13.32). A fim de excluir do passo uma eventual alusão velada a Octávia, referida em Dial. 6 (Consolatio ad Marciam) como alguém que se não tinha conseguido restabelecer da morte do filho Marcelo, situa o investigador o último diálogo referido em data posterior à do primeiro, mais propriamente em 62 d.C., mas, como refere Codoñer, tende a maioria dos investigadores a datar a Consolatio ad Marciam de época anterior ao exílio e a Consolatio ad Heluiam de 43.59

Ao contrário do que sustenta a maioria dos investigadores, não aludiria a forma latro de $A L 409 \mathrm{R}$ (405 ShB), v. 11, a Viriato, que, entre 147 e 139 teria lutado pelos Lusitanos contra os Romanos, mas devia ser encarada no âmbito de uma pilhagem iniciada em Córduba, na Bética, no tempo de Cláudio, e, de acordo com inscrição descoberta em Pagus Marquesiae, na Lusitânia, e publicada em Gruter 138, terminada nesta província na época de Nero. Ainda segundo esta inscrição, estariam esses ladrões - do tratamento que o Laureolus e De clementia dariam a Cristo e da comparação de Cristo com Barrabás depreende Herrmann o uso do termo para qualificar Judeus e Cristãos - lusitanos envolvidos na propagação de nova superstição. Importa, desde já, notar a interpretação abusiva de De clementia, mas ao assunto voltaremos posteriormente.

Em AL 406 R (402 ShB), Séneca acusaria Gneu Pompeio Magno de ter presenciado o sacrifício de uma criança no âmbito de um ritual de necromancia que Herrmann cuida poder ter sido levado a cabo pelo apóstolo Pedro, com o propósito de evocar a sombra de Pompeio, o Grande, a partir dos Campos Elísios. Ora, em Apoc. 11.2, é Augusto quem critica Cláudio por ter sido o responsável pela morte de Gneu Licínio Crasso, da esposa, Escribónia, e do filho, Gneu Pompeio Magno. A propósito da forma Tristionam, que aparece a seguir ao nome da mulher, sugere Herrmann a substituição por christianam, em referência ao credo religioso da senhora. ${ }^{60}$

Em resposta a $A L 408 \mathrm{R}$ (404 $\mathrm{ShB})$, onde Séneca, desiludido com as amizades dos poderosos, diz: <I> nunc et reges tantum fuge! Viuere doctus / uni

${ }^{59}$ Herrmann, 1979, 37; Codoñer Merino, 1999³ 178 e 378.

${ }^{60}$ Herrmann, 1979, 41-2. Em abono da sua teoria, aduz o testemunho de Agostinho, C.D. 18.59, segundo o qual havia Pedro sido acusado de necromancia e de infanticídio por ter supostamente sacrificado uma criança de 365 dias para que a nova religião pudesse durar 365 anos. 
uiue tibi; nam moriere tibi - teria Paulo escrito, em Rom 14.7-8: Nemo enim nostrum sibi uiuit et nemo sibi moritur; siue enim uiuimus, Domino uiuimus, siue morimur, Domino morimur. ${ }^{61}$

Ainda em linha com o Cláudio que, de acordo com Apoc. 8, havia constrangido Lúcio Silano ao suicídio para condenar Júpiter pelo incesto com Juno, acusaria Séneca, em $A L 446 \mathrm{R}$ (444 ShB), Júnia Calvinia de incesto com o irmão, Lúcio Silano. ${ }^{62}$

Em Dial. 3.1.2.1-2, onde, a propósito dos malefícios da ira, se refere alium in cruce membra diffindere, vê Herrmann uma alusão velada à crucifixão de Cristo, após, de forma idêntica segundo o investigador, se ter sugerido o assassínio de Tarquínio, o Antigo, na sua cama, de Filipe da Macedónia em Pela, de Semprónio Aselião no Foro, de Fraates IV pelo filho e de Pompeio, o Grande, no Egipto. ${ }^{63}$

A grande objecção que a esta parte do estudo de Herrmann se pode fazer tem inevitavelmente que ver com as incertezas relativas ao problema da autenticidade dos epigramas. ${ }^{64}$ Quanto à secção seguinte, se o que o investigador pretende demonstrar é que, após o regresso da Córsega e depois de se informar melhor junto de Paulina (Dial. 5.3.36.6) ou dos irmãos Aneu Novato e Aneu Mela sobre a verdadeira natureza do Cristianismo, teria o Filósofo adoptado uma atitude mais tolerante em relação aos Cristãos e teria inclusivamente tentado refrear as perseguições que lhes foram movidas, o mínimo que se pode dizer é que a progressão para este ponto de vista não teria sido linear, uma vez que o próprio Herrmann classifica de "anti-chrétienne" a Diui Claudii Apocolocyntosis, de 54 d.C., que a maioria dos investigadores atribui ao preceptor de Nero, mas o investigador francófono sustenta ser de Fedro. ${ }^{65}$

Embora se não verifique, entre os investigadores, consenso relativamente ao período em que Lúcio Aneu Novato ou Galião, irmão mais velho de Séneca, desempenhou o cargo de procônsul da Acaia - se Scarpat sustenta que teria sido entre a primavera de 52 e a de 53, já Herrmann e Gamba falam de $51-52^{66}-$, do que não restam dúvidas é do que, perante a acusação de que Paulo, na prestação do culto a Deus, não obedeceria à Lei, respondeu Galião (Act 18.14-15): Si quidem esset iniquum aliquid aut facinus pessimum, o Iudaei, merito uos sustinerem; si uero quaestiones sunt de uerbo et nominibus et lege uestra, uos ipsi uideritis; iudex ego horum nolo esse. Em comentário ao passo,

${ }^{61}$ Cito a partir de Noua Vulgata Bibliorum Sacrorum. Editio Sacros. Oecum. Concilii Vaticani II Ratione Habita Iussu Pauli PP. VI recognita auctoritate Ioannis Pauli PP. II promulgata. Libreria Editrice Vaticana, 1986.

${ }^{62}$ Herrmann, 1979, 43-4.

${ }^{63}$ Herrmann, 1979, 44-5.

${ }^{64}$ Sobre o assunto, v. Abel, 1980, 352.

${ }^{65}$ Herrmann, 1979, 38, 49; Waltz, 1966; Eden, 1984.

${ }^{66}$ Scarpat, 1977, 118-119; Herrmann, 1979, 47; Gamba, 1998, 218. 
considou Rodrigues duas hipóteses de interpretação da atitude de Galião: dado o facto de se não tratar de matéria de Direito Civil, teria mostrado certa tolerância relativamente ao Judaísmo, ou poderia a sua atitude decorrer de certa ignorância relativamente à problemática Judaísmo/Cristianismo. Em qualquer dos casos, não deixará este comportamento de nos trazer à memória o de Pilatos perante Cristo no momento da condenação e a tentativa de isentar Roma e os Romanos de culpa em tal decisão (cf. Jo 19.11 e $M t 27.19$ ), e de revelar uma tomada de consciência, por parte do irmão de Séneca, do conflito religioso que no seio da comunidade judaica se começava a delinear. ${ }^{67}$ Resta saber qual foi a profundidade das razões aduzidas por Paulo e pelos Judeus que o acusavam e se o assunto mereceu, da parte de Galião, algum comentário ou troca de impressões com Séneca.

Dos sucessos eventualmente ocorridos durante o quinquennium Neronis (54-59) susceptíveis, segundo Herrmann, de configurar os contornos de uma atitude senequiana relativamente ao Cristianismo, importa, desde logo, notar uma possível intercessão de Séneca e de Burro junto de Pórcio Festo, não só no sentido de este usar de benevolência para com o detido Paulo de Tarso, mas também no de o centurião Júlio da coorte Augusta lhe permitir certa liberdade de contactos e movimentos na viagem escoltada para Roma (Act 27.1-3 e Tit 1.5); e a escrita, por parte de Séneca, de Ad Lucilium epistulae morales pejadas de alusões veladas a Paulo de Tarso e ao Cristianismo $[E p .3 .6$ (cf. 1 Thess. 5-7)], sobre a oposição luz/trevas; Ep. 9 e 13, com eventual alusão ao adiamento da comparência de Paulo em tribunal; $E p$. 10 , sobre a descrença de Séneca relativamente às visões dos amigos de Júlio Cano e dos discípulos de Cristo; 41, com possível alusão velada a Paulo de Tarso; e 42, onde se aludiria à serpente envolvida em milagre de Paulo de Tarso, conforme descrito em Act 18.3-6], entre as quais se conta uma (40), segundo a qual havia Lucílio ouvido, em Siracusa, Serapião, que, por sua vez, já tinha sido ouvido em Roma por Séneca e que, cerca de 15 anos após a carta senequiana, haveria de escrever outra, siríaca, publicada por W. Cureton em Spicilegium Syriacum (Londres 1855), onde confessaria ter tido uma conversa sobre a inconstância das coisas humanas com um filósofo que Herrmann cuida ter sido Séneca - uma vez que considerara argumentos comuns aos de De remediis fortuitorum e na mesma sequência - e aludiria à «exécution par les Juifs de leur roi sage» ${ }^{68}$. O que, desde logo - e para usar palavras do próprio Herrmann no comentário à hipótese de certa epistula atribuir à leitura de textos cristãos a transformação de Séneca ${ }^{69}$-, se pode dizer das alusões veladas das cartas é que não serão menos arriscadas do que aquela possibilidade. Quanto ao texto de Serapião, é, conforme observa

\footnotetext{
${ }^{67}$ Rodrigues, 2007, 707-708.

${ }^{68}$ Hermann, 1979, 54.

${ }^{69}$ Herrmann, 1979, 53.
} 
San Martín, «oscuro, quedan muchos datos por aclarar, y producto en buena parte de la fantasía: vanas elucubraciones desprovistas, en general, de cualquier fundamento» ${ }^{70}$.

Outro momento importante da reflexão de Herrmann sobre a atitude de Séneca relativamente ao Cristianismo durante o quinquennium Neronis é aquele em que, depois de situar o lançamento de De clementia em 58 d.C., vislumbra o investigador, na solicitação de Burro a Nero no sentido de lhe dar os nomes dos dois malfeitores contra quem devia tomar medidas, e de lhe indicar os motivos de acusação, e no desabafo do imperador de que desejaria não saber escrever ( $C l$ 2.1.1-2), alusões veladas ao momento da condenação dos apóstolos Pedro e Paulo. O problema é que, para o lançamento da obra, sugeriu Codoñer a data de 1 de Janeiro de 55, anterior à morte de Britânico e quando Nero celebraria a nuncupatio uotorum, ou outra em finais de Dezembro de 55, posterior ao assassínio de Britânico; Citroni, Consolino, Labate e Narducci situaram referido acontecimento literário no início do principado de Nero, «entre fins de 55 e 56»; Grimal, referido por Abel, já havia estabelecido, como limites temporais para o referido sucesso, as datas de 15 de Dezembro de 55 e 14 de Dezembro de 56; e, entre 54 e 56, andaria Paulo, de acordo com J. Murphy-O'Connor citado por Rodrigues, ocupado em viagens à Macedónia, à Ilíria, a Corinto e a Jerusalém. ${ }^{71}$

${ }^{70}$ San Martín, 1982,387. Herrmann, 1979, 55 ss. sugere a possibilidade de a Séneca, a Burro e a Nero ter Asínio Marcelo, descendente de Asínio Polião e possivelmente a personagem que o apóstolo Pedro teria frequentado (Acta Petri), ficado a dever a isenção de condenação por cumplicidade na elaboração de um falso testamento de Domício Balbo (57 d.C.; Tac. Ann. 14.40); de Séneca e Burro terem sido os mentores da oposição de Nero à moção de Cingónio Varrão que visava a deportação para fora de Itália dos libertos testamentários do assassinado Pedânio Secundo (Tac. Ann.15.14); de Pedro ter, durante o cortejo para o campus Esquilinus dos escravos do referido Pedânio condenados à morte, gritado a sua esposa-irmã que se lembrasse do Senhor, o que teria levado à captura do apóstolo (cf. Clem. Alex. Stromata 7.83, e Eus. HE 3.20.2); de a comunidade cristã de Lião ter, como represálias pelas injustiças de que era alvo (cf. justificação de actos deste tipo em Tertul., Apolog. 38.2-3), incendiado o principal centro do culto imperial nas Gálias; de Dial. 6.20.3 constituir uma referência aos suplícios decorrentes do assassínio de Pedânio Secundo em 57 d.C.; de Séneca e Burro serem os responsáveis últimos pela comutação, por um julgamento levado a cabo pelo próprio marido em conselho familiar - que resultou em absolvição -, da apresentação de Pompónia Grecina, acusada de superstição estrangeira, em tribunal comum ou perante o Senado (Tac. Ann. 13.33). É ainda durante o quinquennium Neronis que as províncias da Ásia, da Cilícia e da Lícia movem, respectivamente a P. Célere, participante no assassínio do cristianizante D. Júnio Silano, a Cossuciano Capitão, genro de Tigelino e feroz cristianófobo (Ann. 14.48), e a Éprio Marcelo, que sucedera a Silano na pretura (Ann.12.4), processos por concussão (Ann.13.33), que não logram a condenação do primeiro, mas apenas a do segundo, e, no caso do último, o envio para o exílio dos acusadores. De acordo com Ann.13.42-43, foi ainda por esta altura que, em resposta a graves acusações lançadas por P. Suílio, Séneca lhe fez mover um processo por ter constrangido Gaio Pompónio a iniciar uma guerra civil, e por ter obrigado Júlia Drusila e Valério Asiático, acusados de Cristianismo, e Popeia Sabina, judaizante, a cometer suicídio. Suílio acabou relegado para as Baleares.

${ }^{71}$ Herrmann, 1979, 61-66; Codoñer Merino, 1988, XXIII-XXIV; Citroni et al., 2006, 733; 
Foi precisamente no templo de Jerusalém que os judeus da Ásia acusaram Paulo de a todos pregar contra os Hebreus, contra a Lei, contra o lugar onde se encontravam, e de introduzir gregos no templo (Act 21.26 ss.). Como o apóstolo tinha sido visto com Trófimo de Éfeso, o povo acreditou e, depois de dele se ter apoderado, logo o arrastou para fora do templo. Quando a população se preparava para o matar, interveio o tribuno da coorte, Cláudio Lísias, que, com os soldados, o salvou. Alegada a sua cidadania romana, foi ouvido no Sinédrio, e, para se esquivar à conjura dos judeus, foi levado para Cesareia, à presença de António Félix, que era liberto da mãe de Cláudio, Antónia, irmão de Palante (o favorito de Agripina) e casado com Drusila, a filha mais nova de «Herodes» Agripa I e irmã de Berenice que com ela não tinha boas relações (Josefo, $A J$ 19.354).

Ora, em Act 24.22, diz-se que Félix conhecia muito bem o Cristianismo (Felix certissime sciens ea, quae de hac uia sunt); em 24.23, que ordenara ao centurião que, na prisão, concedesse a Paulo certa liberdade de contactos com

\footnotetext{
Abel, 1980, 352-353; Rodrigues, 2007, 675. Para a decisão de Burro, Séneca e Nero, muito teria contribuído, ainda segundo Herrmann, 1979, 66-67, a dessecação, em 58, da figueira que teria abrigado Rómulo e Remo; se havia miraculosamente deslocado do Lupercal para o Comitium; e era pelos Romanos encarada como um símbolo do poder de Roma (Tac. Ann.13.58). Em abono da sua teoria, alega o investigador o recurso, por parte de Jesus Cristo, à parábola da figueira para anunciar o advento do reino de Deus ( $M t$ 24.32-36, $M c$ 13.28-32, Lc 21.22-23); ou o facto de, no trajecto entre Jerusalém e Betânia, ter Jesus deparado com uma figueira a secar $(M t 21.18$ 24 e $M c 11.12$ e 14-20); ou ainda a substituição, em Lc 17.5-10 e eventualmente por receio de represálias por parte dos Romanos, da figueira por uma amoreira que cumpriria a ordem de um homem de fé que a mandasse descolar-se para o mar. Se, no tocante ao problema de escala e de difusão do Cristianismo, observa San Martín, 1982, 388, que «en los primeros decenios tras la muerte de Cristo la nueva religión no era conocida sino de una reducidísima minoría, no se le presentaba la menor atención: no era algo importante, es decir, que importara.» - a verdade é que, como alertara Abel, 1980, 352, tal teria sido a perseguição de Nero aos Cristãos que dificilmente poderia ter passado despercebida ao próprio Séneca. A data situada entre 50 e 55 d.C., faz Sanson, 1988, 40, remontar a elaboração, em aramaico, da primeira versão do Evangelho segundo de S. Mateus, que, segundo o mesmo investigador, teria, em 60, sido traduzida para grego; Costa et al., 1991, 1287-1288, situam a tradução e a ampliação por volta do ano 70; e Kingsbury, 1993, 502, céptico quanto ao facto de Mateus ser o autor do evangelho e defensor da ideia de que teria sido escrito por um cristão em Antioquia da Síria, data-o de c. 85 ou 90 d.C. Quanto ao Evangelho segundo S. Marcos, se Sanson, 1988, 40, o data de 60, e Costa et al., 1991, 1332, situam a sua edição em Roma entre os anos 65 e 70, já Hooker, 1993, 493, depois de dizer... sugere que se costuma fazer remontar a data entre 65 e 75 d.C., sugerem a possibilidade de ter sido escrito por volta de 70, data da destruição de Jerusalém. Enquanto Sanson, 1988, 40, sustenta que o Evangelho segundo S. Lucas teria sido escrito entre 60 e 68, Fitzmyer, 1993, 472, depois de referir uma data posterior à queda de Jerusalém em 70 e embora advirta das incertezas relacionadas com a data geralmente aceite, situa-a entre 80 e 85 d.C.; quanto ao Evangelho segundo S. João, cuja edição Sanson, 1988, 40, situa entre 90 e 100, admite Smalley, 1993, 375376, a possibilidade de ter sido escrito no início do séc. II d.C. ou provavelmente mais cedo, por volta de 85 . d.C. É certo que os evangelhos decorrem da cristalização de uma tradição oral que circulava pelas comunidades religiosas locais, mas se os evangelhos foram um dos principais meios de divulgação da mensagem crista fora dos restritos círculos cristãos, seria impossível que o fenómeno romano pudesse ter sido interpretado à luz dos referidos passos bíblicos.
} 
os seus (iubens centurioni custodiri eum et habere mitigationem, nec quemquem probibere de suis ministrare ei); em 24.24, que, alguns dias depois, com Drusila, ouviu Paulo falar da fé em Cristo Jesus (Post aliquot autem dies adueniens Felix cum Drusilla uxore sua, quae erat Iudaea, nocauit Paulum et audiuit ab eo de fide, quae est in Christum Iesum); em 24.26, que estava à espera de algum suborno por parte de Paulo (Simul et sperans quia pecunia daretur sibi a Paulo) - o que, podemos acrescentar, pode, por si só, justificar o tratamento que havia ordenado que fosse dado a Paulo na prisão.

Com base na necessidade de se aguardar a chegada de Jerusalém de todo aquele que desejasse acusar Paulo, situou Gamba em 57 a instrução da causa do apelo de Paulo, e concluiu: «È in questo contesto temporale ed ambientale che há inizio e poi si sviluppa il carteggio tra Seneca e Paolo, almeno per quanto concerne le prime nove lettere non datate. ${ }^{72}$ Assim se entenderia a preocupação de Séneca e de Lucílio, na Ep. 1 (ad Paulum), com a reunião de documentação necessária para o Imperador poder administar a justiça. Para esta empresa contaria o Filósofo com companheiros de fé de Paulo que lhe trariam as duas cartas aos Tessalonicenses e, como ele, teriam acesso à residência estival (Horti Sallustiani) de Nero. Na Ep. 2, responderia Paulo, de forma solícita, aos agradecimentos de Séneca pelo material que tanto o impressionara. Dado o carácter iminente da audiência junto do Imperador, comprometer-se-ia Séneca, na Ep. 3, a rever, com o apóstolo, tudo quanto tinham preparado para a defesa do último. Na Ep. 4, declararia Paulo a sua disponibilidade. Da cumplicidade entre Paulo e Séneca teria, de acordo com a Ep. 5, tomado conhecimento Agripina, que logo se teria dirigirido a Nero para acusar o apóstolo de deslealdade, o que teria sucitado em Paulo maior reserva e prudência, e, em Séneca, grande preocupação. Na Ep. 6, procuraria Paulo tranquilizar Séneca e Lúcílio, recomendando-lhes paciência e cautela. Entretanto, teria Paulo feito chegar a Séneca a carta aos Gálatas e as duas aos Coríntios, que, depois de parcialmente lidas ao Imperador, lhe haviam, de acordo com a Ep. 7, de Séneca a Paulo, causado muito boa impressão. $\mathrm{Na} E p$. 8, manifestaria Paulo receio de Séneca ter sido demasiado ousado e sugeriria outro tipo de atitude para evitar a hostilidade de Agripina. $\mathrm{Na} E p$. 9, que não deveria ser posterior a julho-agosto de 57 , consideraria Séneca justificados os temores de Paulo que, a ponto de escrever às suas comunidades da Grécia e da Ásia, acabaria por ser agraciado com um manual de retórica e da arte de bem escrever.

Seguem-se as seguintes cartas datadas, que assim aparecem numeradas e sequenciadas nas principais edições:

\footnotetext{
${ }^{72}$ Gamba, 1998, 219.
} 


\begin{tabular}{|c|c|l|c|c|c|c|c|}
\hline Data & $\begin{array}{c}\text { Remet. } \\
\text { e } \\
\text { destin. }\end{array}$ & $\begin{array}{c}\text { Cônsules } \\
\text { ordinários (o) e } \\
\text { sufectos(s) }\end{array}$ & $\begin{array}{c}\text { Haase } \\
\mathbf{( 1 9 0 2 )}\end{array}$ & $\begin{array}{c}\text { Barlow } \\
\mathbf{( 1 9 3 8 )}\end{array}$ & $\begin{array}{c}\text { Bocciolini } \\
- \text { Palagi } \\
\mathbf{( 1 9 7 9 )}\end{array}$ & $\begin{array}{c}\text { Franceschini } \\
\mathbf{( 1 9 8 1 )}\end{array}$ & $\begin{array}{c}\text { Natali } \\
\mathbf{( 1 9 9 5 )}\end{array}$ \\
\hline 27-06-58 & P. a S. & $\begin{array}{l}\text { Nero (3a vez) e } \\
\text { Messala (s) }\end{array}$ & X & X & X & X & X \\
\hline $06-07-58$ & S. a P. & $\begin{array}{l}\text { Lurcão e Sabino } \\
\text { (s) }\end{array}$ & XIII & XIII & XIII & XIII & XIII \\
\hline $01-08-58$ & P. a S. & $\begin{array}{l}\text { Lurcão e Sabino } \\
\text { (s) }\end{array}$ & XII & XIV & XIV (XII?) & XIV & XIV \\
\hline 23-03-59 & S. a P. & $\begin{array}{l}\text { Aprónio } \\
\text { Capitão (o) }\end{array}$ & XI & $\begin{array}{c}\text { XII } \\
\text { (XI) }\end{array}$ & XII (XI) & XII (XI) & $\begin{array}{c}\text { XII } \\
\text { (XI) }\end{array}$ \\
\hline 28-03-64 & S. a P. & Frúgio e Basso (o) & XIV & $\begin{array}{c}\text { XI } \\
\text { (XII) }\end{array}$ & XI (XIV?) & XI (XII) & $\begin{array}{c}\text { XI } \\
\text { (XII) }\end{array}$ \\
\hline
\end{tabular}

Se, por altura da elaboração da Ep. 10, andaria Paulo longe de Roma, provavelmente na Acaia, e, entretanto, teria a sua causa sido discutida junto do Imperador com bons resultados, ter-se-ia o apóstolo visto constrangido, no fim da estação própria para a navegação (segundo Vegécio, De re militari 4.39, era perigoso navegar a partir de 14 de setembro e, entre 11 de novembro e 10 de março, a navegação cessava por completo), «a trascorrere il resto dell'anno e l'inverno in parte a Roma, portando a termine la stesura delle cosiddette «lettere della prigionia» (lettere ai Colossessi, agli Efesini, a Filemone e ai Filippesi) e conchiudendo, nel contesto della comunità cristiana, la sua attività "evangelica" che si era rivelata oltremodo ricca di risultati, e in parte nell'Italia meridionale, visitando le altre comunità di fratelli nella fede.» ${ }^{73}$ Ter-se-ia aproximado de Brindes, para navegar para a Grécia, e, estabelecido na Acaia, em Corinto, ter-se-ia sentido obrigado a enviar uma carta a Séneca, a manifestar o seu reconhecimento pela intercessão junto de Nero $(E p .10$, de 27.6.58). Por sua vez, depois de ler cópias das «cartas da prisão», teria Séneca, na Ep. 13, de 6.7.58, manifestado o seu apreço pela doutrina ensinada por Paulo e recomendado que, além do conteúdo, cuidasse e aprimorasse a forma para cativar com mais facilidade os destinatários. Em resposta, enviaria Paulo um convite a Séneca para aderir ao Cristianismo, de modo a usar os seus conhecimentos retóricos para anunciar a fé cristã junto de Nero e da sua corte imperial (Ep. 14 Barlow, de 1.8.58). Séneca teria de esperar pela reabertura da navegação para, a 23.3.59, declinar delicadamente o convite e, ao mesmo tempo, manifestar ao apóstolo a sua estima, admiração e secreta inveja [Ep. 12 (11) Barlow].

Para mais tarde deixaremos a interpretação que Gamba faz da Ep. 11 (12) Barlow, de 28.3.64: por agora, importa contrapor o facto de a maior parte dos investigadores ver na domina das $E p .5$ e 8 uma referência à judaizante Popeia

\footnotetext{
${ }^{73}$ Gamba, 1998, 221.
} 
Sabina; de, na Ep. 7, de Séneca a São Paulo e a um certo Teófilo, a perplexidade de Nero com a falta de formação académica do autor de pensamentos tão elevados como os expressos na Epistula ad Galatas e nas Epistulae ad Corinthios, e a alusão ao caso de Castor e Pólux que, a 22.6.168 a.C., tinham anunciado a um camponês a vitória de Paulo Emílio, funcionarem, para Herrmann, como indício da fonte directa do falsário: as Diuinae Institutiones de Lactâncio; ${ }^{74}$ e de, entre 57 e provavelmente 61 d.C., ter Paulo, de acordo com J. Murphy-O'Connor, prolongado uma estada em Jerusalém e feito uma viagem a Cesareia. ${ }^{75}$

Foi precisamente aqui que, passados dois anos (provavelmente em 60), António Félix foi substituído por Pórcio Festo, e que, para agradar aos Judeus, Félix deixou Paulo na prisão (Act 24.26-27). Mesmo assim, acabou Félix acusado pelos Judeus de Cesareia e salvo por Palante que gozava de grande influência junto de Nero (Josefo, AJ 20.182). Festo levou Paulo ao julgamento onde o apóstolo apelou para César, e proporcionou-lhe a oportunidade de se defender perante Agripa e Berenice (Act 24.27 ss.). Depois de ouvir Paulo, confessou Agripa que por pouco não tinha decidido tornar-se cristão, e concluiu que não encontrara em Paulo nada que lhe fizesse merecer a morte ou os grilhões, e que, se não tivesse apelado para César, podia ser posto em liberdade (Act 26.28 e 31-2). Entregue a Júlio, um centurião da coorte augusta, foi, na viagem para Roma, tratado com humanidade (bumane, Act 27.3); pôde, em Sidónia, visitar os amigos; e, após o naufrágio; em Malta, foi salvo da morte pelo centurião que o escoltava (Act 27.43); foi miraculosamente salvo do ataque de uma serpente (Act 28.3-6); curou pessoas que o abordavam (Act 28.8-10); em caminho para Roma, deparou com irmãos de Roma que tinham vindo ao seu encontro e, já em Roma, foi autorizado a ficar em alojamento próprio com o guarda que o escoltava (Act 28.15-16); uma vez reunido com os Judeus, logrou converter alguns, enquanto outros se mostraram incrédulos (Act 28.24); e, durante os dois anos em que permaneceu no alojamento, recebia todos quantos o procuravam e anunciava o Reino de Deus sem qualquer temor (Mansit autem biennio toto in suo conducto; et suscipiebat omnes qui ingrediebantur ad eum, praedicans regnum Dei et docens quae sunt de Domino Iesu Christo cum omni fiducia sine probibitione. Act 28.30-31).

Ora se pensarmos que, em 58, havia Paulo endereçado aos Cristãos de Roma uma carta onde dava graças a Deus por a fé dos destinatários ser conhecida em todo o mundo (Primum quidem gratias ago Deo meo per Iesum Christum pro omnibus uobis, quia fides uestra annuntiatur in uniuerso mundo; $R m$ 1.8); se tivermos em conta a complexa teia de contactos e relações sociais

${ }^{74}$ Herrmann, 1979, 12. A história talvez remonte a Varrão e aparece em Cic. Nat. Deor. 2.2.6, e em Val. Max. Exempla 1.8.1.

${ }^{75}$ Apud Rodrigues, 2007, 675. 
de António Félix e de «Herodes» Agripa I em Roma; a possibilidade de a Epistula ad Philippenses ter sido escrita por volta de 60, em Roma - e não por volta de 58, na Cesareia -, e de os cristãos referidos na despedida final serem efectivamente os da corte de Nero (Salutant uos omnes sancti, maxime autem, qui de Caesaris domo sunt, 4.22); a consignação de Paulo, chegado a Roma em 61, à guarda de Burro, praefectus praetorio e amigo de Séneca - teremos de admitir que dificilmente poderia o apóstolo ter passado despercebido ao Filósofo de Córduba.

Por fim sustenta Herrmann que a leitura do Apocalipse, de João (o Pontífice) e de teor profundamente anti-romano, teria reavivado em Séneca a primitiva hostilidade contra os Cristãos e levado o Trágico a escrever o Hercules Oetaeus, que, em 1131ss., procuraria estabelecer, com vantagem para o modelo estóico pela actividade que acompanha a morte, um paralelo entre a heróica morte de Hércules e a passiva Paixão de Cristo. ${ }^{76} \mathrm{O}$ problema é que a maioria dos melhores editores de Séneca não acredita na autenticidade da referida peça. ${ }^{77}$

A 28 de março de 64, teria Séneca, de acordo com Gamba, escrito a Paulo uma carta de condolências, onde manifestaria o seu pesar pelo sofrimento que à comunidade judaico-cristã de Roma teria causado Nero.

Embora tentada a admitir a autenticidade de quase todo o corpus, Ilaria Ramelli não deixa de concordar com Bocciolini Palagi e com Herrmann no que toca a necessidade de apartar a Ep. 11 (12) Barlow das demais, uma vez que a datação de 28 de março de 64 torna incompreensível a referência tão pormenorizada ao incêndio de Roma, ocorrido a 19 de julho daquele ano. ${ }^{78}$ Ramelli acaba por formular a hipótese de tal incongruência se dever à tentativa do falsário de situar o incêndio de Roma antes do martírio de Pedro e de Paulo, fixado, desde o séc. III, em 29 de junho.

Além disso, em claro contraste p. ex. com as Ep. 5 e 7, onde se alude a uma domina, Popeia Sabina, simpatizante dos judeus, que se teria indignado com Paulo por este ter abandonado a religião da sua antiga seita e abraçado outra religião, é a associação dos Judeus aos Cristãos vista por modernos investigadores como característica de autores posteriores, nomeadamente Orósio.

Ramelli ainda admite a possibilidade de a Ep. 14 Barlow, de 1.8.58, ter sido posteriormente acrescentada ao corpus, uma vez que é a única a sugerir uma conversão de Séneca ao Cristianismo - essa lenda humanística -; a única onde Nero aparece referido como rex temporalis (cf. Caesar em 3, 8 e 9; Augustus em 7; e princeps em 3); e a única que alguns dos mais antigos códices omitem [p. ex. Bernensis (Berne, Stadt-und Hochschulbibliothek, 969; X; sec. IX) e

\footnotetext{
${ }^{76}$ Herrmann, 1979, 71-80.

${ }^{77}$ Zwierlein, 1986 ; Chaumartin, 1996-1999; Fitch, 2002-2004.

${ }^{78}$ Ramelli, 1997301 ; cf. Herrmann, 1979, 14.
} 
sobretudo o Parisinus (Par. Lat. 2772; P; séc. X)].

Mesmo admitindo o declínio, em meados do séc. I, do ensino do grego em Roma; o facto de Paulo já há algum tempo se encontrar na urbe; e a possibilidade de se tratar de uma correspondência entre amigos num latim vulgar que para nós continua algo desconhecido, ${ }^{79}$ a verdade é que o latim do suposto Séneca no epistolário não é melhor do que o de Paulo; que ambos podiam perfeitamente ter comunicado em língua mais familiar a ambos, que era o grego, tanto mais que foi nesta língua que a maior parte dos evangelhos começou a ser divulgada. Em suma, parecem ter razão quantos defendem tratar-se de uma correspondência forjada entre 324/325 e 392, eventualmente por quem quereria mostrar que o Cristianismo não tinha conquistado adeptos apenas nos estratos sociais mais baixos da sociedade romana, e veria, no Estoicismo, não só uma corrente filosófica com seguidores das mais variadas condições sociais, mas também uma mundividência com alguns pontos aparentemente próximos da cristã.

\section{Estoicismo e Cristianismo}

Dada a complexidade do tema em apreço e a extensão das duas partes consideradas, não se me afigura possível, no espaço restante, considerar todos os motivos onde se viram afinidades entre Estoicismo e Cristianismo. Em todo o caso, restringirei a minha análise a alguns dos motivos susceptíveis de suscitarem dúvidas e de prolongarem vias de reflexão já encetadas ou de abrirem novos caminhos de pesquisa.

Quando se pensa nas tentativas estóicas e cristãs de definição da Divindade, os aspectos que, enquanto denominadores aparentemente comuns, imediatamente chamam a atenção são a sua existência eterna e a sua zelosa omnipotência e presidência sobre todo o mundo:

Primus est deorum cultus deos credere; deinde reddere illis maiestatem suam, reddere bonitatem sine qua nulla maiestas est; scire illos esse quae praesident mundo, qui uniuersa ui sua temperant, qui humani generis tutelam gerunt interdum incuriosi singulorum (Séneca, Ep. 95.50).

«O primeiro acto de culto a prestar aos deuses é acreditar neles; seguidamente, reconhecer neles a majestade, e reconhecer também neles a bondade, sem a qual não há majestade possível; saber que são eles que presidem ao universo, que tudo governam graças ao seu poder, e que velam pela segurança da espécie humana mesmo quando se não preocupam com cada homem individualmente.» ${ }^{80}$

${ }^{79}$ Marrou, 1966, 402 ss.; Franceschini, 1981, 830-831.

${ }^{80}$ Sigo a lição de L. Annaei Senecae ad Lucilium epistulae morales, recognouit et adnotatione critica instruxit L. D. Reynolds, T. I-II. Oxonii, 1965, II 394. A trad. é de Segurado e Campos, 
Séneca e Paulo de Tarso: conjecturas em torno de uma correspondência incerta

Sine fidem autem impossibile placere; credere enim oportet accedentem ad Deum quia est et inquirentibus se remunerator fit (Paulo, Heb 11.6).

«Ora, sem fé, é impossível agradar a Deus, porque é necessário que aquele que se aproxima de Deus creia que Ele existe e que é remunerador daqueles que $\mathrm{O}$ procuram.» $^{81}$

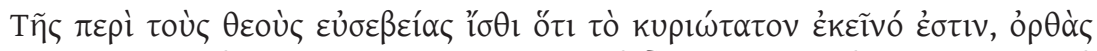

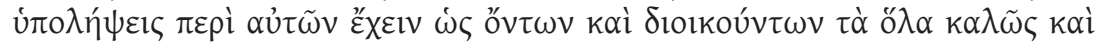

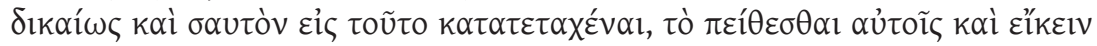

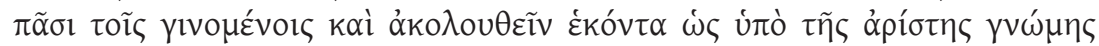

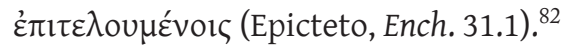

«Acerca da devoção para com os deuses, fica a saber que o mais importante é isto: ter uma opinião correcta sobre eles - de que existem e governam tudo de uma forma bela e justa - e teres-te preparado para lhes obedeceres e para te submeteres a tudo o que suceder, e para o seguires voluntariamente, convencido de que está a ser cumprido pela mais elevada inteligência.»

A divindade ainda se caracteriza pela omnipotência criadora e por ser espírito invisível:

Id actum est, mibi crede, ab illo, quisquis formator uniuersi fuit, siue ille deus est potens omnium, siue incorporalis ratio ingentium operum artifex, siue diuinus spiritus per omnia maxima ac minima aequali intentione diffusus, siue fatum et inmutabilis causarum inter se cohaerentium series - $i d$, inquam, actum est ut in alienum arbitrium nisi uilissima quaeque non caderent (Dial. 12.8.3).

«Isto conseguiu, acredita em mim, ele, seja quem for o criador do universo, seja ele um deus capaz de tudo, seja uma razão incorpórea criadora de obras imensas, seja um espírito divino que tudo penetra, o grande e o pequeno, com igual tensão, seja o destino e a sucessão imperturbável de causas interrelacionadas - isto, digo, conseguiu que nada, senão o desprezível, ficasse submetido à vontade alheia.»

Prope est a te deus, tecum est, intus est. Ita dico, Lucili: sacer intra nos spiritus sedet, malorum bonorumque nostrorum obseruator et custos; hic prout a nobis tractatus est, ita nos ipse tractat. Bonus uero uir sine deo nemo est: an potest aliquis supra

$1991,518$.

${ }^{81}$ Trad. de Costa et al., 1991, 1582.

${ }^{82}$ Sigo a lição de Epictetus, The Discourses as Reported by Arrianus, the Manual, and Fragments, vol. I-II, with an English translation by W. A. Oldfather, Cambridge (Mass.)/London, 19781979,510 e 512 . 
fortunam nisi ab illo adiutus exsurgere? Ille dat consilia magnifica et erecta. In unoquoque uirorum bonorum '(quis deus incertum est) habitat Deus' (Ep. 41.1-2; cit. de Virgílio, A. 8.352).

«A divindade está perto de ti, está contigo, está dentro de ti! É verdade, Lucílio, dentro de nós reside um espírito divino que observa e rege os nossos actos, bons e maus; e conforme for por nós tratado assim ele próprio nos trata. Sem a divindade ninguém pode ser um homem de bem; ou será que alguém pode elevar-se acima da fortuna sem auxílio divino? As decisões grandiosas e justas, é a divindade que as inspira. Em todo o homem de bem, 'qual seja o deus, ignora-se, mas existe um deus!»

Quocumque te flexeris, ibi illum <sc. deum> uidebis occurrentem tibi; nibil ab illo uacat, opus suum ipse implet (Ben. 4.8.2). ${ }^{83}$

«Para onde quer que te voltes, ele <sc. Deus> lá estará, visível aos teus olhos, vindo ao teu encontro; nada está vazio dele, ele próprio enche a sua obra.»

... quamuis non longe sit ab unoquoque nostrum. In ipso enim uiuimus, et mouemur, et sumus, sicut et quidam uestrum poetarum dixerunt: "Ipsius enim et genus sumus" (Act. 17.28)....

«embora se não encontre longe de cada um de nós. É n’Ele, realmente, que vivemos, nos movemos e existimos, como também o disseram alguns dos vossos poetas: 'Pois nós somos também da Sua estirpe'.»

Quicumque enim spitritu Dei aguntur, hi filii Dei sunt (Rom. 8.14).

«Na verdade, todos aqueles que são movidos pelo Espírito de Deus, são filhos de Deus.»

Nescitis quia templum Dei estis et Spiritus Dei habitat in uobis (1 Cor 3.16)?

«Não sabeis que sois templos de Deus e que o Espírito de Deus habita em vós?»

No tocante à existência de Deus, importa, desde já, notar que, ao citar Virgílio, $A .8 .352$ - onde se afirma a aparição, no antigo bosque que haveria de dar lugar ao Capitólio e na rocha que se haveria de chamar Tarpeia, de um deus que os Árcades acreditavam ser Júpiter -, sugere Séneca, em Ep. 41.1-2, a possibilidade de o referido Deus se não encontrar apenas na natureza, mas também no homem de bem, isto é, naquele que vive de acordo com a natureza.

${ }^{83}$ Sigo a lição de Sénèque, Des bienfaits, T. I-II, texte établi et traduit par François Préchac, Paris, 1926-1927, I 105. 
Em estudo de 1992 (Das Angeld des Geistes), discriminou Friedrich Wilhelm Horn seis acepções de pneuma na obra de Paulo: na funcional, é responsável pelas acções e palavras dos crentes (p. ex., 1 Tes 1.5-6, Gal 5.22, 1 Cor 12.11, 14.2); na substantiva, vive nos crentes (p. ex., 1 Tes 4.8, 1 Cor 3.16, 6.19, Rom 8.9, 11); na material, ocorre em contextos sacramentais (p. ex., 1 Cor 10.4, 12.13, 2 Cor 1.21-2, 3.8, Rom 5.5); na "hipostática", distingue-se de Deus e dos crentes (1 Cor 2.10, Rom 5.5, 8.26-7); na normativa, tem implicações éticas (Gal 5.5, 6.1, 1 Cor. 4.21, Rom 8.4, 15.30); e na antropológica, está em cada indivíduo (1 Cor 6.20 v.1., 16.18, Rom 1.9). ${ }^{84}$ Depois de afirmar que, em Paulo, o pneuma pode ocorrer em duas acepções, esclarece Cooper que, numa delas, se refere "to persons simply to denote the self, or some higher principle within him. Thus in Romans 1:9 the phrase, "God... whom I serve with my spirit," is equal to "with my all being or self." Indeed in 1 Corinthians 2:11, the statement that man's spirit knows what is within him" (paraphrased), uses Pneuma in the sense of human consciousness or "mind," a concept usually denoted in Paul - and in Greek literature generally - by the term nous." 85 Se das palavras de Cooper se depreende a possibilidade de, nesta acepção, o pneuma se poder encontrar em pessoas não baptizadas, já Engberg-Pedersen, reconhecendo embora que tanto o estoicismo como Paulo podem empregar pneuma e nous com o valor de 'espírito', afasta a hipótese sugerida por Cooper ao afirmar que “'our' pneuma is not different from God's pneuma (or indeed, from the pneuma itself) - it is God's pneuma, only now as present in human beings." 86

Apesar de coincidentes na ideia de que o carácter material do pneuma não é incompatível com a sua dimensão instrumental, cognitiva e reveladora, parecem estoicismo e Paulo diferir quanto ao momento da entrada inicial de pneuma no indivíduo: o primeiro situa-o na primeira vez que a pessoa inspira, e o segundo no momento do baptismo. ${ }^{87}$ Em 1 Cor $15.35-49$, procede Paulo à distinção entre corpo natural (psychicon soma), terrestre, corrupto e fraco, e corpo espiritual (pneumaticon soma), celestial, incorruptível e forte. Comparado a uma semente que se deita à terra e morre antes de produzir fruto, o primeiro, ao contrário da sequência indicada em Gn 2.7 (cit. em 1 Cor 15.45), antecede o segundo que ressuscita, do mesmo modo que se fez de Adão uma alma vivente ( $\psi \cup x \eta ́ v \zeta \tilde{\omega} \sigma \alpha \nu, G n 2.7$ e 1 Cor 45), e de Cristo um espírito vivificante ( $\pi v \varepsilon \tilde{v} \mu \alpha$ $\zeta \omega o \pi$ oloṽv, 1 Cor 45). Em contraste com Gn 2.7, onde se diz que Deus

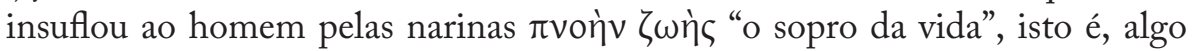
etimologicamente relacionado com o pneuma, nunca sugere Paulo a presença de qualquer tipo de pneuma no corpo natural. Neste particular, encontra-se,

\footnotetext{
${ }^{84}$ Colhi esta informação em Engberg-Pedersen, 2010, 18 e 212.

${ }^{85}$ Cooper, 1996, 5.

${ }^{86}$ Engberg-Pedersen, 2010, 66, cf. 63

${ }^{87}$ Engberg-Pedersen, 2010, 65 e 67-72.
} 
por conseguinte, o estoicismo mais próximo da doutrina veiculada pelo Genesis do que da de Paulo.

Se, em 1 Cor 15.27-8, se diz que Deus tudo sujeitou a Cristo, que, por sua vez e com as demais coisas, se há-de submeter a Quem tudo lhe submeteu; e se Engberg-Pedersen nota a proximidade entre o passo e a ideia de que 'Deus é (agora) tudo em todos', e encontra afinidades entre a conflagração (ecpyrosis) estóica, isto é, a transformação de todos os corpos terrestres no pneuma que é a essência de Deus, e o julgamento final em que tudo quanto é composto por elementos susceptíveis de se destruírem ou de causarem destruição será queimado e transformado em pneuma no regresso de Cristo - não deixa, no entanto, o referido investigador de notar que, por não partilharem do pneuma enquanto garantia de salvação, não podem os não-crentes alcançá-la. ${ }^{88} \mathrm{~A}$ fraca tensão da alma de um indivíduo com muitos vícios era, para os estóicos, um sinal de que se desintegraria no momento da morte.

Depois de afirmar que os ossos, os músculos, a pele, o rosto, as mãos e as demais coisas que nos envolvem não passam de cadeias e trevas que aprisionam e sufocam o espírito (animus), conclui Séneca, em Dial. 6.24.5, acerca desse mesmo espírito: Omne illi cum hac graui carne certamen est, ne abstrahatur et sidat; nititur illo unde demissus est. «Mantém todo o tipo de lutas com esta carne gravosa, para se não deixar arrastar, para não enfraquecer; tenta alcançar o lugar de onde tinha partido.» Kreyher, referido por Sevenster, ${ }^{89}$ havia estabelecido paralelo entre o passo senequiano citado e Paulo, Rom. 7.18, 21-23.

Inuenio igitur hanc legem uolenti mibi facere bonum, quoniam mibi malum adiacet. Scio enim quia non habitat in me, hoc est in carne mea, bonum; nam uelle adiacet mibi, operari autem bonum, non! [....] Condelector enim legi Dei secundum interiorem hominem; uideo autem aliam legem in membris meis repugnantem legi mentis meae et capriuantem me in lege peccati, quae est in membris meis.

«Porque eu sei que não há em mim, isto é, na minha carne, coisa boa, pois quero o bem, que está ao meu alcance, mas realizá-lo não.... Deparo, então, com esta lei: querendo fazer o bem, é o mal que eu encontro. Sinto prazer na lei de Deus, de acordo com o homem interior. Mas vejo outra lei nos membros, a lutar contra a lei da minha razão e a reter-me cativo na lei do pecado, que se encontra nos meus membros.»

e Gal. 5.17:

Caro enim concupiscit aduersus Spiritum, Spiritus autem aduersus carnem; haec enim inuicem aduersantur, ut non, quaecumque uultis, illa faciatis. «Porque os desejos

\footnotetext{
${ }^{88}$ Engberg-Pedersen, 2010, 34-36.

${ }^{89}$ Sevenster, 1961, 79.
} 
da carne são opostos aos do espírito, e estes aos da carne, pois são contrários uns aos outros. É por isso que não fazeis o que quereríeis.»

Embora haja quem tenha visto, no passo senequiano citado e em outras ocorrências senequianas de caro, as únicas em autores greco-latinos não cristãos onde o termo ocorre na acepção bíblica do Novo Testamento, ${ }^{90}$ a verdade é que, de acordo com o próprio Séneca, em Ep. 92.10, teria sido o próprio Posidónio quem teria reconhecido que para mais não serviria a carne senão para a ingestão de alimentos (Prima pars hominis est ipsa uirtus; buic committitur inutilis caro et fluida, receptandis tantum cibis habilis, ut ait Posidonius.). Além disso, no âmbito de um debate com um epicurista e identificadas três coisas

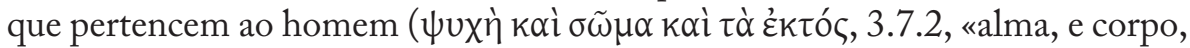
e coisas externas»), haveria Epicteto, depois de perguntar qual delas se deveria

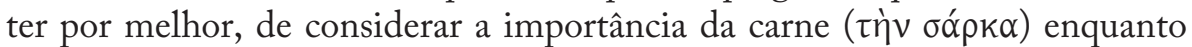
sinónimo de corpo, de levar o seu interlocutor a afirmar que a alma é melhor

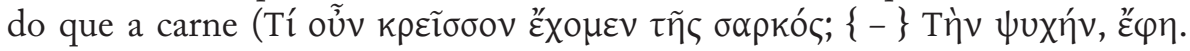
3.7.4), e de concluir que, descoberta a essência do bem, se torna impossível que uma coisa seja boa, e todavia que seja justificável procurarmos satisfação em qualquer outra coisa; e que, quando o antecedente não é bom, o seja o consequente, uma vez que, para justificar o consequente, tem o antecedente de

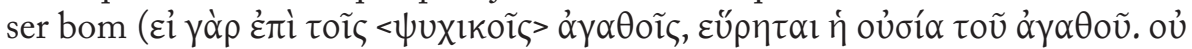

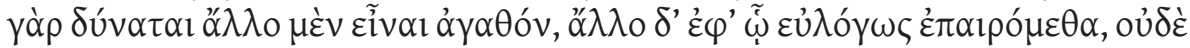

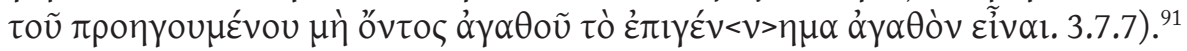

${ }^{90}$ Cf. Bouillet et al., 1829, 468. No que ao uso de caro diz respeito, ainda se registam, em Séneca e Paulo, os seguintes paralelos: entre Ep.65.21-22 e $R m$ 8.4, e entre Ep. 74.16 e $R m$ 8.9 e 13. Embora, no âmbito de outros paralelos, se refira, apud Bouillet et al., 1829, 468 n. 2, a proximidade entre a forma angelus em Ep.20.11 (Nec ego, Epicuri angelus, scio....) e em 2Cor 12.7, a verdade é que Reynolds, 1965, 55, o editor de Oxford, prefere a forma que aparece no seguinte período: Nec ego, Epicure, an †gulus $\dagger$ [si] iste pauper contempturus sit diuitias, si in illas inciderit. «Também eu não sei, Epicuro, como o teu pobre fanfarrão desprezaria a riqueza se nela caísse de repente!» Comum a Séneca e a Paulo seria ainda a ideia de progenitura divina do homem de bem, que ocorre, p. ex., em Dial. 1.1.5-6 e Heb 12.6-7.

${ }^{91} \mathrm{Em}$ 2.22.19, depois de dizer que uma pessoa tem forçosamente de se inclinar para onde puder empregar «eu»e «meu», conclui Epicteto que, se as coisas com que um homem se identifica e o seu interesse pessoal estiverem $\dot{\varepsilon} v \sigma \alpha \rho \kappa i$, aí tem de concentrar a sua atenção; se se interessar por coisas que tiverem um propósito moral, aí se terá de concentrar; e se pensar em coisas exteriores, a elas se tem de devotar; em 2.23.21 ss. e para mostrar a superioridade do propósito moral relativamente à carne, pergunta Epicteto se foi a carne ou o propósito moral que escreveu diversos tratados de Epicuro; que fez com que este filósofo deixasse crescer a barba; e que escreveu que estava a passar o último e o mais feliz dia de vida; em 3.7.25-26, sustenta Epicteto que, no homem, não deve ser a matéria, os pedaços de carne, que se devem valorizar, mas os deveres de cidadania, o casamento, a geração dos filhos, a reverência para com Deus, a preocupação com os pais, em suma, o desejo, a aversão, a escolha, a recusa, o desempenho adequado de cada um destes actos de acordo com a nossa natureza; em 4.1.104, pergunta se um outro não criou o ser humano como alguém destinado a viver sobre a terra $\mu \varepsilon \tau \dot{\alpha}$ ó $\lambda$ íyov

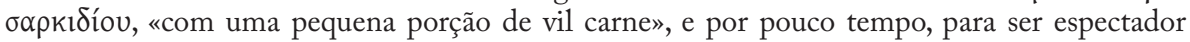


Embora não ocorra no passo, mas apenas em alguns dos resumidos em

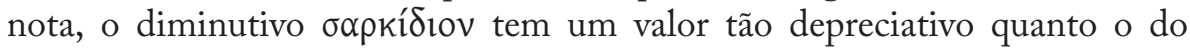
corpusculum senequiano. Embora se não conserve a maior parte da obra dos filósofos do Estoicismo Antigo e Médio, talvez não seja abusivo formular a hipótese de o termo ter ocorrido nos debates entre estóicos e epicuristas ou em reflexões sobre as diferenças entre Estoicismo e Epicurismo.

Além disso, importa perceber se o termo caro tem, na Bíblia em geral e no Novo Testamento em particular, apenas uma ou mais acepções. O problema afigura-se complexo, uma vez que, depois de afirmarem que a «antropologia bíblica desconhece a dicotomia grega: corpo - alma», e que o «homem é concebido como uma unidade vivente»" ${ }^{22}$, sustentam Costa et al. que o substantivo "carne" ora «designa o homem frágil, deixado a si mesmo, mortal pecador» ${ }^{93}$ - e recordam que o "Verbo de Deus assumiu esta carne frágil e mortal» ${ }^{94}-$; ora registam as ocorrências do termo nos sentidos de 'Lei', 'circuncisão' e 'meios humanos ${ }^{95} \mathrm{e}$, por conseguinte, o consideram oposto ao Espírito $^{96}$ e alvo, por parte do cristão, de crucifixão juntamente com Cristo; ${ }^{97}$ ora reconhecem que, em plano mais religioso do que físico, se opõe ao espírito no sentido de «alento vital.... sopro, vento, acção de Deus no homem ${ }^{98}$. Autor algum dos referidos emprega o termo "evolução", mas é precisamente disso que, no entender de White, se trata: «With the introduction of Hellenism into the ancient Near East, Israelite thought began to espouse the notion of a separation of soul and body.» ${ }^{99}$ Esclarece, no entanto, a investigadora que se não tratou de uma evolução regular, uma vez que, se a Paulo remonta o uso de "carne" «as the vehicle for sin in the human being $(R m 7.5)$ », e, em 1Ts 2.8, alude o Apóstolo à psyche como centro da vida interior do ser humano e localização de sentimentos, em especial do amor, ja em 1 Cor 5.35, continua Paulo a empregar, ora com corpus ora com carnis, a forma psyche

do seu governo e para se juntar a Ele no Seu cortejo triunfal e no seu dia sagrado; em 4.1.161, apresenta Sócrates como alguém que preferia, à vil carne, a honra; em 4.7.32, diz que merece permanecer no medo e continuar a adular aquele a quem já prestava adulação, o homem que já ouviu um filósofo e ainda não percebeu que não é carne, nem ossos, nem nervos, mas o que os usa, o que tanto governa as impressões dos sentidos como as compreende;

${ }^{92}$ Costa et al., 1991, 1642.

${ }^{93}$ Cf. Is 31.1-3; Ier 17.5-7; Iob 10.4-12; Mt 26.40-41; 2 Cor 12.7-10; Gn 6.1-4; Ps 4-5; Is 40.3-8; Io 17.2; Lc 3.4-6. A Is 31.3 - onde, para convencer os Hebreus a confiar em Javé, e não nos Egípcios, para vencer Senaqueribe, dos cavalos egípcios, diz Isaías que são caro non spiritus - remonta, no dizer de Hare, 1993, 295, o uso de «carne» e «espírito» no âmbito do contraste entre a esfera natural e a divina..

${ }^{94}$ Cf. Io 1.14; 1 Tim 3.16.

${ }^{95}$ Cf. Rm 9.6-13; Gl 6.12-15; Fil 3.2-5; Ef 2.11.13; Rm 8.12-15; Gl 5.16-23, 6.7-10.

${ }^{96}$ Cf. $R m$ 7, 13.11-14; Ef 2.1-6; Col 2.13-23.

${ }^{97}$ Cf. $R m$ 8.5-13; Gl 5.22-25; Col 1.24-29.

${ }^{98}$ Cf. Gn 2.7, 6.17, 7.22; Rm 8.14-16; 1 Cor 2.10-13; Gl 5.16 - 6.10.

${ }^{99}$ White, 1993, 295. 
para aludir à totalidade da pessoa. Foi, segundo White, a primeira tendência que prevaleceu, e, em 1Ts 5.23, já haviam inclusivamente alguns chegado a ver uma tricotomia 'espírito e corpo e alma', mas, ao considerar o passo, contrapôs entretanto Sevenster: «it is by no means possible to infer that the spirit is to be found in the body and soul, and at the same time above and beyond both.» ${ }^{100}$; em seguida, esclareceu: «Equally correct is the observation that in this passage pneuma is not a reference to the Holy Spirit.»-e, por fim, concluiu: «When Paul mentions 'spirit and soul and body' side by side with one another, he wishes this to mean no more nor less than the complete man, and he does not consider these terms anthropologically at all.» Argumenta ainda Sevenster que, se fosse adepto do dualismo platónico, não poderia Paulo criticar a fornicação, em 1 Cor 6.12-20, criticar a fornicação que mais não seria do que um indiferente que não poria em causa a pureza da alma divina (cf. círculos gnósticos). ${ }^{101}$ Não se afigura, por conseguinte e aos olhos de Paulo, o corpo como uma parte desprezível da pessoa - mas como algo essencial no todo que é o indivíduo -, nem tão significativa e emocionada quanto em Séneca é a exaltação da alma. Soma, psyche e pneuma podem, por conseguinte, ser usados para designar nefes, isto é, a pessoa enquanto todo.

Intimamente relacionado com o tema tratado anda o motivo do destino post mortem da alma e do corpo. Sobre o assunto escreve Séneca:

Per has mortalis aeui moras illi meliori uitae longiorique proluditur. Quemadmodum decem mensibus tenet nos maternus uterus, et praeparat non sibi sed illi loco in quem uidemur emitti iam idonei spiritum trahere et in aperto durare, sic per hoc spatium quod ab infantia patet in senectutem in alium maturescimus partum. Alia origo nos expectat, alius rerum status. Nondum caelum nisi ex interuallo pati possumus. Proinde intrepidus horam illam decretoriam prospice: non est animo suprema, sed corpori. Quidquid circa te iacet rerum tamquam hospitalis loci sarcinas specta: transeundum est. Excutit redeuntem natura sicut intrantem. Non licet plus efferre quam intuleris, immo etiam ex eo quod ad uitam adtulisti pars magna ponenda est: detrahetur tibi haec circumiecta, nouissimum uelamentum tui, cutis; detrahetur caro et suffusus sanguis discurrensque per totum; detrahentur ossa neruique, firmamenta fluidorum ac labentium. Dies iste quem tamquam extremum reformidas, aeterni natalis est. Depone onus: quid cunctaris, tamquam non prius quoque relicto in quo latebas corpore exieris? [.....] aequo animo membra iam superuacua dimitte et istuc corpus inhabitatum diu pone. [...] pereunt semper uelamenta nascentium. [...] ueniet qui te reuellat dies et ex contubernio foedi atque olidi uentris educat. [....]

${ }^{100}$ Sevenster, 1961, 66. Vale, de resto, a pena recordar o passo completo: Ipse autem pacis sanctificet uos per omnia, et interger spiritus uester et anima et corpus sine querela in aduentu Domini nostri Iesu Christi seruetur (1Ts 5.10-28). "Que o Deus da paz vos santifique inteiramente, e que todo o vosso ser - espírito, alma e corpo - se conserve irrepreensível para a vinda do nosso Senhor Jesus Cristo.»

${ }^{101}$ Sevenster, 1961, 75 ss. 
aliquando naturae tibi arcana retegentur... Tunc in tenebris uixisse te dices cum totam lucem et totus aspexeris, quam nunc per angustissimas oculorum uias obscure intueris, et tamen admiraris illam iam procul (Ep. 102. 23-28).

«O tempo que demora esta existência mortal não é para a alma senão o prelúdio de uma vida melhor e mais duradoura. Tal como o ventre materno nos guarda por dez meses e nos prepara, não para nele permanecer mas sim para sermos como que lançados no mundo assim que estamos aptos a respirar e a aguentar o ar livre, também ao longo do espaço de tempo que vai da infância à velhice nós vamos amadurecendo com vista a um novo parto. Espera-nos um outro nascimento, uma outra ordem das coisas. Por enquanto, não suportamos a vista do céu senão a uma certa distância. Encara, portanto, com coragem a tua hora decisiva, a hora derradeira apenas para o corpo, não para a alma. Os objectos que tens à tua volta, olha-os como bagagens numa hospedaria: tu tens de passar adiante. A natureza revista-te à saída, tal como te revistou à entrada. Não podes levar contigo mais do que trouxeste, pelo contrário, tens mesmo que despojar-te de uma boa parte do que trazias ao entrar nesta vida: ser-te-á tirado o teu último revestimento, a pele que te envolvia; ser-te-ão tirados a carne e o sangue que se espalhava e fluía por todo o corpo; ser-te-ão tirados os ossos e os tendões que serviam de sustentáculo aos tecidos moles. Esse dia que tu tanto temes, como se fora o último, marca o teu nascimento para a eternidade. Depõe o teu fardo; porque hesitas, como se não tivesses já um dia abandonado um corpo dentro do qual te ocultavas?! [....] Deita fora sem hesitação esses membros inúteis, põe de lado esse corpo em que por tanto tempo habitaste. [....] Sempre foi costume deitar fora as membranas que envolvem o recémnascido! [....] Estás revestido de um corpo, mas um dia virá em que o despirás, em que deixarás a companhia de um ventre sujo e fétido. [....] Um dia virá em que se te desvelarão os segredos da natureza.... Quando contemplares com todo o teu ser a totalidade da luz - essa luz que agora reduzidamente recebes pelas estreitas aberturas dos teus olhos e que, mesmo assim, e de longe, tanto admiras! - dirás que até agora tens vivido em plena treva.»

Nas palavras de Séneca citadas foram encontradas afinidades com as seguintes de Paulo de Tarso:

Nibil enim intulimus in mundum, quia nec auferre quid possumus (1 Tim 6.7: «Nada trouxemos para este mundo e nada podemos levar dele.»);

Scimus enim quoniam si terrestris domus nostra huius tabernaculi dissoluatur, aedificationem ex Deo habemus domum non manufactam, aeternam in caelis. Nam et in hoc ingemiscimus, habitationem nostram, quae de caelo est, superindui cupientes, si tamen et exspoliati, non nudi inueniamur. Nam et, qui sumus in tabernaculo, ingemiscimus granati, eo quod nolumus exspoliari sed superuestiri, ut absorbeatur, quod mortale est, a uita (2 Cor 5.1-4) 
«Todos nós sabemos que, quando for destruída esta tenda em que vivemos na terra, temos no Céu uma casa feita por Deus, habitação eterna, que não foi feita por mãos humanas. E, por isso, gememos nesta tenda, desejando ser revestidos da nossa habitação celeste, contanto que nos encontremos vestidos e não nus. Porque, enquanto estamos nesta morada, gememos oprimidos, pois não queremos ser despidos mas revestidos, a fim de que o que é mortal seja absorvido pela vida.»;

Videmus enim nunc per speculum in aenigmate, tunc autem facie ad faciem; nunc cognosco ex parte, tunc autem cognoscam, sicut et cognitus sum (1 Cor 13.12).

«Hoje vemos como por um espelho, de maneira confusa, mas então veremos face a face. Hoje conheço de maneira imperfeita: então, conhecerei exactamente, como também sou conhecido.»

Quanto ao passo senequiano citado, vale a pena reiterar, no entanto e conforme se disse, que, no tocante ao destino post mortem da alma, não é o pensamento senequiano uniforme (cf. Dial. 11.9.3): se, no kommos de Tro. 67164, falava o coro da vida feliz de Heitor e Príamo no além, e, de algum modo, preparava o relato da aparição do espectro de Aquiles a exigir o sacrifício de Políxena, na segunda ode (371-408), mais propriamente em 397, deparamos com a defesa de um niilismo post mortem, talvez para negar a veracidade do relato de Taltíbio no que à aparição do espectro de Aquiles diz respeito e como forma de preparar o espectador para o carácter vão do sonho de Andrómaca com Heitor. Embora, na esteira de Epicuro e de Lucrécio, tenda Séneca, como já notou Fantham, para a última posição referida, não deixa o filósofo, na Consolatio ad Marciam, de prometer a imortalidade da alma como recompensa da virtude (Dial. 6.25.1), ainda que, no cataclismo final, ela se transforme nos antigos elementos (Dial. 6.26.7). ${ }^{102}$ Como em Homero, nos trágicos gregos e no Somnium Scipionis ciceroniano e em Virgílio, manifesta o Trágico, no seu drama, uma tendência para a ideia de que a alma sobrevive à morte. Quer isto dizer que a opinião de Séneca relativamente ao destino post mortem da alma varia consoante a caracterização psicológica das personagens, a interferência autoral, a influência dos exercícios retóricos, o género e as circunstâncias gerais em que Séneca trata o assunto. ${ }^{103}$ É certo que uma das referidas formas de encarar a morte se pode considerar cristã, mas, com base no que se disse, não deve ser vista como uma verdadeira convicção senequiana, uma vez que depende do contexto e da influência de toda uma tradição poética anterior que não conhecia a mensagem de Cristo.

\footnotetext{
${ }^{102}$ Fantham, 1982, 78-82.

${ }^{103}$ Marshall, 2000, 37.
} 
$\mathrm{Na}$ tradição judaica, sustentavam os Saduceus a inexistência de vida para além da morte, ao passo que os Fariseus acreditavam na Ressurreição, ideia cuja primeira ocorrência na Bíblia se regista em 2 Mac 7 . No Novo Testamento, se Lc 16.19-31 cuida que, após a morte do corpo, recebe a alma as recompensas e os castigos, e $M c$ 8.36-37 afirma que a alma é o bem mais importante de cada pessoa, a generalidade dos evangelhos e o próprio Paulo, em 1 Cor 15, referem a ressurreição da alma num corpo que não é o terreno, mas um espiritual e glorioso, e Io 11.25 sugere que a alma sobrevive post mortem para se reunir ao corpo numa ressurreição física.

Do exposto, resulta claro que as semelhanças estão sobretudo ao nível da expressão, pelo que não será de pôr totalmente de parte uma raiz comum, que, com base no facto de os Fenícios habitarem a cidade natal de Zenão e de a Bíblia atribuir a Cananeus, Amorritas e Heveus, elementos fenícios, diz Sanson ser Fenícia. Talvez se tenha verificado, neste caso, fenómeno semelhante ao que aproxima o Sansão bíblico do Héracles grego, conjugado com o profundo conhecimento paulino da cultura grega.

\section{Abreviaturas}

AL .... $\mathrm{R}$ = Anthologia Latina siue poesis Latinae supplementum, ed. F. Buecheler et A. Riese. Pars prior: Carmina in codicibus scripta. Rec. A. Riese. Fasc. I: Libri Salmasiani aliquorumque carmina. Fasc. II: Reliquorum librorum carmina. Editio altera denuo recognita. Lipsiae, 1894-1906

AL .... ShB = Anthologia Latina, I: Carmina in codicibus scripta. Rec. D. R. Shackleton Bailey. Fasc. I: Libri Salmasiani aliorumque carmina. Stutgardiae, in Aedibus B. G. Teubneri, 1982.

PIR2= L. Petersen et al. (eds.), Prosopographia Imperii Romani, 2nd Edition (Berlin 1987).

$P L=$ Migne, Patrologia Latina 


\title{
Os Actos apócrifos de Paulo e Tecla: ASPECTOS DA SUA RECEPÇÃO E INTERPRETAÇÃO
}

\author{
Cláudia Teixeira \\ Universidade de Évora \\ Centro de Estudos Clássicos e Humanísticos da Universidade de Coimbra \\ Centro de História da Universidade de Lisboa
}

O texto conhecido pela designação de Actos de Paulo e Tecla ou simplesmente Actos de Tecla, que narra a vida de uma das mais veneradas santas da Antiguidade cristã, constitui-se como um dos mais acabados exemplos das vicissitudes associadas à transmissão textual. Embora parte integrante dos Acta Pauli, a estrutura episódica desta obra permitiu que o segmento que compõe o episódio de Tecla tivesse circulado, na Antiguidade, como um texto autónomo e só a descoberta, já no século XX, de uma manuscrito copta com o texto integral dos Actos de Paulo restabeleceu a condição original do texto como parte integrante de uma obra maior. Ao desenraizamento do texto original acresce ainda o problema da existência de mais cinco lendas que contam a perseguição de Tecla, que apresentam divergências pontuais, mas significativas, no tocante ao tempo, ao espaço e às figuras que intervêm na história, sem que nenhuma destas lendas, mesmo as duas que situam Tecla no século I, a descrevam como convertida e companheira de Paulo. ${ }^{1} \mathrm{E}$ a este problema acrescem ainda as suspeitas relativas à fidedignidade histórica e doutrinal do texto, facto que o levou, em um primeiro momento, ao banimento do cânone e, mais tarde, no final do século V, à classificação de apócrifo pelo Decretum Gelasianum. ${ }^{2}$

O primeiro traço que podemos associar à recepção, no espaço da Antiguidade, da história de Tecla, ${ }^{3}$ que, em linhas gerais, narra o combate de

${ }^{1}$ Vide Boughton, 1991, 365.

${ }^{2}$ Liber qui appellatur Actus Theclae et Pauli-apocryphus.

${ }^{3}$ A história narrada pelos Acta Theclae passa-se na Ásia menor. Paulo encontra-se numa das suas viagens evangelizadoras. Numa casa contígua àquela em que pregava, Tecla ouve-o e, incapaz de se desprender dessa audição, passa vários dias sem comer, nem beber. A mãe convoca o noivo da jovem e dá-lhe conta do fascínio da filha por Paulo. Este acusa-o ao prefeito. Levado para a prisão, é visitado por Tecla, que consegue escapar de casa durante a noite, atitude transgressora das normas do bom comportamento feminino. A família dá-se conta do desaparecimento, surpreende-a junto a Paulo e informa o prefeito (a acusação é estereotipada: Paulo ensina uma nova crença e é cristão). No dia seguinte, Paulo é expulso da cidade e Tecla é condenada à fogueira. A pira é acesa no teatro, mas a chuva extingue o fogo e a jovem é salva. Fruto de um acaso, Tecla encontra-se novamente com Paulo e seguem juntos para Antioquia, onde um certo Alexandre se enamora dela. A jovem rejeita-o e este denuncia-a ao prefeito. Tecla é condenada ad bestias. Afirmando querer permanecer na pureza até à morte, é colocada à guarda da rainha Trifena, prima do imperador [Cláudio]. No dia marcado para a execução, a jovem é trazida para o teatro, mas a leoa que a deveria devorar, não a ataca. No dia seguinte, exposta novamente às feras, é defendida por uma leoa. Enquanto novas feras eram trazidas 
uma jovem mulher para manter a integridade e a fé, resulta da desuniformidade do seu acolhimento: se o Oriente cristão mantém vivo o texto e a vida de Tecla com carácter de exemplaridade, no Ocidente cristão a atenção dada a Tecla e o peso da sua biografia são meramente perfunctórios. ${ }^{4}$ Reconhecida sobretudo pelo exemplo da sua virgindade, acaba, de certa forma, até neste aspecto, secundarizada pela concorrência de Inês, uma virgem de Antioquia martirizada na arena. Pelo contrário, na Ásia Menor, a sua importância foi maior. ${ }^{5}$ Além de ter florescido um culto activo em torno da Santa e de o local da sua sepultura se ter tornado um centro de peregrinação, também na literatura, sobretudo de pendor ascético, Tecla viria a ocupar um lugar destacado. Só para citar alguns exemplos, quando Egéria visita Selêucia, ouve os Actos completos de Tecla (23.26: et lectio omni actu sanctae Teclae), ${ }^{6}$ o que atesta a circulação da obra; e, embora, no início do século IV, Eusébio tenha listado estes Acta entre os livros apócrifos, Metódio de Olímpia faz de Tecla uma das figuras principais do seu Symposium decem virginorum, uma obra dialógica, na qual dez personagens femininas discutem o tema da virgindade;

para a arena, Tecla baptiza-se. As mulheres que se encontravam no público enchem-se de simpatia pela jovem. As feras, trazidas de novo, em vez de a atacarem, adormecem aos seus pés. Como último recurso, é atada a dois touros selvagens, mas um fogo providencial queima as cordas e ela escapa à fúria dos animais. Os jogos são interrompidos e Tecla é libertada. A jovem afirma publicamente a sua dedicação a Deus, declarando-se sua serva. Liberta das suas dificuldades, disfarça-se de homem para procurar Paulo. Quando o encontra, conta-lhe todas as suas aventuras, incluindo o auto-baptismo no teatro. Depois, declara a intenção de voltar a Icónio. Paulo responde-lhe com estas palavras: «vai e ensina aí os mandamentos de Deus». Tecla regressa a Icónio, onde reencontra a mãe. Depois parte para Selêucia, onde, após uma vida dedicada a iluminar muitos com a palavras de Deus, «adormeceu».

${ }^{4}$ Hayne, 1994, 210, observa: «This is particularly evident in the case of Ambrose, who of all churchmens hould have been most enthusiastic, for the comparatively new and extremely arge and expensive cathedral in the heart of Milan was dedicated to St. Thecla, the city's patron. He refers to it as simply the basilica nova, hoc est intramurana, quae maior est (...), but there is no reason to think it was not Thecla's church in his time. This basilica, which remained the cathedral of Milan until 1461, had naturally been the seat of Ambrose's predecessor, the Arian bishop Auxentius. We can only speculate as to why Thecla became the patron saint. It is tempting to suggest she came west with Auxentius, the Cappadocian appointed to Milan in 355 from Alexandria. Krautheimer has suggested, however, that her cathedral was started between 345 and 350 under Constans and completed, perhaps hastily, in time for the Synod of Milan in 355.5 Auxentius became bishop only after Dionysius' deposition at that Synod. It may be, however, that the dedication to Thecla was thanks to the new bishop. It certainly fits an eastern origin. If so, it helps to explain Ambroses' actions. He successfully defied an imperial order to surrender the basilica to the Arians, but his later building activities were surely linked to his desire for Catholic churches that had never been contaminated by heresy. Martyrs' relics were naturally needed, and his discovery in 386 of the bodies of Gervasius and Protasius, followed immediately by healing miracles, must have gone a long way to upstage Thecla's cathedral. Ambrose in fact was buried with them in the church that later bore his name, not in the cathedral.»

${ }^{5}$ Vide Hayne, 1994, 209-218.

${ }^{6}$ Mariano, 1998. 
e Gregório Nazianzeno ${ }^{7}$ alude às provações de Tecla (a salvação do fogo e das feras, a fuga do noivo tirânico e da mãe cruel) e enumera-a entre aqueles que combateram por Cristo. Além disso, também a consideração do valor cultural e doutrinal do texto apresenta oscilações importantes, na medida em que a sua recepção testemunha e opõe, simultaneamente, a enorme popularidade que o exemplo de Tecla adquiriu entre as massas e o desconforto de alguns teólogos relativamente a aspectos indiciados pela narrativa e de que são exemplo o ascetismo, que alimentará a controvérsia da ortodoxia com algumas tendências heterodoxas, o papel activo de Tecla, comissionado por Paulo, na pregação da palavra, e o baptismo. E são precisamente as últimas questões que suscitam não só uma das primeiras reaç̧ões documentadas, hostis à história, como também a suspeita de apocrifia do texto. Tertuliano, em um contexto de combate à proclamação herética, que legitimava o direito de pregar e baptizar por parte das mulheres, traz à colação a história de Tecla, ${ }^{8}$ que considera uma invenção de um presbítero da Ásia Menor, deposto por heresia do seu cargo na Igreja por ter forjado os seus Acta e criado uma falsa visão relativamente ao papel das mulheres na Igreja, ${ }^{9}$ de resto contrária à definida na Primeira Epistola a Timóteo (2,11-15), de cujo sentido decorria a proibição de ensinarem:

"A mulher receba a instrução em silêncio, com toda a submissão. Não permito à mulher que ensine, nem que exerça domínio sobre o homem, mas que se mantenha em silêncio. Porque primeiro foi formado Adão, depois Eva. E não foi Adão que foi seduzido mas a mulher que, deixando-se seduzir, incorreu na transgressão. Contudo, será salva pela sua maternidade, desde que persevere na fé, no amor e na santidade, com recato.»

Não obstante os seus traços polémicos, a história de Tecla continua a fazer o seu caminho ${ }^{10}$ e, desse percurso, talvez o aspecto mais significativo seja -

${ }^{7}$ Além disso, associa Tecla com a ortodoxia religiosa, ao comparar o passado gloriosos da cidade à sua decadência presente, onde dominavam arianos. Vide Hayne, 1994, 212-213.

8 Tertuliano, De Baptismo 17: Petulantia autem mulieris quae usurpavit docere utique non etiam tinguendi ius sibi rapiet, nisi si quae nova bestia venerit similis pristinae, ut quemadmodum illa baptismum auferebat ita aliqua per se [eum] conferat. Quod si quae Acta Pauli, quae perperam scripta sunt, exemplum Theclae ad licentiam mulierum docendi tinguendique defendant, sciant in Asia presbyterum qui eam scripturam construxit, quasi titulo Pauli de suo cumulans, convictum atque confessum id se amore Pauli fecisse loco decessisse. quam enim fidei proximum videtur ut is docendi et tinguendi daret feminae potestatem qui ne discere quidem constanter mulieri permisit? Taceant, inquit, et domi viros suos consulant.

${ }_{9}^{9}$ A história de Tecla, desencorajada do matrimónio e encorajada a ensinar a palavra de Deus, revela, entre outras, tendências Montanistas e Gnósticas e constituía-se como exemplo de legitimação para muitos cristãos (por exemplo, para os cristãos de Alexandria) do facto de as mulheres poderem ensinar e baptizar.

${ }^{10}$ Goodspeed, 1901, 190: «The popularity of this singular romance is well attested and easily 
provavelmente fruto de contaminatio lendária ${ }^{11}$ - a reinvenção da sua morte: se, nos Actos, Tecla morre calmamente depois de uma vida de pregação, essa morte não deixa de conviver com a tradição do martirológio, que a faz morrer na arena, juntamente com outros cristãos. A esta disparidade juntam-se as evidências da cultura material: ao sepulcro de Selêucia, que apoia a referência à sua morte pacífica, corresponde, por sua vez, um sepulcro em Roma, que atesta uma Tecla martirizada ${ }^{12}$.

Os estudos recentes fazem eco dos problemas antigos, mas recontextualizam as soluções. São as circunstâncias e a intencionalidade da produção dos $A T$, o papel social das mulheres na História da Igreja, a indagação das tensões que levaram à apocrificidade do texto e, sobretudo, a relação dos Acta com os textos canónicos que ocupam os especialistas. $\mathrm{E}$ as soluções que apresentam, relativas às questões elencadas resultam, em grande parte, da classificação literária do texto.

Desautorizadas classificações, de certa forma, duvidosas, como as de que os Acta teriam um género similar aos antigos hinos aretológicos, aos contos fantásticos de viagens, ou ainda à literatura de matéria pouco edificante, já a classificação do texto como romance e como narrativa da literatura tradicional parecem mais consentâneas com a sua tessitura narrativa, não obstante estas

understood. Its early separation from the parent Acts of Paul, the selection of it by Tertullian as an object of attack, and its translation, as a separate work, into many languages, illustrate its popularity; and in times when the celibate life was growing in popular favor, when marvelous martyrdoms were increasingly in demand, and when old men and maidens were the favorite figures among Christian confessors, popularity for a work like the Acts of Paul and Thecla was natural and inevitable.»

${ }^{11}$ Boughton, 1991, 381-382, observa: «That the author of the Acts of Paul may have applied such techniques in developing the Thecla story is suggested by another acta that featured one of the other three martyrs. In the "Acts of Agapitus", a work composed. If historical elements are present in the Thecla episode beyond the names and paraphrases of first-century documents, they would most likely be found by comparing the episode with other legends and hagiographies involving a person named Thecla. Eusebius, for example, tells the story of a Thecla who he believed was martyred in 304. According to Eusebius's report, three people, Thecla, Timothy, and Agapius, were arrested in a general persecution of Christians. Timothy, a bishop, was burned to death. Thecla was killed by animals. Agapius, though sentenced to death was detained in prison for two years. After completing the prison term, Agapius was offered clemency if he would sacrifice to the gods. He refused and was sent to the arena where he was mauled by a bear. Having survived this torture, Agapius was executed the next day by being drowned in the sea. The historical details and methods of persecution suggest an event that took place not in the fourth century but during Trajan's reign (98-117). Nevertheless, in Eusebius's simple account, it is not Thecla but one of her male companions who experiences a stay of execution, survival of a con-test with a bear, and a providential "baptism" in which death by immersion assures eternal life. Thecla's glory, like that of the two men with whom she was arrested, lay in martyrdom. It is possible that this early second-century execution was the historical event, or legend, from which the author of the Acts of Paul selected the name of Thecla, attributed to her alone the tribulations of all three martyrs, and worked the story into an account of the life of Paul.»

${ }^{12}$ Vide Boughton, 1991, 365. 
duas classificações subentenderem intencionalidades narrativas distintas, que geram entendimentos doutrinários e culturais distintos: a opção pelo romance situa o texto em uma espécie de grau zero, no tocante aos problemas do contexto intelectual e das controvérsias teológicas que, supostamente, lhe subjazem; a opção pela sua classificação no âmbito da 'literatura tradicional', pelo contrário, configura-os como peça séria da literatura religiosa e, por consequência, com traços de fidedignidade histórica e doutrinal.

A classificação dos $A A$ como romance resulta da proximidade de temas, de caracteres, de estrutura narrativa, de cenas típicas e de ambiente cultural em relação ao romance helenístico. Quer romance grego, quer os Acta Theclae desenvolvem, em comum, temas simples e universais, de acordo com o padrão narrativo das histórias de amor, que liga, como pólos opostos, a separação/ tribulação e a salvação. As suas figuras principais são idealizadas e mantêm padrões elevados de castidade, de piedade e de amor. O herói, um jovem cidadão, virtuoso, casto e carismático, apresenta, por vezes, traços semelhantes aos da divindade. A heroína configura-se como uma figura de estrato social elevado, de beleza superlativizada e de carácter nobre. O desenvolvimento da acção impõe severos desafios à sua castidade e fé. $\mathrm{O}$ conflito desenvolve-se por meio de uma série de aventuras, frequentemente cíclicas e repetitivas, que culminam em um julgamento ou em cena de reconhecimento, às quais se segue um rápido desenlace, que termina com a condição final da salvação. Neste momento, os heróis, no romance grego, adquirem a sua plena identidade através do amor que sentem um pelo outro; nos Actos Apócrifos, o apóstolo adquire identidade final juntando-se a Cristo no martírio, enquanto a heroína encontra a sua identidade no amor de Jesus e na vivência de cristã ideal ${ }^{13}$. À narrativa juntam-se ainda personagens secundárias, em ambos os casos tipificadas em parentes ricos (ATh. 29), multidões simpatéticas (ATh. 21, 27, $32,38)$, classes baixas não sofisticadas (ATh. 64), um fiel companheiro do herói (Onesíforo), rivais sem escrúpulos (Alexandre).

Se $A T h$ e romance grego evidenciam similitudes, quer no desenho dos protagonistas, quer na escolha dos métodos usados no tratamento das personagens e dos seus valores, também não deixam de ecoar um mundo construído literariamente da mesma forma, evidenciado no recurso às mesmas cenas típicas: a prisão, que acentua a relação entre os caracteres, unindo-os no mesmo estado de mente, cria o pathos ou tensão dentro da história, que reivindica a simpatia por parte do leitor em relação às personagens; os tribunais públicos nas cidades, que reflectem o ethos das personagens que os frequentam; os julgamentos melodramáticos, cheios de acusadores imorais e de espectadores que manifestam a sua compaixão e apoio em relação à inocência

${ }^{13}$ Vide Longstreet, Shaun, 1994. Veja-se igualmente o capítulo $3^{\circ}$ sobre as semelhanças entre $A c t a$ e romance grego, das quais se apresenta, em seguida, uma breve resenha. 
dos acusados; a tentativa de execução da heroína ou do herói; tentativas de sedução, fugas com ajuda do divino; e finalmente, o regresso a casa. Em síntese, quer Romance, quer $A T h$ contam uma viagem, simultaneamente espacial e espiritual, por meio de uma narrativa simples, com uma linguagem estilizada e emotiva, que convoca o comprometimento emocional do leitor.

Também no tocante aos aspectos divergentes - erotismo e casamento -, facilmente se entende que o elemento erótico, associado ao amor romântico, é deslocado, nos $A T h$ para o amor associado à conversão, em uma espécie de refinamento do amor profano que domina o romance; e que o problema do papel do casamento e da vida familiar, suporte central e social do romance grego, adquira a sua recontextualização na participação dos heróis em um novo conceito de família, fundada na casa (oikos) de Deus. Modificação relativamente semelhante sucede com o elemento aleatório, que determina que o padrão das aventuras vividas pelos protagonistas do romance grego se estabeleça como uma sequência de acontecimentos que, genericamente, se podem topicalizar na oposição perigo/salvação. Assim, à Tyche, que se assume como elemento dinâmico que favorece e determina esse padrão, corresponde, neste novo contexto, uma espécie de Tyche cristianizada, ou seja, a Providência divina.

A classificação dos Actos de Tecla como romance tem implicações na consideração da sua matéria. Assumindo como objectivo principal o entretenimento do leitor, convidado simpateticamente a entrar na narrativa, a identificar-se com os protagonistas, a partilhar os seus medos e aspirações, a experimentar as suas emoções, em uma jornada de edificação espiritual, os textos não necessitam de representar elementos históricos precisos. Personagens, acontecimentos e mundo circundante, porquanto idealizados, revelam-se mais ajustados à transmissão das preocupações humanas universais ou do universal humano do que com assuntos históricos e culturais específicos. Assim, os $A T h$ constituir-se-iam mais como um texto informativo sobre o estado de mente do primitivo cristianismo do que da situação histórica de um grupo ou de uma comunidade específica. $\mathrm{O}$ uso da estrutura do romance, independentemente dos ecos do debate teológico, perceptíveis da leitura dos textos, que evidenciam laços entre ortodoxia e heresia no movimento dos primeiros cristãos, permitiria apenas, no dizer de Judith Perkins, leituras relativas à emergência, com significado religioso e social global, dos temas do casamento, da castidade e da morte ${ }^{14}$.

Substancialmente diferente é a posição de que a história de Tecla evoca um contexto histórico preciso. Não falamos evidentemente daquele contexto que, pese embora a subtileza do desenho, se adivinha, no modelo anterior, a

${ }^{14}$ Perkins, 1997,247-260. A autora argumenta que os Actos Apócrifos exploram as convenções da literatura romanesca de forma a inverter os valores que normalmente lhe estão associados. 
partir das conjecturas acerca do tempo em que os seus leitores/ouvintes se situam, ou seja, um tempo distanciado do século da prática apostólica. Falamos do contexto que situa os Actos no século I e que, consequentemente, faz deles textos produzidos nas mesmas circunstâncias culturais e intelectuais em que foram produzidos os textos canónicos.

A primeira proposta de que a história de Tecla teria como data de composição o século I é atribuída a W. M. Ramsay. ${ }^{15}$ A posterior descoberta e estudo de uma edição copta por Carl Schmidt com os Actos completos de Paulo apoiou, no entanto, a constatação de que ambos os textos apresentavam uma uniformidade de estilo e de estrutura impeditiva de uma datação que não coincidisse com o século II. Além disso, os episódios dos Acta Theclae parecem não demonstrar, com limitadas excepções, ${ }^{16}$ o conhecimento das estradas, costumes e figuras históricas do século I. Mas tal consideração não afastou definitivamente, entre a comunidade de especialistas, a possibilidade de que os $A T h$, embora cristalizados sob forma escrita apenas no século II, constituíssem uma actualização de tradições orais desenvolvidas no século I.

A consideração dos Acta como representações literárias de tradições orais anteriores, cuja unidade teria dependido da sua transmissão de geração em geração, levou a dois entendimentos distintos: o primeiro, defende que os $A T h$, porquanto representativos dos interesses de leitores cristãos não sofisticados, desejosos de ouvirem histórias do poder do seu Deus e das aventuras dos cristãos lendários do passado, teriam sido dirigidos não pela intenção de executar um programa teológico explícito, ${ }^{17}$ mas por intenções pragmáticas, que visavam entreter, educar, edificar e disseminar a mensagem da abstinência sexual como um traço essencial - ou até como o traço essencial - da mensagem cristã; o segundo, que conheceu grande desenvolvimento nos anos 70 , acondicionado pela perspectiva de que literatura tradicional desempenha uma função mediadora das oposições, de natureza social, moral e local entre o meio popular em que se desenvolvem e o establishment cultural, recuperou matérias para o debate como a do modelo de participação feminina na igreja das primeiras comunidades e a das tensões vividas no quadro da primitiva institucionalização da igreja.

Entre alguns estudos, o de Dennis Macdonald, ${ }^{18}$ sustentado na ideia de que os textos têm origem em tradições orais, narradas por mulheres, considera que os Actos de Tecla reflectem as circunstâncias históricas de algumas comunidades em que as mulheres se converteram ao cristianismo. Nesse sentido, as referências

\footnotetext{
${ }^{15}$ Ramsay, 1911.

${ }^{16}$ Entre essas excepções encontram-se a presença de Trifena, familiar do imperador Cláudio, a estrada para Icónio e alguns elementos da descrição da cidade.

${ }^{17}$ Schneemelcher, Schäferdiek, 1965.

${ }_{18}^{18}$ MacDonald, 1983.
} 
à actividade de Tecla, comissionada por Paulo, não só constituiriam elementos históricos, como atestavam que as mulheres na era apostólica partilhavam o ofício dos apóstolos. $\mathrm{O}$ argumento sustenta-se igualmente na consideração do autor de que as restrições da administração da igreja a homens, manifestas nas epístolas a Timóteo e a Tito, não são nem escritas por Paulo em 60, nem recolecções pseudoepigráficas das suas palavras, reconstituídas mais tarde, durante os anos 80 , mas que, pelo contrário, foram escritas no século II para contrariar a aceitação da liderança das mulheres, visível nas epístolas mais antigas de Paulo, que as louvavam as pela sua dedicação à igreja e que são consistentes com a liderança comissionada a Tecla ${ }^{19}$.

Outros estudos recentes ${ }^{20}$ apresentam fortes evidências de que os $A A$ se constituem como prova a existência comunidades de mulheres cristãs celibatárias nos primeiros séculos da tradição cristã, bem como que as comunidades de viúvas ${ }^{21}$, estabelecidas na era da actividade apostólica, poderiam ter preservado, em forma oral, histórias de relevância particular sobre o seu papel de mulheres cristãs $^{22}$. Nesse sentido, os Acta Theclae reflectiriam o padrão dos contos tradicionais ${ }^{23}$, na medida em que a natureza exemplar das figuras femininas teria servido de modelo de comportamento aos membros das comunidades que produziram os textos. E o processo de sociabilização, encorajado pelas histórias, conferiria ajuda às mulheres no tocante aos conflitos levantados pelas tentativas de se tornarem autónomas e de desenvolverem a espiritualidade ${ }^{24}$. E, note-se, o próprio texto dos Acta Theclae parece oferecer matéria probatória neste sentido, na medida em que o papel das mulheres é, quer colectivamente, quer individualmente, substantivo, não só no tocante ao desenrolar dos acontecimentos, como no tocante ao desenho emocional que à volta desses acontecimentos se vai avolumando. Além de defendida e acarinhada por Trifena, um grupo anónimo de mulheres condena o julgamento de Tecla, feito pelo governador ( $A T$ h 27: «Má sentença! Injusta sentença»); e quando é levada em cortejo, juntamente com as feras, as mulheres, acompanhadas pelos filhos, gritam: «Oh Deus! Nesta cidade, executa-se uma sentença ímpia» ( $A T$ Th 28 ); e durante o confronto com as feras, gritam novamente, emulando um coro grego: «Pereça a cidade por causa desta impiedade! Aniquila-nos a todas, Procônsul! Triste espectáculo; malvada sentença!» (ATh 32), etc ${ }^{25}$.

${ }^{19}$ Vide Boughton, 1991, 369-370.

${ }^{20}$ Vide, entre outros, os estudos de Davies, 1980; e Burrus, 1987.

${ }^{21}$ Davies, 1980, 95-109, sustenta que a autora dos Acta Theclae seria uma mulher.

${ }^{22}$ Vide a discussão sobre as metodologias seguidas por estes estudos, de natureza feminista, em Matthews, 2001, 39-55.

${ }^{23}$ Burrus, 1987, estabelece, da comparação com narrativas semelhantes, um conjunto e sequência de motivos que atestam a possibilidade de existência de um background para uma história de natureza oral.

${ }^{24}$ Burrus, 1987, 81.

${ }^{25}$ Note-se igualmente o pendor 'feminino' da cena do cortejo, no qual, uma leoa lambe os pés 
A actividade de missionação, autorizada por Paulo, e o auto-baptismo atestariam, deste modo, de acordo com as interpretações historicistas da narrativa, que as mulheres nos tempos apostólicos partilhariam o ofício de ensinar, pregar e baptizar. E, nesse sentido, os esforços episcopais, feitos no século IV, para formalizar o cânone ${ }^{26}$ representariam o culminar de um lento programa que excluiu todas as formas de revelação que não apoiassem a visão patriarcal e hierarquizada da sociedade e da igreja. Os Actos de Tecla constituiriam, deste modo, a prova da existência, na Igreja antiga, de duas linhas em competição relativamente à visão de Paulo sobre a mesma Igreja: uma, dada pelas epístolas canónicas; outra, dada pelos Actos Apócrifos. Nesse sentido, o $N T$ não se constituiria como uma compilação de obras seleccionadas com base em critérios objectivos e uniformes, mas como a opção formalizada dos vencedores históricos ${ }^{27}$. No dizer de MacDonald, os Acta Theclae foram excluídos do $N T,^{28}$ porque o estabelecimento do cânon, no século IV, reflectiu as ideias de homens de uma posição social particular que erradicaram o ramo mais radical do legado Paulino em ordem a «to serve the needs of a church increasingly eager to gain social acceptability»"

As posições de cepticismo em relação a este entendimento apoiam-se na ideia de que a existência pré-literária das histórias constitui um postulado não sustentado pela análise da relação entre as histórias e o seu contexto global, facto que impõe limites a uma reconstrução histórica das primeiras comunidades cristãs por intermédio dos Actos de Tecla. No entender de Boughton, as histórias de Paulo e Tecla evidenciam uma perspectiva cultural do século II, inconsistente com o pensamento e expressão do século $I^{30}$. De

de Tecla. Mais tarde, na arena, a mesma leoa defende Tecla do ataque de um leão e de um urso.

${ }^{26}$ Vide Street, 1999.

${ }^{27}$ MacDonald, 1983, 88-90.

${ }^{28}$ Estas considerações levaram, por sua vez, ao problema da intertextualidade com os textos canónicos, sobretudo com os Actos de Lucas, que, segundo alguns autores, teriam fornecido o paradigma para os Actos Apócrifos: ambos os textos ilustram acções de pessoas proeminentes, apresentam elementos aretológicos; revelam um interesse geográfico/etnográfico na descrição dos periodoi das personagens e registam interesses religiosos (vide Schneemelcher, 1965, 152). Apesar de assumida esta relação, é, no entanto, consensual que os Actos Apócrifos teriam auferido de um desenvolvimento independente, visível no facto de a narrativa dos $A L$ apresentar semelhanças com o discurso historiográfico, ao passo que os Actos Apócrifos se apresentam como claramente ficcionais. A ideia de que o autor dos A. Apócrifos conhecia a narrativa de Lucas gerou, entre outras, dois entendimentos significativos em abono da tese de competição subjacente aos textos: ou ao autor $\operatorname{dos} A A$ produziu um texto com o objectivo de dar sequência aos $A L$, ou o autor dos $A A$ tencionou suplantar e corrigir e suplantar os $A L$, o que explica as diferenças teológicas e doutrinais que deles se evidenciam (vide discussão desta controvérsia em Hills, 1997, 145-155).

${ }^{29}$ MacDonald, 1983, 89.

${ }^{30}$ Matthews, 2001, 43, observa, no entanto: «She [Boughton] dismisses as "feminist fantasy" the argument that the Thecla story indicates resistance to patriarchal order. Boughton's pose as an objective historian disguises only thinly her confessional and apologetic approach to 
igual forma, o ataque de Paulo aos adversários com frases aptas, as respostas favoráveis às preces que recebe e o facto de pregar uma mensagem simples, que ganha imediatamente conversões emocionais, parecem inconsistentes com as preocupações administrativas do seu apostolado, com o facto de os seus sermões envolverem uma exegese complexa da Lei e dos profetas e que contrastam com o desapontamento muitas vezes demonstrado nas suas Epistolas ${ }^{31}$. Além disso, elementos como o papel de Tecla na direcção espiritual de uma comunidade cristã, actividade que não indicia o desempenho de funções hierárquicas como a de bispo ou presbítero, estaria acomodado às funções que as hierarquias consideravam apropriadas às mulheres: «The service of women catechists and missionaries is alluded to in epistles formally accepted into the New Testament canon and has been institutionalized for centuries in the traditional apostolates of Roman Catholic and Anglican communities of celibate religious women». Deste modo, «Since nothing done by the Thecla character suggests leadership of the worshiping community or a position in the emerging hierarchy, the story of her adventures can hardly constitute a long-suppressed record of women exercising sacerdotal powers.» $\rangle^{32}$

Também no tocante aos elementos conflituantes com a visão do mundo, expressa nos textos apostólicos, as motivações subjacentes à conversão e ao celibato (condição associada aos movimentos ascéticos heterodoxos) de Tecla não parecem estar associados à ideia de redenção, um elemento importante para a primeira geração de cristãos; pelo contrário, o texto parece indiciar e assumir que "Thecla's religiosity is based on attraction to Paul.»" No entanto, a dissociação que se verifica entre a recusa em aceitar o casamento e os elementos que poderiam atestar a sua ligação ao contexto apostólico (voto de pobreza, abnegação, devoção) não deixa de situar o comportamento de Tecla e os consequentes motivos accionais que, a partir dele, se desenvolvem, na esteira conceptual da tradição romanesca decorrente do romance helenístico e da forte presença de elementos estereotipados, com força de tradição, subjacentes à tessitura narrativa dos Acta Theclae.

Além disso, a discussão relativa a determinados elementos do texto tem recuperado o tema das heresias. Sem se inclinar, no entanto, para a consideração de que o texto contém um propósito doutrinal explícito de um movimento herético preciso, Boughton observa que o episódio de Tecla situa conceitos éticos e cosmológicos do Cristianismo, como a ressurreição, o baptismo e o celibato num contexto distinto dos escritos apostólicos. ${ }^{34}$

historical reconstruction. (...) Moreover, Boughton engages in the dubious methodological practice of faulting "unorthodox" second-century readers for having interpreted texts wrongly.»

${ }^{31}$ Boughton, 1991, 364.

32 Boughton, 1991, 377.

${ }^{33}$ Boughton, 1991, 378.

${ }^{34}$ Vide nota 27. 
Deste modo, o uso de um disfarce masculino por parte de Tecla ecoa a práxis das mulheres marcionitas ${ }^{35}$ que usavam, por vezes, vestuário masculino para demonstrar superioridade em relação às preocupações mundanas relacionadas com a feminilidade ${ }^{36}$. Além disso, esta prática seria inaceitável para as populações familiarizados com a lei de Moisés ou com a Primeira Epistola aos Corintios (11,4-16): «Todo o homem que reza ou profetiza, de cabeça coberta, desonra a sua cabeça. Mas toda a mulher que reza ou profetiza, de cabeça descoberta, desonra a sua cabeça; é como se estivesse com a cabeça rapada. Se a mulher não usa véu, mande cortar os cabelos! Mas se é vergonhoso para uma mulher cortar os cabelos ou rapar a cabeça, então cubra-se com um véu. $\mathrm{O}$ homem não deve cobrir a cabeça, porque é imagem e glória de Deus; mas a mulher é glória do homem. Pois não foi o homem que foi tirado da mulher, mas a mulher do homem. E o homem não foi criado para a mulher, mas a mulher para o homem. Por isso, a mulher deve trazer sobre a cabeça o sinal da autoridade, por causa dos anjos. Todavia, nem a mulher é separável do homem, nem o homem da mulher, diante do Senhor. Pois, se a mulher foi tirada do homem, o homem nasce da mulher, e tudo provém de Deus. Julgai por vós mesmos: será decoroso que a mulher reze a Deus de cabeça descoberta? E não é a própria natureza que vos ensina que é uma desonra para o homem trazer cabelos compridos ao passo que, para a mulher, deixá-los crescer é uma glória, porque a cabeleira the foi dada como um véu? Mas, se alguém quiser contestar, nós não temos esse costume, nem tão-pouco as igrejas de Deus.»

No entanto, como observa Castelli, esta tradição não deixa de conviver com a tradição em que «The notion of ascetic women evading their female nature arises in an interesting narrative motif which appears early in the tradition and remains a controversial sign of female renunciation and spirituality well into the ninth century-the motif of women cutting their hair or disguising themselves as monks. Thecla, who remains the model of virginity for generations of ascetic women, both cuts her hair and wears men's clothing in the Acts of Paul and Thecla while, in other Apocryphal Acts, Mygdonia cuts her hair and Charitine wears men's clothing. (...) Despite their function as a sign of renunciation and holiness, transvestism and hair cutting were not always lauded as a practice demonstrating piety. Jerome warns Eustochium against women who dress as men and the Council of Gangra in the mid-fourth century condemned ascetic women who, as a part of their rigorous renunciation, cut their hair and wore men's clothing.» ${ }^{37}$

${ }^{35}$ Vide Anson, 1974, 1-32.

${ }^{36}$ Boughton, 1991, 378.

${ }^{37}$ Castelli, 1986, 75-76, observa: «The notion of ascetic women evading their female nature arises in an interesting narrative motif which appears early in the tradition and remains a controversial sign of female renunciation and spirituality well into the ninth century-the motif of women cutting their hair or disguising themselves as monks. Thecla, who remains the model 
Também o relato do auto-baptismo, apresenta oscilações interpretativas que o situam entre «um acto de fé», que recompensa a coragem de Tecla, e resultado de uma mera ocorrência providencial, que implica uma visão deste sacramento como um rito de concedido apenas àqueles cujas conquistas foram além dos níveis normais de fé e virtude. Esse entendimento do baptismo está igualmente em conformidade com a prática marcionita de baptizar apenas aqueles que renunciam ao casamento e que deram provas de uma iluminação espiritual que os marcou em virtude de actividade profética ${ }^{38}$.

De igual forma problemática é a presença de animais «milagrosos» na história. O episódio tem sido interpretado de formas distintas: por um lado, o facto de as leoas (e contrariamente ao que sucede no Livro de Daniel em que os leões, apesar de não atacarem, não prestam homenagem ao profeta) resgatarem a heroína, com actos intencionais de devoção, poder ser visto como uma evocação de Cíbele, uma deusa assistida por leões e à qual se encontra associada uma cosmologia dualista, que tende a eliminar as distinções naturais entre homens e animais, homens e mulheres, etc., leva alguns autores a constatar que o episódio indicia a crença de que as distinções naturais são antitéticas em relação às intenções divinas ${ }^{39}$; por outro lado, o carácter milagroso do episódio não deixa de se constituir como legitimação do cristianismo e da autoridade dos seus convertidos: «During the Antioch episode the legitimacy of women's right to a certain form of autonomy, including the inviolability of women's bodies, is confirmed in the chain of miraculous events that result in women's victory over a host of "wild animals". Thecla/woman, "unbound" both from the things of the world and in the end from the apostle Paul, is set free and commissioned to pursue her apostolic activities. Therefore, the most important implication of the relation between women as both performers and beneficiaries of miracles and their position in the Christian community and society at large, is the validation of Thecla as a doule tou theou, and thus of women's position of (apostolic) authority.» ${ }^{40}$

Do exposto facilmente se compreende que uma contextualização acurada do significado dos Acta Theclae não está isenta de problemas. As divergências de análise, no tocante a aspectos doutrinais, à data de composição, ao contexto histórico que lhe subjaz, são alguns dos indicadores

of virginity for generations of ascetic women, both cuts her hair and wears men's clothing in the Acts of Paul and Thecla while, in other Apocryphal Acts, Mygdonia cuts her hair and Charitine wears men's clothing. (...) Despite their function as a sign of renunciation and holiness, transvestism and hair cutting were not always lauded as a practice demonstrating piety. Jerome warns Eustochium against women who dress as men and the Council of Gangra in the mid-fourth century condemned ascetic women who, as a part of their rigorous renunciation, cut their hair and wore men's clothing.»

${ }^{38}$ Boughton, 1991, 378-379.

${ }^{39}$ Boughton, 1991, 380.

${ }^{40}$ Misset van de Weg, 2004, 51. 
da complexidade dos elementos que se colocam ao estudo do texto - novos problemas que, em suma, recontextualizam a ambivalência com que foi recebido e que alimentou o debate, nos primeiros séculos do cristianismo, $\mathrm{da}$ ortodoxia com as heterodoxias que rejeitavam a autoridade episcopal e conciliar.

No entanto, o regresso à discussão sobre o género, poderá repor e criar algumas interrogações acerca da forma e da função destes $A c t a$. Se Perry afasta a hipótese de uma mesma identidade de género entre romance grego e Actos Apócrifos ${ }^{41}$, não afasta, por outro lado, a ideia de que as hagiografias bizantinas se constituem herdeiras da primeira forma. Além disso, o reconhecimento de que as audiências do romance grego e destes apócrifos, quando não as mesmas, se encontravam marcadas por um status cultural semelhante, põe o problema da criação e recepção dos $A A$ na perspectiva da recriação e da releitura: o recurso a uma ou mais formas literárias pré-existentes, nos $A T h$, poder-se-ia encontrar ao serviço de uma formalização discursiva, cujos temas, motivos, padrões narrativos, estados emocionais e culturais teriam sofrido um movimento de adequação ao novo centro ideológico e accional, que determinava o processamento do material narrativo em acomodação a novas condicionantes humanas e religiosas e que explicaria a «cristianização» dos padrões narrativos, das cenas típicas e das motivações das personagens. Considerados neste sentido, embora temporalmente muito distante da narrativa hagiográfica, importa salientar que os Acta Theclae evidenciam marcas de um potencial hagiográfico difícil de suprimir. O grau de exemplaridade de que se revestem, a concessão ao gosto popular, doutrinalmente imaturo, a repetição de elementos narrativos estereotipados, os objectivos de instruir e edificar, a componente retórica do discurso, que assenta na demonstração da santidade da personagem, ${ }^{42} a$ conversão de vocabulário pagão, constituem marcas de uma proto-hagiografia ou, pelo menos, um conjunto significativo de elementos que viria a formar parte da estrutura central deste genéro. Além disso, se o pendor biografista, de influxo clássico, herdado pela hagiografia, assente nos segmentos «vida» e «morte» (assumidas como testemunho de coragem na defesa fé e dos princípios cristãos) dos primeiros mártires cristãos, rapidamente incorporou a necessidade do relato dos milagres operados em contexto post mortem - pois o martírio legitimava o Mártir na mesma proporção em que os milagres, operados pelo martirizado, caucionavam o seu culto e o seu carácter sagrado - curiosamente, a proliferação de lendas, que atestam a martirização de Tecla, não deixa de evidenciar uma acomodação a essa necessidade; uma necessidade sentida também no plano formal e institucional da Igreja no Oriente que fez com que Tecla se visse, por

\footnotetext{
${ }^{41}$ Perry, 1967, 85.

${ }^{42}$ Vide Sobral, 2005, 97-107.
} 
Cláudia Teixeira

intermédio dos seus teólogos, associada à ortodoxia e granjeasse expansões várias no tocante à sua vida e milagres ${ }^{43}$.

${ }^{43}$ Hayne, 1994, 213, observa: «For these Cappadocian fathers Thecla was worthy of the highest praise, so it is not surprising that it was the east that produced the expanded Life and Miracles.» 


\title{
IN VIRTVTE SIGNORVM: \\ Paulo de Tarso na hagiografia Medieval
}

\author{
Cristina Sobral \\ Universidade de Lisboa \\ Centro de Linguística da Universidade de Lisboa
}

in uirtute signorum, et prodigiorum, in uirtute Spiritus Sancti: ita ut ab Jerusalem per circuitum usque ad Illyricum repleuerim Euangelium Christi. Sic autem predicaui Euangelium hoc, non ubi nominatus est Christus, ne super alienum fundamentum adificarem: sed sicut scriptum est: Quibus non est annuntiatum de eo, uidebunt: et qui non audierunt, intelligent. (Rom 15: 19-21)

Entendida a história da salvação como um percurso terreno que se completará no futuro, com a segunda vinda de Cristo, e cujos acontecimentos os homens conduzem no rumo certo graças à contínua e persistente intervenção de Deus no seu destino ${ }^{1}$, viam os cristãos medievais apontado o caminho por meio de sucessivas epifanias que mantêm entre si uma relação de coerência semântica que se manifesta na sua inter-referencialidade, na sua actualização sucessiva, ou seja, em termos muito simples, na sua repetição. Assim, a leitura do Novo Testamento mostrava-lhes a actualização de factos e de situações prefiguradas no Antigo Testamento e à hagiografia cabia a função de contar, em época pós-testamentária, os momentos seguintes de intervenção de Deus na História ${ }^{2}$. Nesta perspectiva, as narrativas sobre santos inscrevem-se numa linha contígua de relatos, em alinhamento coerente com o texto bíblico. $\mathrm{O}$ elo de ligação encontrava-se sem dúvida no livro dos Actos dos Apóstolos que, depois de Jesus, assumiram a tarefa entregue por Cristo: ensinar aos homens o caminho para Deus. No mesmo livro se prefiguram já alguns dos meios por que o ensinamento se fará: a evangelização e o martírio.

Ao contrário dos textos canónicos, de veracidade validada pela Igreja, muitos outros textos se apresentaram nos primeiros séculos do cristianismo a contar a história da salvação que não recolheram igual certificação: os apócrifos. $\mathrm{Na}$ sua classificação, dois critérios devem ser tomados em conta: são textos que não reuniam condições para garantir a veracidade dos factos que narravam (pela posterioridade dos seus autores ao tempo da narrativa e pela ausência de testemunhos escritos ou orais considerados fidedignos) ou são textos cuja mensagem não foi reconhecida como verdadeira para conduzir os homens a Deus. Temos, portanto, sobre estes textos, uma desconfiança histórica

\footnotetext{
${ }^{1}$ Guenée, 1980, 20-21, 29.

${ }^{2}$ Van Uytfanghe, 1987, 25.
} 
strictu sensu e uma desconfiança doutrinal que ditou a sua estigmatização na Antiguidade tardia sem, todavia, lograr atalhar a sua transmissão à Idade Média. O interesse que os apóstolos neo-testamentários despertaram ${ }^{3} \mathrm{e}$ o facto de os textos canónicos não responderem senão parcialmente pelo seu percurso de vida abriram campo à composição de narrativas que mostrassem a chegada dessas personagens ao momento em que culmina o sentido da vida cristã: a morte em circunstâncias que asseguram a salvação, a entrada na glória.

\section{Os Acta Pauli}

De entre os apóstolos, dois gozaram de estatuto proeminente, justificando a composição dos apócrifos Acta Petri (180-190) e Acta Pauli (190-200), os primeiros textos do género. Os Acta Pauli são escritos por amor ao apóstolo, segundo a confissão do seu autor, um presbítero da Ásia que, no testemunho de Tertuliano ${ }^{4}$, teria confessado a falsidade do texto. A obra, que levou à punição do autor com o seu afastamento do cargo, revela influência directa do Novo Testamento e dos Acta Petri e alguma formação cultural profana, recebida em ambiente greco-romano erudito ${ }^{5}$. Dos originais Acta Pauli perdeu-se cerca de metade do texto, constituído por diferentes peças, algumas provavelmente compiladas de fontes anteriores, como deverá ser o caso dos Acta Pauli et Theclae $e^{6}$, escritos, ao que tudo indica, por uma mulher para uma comunidade feminina ${ }^{7}$. A peça que maior difusão teve no ocidente foi, sem dúvida, o Martyrium Pauli que, na Idade Média, se transmitiu também autonomamente e que, nos códices mais antigos, é transmitida com o martírio de Pedro, precedendo-o imediatamente ${ }^{8}$.

Polémicos desde o início da sua recepção, os Acta Pauli foram rejeitados e decididamente condenados por autores como Tertuliano e Jerónimo ${ }^{9}$ e listados entre os apócrifos a excluir das leituras aceites pelos cristãos no decreto pseudogelasiano (ca. 500) ${ }^{10}$. Orígenes de Alexandria, por outro lado, aceita-os como legítimos e Eusébio de Cesareia hesita em classificá-los no mesmo nível dos apócrifos de André, João e outros apóstolos, de composição posterior ${ }^{11}$.

${ }^{3}$ Aos apóstolos há que juntar, naturalmente, outras figuras que foram objecto de narrativas apócrifas, com destaque para Jesus, Maria e os seus pais (Ana e Joaquim).

${ }^{4}$ Sciant in Asia presbyterum, qui eam scripturam construxit, quasi titulo Pauli de suo cumulans, convictum atque confessum id se amore Pauli fecisse, loco decessisse. (Tertuliano, De baptismo 17, PL, 1, col.119A).

${ }^{5}$ Erbetta, 1966, 250, 256.

${ }^{6}$ Lipsius, 1972, 235-72.

${ }^{7}$ Kaestli, 1990, 294.

${ }^{8}$ Erbetta, 1966, 249.

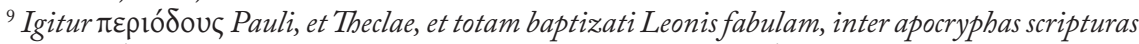
computamus. (S. Jerónimo, De Viris Illustribus, 7, PL, 23, col. 619C).

${ }^{10}$ Erbetta, 1975, 27-31.

${ }^{11}$ Erbetta, 1975, 251. Sobre a história da recepção crítica da literatura apócrifa v. Picard, 1990. 
$\mathrm{Na}$ raiz das condenações não devemos entender apenas o reconhecimento do carácter ficcional da narrativa. S. Jerónimo, por exemplo, conhecia bem a utilidade simbólica e edificante de uma narrativa hagiográfica ficcional. Ele próprio tinha composto algumas. $\mathrm{O}$ desgosto perante os apócrifos Acta de Paulo e de Pedro advinha da sua utilização doutrinalmente suspeita, por comunidades próximas do gnosticismo, do maniqueísmo e das suas facções mais radicais, como a encratita ${ }^{12}$. No caso particular dos Acta Pauli, a estas razões junta-se uma outra, de igual peso: a presença da peça sobre Santa Tecla, responsável pela áspera censura dos Acta na pena de Tertuliano e de Jerónimo. Tecla autobaptiza-se e é investida por S. Paulo na missão de pregar e evangelizar. O texto institui, portanto, um modelo de mulher cristã investida de prerrogativas sacerdotais ${ }^{13}$.

Nas suas traduções latinas, tanto os Acta Petri como os Acta Pauli sofreram, ao longo da história da sua transmissão, refundições e paráfrases, algumas com uma recensão mais numerosa do que a das traduções originais. Destaquemos, destas numerosas paráfrases, a Paixão de Paulo do Pseudo-Lino, reescrita nos sécs. IV-V do Martyrium Pauli, a peça final dos Acta Pauli. Atribuída a um desconhecido papa, amplifica o texto original, acrescentando alguns episódios, e dela se conhecem mais de 80 manuscritos que vão do séc. $\mathrm{X}$ ao séc. XV.

\section{Iacopo de Varazze e a Legenda Aurea}

No séc. XIII, a narrativa do Pseudo-Lino sobre S. Paulo alcança uma difusão que vai muito para além da que lhe permitiam os Acta Pauli, graças ao seu acolhimento na mais importante recolha hagiográfica medieval, a Legenda Aurea do dominicano Iacopo de Varazze ${ }^{14}$. Apesar do vínculo com a verdade que assume o programa hagiográfico prosseguido na Ordem dos Pregadores a partir de Humberto de Romanis, tem sido evidenciado pelos estudiosos o facto de o mais universal legendário saído daquele programa utilizar textos apócrifos ${ }^{15}$. Por vezes, o autor da compilação previne o leitor

${ }^{12}$ Erbetta, 1966, 8-9. Nos Acta Petri é feita a apologia da castidade e da recusa do casamento. É mesmo a divulgação desta doutrina entre as concubinas do prefeito de Nero que atrai sobre o santo a ira e o desejo de vingança do rejeitado, servindo de motor narrativo ao desencadear da prisão e condenação do mártir. Já nos Acta Pauli, é apenas na peça sobre Tecla que ela emerge. Em todo o caso, há que distinguir a utilização dos textos por seitas heréticas da inspiração autoral em doutrinas encratitas, a qual tem sido questionada pelos críticos (cf. Kaestli, 1990).

${ }^{13}$ Petulantia autem mulieris quae usurpavit docere, utique non etiam tinguendi jus sibi pariet, nisi si quae nova bestia evenerit similis pristinae: ut quemadmodum illa Baptismum auferebat, ita aliqua per se eum conferat. Quod si quae Paulo perperam adscripta sunt, exemplum Theclae ad licentiam mulierum docendi tinguendique defendunt... (Tertuliano, De baptismo, 17, PL, 1, col. 119A); baptizati Leonis fabulam (S. Jerónimo, De Viris Illustribus, 7, PL, 23, col. 619C).

${ }^{14}$ Iacopo da Varazze, Legenda Aurea, 576-597 (Capítulo 90). A partir de agora citarei as cláusulas desta edição sempre que citar textos voragianos.

${ }^{15}$ Dubreuil-Arcin, 2006, 276-77. 
deste facto, entregando ao seu juízo a decisão de utilizar da melhor maneira a narrativa disponibilizada ${ }^{16}$. Em muitos casos, porém, e entre eles a Paixão de $\mathrm{S}$. Paulo, não o faz, adoptando uma atitude que claramente privilegia a utilidade doutrinal em detrimento da estrita verdade histórica. Como nota Agnès Dubreuil-Arcin, o uso de fontes apócrifas pelo hagiógrafo genovês encontra a sua justificação quando elas podem reforçar um elemento canonicamente aceitável ${ }^{17}$. Relativamente a S. Paulo, a escolha da narrativa sobre o martírio e a ausência de qualquer menção a Santa Tecla poderia entender-se como reconhecimento da utilidade doutrinal da primeira e como rejeição da segunda, rejeição que dependeria, é claro, da actualidade das razões (atribuição de prerrogativas sacerdotais a uma mulher) que levaram à condenação deste texto ao longo da sua transmissão. Este acto criterioso de selecção, porém, só poderia atribuir-se a Iacopo de Varazze se admitíssemos que ele conheceu os Acta Pauli numa forma que contivesse as duas peças em causa, conclusão cuja legitimidade pode ser questionada pelo facto de não utilizar a tradução latina do Martyrium mas sim uma das suas paráfrases (a do Pseudo-Lino) e, sobretudo, pelo facto de, na sua utilização, dever ter-se em conta a mediação de outros legendários, como o de Bartolomeu de Trento e o de Jean de Mailly, precursores de Iacopo de Varazze no género legendae novae inaugurado pelos dominicanos, e amplamente compilados pelo autor da Legenda Aurea ${ }^{18}$.

Está por fazer um estudo sistemático sobre o tratamento dado, na Legenda Aurea, às fontes apócrifas. Seria pertinente estudar, com pormenor, o conjunto seleccionado de entre um corpus apócrifo possível, o modo como estes textos contribuem para o proveito edificante pretendido pelos dominicanos do séc. XIII e os procedimentos que são adoptados para prevenir leituras indesejadas. Sem um estudo desta natureza, as considerações sobre a Paixão de S. Paulo perdem força de enquadramento. Será, ainda assim, legítimo admitir que, se em todo o capítulo 90 da Legenda Aurea, Iacopo de Varazze não fornece ao leitor qualquer indicação sobre a natureza apócrifa da fonte nem coloca nenhum dos factos narrados sob prevenção judiciosa, será por não recear deste texto leituras inconvenientes. Nesse caso, será pertinente perguntar se, no seu trabalho de compilação e de reescrita de fontes, teve em conta a necessidade de conformar a narrativa a uma linha de sentido estritamente ortodoxo ou se adoptou procedimentos destinados a desviar quaisquer suspeitas de heterodoxia.

${ }^{16}$ A palavra «apocryphus» ocorre apenas em 8 textos (Tomás, Matias, Tiago Menor e Pedro, Paixão, Invenção da Cruz, Assunção da Virgem e Clemente) e pode ser acompanhada de uma nota que exprime a decisão de deixar o leitor julgar: Vtrum autem haec hystoria narranda sit, lectoris judicio relinquatur (Dubreuil-Arcin, 2006, 276-277).

${ }^{17}$ Dubreuil-Arcin, 2006, 277-78, 284.

${ }^{18} \mathrm{Cf}$. aparato de fontes, na edição crítica de G. P. Maggioni, e a sua introdução (p.xx). Sobre as legendae novae dominicanas v. Phillipart, 1981 e 1977, e sobre a sua compilação por Iacopo v. Ferrua, 2001, 44; Bertini, 2001, 62. 
O autor da legenda voragiana anuncia à cabeça a principal fonte utilizada, identificando-a como pertencendo ao papa Lino (Passionem sancti Pauli Linus papa conscripsit 18), sem qualquer outro elemento adicional que permita situálo na história ou na bibliografia nem tão pouco que permita questionar a sua credibilidade. É, na verdade, a paixão do papa apócrifo o núcleo central da narrativa da Legenda Aurea (32-126). A acção decorre em Roma, desde a chegada de Paulo à cidade e a sua crescente influência entre os cortesãos de Nero, até à sua decapitação, depois de vários acontecimentos que explicam a condenação pelo imperador, seguida de um epílogo destinado a demonstrar a glorificação post-mortem do mártir e a eficácia da sua acção evangelizadora (conversão dos romanos e baptismo dos algozes). Estamos aqui perante a estrutura clássica do género hagiográfico passio: confronto ideológico entre o mártir cristão e o representante do paganismo (imperador), prisão, interrogatório, condenação, martírio, glorificação. Aos leitores da Legenda Aurea esta é uma estrutura familiar que, cumprida com diversidade de motivos e recursos diegéticos, poderiam ler em muitas outras passiones.

No horizonte de expectativas deste público está igualmente o conhecimento da informação que liga a narrativa situada no passado com o presente tangível: a invenção das relíquias localizadas no espaço presente e a narrativa de milagres póstumos que fundamenta a sua eficácia (127-147). A resposta de Iacopo de Varazze a esta exigência encontra solução no uso de outras fontes, que cita criteriosamente: Dionísio Aeropagita (Epistola a Timóteo) e Gregório de Tours, ambos de autoridade inquestionável.

Com uma legenda assim composta já o arcebispo genovês poderia ter correspondido ao interesse e aos hábitos de leitura dos seus leitores, curiosos acerca do percurso paulino que os textos neotestamentários não contavam. Porém, ele oferece mais do que isto, fazendo anteceder a passio de uma breve súmula das viagens apostólicas do santo na perspectiva martirial, ou seja enumeradas como um périplo de sofrimentos passados em cada uma das etapas, com destaque para o episódio passado em Malta, onde Paulo sobrevive à picada de uma víbora (Act 28,1-6). Apresenta ainda uma discussão sobre a primazia apostólica de S. Paulo e de S. Pedro (resolvida a favor do segundo, quanto à cronologia, e a favor do primeiro, quanto à importância da pregação), uma breve descrição dos costumes de Paulo e a evocação da livre circulação do santo em Roma, no início do reinado de Nero. Para todos estes elementos textuais são evocadas as fontes utilizadas, cuja exactidão pode ser conferida no aparato de fontes da edição crítica: Haymo de Auxerre e S. Jerónimo, eventualmente mediatizados por Bartolomeu de Trento e Jean de Mailly. No final, após os dois milagres post mortem que encerram a legenda, Iacopo não poupa no espaço que concede a duas outras peças textuais: um pranto à morte de S. Paulo por Dionísio Aeropagita e um elogio do apóstolo por João Crisóstomo, ambos explicitamente evocados. 
De resto, o primeiro destes dois, na sua Epistola a Timóteo, aparece como fonte alternativa na passio, para o nome a dar à mulher (Plautilha segundo o Pseudo-Lino, Lemobia segundo Dionísio) que oferece o seu véu ao mártir e que o vê milagrosamente devolvido com o seu vulto impresso. Assumido embora algum desacordo com o Pseudo-Lino, a divergência entre as fontes não atinge a credibilidade do episódio do véu mas apenas o pormenor do nome da sua possuidora. Devemos concluir que o apócrifo papa ganha em ver-se apresentado ao lado das auctoritates citadas e que não existem, para Iacopo, dúvidas sobre a ortodoxia semântica da paixão de S. Paulo segundo Lino. Pelo contrário, o seu acolhimento nos legendários dominicanos, especialmente naquele que the deu maior difusão, deve entender-se como o reconhecimento da sua utilidade doutrinal e da sua validade representativa, não dos pressupostos ideológicos que poderão tê-lo enformado no século II e sim do pensamento dominicano do séc. XIII.

No seu núcleo central, exclusivamente narrativo, da passio importada do apócrifo Lino, o texto pode ser lido como uma história sobre o caminho a seguir para alcançar a salvação, o qual passa pela instituição, na terra, de uma ordem cristã, fiel à verdade de Cristo e adversa ao paganismo. A missão de Paulo em Roma é a conversão dos romanos a essa nova ordem, ensinando-lhes o valor da fidelidade a Cristo e o reconhecimento da sua omnipotência. O sucesso alcançado na pregação e a conversão dos cortesãos de Nero, que admiram a sua sabedoria (32-33) é o ponto prévio de estabilidade diegética cuja quebra dá início ao combate que se seguirá, como em todas as narrativas martiriais, entre o mártir e o seu oponente perseguidor, aqui representado por Nero. O acontecimento que o desencadeia é a morte acidental de Pátroclo, jovem pajem do imperador que tinha ido assistir a uma das pregações do apóstolo e que cai de uma janela. Ressuscitado pelo santo, é por ele enviado ao imperador. Muito se poderia dizer sobre a importância simbólica e sobre a recorrência dos milagres de ressurreição em hagiografia. Reterei apenas dois aspectos: enquanto vitória sobre a morte, as ressurreições operadas através dos santos possuem um significado eminentemente escatológico, anunciam a fragilidade da vida terrena, o poder divino sobre ela e a sua continuidade na verdadeira vida. A ressurreição anula, assim, a oposição radical que, no universo terreno, existe entre vida e morte. Mais do que ser apenas uma exibição taumatúrgica destinada a provar o estatuto do santo, o facto de a morte poder transformar-se em vida convoca o homem a pensar sobre a natureza desta segunda vida, a sua causa e o seu objectivo. Por isso, quando Paulo envia a Nero o seu jovem pajem ressuscitado, na verdade desafia-o a entender o que aconteceu e a aceitar uma ordem diferente daquela por que até então se regeu.

O conceito de ordem universal imposta por Deus aos chefes terrenos exprime-se, desde a Escritura, por um léxico onde «rei», «reino» e «reinar» detêm 
valor simbólico, pela comparação de superioridade que permitem estabelecer entre os poderes terrenos e a omnipotência divina que os regula. Assim é, com particular evidência, em livros escritos sob a influência da resistência ao helenismo, como Daniel e os Macabeus, e no Apocalipse. Assim é, também, na evocação paulina do triunfo escatológico de Cristo ${ }^{19}$. A missão do cristão, enquanto preparador dessa nova ordem, encontra, nas cartas paulinas, expressão na metáfora da militia Christi, onde se expõe o significado espiritual do léxico militar utilizado ${ }^{20}$. É escatológico, portanto, o evento desencadeador da acção na passio de S. Paulo e não surpreende que o combate que, a partir daí, se trava entre o mártir e o seu oponente radique na diferença de entendimentos sobre a ordem universal e sobre a natureza do poder nem tão pouco que o diálogo utilize o léxico militar. Ao leitor do séc. XIII, o sentido espiritual e metafórico deste léxico é de simples descodificação, não só pela familiaridade com as epístolas paulinas, citadas recorrentemente na literatura de espiritualidade medieval, mas também pela longa fortuna que a metáfora da militia Christi teve como motivo hagiográfico ${ }^{21}$. O leitor sabe ler as equivalências analógicas que o texto evoca e cuja ocorrência pode ser listada:

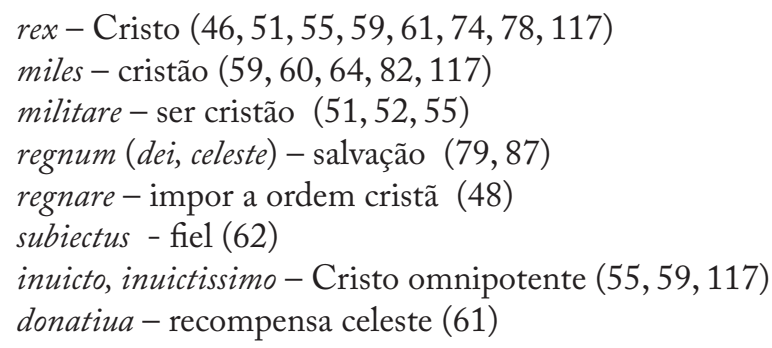

Admitido Pátroclo à presença do imperador, que o espera aterrorizado pela manifestação de poder que a sua ressurreição representa, é no diálogo que travam que ficam definidas as duas leituras possíveis do léxico militar: a de Pátroclo, cristão, que o usa no seu sentido metafórico, e a de Nero, que o entende no sentido literal. Quando o imperador pergunta ao jovem quem o fez viver e ele the responde que foi Jesus Cristo, rex omnium seculorum (46), Nero interroga-o: Ergo ille regnabit in secula ${ }^{22}$ et resoluet omnia regna mundi? (48). Perante o assentimento do pajem, Nero dá-lhe uma bofetada e pede uma confirmação (ergo militas illi regi? 51), a qual recebe: Vtique milito... (52). Está instaurado na narrativa um discurso equívoco de que encontramos exemplo

\footnotetext{
${ }^{19}$ Dn 2,37; 4,34; $2 M a c 7,9 ; 13,4 ;$ Ap 1,5; 17,14; 19,16; 1 Tm 6,15.

${ }^{20} 1 \operatorname{Tm} 6,12 ; 2 \operatorname{Tm} 2,3 ; 2 \operatorname{Cor} 10,3-4 ;$ Ef $6,11-17 ; 1$ Ts 5,8 .

${ }^{21} \mathrm{~V}$. Van Uytfanghe, 1987, 109-110.

22 A fórmula tem ressonâncias bíblicas (cf. Sl 145,10: Regnabit Dominus in saecula) e litúrgicas, pela inclusão deste versículo no ofício de defuntos.
} 
também noutras passiones ${ }^{23}$, e que se repete nos diálogos entre Nero e S. Paulo, entretanto preso e acusado de estar na origem da perturbação social que o imperador foi obrigado a desencadear, perseguindo, prendendo e torturando cristãos.

A tensão gerada na narrativa pelo equívoco e a intangibilidade dos dois discursos, o do mártir-apóstolo e o do pagão-imperador, alcança momentos de frustrada ironia, como aquele em que Nero se dirige a Paulo com as palavras $O$ homo, magni regis seruus, mibi autem uinctus... (59) mas, em vez de obter uma rendição, ouve um convite para que se torne também ele subiectus, a fim de participar nos donatiua do rei. No plano terreno em que Nero se coloca, a simples hipótese de o imperador se sujeitar a outro rei não pode senão ser entendida como uma provocação e, longe de fazer esclarecer o equívoco comunicativo em que ambos laboravam, conduz a um inevitável endurecimento de posição, que culminará com a condenação de Paulo à decapitação e com a sua promessa de, logo depois, voltar vivo a visitar o imperador, a fim de provar o poder do seu rei. A narrativa encontra a sua coesão diegética quando Paulo comparece brevemente, depois do martírio (Cesar, ecce Paulus, regis eterni et inuicti miles, uel nunc crede quia non sum mortuus sed uiuus; sed tu miser eterna morte morieris..., 117-119), perante um Nero aterrorizado e enlouquecido (Nero autem ex nimis timore uelut amens effectus quid ageret ignorabat 121), tornando visíveis a todos os «efeitos de Deus», o qual só pode ser conhecido através das coisas sensíveis, como ensinava Tomás de Aquino, contemporâneo de Iacopo de Varazze e seu irmão dominicano ${ }^{24}$. A mesma leitura poderá fazer-se do leite que jorra da cabeça cortada de Paulo no momento do martírio, logo seguido de um jorro de sangue que o mártir imprime no véu emprestado por Plautilha/Lemobia. Símbolos de imortalidade ${ }^{25}$ e de redenção, o leite e o sangue remetem-nos de novo para o sentido escatológico da narrativa e para a necessidade de conhecer o caminho para Deus através dos sinais sensíveis com que ele o aponta ao homem.

A Legenda Aurea, que posteriormente se tornou obra de leitura de leigos, foi inicialmente escrita como uma colecção de narrativas hagiográficas para uso dos pregadores dominicanos, aos quais coube, no séc. XIII, o combate espiritual contra as heresias que então percorriam a França e a Itália e que haviam já feito, em 1252, um mártir dominicano, Pedro de Verona, morto perto de Seveso pelos cátaros e cuja passio Iacopo inclui no seu legendário (421-442, cap. 61) ${ }^{26}$. Nela tem função diegética e doutrinalmente estruturante a discussão sobre a autoria

${ }^{23}$ Veja-se, por exemplo, a paixão de Santa Inês (cuja versão original escreveu S. Ambrósio de Milão), onde a jovem recusa casar-se por ter encontrado um noivo mais belo e mais poderoso, que lhe dá melhores presentes do que o filho do prefeito (na versão voragiana, 167-173, cap. 24).

${ }^{24}$ Gilson, 1986, 121.

${ }^{25}$ Erbetta, 1966, 288, n.10.

${ }^{26}$ Vauchez, 1986, 38-39. 
divina ou diabólica das coisas visívei ${ }^{27}$, que separava católicos de cátaros. Por isso, podemos compreender que, para Iacopo, a paixão do maior dos pregadores, S. Paulo, em confronto com um senhor poderoso que se recusa a aceitar a verdade espiritual dos sinais enviados por Deus para instrução dos homens acerca da vida eterna é muito mais do que uma narrativa mítica ou de simples entretenimento: é ela própria um dos sinais, que o pregador dominicano deve expor e glosar no exercício da sua pregação e que, pela sua inter-referencialidade no interior da longa história hagiográfica da salvação, prepara a sua própria actualização na história da Europa, cuja ordem cristã periga face à ameaça cátara combatida pelos dominicanos. E é esta utilidade significativa que pode tornar insignificante a origem apócrifa da fonte.

\section{A Legenda Aurea em Portugal}

À semelhança de outros países, também Portugal leu a Legenda Aurea em manuscrito latino. Os quatro testemunhos que sobreviveram ${ }^{28}$ documentam suficientemente a sua recepção desde o final do séc.XIII. Mas foi sobretudo a sua vernaculização que, em toda a Europa, abriu o caminho à leitura pelos leigos em contexto de devoção ou lazer. Em Espanha, as traduções cedo acompanharam a difusão do texto. De uma delas (conhecida como Compilação B), sob o título Leyenda de los Santos, chegaram até nós seis manuscritos, que deram origem a impressos incunabulares ${ }^{29}$. Desta tradição textual hispânica derivam as traduções portuguesas de que temos conhecimento. Sabemos que existiu uma no início do século XV, cuja filiação na tradição manuscrita castelhana é clara, e de que sobreviveu apenas um fragmento, entretanto desaparecido ${ }^{30}$. Do mesmo modo que este precioso fragmento, outros testemunhos portugueses terão provavelmente desaparecido. De 1513 data outra tradução portuguesa da Leyenda hispânica (conhecida por Flos Sanctorum de 1513), a única que nos chegou em forma não fragmentária.

Traduzida directamente do castelhano ${ }^{31}$, a versão portuguesa de $1513 \mathrm{da}$ paixão de S. Paulo nada inova relativamente ao conteúdo, mantendo-se, mesmo

\footnotetext{
${ }^{27}$ Noli dicere creatorem celi et terre, cum ipse uisibilium creator nom fuerit, sed dyabolus omnia ista que uidentur creuerit (12), Ad hoc, quod uerus deus uisibilium et inuisibilium creator monstretur et ad consalationem fidelium et confusionem hereticorum... (43).

${ }^{28}$ Alc. 40 (sécs. XIII/XIV), Alc. 39 (séc. XIV), Cod. 49 de Santa Cruz de Coimbra (sécs. XIV-XV) , Ms 180 do IANTT (séc. XV).

${ }^{29}$ Sobre a tradição textual das traduções castelhanas da Legenda Aurea v. Aragües Aldaz, 2007.

${ }^{30}$ Cf. Sobral, (2010); Viegas, (1916).

${ }^{31} \mathrm{O}$ texto encontra-se nos fls. 99d-101a d'Ho Flos Sanctorum em lingoagẽ português, impresso em Lisboa, em 1513, por Hermão de Campos e Roberto Rabelo. O antecedente directo deste legendário é uma perdida Leyenda de los Santos, talvez impressa em Saragoça, por Paulo Hurus, em 1490 ou 92 (cf. Sobral, (2009); Aragües Aldaz, (2007). As conjecturas sobre a lição provável deste incunábulo apoiam-se na colação entre um seu descendente directo, La Leyenda de los Santos, Burgos, Juan de Burgos, 1500, e o Flos Sanctorum português.
} 
no que à literalidade se refere, muito próxima do texto castelhano traduzido, o qual refundiu parcialmente o texto latino. Assim, seguindo fielmente a versão castelhana, do texto português desapareceu toda a matéria não narrativa ou que escapa à estrutura formal hagiográfica. Dos elementos anteriores à passio liniana, conserva-se apenas o périplo martirial e a breve descrição dos costumes do santo, ambos os elementos com lugar funcional numa legenda. Dos elementos posteriores, o pranto e o elogio, não narrativos, nada se conservou. Também a evocação de fontes quase desaparece, apenas «Santo Yllario» (fl.99d) no princípio e «sam Gregório» (fl.101a) no final formam uma espécie de «balizas» de autoridades onde saber qual o santo de nome Gregório que se alega é menos importante do que a ressonância que o nome, só por si, pode ter. Assistimos, portanto, a uma depuração do texto, liberto de tudo aquilo que não seja estritamente narrativo e formalmente hagiográfico.

O léxico militar assume formas caracteristicamente feudais:

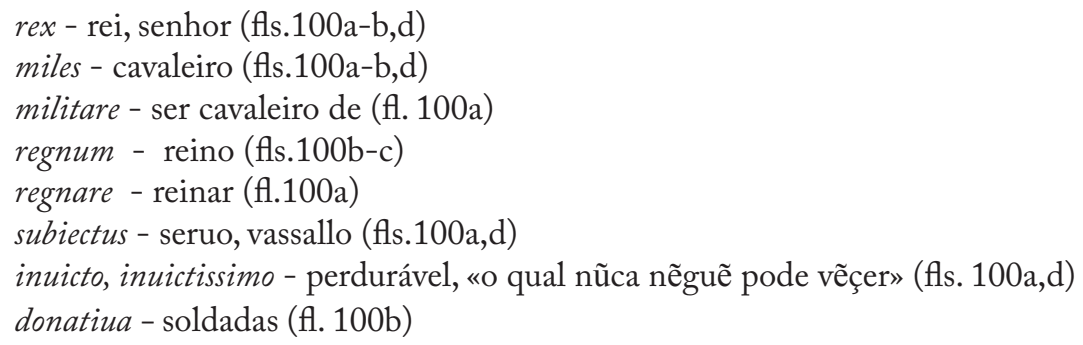

As traduções, e explicitamente a do Flos Sanctorum de 1513, visam como público leitor «os que a lengua latina nom entẽdem», para que «nom sejam priuados de tam exçellentes e marauilhosas vidas e exempros. Et por que cada hũ estando em sua casa despenda o tẽpo em leer tam exçellentes e sanctas vidas e exempros que outras ystoreas vaãs ou liuros de pouco fructo» (cólofon), isto é um público leigo (nobre e burguês), instruído, com uma cultura própria, que não lê latim mas gosta de histórias de aventuras, fábulas, romances de cavalaria, narrativas míticas ou históricas profanas («ystoreas vaãs ou liuros de pouco fructo»), que lê habitualmente. É um público com suficiente poder económico para comprar singularmente os seus livros (agora mais acessíveis devido aos menores custos de produção permitidos pela tipografia) e que os lê individualmente nos momentos de lazer da vida privada. Num contexto histórico sem heresias sistematizadas e em que o contacto com outras normas religiosas (judaica ou muçulmana) não representa significativo risco para os cristãos, há que supor uma recepção do texto menos pragmática do que a que poderá ter tido a legenda voragiana original. Com o seu significado simbólico-espiritual perfeitamente válido, a paixão de S. Paulo ocuparia, no séc. XV português, e ainda no início do XVI, o seu lugar como um dos elos da 
longa cadeia de epifanias que, na consciência histórico-religiosa dos cristãos, constituía a história da salvação. A libertação, nas versões hispânicas, de todos os elementos não narrativos e não hagiográficos favorece essa leitura e acentua o paralelismo formal com a série de outras paixões que o legendário oferece e ainda com aquelas outras, regionais, de que foi sendo acrescentado, quer na tradução castelhana quer na tradução portuguesa ${ }^{32}$.

\section{Paulo, companheiro de Pedro}

$\mathrm{O}$ retrato hagiográfico de $\mathrm{S}$. Paulo não estaria completo se não considerássemos ainda os textos em que nos é apresentado como personagem secundária ou em que divide a cena com S. Pedro. É o caso da Vida de S. Pedro compilada por Iacopo de Varazze (pp. 559-575, cap. 84) e traduzida do castelhano no Flos Sanctorum de 1513.

Recorrendo mais uma vez a fontes apócrifas (Pseudo-Marcelo, PseudoLino, Hegesipo e Pseudo-Leão, parafraseadores dos Acta Petri), desta vez temos uma narrativa onde constitui parte importante o combate entre Pedro e Simão Mago, prefiguração demoníaca e anti-crística, que Pedro vence em sucessivas batalhas taumatúrgicas até à queda final do encantador. $\mathrm{O}$ papel reservado a Paulo é aqui de simples ajudante, fornecedor de conforto espiritual na fraternidade e de auxílio pragmático na pregação. No episódio final da queda de Simão, fica claro o seu papel secundário: Dixit autem Paulus ad Petrum: «Meum est orare et tuum est imperare» (136). Muitas vezes a sua presença na acção apenas é perceptível pela associação de ambos em vocativos ou no discurso do narrador, embora nas cenas narradas apenas Pedro seja sujeito da acção. Presença compreensivelmente discreta, uma vez que, neste texto, é Pedro o herói e o seu brilho não deve ser ofuscado pelo de outra personagem de peso equivalente, poderíamos perguntar porque é que, apesar disso, Iacopo lembra ocasionalmente a sua presença. $\mathrm{O}$ facto resulta, em primeiro lugar, da utilização dos refundidores dos Acta Petri, Pseudo-Marcelo, Pseudo-Lino e Hegesipo, que, entre os séculos IV e VI, associaram os dois santos na mesma narrativa ${ }^{33}$. Mas trata-se sobretudo de dar fundamento e continuidade à tradição que associa ambos no imaginário medieval, em consequência do culto que, já desde o séc.III em Roma, lhes era prestado em conjunto ${ }^{34}$, na tradição das peregrinações a Roma e na liturgia ${ }^{35}$.

Mas não só o dominicano de Varazze divulgou Paulo na Idade Média. Em finais do séc. XIII, Bernardo de Brihuega, clérigo e colaborador de Afonso X,

\footnotetext{
32 Sobre a composição do Flos Sanctorum de 1513 v. Sobral, 2002-2003.

${ }^{33}$ Cf. Erbeta, 1966, 169-198.

${ }^{34}$ Bibliotheca Sanctorum X, col.196.

${ }^{35}$ Bibliotheca Sanctorum X, col.201-202.
} 
abraçou um vasto projecto hagiográfico em que planeava escrever, em cinco livros, toda a história do cristianismo: Vida de Cristo e de Santa Maria (Livro I), Vidas e Paixões dos Apóstolos (Livro II), Vidas e Paixões dos Mártires (Livro III), Vidas dos Confessores (Livro IV) e Vidas das Virgens (Livro V). Actualmente perdida a obra castelhana ${ }^{36}$, conserva-se em português o texto dos livros II e III. É no livro sobre as Vidas e Paixões dos Apóstolos ${ }^{37}$ que reencontramos S. Paulo. $\mathrm{O}$ público que o leu atravessou quase um século e meio. A tradução original remonta ao séc. XIV e foi, talvez, feita na corte de D. Dinis ${ }^{38}$ (onde se traduziram muitas outras obras de Afonso X). Dela sobreviveu apenas um fragmento ${ }^{39}$. Os monges de Alcobaça leram-na em cópia (Alc. cclXXXII/280) feita no séc.XV (1442-1443) e, em 1505, o impressor alemão da Vita Christi, Valentim Fernandes, a pedido da rainha D. Leonor, leva-a ao prelo, abrindo-lhe assim caminho a maior difusão.

A estrutura da obra é muito diferente daquela que é habitual em compilações hagiográficas, onde cada santo tem a sua própria legenda, isolada das restantes e na qual ocupa, sem competição, o papel principal. Poderíamos mesmo dizer que Bernardo de Brihuega não pensou numa estrutura específica para esta obra, limitando-se a seguir aquela que a justaposição das fontes utilizadas lhe impunham, razão pela qual só alguns apóstolos surgem mais ou menos isolados no conjunto. E, embora isto não deixe de ser verdade, também o é o facto de notoriamente ter procurado construir entre as fontes compiladas um encadeamento histórico, com recurso a fórmulas recorrentes em historiografia como «E por ende vos leixaremos aqui de falar del e contar-vos-emos de como...» (II, p. 42) e «E pois agora ouvide e contar-vos-emos...» (II, p.103) e com titulação narrativa de capítulos, na boa tradição historiográfica afonsina: «De como Sam Pedro e Sam Paulo forom presos e recadados» (II, 132). A vida do apóstolo cabe assim no devir histórico universal, tal como Afonso X o concebia.

Nos primeiros 128 capítulos, as Vidas e Paixóes dos Apóstolos traduzem os Actos canónicos, mostrando de S. Paulo a imagem neo-testamentária mais conhecida.

A partir daí, as fontes são apócrifas: vemos contado o episódio de Pátroclo, que terá sido colhido num dos refundidores dos Acta Pauli impossível de identificar com exactidão. Tudo o resto, até à morte de Paulo, foi colhido dos apócrifos Acta Petri et Pauli do Pseudo-Marcelo, embora, sobretudo na sequência relativa à condenação e martírio dos apóstolos, com um grau

\footnotetext{
${ }^{36}$ Sobre a obra de Bernardo de Brihuega v. Díaz y Díaz, 1963; Martins, 1949; Martins, 1963; Cepeda, 1975; Cepeda I, 1982-1989, xi-xcvi.

${ }^{37}$ Cepeda, 1982-1989.

${ }^{38}$ Cepeda, 1993, 76.

${ }^{39}$ Guardado nos Manuscritos Avulsos da Biblioteca Nacional de Lisboa (MSS. 5, nº 28), v. Cepeda, 1975.
} 
considerável de refundição $0^{40}$. Desta fonte não é usada a sequência inicial, onde se contam episódios da viagem de Paulo, desde que chega à Itália até Roma. E é só nessa sequência que ele tem destaque de protagonista. Nas Vidas e Paixóes dos Apóstolos, a narrativa canónica, traduzida dos Actos de Lucas, colase perfeitamente à chegada de Paulo a Roma, passando logo depois à disputa dos dois apóstolos com Simão Mago. Por isso, também aqui, como na Paixão de Pedro da Legenda Aurea, Paulo tem um papel secundário. Quanto ao relato do martírio, a desproporção de atenção e espaço dados a um e outro apóstolos também é notória, com o relato pormenorizado da prisão de Pedro, o famoso episódio do Quo vadis? e o prolongado martírio a contrastar com o resumo num simples parágrafo (p. 146) da decapitação de Paulo.

Numa visão de conjunto da obra, lida em Portugal pelos cortesãos de D. Dinis, por monges alcobacenses e pelo mesmo tipo de público que leu o Flos Sanctorum de 1513, a imagem de Paulo que sobressai, além do companheiro fiel de S. Pedro, na pregação como na morte, é sobretudo a do apóstolo evangelizador dos gentios, que os textos canónicos transmitem e que consagra a designação corrente de S. Paulo na literatura religiosa medieval, onde é omnipresente enquanto autor citado: «o Apóstolo», por antonomásia.

\footnotetext{
${ }^{40} \mathrm{Ou}$ talvez com recurso a um testemunho latino refundido do apócrifo (Martins, 1980).
} 


\title{
São Paulo na Arte Portuguesa da Idade Média
}

\author{
Luís U. Afonso \\ Universidade de Lisboa \\ Instituto de História da Arte da Universidade de Lisboa
}

\section{Introdução}

No verbete dedicado a S. Paulo, da monumental Iconographie de l'Art Chrétien, Louis Réau destaca que este santo nunca teve uma representação artística minimamente adequada à enorme importância que possui na história do cristianismo. ${ }^{1} \mathrm{O}$ principal motivo para esta escassa representação nas artes, segundo o mesmo autor, residiu no facto de o Apóstolo dos Gentios não ter recebido grandes manifestações devocionais por parte dos fiéis. Embora the seja reconhecido um papel chave na transformação do cristianismo numa religião ecuménica, contribuindo para o adequar à cultura greco-romana, do mesmo modo que lhe é atribuída a co-fundação simbólica da Nova Roma, juntamente com S. Pedro, nunca Paulo de Tarso alcançou a projecção visual e devocional do seu companheiro de martírio na capital do império. Enquanto o Clavígero se tornou orago de grande número de igrejas e paróquias, especialmente na Antiguidade Tardia e na Idade Média, são muito escassas as que foram dedicadas S. Paulo no mesmo período. Convenhamos, em todo o caso, que não era fácil competir com a figura simpática e paternal de $\mathrm{S}$. Pedro, o Porteiro do Paraíso e a quem se atribuía a faculdade de enviar chuva. Estes atributos constituíam, pois, um sério obstáculo para um pequeno e calvo ex-judeu, odiável ex-funcionário da máquina fiscal romana, temível experseguidor de cristãos e a quem foi necessário derrubar do cavalo, como nas imagens do Orgulho, para se converter ao cristianismo. Este neófito, apesar de reconhecidamente culto e inteligente, não mereceu a confiança de todos os Apóstolos quando se reuniu a eles em Jerusalém, muito depois da Morte e Ressurreição de Cristo. Em suma, apesar de S. Paulo ter ocupado o lugar de Judas entre o Colégio dos Apóstolos e de ter sido equiparado em importância a S. Pedro, enquanto refundador de Roma, quais novos Rómulo e Remo, as artes visuais e a devoção popular nunca fizeram justiça à importância histórica e teológica de S. Paulo.

Efectivamente, as imagens de S. Paulo realizadas em território português durante a Idade Média são pouco numerosas e pouco diversificadas, não se conhecendo ciclos narrativos dedicados à vida deste santo ${ }^{2}$. $\mathrm{O}$ estudo que se

\footnotetext{
${ }^{1}$ Réau, t. III, vol. 3, 1959, 1034-1050.

${ }^{2}$ Sobre a ilustração de episódios da uita de S. Paulo na arte nacional, especialmente no período moderno e contemporâneo, veja-se o recente estudo de Azevedo, 2010, 6-13.
} 
apresenta de seguida baseia-se numa selecção arbitrária de suportes artísticos de diferentes períodos cronológicos, ainda assim com o intuito de oferecer uma imagem aproximada do modo como S. Paulo foi representado entre nós durante a Idade Média.

\section{Frontais e tábuas de altar argentíferas do período românico}

Apesar de nenhum objecto artístico deste tipo ter chegado até nós, as fontes escritas portuguesas registam a encomenda, ou a existência, de algumas dezenas de tábuas e frontais de altar argentíferos desde os finais do século XI até ao século XIV. Na documentação medieval as tábuas colocadas em frente ao altar eram designadas como antependium ou tabula de ante altare, enquanto as tábuas colocadas sobre a mesa de altar eram designadas como tabulam altaris ou tabula de super altare. Estes objectos tinham uma estrutura em madeira revestida com uma superfície metálica em cobre ou prata dourada trabalhada com incisões e em relevo. Estas peças davam a sensação de as zonas frontais dos altares e das tábuas que se colocavam sobre os mesmos serem revestidas a ouro maciço, pelo que o prestígio deste tipo de objectos ultrapassava largamente o das tábuas pintadas. A julgar pelos poucos exemplares remanescentes no estrangeiro, em prata dourada ou em cobre dourado, e com base nas escassas descrições destas peças, o Apostolado era um dos temas mais frequentes neste tipo de objectos. ${ }^{3}$ Sem pretendermos ser exaustivos, apresentamos aqui uma lista de tábuas deste tipo referidas na documentação nacional:

1. Em 1087 o conde moçárabe de Coimbra D. Sesnando lega à igreja de $\mathrm{S}$. Miguel, situada no lugar de Mirleus (Ventura, 2003, 24), alguns bens em ouro, destinados a serem empregues na produção de um frontal, cruzes, cálices e outros recipientes litúrgicos. ${ }^{4}$

2. Entre 1086 e 1091 D. Boa Mendes doa cinquenta metcales de ouro à catedral de Coimbra para o douramento do altar de Santa Maria (idem,27).

3. Durante o episcopado de D. Miguel Salomão (1162-76) na Sé de Coimbra foram realizados ou melhorados um frontal e duas tábuas de altar pelo Mestre Ptolomeu (Rodrigues, Costa, 1999, 10). Presumimos que os sete marcos de prata doados por D. Afonso Henriques para a ampliação de uma tábua de altar da Sé de Coimbra tenham sido empregues numa das obras realizadas pelo referido mestre bizantino (Costa, 1983, 66).

\footnotetext{
${ }^{3}$ Sobre este tipo de objectos veja-se Afonso, 2010, 94-107.

${ }^{4}$ "frontalem, cruces, calices et capsas et quod de ornamento ecclesie fuerit» in Ventura, 2003, 24.
} 
4. Em 1172 é referida a doação de uma tábua de altar em prata à Sé de Coimbra por parte de um cavaleiro de nome Cipriano, falecido em $1172 .^{5}$

5. No testamento de D. Toda Viegas, padroeira e abadessa do mosteiro de S. Pedro de Arouca, redigido entre 1157 e 1167, refere-se também a doação de tábuas de altar (Coelho, 1977, 296).

6. No codicilo do primeiro testamento de D. Sancho I, datado de 1188 , estava prevista a doação de cinquenta marcos de prata para se fazer um frontal para a Sé de Évora (Martins, 1999, 32).

7. D. Sancho I, falecido em 1211, deixa ao Mosteiro de Santa Cruz de Coimbra cem marcos de prata para fazerem dois frontais de altar. (Sousa, 1946, 24-25). ${ }^{6}$

8. À igreja de Santa Maria de Santarém D. Sancho lega cinquenta marcos de prata para se fazer um frontal de altar (ibidem). ${ }^{7}$

9. D. Constança Sanches, falecida em 1269, doou aos Franciscanos de Coimbra cinquenta libras para se fazer um altar dedicado a Santa Catarina (Sousa, 1946, 29). ${ }^{8}$

10. D. Afonso III, falecido em 1279, mandou refazer o frontal e o crucifixo em prata da catedral de Coimbra (Costa, 1983, 69), tratando-se, eventualmente, do mesmo frontal que tinha sido realizado por Mestre Ptolomeu um século antes.

11. O bispo de Coimbra D. Pedro Martins, referido também como D. Pedro II, falecido em 1301, legou ao cabido da catedral de Coimbra quarenta marcos de prata, quinze dobras e seis morabitinos de ouro para se fazer e dourar uma tábua de altar lavrada com a história de Santa Maria (ibidem).

12. D. Raimundo de Ébrard (f.1324), bispo de Coimbra, e o chantre D. André Anes restauraram o antigo frontal do altar-mor da catedral, deixando a marca dessa intervenção em quatro brasões esmaltados (idem: 74-77).

13. De data desconhecida, registe-se ainda um sobrefrontal pertencente ao altar-mor da Sé de Coimbra representando Jesus Cristo a Coroar a Virgem, ao centro, rodeado por oito arcadas alusivas a vários passos da Vida de Cristo, designadamente a Natividade, a Ascensão e a Deposição no Túmulo (idem: 77).

${ }^{5}$ "Ciprianus miles qui fecit illam tabulam argenteam de altari» in Costa, 1983, 61.

${ }^{6}$ Importa ter presente, porém, que o grau de pureza da prata era bastante inferior ao dos nossos dias.

${ }^{7}$ Do seu tesouro pessoal, D. Sancho I ofereceu ainda uma taça de ouro com a respectiva cobertura para se fazerem dois cálices para as Sés de Braga e Lisboa: «Mando, Eं de meo vase auri cum suo coapertorio, ut faciant inde duos calices, E' dent inde unum Bracharensi Ecclesiae, E' alium Sedi Ulixbonensi.», in Caetano de Sousa, 1946, 24-25.

${ }^{8}$ Sobre os bens e legados de D. Constança Sanches veja-se o estudo de Vivas, 2007, 223-241. 
Infelizmente, de todas as referências que acabámos de enumerar, são raros os casos onde a iconografia e a forma das peças mereceu a atenção dos escribas, preocupados que estavam em registar o peso dos materiais nobres legados por piedosos benfeitores. Para o caso que nos interessa, apenas a descrição do antigo frontal do altar-mor da Sé de Coimbra oferece elementos de interesse. Realizado nos meados do século XII e restaurado nos inícios do século XIV, por ordem do bispo D. Raimundo de Ébrard (f.1324) e do chantre D. André Anes, a peça é descrita com algum detalhe no inventário de 1393 do tesouro da Sé de Coimbra (Costa, A. J., 1983: 74-77). De acordo com esta descrição, o frontal românico tinha um medalhão central que representava a Santíssima Trindade rodeada pelo Tetramorfo, sendo este medalhão ladeado pela representação dos doze Apóstolos, aos quais nessa altura já faltavam nove mãos. Atendendo aos modelos mais comuns, S. Pedro e S. Paulo seriam os apóstolos mais próximos da zona central, flanqueando o medalhão à esquerda e direita.

Embora a diferença entre as catedrais de Coimbra e de Compostela fosse grande no século XII, cremos que o antigo frontal e retábulo-mor da sé compostelana poderão servir-nos de termo de comparação para o frontal de Coimbra. O arcebispo de Compostela, D. Diego Gelmírez, dotou o altar-mor da Catedral de Santiago de Compostela com duas tábuas deste tipo, complementando o conjunto com um imponente baldaquino à maneira das basílicas de Roma. Num primeiro momento, o polémico arcebispo encomendou apenas um enorme frontal de altar em prata dourada, realizado em 1105-06, tendo posteriormente encomendado uma tabula retro altaris, realizada em 1135. Embora nenhuma destas peças se conserve, subsistem boas descrições contemporâneas deste altar e preserva-se ainda um desenho da tábua de altar realizado no século XVII. Em conjunto, estas informações permitem-nos ter uma ideia aproximada de como seria esta imponente peça litúrgica, apresentando-se aqui uma proposta de reconstituição realizada por Serafim Moralejo (Fig. 1). ${ }^{9}$

Também em Espanha, na Galiza, subsiste uma peça de altar deste tipo, embora esculpida em pedra, que nos oferece um paralelo muito preciso para as tábuas argentíferas. Trata-se do retábulo-mor da igreja do mosteiro de Santo Estêvão de Ribas de Sil, datado de inícios do século XIII, que representa Cristo rodeado pelos 12 Apóstolos, com S. Pedro e S. Paulo mais próximos do Redentor. Estas figuras, curiosamente, são esculpidas em crescendo, acompanhando a inclinação do remate da peça, ficando cada vez maiores à medida que se aproximam do centro da composição. Poderia dizer-se que o seu tamanho é directamente proporcional à maior ou menor importância simbólica de cada Apóstolo. Estas figurinhas apoiam-se sobre um conjunto

\footnotetext{
${ }^{9}$ Moralejo, 2004a, 161-188; 2004b, 289-299.
} 
de arcos/portas que ocupam o registo inferior, eventual alusão aos pontos de passagem dos eleitos no Paraíso (Fig. 2).

Em qualquer um destes casos - Coimbra, Compostela, Ribas de Sil - as imagens destacam a elevada preeminência dada ao Colégio Apostólico, expressa na sua proximidade a Cristo e na ideia de delegação de funções deste nos segundos. Outro facto que se destaca, a partir do exemplo remanescente, é que S. Pedro e S. Paulo surgem como «braços direito e esquerdo», respectivamente, de Jesus Cristo. Em Ribas de Sil estas três figuras são isoladas do restante grupo de personagens pela inclusão de duas colunas de separação. Cristo apresenta um nimbo cruciforme e está coroado. Enquanto faz o habitual gesto da bênção com a mão direita, segura na mão esquerda uma cruz processional de haste longa. À sua direita encontra-se S. Pedro, de barba encaracolada e farta cabeleira, que segura duas chaves na mão direita e um livro na mão esquerda. À esquerda de Cristo encontra-se S. Paulo, reconhecível pela calvície e pela barba pontiaguda. Em vez da habitual espada, este santo apoia-se num inabitual báculo em forma de tau e suspende na mão esquerda um rolo de pergaminho, aberto, que se estende até meio das canelas.

A importância dada aos apostolados na arte românica deve ser atribuída ao espírito da Reforma Gregoriana, que nessa época pugnava pelo regresso aos tempos apostólicos primitivos e à pureza da Igreja paleocristã. Se esta explicação tem todo o sentido nas obras associadas ao altar, local por excelência da performatividade litúrgica dos membros da Igreja, o mesmo não explica a razão de ser da preferência dada às imagens do Apostolado na tumúlaria medieval portuguesa, assunto que abordaremos de seguida.

\section{Túmulos românicos e góticos}

$\mathrm{Na}$ arte funerária portuguesa existe um conjunto de monumentos funerários que apresentam nas faces mais longas das arcas tumulares as figuras dos apóstolos. Com efeito, subsistem oito monumentos funerários, íntegros ou fragmentados, datados entre 1200 e 1400 que apresentam o Apostolado. Subsistem ainda mais dois outros túmulos do mesmo período que apresentam os Apóstolos na cena da Última Ceia, onde naturalmente S. Paulo não figura. Finalmente, subsiste ainda um túmulo onde S. Pedro e S. Paulo são representados isoladamente. Em relação aos monumentos que representam o Apostolado a organização das figuras pode ser realizada de acordo com duas tipologias:

a) os Apóstolos, incluindo S. Paulo, são representados em dois grupos de seis figuras, ficando cada grupo num dos lados maiores da arca;

b) os Apóstolos, incluindo S. Paulo, são representados todos no mesmo lado, podendo ter, ou não, a figura de Cristo ao centro.

A primeira tipologia está representada pelos seguintes monumentos: o túmulo de um Infante anónimo sepultado no panteão de Alcobaça, datável de 
c.1200; o túmulo da rainha D. Urraca (ou D. Beatriz), realizado nos meados ou finais do século XIII, também situado em Alcobaça; e o túmulo do bispo D. Pedro de Évora, datável de c.1350. De uma maneira geral, esta solução parece ser a mais antiga, sendo um arcaísmo a solução encontrada para o túmulo do bispo de Évora.

A segunda tipologia está representada pelos seguintes monumentos: o túmulo de D. Rodrigo Sanches, realizado por volta de 1245 , situado no Mosteiro de Grijó, apresentando ao centro a figura de Cristo; o túmulo do arcebispo de Braga D. Gonçalo Pereira, datado de 1334, apresentando o colégio dos Apóstolos sem a figura de Cristo; o túmulo da rainha santa D. Isabel, datado de c.1330, tendo a figura de Cristo no centro (Fig. 3); o túmulo de Rui Garcia do Casal, ou o que sobra dele, conservado em Santarém e datado c.1336, vendo-se o início da sequência de um apostolado figurado por três Apóstolos; e, finalmente, o túmulo de D. Inês de Castro, realizado entre 1358 e 1363, onde no segundo registo de uma das faces da arca encontramos os doze Apóstolos sem a figura de Cristo.

Os dois túmulos que representam a Última Ceia numa das faces maiores, pertencentes ao bispo do Porto D. Afonso Pires, datado de c.1360 (Lamego), e a João Gordo, datado de c.1330 (Sé do Porto), têm em comum a disposição das figuras ao longo da mesa rectangular: ao centro encontra-se Cristo, ladeado por seis Apóstolos de cada lado. Finalmente, refira-se ainda a representação das cabeças de S. Pedro e S. Paulo dentro de medalhões circulares no túmulo de D. Fernando, datado de c.1380. Refira-se que estes dois santos são reconhecíveis pela composição,já que flanqueiam um medalhão com a cabeça de Cristo, e pelas respectivas efígies, pois não apresentam qualquer atributo além da morfologia do rosto. Ou seja, S. Pedro tem barba e cabelo encaracolado e S. Paulo é calvo e tem barba pontiaguda. Neste caso, S. Pedro e S. Paulo são representados como os dois pilares da Igreja de Roma, solução que foi particularmente fecunda na pintura mural dos séculos XV-XVI.

\section{Pintura mural}

Num estudo anterior sobre a pintura mural produzida em Portugal entre c.1400 e c.1550 tivemos oportunidade de estudar os santos que estavam mais associados à autoridade papal e os santos que representavam as raízes do monaquismo ocidental. ${ }^{10}$ Em relação ao primeiro caso, verificámos que $\mathrm{S}$. Paulo praticamente nunca surge representado sem a companhia de S. Pedro. O inverso, porém, não se verifica, na medida em que o Clavígero surge mais vezes representado na pintura mural, sozinho, seguindo o modelo da entronização papal. Em todo o caso, as representações conjuntas de S. Pedro e S. Paulo

\footnotetext{
${ }^{10}$ Afonso, 2009, I, 399-401.
} 
parecem ter tido por objectivo acentuar a autoridade episcopal e eclesiástica, na medida em que se pretende sublinhar a autoridade dos dois fundadores da Roma Cristã e os valores apostólicos primevos que eles representavam. No segundo caso, referente à autoridade monástica, verificámos que existe uma insistência na representação dupla de S. Bento e S. Bernardo, procurando-se assim reforçar a legitimação da organização monástica onde tais figuras eram pintadas.

Quer num caso quer noutro, estas representações duais de S. Pedro e S. Paulo ou de S. Bento e S. Bernardo foram pintadas exclusivamente na capelamor das igrejas, não por acaso sobre a parede do altar-mor. Normalmente, o direito de padroado deste espaço estava na posse dos elementos mais privilegiados da sociedade, designadamente membros do alto clero ou da aristocracia, enquanto o corpo das igrejas ficava a cargo da comunidade de fiéis. Como sublinhámos no estudo já referido anteriormente,

“a conjugação destes dois dados complementares, de natureza iconográfica e de natureza topográfica, revela uma intencionalidade específica no que toca à afirmação de uma certa legitimidade da autoridade religiosa, eclesiástica e monástica, pelo que estas imagens devem ser analisadas em separado face às restantes representações hagiográficas, mais vocacionadas para a devoção dos fiéis e para a satisfação das suas necessidades." ${ }^{11}$

Nesse estudo verificámos que S. Pedro é um santo bastante popular contando-se doze representações suas. Como já referimos anteriormente, esta popularidade resulta da fama deste santo como «Porteiro do Paraíso» e de lhe ser atribuído um suposto controlo das condições metereológicas. Por sua vez, S. Paulo é um santo um pouco menos representado, do qual subsistem oito pinturas. Embora S. Paulo também fosse invocado contra os relâmpagos, o medo, a cegueira e o veneno das serpentes, ou contra as tempestades no mar, a verdade é que nestas oito representações S. Paulo está quase sempre dependente da representação de S. Pedro. Com efeito, em cinco das oito imagens este santo surge ao lado do Clavígero, em que a dupla assume a sua condição de novos Rómulo e Remo. Esta situação verifica-se nas igrejas de S. Tiago de Folhadela (Vila Real) (Fig. 4), na igreja de Santa Leocádia situada na localidade homónima (Chaves), na igreja de S. João Baptista de Souto de Lafões, na Capela de S. Brás da igreja de S. Dinis de Vila Real e, finalmente, na igreja de S. Paio em Vila Verde (Braga). Em todos estes templos, os dois santos são sempre representados na parede fundeira da capela-mor. Os dois santos são representados num enquadramento semelhante a um tríptico, ocupando os dois «volantes», enquanto o orago da igreja ou uma cena de índole mariana

\footnotetext{
${ }^{11}$ Idem, 399.
} 
ocupava o «painel» central. Finalmente, gostaríamos de referir que a festa destes dois santos se realizava no mesmo dia, a 29 de Junho, o que acentuava o carácter indissociável dos dois co-fundadores da Igreja de Roma.

Mantendo o mesmo princípio que observamos nas representações existentes na tumularia, nos frontais e retábulos de altar e na escultura arquitectónica, S. Pedro é sempre representado na direita heráldica, ou seja, está sempre à direita da figura central, enquanto $\mathrm{S}$. Paulo flanqueia a personagem central sempre no lado oposto. A única vez em que isso não sucede encontra-se no santuário rupestre de «Os Santos», situado junto ao rio em Sendim (Miranda do Douro). Nessa pintura, S. Paulo surge a ladear a Coroação da Virgem pela Santíssima Trindade, figurando na direita heráldica. No entanto, como nesta pintura falta a representação de um outro santo (ou santa) no lado oposto, não sabemos se a troca se fez com S. Pedro ou com outra figura. Contudo, julgamos que esta pintura não pode ser desligada da criação do episcopado mirandês, pela mesma altura, instituição que terá procurado tutelar este pequeno santuário eremítico, apoiando-se, simbolicamente, na autoridade de S. Pedro e S. Paulo.

De um modo geral, podemos concluir que as pinturas murais deste período, representando S. Pedro e S. Paulo, visavam acentuar o papel apostólico destes dois santos e a sua importância fundacional para o cristianismo. Daí que ambos sejam representados com um livro, aberto ou fechado, alusivo à autoridade das Escrituras. Como atributos específicos, normalmente S. Pedro tem as chaves do Paraíso enquanto S. Paulo apresenta uma espada, alusiva à sua decapitação. $\mathrm{Na}$ maior parte dos casos os santos encontram-se de pé e descalços, vestindo um manto sobre uma túnica simples, em memória da vida apostólica e do esforço de evangelização e proselitismo dos primeiros tempos da Igreja. Em relação a S. Paulo, apenas na pintura da igreja de Folhadela se optou por uma representação mais sacerdotal que apostólica, vestindo o santo com casula, em vez da capa utilizada nas restantes representações.

As únicas ocasiões em que $\mathrm{S}$. Paulo não surge representado na companhia de S. Pedro encontram-se na igreja paroquial de Valadares (concelho de Baião, distrito do Porto) e no claustro do Mosteiro da Batalha. Em relação a Valadares, a figura do santo encontra-se pintada na parede sul da capela-mor. A figura consiste num santo de barbas cinzentas que empunha na mão direita uma espada de pomo circular e guardas curvas, enquanto na sinistra segura um livro junto ao peito (Fig. 5). ${ }^{12}$ Em relação ao Mosteiro da Batalha a figura de S. Paulo surge isolada pintada num tramo de uma ala do claustro, representando-se também as arma Christi e $S$. João Evangelista em tramos autónomos de outras alas (Fig. 6). Trata-se de uma pintura da primeira metade do século XVI, alvo de uma recente intervenção de conservação e restauro, que

${ }^{12}$ É uma pintura em mau estado de conservação, pelo que é preferível recorrermos ao desenho que o director do Museu de Lamego fez desta figura em 1923. 
mostra o santo ao ar livre, numa paisagem com árvores e um edifício religioso, segurando uma espada e um livro. É representado com um nimbo circular, calvo e com barbas compridas, vestindo uma indumentária eclesiástica, tal como sucede em Folhadela.

\section{Conclusão}

Esta curta incursão na iconografia paulista portuguesa medieval permite concluir que este santo foi representado, maioritariamente, segundo uma destas tipologias:

1) o santo é representado como um dos doze Apóstolos, integrando de pleno direito o colégio apostólico. Esta terá sido a solução mais comum em frontais e tábuas de altar argentíferas, em monumentos funerários e em portais de igreja. Embora não tenhamos tido oportunidade de o referir, é precisamente esta a situação que encontramos no portal axial da Sé de Évora (c.1330), na entrada axial da igreja do Mosteiro da Batalha (c.1415-40) e na igreja matriz de Viana do Castelo (c.1430), com a particularidade de S. Pedro e S. Paulo serem as figuras mais próximas da entrada em cada jamba.

2) o santo é representado a par de S. Pedro, assumindo-se como um dos dois pilares da Igreja. Esta é a solução mais comum ao nível da pintura mural, como vimos, e representa uma selecção, ampliada, do Colégio dos Doze Apóstolos, na medida em que também aí S. Pedro e S. Paulo se encontravam em torno na figura central de Cristo.

3) o santo é representado isolado, num painel ou escultura própria, tendo como atributos a espada e o livro. Esta é a solução mais comum na escultura de vulto e na célebre tábua representando este santo atribuída à oficina de Nuno Gonçalves conservada no Museu Nacional de Arte Antiga. 


\section{Anexos}

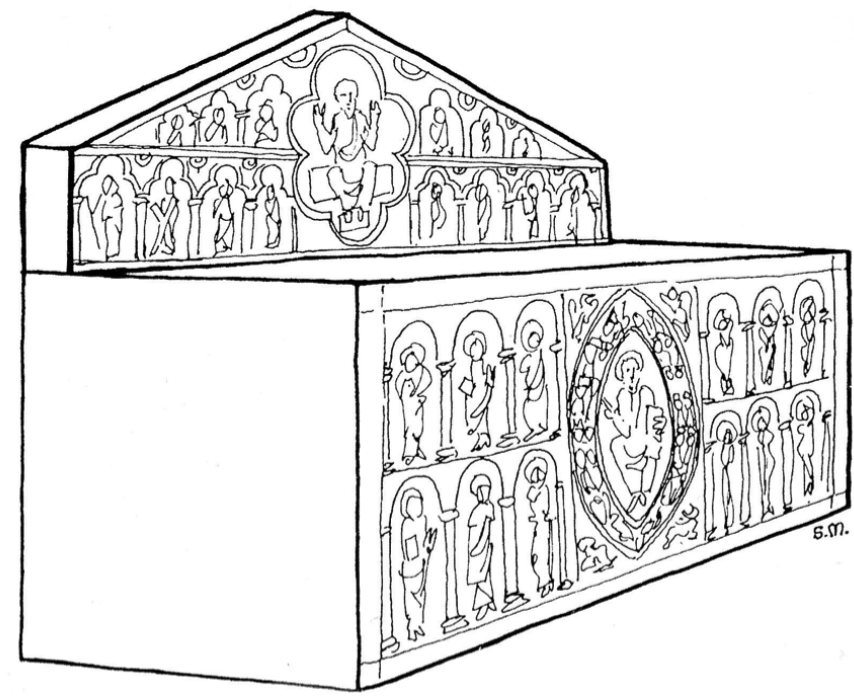

Fig. 1. Proposta de reconstituição do altar-mor da Catedral de Santiago de Compostela, 1105-06 (frontal), e 1135 (retábulo), segundo Serafim Moralejo.

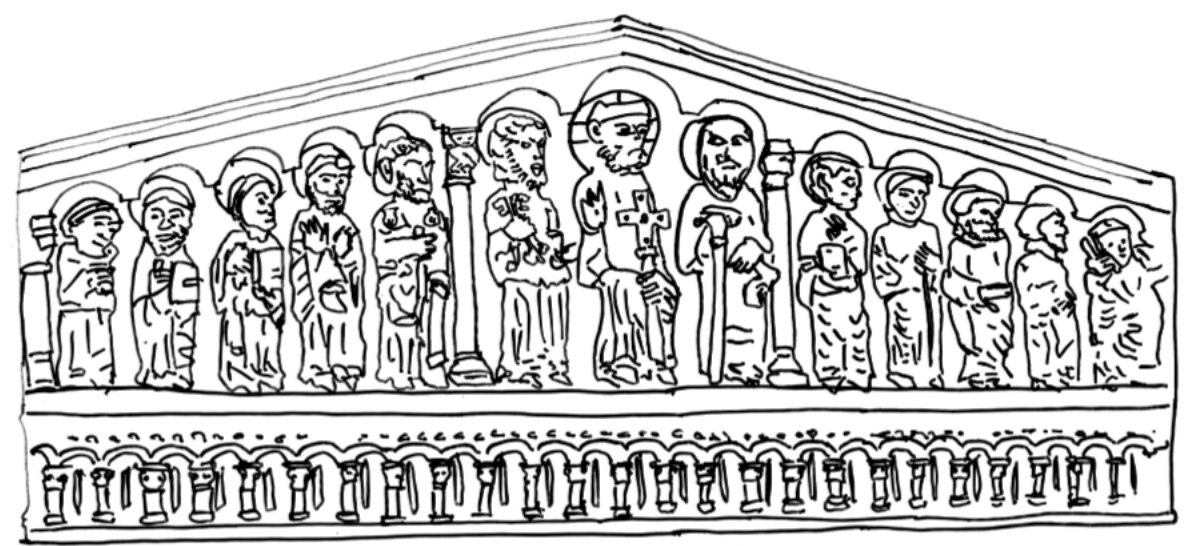

Fig. 2. Retábulo-mor da igreja do mosteiro de Santo Estêvão de Ribas de Sil, inícios do século XIII. Desenho: Luís U. Afonso. 


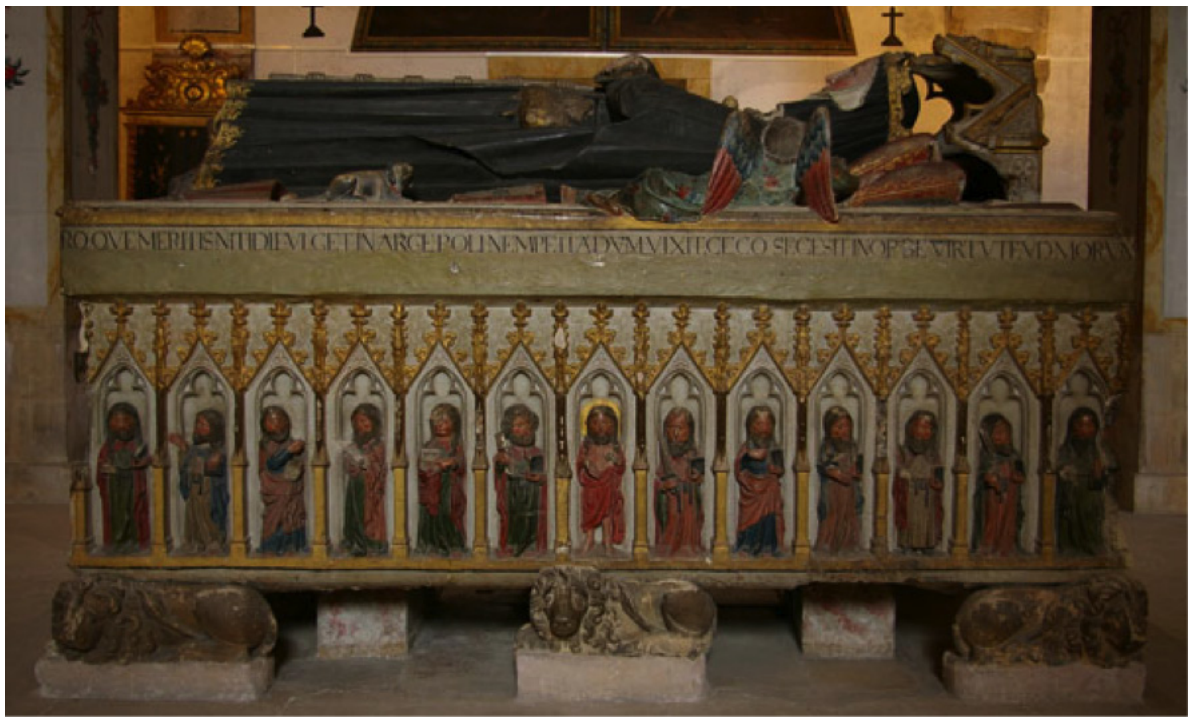

Fig. 3. Túmulo da rainha Santa Isabel. Mosteiro de Santa Clara-a-Nova, c.1330. Na imagem atente-se à representação dos Apóstolos no frontal da arca, com Cristo a ser ladeado por S. Pedro e S. Paulo, respectivamente à direita e à esquerda de Cristo. Foto: José Custódio Vieira da Silva (http://imago.fcsh.unl.pt/).

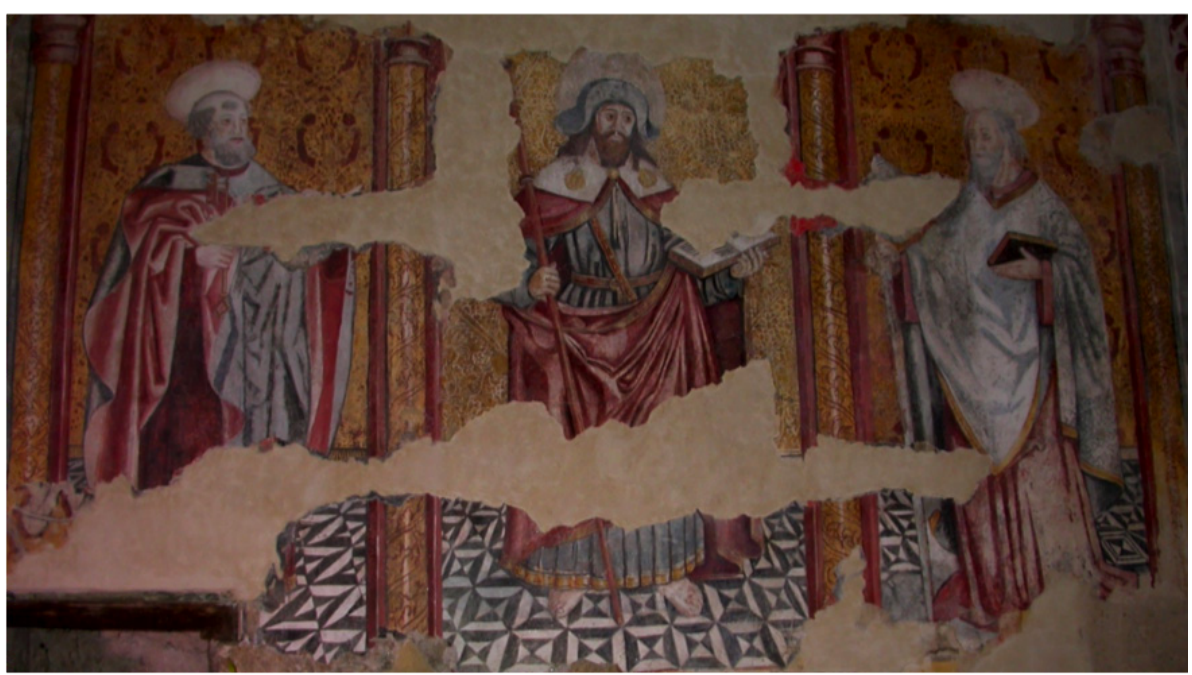

Fig. 4. Pintura mural da capela-mor da igreja de S. Tiago de Folhadela (concelho de Vila Real). A pintura representa S. Pedro e S. Paulo flanqueando o orago desta igreja, com $\mathrm{S}$. Pedro à direita do orago e $\mathrm{S}$. Paulo à esquerda. Pinturas realizadas por volta de 1520-30. Foto: Luís U. Afonso. 


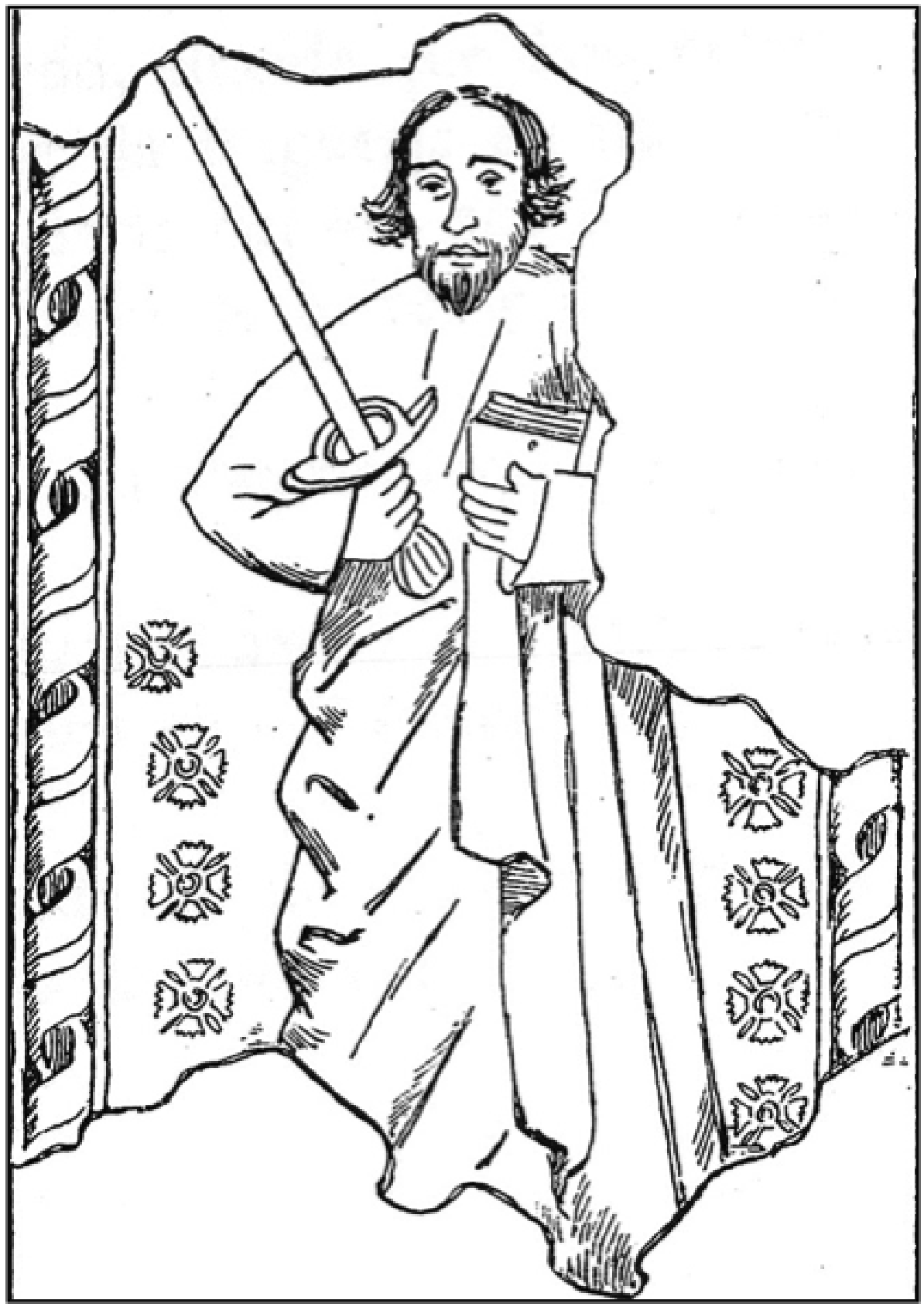

Fig. 5.S. Paulo, representado na parede norte da capela-mor da igreja paroquial de Valadares (Baião, Porto). Pintura realizada no último quartel do século XV. Desenho realizado por João Amaral em 1923 e publicado por Vergílio Correia em 1924 na obra Monumentos e Esculturas (Séculos III a XVI). 


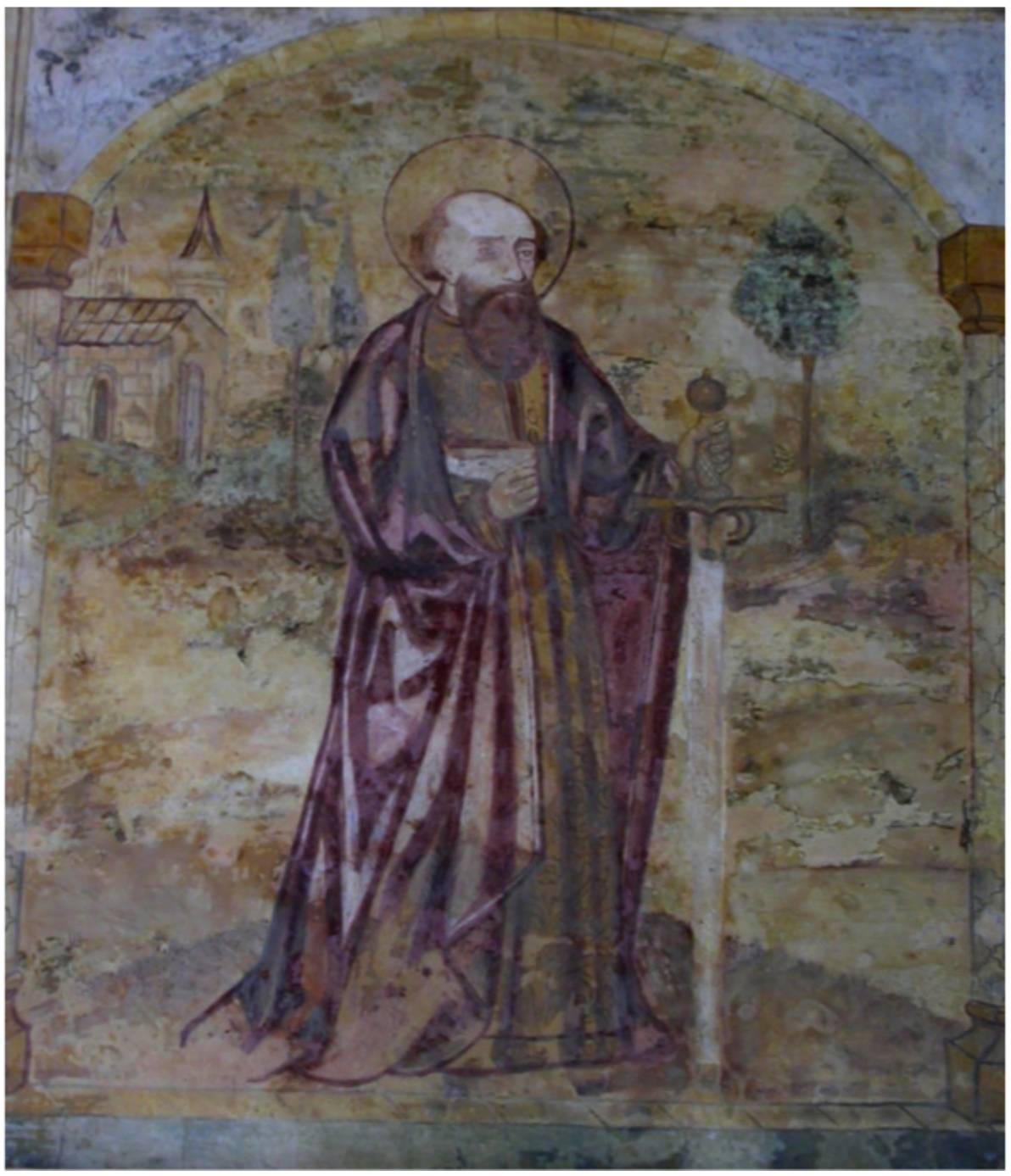

Fig. 6. S. Paulo. Pintura mural do Claustro do Mosteiro da Batalha, realizada entre c. 1520 e c. 1540 . 


\title{
O Apóstolo na obra de Vieira
}

\author{
Arnaldo do Espírito Santo \\ Universidade de Lisboa \\ Centro de Estudos Clássicos da Universidade de Lisboa \\ Centro de Estudos de Filosofia da Universidade Católica Portuguesa
}

Desde há vários anos que a obra de Vieira, principalmente a chamada obra profética, tem sido analisada sob as mais diversas perspectivas, onde predominam as tendências voltadas para o esoterismo, o milenarismo, a cabala judaica, a literatura rabínica da idade antiga e, sobretudo, a da moderna, e se privilegiam as fontes apocalípticas e visionárias, com predominância das profecias de Daniel e de Ezequiel, e ainda o Livro do Apocalipse. Não têm sido esquecidos, nem Joaquim de Fiore, nem Ubertino de Casalis, nem alguns dos construtores de miragens e utopias. Raramente se tem chamado a atenção para o peso, na obra de Vieira, da grande visão barroca do teatro do mundo, versátil como as próprias circunstâncias de um mundo em permanente mudança, e muito menos para o facto de Vieira ser Jesuíta e missionário, com uma formação teológica e bíblica entranhada até à medula.

Vem isto a propósito do tema que vou tratar. A minha intenção era falar da presença de São Paulo na obra de Vieira em geral. Mas ao fim de algumas horas de escrita dei-me conta de que a matéria é tão extensa que se revelou impossível ir além de alguns aspectos do pensamento paulino numa parte reduzida da obra de Vieira, isto é, na Clavis, e mesmo assim seleccionando apenas a estrutura do edifício, deixando de lado os ornamentos. É isso o que farei. No fim, talvez fique evidente que a arquitectura teológica da chamada obra profética do Pregador é toda ela edificada sobre a vida e as Epístolas do Apóstolo, entendendo por isso os Actos dos Apóstolos, as Epístolas autênticas e a Epístola aos Hebreus que Vieira considerava de São Paulo. A título de curiosidade faço notar que as ocorrências de Paulo e de «o Apóstolo» são cerca de 330, só na Clavis, sem contar as inúmeras alusões anónimas. Em um pouco mais de $1 / 4$ do total dessas ocorrências, São Paulo é designado pela antonomásia, «o Apóstolo», isto é, o Apóstolo por excelência que Vieira toma como guia no pensamento e exemplo na acção.

\section{Paulo e a doutrina da ignorância invencível}

As Epístolas paulinas são o grande alicerce bíblico em que Vieira assenta todo o edifício das suas ideias sobre o Reino de Cristo consumado na terra, 
sobre a legitimidade de perscrutar o futuro ${ }^{1}$, sobre a pregação universal ${ }^{2}$ e sobre a conversão de todos os povos a Cristo. As palavras do Apóstolo acerca da conversão dos Judeus depois da dos gentios servem de argumento a Vieira para provar que as dez tribos desaparecidas desde o tempo do exílio na Babilónia hão-de regressar ${ }^{3}$ e converter-se. Portanto, conclui Vieira, «o Evangelho, até aos nossos tempos, não foi pregado em todo o mundo, nem mesmo no tempo de S. Paulo» ${ }^{4}$. O que levou Vieira a interpretar como hipérboles os passos em que o Apóstolo o afirma. O Paulo Israelita, símbolo do judeu convertido, merece a Vieira manifestações de apreço e de emoção, pelo amor que o liga ao seu povo, como esta que passo a citar: «Paulo, levado por um incomensurável e ardentíssimo amor do seu povo, prefere sofrer não só toda a espécie de tormentos e a morte mais horrorosa possível, mas ainda ser privado, em favor dos Israelitas seus consanguíneos, do próprio Cristo, da glória celestial, da visão de Deus (salva apenas a sua graça), não por uma espécie de ausência e exílio temporais, mas durante toda a eternidade. Nada de mais extremo se pode dizer ou pensar, nada de mais evidente para provar a nossa hipótese, do que este acto, ou, para ser mais exacto, do que este portento de ferventíssimo amor e do que este excesso de expressão que supera todas as hipérboles e amplificações.. ${ }^{5}$ Vieira identifica em Paulo o paladino das mesmas causas que o motivaram a si próprio, a saber, a defesa dos novos gentios do seu tempo (os Índios) e a dos Judeus. $\mathrm{Na}$ interpretação de Vieira, as palavras do Apóstolo não há distinção entre gentios e Judeus, lidas em partitura moderna, significam «não há distinção entre cristãos-velhos e cristãos-novos», pois o mesmo é o Senhor de todos ${ }^{6}$.

Há, todavia, um aspecto que, pelo seu alcance teológico, merece uma atenção especial. Refiro-me à doutrina desenvolvida por Vieira em torno da chamada ignorância invencível, que em termos genéricos se define assim: todos aqueles que, sem culpa sua, ignoram a Deus são escusáveis de todas as ofensas que contra ele cometem. Mas, em termos também genéricos, ninguém

${ }^{1}$ Cf. $1 T s$ 5,1, citada em Padre António Vieira, Clavis Prophetarum - Chave dos Profetas, Livro III (Lisboa, 2000), pp. 19, 29, 31-33, 77, 79, 81. Conclusão de Vieira: «Demasiado à letra e aquém da intenção do Apóstolo ampliaria esta doutrina de Paulo, própria e peculiar, acerca daquele dia singular, quem a entendesse como referida a toda a espécie de preocupação sobre os tempos futuros, como se se tratasse de uma questão ociosa e inútil e que não nos diz respeito. Além disso, pareceria pensar menos rectamente acerca do Apóstolo que nós sabemos ter frequentemente revelado e vigorosamente inculcado nos seus ouvintes não poucos arcanos das coisas futuras com a sua palavra e as suas epístolas, como sendo proveitosas à salvação deles.» (Clavis III, 81).

${ }^{2} R m$ 1,8 e Cl 1,5 (Clavis III, 97); Rm 15,19-29 (Clavis III, 99); $R m$ 11,12.26 (Clavis III, 137); Cl 1,5 e $R m$ 1,8 (Clavis III, 139); $R m$ 10,18 (Clavis III, 175-181).

${ }^{3}$ Sobre a localização dessas tribos algures, nas regiões menos plausíveis, falava a literatura rabínica dos séculos anteriores e a contemporânea de Vieira.

${ }^{4}$ Clavis III, 139.

${ }^{5}$ Clavis III, 201-203.

${ }^{6} \mathrm{Rm} 10,12$. 
é escusável, porque, segundo o Apóstolo, que Vieira cita, "Os atributos invisíveis de Deus, incluindo o seu poder sempiterno e a sua divindade são entendidos e contemplados a partir da criação do mundo por meio das coisas que foram criadas» ${ }^{7}$. Num primeiro momento, Vieira, com o Apóstolo, declara que «os Romanos [...] e os seus filósofos, bem como os Gregos que eles seguiram e imitaram, eram réus de condenação eterna e absolutamente inescusáveis. ${ }^{8}$ " Num segundo momento, porém, lança o seguinte repto à ilação que os teólogos tiram das palavras de Paulo: se o simples conhecimento da verdade pode levar à prática de actos meritórios, então não será heresia dizer que todos os homens podem atingir a salvação pelas suas forças e méritos sem necessitarem do auxílio de Deus. O que em termos práticos é o mesmo que dizer que a humanidade, filósofos cultos ou índios incultos, não necessitava nem de evangelização nem de conversão, pois lhe bastará a prática de boas obras. E Vieira ilustra o seu pensamento com uma alegoria que vai buscar a Salmerón, um dos companheiros de Santo Inácio e teólogo reputado do Concílio de Trento.

Imagine-se um homem cego e paralítico, deixado à beira da estrada, próximo da cidade para onde se dirigia. Se viesse uma ordem que o mandasse entrar na cidade, o cego seria inescusável, se «a vista e as forças lho permitissem ${ }^{9}$. Mas se apenas a vista sem as forças ou as forças sem vista lho permitissem, neste caso seria escusável. Depois da alegoria, vem a pergunta nos próprios termos em que a formulou Salmerón: «Assim sendo, como é que o Apóstolo declara inescusável o gentio, por ele não ter posto em prática a verdade conhecida, quando ainda lhe faltava o auxílio da divina graça?» ${ }^{10}$

É neste sentido, partindo do Apóstolo, que se encaminha o pensamento de Vieira. Mas para inflectir nessa direcção, volta à Epistola aos Romanos, da qual cita o seguinte passo: «a ira de Deus manifesta-se do Céu contra toda a impiedade e injustiça daqueles homens que retêm a verdade de Deus na injustiça» ${ }^{11}$. Reter a verdade cativa da injustiça é, para Vieira, terem alguns homens chegado, antes de Cristo, ao conhecimento da unidade de Deus e, apesar disso, não o terem adorado e, em vez disso, terem prestado às criaturas e aos ídolos o culto devido só ao Criador. Aqui residiu, palavras de Vieira, «a iniquidade e a maldade daqueles homens, isto é, dos filósofos, que conheceram a Deus pelo raciocínio natural, e que opuseram à graça subsequente tão grande entrave, que se tornaram [...] merecedores de que a ira de Deus se manifestasse do Céu contra eles. ${ }^{12}$ » Mas não é isto

\footnotetext{
${ }^{7} \mathrm{Rm}$ 1,20. Cf. Clavis III, 249-251.

${ }^{8}$ Clavis III, 253-255.

${ }^{9}$ Clavis III, 257-259.

${ }^{10}$ Clavis III, 259.

${ }^{11} \mathrm{Rm} 1,18$.

${ }^{12}$ Clavis III, 267-269.
} 
mesmo o que diz o Apóstolo? Sem dúvida. Quer dizer, Vieira conhece tão profundamente o pensamento de São Paulo, que vai muito além de uma leitura restritiva das suas Epístolas, sem se deixar paralisar por pequenas contradições internas ou dificuldades de interpretação. E nesse sentido defendeu toda a sua vida a escusabilidade dos índios, opondo os raciocínios dos grandes teólogos ao simples bom senso do pensamento de um escravo negro, ainda criança, do colégio da Baía. Vieira felicitou-o por ter sido arrancado à cegueira do paganismo. Uma vez que foi baptizado, irá para o Céu, ao contrário do que aconteceu aos seus avós e antepassados. Ao ouvir estas palavras, «Ele - escreve Vieira - deteve-se um pouco, erguendo as sobrancelhas, e respondeu intrepidamente e seguro de si: "Os meus avós e os meus antepassados não estão no Inferno". E, antes que eu lhe perguntasse porquê, acrescentou: "Porque, se eles não conheceram a Deus, como podia Deus mandá-los para o Inferno? Ou como podiam eles ofender tanto a Deus ignorado que merecessem ser assim atormentados?” ${ }^{13}$.

Vieira explicita ainda mais o pensamento de São Paulo e o seu com a imagem de escada de Jacob pela qual subiam «anjos», não «homens», como faz questão de salientar. Em exegese alegórica este pormenor, diz Vieira, é «prova evidente de que este género de ascensão ao conhecimento de Deus, por meio das criaturas, foi apenas concedido e reservado àqueles que da natureza obtiveram uma inteligência mais sublime que a humana e quase igual à angélica, como foi o caso de um Platão, um Aristóteles, um Mercúrio Trismegisto. ${ }^{14}$ »

Com este raciocínio, Vieira não pretende enveredar por uma doutrina da salvação de pendor intelectualista. O ponto a que quer chegar é exactamente o contrário, pois declara como primeira conclusão que, por sua natureza simples, grosseira e rude, são escusáveis os índios do Brasil, os pobres, os desgraçados, os escravos. Mas mesmo entre os que se guindam com esforço pela escada acima, há muitos que se ficam pelos degraus intermédios, aqueles que «tendo diante o sol, a lua e as estrelas, se ficaram por esse degrau da escada, não subiram mais além, pensando que já tinham chegado a Deus» ${ }^{15}$. Basta olhar para as civilizações antigas. Fica no ar a pergunta: serão estes inescusáveis? Mas também está sempre latente a resposta do Apóstolo: qui omnes homines vult salvos fieri et ad agnitionem veritatis venire - «Ele quer que todos os homens se salvem e venham para o conhecimento da verdade» ${ }^{16}$.

Prosseguindo no comentário à Epístola aos Romanos, Vieira observa que «Além avançou o mais engenhoso de todos os poetas, o qual, depois de descrever artisticamente a criação do mundo, à qual Paulo se refere, vindo

\footnotetext{
${ }^{13}$ Clavis III, 331.

${ }^{14}$ Clavis III, 271.

${ }^{15}$ Ibid.

${ }^{16} 1 \operatorname{Tm} 2,4$.
} 
finalmente a designar o autor de tão grande obra, nega-lhe a unidade de verdadeiro Deus e, como que precipitando-se do mais alto degrau da escada, disse: 'Qualquer dos deuses que ele tenha sido'» ${ }^{17}$. Aqui «o mais engenhoso de todos os poetas» é Ovídio, que Vieira muito admira.

A segunda conclusão é, pois, que, nas palavras de Vieira, «nenhum dos antigos filósofos, ou pelo menos só com raríssimas excepções, foi mais além a partir do conhecimento do verdadeiro Deus adquirido pela contemplação das criaturas» ${ }^{18}$. Logo, também eles são «merecidamente» escusáveis, a ponto de escaparem «à pena da condenação eterna» ${ }^{19}$. E assim nos aproxima da universal vontade salvífica de Deus, segundo o princípio da primeira Epistola a Timóteo.

Argumentos, além dos de São Paulo, encontram-se nos historiadores pagãos e, particularmente em Diógenes Laércio, autor da Vida dos Filósofos Ilustres, o qual "passa a pente fino todas as suas nefandas e monstruosas paixões, com horror da própria natureza $»^{20}$, como diz Vieira, recorrendo ainda ao testemunho dos Padres da Igreja que «abominam neles a mesma corrupção de costumes ${ }^{21}$. Se tivessem chegado ao verdadeiro conhecimento de Deus, as suas acções não seriam tão más, porque «o verdadeiro conhecimento de Deus, quanto de si depende, induz os homens ao bem, mas fica amarrado, como que detido em cativeiro, pela prática da injustiça», como escreveu Alápide no comentário à Epistola aos Romanos, citado por Vieira ${ }^{22}$. Ora é precisamente o desconhecimento profundo e verdadeiro de Deus que os torna escusáveis. E, com isso, fecha-se o círculo e voltamos ao passo da Epistola aos Romanos, donde partimos: «Manifesta-se do Céu a ira de Deus contra a impiedade e a iniquidade daqueles homens que retêm na injustiça a verdade de Deus».

Além disso, para alcançar a salvação é necessária, absolutamente, a Fé na encarnação do Verbo e na Santíssima Trindade. E aqui entre de novo o Apóstolo com a máxima: «Como hão-de crer naquele de quem não ouviram falar? E como ouvirão sem haver quem lhes pregue?» ${ }^{23}$ Isto diz a Epistola aos Romanos, que Vieira cita ${ }^{24}$. Sem a Fé, insinua Vieira, interpretando São Paulo, realmente todos são inescusáveis. Mas com a seguinte ressalva: «Quem não crer será condenado» ${ }^{25}$, mas só depois de ter recebido a palavra do pregador.

É assim que o Apóstolo atravessa os aspectos mais sensíveis e mais originais do pensamento de Vieira nas questões que envolvem a acção missionária da

\footnotetext{
${ }^{17}$ Clavis III, 273. Cf. Ovídio, Met. 1, 12.

${ }^{18}$ Ibid.

${ }^{19}$ Ibid.

${ }^{20}$ Clavis III, 275.

${ }^{21}$ Ibid.

${ }^{22}$ Clavis III, 167.

${ }^{23} \mathrm{Rm} 10,14$.

${ }^{24}$ Cf. Clavis III, 277.

${ }^{25}$ Mc 16,16.
} 
Igreja, a evangelização dos gentios, a conversão dos Judeus e a vexata quaestio da ignorância invencível.

\section{Deus providenciou não providenciando}

«Salvação e Providência» poderia ser o título de uma questão complementar da secção da Ignorância Invencível. Vieira preferiu formulá-la em termos de uma interrogação: «Porventura Deus proporciona a todos, em medida suficiente, os meios necessários à salvação?26» A sua resposta, formulada parodoxalmente, é que Deus «providenciou não providenciando» ${ }^{27}$. Para conduzir a sua argumentação, Vieira socorre-se, mais uma vez, de São Paulo.

Em primeiro lugar é analisada a hipótese do ponto de vista das crianças. Segundo as palavras de Vieira, «Nas selvas mais profundas ou nos sertões desta América nascem com frequência crianças sadias e robustas, que, pouco depois, são levadas desta vida por uma doença súbita, sem serem baptizadas. ${ }^{28}$ » Esta, a situação real. Mas a quem se imputará a culpa disso «quando nem os pais, nem os habitantes da mesma aldeia, nem ninguém em toda a tribo, alheia a todo o contacto humano, nunca ouvira, nem mesmo em sonhos, a palavra 'baptismo'»??

A conclusão que Vieira não formula, mas que está implícita no tom das suas palavras, é que não foram concedidas a essas crianças os meios para se baptizarem e, mais ainda, sem culpa nem negligência de ninguém. Ora, como São Paulo afirma na primeira epístola a Timóteo ${ }^{30}$ que «Deus quer que todos os homens se salvem e que é um só o mediador entre Deus e os homens», daí se segue que Deus não proporcionou a todos os homens os meios de salvação (como ficou provado com as crianças dos índios), pois «Deus não é menos Deus das crianças do que dos adultos» ${ }^{31}$. Por mais que São Tomás, alegado em tom respeitosamente crítico, diga que se eles, os adultos infiéis, a quem não chegou a pregação, «[...] tivessem feito o que de si depende, o Senhor, segundo a sua misericórdia, teria providenciado enviando-lhes um pregador da fé, tal como enviou [...] Paulo aos Macedónios»² , Vieira rejeita a paridade de situação entre os Macedónios e os índios. De facto, como ele mesmo salienta, «a questão apresentada por $\mathrm{S}$. Tomás fala dos bárbaros criados nas selvas, como são hoje os de África, Ásia e América, povos rudes e completamente selvagens. Mas os dois exemplos aduzidos por S. Tomás são ambos de europeus, e, mais

\footnotetext{
${ }^{26}$ Clavis III, 431.

${ }^{27}$ Clavis III, 463, cf. 467, 473.

${ }^{28}$ Clavis III, 437.

${ }^{29}$ Ibid.

${ }^{30} 2,4-6$.

${ }^{31}$ Clavis III, 437-439.

${ }^{32}$ Clavis III, 441. Cf. Act 10,16.
} 
que isso, são especificamente daqueles que na Europa sempre foram tidos por mais sábios entre os restantes» ${ }^{33}$.

Posta esta reserva à opinião de $\mathrm{S}$. Tomás, que no fundo se refugia na exclamação do Apóstolo: «Ó profundidade das riquezas da sabedoria de Deus! Como são imperscrutáveis os seus caminhos!», Vieira passa a expor «uma opinião mais benigna sobre a bondade de Deus para com os selvagens» $»^{34}$, cujo fundamento sintetiza da seguinte forma: «Sendo, portanto, sacrilégio crer que lhes tinha faltado a Divina Providência, e, por outro lado, não sendo eu capaz de encontrar uma razão ou modalidade de tal providência, vim parar à ideia de que podia crer que Deus lhes providenciou, mas providenciou não providenciando. ${ }^{35}$ »

Permitam-me que anote desde já que os raciocínios de que Vieira parte são os mesmos da filosofia escolástica em relação à omnisciência de Deus, que engloba o conhecimento de todos os futuros, mesmo os chamados futuros condicionados. Mas voltemos a São Paulo.

Para argumentar em defesa da doutrina da Providência que providencia não providenciando, Vieira recorda dois episódios dos Actos dos Apóstolos ${ }^{36}$ : aquele em que Paulo e Timóteo «foram proibidos pelo Espírito Santo de anunciar a palavra de Deus na Ásia»; e aquele em que «Tendo chegado à Mísia, intentavam passar à Bitínia, mas não lho permitiu o Espírito de Jesus». São estes dois episódios da actividade apostólica e missionária de Paulo que determinam o pensamento de Vieira. Se um missionário é objecto de intervenção tão direccionada nos seus movimentos, com impedimento de pregar a uns e imposição de ir anunciar a fé a outros, é porque há uma razão profunda da parte da Providência. Além disso, Vieira recorda que o próprio Apóstolo, na Epístola aos Romanos, diz que foram muitas as vezes que se propusera ir pregar a fé em Roma, mas que foi impedido ${ }^{37}$. Conclusão de Vieira, tirada da meditação destes passos e do comentário de São Basílio: «Deus toma a seu cargo tanto as palavras como as viagens dos seus pregadores e fá-las depender dos sinais da sua vontade. ${ }^{38}$ » E como prevê, em toda a sua omnisciência, que a pregação da fé ou pode ser recusada, ou mal recebida, ou renegada, desvia os pregadores do seu percurso, impedindo que a mesma fé seja pregada, não para negar a graça mas para a diferir. Por outras palavras, Deus «Desistiu ou absteve-se de lhes conceder a perspicácia do intelecto e a pregação do Evangelho, e, negando estes dois benefícios, com um novo género

\footnotetext{
${ }^{33}$ Clavis III, 447-449.

${ }^{34}$ Clavis III, 453.

${ }^{35}$ Clavis III, 463.

${ }^{36} 16,6-7$.

${ }^{37} \mathrm{Rm} 1,13$.

${ }^{38}$ Clavis III, 469.
} 
de misericórdia, desta sorte providencia não providenciando. ${ }^{39}{ }$ 》 Proposição esta de Vieira, que se insere no espírito da exclamação paulina repetidamente citada: «Ó profundidade das riquezas da sabedoria e da providência de Deus!» Exclamação que se aplica também ao caso em que Cristo ordenou a Paulo que saísse de Jerusalém, porque os Judeus não receberiam o seu testemunho. Por tal motivo, é melhor para os Judeus que Paulo não pregue do que, pregando, se recusem eles a receber a pregação, uma vez que «Se taparem os ouvidos, não ouvirem nem crerem, já lhes foi ditada a sentença» ${ }^{40}$. Foi por essa mesma razão, conclui Vieira, que «os habitantes do continente americano estiveram privados da pregação do Evangelho» ${ }^{41}$.

\section{«Ele mesmo vos ensinará»}

Outro tópico vieirino em que São Paulo teve parte importante é o da «unção do Espírito Santo que por si mesmo» ensina a alma ${ }^{42}$. A formulação deste terceiro meio com que Deus incrementa a pregação do Evangelho (o primeiro é a pregação, o segundo os milagres) não podia deixar de levantar algumas suspeições sobre a ortodoxia de Vieira, dado o contexto da expansão das teses doutrinais das Igrejas reformadas no séc. XVII, um pouco por toda a parte, mesmo nos países católicos. Dizer, por exemplo, que Deus «ensina os homens por si mesmo, e que um dia deverão ser ensinados exclusivamente por Deus, e que assim será supérflua, inútil e desnecessária a doutrina humana que soa do exterior» ${ }^{43}$, era ir além de uma proposição que a sentença do Tribunal do Santo Ofício de Coimbra censurara em 1667, quando Vieira foi chamado a depor, por ter afirmado «que todas as nações do mundo hão-de crer em Cristo [...]; e há-de ser tão copiosa a graça de Deus que todos ou quase todos que então viverem, se hão-de salvar, para se perfazer o número dos predestinados» ${ }^{44}$. Mas o Padre Vieira tinha diante de si as palavras do Profeta Jeremias: «E ninguém ensinará o seu próximo nem o seu irmão, dizendo: conhece o Senhor; pois todos hão-de conhecer-me, do mais novo ao mais velho, diz o Senhor», palavras que ele próprio cita por três vezes e foram avalizadas por São Paulo, quando escreveu: «Vós mesmos aprendestes de Deus», que ele, Vieira, refere por duas vezes, passo que em sua opinião significa o mesmo que dizer que há "pessoas ensinadas só por Deus» ${ }^{45}$.

\footnotetext{
${ }^{39}$ Clavis III, 467.

${ }^{40}$ Clavis III, 485.

${ }^{41}$ Clavis III, 483.

${ }^{42}$ Clavis III, 513.

${ }^{43}$ Clavis III, 534-535.

${ }^{44}$ António Vieira, Obras Escolbidas VI, pref. e notas de António Sérgio e Hernâni Cidade, Lisboa, Sá da Costa, 1952, 185-186.

${ }^{45}$ Clavis III, 537.
} 
É este o caminho que leva o Padre Vieira a refutar a doutrina da predestinação institucionalmente aceite, opondo a opinião do Apóstolo Paulo à do filósofo Francisco Suárez. Os teólogos parecem esquecer a Escritura quando formulam as suas doutrinas. «Julga Suárez - afirma Vieira - que Deus predestinou e ordenou as coisas dos seres humanos de tal maneira que entre eles haja sempre bons e maus, fiéis e infiéis, e que esta mistura há-de durar sempre até ao fim do mundo. Retire aquele «sempre» e conciliará as Escrituras com a sua opinião. Com efeito, assim como é certo que a dita mistura durou muitos séculos, como distintamente vemos, assim também não se pode duvidar de que muitas pessoas predestinadas do mesmo povo sejam reservadas para outro tempo futuro em que todos se salvem» ${ }^{46}$. E o argumento de que o Pregador se serve é, muito a propósito, tirado da Epístola aos Romanos: «Porque uma parte de Israel caiu na cegueira até que entrasse a plenitude dos gentios, e assim todo o Israel se salvasse» ${ }^{47}$.

Em toda a obra de Vieira perpassa a certeza de que, a partir da Encarnação do Verbo, toda a humanidade em todo o universo se dirige para Cristo. Dos dois povos de que é constituído o mundo, o judeu e o gentio, Cristo fará um só povo, como um só redil sob um só pastor. E Vieira recorda que o Apóstolo, na Epístola aos Efésios ${ }^{48}$, escreveu que Cristo eliminou e destruiu o muro que separava os Judeus e os gentios. Trata-se de um muro imaginário, mental, como a linha do equinócio (comparação vieirina) que cabe aos Apóstolos e seus sucessores derrubar. De Paulo - sempre Paulo na mira de Vieira - disse Cristo: «Este é um instrumento escolhido por mim para levar o meu nome aos gentios, aos reis e filhos de Israel $»^{49}$ Mas serão duas conversões que se processam em paralelo, mais rapidamente a dos gentios do que a dos Judeus, até que, já crentes, uns e outros ingressem no mesmo redil «e assim todo o Israel será salvo, como ensina o Apóstolo» ${ }^{50}$, que Vieira cita e segue para construir a sua grande visão da marcha do mundo para o Império de Cristo, o quinto sobre a terra.

Os comentadores de Vieira, quando falam da sua visão profética que envolve a Igreja e o mundo, geralmente esquecem ou ignoram esta dimensão teológica profundamente paulina, arreigada na alma de um sucessor dos Companheiros de Inácio de Loiola, conhecidos popularmente por «os Apóstolos». A figura de Paulo, os seus actos, a sua personalidade, a sua vivência, a sua adesão a Cristo, a sua grandiosa visão de Cristo Senhor do Universo e fim supremo da História, não podem deixar de se ter em consideração quando se lê e comenta a obra e o pensamento do Padre António Vieira.

\footnotetext{
${ }^{46}$ Clavis III, 627.

4711,25 .

${ }^{48} 2,14$.

${ }^{49}$ Act 9,15. Cf. Clavis III, 693.

${ }^{50}$ Clavis III, 699.
} 


\title{
Paulo de Tarso e Teixeira de Pascoaes
}

\author{
António Cândido Franco \\ Universidade de Évora \\ Centro de Estudos em Letras da Universidade de Évora
}

São Paulo de Teixeira de Pascoaes (1877-1952), publicado em 1934, é um livro marcante na obra do autor e traça mesmo uma fronteira entre o que está antes e o que vem depois. Pascoaes sobreviveu ao livro dezoito longos anos, que foram dos mais activos e laboriosos da sua vida de poeta. Nesse período deu à estampa quatro outras biografias (São Jerónimo, Napoleão, Camilo e Santo Agostinho), uma autobiografia espiritual, um livro de viagens (que é talvez o acume da sua obra de escritor), dois romances, dois livros de versos, uma súmula de ideias, num total de milhares páginas, isto sem falar das outras milhares que deixou inéditas, algumas delas ainda hoje por publicar.

O livro de 1934 está na origem duma reviravolta decisiva da obra de Pascoaes, que a partir dessa altura trocou quase em absoluto o verso pela prosa. A chave que nos permite entender este modo poético final de Teixeira de Pascoaes, que vai de 1934 a 1952, encontra-se com certeza na abordagem cerrada do processo narrativo desse período, mormente das particularidades do seu narrador. A parcela poética de que estamos aqui a falar foi toda ela dada a conhecer depois do desaparecimento de Fernando Pessoa - salvo o São Paulo, dado à estampa uns meses antes da morte do autor de Mensagem - e pode ser tida por múltiplas razões, desde logo cronológicas, como pós-pessoana.

Julgo por isso que a decisiva afirmação que o grande poeta surrealista português Mário Cesariny fez em 1973 - Teixeira de Pascoaes, poeta bem mais importante, quanto a nós, do que Fernando Pessoa - só no quadro destes dezoito anos finais se entende em plenitude.

São Paulo de Teixeira de Pascoaes é uma obra enganadora e esmagadora. O leitor que da literatura do autor não conheça mais que superficialidades feitas, como as que enxameiam os manuais, espera porventura encontrar uma hagiografia canónica, presa de simpatia, com um processo narrativo de aproximação à personagem, em que a dramatização, o ponto de vista interno, $\mathrm{o}$ diálogo mimético, tenham um lugar de relevo. Demais, num livro que trabalha o século I, aguardará ainda uma reconstituição histórica do Médio Oriente bíblico, uma arqueologia histórico-cultural capaz de fazer reviver os espaços e as figuras que deram vida ao passado.

Ao invés, a biografia de Teixeira de Pascoaes contraria estas expectativas, a ponto de a podermos classificar de biografia desalinhada, logo a começar pela narração. Não há, salvo duas excepções irrelevantes (cap. II e cap. XIV), um 
único diálogo ao longo dos vinte e três capítulos que a constituem. Também as formas de perspectivar a história a partir do ponto de vista interno à personagem, o monólogo interior, não são significativas. Daí que toda a fonte de informação desta narrativa nunca saia das mãos do narrador. A primeira grande novidade do Paulo de Pascoaes prende-se com esta subversão do modelo narrativo mais comum; sem dramatização, sem diálogo, sem imitação não há verosimilhança poética.

A primeira consequência de vulto desta opção narrativa, que passa por retirar a palavra às personagens, rasurando o discurso directo da narração, é o papel do narrador. É dele o ponto de vista permanente com que se aborda a matéria narrada; é ele que desde o princípio ao fim do livro, em qualquer momento, está em contacto directo com o leitor. Mesmo que conte uma história, ele, o narrador, nunca abandona o proscénio. É óbvio que uma presença assim compacta e avassaladora não pode deixar de representar na narrativa em causa uma entidade própria, que ao longo das páginas se revela porventura mais definida e actuante que o próprio protagonista.

Quer isto dizer, que o Paulo de Pascoaes é uma autobiografia, em que o protagonista se confunde ao narrador? Paulo metáfora de Pascoaes? Já lá iremos. Para já importa conhecer, em narrativa assim diegética, com tão pouca dramatização, qual a identidade deste narrador sempre presente; é quase certo que dele depende a forma de modelação do Paulo que encontramos neste livro. Percebendo os traços deste narrador, ficamos com certeza a saber alguma coisa da sua personagem, antes mesmo de nos debruçarmos sobre ela.

O narrador do São Paulo de Pascoaes não tem uma identidade ficcional. Não lhe conhecemos nome, passado ou presente. Trata-se tão-só duma instância enunciativa, uma voz que narra. Ainda assim o narrador do São Paulo tem um perfil, um perfil consistente de valores, cujo conhecimento se mostra na verdade intorneável para um conhecimento prévio da sua personagem. Este narrador declara os seus gostos, faz afirmações de princípio, toma posições, mostra inclinações, professa uma linha de valores. Em resumo, é uma voz activa e bem definida dentro da narração, como não podia deixar de ser num caso de representação não-mimética.

Se nos pedissem três elementos representativos deste perfil, capazes de ajudarem ao entendimento prévio da história e ao mesmo tempo a uma definição concisa do ideário da voz de enunciação, seleccionaríamos os seguintes artigos, até pela frequência com que aparecem repetidos ao longo da narrativa: a criação do mundo é encarada como um pecado; Deus, o Criador, arrependeu-se do seu pecado, a criação (o mundo); é preciso valorizar o pecado como loucura sublime e o remorso como força de resgate.

Seria demasiado moroso ilustrar com exemplos tirados do livro, tanto mais que como se disse eles se repetem com apertada regularidade. Bastam 
dois parágrafos, inseridos estrategicamente no longo «Prefácio» que antecede os vinte e três capítulos da narração, para se perceber a importância crucial dos três artigos atrás referidos. De resto, o «Prefácio» tem papel determinante na delineação do narrador como instância bem definida em termos de ideias próprias, o que se compreende tendo em atenção o seu aspecto introdutório.

A criação é imperfeita; e, por isso, o homem é o pecado. Criar é ofender a lei, é um acto criminoso. Deus, que é vida, sonhou a existência, a morte. $\mathrm{E}$ realizou o seu desejo em Adão e Eva. Realizou, pecou. O pecado, ou o crime, está na origem de todas as cousas. Cada estrela é uma ferida aberta, a sangrar, e é uma nódoa de sangue a Via Láctea. A existência é um crime perpétuo. Que é viver, senão morrer, matando? A terra foi natural, quando pertenceu a todos os animais à solta e a todas as árvores crescendo livremente, a terra antes do homem espiritual, visionado por S. Paulo.

Deus, sentindo a imperfeição da sua obra, não a pôde destruir. Noé salvou-se na barca. Resta apenas emendá-la, expiar o crime. É o significado do Calvário. Jesus é o remorso de Deus, o Filho. (2002: 30)

Esta concepção dum Deus pecador, cujo maior pecado é o homem, atravessa todo o livro e ajuda a perceber muita da importância que Paulo de Tarso tem aos olhos de Pascoaes. Mas antes mesmo de explicar Paulo, esta noção do homem como pecado de Deus serve de ponte para outro dos complicados e capitais enredos do narrador de Pascoaes, a valorização do ateísmo, que levará depois, no Santo Agostinho (1945), à canibalização da santidade e à ideia dum ateoteísmo ou dum ateísmo divino, que nos parece já fora de propósito textualizar aqui. O São Paulo é apenas o ponto de viragem duma poética, que depois se aprofundou em sucessivos livros, ao longo de quase vinte anos.

Esta valorização do ateísmo ou das experiências da negação em relação a Deus é um dos tópicos que o narrador de Pascoaes arrecadará deste livro, transmitindo-o em herança aos narradores posteriores, que a desenvolverão e alargarão em sentidos inauditos. É por esse motivo que muita desta literatura final do autor é credora do livro publicado em 1934. No seu estado inaugural a valorização do ateísmo pelo narrador hagiográfico - melhor diríamos hagiomáquico - de Pascoaes é como segue.

O moderno ateísmo, essencialmente político, não resulta dum estado definitivo do nosso espírito. E a acção dos ateus é mais fecunda, no campo religioso, que a dos crentes. É uma aç̧ão de hostilidade criadora; e a crença dos crentes representa um acordo estéril e pacífico. (2002: 263)

Depois de vivermos a intimidade deste narrador, não é difícil perceber quem é o Paulo de Pascoaes. É o pecador, quer dizer, uma imagem de Deus, 
do Deus possuído pela sublime loucura da criação. Logo aquilo que o narrador mais decisivamente valoriza na sua personagem é o pecado de Paulo, como homicida de Estêvão, lapidado em Jerusalém por volta do ano 35, e perseguidor dos primeiros cristãos. De resto todos os santos tratados por Pascoaes neste seu período final são "pecadores», ao ponto de o narrador de Santo Agostinho afirmar mesmo que o mais belo de um santo são os seus pecados. A primeira consequência duma tal asserção é a impossibilidade da santidade, que se volverá impossibilidade narrativa em torno dum santo. Daí a hagiomaquia, tão consistente e tão presente no Santo Agostinho com o declarado abandono da narrativa. Mas em 1934 estamos ainda longe desta desconstrução absoluta da vida dum santo (que é aquilo que se passa no livro de 1945).

Por esse motivo o Paulo de Pascoaes, ainda à imagem do Criador, é outrossim o arrependido, mordido pelo remorso do pecado. Deste estado resulta a decisão de corrigir a trajectória do erro. Esta decisão, que no Santo Agostinho é desvalorizada, é no caso do São Paulo de primeira importância. A narração da vida de Paulo, como facto empolgante, é aí que toma lugar. O que está em causa é a transformação do homem clássico, melhor, do cidadão romano, materialista e desiludido, no homem novo, ascético e moral, de genealogia bíblica. Temos então Paulo possuído pelo impulso poético de criar um mundo novo, teimando com contumácia em alargar o Evangelho aos gentios. A subversão do mundo clássico faz-se pelo incêndio desta novação.

De qualquer modo, por muito que os passos deste Paulo poeta e sonhador duma nova idade sejam de molde a entusiasmar o narrador de Pascoaes, criando uma linha de narrativa que nunca perde o fio, a representação anti-dramática da história acaba por se impor, sobrepondo o plano da «narração» ao da «narrativa». Prova disso é por exemplo a passagem do tempo enunciado ao da enunciação. Dito de outro modo o passado da história sofre sobressaltos importantes, subversões de princípio, aparecendo em momentos estratégicos substituído pelo presente do discurso ou da enunciação. Veja-se o seguinte exemplo, que carreia inclusive a dramatização da vida do narrador, sem que mesmo assim o avaliemos como personagem com identidade ficcional:

A subida de Paulo a Jerusalém é uma cena, como, por exemplo, a morte de Tolstoi, a única cena bíblica dos tempos de hoje. Também me faz pensar numa avezinha, que passa as noites de Inverno, sob o tecto do pátio de entrada de minha casa, num pequeno recanto, que a protege contra a escuridão tempestuosa. A presença de pessoas não a intimida, nem a luz dum foco eléctrico, acendido, de repente. Lá está, toda metida nas suas asas, imóvel, com o bico pendido e triste, nessa atitude suprema de desolação, resignada. É ela, tão pequenina e desprotegida, e a negra noite infinita... (2002: 116), 
Um facto da narrativa, relativo ao ano de 47 (saída de Antioquia e chegada a Jerusalém de Paulo, Tito e Barnabé) serve de trampolim ao aparecimento dum facto do século XX, a morte de Leão Tolstoi, que só pode ser entendido dentro do tempo próprio da enunciação e não do enunciado. Não satisfeito com esse salto temporal da narrativa para a narração, o narrador de Pascoaes dá-se ainda a liberdade de permanecer no plano da enunciação, dramatizando um recanto da entrada da sua casa e abandonando por largos momentos a sua personagem e o tempo do enunciado.

É evidente que um tal processo de narração nos faz lembrar os sobressaltos narrativos de autores românticos como Garrett ou Camilo. Quem não se lembra das longas divagações do narrador de Viagens na Minha Terra, que lhe permitem transformar uma modestíssima viagem de Lisboa a Santarém num denso romance de quarenta e nove capítulos? O mesmo para Camilo.

O caso de Pascoaes é porém diferente. Enquanto Camilo e Garrett avançam os seus longos excursos relativos ao tempo da enunciação ou por diletantismo lúdico, como é muitas vezes o caso de Camilo, ou por simples necessidade de alongar um curto espaço narrativo, como acontece no romance de Garrett, Pascoaes não parece partilhar nenhum desses motivos. O seu narrador não tem os tiques da distanciação, nem tão pouco precisa de efectuar cortes na narrativa de modo a fazer durar o seu caso. A sua matéria narrativa é suficientemente longa para lhe permitir a narração e o perfil do seu narrador, por vincado que seja, tem sobriedade bastante para não se entregar aos jogos do esconde-esconde do narrador camiliano.

Perguntar-se-á então que razões podem motivar numa narrativa de matéria ampla e narrador sóbrio a sobreposição da enunciação ao enunciado, mostrando uma narrativa em que o presente da narração se acaba por sobrepor múltiplas vezes ao passado da narrativa e em que o narrador toma em momentos tão decisivos o lugar da personagem? A resposta só pode ser a seguinte: Pascoaes quis escrever um Paulo cuja história não estivesse para sempre enterrada no passado; quis um Paulo vivo, que interpelasse o presente da leitura e todos pudessem sentir como um homem comprometido no contemporâneo. Dito de outro modo, Pascoaes quis ver o Cristianismo como um facto do presente e não do passado.

Se atentarmos nos momentos cruciais do sobressalto narrativo, em que o tempo da enunciação toma o passo ao enunciado narrativo, reparamos que alguns deles, ou mesmo todos por interpostas figuras, se fazem em função dum paralelo entre mundo romano e modernidade filosófica e científica. Por isso este livro mais do que um livro sobre o passado pretende ser um livro sobre o presente; o passado é apenas uma forma de falar do presente. Falar de Roma é falar de Londres, Paris ou Nova Iorque. Este Paulo é de feito uma metáfora do próprio Pascoaes (enquanto Tolstoi amarantino), corpo e imagem um do outro, como neste livro o passado romano o é do presente americano. 
Neste sentido, o livro de 1934 mostra claramente o propósito de intervir no presente. É um livro que não hesita em falar dos problemas civilizacionais da contemporaneidade, debatendo-os em momentos cruciais da narrativa, aqueles mesmos em que o tempo da enunciação se sobrepõe ao da narrativa. Se quisermos perceber em que sentido é que este debate se faz vale a pena atentar nos sobressaltos narrativos do último capítulo, pela excelente posição que ocupam junto da memória do leitor, se bem que todos os anteriores, e alguns são, tenham papel também determinante. Vejam-se alguns períodos desse derradeiro capítulo.

O mundo foi da Poesia, nos primeiros séculos da nossa era. Repetir-se-á o milagre? Voltará o deus dos poetas contra os sábios, que só acreditam na matéria, e com elas fabricam explosivos, gases asfixiantes, máquinas pavorosas? Nesta orgia industrial moderna, paródia em ferro e vapor, da orgia pagã, o homem está morto ou isolado do seu espírito. Existe, mas não vive. Existe a duzentos quilómetros à hora, mas com a vida parada, dentro dele. Vida inerte numa existência delirante. Seduzido pelo ruído e movimento, as duas faces desta civilização americana ou neo-neroniana, integrou-se num sistema mecânico industrial e é simplesmente uma engrenagem. (...)

Esta civilização americana depende materiais esgotáveis ou em quantidade limitada. A fábrica, esse templo moderno, há-de ser destruída, como o templo de Artemisa, em Éfeso, e o de Vénus, em Pafos. Templo quer dizer túmulo, casa dos mortos, que os mortos foram os primeiros deuses. Foram eles que dirigiram, para além do mundo, a atenção dos vivos. Destruída a fábrica pagã, teremos a igreja de Cristo, a confraria dos irmãos, o convívio universal e amoroso. (2002: 305-6)

Faz-se agora claro porque motivo a morte de Tolstoi é para o narrador de Pascoaes o único facto contemporâneo digno da história de Paulo. Não vale a pena explorar aqui o tópico, mas ainda assim paga a pena lembrar Tolstoi como tendo sido dentro da modernidade o crítico da técnica como meio social de progresso. Nessa linha são notáveis as antecipações ecológicas, em termos de recursos, datando de 1934, do narrador de Pascoaes. E é por esse motivo que uma biografia que ludibria todas as regras da poética aristotélica verosimilhança, imitação, discurso directo das personagens - pode no entanto ser aceite pelo leitor como um livro de leitura comovente.

O narrador de Pascoaes apela no presente a uma ruptura civilizacional, à imagem daquilo que Paulo de Tarso fez em relação ao mundo romano. $\mathrm{O}$ passado, repito, não mais é neste livro do que uma outra forma de falar do presente. Por isso as identificações ou homologias que nele se estabelecem de forma cerrada entre a fábrica e o templo, a América e o império de Nero, Tolstoi e Paulo, são aquelas que melhor nos servem para perceber a passagem do enunciado à enunciação. 
Antes de fechar sumarie-se a questão do moderno. Por um lado o narrador de Pascoaes não se coíbe de encetar a crítica do moderno, como se percebe pela anterior transcrição; por outro topamos nesse narrador com um conhecimento por dentro dele, que não nos deixa classificar este pensamento como ante ou pré-moderno. Há na sua posição um desengano e um cansaço, já posteriores ao moderno. O desencanto do narrador de Pascoaes diante da ciência é de alguma maneira o de Einstein depois das explosões nucleares de 1945.

É natural que um livro com estas características esbarrasse em Portugal, onde os atrasos são mais fundos que as antecipações, com algumas dificuldades de leitura. Por isso o livro esperou vinte e cinco anos para ter uma reedição e outros vinte e cinco para nova impressão. Ao invés, na Europa central, num momento em que os totalitarismos tecnológicos se impunham, ele pôde encontrar os leitores ideais e atentos, que esgotaram em poucos anos várias edições do livro. 


\section{Bibliografia}

AA. VV. (1996), Uma leitura dos Actos dos Apóstolos, Lisboa, Difusora Bíblica.

(2008), Olhares recentes sobre São Paulo - Didaskalia 38, Lisboa, Faculdade de Teologia da Universidade Católica Portuguesa.

(2008), S. Paulo, Apóstolo da Palavra - Bíblica (Série Científica) 17, Lisboa/Fátima, Difusora Bíblica.

(1964), Bibliotheca Sanctorum, Roma, Instituto Giovanni XXIII della Pontificia Universidade Lateranense.

Abascal Palazón, J. M.; Espinosa, U. (1989), La ciudad hispano-romana: privilegio y poder, Logroño, Colegio Oficial de Aparejadores e Arquitectos Técnicos de La Rioja.

Aвel, K. (1980), «L. Herrmann: Sénèque et les premiers chrétiens. Bruxelles (Latomus) 1979. Coll. Latomus: 167. 92 S. BF 375», Gymnasium 82, 351-353.

Acta Apostolorum apocrypha, post Constantinum Tischendorf denue ediderunt Ricardus Adelbertus Lipsius et Maxmilianus Bonnet, Hildesheim/New York, Georg Olms Verlag, 1972.

Afonso, L. U. (2009), A Pintura Mural Portuguesa entre o Gótico Internacional e o Fim do Renascimento: Formas, Significados, Funções, Lisboa, Fundação Calouste Gulbenkian e Fundação para a Ciência e Tecnologia.

(2010), «Em demanda da pintura medieval portuguesa (1100-1400)» in J. A. Carvalho, ed., Primitivos Portugueses (1450-1550). O século de Nuno Gonçalves, Lisboa, MNAA/Athena, 94-107.

Alarcão, J. de (1985), «Sobre a romanização do Alentejo e do Algarve», Arqueologia 11, 99-111.

(1988), O dominio romano em Portugal, Mem Martins, Publicações Europa-América.

- (1990), «O reordenamento do território» in J. de Alarcão, coord., Portugal das origens à romanização, Lisboa, Editorial Presença, 352-382.

(1999), «Três notas sobre o Alentejo romano», Almadan 8, 72-74.

(2004), «Notas de arqueologia, epigrafia e toponímia», Revista Portuguesa de Arqueologia 7/1, 317-342.

Alarcão, J. de; André, P.; Barrelas, P.; Carvalho, P.; Santos, F.; Silva, R. (2009), O forum de Aeminium: A busca do desenho original, Lisboa, Instituto de Museus e da Conservação/Edifer. 
Alexander, L. (2001), «Acts» in J. Barton, J. Muddiman, The Oxford Bible Commentary, Oxford, University Press, 1028-1061.

Alföldy, G. (1969), Fasti Hispanienses senatorische Rechtsbeamte und Offiziere in den spanischen Provinzen des Römischen Reiches von Augustus bis Diokletian, Wiesbaden, F. Steiner.

Álvarez Martínez, J. M.; Nogales Basarrate, T. (2003), Forum Coloniae Augustae Emeritae. Templo de Diana, Mérida, Museo Nacional de Arqueología Romana.

(2006), «Foros de Augusta Emerita: Espacios y símbolos de poder en Hispania» in M. Navarro, J. M. Roddaz, eds., La transmission de lidéologie impériale dans l'Occident romain, Bordeaux, Comité des travaux historiques et scientifiques - CTHS, 129-177.

Alvarez Valdés, A. (2008), «Como foi a conversão de S. Paulo», Bíblica 316, 2008, 4-10 (100-106).

André, P. (2009), «Prolegómenos a um estudo do forum de Aeminium» in J. de Alarcão et al., O forum de Aeminium: A busca do desenho original, Lisboa, Instituto de Museus e da Conservação/Edifer, 93-107.

Andreu Pintado, J. (2004), «Apuntes sobre la Quirina tribus y la municipalizacón flavia de Hispania», Revista Portuguesa de Arqueologia 7/1, 343-364.

Anson, J. (1974), «The Female transvestite in early monasticism: the origin and development of a motive», Viator 5, 1-32.

Applebaum, S. (1974a), "The Legal status of the Jewish communities in the Diaspora» in S. Safrai, M. Stern, eds., The Jerwish people in the first century: Historical geography, political history, social, cultural and religious life and institutions 1, Assen, Van Gorcum, 420-463.

(1974b), «The organization of the Jewish community in the Diaspora» in S. Safrai, M. Stern, eds., The Jewish people in the first century: Historical geography, political history, social, cultural and religious life and institutions 1, Assen, Van Gorcum, 464-503.

(1974c), «The social and economic status of Jews in the Diaspora» in S. Safrai, M. Stern, eds., The Jewish people in the first century: Historical geography, political history, social, cultural and religious life and institutions 1, Assen, Van Gorcum, 701-727.

Aragües Aldaz, J. (2007), «El Flos Sanctorum con sus ethimologías. E1 incunable, la Compilación B y la Leyenda de los santos» in A. López Castro y M. L. Cuesta Torre, eds., Actas del XI Congreso de la Asociación Hispánica de Literatura Medieval (León, 16-21 de septiembre de 2005) I, Léon, Universidad, 197-215. 
(no prelo), «La Leyenda de los santos: trayectoria editorial» in Homenaje a Claude Chauchadis.

Ariño Gil, E.; Gurt Esparraguera, J. M.; Palet I Matínez, J. M. (2004), El pasado presente: arqueología de los paisajes en la Hispania romana, Salamanca/Barcelona, Universidad de Salamanca e Publicacions y Edicions de la Universitat de Barcelona.

Aubin, M. (1998), «Reversing Romance? The Acts of Thecla and the Ancient Novel» in R. F. Hock et al., Ancient Fiction and Early Christian Narrative, Atlanta, Scholars Press, 257-272.

Aune, R. S. (1997), What are they saying about the Formation of Pauline Churches?, New York, Paulist.

Aus, R. D. (1979), «Paul's Travel Plans to Spain and the "Full Number of the Gentiles" in Rom. XI 25», NouT 21, 232-262.

Ayerbe, R.; Barrientos, T.; Palma, F., eds. (2009), El foro de Augusta Emerita. Génesis y evolución de sus recintos monumentales, Madrid/ Mérida, CSIC.

Azevedo, C. M. (2010), «São Paulo na arte portuguesa», Invenire. Revista de bens culturais da Igreja 1, 6-13.

Barbaglio, G. (1980) Le Lettere di Paolo, Roma, Borla (trad. port. As Cartas de Paulo (1989), S. Paulo, Edições Loyola).

Barbero, M. (2001), A First-century Couple, Priscilla and Aquila: Their House Churches and Missionary Activity, Washington DC, Catholic University of America.

Barlow, C. W. (1938), Epistolae Senecae ad Paulum et Pauli ad Senecam <quae uocantur>, Roma, American Academy in Rome.

Barret, C.K. (1973), The Second Epistle to the Corinthians, London, Black's New Testament Commentary.

Barrett, A. A. (1989), Caligula: The Corruption of Power, London, Batsford.

Baslez, M.-F. (1991, 2008), Saint Paul, artisan d'un monde chrétien, Paris, Fayard.

Becker, C. (1980), Paul the Apostle: the Triumph of God in Life and Thought, Philadelphia, Fortress.

Becker, J. (1989), Paulus. Der Apostel der Völker, Tübingen, Mohr.

Beinart, H. (1962), «¿Cuando llegaron los judíos a España?», Estudios 3, 1-32.

(1992), Los Judíos en España, Madrid, Mapfre.

Bello Diéguez, J. M. (1997), «Excavaciones bajo el faro romano de la Torre 
de Hércules» in La Coruña, Paraiso del Turismo (http://www.ctv.es/ USERS/sananton/torre.pdf consultado em Janeiro de 2011).

Beltrán Fortes, J. (1999), «Las Cabezas de S. Juán (Sevilla): De Vgia a Conobaria», Habis 30, 283-295.

Benediktson, D. T. (1989), «Caligula's madness: Madness or interictal temporal lobe epilepsy», Classical World 82, 370-375.

Bento XVI (2008), Paulo, o Apóstolo dos gentios, Lisboa, Paulus.

Bertini, F. (2001), «Le fonti classiche in Iacopo» in S. B. Guidetti, cur., Il Paradiso e la Terra. Iacopo da Varazze e il suo tempo, Firenze, SismelEdizioni del Galluzzo, 61-70.

Billows, R. (2008), «Cities» in A. Erskine, ed., A Companion to the Hellenistic World, Oxford, Blackwell, 209-211.

Blumenkranz, B. (1969), «Les premières implantations de Juifs en France: du Ier au début du Ve siècle», Comptes rendus de l'Académie des inscriptions 113/4, 159-187.

(1971), «Les Juifs en Gaule romaine», Arch 38, 62-64.

BöHlig, H. (I9I3), Die Geisteskultur von Tarsos im augusteischen Zeitalter mit Berücksichtigung der paulinischen Schriften, Gottingen, Vandenhoeck \& Ruprecht.

Boughton, L. C. (1991), «From Pious Legend to Feminist Fantasy: Distinguishing Hagiographical License from Apostolic Practice in the Acts of Paul/Acts of Thecla», The Journal of Religion 71, 362-383.

Boulllet, M. N. et al. (1829), L. Annaei Senecae Pars prima sive Opera Philosophica (quae recognovit et selectis tum J. Lipsii, Gronovii, Gruteri, B. Rhenani, Ruhkophii aliorumque commentariis; tum suis illustravit notis M. N. Bouillet, vol. IV). Parisiis, colligebat Nicolaus Eligius Lemaire, 1827-1832 (DondeyDupré).

Bourdieu, P. (1979) La Distinction: critique socialle du jugement, Paris, Ed. du Minuit.

Bowers, W. P. (1975), «Jewish communities in Spain in the Time of Paul the Apostle», JTS 26, 390-402.

Brenk, F. (2007), «Mixed Monotheism? The Areopagos Speech of Paul» in With Unperfumed Voice: Studies in Plutarch, in Greek Literature, and in the New Testament, Stuttgart, Background, 470-490.

Brickhouse, T. C.; Smith, N. D., eds. (2002), The Trial and Execution of Socrates. Sources and Controversies, New York/Oxford, Oxford University Press.

Brisson, L. (1976), Le mythe de Tirésias, Leiden, Brill. 
Brown, R. E. (1997), An Introduction to the New Testament, New York, Doubleday.

Bruce, F. F. (1977), Paul: Apostle of the Free Spirit, Exeter, Paternoster. (1977a), Paul: Apostle of the Heart Set Free, Grande Rapids, Eerdmans. (1988 $\left.{ }^{\mathrm{rev}}\right)$, The Acts of the Apostles: the Greek text with introduction and commentary, Grand Rapids, Eerdmans.

Bultmann, R. (1969), Le christianisme primitif dans le cadre des religions antiques, Paris, Payot.

Burrus, V. (1987), Chastity as Autonomy: Women in the Stories of Apocryphal Acts, Lewiston/Queenston, Edwin Mellen.

Busch, A. (2004), Convictions and Questions: Philosophy and Muthos in Paul, Mark, and Senecan Corpus, Diss. Indiana University.

Caballero Zoreda, L.; Latorre González-Moro, P. (1999), «El Faro de La Coruña llamado "La Torre de Hércules"» in J. M. Álavrez Martínez, M. Almagro Gorbea, eds., Hispania: El legado de Roma, Mérida, Museo Nacional del Arte Romano, 504-509.

Caldelli, M. L. (2007), «Le iscrizioni della via Puteoli-Neapolis» in M. Mayer i Olivé, G. Baratta, A. Guzmán, eds., Acta XII Congressus internationalis Epigraphiae Graecae et Latinae. Provinciae Imperii Romani inscriptionibus descriptae (Barcelona, 2002), Barcelona, Institut d'Estudis Catalans, Universitat de Barcelona, Universitat Autònoma de Barcelona, 223-230.

Camodeca, G. (1982), «Ascesa al senato e rapporti com i territori d'origine; Italia: Regio I (Campania, esclusa la zona di Capua e Cales, II (Apulia et Calabria), III (Lucania et Bruttii)» in AA. VV., Epigrafia e ordine senatorio. Atti del Colloquio Internazionale AIEGL su epigrafia e ordine senatorio II, Roma, Quasar, 101-163.

CAncıK, H. (2003), «Der Kaiser-Eid: Zur Praxis der römische Herrschervervehrung» in H. Cancik, K. Hitzl, eds., Die Praxis der Herrscherverehrung in Rom und seinen Provinzen, Tübingen, Mohr Siebeck, 29-45.

Cartlidge, D. R., «Thecla: The Apostle who Defied Women's Destiny», Bible Review 20/6, 2004, 25-33.

Carvalho, P. (1998), O forum de Aeminium, Lisboa, Ministério da Cultura, Instituto Português de Museus.

(2009), «O forum dos Igaeditani e os primeiros tempos da civitas Igaeditanorum (Idanha-a-Velha, Portugal)», Archivo Español de Arqueología 82, 115-131. 
et al. (2010), "Caminhando em redor do forum de Aeminium» in T. Nogales, ed., Ciudad y foro en Lusitania Romana, Mérida, Museo Nacional de Arte Romano, 69-88.

Castelli, E. (1986), «Virginity and Its Meaning for Women's Sexuality in Early Christianity», Journal of Feminist Studies in Religion 2, 75-76.

Castillo, C. (1988), «La tribu Galeria en Hispania: ciudades y ciudadanos» in J. González, J. Arce, eds., Estúdios sobre Ia Tabula Siarensis: actas de las jornadas celebradas en Hevilla en 1986, Madrid, C.S.I.C, Centro de Estúdios Históricos, 233-241.

Cepeda, I. (1975), «Um fragmento inédito das Vidas e Paixões dos Apóstolos», Boletim de Filologia 24, 295-304.

(1993), «Autos dos Apóstolos» in G. Tavani, G. Lanciani, org., Dicionário da Literatura Medieval Galega e Portuguesa, Lisboa, Caminho, 75-76.

___ ed. (1982), Vidas e Paixóes dos Apóstolos, Lisboa, Instituto Nacional de Investigação Científica, 1982, 1989.

Сhapot, F., Laurot, B. (2001), Corpus des prières grecques et romaines, Turnhout, Brepols.

Chaumartin, F.-R. (1996-1999), Sénèque. Tragédies, Paris, Les Belles Lettres.

Childs, B. S. (1984), The New Testament as Canon: an Introduction, London, SCM.

Citroni, M. et al. (2006), Literatura de Roma antiga, Lisboa, Fundação Calouste Gulbenkian.

Clark, D. L. (1966), Rhetoric in Greco-Roman Education, New York/London, Columbia University Press.

Codoñer Merino, C. (1999³), Lucio Anneo Séneca. Diálogos, Madrid, Tecnos.

Coelro, M. H. C., 1977. O Mosteiro de Arouca do Século X ao Século XIII, Coimbra, Universidade de Coimbra.

Cohen, D. (1991), Law, Sexuality, and Society. The Enforcement of Morals in Classical Athens, Cambridge, University Press.

Collins, A. Y. (1996), Cosmology and Eschatology in Jewish and Christian Apocalypticism, Leiden/New York, E. J. Brill.

Collins, J. J. (19982), The Apocalyptic Imagination: An Introduction to Jewish Apocalyptic Literature, Grand Rapids, Eerdmans.

(1993), Daniel: A Commentary on the Book of Daniel. With an Essay "The Influence of Daniel on the New Testament», by Adela Yarbro Collins, Minneapolis, Fortress Press. 
Conzelmann, H. (1981), 1Corinthians: A Commentary on the First epistle to the Corinthians, Philadelphia, Fortress Press. (1987), Acts of the Apostles, Philadelphia, Fortress Press.

Cooper, John Charles (1996), The "Spiritual Presence" in the Theology of Paul Tillich. Tillich's Use of St. Paul, Georgia, Mercer University Press.

Cornide, J. (1792), Investigaciones sobre la fundacion y fábrica de la Torre llamada de Hércules, situada á la entrada del puerto de La Coruña, Madrid, D. Benito Cano.

Costa, A. et al., eds. (1991515), Bíblia Sagrada, Lisboa, Difusora Bíblica. (1983), A Biblioteca e o Tesouro da Sé de Coimbra nos Séculos XI a XVI, Coimbra, Coimbra Editora.

Cothenet, E. (1983), São Paulo no seu tempo, Lisboa, Difusora Bíblica. (1991), A Carta aos Gálatas, Lisboa, Difusora Bíblica.

Crouzer, H. (1970), «Le lieu d'exil d'Hérode Antipas et d'Hérodiade selon Flavius Josèphe», Studia Patristica 107, 275-280.

Cumont, F. (1901), «Un serment de fidélité a l'empereur Auguste», Revue des Études Grecques 14, 26-45.

(1987), Las religiones orientales y el paganismo romano, Madrid, Akal.

Daniélou, J. (1961), Message Évangélique et culture Hellénistique, Paris, Desclée.

DAs, A. A. (2008), «Paul of Tarshish: Isaiah 66.19 and the Spanish Mission of Romans 15.24, 28», NTS 54, 60-73.

Daube, D. (1949), «Rabbinic methods of interpretation and Hellenistic rhetoric», HUCA 22, 239-264,

Dauvillier, J. (1960), «À propos de la venue de saint Paul à Rome. Notes sur son procès et son voyage maritime», $B L E 60,3-26$.

Davies, S. L. (1980), The Revolt of the Widows: The social world of the Apocryphal Acts, Carbondale, Southern Illinois University Press.

De Ruggiero, E.; Passerini, A. (1961), «Ius iurandum» in Dizionario epigrafico di antichità romane, Roma, L'Erma di Bretschneider.

Deissmann, A. (1910), Light from the Ancient East: The Nerw Testament Illustrated by recently discovered Texts of the Graeco-Roman World, London, Hodder \& Stoughton. (1926), Paul: a study in social and religious history, [S.1.], Hodder and Stoughton. 
Costa (1926), Paul: a Study in Social and Religious History, London/New York, Hodder and Stoughton.

Detienne, M.; Vernant, J.-P. (1989), The Cuisine of Sacrifice among the Greeks, Chicago, The University of Chicago Press.

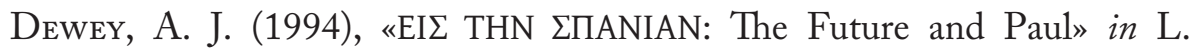
Bormann, K. Del Tredici, A. Standhartinger, eds., Religious Propaganda E Missionary Competition in the New Testament World: Essays Honoring Dieter Georgi, Leiden, E. J. Brill, 321-349.

Dias, P. B. (2008), «A Linguagem dos alimentos nos textos bíblicos. Sentidos para a fome e para a abundância», Humanitas 60, 157-175.

Díaz y DíAz, M. C. (1962), «La Obra de Bernardo de Brihuega, colaborador de Alfonso X» in A. Tovar et al., Strenae. Estudios de Filologia e Historia dedicados al profesor Manuel García Blanco, Salamanca, Universidad de Salamanca, 145-161.

(1967), «En torno a los orígenes del cristianismo hispánico» in J. M. Gómez-Tabanera, ed., Las raices de España, Madrid, 1967, 423-443.

Dodds, E. R. (1971), The Greeks and the Irrational, Berkekey, University of California Press.

Donaldson, T. L. (1993), «Introduction to the Pauline Corpus» in B. M. Metzger, M. D. Coogan, eds., The Oxford Companion to the Bible, Oxford, University Press, 1062-1083.

(1997), Paul and the Gentiles: Remapping the Apostle's Convictional World, Minneapolis, Fortress.

Douglas, M. (1966), Purity and Danger. An Analysis of Concepts of Pollution and Taboo, New York, Praeger.

(1971), «Deciphering a meal», Daedalus, 101, 61-81.

(1991), Pureza e Perigo, Lisboa, Edições 70.

Droysen, J. G. (1952-1953), Geschichte des Hellenismus, Tübingen, Wiss. Buchgemeinschaft.

- (2005), Histoire de L'Hellénisme, Grenoble, Jerôme Millon.

Dubreuil-Arcin, A. (2006), «La critique dans l'Écriture hagiographique dominicaine (1250-1325 environ)», M. Chazan, G. Dahan, eds., La méthode critique au Moyen Âge, Turnhout, Brepols, 269-288.

Dunn, J. D. G. (1988), The Theology of Paul the Apostle, Grand Rapids, Eerdmans. (2003), A teologia do Apóstolo Paulo, São Paulo, Paulus.

Eden, P. T. (1984, rep. 2002), Seneca. Apocolocyntosis, Cambridge, University Press. 
Encarnação, J. d' (1984), Inscrições romanas do conventus Pacensis, Coimbra, Instituto de Arqueologia da Universidade de Coimbra.

- (2007), «O culto imperial na epigrafia da Lusitânia ocidental: novidades e reflexões» in T. Nogales Basarrate, J. González, eds., Culto imperial, politica y poder, Roma, L'Erma di Brestscnheider, 349-367.

Engberg-Pedersen, Troels (2010), Cosmology and Self in the Apostle Paul. The Material Spirit, Oxford, University Press.

Erbetta, M. (1966), Gli Apocrifi del Nuovo Testamento, II. Atti e leggende, Torino, Marietti.

(1975), Gli Apocrifi del Nuovo Testamento, I/1. Vangeli, Torino, Marietti.

Étienne, R. (1958), Le culte impérial dans la Péninsule Ibérique d'Auguste à Diocletien, Paris, De Boccard.

FAbiño, C. (2006), A herança romana em Portugal, Lisboa, CTT.

(2010), «Modelos forenses nas cidades da Lusitânia: Balanço e perspectivas» in T. Nogales Basarrate, ed., Ciudad y foro en Lusitania romana, Mérida, Museo Nacional del Arte Romano, 343-359.

Fairweather, J. (i 994), «The epistle to the Galatians and classical rhetoric. Parts 1\&2», Tyndale Bulletin 45/1, 23-30.

Fantham, E. (1982), Seneca's Troades, Princeton, University Press.

Faria, A.M. de (1995), «Plínio-o-Velho e os estatutos das cidades privilegiadas hispano-romanas localizadas no actual território português», Vipasca 4, 89-99.

de (1999), «Colonização e municipalização nas províncias hispano-romanas: reanálise de alguns casos polémicos», Revista Portuguesa de Arqueologia 2/2, 29-50.

de (2002), «Recensão a E. García Fernández, El municipio latino: origen y desarrollo constitucional, Madrid, Universidad Complutense, 2001 (Gerión. Anejos 5) 196 p. ISBN: 84-95215-22-5», Revista Portuguesa de Arqueologia 5/2, 417-422.

Fernandes, L. (2005), «Caius Heius Primus, augustalis perpetuus: teatro e encenação do poder em Olisipo», Mathesis 14, 29-49.

(2007), «Teatro romano de Lisboa: o caminho da descoberta e os percursos da investigação arqueológica», Almadan 15, 28-39.

Ferrua, V. (2001), «L'Ordo Praedicatorum nella vita di Iacopo da Varazze » in S. B. Guidetti, cur., Il Paradiso e la Terra. Iacopo da Varazze e il suo tempo, Firenze, Sismel - Edizioni del Galluzzo, 31-48. 
Fitch, J. G. (2002-2004), Seneca. Tragedies, Cambridge/London, Harvard University Press.

Fitzmyer, J. A. (1970), «The languages of Palestine in the first-century A. D.», $C B Q 32,501-532$.

(1993), «Luke, The Gospel According to» in B. M. Metzger, M. D. Coogan, eds., The Oxford Companion to the Bible, Oxford, University Press, 469-474.

Fleury, A. (1853), Saint Paul et Sénéque. Recherches sur les rapports du Philosophe avec l'Apôtre et sur l'infiltration du Christianisme naissant, Paris, Librairie Philosophique de Ladrange.

Franceschini, E. (1981), «È veramente apocrifo l'epistolario Seneca-S. Paolo?» in M. Simonetti, ed., Letterature Comparate: Problemi e metodo. Studi in honore di E. Paratore, Bologna, Patron, 827-841.

Fucks, G. (1985), «Where have all the Freedmen gone? On an anomaly in the Jewish Grave-Inscriptions from Rome», JJS 36, 25-32.

Fuller, R. H. (1993), «Jesus Christ» in B. M. Metzger, M. D. Coogan, eds., The Oxford Companion to the Bible, Oxford, University Press, 356-366.

Furnish, V. P. (1984), II Corinthians, Garden City, Doubleday.

Gagé, J. (1964), Les Classes sociales dans l'Empire romain, Paris, Payot.

Gallicet, E. (2000), «Seneca nel De Ciuitate Dei di Agostino», P. Parroni, cur., Seneca e il suo tempo. Atti del convegno internazionale di RomaCassino, 11-14 novembre 1998, Roma, Salerno, 445-467.

Gamba, G. G. (1998), «Il carteggio tra Seneca e San Paolo. Il "problema” della sua autenticità», Salesianum 60, 209-250.

Gamble, H. (1975), «The Redaction of the Pauline Letters and the Formation of the Pauline Corpus», JBL 94, 403-418.

Gant, R. M. (1982), «The Description of Paul in the Acts of Paul and Thecla», $V C h r 36,1-4$.

García Iglesias, L. (1978), Los Judios en la España Antigua, Madrid, Ediciones Cristiandad.

García Moreno, L. A. (1994), Los Judios de la España Antigua: del Primer Encuentro al Primer Repudio, Madrid, Rialp.

García y Bellido, A. (1955), «Nombres de artistas en la España romana», Archivo Español de Arqueologia 28, 3-19.

Gargani, A. G. (1997), «A experiência religiosa como acontecimento e interpretação» in J. Derrida, G. Vattimo, et al., A religião, Lisboa, Relógio D'Água, 133-161. 
Gauthier, P. (1974), «"Generosité" romaine et "avarice” grecque: sur l'octroi du droit de cite» in J. Tréheux, org., Mélanges d'Histoire Ancienne offerts à William Seston, Paris, Ed. De Boccard, 207-215.

Gerhardson, B. (1998 $\left.{ }^{\mathrm{rev}}\right)$, Memory and manuscript: oral tradition and written transmission in Rabbinic Judaism and early Christianity, Grand Rapids, Eerdmans.

Gill, D. W. J.; Gempf, C. (1994), The Book of Acts and Paul in Roman Custody, Grand Rapids/Carlisle, Eerdmans.

Gilson, E. (1986), Le Thomisme. Introduction à la philosophie de Saint Thomas d'Aquin, Paris, Librairie Vrin.

Goldstein, J. (1981), «Jewish Acceptance and Rejection of Hellenism» in E. P. Sanders et al., eds., Jerwish and Christian Self-Definition, vol. II, Philadelphia, Fortress, 64-87.

Gomes, F. B. (2011), Contextos de culto de matriz mediterrânea na Idade do Ferro do Sul do actual território português (sécs. VIII-III a.n.e.): Aspectos do sagrado na colonização fenícia e no processo histórico subsequente, Lisboa, Universidade de Lisboa.

González Luis, J. (1997), «Séneca y Pablo» in M. Rodríguez-Pantoja, ed., Séneca, dos mil años después, Córdoba, Universidad de Córdoba, 413-418.

GonzÁlez, J. (1988), «The first oath pro salute Augusti found in Baetica», ZPE 72, 113-127.

(1990), Bronces jurídicos romanos de Andalucía, Sevilla, Junta de Andalucía.

Goodspeed, E. J. (1901), «The Acts of Paul and Thecla», The Biblical World 17/3, 185-190.

Goulart, A. P. M. (2001), O Êxodo e os êxodos por entre história e mito, Lisboa, Faculdade de Letras da Universidade de Lisboa.

Griffin, M. T. (1976). Seneca: A Philosopher in Politics, Oxford, Clarendon Press.

Gruen, E. S. (2002), Diaspora. Jerws amidst Greeks and Romans, Cambridge, Mass., Harvard University Press.

(2003), «Jews and Greeks» in A. Erskine, ed., A Companion to the Hellenistic World, Malden/Oxford/Victoria, Blackwell Publishing, 264279.

Gruterus, I. (1603), Inscriptionum Romanarum Corpus absolutissimum. Heidelbergae.

Guenee, B. (1980), Histoire et culture historique dans l'Occident médiéval, Paris, Aubier Montaigne. 
Guerra, A. (1996), "Ammaia, Medobriga e as ruínas de S. Salvador de Aramenha: dos antiquários à historiografia actual», A Cidade 11, 7-33.

- (1998), Nomes pré-romanos de povos e lugares do Ocidente peninsular. Dissertação de Doutoramento apresentada à Universidade de Lisboa, Lisboa, Universidade de Lisboa.

(2006), «Os mais recentes achados epigráficos do Castelo de S. Jorge, Lisboa», Revista Portuguesa de Arqueologia 9/2, 271-297.

- (2007), «Sobre o território e a sede dos Lancienses (Oppidani e Transcudani) e outras questões conexas», Conimbriga 46, 161-206.

Gutiérrez Martin, D. (1999), Pablo, perfil psicológico de un apóstol, Madrid, BAC.

HaAse, F. (1902), Literarkritische untersuchungen zur orientalische-anokryphen evangelien-literatur, Leipzig, Teubner.

Hachlili, R. (1979), «The Goliath family in Jericho: funerary inscriptions from a first-century AD Jewish monumental tomb», BASOR 235, 31-65.

Haenchen, E. (1971), The Acts of the Apostles. A commentary, Oxford, Westminster.

Hare, D. R. A. (1993), «Flesh and Spirit» in B. M. Metzger, M. D. Coogan, eds., The Oxford Companion to the Bible, Oxford, University Press, 231.

Harnack, A. von (1919), Der kirchengeschichtliche Ertrag der exegetischen Arbeiten des Origenes, 2. Teil, Die beiden Testamente mit Ausschluß des Hexateuchs und des Richterbuchs, TU 42/4, Leipzig, Hinrichs.

(19244), Die Mission und Ausbreitung des Christentums in den ersten drei Jahrbunderten, Leipzig, Hinrichs.

Harril, J. A. (2008), "Cannibalistic Language in the Fourth Gospel and Greco-Roman Polemics of Factionalism (John 6:52-66)», JBL 127, 133-158.

Harrison, P. N. (1921), The Problem of the Pastoral Epistles, Oxford, University Press.

Hauschild, T. (1977), «El faro romano de La Coruña (Torre de Hércules): problemas de su reconstrucción», Actas del Coloquio Internacional sobre el milenário de Lugo, Lugo, Patronato del Bimilenario de Lugo, 131-156. (1990), «Das römische Theater von Lissabon. Planhaufnahme 1985-88», Madrider Mitteilungen 31, 348-392.

(1994), «O teatro romano de Lisboa» in A. M. Arruda, org., Lisboa subterrânea: Catálogo da exposição, Lisboa, Museu Nacional de Arqueologia/Lisboa Capital Europeia da Cultura, 64-66. 
Hayne, L. (1994), «Thecla and the Church Fathers», VChr 48, 209-218.

Hemer, C. J. (1985), «The name of Paul», Tyndale Bulletin 36, 179-183.

Hengel, M. (1971), «Proseuche und Synagoge. Judische Gemeinde, Gotteshaus und Gottesdienst in der Diaspora und in Palastina» in G. Jeremias, H.-W. Kuhn, H. Stegemann, Hrsg., Tradition und Glaube. Das frübe Christentum in Seiner Umwelt. Festgabe für Karl Georg Kuhn zum 65. Geburtstag, Göttingen, Vandenhoeck \& Ruprecht, 157-184.

- (1974), Judaism and Hellenism: studies in their encounter in Palestine during the Early Hellenistic Period, vol. I, Philadelphia, Fortress Press.

(1977), "Crucifixion and Roman citizens», Crucifixion in the ancient world and the folly of the message of the Cross, Philadelphia, Philadelphia, Fortress Press, 39-45.

(1991), The pre-Christian Paul, Philadelphia, Trinity Press International.

Hengel, M., Markschies, C. (1989), The «Hellenization» of Judaea in the first century after Christ, London, SCM Press.

Hengel, M., Schwermer, A. M. (1997), Paul between Damascus and Antioch: the Unknown Years, Louisville, Westminster, John Knox.

Herrmann, L. (1973), «Hérodiade», REJ 132, 55.

- (1979), Sénèque et les premiers chrétiens, Bruxelles, Latomus.

Herrmann, P. (1960), «Die Inschriften römischer Zeit aus dem Heraion von Samos», Mitteilungen des Deutschen Archäologischen Instituts. Athenische Abteilung 75, 68-183.

(1969), Der römischen Kaisereid: Untersuchungen zu seiner Herrkunft und Entwicklung, Göttingen, Vandenhoeck \& Ruprecht.

Heszer, C. (2001), Jerwish literacy in Roman Palestine, Tübingen, Mohr.

Hills, J. V. (1997), «The Acts of Paul and the legacy of the Lukan Acts», Semeia $80,145-155$.

Hock, R. F. (1980), The Social Context of Paul's Ministry: Tentmaking and Apostleship, Philadelphia, Fortress.

(2003), «Paul and Greco-roman education» in J. P. Sampley, ed., Paul in the Graeco-Roman World: a Handbook, Harrisburg, Trinity Press, 198-227.

(2008), «The problem of Paul's social class: further reflexions» in S. E. Porter, ed., Paul's world, Leiden, Brill, 7-18.

Holzner, J. (196325), Paulus, sein Leben und seine Briefe, Freiburg im Breisgau, Verlag Herder GmbH. 
Hooker, M. D. (1993), «Mark, The Gospel According to» in B. M. Metzger, M. D. Coogan, eds., The Oxford Companion to the Bible, Oxford, University Press, 492-496.

Horsley, R. A. (1997), Paul and Empire: Religion and Power in Roman Imperial Society, Harrisburg, Trinity Press.

Horsley, R. A., ed. (2000), Paul and Politics. Ekklesia. Israel. Imperium. Interpretation, Harrisburg, Trinity Press International.

Howell, E. B. (1964), «St. Paul and the Greek world», GERR 11, 7-29.

Hutter, S. (1973), Der römische Leuchtturm von La Coruña, Mainz, Ph. Von Zabern.

Jaeger, W. (1991), Cristianismo primitivo e Paideia grega, Lisboa, Edições 70.

Jalhay, E. (1947), «Epigrafia amaiense: contribuição para o estudo de Aramenha romana (concelho de Marvão)», Brotéria 45/6, 615-633.

Jeremias, J. (1969a), «Paulus als Hillelit» in E. E. Ellis, M.Wilcox, eds., Neotestamentica et Semitica: Studies in Honour of Matthew Black, Edinburg, T. \& T. Clark, 88-94.

- (1969b), Jerusalem in the time of Jesus, London, SCM.

Jewett, R. (1982), «Romans as an Ambassadorial Letter», Int 36, 5-20.

(1988), «Paul, Phoebe, and the Spanish Mission» in J. Neusner, P. Borgen, E.S. Frerichs, R. Horsley, eds., The Social World of Formative Christianity and Judaism: Essays in Tribute to Howard Clark Kee, Philadelphia, Fortress Press, 1988, 142-161.

(2007), Romans: A Commentary, Minneapolis, Fortress Press.

Jones, A. H. M. (1940), The Greek City from Alexander to Justinian, Oxford, The Clarendon Press.

(1968), «I appeal unto Caesar» in Studies in Roman government and law, Oxford, Basil Blackwell, 51-65.

(19712), Cities of the Eastern Roman provinces, Oxford, The Clarendon Press.

Kaestli, J.-D. (1990), «Fiction Littéraire et réalité sociale: que peut-on savoir de la place des femmes dans le milieu de production des Actes Apocryphes des Apôtres?» in P. Geoltrain, J.-C. Picard, A. Desreumaux, dir., Apocrypha, Le Champ des Apocryphes, I. La Fable apocryphe, Brepols, Turnhout, 1990, 279-302.

Kaimio, J. (1979), The Romans E' the Greek Language, Helsinki, Societas Scientiarum Fennica.

Kasher, A. (1985), The Jews in Hellenistic and Roman Egypt: the struggle for 
equal rights, Tübingen, Mohr.

Kelly, J. N. D. (1975), Jerome. His life, writings, and controversies, London, Duckworth.

Kennedy, G. A. (1984), New Testament Interpretation through Rhetorical Criticism, Chapel Hill, University of North Carolina Press.

Kingsbury, J. D. (1993), "Matthew, The Gospel According to» in B. M. Metzger, M. D. Coogan, eds., The Oxford Companion to the Bible, Oxford, University Press, 502-506.

Knox, J. (1950), Chapters in a Life of Paul, New York/Nashville, Abingdon-Cokesbury.

Koch, D. A. (1986), Die Schrift als Zeuge des Evangeliums: Untersuchungen zur Verwendung und zum Verständnis der Schrift bei Paulus, Tübingen, Mohr.

Kraabel, A. T. (1982), «The Roman Diaspora: Six Questionable Assumptions», JJS 33, 445-464.

Kraabel, A. T., Seager, A. R. (1983), «The Synagogue and the Jewish Community» in G. M. A. Hanfmann, ed., Sardis from Prehistoric to Roman times: results of the archaeological exploration of Sardis 1958-1975, Cambridge, Mass./London, Harvard University Press, 168-190.

Kreitzer, L. J. (1993), «Eschatology» in G. F. Hawthorne, R. P. Martin, eds., Dictionary of Paul and His Letters, Leicester, Inver Varsity Press, 259.

Kümmel, W. E. (1975), Introduction to the New Testament, Nashville, Abingdon.

KüNG, H. (1994), O cristianismo: essência e história, Lisboa, Círculo de Leitores.

Ladouceur, D. (1980), «Hellenistic Preconceptions of Shipwreck and Pollution as a Context for Acts 27-28» HTR 73, 435-449.

Lafaye, G. (1927), Inscriptiones Graecae ad res Romanas pertinentes, Tomus IV, Paris, Libr. Ernest Lezoux.

Lamelas, I. P. (2009), São Paulo: textos apócrifos, Coimbra, Ed. Tenacitas.

Laredo, A. I. (1944), «Sefarad en la literatura hebraica», Sefarad 4, 351-352.

LE GALL, J. (1985), «Le serment à l'empereur: una base méconue de la tyrannie impériale sous l'Haut-Empire?», Latomus 44, 767-783.

Le Roux, P. (1990), «Les villes de statut municipal en Lusitanie romaine» in J.-G. Gorges, ed., Les villes de Lusitanie romaine: Hiérarchies et territoires. Table ronde internationale du CNRS (Talence, le 8-9 décembre 1988), Paris, Centre National de la Recherche Scientifique, 
35-49.

(1994), «Cités et territoires en Hispanie: l'épigraphie des limites», Mélanges de la Casa Vélazquez 21, 37-51.

(1995), Romains d'Espagne. Cités et politique dans les provinces IIe siècle av. J.C.-IIIe siècle ap. J.C., Paris, Armand Colin.

LEÃo, D. F. (2004), «Matéria religiosa: processos de impiedade (asebeia)» in D. F. Leão, L. Rossetti e M. C. Fialho, coords., Nomos. Direito e Sociedade na Antiguidade Clássica/Derecho y Sociedad en la Antigüedad Clásica, Coimbra/Madrid, 201-226.

LÉgasse, S. (2000²), Paul apôtre: essai de biographie critique, Paris, Cerf.

Lentz, J. C. (1993), Luke's portrait of Paul, Cambridge, University Press.

Levine, L. I. (1999), Judaism and Hellenism in antiquity: conflict or confluence, Seattle/London, University of Washington Press.

Liebermann, S. $\left(1965^{2}\right)$, Greek in Jerwish Palestine: studies in the life and manners of Jewish Palestine in the II-IV centuries C.E., New York, P. Feldheim.

Lipsius, J. H., Das attische Recht und Rechtsverfahren, Leipzig, Reisland, 1905-1915.

Litrin, D. (1994), St. Paul's Theology of Proclamation: 1Corinthians 1-4 and Greco-Roman Rhetoric, Cambridge, University Press.

Longstreet, C. S. (1994), The Romance of Apocryphal Acts of the Apostles, diss. polic., Ottawa, Carleton University.

Lourenço, J. (2005), O mundo judaico em que Jesus viveu, Lisboa, Universidade Católica Editora.

Lüdermann, G. (1984), Paul Apostle to the Gentile: Studies in Chronology, London, SCM.

(2002), Paul: the founder of Christianity, Amherst, Prometheus.

Macdonald, D. R. (1983), The Legend and the Apostle: The Battle for Paul in Story and Canon, Philadelphia, Westminster.

Macdowell, D. M. (1978), The Law in Classical Athens, London, Thames and Hudson.

Macк, B. L. (1990), Rhetoric and the New Testament, Minneapolis, Fortress.

Maggioni, G. P., ed. $\left(2000^{2}\right)$, Iacopo da Varazze. Legenda Aurea, Firenze, Sismel-Edizioni del Galluzo.

Manns, F. (1992), Le judaïsme, milieu et mémoire du Nouveau Testament, Jerusalém, Fransciscan Printing Press.

Mantas, V. G. (1988), «Orarium donavit Igaeditanis: epigrafia e funções 
urbanas numa capital regional da Lusitânia» in G. Pereira Menaut, dir., Actas del I Congreso Peninsular de Historia Antigua II, Santiago de Compostela, Universidad de Santiago de Compostela, 415-439.

(1992), «Notas sobre a estrutura urbana de Aeminium», Biblos 68, 487513.

(1993), "A cidade luso-romana de Ossonoba» in J. F. Rodríguez Neila, dir., Actas del I Coloquio de Historia Antigua de Andalucia (Córdoba, 1988), Córdoba, Monte de Piedad y Caja de Ahorros, 515-537.

(2000), «A sociedade do município luso-romano de Ammaia» in J.G. Gorges; T. Nogales Basarrate, eds., IV Mesa Redonda Internacional Sociedad y Cultura en Lusitania Romana, Mérida, Junta de Extremadura, 391-420.

- (2010), «Ammaia e Civitas Igaeditanorum: dois espaços forenses lusitanos» in T. Nogales Basarrate, ed., Ciudad y foro en Lustania Romana, Mérida, Museo Nacional de Arte Romano, 167-199.

Mariano, A. (1998), Egéria: Viagem do ocidente a Terra Santa, no século IV (Itinerarium ad Loca Sancta), Lisboa, Ed. Colibri.

Marrou, H.-I. (1948), Histoire de l'éducation dans l'Antiquite. 1. Le monde grec. 2. Le monde romain, Paris, Seuil.

(1966), História da educação na Antiguidade, São Paulo, Herder.

Marshall, C. W. (2000), «Location! Location! Location! Choral absence and theatrical space in the Troades» in G. W. M. Harrison, ed., Seneca in performance, London, Duckworth, 27-52.

Martin, D. B. (i 995), The Corinthian Body, New Haven/London, Yale University Press.

Martins, A., 1999. «Dois bispos portugueses da segunda metade do seculo XII», inM. J. Barroca (coord.), Carlos Alberto Ferreira de Almeida: in memoriam, vol. II, Porto, Faculdade de Letras da Universidade do Porto, pp. 27-40.

Martins, M. (1949), «Vidas e Paixões dos Apóstolos», Brotéria 49, 521-528. (1963), «Bernardo de Brihuega, compilador dos Autos dos Apóstolos», Boletim de Filologia 21, 69-86.

- (1980), «O romance do Pseudo-Marcelo» in Estudos de Cultura Medieval II, Lisboa, Brotéria, 217-228.

Mastandrea, P. (1988), Lettori cristiani di Seneca filosofo, Brescia, Paideia.

Mateos, P. (2001), "Augusta Emerita: la investigación arqueológica en una ciudad de época romana», Archivo Español de Arqueología 74, 183-208. 
coord. (2006), El foro provincial de Augusta Emerita: un conjunto monumental de culto imperial, Madrid/Mérida, CSIC.

Matthews, S. (2001), "Thinking of Thecla: Issues in Feminist Historiography", Journal of Feminist Studies in Religion 17, 39-55.

Mayer, M.; RodÀ, I. (1998), «Claudio e Hispania» in Y. Burnand, Y. Le Bohec, J.-P. Martin, eds., Claude de Lyon, empereur romain. Actes du Colloque de Paris-Nancy-Lyon, Paris, Presses Universitaires de France, 243-254.

Mcdonald, L. M.; Porter, S. E. (I 999), Early Christianity and its Sacred Literature, Peabody, Hendrickson Publishers.

McElderry, K. (1918), «Vespasian's reconstruction of Spain», JRS 8, 53-102.

Medeiros, W. de (2000), «Retórica do naufrágio e da morte no romance de Petrónio» in J. Ribeiro Ferreira, ed., A retórica greco-latina e a sua perenidade, Coimbra, Instituto de Estudos Clássicos, 519-526.

Meens, W. A. (1983), The First Urban Christians: The Social World of the Apostle Paul, New Haven, Yale University Press.

(1992), Os primeiros cristãos urbanos: o mundo social do apóstolo Paulo, São Paulo, Paulus.

Meens, W.; Fitzgerald, J. (1978, 2007²), The Wrintings of St. Paul, New York/London, W. Norton \& Company.

Meinardus, O. (1978), «Paul's Missionary Journey to Spain: Tradition and Folklore», Biblical Archaeologist 41, 61-63.

Mélèze-Modrzejewski, J. (1989), «Les tourments de Paul de Tarse» in J. L. Harouel, ed., Histoire du Droit Social. Mélanges Jean Imbert, Paris, Presses Universitaires de France, 397-412.

__ (2005), «Greek Law in the Hellenistic Period: Family and Marriage» in M. Gagarin, D. Cohen, ed., The Companion to Ancient Greek Law, Cambridge, University Press, 343-354.

Metzger, B. M.; Coogan, M. D., eds. (1993) The Oxford Companion to the Bible, New York/Oxford, Oxford University Press.

Miles, G. B.; Trompf, G. (1976), «Luke and Antiphon: The Theology of Acts 27-28 in the Light of Pagan Beliefs about Divine Retribution, Pollution, and Shipwreck», HTR 69, 259-267.

Milgrom, J. (1963), «The Biblical Diet Laws as an Ethical System», Interpretation 17, 288-301.

Misset-Van De Weg, M. (2004), «Magic, miracle and miracle workers in the Acts of Thecla» in A.-M. Korte, ed., Women and Miracle Stories: a Multidisciplinary Exploration, Leiden, Brill. 
Mitford, T. B. (1960), «A Cypriot oath of Allegiance to Tiberius», JRS 50, 75-79.

Momigliano, A. (1950), «Note sulla leggenda del Cristianesimo di Séneca», RSI 52, 325-344.

Mommsen, T. (1895), C. Iulii Solini collectanea rerum memorabilia, Berlin, Weidmann.

Moralejo, S. (2004a), «Ars Sacra et sculpture romane monumentale: le trésor et le chantier de Compostelle» in A. Franco Mata, Patrimonio Artístico de Galicia y Otros Estúdios: Homenaje al Prof. Dr. Serafin Morelajo Álvarez I, Santiago de Compostela, Universidad de Santiago de Compostela, 161-188 (=CCuixdi 11, 1980, 189-238).

(2004b), «El patronazgo artístico del arzobispo Gelmírez (11001140): su reflejo en la obra e imagen de Santiago» in A. Franco Mata, Patrimonio Artístico de Galicia y Otros Estúdios: Homenaje al Prof. Dr. Serafin Morelajo Alvarez I, Santiago de Compostela, Universidad de Santiago de Compostela, 289-299.

Muggeridge, M., Vidler, A. (1972), Paul: Envoy Extraordinary, London, Collins.

Murphy-O'connor, J. (1991), The Theology of the Second Letter to the Corinthians, Cambridge/New York, Cambridge University Press.

- (1994), A Antropologia pastoral de Paulo, São Paulo, Paulus.

(1996), Paul: a critical life, Oxford, University Press.

- $\left(2002^{3}\right)$, St. Paul's Corinth: Texts and Archaeology, Collegeville, Liturgical Press.

__ (2004) Paul. His story. Oxford, University Press

__ (2007), Jesus and Paul: Parallel Lives, Collegeville, Liturgical Press.

-_ (2008), Paulo, um homem inquieto um apóstolo insuperável, Prior Velho, Paulinas.

- (20082), Jesus e Paulo, Prior Velho, Paulinas.

Mussies, G. (1976), «Greek in Palestine and the Diaspora» in S. Safrai, M. Stern, eds., The Jewish people in the first century: Historical geography, political bistory, social, cultural and religious life and institutions 2, Philadelphia, Fortress Press, 1040-1064.

Natali, M. (1995), Anonimo. Epistolario tra Seneca e San Paolo, Milano, Rusconi.

Neiman, D. (1963), «Sefarad, the name of Spain», JNES 22, 128-132.

Neusner, J. (1971), The rabbinic traditions about the Pharisees before 70. I. The 
masters, Leiden, Brill.

NG, E. Y. L. (2004), «Acts of Paul and Thecla. Womens' Stories and Precedent?», JTS 55/1, 1-29.

Nicolas, C. (1996), Utraque língua. Le calque sémantique: domaine gréco-romain, Leuven/Paris, Peeters.

Nock, A. D. (1972), «Isopoliteia and the Jews» in Z. Stewart, ed., Essays on Religion and the ancient world 2, Cambridge, MA, Harvard University Press, 960-962.

Nogales Basarrate, T. (2009), «Foros de Augusta Emerita: urbanismo, monumentalización y programas decorativos» in J. M. Noguera, ed., Fora Hispaniae. Paisaje urbano, arquitectura, programas decorativos y culto imperial en los foros de las ciudades hispanorromanas, Murcia, Universidad de Múrcia, 123-154.

Nogales Basarrate, T.; Álvarez Martínez, J. M. (2010), «Foros de Augusta Emerita: modelos en Lusitânia» in T. Nogales Basarrate, ed., Ciudad y foro en Lusitania romana, Mérida, Museo Nacional del Arte Romano, 231-259.

Nony, D. (1968), «Claude et les Espagnols: sur un passage de l'Apocoloquintose», Mélanges de la Casa Velásquez 4, 51-71.

Norden, E. (1974), Agnostos Theos. Untersuchungen zur Formengeschichte religioser Rede, Stuttgart, BG Teubner.

Ochs, E. et al., (1996), «Socializing taste», Ethnos 61, 7-46.

Oleiro, J. M. B. (1955-1956), «O criptopórtico de Aeminium», Humanitas 4-5, 151-160.

Oleiro, J. M. B.; Alarcão, J. de (1973), «Le cryptoportique d'Aeminium (Portugal)» in AA. VV., Les cryptoportiques dans l'architecture romaine, Roma, École Française de Rome, p. 349-369.

Oliveira, A. de (2008), Um ano a caminhar com São Paulo, Palheira, Gráfica de Coimbra.

Olsson, B. et al. (2001), The Synagogue of Ancient Ostia and the Jerws of Rome: Interdisciplinary Studies, Stockholm, Jonsered.

Omerzu, H. (2002), Der Prozeß des Paulus. Eine exegetische und rechtshistorische Untersuchung der Apostelgeschichte, Berlin/New York, De Gruyter.

Osgood, J. (2006), Cesar's legacy: civil war and the emergence of the Roman Empire, Cambridge, University Press.

Oтт, H. (1967), «Um die Muttersprache Jesu Forschungen seit Gustaf Dalman», Nouum Testamentum 9, 1-25. 
Palagi, L. B., int. (1978), Il carteggio apocrifo di Seneca e San Paolo, Firenze, Leo S. Olschki.

Pascones, T. de $\left(1934 ; 1959^{2} ; 1984^{3} ; 2002^{4}\right)$, São Paulo, Porto, Livraria Tavares Martins; Lisboa, Ática; Lisboa, Assírio \& Alvim.

(1935), San Pablo, Barcelona, Editorial Apolo.

(1937), Paulus, Amesterdam, Meulenhoff.

(1938), Paulus der Dichter Gottes, Zurich, Rascher Verlag.

(1943), Pál, Budapest.

Perkins, J. (1997), «This world or another? The intertextuality of the Greek romances, the Apocryphal Acts and Apuleius' Metamorphoses», Semeia 80, 247-260.

Perry, B. E. (1967), The Ancient Romances. A literary-historical account of their origins, Berkeley, University of California Press.

Pherigo, L. P. (1951), «Paul's Life after the Close of Acts», JBL 70, 277-284.

Phillipart, G. (1977), Les Légendiers Latins et autres manuscrits hagiographiques, Turnhout, Brepols.

- (1981), «L'édition médiévale des légendiers dans le cadre d'une hagiographie génerale» in $\mathrm{H}$. Bekker-Nielsen,P. Foote, J. H. Jorgensen, T. Nyberg, eds., Hagiography and Medieval Literature. A Symposium, Odense, University Press, 127-158.

Picard, J.-C. (1990), «L'Apocryphe a l'étroit. Notes Historiographiques sur les corpus d'apocryphes bibliques» in P. Geoltrain, J.-C. Picard, A. Desecumaux, dir., La Fable Apocryphe I, Turnhout, Brepols, 69117.

Pimentel, M. C. (2000), Séneca, Mem Martins, Inquérito.

PiñEro, A., ed. (1996), Origenes del cristianismo: antecedentes y primeros pasos, Córdoba, E1 Almendro.

Pitts, A. W. (2008), «Hellenistic Schools in Jerusalem and Paul's Rhetorical Education» in S.E. Porter, ed., Paul's World, Leiden, Brill, 19-50.

Porter, S. E. (1994), «Jesus and the use of Greek in Galilee» in B. Chilton, C. A. Evans, eds., Studying the historical Jesus: evaluations of the state of current research, Leiden, Brill, 123-154.

Porter, S. E.; Pitts, A. W. (2008), «Paul's Bible, his Education and his Access to the Scriptures of Israel», JGRChJ 5, 9-41.

Premerstein, A. von (1937), «Vom Werden und Wesen des Prinzipats», Abbandlungen der Bayerischen Akademie der Wissenschaften, Philosophisch-Historische Abteilung, neue Folge 15, 158-202. 
Puig, A. (2006), Jesus. Uma biografia, Lisboa, Paulus.

Pulcinelli, G. (2008), Para conhecer o Apóstolo Paulo, Lisboa, Paulus.

Rabello, A. M. (1980), «The Legal Condition of the Jews in the Roman Empire», $A N R W$ II.13, 662-762.

(2000), The Jews in the Roman Empire. Legal Problems from Herod to Justinian, Aldershot, Ashgate Publishing.

Rahmani, L. Y. (1994), A catalogue of Jewish ossuaries in the collections of the state of Israel, Jerusalem, Israel Antiquities Authority, Israel Academy of Sciences and Humanities.

Rajak, T. (1984), Josephus: the Historian and his Society, Philadelphia, Fortress Press.

Rambo, L. R. (1993), Understanding Religious Conversion, New Haven, Yale University Press.

Ramelli, I. (1997), «L'epistolario apocrifo Seneca-san Paolo: alcune osservazioni», $\operatorname{Vet} C h r$ 34, 299-310.

(2008), «Alle radici della filosofia patrística: Paolo all'Areopago e il pensiero greco», Invigilata Lucernis 30, 149-176.

Ramos, J. A. M. (2009), «Paulo de Tarso: um mundo com 2000 anos», ISTA - Instituto São Tomás de Aquino 22, 7-29.

Ramsay, W. M. (1907), St. Paul the Traveller and the Roman Citizen, London, Hodder \& Stoughton.

(1908), The cities of St. Paul: their influence on his life and thought: the cities of Eastern Asia Minor, New York, Armstrong.

(1911), The Church in the Roman empire before A.D. 170, New York/ London, G. P. Putnam's Sons, The Knickerbocker Press.

Rapske, B.M. (1994), «Acts, Travel and Shipwreck» in D. W. J. Gill, C. Gempf, The Book of Acts and Paul in Roman Custody, Grand Rapids/ Carlisle, Eerdmans, 1-47.

RAtzinger, J. (1960), «Licht und Erleuchtung. Erwägungen zur Stellung und Entwicklung des themas in der abendländischen Geistesgeschichte» Studium Generale 13, 368-378.

RÉAu, L. (1959), Iconographie de l'Art Chrétien, Paris, Presses Universitaires de France.

Reynolds, L. D. (1965), L. Annaei Senecae ad Lucilium epistulae morales, Oxonii, E Typographeo Clarendoniano.

Reynolds, L. D.; Griffin, M. T.; Fantham, E. (2003), «Seneca» in S. Hornblower, A. Spawforth, eds. The Oxford Classical Dictionary, Oxford, 
University Press.

Ribagorda Serrano, M. (1992), Claudio y las provincias occidentales del imperio: el caso de Hispânia, Madrid, Universidad Complutense.

(1994), «En torno a tres inscripciones de Ammaia (CIL II 158 y159; IRPC 604)», Studia Histórica. Historia Antigua 12, 51-59.

Riesner, R. (1998), Paul's early period: Chronology, Mission, Strategy, Theology, Grand Rapids, Eerdmans.

Robert, L. (1940), «La vente du droit de cité», Hellenica 1, 37-42.

(1964), Nouvelles Inscriptions de Sardes, Paris, Librairie d'Amérique et d'Orient A. Maisonneuve.

Roddaz, J.-M. (2002), «Hispania pacata: l'empereur et les Espagnes aux deux premiers siècles de l'empire» in G. Urso, ed., Hispania terris omnibus felicior: premesse ed esiti di un processo di integrazione: Atti del convegno internazionale, Cividale del Friuli, 27-29 settembre 2001, Pisa, Edizioni ETS, 201-223.

Rodrigues, Manuel A. e Avelino J. COSTA (eds.),1999. Livro Preto. Cartulário da Sé de Coimbra. Coimbra, Arquivo da Universidade de Coimbra.

Rodrigues, N. S. (2005), «Hipóteses para o estudo dos Judeus na Hispânia no período antonino» in L. Hernández Guerra, ed., Actas del II Congreso Internacional de Historia Antigua "La Hispania de los Antoninos", Valladolid, Universidad de Valladolid, Centro de Buendía, 417-431.

(2006), «Os Judeu na Hispânia na Antiguidade», Cadernos de Estudos Sefarditas 6, 9-34.

(2007), «Iudaei in Vrbe». Os Judeus em Roma de Pompeio aos Flávios, Lisboa, Fundação Calouste Gulbenkian, Fundação para a Ciência e a Tecnologia.

Rodríguez-Fernández, C. (1997), «Epistulae morales ad Lucilium: Séneca Cristiano» in M. Rodríguez-Pantoja, ed., Séneca, dos mil anôs después. Actas del Congreso Internacional conmemorativo del Bimilenario de su Nacimiento (Córdoba, 24 a 27 de Septiembre de 1996), Córdoba, Universidad de Córdoba Y Cajasur, 1997, 307-332.

Roetzel, C. J. (19984), The Letters of Paul: Conversation in Context, Louisville, Westminster, John Knox.

Rosado Martín, M. C. (2010), «El juramento de fidelidad a Octaviano del año 32 a. C.», El Futuro del Passado 1, 337-347.

RougÉ, J. (1952), «La navigation hivernale sous l'Empire romain», REA 54, 316-325.

—_ (1960), «Actes 27,1-10», VCh 14, 193-203. 
(1967), «Le voyage de saint Paul en Occident», Cabiers d'Histoire 12, 237-247.

- (1975), La marine dans l'Antiquité, Paris, Presses Universitaires de France.

Rudhardt, J. (1960), «La définition du délit d'impiété d'après la législation attique», Museum Helveticum 17, 87-105.

Rutgers, L. V. (1995), The Jerws in Late Ancient Rome. Evidence of Cultural Interaction in the Roman Diaspora, Leiden/Boston/Koln, Brill.

Salinas De Frías, M.; Rodríguez Cortés, J. (2000), «Substrato y romanización de las oligarquías locales de la provincia romana de Lusitania» in J.-G. Gorges; T. Nogales Basarrate, eds., IV Mesa Redonda Internacional Sociedad y Cultura en Lusitania Romana, Mérida, Junta de Extremadura, 17-34.

Sampley, J. P., ed. (2003), Paul in the greco-roman world. A handbook, Harrisburg, Trinity Press.

San Martín, M. A. (1982), «Herrmann, Léon, Sénèque et les prémiers chrétiens, Bruxelles, Latomus, 1979, 92 pp.», Emerita 50, 386-388.

SÁnchez Salor, E. (1986), «Orígenes del cristianismo en la Lusitania» in C. Chaparro Gómez, coord., Manifestaciones religiosas en la Lusitania, Cáceres, Universidad de Extremadura, Servicio de Publicaciones, 69-84. (1995), «Los orígenes del cristianismo en Hispania. Los casos de Mérida y León-Astorga» in J.-Ma. Nieto Ibáñez, coord., Estudios de Religion y Mito en Grecia y Roma. X Jornadas de Filologia Classica de Castilla y Leon, Leon, 165-181.

Sanders, E. P. (1977), Paul and Palestinian Judaism. A comparison of patterns of religion, London, Philadelphia, SCM Press, Fortress Press.

SAndison, A. T. (1958), «The madness of the emperor Caligula», Medical History 2, 202-209.

Sanson, V. F. (1988), Estoicismo e Cristianismo, Caxias do Sul, EDUCS.

Santos Yanguas, N. (1978), "Los judíos en la Bética en época romana» in Actas I Congreso de Historia de Andalucía (Córdoba 1976): Fuentes y Metodología, Córdoba, Publicaciones del Monte Piedad y Caja de Ahorros de Córdoba, 271-278.

Scarpat, G. (1977), Il pensiero religioso di Seneca e l'ambiente ebraico e cristiano, Brescia, Paideia.

Schneemelcher, W.; Schäferdiek, K., eds. (1965), Second and third century Acts of the Apostles: introduction, London, Lutterworth Press.

Schoeps, H.-J. (1961), Paul: the Theology of the Apostle in the Light of Jewish 
Religious History, Philadelphia, Westminster.

Scholz, P. (2000), «Der Prozeß gegen Sokrates. Ein "Sündenfall” der athenischen Demokratie?» in L. Burckhardt, J. von UngernSternberg, hrsg., Grosse Prozesse im antiken Athen, München, Beck, 157-173.

Schürer, E. (1985), Historia del pueblo judio en tiempos de Jesus, 175 a.C.-135 d.C., Madrid, Cristiandad.

Schwiebert, J., (2008), «Table Fellowship and the translation of 1Corinthians 5:11», JBL 127, 159-164.

Scott, J. M. (1995), Paul and the Nations, Tübingen, Mohr.

Segal, A. F. (1990), Paul the Convert: the Apostolate and Apostasy of Saul the Pharisee, New Haven, Yale University Press.

Segurado e Campos, J. A. (1991), Lúcio Aneu Séneca. Cartas a Lucílio, Lisboa, Fundação Calouste Gulbenkian.

Sérgio, A.; Cidade, H., pref., not. (1952), António Vieira. Obras Escolbidas VI, Lisboa, Sá da Costa.

Sevenster, J. N. (1961), Paul and Seneca, Leiden, Brill.

(1968), Do you know Greek? How much Greek could the first Jewish Christians have known?, Leiden, Brill.

Sherwin-White, A. (1963), «Paul at Rome» in Roman Society and Roman Law in the New Testament, Oxford, Clarendon Press, 108-119.

__ (1972), «The Roman Citizenship. A Survey of its Development into a World Franchise», ANRWI.2, 23-58.

Sidwell, B. (2010), «Gaius Caligula’s mental illness», CW103, 183-206.

Silva, A. C. F. da (1980), «Novos dados sobre a organização social castreja» in J. deHoz, ed., Actas del III Coloquio sobre Lenguas y Culturas Paleobispánicas (Lisboa, 5-8 Novembre 1980), Salamanca, Ed. Universidad Salamanca, 201-224.

Smalley, S. S. (1993), «John, The Gospel According to» in B. M. Metzger, M. D. Coogan, eds., The Oxford Companion to the Bible, Oxford, University Press, 373-377.

Smallwood, E. M. (1967), Documents illustrating the Principates of Gaius, Claudius and Nero, Cambridge, University Press.

(1976, 2001), The Jews under Roman rule from Pompey to Diocletian, Leiden, Brill.

Sobral, C. (2002-2003), «O Flos Sanctorum de 1513 e suas adições portuguesas», Lusitania Sacra 13-14, 531-568. 
(2005), «O modelo discursivo hagiográfico» in A. S. Laranjinha, J. C. Miranda, org., Actas do V Colóquio da Associação Hispânica de Literatura Medieval, Porto, Faculdade de Letras da Universidade do Porto, 97107.

- (2009), «Eremitas na Leyenda de los Santos (Burgos, 1500) e no Flos Sanctorum (Lisboa, 1513)» in J. Cañas Murillo, F. J. Grande Quejigo, J. Roso Díaz, coord., Medievalismo en Extremadura. Estudios sobre Literatura y Cultura Hispánicas de la Edad Media, Cáceres, Universidad de Extremadura, 589-601.

(2010), «Um manuscrito da Tradição B dos legendários ibéricos» in J.M. Fradejas Rueda, D. D. Smithbauer, D. Martín Sanz, M.J. Díez Garretas, coord., Actas do XIII Congresso da Associação Hispânica de Literatura Medieval, Valladolid, Ayuntamento de Valladolid y Universidad de Valladolid, pp. 1681-1696.

Soggin, J. A. (1984), «šub, zurückehren» in E. Jenni, C. Westermann, eds., Theologisches Handwörterbuch zum Alten Testament II, München/Zurich, Chr. Kaiser Verlag, Theologischer Verlag.

- (1997), Nueva Historia de Israel, Bilbao, Desclé de Brouver.

Sordi, M. (1960), «Sui primi rapporti dell'autorità romana con il Cristianesimo (a proposito della cronologia degli Atti)», StudRom 8, 393-409.

(2000), «I rapporti personali di Seneca con i Cristiani», Aevum Ant. $13,113-122$.

Sousa, A. C. de $\left(1738,1946^{2}\right)$, Provas da História Genealógica da Casa Real Portuguesa I, Coimbra, Atlântida.

Stadter, P. A. (1989), A Commentary on Plutarch's Pericles, Chapel Hill, University of North Carolina Press.

Stamps, D. L. (1995), «Rhetorical criticism of the New Testament: ancient and modern evaluation of argumentation» in S. E. Porter, D. Tombs, eds., Approaches to New Testament Study, Sheffield, Sheffield Academic Press, 77-128.

Stark, R. (1996), The Rise of Christianity: a Sociologist Reconsiders History, Princeton, University Press.

Stendahl, K. (1976), Paul among Jerws and Gentile, and other Essays, Philadelphia, Fortress.

Stern, J. (1987), «A propos de la vente du droit de cite: les examnaioi d'Ephese», Chiron 17, 293-298.

Stowers, S. K. (1986), Letter Writing in Greco-Roman Antiquity, Philadelphia, Westminster. 
Street, G. C. (1999), «Women as Sources of Redemption and Knowledge» in R. Shepard, M. R. d'Angelo, eds., Women E Christian Origins, Oxford, University Press.

Stylow, A. (1995), «Apuntes sobre las tribus romanas en Hispânia», Veleia $12,105-123$.

- (2001), «Las estatuas honoríficas como medio de autorrepresentación de las elites locales de Hispânia» in M. Navarro Caballero, S. Demougin, eds, Élites hispaniques, Bordeaux, Ausonius, 143-155.

Tajra, H. W. (1989), The trial of St. Paul: a juridical exegesis of the second half of the Acts of the Apostles, Tübingen, Mohr.

Tarn, W. W.; Griffith, G. T. (1959), Hellenistic civilization, London, Edward Arnold.

Tavares, R. (2003), Os incêndios de Roma. Séneca e São Paulo. Cartas, Almada, Íman.

Tcheri kover, V. (1961), Hellenistic civilization and the Jerws, Philadelphia, Jewish Publication Society.

Thiede, C.P. (1986), Simon Peter. From Galilee to Rome, Exeter, Paternoster.

Thiselton, A. C. (2000), The First Epistle to the Corinthians: A Commentary on the Greek Text, Grand Rapids, Eerdmans.

Thomsen, P. (1907), Loca Sancta. Verzeichnis der im 1. bis 6. Jabrhundert n. Chr. erwähnten Ortschaften Palästinas mit besonderer Berücksichtigung der Lokalisierung der biblischen Stätten I, Leipzig, Reprografischer Nachdruck der Ausg.

Todn, S. C. (1995), The Shape of Athenian Law, Oxford, University Press.

Trebilco, P. R. (1991), Jerwish Communities in Asia Minor, Cambridge, University Press.

Unniк, W. C. van (1962), Tarsus or Jerusalem. The City of Paul's Youth, London, Epworth.

Uytfanghe, M. van (1987), Stylisation biblique et condition humaine dans l'hagiographie mérovingienne [600-750], Brussel, Paleis der Academien.

VAldez, M. A. (2007), «From the Periods of History towards the End», Cadmo 17, 55-80.

Vasconcelos, J. L. de (1935), «Localização da cidade de Ammaia», Ethnos $1,5-9$.

Vauchez, A. (1886), «Jacques de Voragine et les saints du XIIIe s. dans la Légende dorée» in B. Dunn-Lardeau, dir., Legenda Aurea: sept siècles de diffusion. Actes du coloque international sur la Legenda Aurea: texte latin et branches vernaculaires à l'Université du Québec à Montréal (11-12 mai 
1983), Montréal/Paris, Édition Bellarmin-Librairie J.Vrin, 27-56.

VAz, J. L. I. (1979), «Término augustal de Goujoim (Armamar)», Conimbriga $18,133-138$.

(2007), Lamego na época romana, capital dos Coilarnos, Lamego, Associação para a Valorização e Desenvolvimento do Vale do Douro.

- (2010), «Elementos para o estudos dos fora das cidades do norte da Lusitânia» in T. Nogales Basarrate, ed., Ciudad y foro en Lusitania Romana, Mérida, Museo Nacional del Arte Romano, 315-324.

Velissaropoulos, J. (1980), Les Nauclères Grecs. Recherches sur les institutions maritimes en Grèce et dans l'Orient hellénisé, Paris, Minard.

Ventura, L. (2003), «Coimbra medieval: uma cidade em formação» in A. Alarcão, ed., Inventário do Museu Nacional de Machado de Castro. Colecção de ourivesaria medieval. Séculos XII-XV, Lisboa, IPM.

Vermeulen, F.; Taelman, D. (2010), «From Cityscape to Landscape in Roman Lusitania. The municipium of Ammaia» in C. Corsi, F. Vermeulen, eds., Changing Landscapes: The impact of Roman towns in the Western Mediterranean, Bologna, Ante Quem, 311-324.

VIDAL, C. (2009), Los primeros cristianos: los judeo-cristianos en el Israel del siglo I, Barcelona, Editorial Planeta.

Viegas, A. (1916), Um códice português da Legenda Aurea: fragmentos duma versão inédita do séc.XV, Lisboa, Tip. e Pap. José Soares e Irmão.

Vivas, D. (2007), «Constança Sanches. Algumas observações em torno de uma bastarda régia», Clio 16-17, 223-241.

Vos, C. S. de (1999), «Finding a charge that fits: the accusation against Paul and Silas at Philippi (Acts 16.19-21)», JSNT 74, 51-63.

Vouga, F. (2008), Eu, Paulo, Prior Velho, Paulus.

Wacholder, B. Z. (1960), Nicolaus of Damascus, Berkeley, University of California Press.

Walker, P. (2008), Nas pegadas de São Paulo: um guia ilustrado das viagens de São Paulo, Prior Velho, Paulus.

Wallace, R., Williams, W. (1998), The Three Worlds of Paul of Tarsus, London, Routledge.

Waltz, R. (1966), Sénèque. L'Apocoloquintose du Divin Claude, Paris, Les Belles Lettres.

Wardle, D. (1997), «An allusion to the Kaisereid in Tacitus Annals 1.42?», CQ 47/2, 609-613. 
Watson, F. (1986), Paul, Judaism and the Gentiles, Cambridge, University Press.

Wenham, D. (1995), Paul, Follower of Jesus or Founder of Christianity, Grand Rapids, Eerdmans.

White, S. A. (1993), «Human Person» in B. M. Metzger, M. D. Coogan, eds., The Oxford Companion to the Bible, Oxford, University Press, 295-296.

Will, E.; Mossé, C.; Goukowsky, P. (1985), Le monde grec et l'Orient. Tome II, Le IVe siècle et l'Époque hellénistique (510-403), Paris, Presses Universitaires de France.

- (1998), El mundo griego y el Oriente. Tomo II, El siglo IV y la época helenistica, Madrid, Akal.

Witherington, B. (1998), The Paul Quest: the Renewed search for the Jew of Tarsus, New Haven, Downers Grove.

Zahn, T. (1904), «Zur Lebensgeschichte des Apostels Paulus», Neue Kirchliche Zeitschrift 15, 24-34.

Zeller, D. (1973), Juden und Heiden in der Mission des Paulus: Studien zum Römerbrief, Stuttgart, Katholisches Bibelwerk.

Zwierlein, O. (1986), L. Annaei Senecae tragoediae, Oxford, Clarendon Press. 


\section{INDEX NOMINVM}

Abdias: 76-77

Abelardo: 157, 275

Aвrã̃o: 49, 57, 73, 132, 162

Abravanel, Isaac: 77

Absoluto: 53

AcAiA: 112, 166, 171

Áccio: 29, 36, 85

Acmoneia: 19

Actéon: 49

Ad̃̃o: 137, 147, 177, 187, 239

Adriano: 31

Adriático: 32, 70

AEMINIUM: 83, 89, 91-92

Afonso X, rei de Leão e Castela: 209210

ÁfricA: 8, 41, 85, 232

Afrodite: 39

Agostinho de Hipona (Santo): 14, 34, 136, 152-157, 162, 165, 237, 239-240, 275

Agostinho, pseudo-: 157

Agripina Menor: 70, 72, 89

AlÁpIDE: 231

Alcibíades: 109, 112

Alcobaça: 210, 217-218

Alcuíno: 156

Alexandre: Magno 30, 36
Alexandria: 13-14, 16, 18-19, 22, 24, 30, 32-33, 35, 38, 41, 70, 161-162, 186-187, 200

Almeida Garrett: 241

Alvega: 86

Ambrósio de Milão: 14, 206,

AMÉRICA: 232

AмMALA: 83, 91-92, 94-95

Ananias: 46, 47, 50, 60

AnAxágoras: 106, 107

André (Santo): 22, 200

André Anes, D.: 215-216

Andrómaca: 183

Andronico: 33, 76

Antigo Testamento: 57, 59

Antíoco (judeu de Antioquia): 19

Antíoco IV: 18, 36

Antioquia: 7, 16, 18-19, 35-36, 64, $69,79,121-122,146,169,185-$ 186,241

Antípatro (pai de Herodes-oGrande): 20

Antónia: 164, 169

António FÉLix: 16, 70, 169, 172-173

António, Marco: 29

Apameia: 20

Apocalipse: 134, 141, 173, 203, 227

Apolo (cidadão alexandrino): 42 
Apolo: 50, 103, 110

Apolónia: 50

Apolónio de Rode: 70

Apolónio de Tíana: 31, 75

Apóstolo das Nações: 9, 70

Apóstolos: 51

AQUIFLAVIENSES: 89

Áquila: 39, 76, 148, 247

Aquiles: 103, 183

Aquiles Tácio: 42

ArÁbia: 45, 69

ARABRIGA: 83

ARABRIGENSES: 96-97

Arato 37

Archena (Múrcia): 98

Areópago: 37-38, 112, 248, 266

Aricienses: 86

Aristobulo: 162, 164

Aristóteles: 31, 33, 35, 42, 104, 106, 230, 277

ARITIUM VETUs: 83-86, 91-92

Arouca: 215, 249

Ártemis: 37, 42, 49, 242

Asclepíades de Prusa: 39

AsCLÉPIO: 38-39, 41

ÁsıA: 18, 22, 30, 32, 36, 60, 69, 76, 87, 168-170, 187, 200, 232-233,

Ásia Menor: 7, 20, 29-30, 33, 36, 39$40,69,76,87,185-187$

Aspásia: 107

Assenat: 162

Assos: 84-86

Astarte: 41

Atena: 49

Atenas: 16, 19, 24, 29-30, 34-35, 3739, 69, 102, 106-107, 109-110, 112,148

Atenienses: 113

Atenodoro de Tarso: 17, 31

AUFKLÄRUNG: 106
Augusta EMERITA: 88

Augusto: 17, 19-20, 31-32, 38, 83-85, 87-89, 96, 161, 165

AURELIA (GENS): 164

AVILE(N)SES: 96

Babilónia: 228

BABILÓNIOS: 76

BACANTES: 117

BAETICA: 97

BAÍA: 230

BALEARES: 168

Bar Кокнва: 75

BARnAbÉ (São): 22, 121-122, 147, 241

BARRABÁs: 165

Bartolomeu (São): 22

Bartolomeu de Trento: 202-203

BASEL: 158

BAsileia, ver Basel

BAsílio (São): 233

Batalha: 220-221, 225

Beatriz, D. : 218

BELÉM: 13

Beleza: 53

BEM: 53

Benjamim: 16-17, 23, 32

Bento (São): 219

BEREIA: 69

Berenice: 169, 172

Berenice na Cirenaica: 18

BERnARdo (São): 219

Bernardo de Brihuega: 209-210, 252,261

BÉTICA: 84, 93, 165, 268

BETSAIDA: 22

Bíblia: 58, 64, 103, 143

Bitínia: 233

BoA Mendes, D.: 214

Bobadela: 83

Boccaccio, Giovanni: 158 
Braga: 215, 218-219

BRASIL: 230

BRINDES: 171

BRITÂNICO: 168

Burro: 167-169, 173

C(IVITAS) C(OLARNORUM): 97

CÁdiz: 72

CAdmo: 41

Calígula: 7, 75, 81, 83-84, 86, 92, 165, 247-248, 268-269, ver Gaio Calígula

Calvário: 239

Calvêncio Velho Carmínio, Lúcio: 92, 95

CAMPÂNIA: 98

Campos Elísios: 165

Capitão, Cossuciano: 168, 171

Capitão, Quíncio: 93

Capitão, Quinto: 93

Capitólio: 154, 176

Caracala: 19

Carlos Magno: 156

CARMINII 95

Castelo Branco, Camilo: 237, 241

Castor: 41,172

Catalunha: 73

Cefas: 35

Célere, P.: 168

Cêncreas: 76, ver Cencres

Cencres: 39, ver Cêncreas

Cerices: 103

CÉsAR: 29, 32, 38, 70, 85, 92, 172, 206, 264

César Augusto Germânico, Tibério Cláudio: 92

Cesareia: 14, 40, 79, 152, 163, 169 , 172-173, 200

Cesariny, Mário: 237

Chipre: 7, 69, 84, 86, 121, 164

Cíbele: 196
Cícero: 29, 38, 154-155

Cidno: 29

Cilaio: 92

Cilícia: 5, 7, 10, 13-16, 19, 22-23, 28 29, 31-32, 36-37, 79, 168

Cipriano (cavaleiro): 215

Cipriano de Antioquia: 150

Cirene: 22, 36, 121

Ciudad Rodrigo: 96

Ciuitas Aeminiensis: 87

Ciuitas Ammaiensis: 92

CiUitas CobelCoRum: 83

CIUITAS IGAEDITANORUM: 83, 88

CLAUDIA (gens): 94, 164

Cláudia: 148

Cláudio: 7, 20, 33, 39, 75-76, 81, $92-$ 94, 96-97, 148, 164-165, 169, 185, 191, 262, 267

Cláudio Lísias: 169

CLAUis PROPHETARUM: 131, 228

Cleantes: 155

Cleanto: 34,37

Clemente de Alexandria, Tito Flávio: 37

Clemente Romano (São): 73, 202

Cleópatra: 29

COBELCORUM: 83

COILARNI: 83, 96-97

Coimbra: 89, 207, 214-217, 234, 272

Colonna, Giovanni: 157-158

Colono: 49

Colossenses: 16,71

Concílio de Trento: 229

CONIMBRIGA: 88-89

Conobaria: 84

Constança Sanches, D.: 215, 272

Constantino: 154

Conuentus CoRDUBEnsis: 97

Córduba: 151, 156, 165, 173

Coríntios: 34, 39-40, 133, 146, 170 
Corinto: 7, 16, 18, 29, 34, 37-40, 69, 76, 79, 109-111, 124, 129, 131, $134-138,140-141,148,168,171$

Cornélio: 25, 127

Cornélio Boco: 95

Cornélio Dolabela, Públio: 21

Cornélio Lêntulo Crus, Lúcio: 21

Cornélio Macro, Públio: 93-94

Cornide: 89

Connuto, Aneu: 38

Córsega: 165-166

Cortijo de las Palmillas, Cabezas de S. Juán: 84

Coruña: 89

Cós: 30,69

Creta: 41,70

Crises: 103

Cristãos: 45, 51, 103

Cristo: 45, 48, 50, 51-53, 61, 64, 67, 101-102, 110, 112, 145, 147-148, 227-229, 234-235

CRisto, ver Jesus

Damasco: 9-10, 16, 24, 38, 45-47, 50, 52-53, 55-56, 58-59, 63, 69, 79, $145-147$

DANIEL: 227

DANTE: 158

DAVID: 50

DeCÁPOLE: 163

Delfos: 103

Demódoco: 50

Demóstenes: 31,106

Deus: 67, 68, 112, 119-121, 123, 125, 127, 131, 133-134, 136-142, $144,155,166,169,172,175-181$, 183, 186-187, 190-192, 195, 199, 204, 206-207, 228-231, 233-235, 238-240

Deuteronómio: 119, 147

Diana «templo»: 88

Diego Gelmírez, D.: 216
Dinis (São): 219

Dinis, D. (rei de Portugal): 210-211

Diógenes LAÉrcio: 106, 109, 231

Díon CÁssıo: 85

Díon Crisóstomo: 16, 20

Díon de Prusa: 30

Dionísio Aeropagita: 203-204

Dionísio-o-Pequeno: 161

Dioniso Trácio: 32

Diopites: 107, 109

Dioscórides: 39

Dioscuros: 41

Domiciano: 37,75

Domício Balbo: 168

Dositeu: 19

EBORA: 88

ÉDIPO: 39, 49-50

EFÉsIos: 16, 71, 235

Éfeso: 7, 16, 35, 37, 39, 42, 69, 76, 79, 169,242

EgÉRIA: 186, 261

Egev: 32, 78-79

Еgipto: 13, 29-30, 33, 58, 70, 118, 161-163, 166

Einstein: 243

Eleazar: 25

ELÊUSIS: 103, 109

Elias: 58, 148

Eliseu: 58

EMERITENSES: 77

Emílio, Paulo: 172

ENCARNAÇÃO: 235

Eрicteto: 34, 38, 175, 179

Epicuro: 153, 179, 183

Epifânio de Salamina: 25

EPIMÉNIDEs: 34, 37

Erasístrato: 39

Erasmo: 151, 158-259

EsCRIBÓNIA: 165 
ESMIRNA: 19

EsPANHA: 207, 216

Espírito SAnto: 51, 111, 123, 127, 139, 233-234

Ésquines: 106

Estesícoro: 50

Estêvão (Santo): 35, 48, 56, 144, 240

Estêvão de Ribas de Sil (Santo, mosteiro): 216, 222

Estrabão: 16, 24, 29-30, 38, 73

Eucaristia: 120, 128

Eumólpidas: 103

Europa: 29, 41, 207, 233, 243

Eusébio de Cesareia: 14, 152, 200

Eustóquio: 13

Eva: 187, 239

EvÉNIO: 50

Évora: 215, 218, 221

Êxodo: 147

Extremo Oriente: 8

Ezequiel: 162-163, 227

Ezequiel, pseudo-: 163

FALERos: 37

FÉ: 231

FEACES: 50

Febe: 76

Fево: 39

FEDRO: 166

FÉLIx, [António?], ver António Félix

Fenícia: 70, 163, 184

Fernandes, Valentim: 210

Fídias: 107

Filémon: 7, 13, 16, 18-19, 71, 159, 171

Filipe (São): 22

Filipe da Macedónia: 166

Filipenses: 16, 71

Filipos: 39, 42, 69, 101-102, 109-110, 163

Fílon de Alexandria: 14, 33, 35
Filóstrato: 16, 29, 31

Fineu: 50

FLAUIA (gens): 164

Flávios: 83

Fócio: 14-15, 19, 28

Folmadela (Vila Real): 219-221, 223

FortunAe OMNES: 85

FraAtes IV: 166

França: 206

FreCUlFo: 157

FrígIA: 19

Fúlvia: 163

Gaio Calígula: 7, 75, ver Calígula

Gaio SÉvio Lupo: 89-90

Galácia: 7, 59, 79

GÁlatas: 8, 16, 35, 48, 51-52, 59-62, $69,122,170,172,251$

Galba: 83

GAlÉRIO, Gaio: 161, 163

GÁLIA: 73-75, 77-78, 85, 168

GALIÃo: 112

Galileia: 13, 15-16, 22

Galo, Canínio: 163

Gamaliel: 15-17, 23-24, 26-27, 34$35,62,67,144$

Garcia do Casal, Rui: 218

GAZA: 162

GÉNEsis: 147, 162, 178

GÉNIO: 91

GENIO BASELECAE: 91

Gentios: 51

Germânico: 85, 92, 162, 164

Gibraltar: 75

Gíscala: 13-16, 24, 26, 28

Gíscalis: 13

Godofredo de Saint-Victor: 157

Gonçalves, Nuno: 221, 245

Gortina: 41

Goujoim (Armamar): 96 
Grécia: 15, 30，33，37-38，49，102$103,110,112,170-171$

Gregório Nazianzeno: 187

Gregos: 15, 49, 103-104, 112, 229, 276

GRIJó: 218

Guardẽo (Tondela): 96, 98

Guarino da Verona: 158

Guerra do Peloponeso: 107

Guilherme de Malmesbúria: 157

Guilherme de Saint-Thierry: 157

Gush Halav: 13

Hecateu de Abdera: 161

Heitor: 183

HÉLAde: 102, 103

Helena: 50

Heliodoro:58

Heliópolis 162

HeLoísa: 275

HÉlvia: 161

Hera: 50

Hércules: 173

Hércules, Torre de: 89-90, 240, 249, 251,256

Hermes: 34, 109

Hermógenes de Tarso: 31

Herodes Agripa I: 169, 173

Herodes Agripa II: 23, 25, 35, 47-48, 51, 101, 164, 172

Herodes Ântipas: 75-76

Herodes-o-Grande: 20, 161

Herodíade: 75, 251, 257

Heródoto: 50

Herófilo: 39

HiLel: 25-26, 77

HispÂNiA: 71-79, 81-82, 84-85, 94-95, 98, 246-247, 249-250, 260, 264, 267-268, 271

Homero: 22, 34, 36, 50, 103, 155, 183

Honório de Autun: 157
HoRÁcIO: 33

Horn, Friedrich Wilhelm: 177

HoRTI SALLUSTLANI: 170

Humberto de Romanis: 201

IBÉRIA: $74-75$

ILÍRIA: 79, 168

InÁcIo (Santo): 229

ÍNDIA: 31,162

ÍnDios: 228

INÊS (Santa): 186, 206

Inês de Castro, D.: 218

IsAbel, D. (Rainha Santa): 218, 223, 275

IsAíAs: $23,72,180$

IsÓCRATES: 31

Israel: $17,25,47-48,58,64,73,76$, $163,235,258,265-266,270,272$

ITÁliA: 32, 70, 84-85, 98, 148, 162, 168, 171, 206, 211, 249

IULIA (gens): 164

Iulius: $32,41,164$

JАсов: $17,58,230$

JACOPO DA VARAZZE: 153

JANEIRO: 57

Jarandilla de la Vera (Cáceres): 96

JASÃO: 39

JasÃo de Cirene: 36

JAVÉ: 49, 73, 145, 147, 180

JeHuda ben Bathyra: 26

JEHUDA-HA-NASI: 17

JEREMIAS: 234

Jerónimo (São): 13-15, 18-19, 21, 28, 151-154, 157-159, 200-201, 203, 237

JERUSALÉM: 7, 14-17, 20, 22-27, 34-35, 45, 47-48, 51, 56, 60, 63, 69-70, 76, 79, 101, 115, 121-122, 127, 137, 162-163, 168-170, 172, 199, 213, 234, 240-241, 258, 265, 271

JEsus: 46, 47, 48, 55, 56, 57, 58, 59, 61, 62, 63, 64, 66, 101, 148, ver Jesus Cristo 
Jesus Cristo: 7-8, 13, 45, 48, 61, 70, 101, 158, 161, 169, 181, 205, 215, 217 , ver Jesus $e$ Cristo

Jetro: 145

JisH: 13

JoÃo (São): 22, 50,61, 63, 111, 128, 169, 173, 200, 220

JoÃo Baptista (São): 50, 63

João Baptista de Souto de Lafões (São, igreja): 219

JoÃo CRisóstomo: 203

JoÃo De Gíscala: 13

JoÃo DE SAlisbúria: 157

JoÃo GoRdo: 218

JoÃo MARcos: 22

JoAquim DE FioRe: 227

JónAtas BEN UZiel: 76

JóNIA: 18

José (do Egipto): 162

Josefo, Flávio: 18, 22, 24, 70, 75, 151, 161-163, 169, 172

Judah Ben Hezekiah: 14

JudAísmo: 45

JUDAS: 213

Judeia: 13, 33, 40, 70, 72-73, 75-76, 161

Judeus: 8, 13, 15-22, 28, 33-36, 39, $51,74,133,155-156,167,172-$ $173,228,232,234-235,267$

Júlia Drusila: 164, 168

Júlia Livila: 165

Juliano: 31

Júlio (centurião da corte augusta): 167,172

Júlio CANo: 167

Júlio CÉsar, ver César

Júlio Hérmias: 164

JÚNIA: 33, 76

Júnia Calvina: 166

Júnio Silano, D.: 168

Juno: 166
JÚPITER: 85, 97, 158, 166, 176

Justo de Tiberíades: 151

KYRIOS: 46, 47, 51

LACTÂNCIO: 14, 150, 172

LÁGIDAS: 162

LAmego: 97, 218, 220, 272

LAUREOLUS: 165

LEÃo, pseudo-: 209

Ledesma: 96

LEI: 50, 53, 110, 112, 147

Lemobia: 204, 206

Leocádia (Santa): 219

LEONOR, D.: 210

LEONTÓPOLIS: 162

LERNa: 39

Lesbos: 40

LEVI: 143

LIÃO: 168

Lícia: 168

Licínio Crasso, Gneu: 165

Lídia de Tiatiros: 163

Lino: 152, 156, 203

Lino, pseudo-: 156, 201-202, 204, 209,

Lionello D'Este: 158

Lípsio, Justo: 161

Lisboa: 98, 210, 215, 241

LisTRA: 34,42

Lívia: 89

LONDRES: 241

Lucas (São): 7, 15-17, 20-21, 23-25, 27, 45-46, 53, 55-60, 62-63, 67, $111,163,169,193,211$

Lucílio: 167, 170, 176, 269

LUCRÉCIO: 183

LUPERCAL: 169

LusitÂNiA: 81-83, 86-9, 91-92, 9697, 100

Macedónia: 7, 37, 79, 110, 168

Macedónios: 232 
MACER, P. Cornelius: 93

Macro (prefeito do pretório): 86, 93

MADIÃ: 145

Magacela (Badajoz): 97

Malta: 42, 70, 146, 172, 203

Marcelo: 165

Marcelo, Asínio: 168

Marcelo, Éprio: 168

Marcelo, pseudo-: 209-210, 261

Marco António, ver António, Marco

Marcos (São): 22, 129, 169

Maria (mãe de Jesus): 200, 210, 215

Maria de Santarém (Santa): 215

MÁrio: 163

MÁrtires: 210

Mateus (São): 148, 169

Mauritânia Cesariense: 95

Medeia: 39-40

Médio Oriente: 237

Mediterrâneo: 7, 20, 35, 40-41, 49, $64,71,78,110$

Mela, Aneu: 166

Menandro: 21, 37

Menasão: 22

Mercúrio: 230

Messias: 63-65, 69, 73, 121, 128, 131-132, 134-135

Metódio de Olímpia: 186

Miguel Salomão, D.: 214

Mileto: 30,36

Minúcio FÉLIx: 150

Mira: 41

Mirleus: 214

Mísia: 233

Mistérios de Elêusis: 103, 109

Moisés: 49, 58, 63, 125, 133, 138141, 143-148, 162, 195

MUNDA :91

Musas: 50
MYRTILIS: 88

Nabateia: 69

NABUCODONOSOR: II 76-77

NÁpoles: 42

NAzARENo: 9, 76

NAzireus: 16

NeÁPolis: 84-85

NÉgueb: 76

Nero: 7, 22, 40, 70, 72, 75-76, 81, 94, 97-99, 151, 153, 158-160, 163173, 201, 203-206, 242, 269

Nerva: 97

Niceia: 20

Nicolau (diácono): 22, 272

Nicolau de Damasco: 24

NicomÉdia: 20

NiLO: 50, 143

Nisibis: 26

NoÉ: 239

Nova Aliança: 132, 138-141

Nova Iorque: 241

Novato (ou Galião), Lúcio Aneu: 166

Novo Testamento: 61, 66

Ocidente: 53

Octávia: 165

Odisseia: 70

OLISIPO: 83, 88, 98

Olisiponenses: 77

Oliveira de Azeméis: 96

OMUnCIÃo: 92

OMUNCIÃo: 92

OnIAS: 162

ORARIUM: 88

Orígenes: 13-14, 200

Orósio: 39, 173

Osca: 98

Óstia: 73, 76, 264

OtÃo de Frisinga: 157

OтÃo, Marco Sálvio: 75, 82 
Otloh de Saint'Emmeran: 157

Ovídio: 231

OXFORD: 179, 246

Paflagónia: 84-85

PAfos: 242

Pagus Marouestae (Lusttania): 165

Palaipaphos: 84,86

Palante: 169,172

Palestina: 13, 16, 18, 21-22, 25-26, $32,36,64,75-76,121,162$

PARIS: 160, 241

PÁtaros: 69

PÁtroclo (pajem de Nero): 204-205, 210

PÁtroclo: 103

Paula: 13

Paulina: 166

PAULUS: 33

Pausânias: 38

Pedânio Secundo: 168

Pedro (São): 25, 76, 111, 122, 127, $147-148, \quad 151-153,156,165$, 168, 173, 200-203, 209-211, 213, 216-221, 223

Pedro Comestor: 157

Pedro de Balsemão, S. (Lamego): 97

Pedro de Évora, D.: 218

Pedro de Verona (São): 206

Pedro Martins (D. Pedro II), D.: 215

Pedro-o-Venerável (abade de Cluny): 157

Pela: 30, 166

Pelágio: 154

Peloponeso: 107

Pelúsio: 162

Península Ibérica: 7, 72-78, 84, 90

Pentateuco: 143

Pérgamo: 30, 32

PÉRICles: 107
Periegeta: 38

Peroviseu (Fundão): 96

Perseu: 36

Pessoa, Fernando: 237

Petra: 69, 79

Petrónio: 70, 262

Phazimon: 84

Pilatos, Pôncio, ver Pôncio Pilatos

Pisiro: 92

Platão: 31, 34, 37, 103, 105, 108109, 230

Pláucia Urgulanila: 164

Pláucio, Aulo: 164

Plautilla: 204, 206

Plínio-o-Velho: 88, 253

Plutarco: 107

Poliño, Asínio: 161, 163, 168

Políxena: 183

Polono, Martinho: 157

Pólux: 41, 172

Pompeio: 32, 40, 75, 264

Pompeio Magno, Gneu: 165

POMPONIA (gens): 164

Pompónia Grecina: 164-165, 168

Pompónio Flaco, Lúcio: 164

Pompónio Secundo, Públio: 163

Pompónio, Gaio: 168

Pompónio, Quinto: 163

Pôncio Pilatos: 70, 1.67

Ponto: 148

Popeia Sabina: 72, 168, 173

Pórcio Festo: 167, 172

Porto: 218, 220, 224

Portugal: 207, 211, 218, 243, 245, 250, 253, 264

Posidónio: 179

Praxágoras: 39

Pressocráticos: 53

Príamo: 183 
Primo, Gaio Heio: 98-99

Priscila: 39, 76, 148

Próculo: 92

Protágoras: 106

ProvidênCIA: 233

Próximo Oriente: 275

Ptolemeu Filadelfo: 35

Ptolemeu I Sóter: 161

Ptolemeu XII: 162

Ptolomed: 161, 214-215

Putéolos 70, ver Puzoles

Puzoles: 42, ver Putéolos

Quintiliano: 34, 163

Quirina: 93-95

RÁ: 144

Raimundo de Ébrard, D.: 215-216

Rainha SAnta, ver Isabel, D. (Rainha Santa)

RAMSÉs: 144

RAZÃo: 51

RÉ: 144

Reino de CRisto: 227

Reino dos Céus: 52

Remo: 169, 213

Ressurreição: 66, 132, 135-138, 140-141, 184, 194, 204-205, 213

Ribas De SiL: 216-217, 222

Rodes: 41, 69-70

Rodrigo Sanches, D.: 218

Rома: 7, 17, 20-21, 24-26, 29, 33, 39, 40, 42, 51, 58, 62, 69-79, 81, 84, 87, 98, 101, 123, 147-148, 158, 161-165, 167, 169, 171-174, 188, 203-204, 209, 211, 213, 216, 218-220, 233, 241, 249, 250, 267, 271

Romanos: 13, 71-72, 74, 147, 158, $165,167,169,229-230,233,235$

Rómulo: 169, 213, 219

Rubélio Blando: 164

Rufino de Aquileia: 14
SALACLA: 88

Salamanca: 96

SALmerón: 229

Salvador (Penamacor): 96

SAMARIA: 163

SAMos: 84

SAmuel: 58

SAn Martín: 168-169, 268

SAncho I, D.: 215

SANSÃo: 184

SAntARÉm: 215, 218, 241

Santiago de Compostela: 216, 222, 263

Santíssima Trindade: 231

SAnto Ofício: 234

São Salvador de Aramenha: 91-92

SAOULOS: 33

SARDENHA: 85

SARDES, ver Sárdis

SÁrdis: 76, 259

SATANÁs: 47

SAulo: 7, 15, 17, 29, 32-34, 37, 45-48, $69,144-145$

SEFARAD: 76-77, 259, 263

SÉFORA: 145

SÉForis: 22

SEJANO: 163

SelÊuCIa: 186, 188

Selêucida-sobre-o-Tigre: 18

Seleuco I: 18

Semprónio Aselião: 166

Senaqueribe: 180

Sêncio SAturnino: 163

SEndim: 220

SÉNECA: $38,40,149-174,176,178-$ 179, 181-183, 247-250, 252-255, 261, 263, 265-271, 273

SEPTUAGINTA: 22-23

Serapião: 167

SERTÓRIo: 75 
Sesnando, D.: 214

Sesóstris: 50

Sestinum: $84-85$

Seveso: 206

Sevilha: 84

Shammai: 26

Sicília: 85, 109

Sídon: 41, 70, ver Sidónia

Sidónia: 172 , ver Sídon

Silano, Júnio: 168

Silano, Lúcio: 166

Silas: 20, 22, 102, 110-111, 272

Silvano: 20

Simão Mago: 209, 211

Simão Pedro, ver Pedro (São)

Siracusa: 167

SíriA: 7, 18, 40, 75, 79, 163-164, 169

Sísifo: $39-40$

Sócrates: 36, 52, 104, 107-109, 112, 180,248

SófoCles: 50

SOMNIUM SCIPIONIS: 183

Souto de Lafões: 219

SuÁrez, Francisco: 235

Suetónio: 13, 81-82, 86

Suílio, P. :168

TÁciтo: 70, 158-159, 163-165

TÁlio, Q: 88

Taltíbio: 183

TAPORI: 83

Tarpeia: 176

Tarquínio-o-Antigo: 166

TARraconenses: 77

TArso: 7-10, 13-24, 26-34, 36-39, 43, 55-56, 72-79, 81, 100, 102, 144, 148-149, 151-152, 156-158, 160$164,167,182,213,239,242,248$

Tauro: 29,32

Tecla: (Santa) 185-188, 190-197, 201-202
Templo de Jerusalém: 45, 56, 162 163, 169

Teódoto: 22

TEÓfILO: 172

Teofrasto: 35

TÉON: 31

Teos: $30-31$

Termini Augustales: 96

TERMINUS: 97

Tertuliano: 147

Tertuliano, Quinto: 149

TÉRtulo: 24

Teseu: 49

Tessalonica: 69

Tiago (São): 121-122

Tiago de Folhadela (São, igreja): 219, 223

Tiago-o-Menor (São): 152, 202

Tiberíades: 22, 151

Tiвério: 7, 29, 32, 69, 75, 84-86, 161 , 163

Tigelino: 168

Timóteo: 7, 192, 232-233

Tirésias: 49,50

Tiтo: 16, 75, 126, 192, 241

Tовіте: 51

Toda Viegas, D.: 215

Tolstoi, L.: 240-242

Tomás de Aquino (São): 206, 232

Trajano: 89

Trasilo: 163

Trento: 229

Trimegisto: 230

Tróade: 84

Trófimo de ÉfESo: 169

Tucídides: 35,112

Ubertino de Casalis: 227

ULisses: 40, 42, 70

ÚMBRIA: 84

URBE: 20, 78, 83 
URRACA, D.: 218

VALADARES: 220, 224

VALÉRIo Asiático: 168

VALLA, Lorenzo: 158

VArrão, Cingónio: 168

VArrão, Marco Pórcio: 154, 172

VATICANO: 9

VEGÉCIO: 171

VÉNus: 242

VERbo: 231, 235

VERDADE: 47

Vergílio, ver Virgílio

VERONA: 158, 206

Vespasiano: 89, 94-95

VIA ÁPIA: 42

Via Egnatia: 32

Viana do Castelo: 221

Vicente de Beauvais: 157

Vieira, António: 131, 142, 227-235, 269

VILA REAL: 219, 223

VILA VERDE: 219

VIRGENS: 210

Virgílio: 176, 183

VIRIATO: 165

VItÉLIo (imperador): 82, 164

Vitélio, Públio: 164

Vivaldo, abade de Corvey: 157

Voz: 46

Xenofonte: 31, 108-109

Yecla de Yeltes: 96

ZACARIAS: 50

ZEus: 34, 41, 50, 85, 103, 147 


\section{INDEX GRAECUS, RomanVs HebRaICUSQUe}

ad bestias: 185

adikia: 104, 105

aedilis:93

aeon: 132, 135-136, 138-139, 141

affectus: 159

agnostos theos: 37, [112-113]

anoetoi: 52

anosios: 104

apokalypsis: 61

apokalypto: 61

archontes: 105

asebeia:102, 103, 104, 105, 106, 107, 109, 111, 113

auctoritates: 90

boule: 109

ciuis romanus: 33,94

ciuitas: 83, 87-89, 91-92, 94, 97, 249

constantia: 31,52

constitutio antoniana: 164

credo niceno: 156

curriculum: 15, 25, 36

custodia militaris: 71

daimones: 104

decretum Gelasianum: 185

dies natalis: 57

dispositio: 40

ecpyrosis: 178

ecumene: 40 eimarmene: 52

eisangelia: 109

eisodos: 147

ekklesia: 109

elocutio: 40

enkyklios paideia: 24

ennoia: 52

ethe: 111

eusebeia: 112

factio: 72

fides: 31, 84, 87, 172

fortitudo: 31

forum: 87-90, 245-246

gradus eliminat: 163

grammatistes: 31

graphe asebeias: 109

grauitas: 31

gymnasiarchos: 30

gymnasium: 17, 22

hellenismos: $35-36$

bierosylia: 105

homologiai: 105

hosios: 104

bybris: 49, 104, 105, 106

Incolumitas: 85

Ius iurandum: 85-86

kletos apostolos: 61

koine: 33 
kosmopolites: 102

kyrios: 46, 47, 51

lex Irnitana: 93

lex Iulia de ui publica: 70

lex Porcia: 101

libertinoi: 20

logos: 36-37, 51, 53

ludus literarius: 31

machah: 144

magistrati: 85

magistri: 85

magister ludi: 31

mania: 40

Manumissio: 100

mare clausum: 40

Marmor: 99

meikarion: 32

mirabilia: 42

mousika: 31

neos: 32,34

nomima: 105

nomoi: 105

nuncupatio uotorum: 168

occidua plaga: 43

oikos: 40

omophagia: 117

oppida stipendiaria: 85

oppidum: 84, 88-89

orthoepeia: 31

paideia: $31,35-36$

paides: 30

paranomia: 112

parousia: 131-132, 136-138, 141-142

parrhesia: 37

patria: 85, 105

peregrinus: 15, 92

phauloi: 52

philanthropia: 41

philomatheis: 29, 34 pisteis: 105

pleonexia: 104, 105

pneuma: 110, 177-178, 181

polis: 17, 19-20, 25, 31, 38, 111, 162

politeia: 18

politeuma: 18-19

populi: 96

princeps: 84-87, 94, 96-97, 99, 173

progymnasmata: 30,34

pronoia: 52

proscaenium et orchestram cum ornamentis: 99

prostatos: 39

prouocatio ad imperium: 20,70

psephisma: 107

psyche: 180-181

quaestor: 93

quinquennium Neronis: 167-168

res gestae divi Augusti: 85

rex temporalis: 173

sabbat: 143

salos : 40

saulósch: 145

senatus populusque: 84

soma: 39

sophoi: 52

sparagamos: 117

spermologos: 38

symbolaia: 104

techne grammatike: 32

theios aner: 42

theoi: 104

theomises: 104

theophiles: 104

torah: 26-27, 35

tria nomina: 33

uirtus: 52 


\section{INDEX LOCORVM}

ABDIAS

Abd 20: 76 n.33

ACTOS APÓCRIFOS: 151

Actos de André: 200

Actos de João: 200

Actos de Paulo: 156, 185, 201-2, 201

$$
\text { n.12 }
$$

Actos de Paulo e Tecla: 200

Actos de Pedro

$$
\text { 1: } 73 \text { n.17 }
$$

1.3: 78 n.41

Actos de Pedro e Paulo: 156, 210

Actos de Tecla: 185-97

ATh 27: 192

ATh 28: 192

ATh 32: 192

ACTOS DOS APÓSTOLOS

Act 1,8: 58 n.17

Act 2,26: 146

Act 2,9-11: 74 n.20

Act 2,38: 57

Act 2,41: 63 n.39

Act 9,3-4: 59 n. 23

Act 5,33-39: 67 n.50

Act 5,36-39: 62 n.36

Act 6,5: 22

Act 6,9: 20, 22
Act 7,20: 144 n.4

Act 7,30: 145

Act 8,5: 163 n.50

Act 8.9-11: 111 n.27

Act 8,19.22: 57

Act 9: 59 n. 21, 123

Act 9,1-19: 45, 55

Act 9,3: 63 n.40

Act 9,3-4: 59 n.23

Act 9,3-9: 46

Act 9,3-19: 55

Act 9,10: 47

Act 9,10-18: 60 n. 26

Act 9,11: 16

Act 9,13-28: 15 n.11

Act 9,9-15: 47

Act 9,15: 235 n.49

Act 9,17: 15 n.11

Act 9,19-30: 69 n.3

Act 9,22: 163

Act 9,30: 16

Act 9,34: 145 n.10

Act 9,4: 15 n.11

Act 10,9-16: 127 n.19

Act 10,16: 232 n.32

Act 10,28: 25

Act 10,37: 13 
Act 11,3: 127

Act 11,19: 163

Act 11,19-26: 121 n.11

Act 11,25: 16

Act 11,26: 64 n.43

Act 13,4-5: 164

Act 13,16-50: 69 n.3

Act 13,45: 163

Act 14,1-20: 69 n.3

Act 14,13-14: 147

Act 15,1-20: 121 n.11

Act 15,1-5: 110

Act 15,7-11: 110

Act 15,20: 121

Act 15,23: 16

Act 15,29: 121

Act 15,35-21,16: 109

Act 15,41: 16

Act 15,7-11: 110

Act 16,6-7: 233 n.36

Act 16,11-13: 69 n.3

Act 16,14: 39 n.38

Act 16,16: 110

Act 16,16-18: 146

Act 16,10-17: 16 n.13

Act 16,16-40: 102

Act 16,19-21: 111

Act 16,35-39: 101

Act 16,37: 20

Act 16,37-38: 20

Act 17,1-8: 69 n.3

Act 17,10-34: 69 n.3

Act 17,16ss: 37

Act 17,22-23: 112

Act 17,28: 176

Act 18,1-4: 148

Act 18,1-11: 69 n.3

Act 18,3-6: 167

Act 18,12-13: 111
Act 18,14-15: 166

Act 18,19: 69 n.3

Act 19,1-11: 69 n.3

Act 19,19: 111

Act 19,9-23: 63 n.40

Act 19,21: 101 n.2

Act 20,5-15: 16 n.13

Act 21,1-18: 16 n.13

Act 21,1-3: 69 n.3

Act 20,17-38: 69 n.3

Act 21,23: 17

Act 21,26: 169

Act 21,27-36: 14

Act 21,39: 14

Act 22: 59 n.22

Act 22,4: 63 n. 40

Act 22,4-21 : 45, 47

Act 22,6-16 : 56 n.4

Act 22,13: 15 n.11

Act 22,14-15: 47

Act 22,18: 47

Act 22,25-28: 15

Act 22,25-29: 20

Act 22,28: 21, 101

Act 22,23-29: 101

Act 22,3: 25

Act 22,7: 15 n.11

Act 23,6: 25

Act 23,16: 23

Act 23,11: 101 n.2

Act 23,27: 101 n.1

Act 23,6: 25

Act 24,1-9: 24

Act 24,22: 63 n. 40,70 n. 4,169

Act 24,23: 169

Act 24,24: 169

Act 24,26: 17, 170

Act 24,26-27: 72 n.14, 172

Act 26,28: 172 
Act 26,31-32: 172

Act 25,9: 70 n.5

Act 25,10-12: 20

Act 25,11: 17

Act 26,14: 15 n.11

Act 26,4: 23

Act 26,5: 25

Act 26,8-18: 45

Act 26,12-19: 47, 56 n.5

Act 26,22-23: 63 n.38

Act 26,31-2: 172

Act 26,32: 101 n.2

Act 27,1-3: 167

Act 27,1-29: 16 n.13

Act 27,3: 172

Act 27,43: 172

Act 28,1-6: 146, 203

Act 28,1-16: 16 n.13

Act 28,3-6: 172

Act 28,8-10: 172

Act 28,15-16: 172

Act 28,16: 71 n.10, 71 n.11

Act 28,24: 172

Act 28,30: 19 n.31

Act 28,30-31: 172

Anthologia Graeca

7.289-290: 70 n.8

7.550: 70 n. 8

Apolónio de Rodes

Argonáutica 4.1223-1240: 70 n.8

Agostinho

Ciuitate Dei

5: 155

6.1: 156

6-7 : 154

$6.11: 154$

7.14: 34 n.19, 155

18.59 : 165 n. 60
Confessiones

7.8: 155

8.5.11: 155

De correptione et gratia : 155

De libero arbitrio : 155

Epistulae 153.14 (ad Macedonium) $=$ PL 33, 659: 153 e n. 20; 154

Opus imperfectum contra Iulianum 6.11: 155

ANTHOLOGLA LATINA

$406 \mathrm{R}$ (402 ShB): 165

408 R (404 ShB): 165

$409 \mathrm{R}$ (405 ShB): 165

446 R (444 ShB): 166

Apiano

$B C, 4,52,60,64: 29$ n.2

Apocalipse: 227

Ap 1,5: 205 n.19,

Ap 17,14: 205 n.19

Ap 19,16: 205 n.19

Apolónio de Rodes

Argonáutica

4.1223-1240: 70 n.8

4.1634-1690: 70 n.8

Aquiles Tácio

Leu. Clit., 1,18: 42 n.47

Aristóteles

HA, 504b 34: 42 n.47

Pol., 8,2, 1337a: 31 n.9

Rhet. 137a: 106 n.13

Sobre as Virtudes e os Vicios 1251a301251b2: 104

Bernardo de Brihuega

Vidas e Paixões dos Apóstolos: 210, 211

Celso

De med., 5,27,3c: 42 n.46

Cícero,

De diuinatione 2.70: 154 n. 22

De fato, fr. 4 : 155

De natura deorum 2.2.6: 172 n. 74 
De officiis, I,42,: 150-151

Balb. 8.19: 20

Clemente de Alexandria

Stromata 7.83 : 168 n. 70

Decretum Gelasianum: 185

Demóstenes

21.45-48: 106 n.11

Dion Crisóstomo

33.17: 16

33.28: 16

33.49: 16 n.15

34.21-23: 17

34.23: 17 n. 17

54.7: 19

Diodoro Sículo

Diod. 12.39.2: 106 n.15

Díon CÁssio

Hist. Rom., 55.27: 76

Hist. Rom., 57.3.2: 85

Hist. Rom., 59.3.1: 34

Hist. Rom., 67.14.1-3: 37

Dionísio Aeropagita

Epistola a Timóteo 2, 11-15: 187

Epistola a Timóteo 2, 4-6: 232 n.30

Epistola a Timóteo 4,7: 148

Diógenes LAércio

2.12.4-8: 106 n.15

2.40: 109

Deuteronómio

Dt 14, 3-20 : 119 n.8

Dt 26,5-9: 147 n.13

Eрістето

Enchiridion 31.1: 175

Epistola a Filémon

Flm 24: 24

EPÍSTOLA A TITO

Ti 1,10: 126

Ti 1,10-12: 126 n.16

Ti 1,12: 126
Ti 1,15: 126

EPÍstola aos Colossenses

Col 1,15-20: 65 n.44

Col 1,21-23 : 67 n.48

Col 1.24-29 : 180 n. 97

Col 2.13-23: 180 n. 96

Col 2,16: 125 n.15

Col 2,21 : 125 n.15

Col 4,14: 16 n.13

Epístolas aos Coríntios

1Cor 1,1: 61 n.30

1Cor 1,2: 16

1Cor 2,2: 66 n. 47

1Cor 2,10: 177

1Cor 2,10-13: 180 n.98

1Cor 2,11: 177

1Cor 3,16: 176

1Cor 4,21: 177

1Cor 5,3-5: 181

1Cor 5, 9-11: 129

1Cor 6,12-20: 181

1Cor 6,19: 176

1Cor 6,20: 177

1Cor 8,1: 124

1Cor 8,8: 124

1Cor 8,10: 124

1 Cor 8,13: 124

1 Cor 9,1: 45 n.2, 53, 59 n.24

1 Cor 10,4: 177

1Cor 10,23-33: 124

1Cor 12,11: 176

1Cor 12,12-31: 39

1Cor 12,13: 177

1Cor 14,2: 176

1Cor 14,11: 37 n.31

1Cor 14,13: 32

1Cor 14,28: 32

1 Cor $15 x v 184$

1Cor 15,8-9: 21 n.41, 45 n.2, 59 
n. 24,61 n. 30

1Cor 15,20: 135, 136

1Cor 15,20-28: 135

1Cor 15,27-28: 177

1Cor 15,32: 16

1Cor 15,33: 121

1Cor 15,35-49: 177

1Cor 15,45: 177

1Cor 16,3: 16

1Cor 16,8: 16

1Cor 16,18: 177

2Cor 1,21-22: 177

2Cor 1,23: 16

2Cor 2,17: 138

2Cor 3,1: 138

2Cor 3,3: 147 n.14

2Cor 3,6: 138

2Cor 3,7-18: 137

2Cor 3,8: 177

2Cor 3,11: 139

2Cor 3,3: 147

2Cor 4,10-11: 52, 67 n. 49

2Cor 4,18: 53

2Cor 5,1-2: 52

2Cor 6,5: 20

2Cor 10,3-4: 205 n.20

2Cor 11,22: 16, 20, 23, 25, 132

2Cor 11,23-24: 20

2Cor 11,24: 40 n.42, 146 n.11, 146

2Cor 11,25: 20

2Cor 11,32: 16

2Cor 12,1-8: 47 n.4

2Cor 12,2: 61 n.35

2 Cor 12,7: 179 n.90

2Cor 12,7-10: 180 n.93

EPÍSTOLA AOS EFÉSIOS

Ef 2,1-6: 180 n.96

Ef 2,11-13: 180
Ef 2,14: 235 n. 48

Ef 2,15 : 125 n. 15

Ef 2,19: 125 n.15

Ef 3,6: 125 n.15

EPÍSTOLA AOS GÁLATAS

Gl 1,1: 61 n.31

Gl 1,11: 60 n.25

Gl 1,11-12: 59 n.19

Gl 1,11-17: 45 n.2, 60 n.29

Gl 1,12: 52, 61 n.34

Gl 1.13-14: 25

Gl 1,15: 59 n.20

Gl 1,15-16: 60 n.27

Gl 1,15-17: 51

Gl 1,16: 69 n.1

Gl 1,17: 69 n.2

Gl 1,21: 59 n.19

Gl 2,11: 16

Gl 2,20: 52

Gl 3,19: 53

Gl 2,12: 122

Gl 3,1: 8

Gl 4,12: 152

Gl 5,5: 177

Gl 5,16: 180 n.98

Gl 5,16-23: 180 n.95

Gl 5,16-6,10: 180 n.98

Gl 5,22-25: 180 n.97

Gl 6,1: 177

Gl 6,7-10: 180 n.95

Gl 6,10: 180 n.98

Gl 6,11: 10 n.3

Gl 6,12: 180 n.95

EPÍSTOLA AOS HEBREUS

Heb 11,6: 174

Heb 12,6-7: 169 n.70

EPÍSTOLA Aos TESSALONICENSES

1Ts 1,5-6: 205 n.20

1Ts 2,8: 176 
1Ts 4,8: 176

1Ts 5,1: 180,228 n.1

1Ts 5,8: 205 n.20

1Ts 5,10-28: 181 n.100

1Ts 5,23: 181

2Ts 2,1-12: 160

EPÍSTOLA A TIMÓTEO

1Tm 2,4: 230 n.16

1Tm 2,4-6: 232 n.30

1Tm 3,16: 180 n.94

1Tm 6,7: 182

1Tm 6,12: 205 n.20

1Tm 6,15: 205 n.19

2Tm 2,3: 205 n.20

2Tm 2,9: 78 n.44

2Tm 4,6-8: 67 n.49

2Tm 4,7: 148

2Tm 4,11: 16 n.15

EPÍSTOLA AOS FILIPENSES

Fl 1,2,24: 67 n.49

Fl 3: 125

Fl 3,2-5: 180 n.95

Fl 4,22: 172

EPÍSTOLA AOS ROMANOS

$R m$ 1,1: 61 n.30

$R m$ 1,8: 172, 228 n.2, 229 n.11

$R m$ 1,9: 177

$R m$ 1,12-20: 68 n. 51

$R m$ 1,13: 233 n.37

$R m$ 1,16: 74

$R m$ 1,18: 229 n.11

$R m$ 1,20: 228 n.2, 229 n.7

$R m$ 5,13-14: 147 n.12

$R m$ 5,5: 177

$R m$ 7: 180 n.96

$\operatorname{Rm}$ 7,5: 180

$R m$ 7,18: 178

$R m$ 7,21-23: 178

$R m$ 8,4: 177,179 n. 90
Rm 8,5-13: 180 n. 97

$R m$ 8,9: 176, 179 n.90

$R m$ 8,11: 176

$R m$ 8,12-15: 180 n.95

$R m$ 8,13: 179 n.90

$R m$ 8,14: 123, 176

$R m$ 8,14-16: 180 n.98

$R m$ 8,26-27: 177

$R m$ 9,3b-5: 16

$R m$ 9,6-13: 180 n.95

$R m$ 11,25: 235 n.47

$R m$ 10,12: 228 n.6

$R m$ 10,14: 231 n.23

$R m$ 10,18 : 228 n.2

$R m$ 11,1: 25, 32

$R m$ 11,12-26: 228 n.2

$R m$ 13,11-14 : 180 n.96

$R m$ 14,7-8: 166

Rm 14,13: 123

$R m$ 14,15: 123

$R m$ 14,17: 123

$R m$ 14,20: 123

$R m$ 14,21: 123, 124

Rm 15,19-21: 199

$R m$ 15,19-29: 228 n.2

$R m$ 15,23-24: 71 n.12

$R m$ 15.25: 16

$R m$ 15,28: 71, 228 n.2

$R m 15,30: 177$

ÉsQUINES

1.15-17 : 106 n.11

Estrabão

5,1,6: 20

14,5,12-15: 16

14,5,13: 24, 29 n.2, 30 n.6

14,14: 29 n.2

17,1,12-13: 14

EuríPIDES

Bacantes 913-1150: 117 
Eusébio de Cesareia

Chronicon: 152

Historia Ecclesiastica 3.20.2 : 168

$$
\text { n. } 70
$$

EVANGELHO DE LUCAS

Lc 2,21: 162 n.2

Lc 3,4-6: 180

Lc 4,2: 128 n.20

Lc 5,33: 128 n.20

Lc 7,18-28: 63 n.41

Lc 9,61-2: 58 n.15

Lc 15,15: 19 n.31

Lc 16,19-31: 184

Lc 17,5-10: 169

Lc 19,19: 19 n.31

Lc 21,22-23: 169

Lc 22,21: 129 n.24

Lc 23,6-12: 70 n.6

Lc 24,30: 128 n.23

Lc 24,41: 128 n.23

$\hat{\mathrm{E} x O D O}$

Ex 2: 143

Ex 2,6: 143 n.2

Ex 2,10: 144 n.5

Ex 3, 2-10: 58 n.11, 59 n.18

Ex 4,2-5: 146

Ex 4, 31: 146

Ex 2,11-12: 145 n.8

Ex 21: 143

Ex 23,14-19: 118

Ex 24,18: 145

Ex 32: 147

EzequieL

Exagoge: 162 n. 50

Fílon

Mut., 59-65: 33 n.15

In Flaccum

53: 162 n. 50

55-56: 18
Legatio ad Gaium

132: 162 n. 50

23: $155-157$

all $2.84: 14$

all 3.13: 14

all 3.38: 14

all 3.81: 14

all $3.87 \mathrm{v} 14$

de somn. 2.55: 14

Filóstrato

Vida de Apolónio de Tíana AV 1.12: 29 n.2

AV 1.7: 16

AV 4,19: 31 n.7

$A V$ 4.37-38: 75 n.30

GÉNESIS

Gn 2.7: 177,180 n. 98

Gn 6.1-4 : 180 n. 93

Gn 6.17: 180 n. 98

Gn 7.22: 180 n. 98

Gn 12,1-3: 58 n.7

Gn 17, 3: 49

Gn 22,1-2: 58 n.8, 59 n.18

Gn 31,11-13: 58 n.9, 59 n.18

Gn 35,16: 17

Gn 46,2-4: 58 n.10, 59 n.18

Giovanni Colonna

De uiris illustribus : 157

Haymo de Auxerre

Heb. 8.11: 19

Heródoto

2.111: 50

9. 93-94: 50

Hesíodo

Trabalhos e Dias 147-148: 117 n.3

Homero

Il. 1.33-42: 103 n. 4

Il. 16.231-248: 103 n. 4

Od. 9.82-97: 117 n.3 
Od. 9.190-193: 117 n.3

Od. 10.100: 117 n.3

Od. 14.250-320: 70 n.8

Od. 18.136-7: 155

HorÁcio

Carmen, 3.8.5: 34 n.17

Sat 1.10.20-30: 34 n.17

IACOPO DE VARAZZE

Legenda Aurea 90: 202

Legenda Aurea 90, 32-126: 203

Legenda Aurea 61, 421-442: 206 IsAÍAS

Is 6,1-13: 58 n.13

Is 31.1-3: 180 n. 93

Is 31.3: 180 n. 93

Is 40.3-8: 180 n. 93

JERónimo

Contra Vigilianum: 75

Aduersus Iouinianum 2.6: 153

Biblia Sacra Vulgata: 156

De uiris illustribus

uir. Ill. 5: 13

uir. Ill. 11: 151

uir. Ill. 12: 151, 157 n. 33, 154, 159

uir. Ill. 13: 151

uir. Ill. 14: 151

JEREMIAS

Jr 1, 4-19: 58 n.103

Jr 17.5-7: 180 n. 93

João

Apocalypsis (Ioannis): 173

Euangelium (secundum Ioannem):

169 n. 71

1.14: 180 n. 94

11.25: 184

17.2: 180 n. 93

19.11: 167

Jo 5,2: 14
Jo 5,66: 128

Jo 6,53: 128

Jo 6,61: 128

Jo 14,26: 129

Jo 19,11: 167

Jo 21,15: 128

JONAS

Jn 1,3: 75 n.23

Flávio Josefo

Antiquitates Iudaicae

AJ 1.6.7: 14, 16 n.15

AJ 1.110: 25

AJ 12.1: 18

AJ 12.121: 18

AJ 12.125-127: 18

AJ 14.137: 20

AJ 14.226: 21

AJ 14.228: 20

AJ 14.232: 20

AJ 14.234: 20

AJ 14.237: 20

AJ 14.240: 20

AJ 16.27-60: 18

AJ 17.81-82: 163

AJ 17.271: 14

AJ 17.300: 20

AJ 18.228: 14

AJ 18.252: 75

AJ 18.372-378: 18 n.30

AJ 19.5: 18

AJ 19.281: 18

AJ 19.354: 169

AJ 20.38-41: 25

AJ 19.52: 20

AJ 19.354: 169

AJ 20.97-203: 163 n. 54

AJ 20.100: 19

AJ 20.182: 172

AJ 20.189-195: 72 n.14 
AJ 20.263: 22

De bello iudaico

BJ 1.194: 20

BJ 2.21: 22, 24

BJ 2.111: 76

BJ 2.181: 75

BJ 2.261-263: 14 n.9

BJ 2.308: 20

BJ 2.309: 19

BJ 2.492: 19

BJ 4.616: 19

Contra Apion

c. Apion 2.38-39: 18

c. Apion 2.41: 14

Juízes

Jz 6,11-24: 58 n.13

Jz 13,1-25: 48 n.13

JUVEnAL

15.110: 34

LACTÂNCIO

Diuinae institutiones

1.5.19: 150

1.5.28: 150

6.24.13-14: 150

$I O B$

Jb 10.4-12: 180 n. 93

Levítico

Lv 1-2: 118

Lv 11,1-47: 118

Lv 11,2-47: 119 n.8

Lv 17: 118

Lv 20, 22-26: 119 n.8

LIVRO DOS NÚMEROS

$N m$ 11,4-5: 118

LIVRO DOS SEGREDOS DE ENOCH: $163 \mathrm{n}$.

53

LUCAS

Lc 2.21: 162

Lc 3.4-6: 180 n. 93
Lc 16.19-31: 184

Lc 17.5-10: 169 n. 7

Lc 21.22-23: 169 n. 71

MARCOS

Mc 5.20: 163 n. 53

Mc 7.24: 163 n. 53

Mc 7.31: 163 n. 53

Mc 8.27: 163 n. 53

Mc 8.36-37: 184

Mc 11.12: 169 n. 71

Mc 11.14-20: 169 n. 71

Mc 13.28-32: 169 n. 71

Macabeus

1Mac 1.14: 22

2Mac 3: 58 n.16

2Mac 4.9-14: 22

2 Mac 7,9: 205 n.19

2Mac 13,4: 205 n.14

3Mac 1.3: 19

Marcos

Mc 2,13-16: 127 n.18

Mc 2,18-20: 128 n.20

Mc 7,1-15: 127 n.17

Mc 11,12: 129 n.24

Mc 13,28-32: 169

Mc 14,20: 129 n.24

Mc 16,16: 231 n.25

Mc 18,19: 127

Menandro

Monostichoi 88: 21 n.43

Mateus

Mt 2,13-18: 162

Mt 2,16-18: 161

Mt 4,2: 128 n.20

Mt 6,16-18: 128 n.20

Mt 9,14-15: 128 n.20

Mt 11,2-15: 63 n.41

Mt 15,1-20: 127 n.17

Mt 17: 148 
Mt 21,18-24: 169 n. 71

Mt 23.15: 25

Mt 24,32-36: 169 n. 71

Mt 26,23: 129 n.24

Mt 26,40-41: 180 n. 93

Mt 27,19: 167

Minúcio FÉLix

Octanius 20.1 : 150

Ovídio

Metamorfoses 1, 12: 231 n.17

Padre António Vieira

Clauvis III, 81: 228 n.1

Clauvis III, 97: 228 n.2

Clauvis III, 99: 228 n.2

Clauvis III, 137: 228 n.2

Clauvis III, 139: 228 n.2, 228 n.4

Clauvis III, 167: 231 n.22

Clauvis III, 175-81: 228 n.2

Clauvis III, 201-3: 228 n.2, 228 n. 5

Clauvis III, 249-51 : 228 n.2, 229 n.7

Clauvis III, 253-5: 229 n.8

Clauvis III, 259 : 229 n.10

Clauvis III, 267-9 : 229 n.12

Clauvis III, 271: 230 n.14

Clauvis III, 273: 231 n.17

Clauvis III, 275: 231 n.20

Clauvis III, 277: 231 n.24

Clauvis III, 331: 230 n.13

Clauvis III, 431: 232 n.26

Clauvis III, 437: 232 n.28

Clauvis III, 437-439: 232 n.31

Clauvis III, 441: 232 n.32

Clauvis III, 447-449: 233 n.33

Clauvis III, 453: 233 n.34

Clauvis III, 463: 232 n.27, 234 n. 35

Clauvis III, 467: 234 n.39

Clauvis III, 469: 233 n.38
Clauvis III, 483: 234 n.41

Clauvis III, 485: 234 n.40

Clauvis III, 513: 234 n.42

Clauvis III, 534-35: 234 n.43

Clauvis III, 537: 234 n.45

Clauvis III, 627: 235 n.46

Clauvis III, 699: 235 n.50

Pausânias

Descrição da Grécia

I, 36, 3: 38

I, 44, 10: 38

Photius

quaest. Amphil. 116: 14

Platão

Apologia 24b-c: 108

Eutifron 7a: 103

Republica 427b-c: 103 n.5

Plínio-o-Velho

História Natural

9.39.76: 42

19.1.3: 70 n. 8

32.5.14: 42

Plutarco

Vida de Galba 20.1: 75 n.31

Vida de Nicias 23: 106 n.15

Vida de Péricles

32.2: 107

32.1: 107 n.16

Vida de Sertório 12.2: 75 n.31

Pseudo-Ezequiel

Exodus: 163 n. 53

Pseudo-Lino

Passio sancti Pauli apostoli, Acta apostolorum apocrypha: $156 \mathrm{e}$ n. 25

Pseudo-Paulo

Ep. 2 Barlow: 170

Ep. 4 Barlow: 170

Ep. 6 Barlow: 170 
Ep. 8 Barlow: 170, 171

Ep. 10 Barlow: 170, 171

Ep. 11 (12) Barlow: 171, 173

Ep. 14 Barlow: 171

Ep. 14.9 Barlow: 158, 173

Pseudo-SÉneca

Ep. 1 Barlow: 170

Ep. 3 Barlow: 170

Ep. 5 Barlow: 170, 171, 173

Ep. 7 Barlow: 170, 171, 173

Ep. 9 Barlow: 170

Ep. 12 (11) Barlow: 151, 152, 171

Ep. 13 Barlow: 171

Hercules Oetaeus 1131 ss.: 173

Quintiliano

Institutio oratoria

Inst. or., 8.3.31: 163

Inst. or., I,1,12-14: 34 n.17

Quinto Tertuliano

Apologeticum

12.6: 149 n. 1

22.11: 149 n. 1

38.2-3 : 168 n. 70

48.8: 149 n. 1

50.5: 149 n. 1

$50.14 \mathrm{v} 149$ n. 1

De Anima

$20.1: 149$

42.2: 149 n. 1,153 n. 19

De resurrectione carnis

1.4: 149 n. 1 e 153 n. 19

3.3: 153 n. 19

Res gestae 25.2: 85 n.7

REIS

1Rs 1,19-21: 58 n.14

SAMUEL

1Sm 3, 4-14: 58 n.12, 59 n.18

SÉnecA

Contra superstitiones: 154
De beneficiis

3.36: 163

4.8.2: 176

De clementia

2.1.1-2: v 168

De immatura morte: 153 n. 19

De remediis fortuitorum: 167

De situ et sacris Aegyptiorum: 161

De situ Indiae: 161

De superstitione: 162

Dialogi

1.1.5-6: 179 n. 90

3.1.2.1-2: 166

5.3.36.6: 166

6.20.3: 168 n. 70

6.24.5: 178

6.25.1: 183

6.26.7: 183

7.17-28: 154 n. 21

9.17.7: 161 n. 44

11.9.3: 183

12.8.3: 175

12.16.2: 165

Diui Claudii Apocolocyntosis

8: 166

11.2: 165

Epistulae morales ad Lucilium

3.6: 167

9: 167

10: 167

13: 167

20.11: 169 n. 90

40: 157 n. 33,167

41: 167

41.1-2: 175, 176

42: 167

65.21-22: 169 n. 90

72: 157 n. 33

74.16: 169 n. 90 
$82.3-157$ n. 33

92.10: 178

95.50: 174

102.23-28: 182

107.11: 155

108.22: 161 n. 44

Naturales Quaestiones

1.1.3: 161 n. 44

Troades

67-164: 183

371-408: 183

397: 153,183

Sófocles

Édipo em Colono v. 1650: 49

Suetónio

Aug. 17.2: 85 n.7

TÁcito

Annales

5.8: 163 n. 55

5.18: 163

6.3: 163 n.55

6.12: 163

6.27: 163

6.33: 163

11-16: 157

12.4: 168 n. 70

13.32: 165

13.33: 168 n. 70

13.42-43: 168 n. 70

13.58: 168 n. 71

14.40: 168 n. 70

14.48: 168 n. 70

15.14: 168 n. 70

15.28.4: 19

15.64: 158

\section{Historiae}

$$
\text { 1-5: } 157
$$

Tertuliano

De baptismo 17: 187 n.8,200 n.4,201
TiBÉRIO

Edicto de Nazaré: 163

Tucídides

6.28.2: 112

VALÉrio Máximo

Factorum et dictorum memorabilium libri (IX) 1.8.1: 172 n. 74

Xenofonte

Anab. 1.2.22-33

Mem. 1.1.1: 108 


\section{Os Autores}

Abel N. Pena-Doutor em Letras, na especialidade de Literatura Grega, pela Universidade de Lisboa, é Professor Auxiliar da Faculdade de Letras e investigador do Centro de Estudos Clássicos da mesma Universidade. As suas áreas de interesse científico são a cultura clássica, a recepção da mitologia greco-romana no século XVI e os fenómenos literários dos primeiros séculos da nossa era. Publicou Aquiles Tácio. Os amores de Leucipe e Clitofonte (Lisboa, 2005) e Abelardo e Heloísa. «Historia calamitatum»-Cartas (Lisboa, 2008).

Amílcar Guerra - Doutor em Letras, na especialidade de História Clássica, pela Universidade de Lisboa, é Professor Auxiliar da Faculdade de Letras e investigador dos Centros de Arqueologia e de História da mesma Universidade. As suas áreas de interesse científico são a epigrafia latina, topoantroponímias da Hispânia Antiga, a arqueologia clássica e a romanização. Publicou Resistência à aculturação no Ocidente Hispânico: Defesa do território e identidade linguística (Lisboa, 2001) e Plinio-o-Velho e a Lusitânia (Lisboa, 1995).

Ana Paula Goulart - Mestra em História e Cultura Pré-Clássica e doutoranda em História, na especialidade de História Antiga, na Universidade de Lisboa, é investigadora do Centro de História da mesma Universidade. As suas áreas de interesse científico são os estudos bíblicos, em particular o livro do Exxodo, a composição e recepção da figura de Moisés e as problemáticas helenísticas. Publicou $O$ êxodo e os êxodos: por entre História e Mito (Lisboa, 2001) e $A$ mulher com o menino ao colo. Proposta de leitura para uma iconografia do Próximo Oriente Antigo (Lisboa, 2007).

António Cândido Franco - Doutor em Literatura Portuguesa, pela Universidade de Évora, é Professor Auxiliar com Agregação e investigador do Centro de Estudos em Letras daUniversidade de Évora da mesma Universidade. As suas áreas de interesse científico são a literatura, a antropologia e a história portuguesas. Publicou, entre outros, os seguintes livros: A Literatura de Teixeira de Pascoaes (2000), A Rainha Morta e o Rei Saudade (2003), Viagem a Pascoaes (2006), A Herança de D. Carlos (2008) e Os Pecados da Rainha Santa (2010).

Arnaldo do Espírito Santo - Doutor em Letras, na especialidade de Literatura Latina, pela Universidade de Lisboa, é Professor Catedrático da Faculdade de Letras e investigador do Centro de Estudos Clássicos da mesma Universidade. As suas áreas de interesse científico são o latim e a cultura medievais, Santo Agostinho e o Padre António Vieira. Publicou Padre António 
Vieira, Clavis Prophetarum - Chave dos Profetas, Livro III (Lisboa, 2000) e Santo Agostinho, Confissões (em co-autoria, Lisboa, 2001).

Cláudia A. Teixeira-Doutora em Literaturas Clássicas, na especialidade de Literatura Latina, pela Universidade de Évora, é Professora Auxiliar da mesma Universidade e investigadora do Centro de Estudos Clássicos e Humanísticos da Universidade de Coimbra. As suas áreas de interesse científico são a épica, o romance e a historiografia latinos. Publicou Estrutura da viagem na épica de Virgílio e no romance latino (Lisboa, 2007) e Librorum monimenta: imagens da cultura eborense (sécs. XVI a XVIII) (em co-autoria, Évora, 2006).

Cristina Sobral - Doutora em Letras, na especialidade de Literatura Portuguesa Medieval, pela Universidade de Lisboa, é Professora Auxiliar e investigadora do Centro de Linguística da mesma Universidade. As suas áreas de interesse científico são a literatura e a cultura portuguesa medievais, hagiografia medieval e a crítica textual. Publicou Paulo de Portalegre, Novo Memorial do Estado Apostólico. Primeira Crónica dos Lóios (Lisboa, 2007) e Hagiografia em Portugal: balanço e perspectivas (Lisboa, 2007).

Delfim F. Leão - Doutor em Letras, na especialidade de História da Cultura Clássica, pela Universidade de Coimbra, é Professor Catedrático da Faculdade de Letras, investigador do Centro de Estudos Clássicos e Humanísticos e actual director da Imprensa da mesma Universidade. As suas áreas de interesse científico são a história antiga, o direito e a teorização política dos Gregos, a pragmática teatral e a escrita romanesca antiga. Publicou Law and Drama in Ancient Greece (em co-autoria, Londres, 2010) e Dez Grandes Estadistas Atenienses (em co-autoria, Lisboa, 2010).

José A. Ramos - Doutor em Letras, na especialidade de História Antiga, pela Universidade de Lisboa, é Professor Catedrático da Faculdade de Letras e director do Centro de História da mesma Universidade. As suas áreas de interesse científico são a história, a cultura, as línguas e as literaturas antigas - em particular as do espaço siro-palestinense -, a história das religiões e a tradução bíblica. Publicou Bíblia Sagrada (coordenação, Fátima, 2008) e $A$ sexualidade entre os Hebreus: caminhos essenciais do sentido (Lisboa, 2009).

Luís U. Afonso - Doutor em História da Arte, na especialidade de Arte Medieval, pela Universidade de Lisboa, é Professor Auxiliar e investigador do Instituto de História da Arte da mesma Universidade. As suas áreas de interesse científico são a arte medieval e os mercados da arte. Publicou $O$ Convento de S. Francisco de Leiria: estudo monográfico (Lisboa, 2003), O Ser 
e o Tempo: as Idades do Homem no gótico português (Lisboa, 2003) e A Pintura Mural Portuguesa entre o Gótico Internacional e o Fim do Renascimento: Formas, Significados, Funções (Lisboa, 2009).

Maria Ana Valdez - Doutora em História Antiga, pela Universidade de Lisboa, é Postdoctoral Fellow no Departamento de Estudos Religiosos da Universidade de Yale e investigadora do Centro de História da Universidade de Lisboa /Yale University. As suas áreas de interesse científico são o judaísmo e o cristianismo antigos, a literatura apocalíptica judaico-cristã, a tolerância religiosa entre Jesuítas e Sefarditas portugueses do século XVII e a religiosidade ibérica. Publicou From Antiquity to the Present: The 2008 European Association of Biblical Studies Lisbon Meeting (em co-autoria, Lisboa, 2009) e Historical Interpretations of "Fifth Empire»: Dynamics of Periodization from Daniel to António Vieira, S.J. (Leiden, 2010).

Maria Cristina de Sousa Pimente1-Doutora em Letras, na especialidade de Literatura Latina, pela Universidade de Lisboa, é Professora Catedrática e directora do Centro de Estudos Clássicos da mesma Universidade. As suas áreas de interesse científico são a literatura latina - em particular, a filosofia de Séneca, o epigrama de Marcial e a historiografia de Tácito - e a história de Roma. Publicou Séneca (Mem Martins, 1995) e Sociedade, Poder e Cultura no tempo de Ovídio (em co-autoria, Coimbra, 2010).

Maria do Céu Fialho - Doutora em Letras, na especialidade de Literatura Grega, pela Universidade de Coimbra, é Professora Catedrática da Faculdade de Letras e directora do Centro de Estudos Clássicos e Humanísticos da mesma Universidade. As suas áreas de interesse científico são a literatura grega - em especial Sófocles, Aristóteles (Ética e Poética) e Plutarco - as reescritas do mito e as problemáticas de identidade. Publicou Luz e trevas no Teatro de Sófocles (Coimbra, 1992) e Plutarch's Moral Values (em co-autoria, Leuven/Coimbra, 2008).

Nuno Simões Rodrigues - Doutor em Letras, na especialidade de História da Antiguidade Clássica, pela Universidade de Lisboa, é Professor Auxiliar da Faculdade de Letras, investigador coordenador da linha de História Antiga do Centro de História da mesma Universidade e investigador do Centro de Estudos Clássicos e Humanísticos da Universidade de Coimbra. As suas áreas de interesse científico são a cultura grega e a história social e política da Roma Antiga. Publicou A Sexualidade no Mundo Antigo (em co-autoria, Lisboa, 2009) e Iudaei in Vrbe. Os Judeus em Roma de Pompeio aos Flávios (Lisboa, 2007). 
Paula Barata Dias - Doutora em Letras, na especialidade de Literatura Latina Medieval, pela Universidade de Coimbra, é Professora Auxiliar da Faculdade de Letras e investigadora do Centro de Estudos Clássicos e Humanísticos e da mesma Universidade. As suas áreas de interesse científico são o cristianismo, a patrística e sua inserção no Mundo Antigo, a Antiguidade Tardia e a Alta Idade Média, o monaquismo antigo e a tradição monástica de São Frutuoso. Publicou Os Textos Monásticos de ambiente frutuosiano (Viseu, 2008) e La religion égyptienne chez Plutarque et chez Athanase d'Alexandrie - Les animaux, des signes d'une continuité (Lille, 2005).

Paulo Sérgio Ferreira - Doutor em Letras, na especialidade de Literatura Latina, pela Universidade de Coimbra, é Professor Auxiliar da Faculdade de Letras e investigador do Centro de Estudos Clássicos e Humanísticos da mesma Universidade. As suas áreas de interesse científico são a literatura latina, em particular o romance, a sátira menipeia, a paródia e autores como Séneca e Marcial. Publicou The Satyricon of Petronius: Genre, Wandering and Style (em co-autoria, Coimbra, 2008) e Séneca em cena: enquadramento na tradição dramática greco-latina (Lisboa, 2011).

Rodrigo Furtado - Doutor em Letras, na especialidade de Literatura Latina, pela Universidade de Lisboa, é Professor Auxiliar da Faculdade de Letras e investigador do Centro de Estudos Clássicos da mesma Universidade. As suas áreas de interesse científico são a história de Roma e a historiografia latina tardia e medieval. Publicou From Gens to Imperium: a Study on Isidore's Political Lexicon (Hildesheim/Zurique/Nova Iorque, 2008) e Las Historiae de Isidoro en el reino de León (León, 2007). 


\section{Volumes publicados na Coleç̧ão Hvmanitas SVPPLEMENTVM}

1. Francisco de Oliveira, Cláudia Teixeira e Paula Barata Dias: Espaços e Paisagens. Antiguidade Clássica e Heranças Contemporâneas. Vol. 1 - Linguas e Literaturas. Grécia e Roma (Coimbra, Classica Digitalia/CECH, 2009).

2. Francisco de Oliveira, Cláudia Teixeira e Paula Barata Dias: Espaços e Paisagens. Antiguidade Clássica e Heranças Contemporâneas. Vol. 2 - Linguas e Literaturas. Idade Média. Renascimento. Recepscão (Coimbra, Classica Digitalia/CECH, 2009).

3. Francisco de Oliveira, Jorge de Oliveira e Manuel Patrício: Espaços e Paisagens. Antiguidade Clássica e Heranças Contemporâneas. Vol. 3 - História, Arqueologia e Arte (Coimbra, Classica Digitalia/CECH, 2010).

4. Maria Helena da Rocha Pereira, José Ribeiro Ferreira e Francisco de Oliveira (Coords.): Horácio e a sua perenidade (Coimbra, Classica Digitalia/CECH, 2009).

5. José Luís Lopes Brandão: Máscaras dos Césares. Teatro e moralidade nas Vidas suetonianas (Coimbra, Classica Digitalia/CECH, 2009).

6. José Ribeiro Ferreira, Delfim Leão, Manuel Tröster and Paula Barata Dias (eds): Symposion and Philanthropia in Plutarch (Coimbra, Classica Digitalia/CECH, 2009).

7. Gabriele Cornelli (Org.): Representaçôes da Cidade Antiga. Categorias históricas e discursos filosóficos (Coimbra, Classica Digitalia/CECH/Grupo Archai, 2010).

8. Maria Cristina de Sousa Pimentel e Nuno Simões Rodrigues (Coords.): Sociedade, poder e cultura no tempo de Ovidio (Coimbra, Classica Digitalia/ $\mathrm{CECH} / \mathrm{CEC} / \mathrm{CH}, 2010)$.

9. Françoise Frazier et Delfim F. Leão (eds.): Tychè et pronoia. La marche du monde selon Plutarque (Coimbra, Classica Digitalia/CECH, École Doctorale 395, ArScAn-THEMAM, 2010).

10. Juan Carlos Iglesias-Zoido, El legado de Tucídides en la cultura occidental (Coimbra, Classica Digitalia/CECH, ARENGA, 2011).

11. Gabriele Cornelli, O pitagorismo como categoria historiográfica (Coimbra, Classica Digitalia/CECH, 2011).

12. Frederico Lourenço, The Lyric Metres of Euripidean Drama (Coimbra, Classica Digitalia/CECH, 2011). 
13. José Augusto Ramos, Maria Cristina de Sousa Pimentel, Maria do Céu Fialho, Nuno Simões Rodrigues (coords.), Paulo de Tarso: Grego e Romano, Judeu e Cristão (Coimbra, Classica Digitalia/CECH, 2012). 
QR

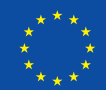

COMPETE

$\star \star \star \star$ 